TÓPICOS EM GESTÃO DA PRODUÇ̧̃̃O
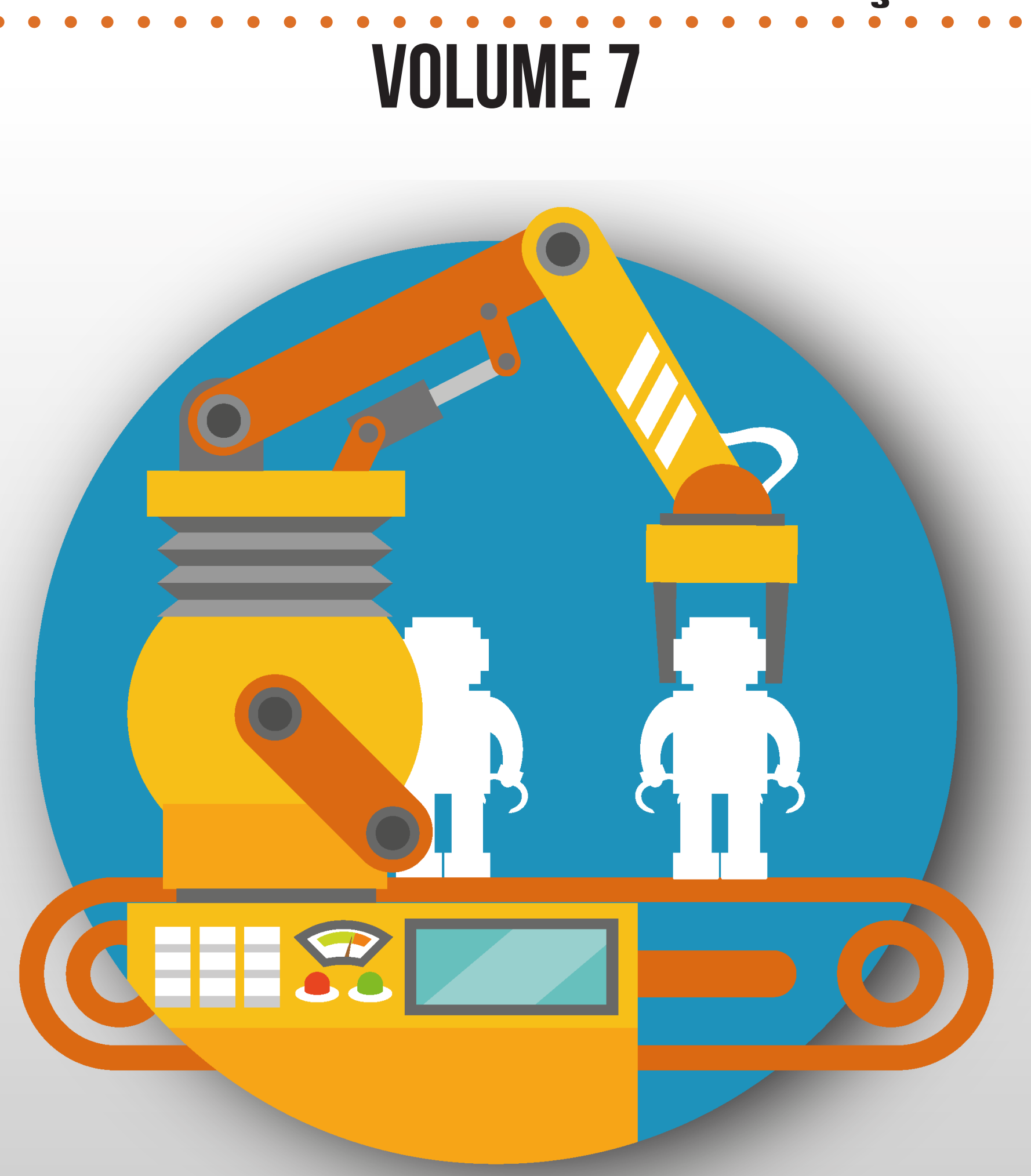

Hélcio Martins Tristão

(organizador)

Editora Poisson 
Hélcio Martins Tristão

(organizador)

\title{
Tópicos em Gestão da Produção Volume 7
}

\author{
1르 Edição
}

Belo Horizonte

Poisson

2017 


\section{Conselho Editorial}

Dr. Antônio Artur de Souza - Universidade Federal de Minas Gerais Dra. Cacilda Nacur Lorentz - Universidade do Estado de Minas Gerais Dr. José Eduardo Ferreira Lopes - Universidade Federal de Uberlândia Dr. Otaviano Francisco Neves - Pontifícia Universidade Católica de Minas Gerais

Dr. Luiz Cláudio de Lima - Universidade FUMEC

Dr. Nelson Ferreira Filho - Faculdades Kennedy

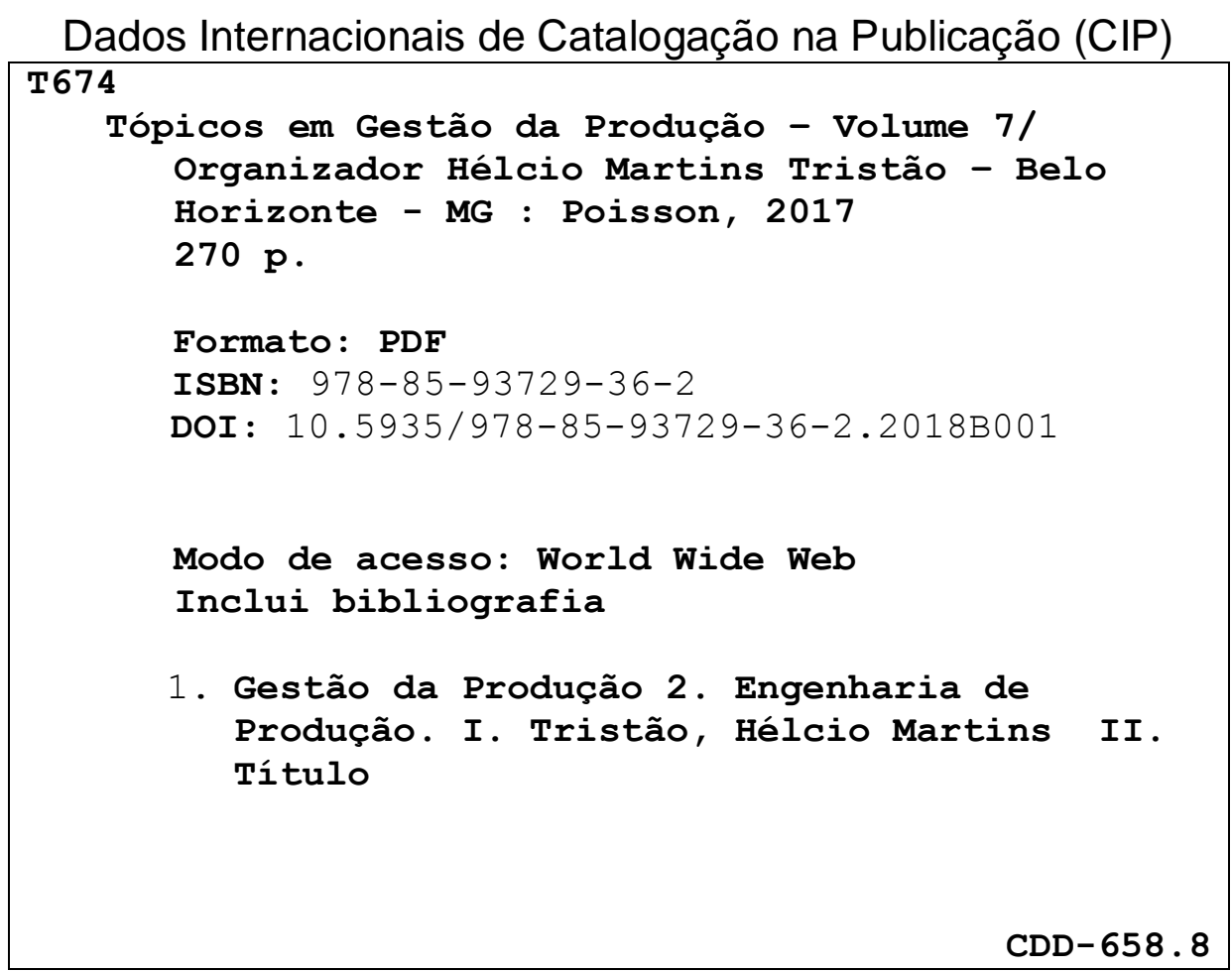

O conteúdo dos artigos e seus dados em sua forma, correção e confiabilidade são de responsabilidade exclusiva dos seus respectivos autores.

www.poisson.com.br

contato@poisson.com.br 
Apresentação

Na dinâmica da competitividade e efetividade da "Gestão da Produção" destacam- se cada vez mais tópicos inerentes à busca pela excelência em resultados econômicos e financeiros das organizações privadas e públicas.

Nesse escopo, este e-book apresenta contribuições da academia por meio de autores dedicados e com conhecimentos específicos que investigam, analisam métodos e aplicações, propõem soluções, desenvolvem formulações e abordam temas sobre: levantamento de estudos, análises e comparações de meios utilizados pelas organizações para o alcance de níveis de desempenho competitivos; da elaboração de propostas de soluções para problemas e melhoria do processo de gestão da produção, sejam eles voltados para a otimização dos recursos utilizados - tempo, recursos físicos e materiais, ou na formulação de instrumentos que permitam controle efetivo sobre - vendas, demandas e eliminação de fatores desnecessários para a produção de produtos e serviços.

Não obstante, ainda traz ampla abordagem de métodos, técnicas, modelos e impactos das novas tecnologias sobre as organizações e que permitem ao leitor ter um contato pragmático com resultados obtidos a partir do uso desses conhecimentos.

Assim, as contribuições inseridas nesse conjunto de abordagens corroboram tanto para acadêmicos quanto para profissionais dos setores privados e públicos, uma vez que não se limitam aos aspectos teóricos e conceituais, mas apresentam formas de integrar conhecimentos específicos dos "Tópicos Modernos da Gestão da Produção" com objetivos de melhoria dos resultados operacionais e da otimização na preservação e uso dos recursos produtivos.

Aos colegas acadêmicos, parceiros profissionais, editores, agradecimentos respeitosos e aos leitores desejo ótimas e profícuas leituras.
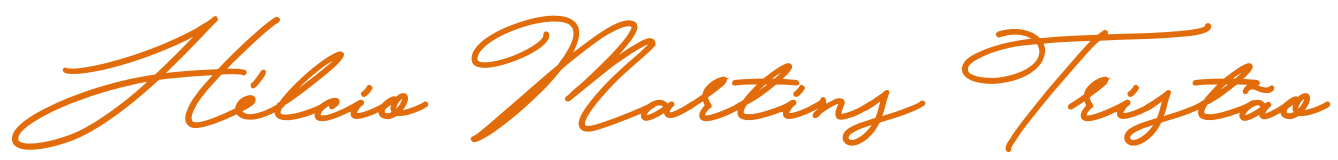


\section{SUMÁRIO}

Capítulo 1 - Estudo comparativo da aplicação entre torque e ângulo e torque simples no

mancal do Virabrequim do motor automotivo

Willian de Morais, Renato Cristofolini, Claiton Emilio do Amaral, Emerson Jose Corazza, Custódio da Cunha Alves

Capítulo 2 - Análise de manifestações patológicas em passarela de concreto armado na região Centro-Sul de Manaus

Daniela Oliveira De Lima, Janiely Lima De Almeida, Rennan Silva Italiano, Wesley Gomes Feitosa,

José Roberto De Queiroz Abreu

Capítulo 3 - Viabilidade da substituição de caldeiras de acordo com a utilização de diferentes topos de combustíveis

Luciana Cristina de Carvalho Ramos, Alexandra Maria Sandy, Luciene Vanessa Maia da Rocha Judice,

Gustavo Henrique Judice, Diego Henrique de Almeida

Capítulo 4 - Estudo dos efeitos da filtração de efluente de laticínio na redução do fluxo permeado e na colmatação de membranas de microfiltração e ultrafiltração

Douglas Felipe Galvão, Eliane Rodrigues dos Santos Gomes

Capítulo 5 - Orange county e a rede de produtos agrícolas do slow food

Franciele Lourenço, Luciane Cristina Ribeiro dos Santos, Osíris Canciglieri Junior,

Liliane Cristina Schlemer Alcântara

Capítulo 6 - O design e os sistemas produto-serviço na economia da funcionalidade: Uma análise bibliométrica

Manuela Gortz, Décio Estevão do Nascimento

Capítulo 7 - Políticas públicas na cadeia produtiva de energia elétrica e a influência nas perdas de energia

Marcos Roberto Lopomo, Kátia Madruga

Capítulo 8 - A importância da adequada separação de resíduos

sólidos na construção civil

Rodrigo Vielmo Moura, Maiara Baldissarelli, Jamile Pereira da Silva, DiegoWillian Nascimento Machado,

Mario Fernando de Mello

Capítulo 9 - Estudo de tempos e movimentos: Um estudo de caso em uma empresa produtora de picolés na cidade de Belém - PA

Ana Elaje Azevedo Simões da Mota, Bárbara Heliodora Negreiros Salomão, Matheus Amaral Damasceno,

Renato Augusto Pereira Archer, André Clementino de Oliveira Santos

Capítulo 10 - Determinação da capacidade produtiva em uma indústria de farinha de tapioca no Nordeste do Pará: Uma aplicação da engenharia de métodos.

Antonio Andrei Braga, Denilson Ricardo de Lucena Nunes, Edullis Garcia Rodrigues, Igor Santos Costa,

Jonathas Sampaio dos Santos 
Capítulo 11 - O uso do plano mestre de produção com suporte na gestão de suprimentos em um empreendimento comercial

Antônio Caio Cézar Costa dos Santos, Ana Paula Souza de Freitas, Ayllan Cesar de Sousa Galvão,

Aiury Daniele Correa da Silva, Leony Luis Lopes Negrão

Capítulo 12 - Troca rápida de ferramentas (TRF): Análise da literatura para identificação de oportunidades de pesquisa

Edimar Nunes Dias, Claudilaine Caldas de Oliveira, Rony Peterson da Rocha, Tânia Maria Coelho,

Márcia de Fátima Morais

Capítulo 13 - Parametrização do MRP e Implantação de tempo de segurança no setor de programação de materiais em uma empresa multinacional do setor aeronátutico

Ferdinand Van RuN

Capítulo 14 - Estudo de movimentos e tempos: Exemplificação a partir de um processo do cotidiano domiciliar. Jackson de Sousa Silva, Thalasso Bezerra Bispo, Jair Paulino de Sales, Cássia Taisy Alencar de Andrade

Capítulo 15 - Introdução da curva ABC no processo de análise da demanda em uma empresa do segmento metalomecânico Juan Pablo Silva Moreira, Jaqueline Luisa Silva, Igor Caetano Silva, Felipe Augusto da Silva, Janser Queiroz Oliveira

Capítulo 16 - Análise da viabilidade de aplicação da estratégia make or buy no processo de usinagem em uma indústria do segmento automotivo Juan Pablo Silva Moreira, Jaqueline Luisa Silva, Igor Caetano Silva Felipe Augusto da Silva, Janaína Aparecida Pereira

Capítulo 17 - A importância da redução na geração de resíduo limalha de aço pela alteração das etapas de um processo de fabricação Mario Fernando Mello, Jéssica Citron Muneroli

Capítulo 18 - Fabricação de carrocerias de ônibus utilizando projeto elétrico modular Alencar Silveira Roth, Jocarly Patrocínio de Souza

Capítulo 19 - Análise das fases de desenvolvimento de produtos aplicadas na criação de um mobiliário urbano

Amanda Daniele de Carvalho, Rayane Ester Felício Santiago, Luciano Wallace Gonçalves Barbosa, Camila Gonçalves Castro

Capítulo 20 - Análise da cadeia de suprimentos sob à luz do Lean Logistics. 
Capítulo 21 - Análise sistemárica do estoque obsoleto de uma concessionária de caminhões: Aplicação da curva ABC

Franco da Silveira, Ederson Djair Sanches do Nascimento, Filipe Molinar Machado, Janis Elisa Ruppenthal,

Luis Cláudio Villani Ortiz

Capítulo 22 - Utilização de um software de gestão de cadeia produtiva agroindustrial em uma usina de açucar e álcool.

Mario Henrique Bueno Moreira Callef, Eduardo MeneguettiHizo, Bruna Maria Gerônimo, FrancielyVelozo Aragão, Willyan Prado Barbosa

Capítulo 23 - O uso de certificações ambientais como forma de promover o Desenvolvimento Sustentável na construção civil

Diego Vieira Ramos, André Fogolin Machado, Marcelo Luiz Chicati, Generoso de Angelis Neto

Capítulo 24 - Escritório Verde: A contribuição da Universidade Tecnológica

Federal do Paraná - UTFPR para o Desenvolvimento Sustentável.

Diego Vieira Ramos, André Fogolin Machado, Marcelo Luiz Chicati, Generoso de Angelis Neto

Autores 


\title{
CAPÍTULO 1
}

\section{ESTUDO COMPARATIVO DA APLICAÇÃO ENTRE TORQUE E ÂNGULO E TORQUE SIMPLES NO MANCAL DO VIRABREQUIM DO MOTOR AUTOMOTIVO}

\author{
Willian de Morais \\ Renato Cristofolini \\ Claiton Emilio do Amaral \\ Emerson Jose Corazza \\ Custódio da Cunha Alves
}

Resumo: O presente trabalho visa expor um estudo comparativo entre a aplicação do torque e ângulo com o torque simples no mancal do virabrequim do motor automotivo. O aperto controlado por ângulo é um método indireto de medição de alongamento que minimiza o atrito entre as partes aparafusadas visando uma padronização e maior precisão do aperto em torques altos. Diante da problemática de quais as vantagens da utilização do torque ângulo em relação ao torque simples na fabricação de motores automotivos. Este estudo tem como objetivo geral realizar um comparativo destas aplicações especificamente no mancal do virabrequim do motor automotivo. O método utilizado neste trabalho é o estudo de caso descritivo que tem como intenção mostrar uma realidade não conhecida. Inicialmente foi realizada a revisão bibliográfica visando conhecer mais sobre o tema e após o embasamento, com objetivo de verificar de modo prático os limites elásticos e plásticos, foram feitos testes de ensaio de ruptura em parafusos liga SAE 10B30, utilizados no mancal dos motores automotivos. Com o estudo concluiu-se que, com as variações de atrito no processo o torque simples, pode gerar um grave problema na montagem dos mancais, pois em alguns casos, o parafuso pode não chegar ao torque nominal, levando a sua ruptura e em outros casos o parafuso pode não chegar a sua tensão elastoplástica, entre a região elástica e plástica), que é a tensão indicada para o aperto da junta, devido o atrito gerado, o parafuso pode não atingir seu torque corretamente.

Palavras chave: Torque; ângulo; motor automotivo; parafusamento; atrito; fadiga. 


\section{INTRODUÇÃO}

O presente trabalho expõe um estudo comparativo da aplicação do torque e ângulo com o torque simples no mancal do virabrequim do motor automotivo.

Neste trabalho optou-se em utilizar um torque diferenciado denominado torque de aperto controlado por ângulo, que é um método indireto de medição de alongamento que minimiza o atrito entre as partes aparafusadas, visando uma padronização e maior precisão do aperto em torques altos, mas sabe-se que normalmente os torques mais utilizados são: o torque dinâmico, torque estático e torque falso, que são definidos pela forma de medição,.

A problemática consiste em dicernir as vantagens da utilização do torque ângulo em relação ao torque simples na manufatura de motores automotivos, portanto, realizou-se um estudo que tem como objetivo geral realizar um comparativo destas aplicações especificamente no mancal do virabrequim do motor automotivo, mostrando uma realidade ainda pouco conhecida.

Inicialmente foi realizada a revisão bibliográfica visando conhecer mais sobre o tema e após o embasamento, com objetivo de verificar de modo prático os limites elásticos e plásticos. Em seguida foram feitos testes de ensaio de ruptura em 10 parafusos liga SAE 10B30 utilizados no mancal dos motores automotivo. Posteriormente para se ter conhecimento da função do atrito no parafusamento, foram realizados outros dez testes, sendo cinco utilizando parafusos secos (sem óleo) e outros cinco com excesso de óleo. Finalmente foram realizados dez ensaios de torque de processo, com o mesmo programa usado nas linhas de montagem, a fim de obter dados para o comparativo com os ensaios citados anteriormente.

Entendendo-se que a utilização do torque ângulo tem sido cada vez mais aplicada em sistemas que necessitam de precisão e garantia de padronização, procurou-se conhecer as suas vantagens em relação ao torque simples e ajudará em futuros estudos desta aplicação em outros sistemas de montagens de máquinas.

\section{2. REVISÃO DA LITERATURA 2.1 2.1 MANCAL E VIRABREQUIM}

Para definir mancais, Collins (2006, p.339) cita que "são elementos de máquinas que permitem movimento relativo orientado entre dois componentes, enquanto transmitem forças de um componente para o outro sem permitirem movimento na direção da aplicação das cargas". Os mancais podem ser fabricados para sustentarem cargas axiais, radiais ou uma combinação de ambos os tipos de carga (BUDYNAS \& NISBETT, 2011). Estes podem ser classificados, amplamente, em dois tipos: mancais de deslizamento, são os que possuem o escorregamento de uma superfície móvel sobre outra, e os mancais de rolamento, que são os que possuem elementos de máquinas com rolos ou esferas entre as superfícies móveis (COLLINS, 2006). No caso do motor automotivo, são utilizados mancais de deslizamento.

O virabrequim, também chamado como eixo de manivela, é definido como um elemento de máquina que transmite movimento linear em movimento rotativo (COLLINS, 2006). Num motor automotivo, quando a energia da combustão do ar e do combustível é liberada, os pistões deslizam no cilindro de cima para baixo e como os pistões estão ligados ao virabrequim por bielas, estes transmitem o movimento e geram a rotação, quando o virabrequim passa por uma rotação completa o pistão inverte o movimento e desliza novamente subindo no cilindro, e sucessivamente o movimento é repetido.

A figura 1 mostra este funcionamento do sistema de um motor de combustão interna, o virabrequim deve ser considerado como perpendicular à página e representado pelo ponto A (GRAY, COSTANZO \& PLESHA, 2014). 
Figura 1: Funcionamento do conjunto pistão, biela e virabrequim.

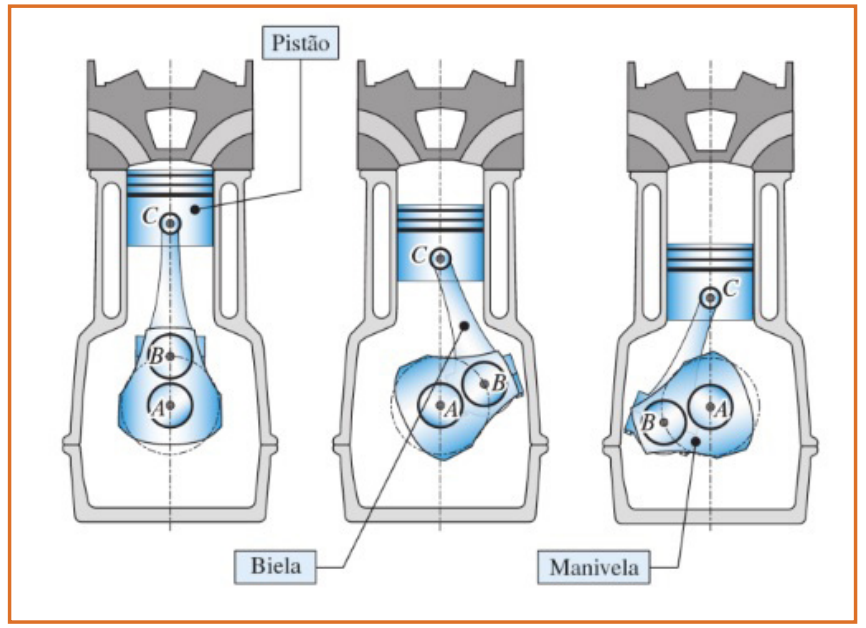

\subsection{FERRAMENTAS DE APERTO}

A utilização de ferramentas de aperto tem como principal razão diminuir o tempo do processo, otimizando a capacidade do operador e melhorando os requisitos de qualidade. A alta velocidade deste tipo de ferramental é que traz o maior interesse das indústrias. Normalmente as ferramentas quando acionadas iniciam o processo em alta velocidade e diminuem conforme encontram resistência (ATLAS COPCO, 2016).

Dentre as ferramentas de aperto temos: ferramentas de impacto, ferramentas de impulso, parafusadeiras, apertadeiras, parafusadeiras e apertadeiras elétricas, apertadeiras múltiplas e ferramentas à bateria.

No desenvolvimento dos testes foi utlizado a apertadeira elétrica. As parafusadeiras e apertadeiras elétricas são normalmente acionadas por motores de corrente contínua de baixa voltagem e são bastante utilizadas em linhas de montagem de veículos motorizados ou em indústria com exigências de controle de junta de segurança e registros de qualidade. Estes equipamentos são sistemas elaborados que possibilitam o controle contínuo do processo de aperto pelo controle de corrente. Indicadas para processos com controle de torque e alta precisão (ATLAS COPCO, 2016).

\subsection{PARAFUSOS E ROSCAS}

\subsubsection{PARAFUSOS}

Os parafusos em geral são utilizados para unir duas partes, em alguns casos utiliza-se de porcas e arruelas e em outros a fixação é direta na peça. Podem ser fabricados em materiais metálicos e não metálicos, mas na maioria dos casos são fabricados em aço. Suas características que diferenciam de um parafuso para outro são: comprimento do corpo, tipo de rosca, altura da rosca e tipo de cabeça. As classificações dos tipos de rosca são seus diâmetros que são o diâmetro externo, diâmetro médio e diâmetro menor; o passo da rosca, o ângulo da rosca e a forma dos filetes (NORTON, 2013).

a) Parafusos hexalobulares: Os parafusos conhecidos como Torx®, ou hexalobular, não são muito utilizados devido à complexidade de fabricação e a existência de poucas ferramentas de aperto, sendo recursos para aplicações que exijam torque elevado em projetos mais específicos (THOMÉ, 2015). Nestes casos, são utilizados por suas características principais, dentre elas a montagem eficiente, visto que o torque é transmitido por toda a superfície, sem

risco de danificar a cabeça e mantendo o tratamento contra corrosão. O Custo de ferramentas também é reduzido, visto que o parafusamento é feito de forma perpendicular, evitando o desgaste precoce da ferramenta. A cabeça deste tipo de parafuso é menor, logo utiliza menos material. Ao mesmo tempo, tem um grande potencial de padronização já que o sistema de acionamento é utilizado em diversos tipos de parafusos, reduzindo custos com ferramentas. (BOELLHOFF, 2016)

Existe dois tipos: o hexalobular externo e hexalobular interno (THOMÉ, 2015). Neste trabalho iremos abordar o parafuso hexalobular externo, conforme demonstrado na figura 2. 
Figura 2: Parafuso Hexalobular externo.

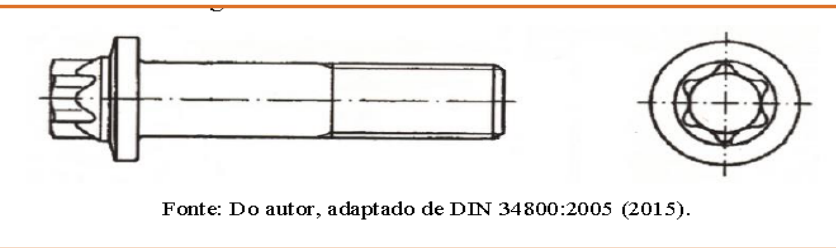

Conforme Hassmann (2012 apud THOMÉ, 2015), o parafuso hexalobular externo conforme demonstrado na figura 2, possui uma grande vantagem na realização do torque comparado comparafusos sextavados e flangeados.

b) classe do parafuso: a classe do parafuso representa a classe de resistência que o parafuso possui. Esta numeração permanece gravada na cabeça do parafuso (TORK FORT, 2016). A classe do parafuso utilizado nos testes é 10.9. Segundo Garcia (WEB, 2016) o cálculo da resistência do parafuso é realizado conforme figura 4.

Figura 4: Cálculo da resistência do parafuso.

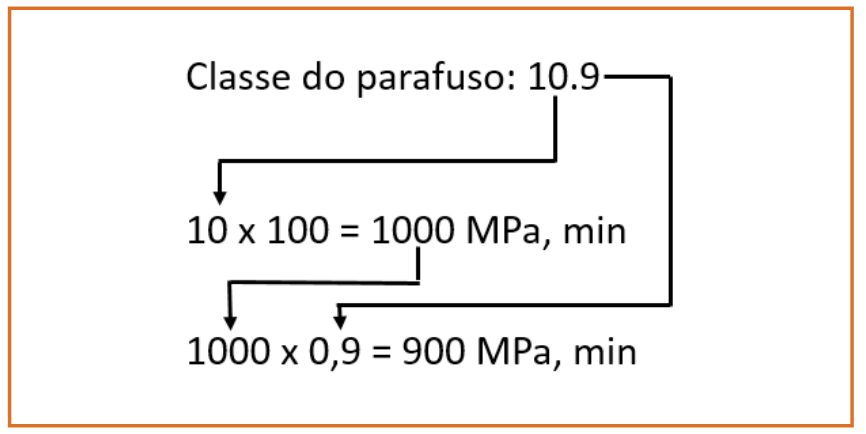

Com esses resultados tem-se: resistência a tração = $1000 \mathrm{MPa}$, min; limite de escoamento = $900 \mathrm{MPa}$, min

Conforme Tork fort (WEB, 2016) "Quanto menor for a classe de resistência do parafuso, maior será sua ductilidade (capacidade de deformação do material até sua ruptura, sendo que, quanto mais dúctil for o parafuso, maior será sua capacidade de alongamento sem se romper), porém menor será a sua capacidade de gerar força. Em outras palavras, suporta menos torque".

\subsubsection{FORÇA DE ATRITO}

O aperto de uma junta parafusada possui tendências ao afrouxamento. Normalmente este problema ocorre mais por causa da falha na aplicação do pré-torque do que afrouxamento externo. Isso é devido a utilização de pré-cargas inadequadas somadas com o atrito no aperto (PIZZIO, 2005).

Segundo Muniz(2007 apud RODRIGUES, 2015), o atrito em uma definição simples, seria como dois corpos deslizando um sobre o outro. Esta resistência gerada durante o movimento é chamada de atrito.

O coeficiente de atrito altera dependendo das condições operacionais como temperatura, velocidade, pressão de contato, também varia com a lubrificação(BREGANON, 2015).

O coeficiente de atrito é: $\mu=F / N$

Onde $\mu$ é o coeficiente de atrito, $\mathrm{F}$ a força tangencial $\mathrm{e}$ o $\mathrm{N}$ é a força normal. O coeficiente de atrito não possui unidade devido a divisão das duas forças na equação. Do coeficiente de atrito dividimos em duas partes: o coeficiente de atrito dinâmico e estático. Coeficiente de atrito dinâmico é o atrito gerado durante o aperto da junta e o estático ocorre quando gerado uma força depois da junta torqueada (em repouso) (RODRIGUES, 2015).

No trabalho em questão o coeficiente de atrito relevante é o dinâmico.O atrito deve ser considerado de grande importância pois, $10 \%$ do torque dado é revertido em energia potencial, mantendo a tensão na junta, o restante é perdido através de atrito. Com isso necessita utilização de lubrificação, assim faz com que a relação de atrito entre parafuso e porca seja semelhante tento igualmente uma perda de energia(VISINTIN 2016).

\section{MATERIAIS, PROCEDIMENTOS EXPERIMENTAIS E ANÁLISE DOS RESULTADOS.}

\subsection{1 PREPARAÇÃO DE MATERIAL}

Para os testes foram utilizados: uma bancada móvel da Cleco® para a realização dos torques. Esta bancada possui um monitor de navegação aonde se visualiza o torque e ângulo dado no momento do aperto, o gráfico de força em relação ao aperto, todos os programas e 
suas etapas no processo de cada programa, dentre outras funções.

\subsection{TESTES DE RUPTURA}

Para melhor entender os limites de tensão que o parafuso estudado suporta, foi realizado o teste em 10 parafusos de um bloco torqueando até a sua ruptura.

Foi criado um programa de torque para a realização dos testes com as mesmas características da linha de montagem, somente foi retirado o monitoramento por ângulo e aumentado o torque final para 160 N.m.

Foi realizado o torque nos dez parafusos de fixação dos mancais do bloco, porém, só sete parafusos chegaram ao limite de ruptura. Os outros três parafusos espanaram a cabeça durante a execução do torque. Não foi possível trocar estes parafusos para fazer um reteste, pois, devido ao atrito gerado quando efetuado o torque, faz com que as roscas desgastem e se for trocado o parafuso e dado o torque novamente, o resultado não será igual, pois a superfície da rosca estará mais lisa, com isso, alterará o resultado do teste. Uma superfície lisa fará com que o torque do parafuso seja mais alto pois as roscas deslizarão com mais facilidade levando mais tempo para a ruptura.

Após realizado os torques e gerado os gráficos, foi efetuado a junção das sete curvas em um único gráfico só, conforme anexo 1.

Com esses dados mostrado no gráfico 2, conseguimos definir a região elástica, elastoplástica, plástica e ruptura que são os dados que necessitamos para a avaliação dos testes e principalmente conseguimos encontrar a tensão nominal para a comparação dos testes a seguir.

\subsection{TORQUE DE PROCESSO}

O torque de processo possui quatro etapas. Primeira etapa a torqueadeira gira no sentido anti-horário em $1080^{\circ}$ para encontrar a cabeça do parafuso, segundo a torqueadeira começa a parafusar até chegar a um torque de 5 N.m., quando chega a 5 N.m. é o momento em que o parafuso encosta na peça. A partir daí inicia o pré-torque especificado por engenharia, que é a terceira etapa. Este torque é dado até chegar a 50 N.m. Por definição de engenharia, com 50 N.m a junta (capa do mancal e mancal) está totalmente encostada eliminando a folga entre juntas. Chegando a 50 N.m. inicia a quarta etapa que é o monitoramento por ângulo. A faixa nominal de de ângulo é de $52^{\circ}$, que a torqueadeira utiliza, mas sua tolerância é de $45^{\circ}$ a $60^{\circ}$ isso faz com que todos os parafusos cheguem a um torque aproximado.

Segue o gráfico 3 com os dez torques de processo realizado. 
Gráfico 3: Torques de processo

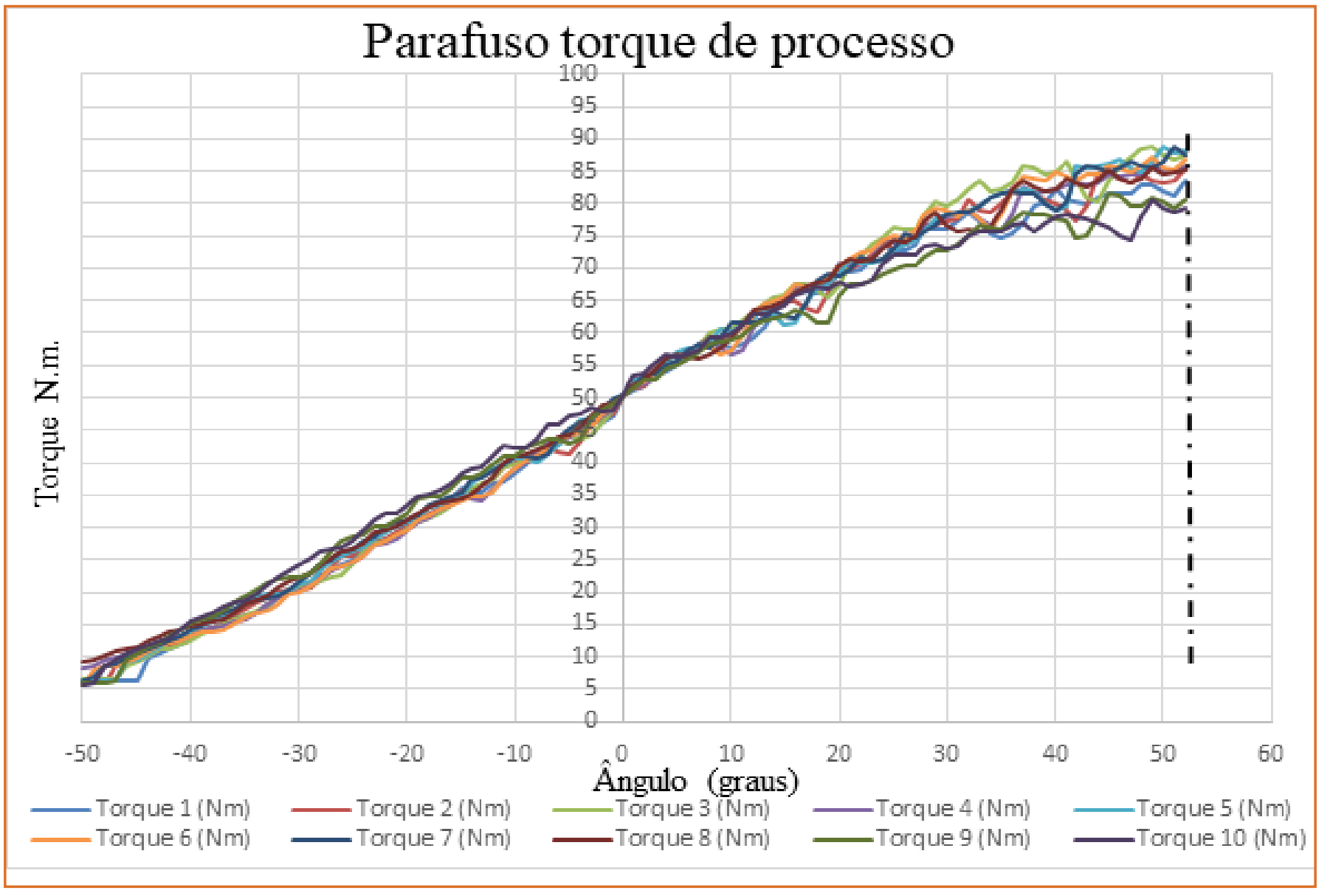

Os torque de processo demonstrados no gráfico 3, foram ilustrados a fim de comparar com as variações de torques dos testes a seguir. Verifiicou-se que, os torques de processo não chegaram a $90 \mathrm{~N}$.

\subsection{TORQUE PARAFUSO SEM ÓLEO}

A fim de exemplificar na prática como o atrito interfere diretamente no torque, foi realizado outro teste com o programa de processo mas com 5 parafusos sem óleo, como demonstrado na gráfico 4 
Gráfico 4: Torque parafuso sem óleo

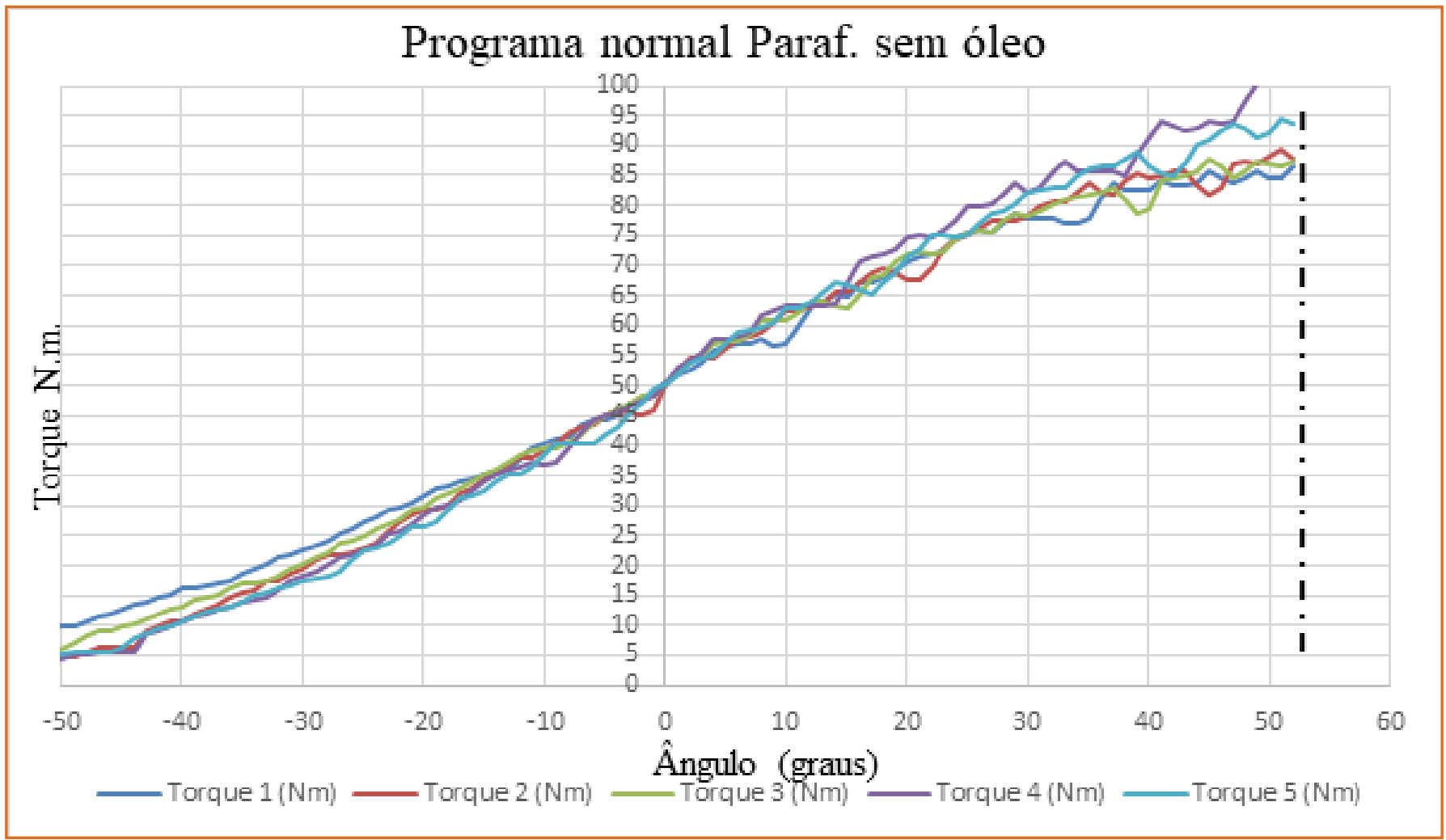

No gráfico 4 pode-se verificar, que neste processo, o atrito gerado fez com que o parafuso necessitasse de um torque mais alto para chegar no ângulo especificado no processo de aperto da junta.

\subsection{PARAFUSO COM EXCESSO DE ÓLEO}

Neste estudo, foi lubrificado 5 parafusos e as roscas do mancal com muito óleo, para analisao comportamento de torque com a redução do atrito, conforme demonstrado na gráfico 5 . 
Gráfico 5: Torque parafuso com excesso de óleo.

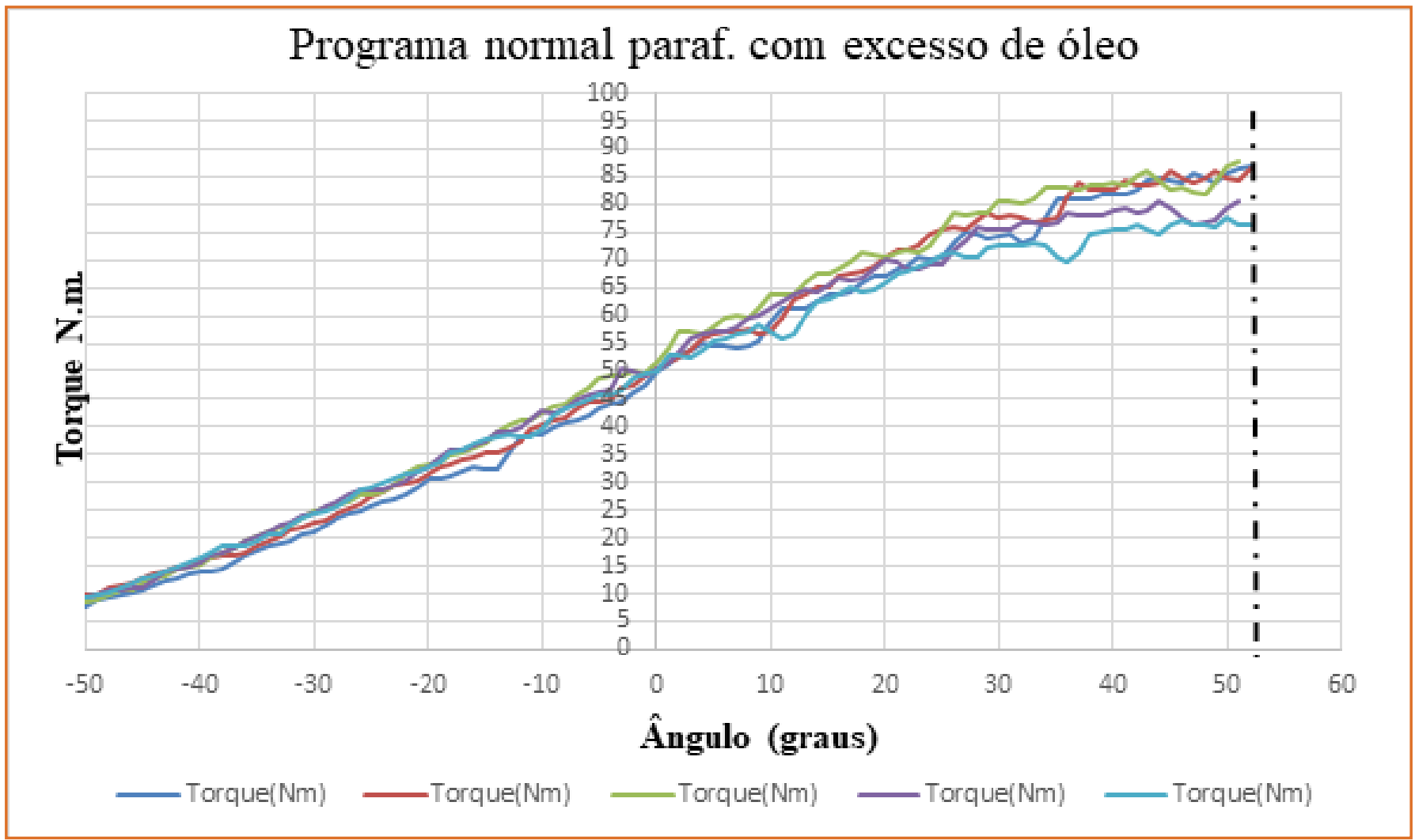

Conforme gráfico 5, verificamos que o torque do parafuso com excesso de óleo comparado com o torque processo (grafico 3) apresentou-se mais baixo, devido a diminuição do atrito por causa do excesso de óleo.

\subsection{ANÁLISE DO GRÁFICO}

Para analisar os resultados, foi realizado a média com torque de ruptura, do torque de processo, os parafusos sem óleo e com óleo foi utilizado, o pior caso de cada um para melhor visualização e estudo do gráfico. Conforme gráfico 6 segue o comportamento das médias das curvas geradas. 
Gráfico 6: Análise de torque e ângulo

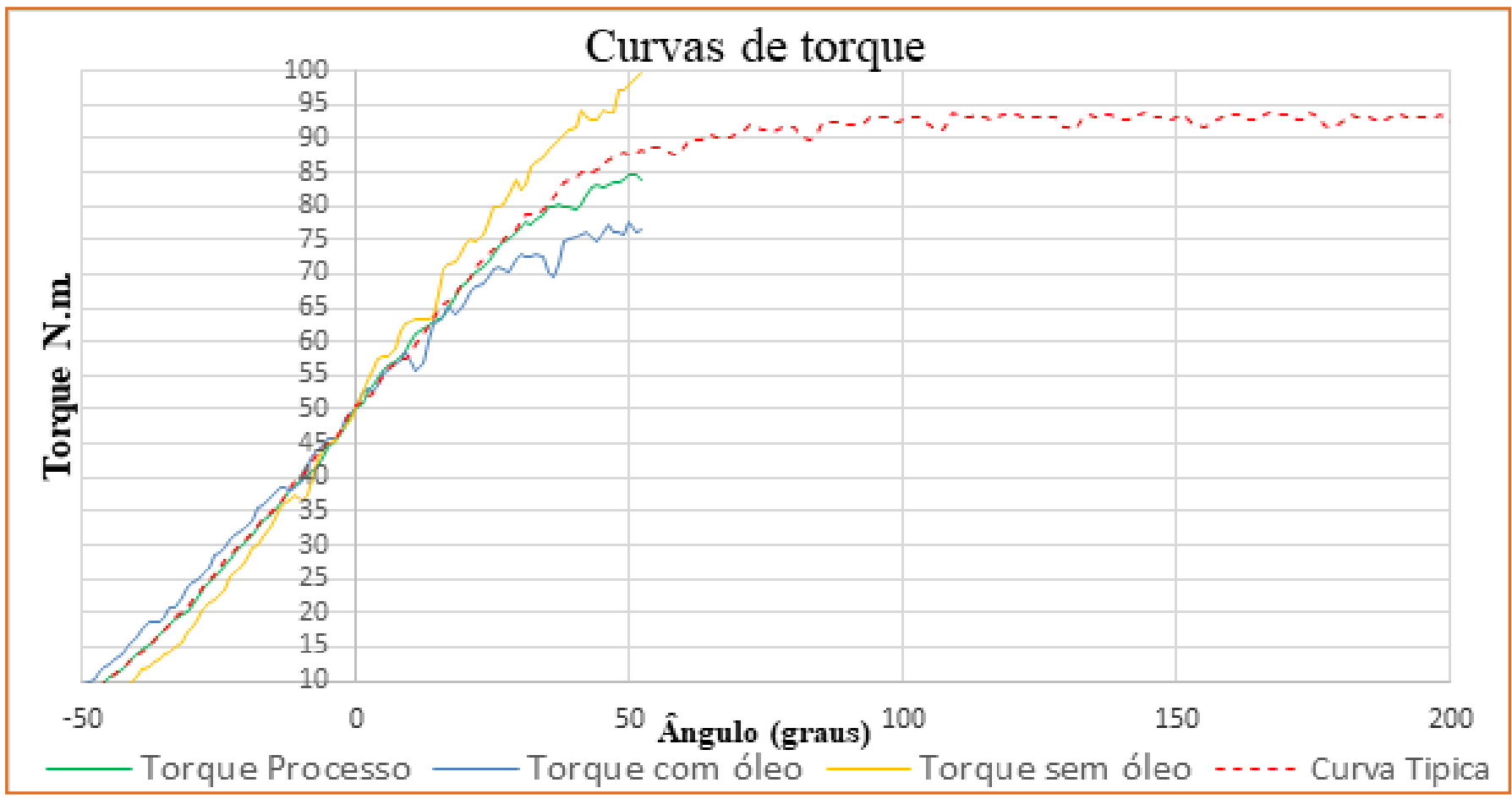

Pelo gráfico 6 compreende-se que, o atrito é um fator que se deve ser levado em consideração. Verificouse que o parafuso sem óleo atingiu seu limite plástico. Comparando o torque do parafuso sem óleo com os torques realizados no gráfico 2, verificou-se que a $100 \mathrm{~N}$. o parafuso entra no regime plástico, ou seja, inviabilizando o processo já que o indicado é o parafuso ser torqueado no seu limite elastoplástico. Já o parafuso com excesso de óleo atingiu a região elastoplástica antes, comparado com os troque de processo. Como o último estágio o torque no ângulo não pode passar de 95 N.m., a máquina irá rejeitar o torque bloqueando as próximas etapas de montagem do motor.

\subsection{TORQUE ÂNGULO VERSUS TORQUE SIMPLES}

No gráfico 7, foi feito a análise de torque sem o monitoramento por ângulo. Foi utilizado o mesmo gráfico com os mesmos dados para a analise o único requisito que foi dispensado no gráfico, foi o ângulo. 
Gráfico 7: Análise de torque simples.

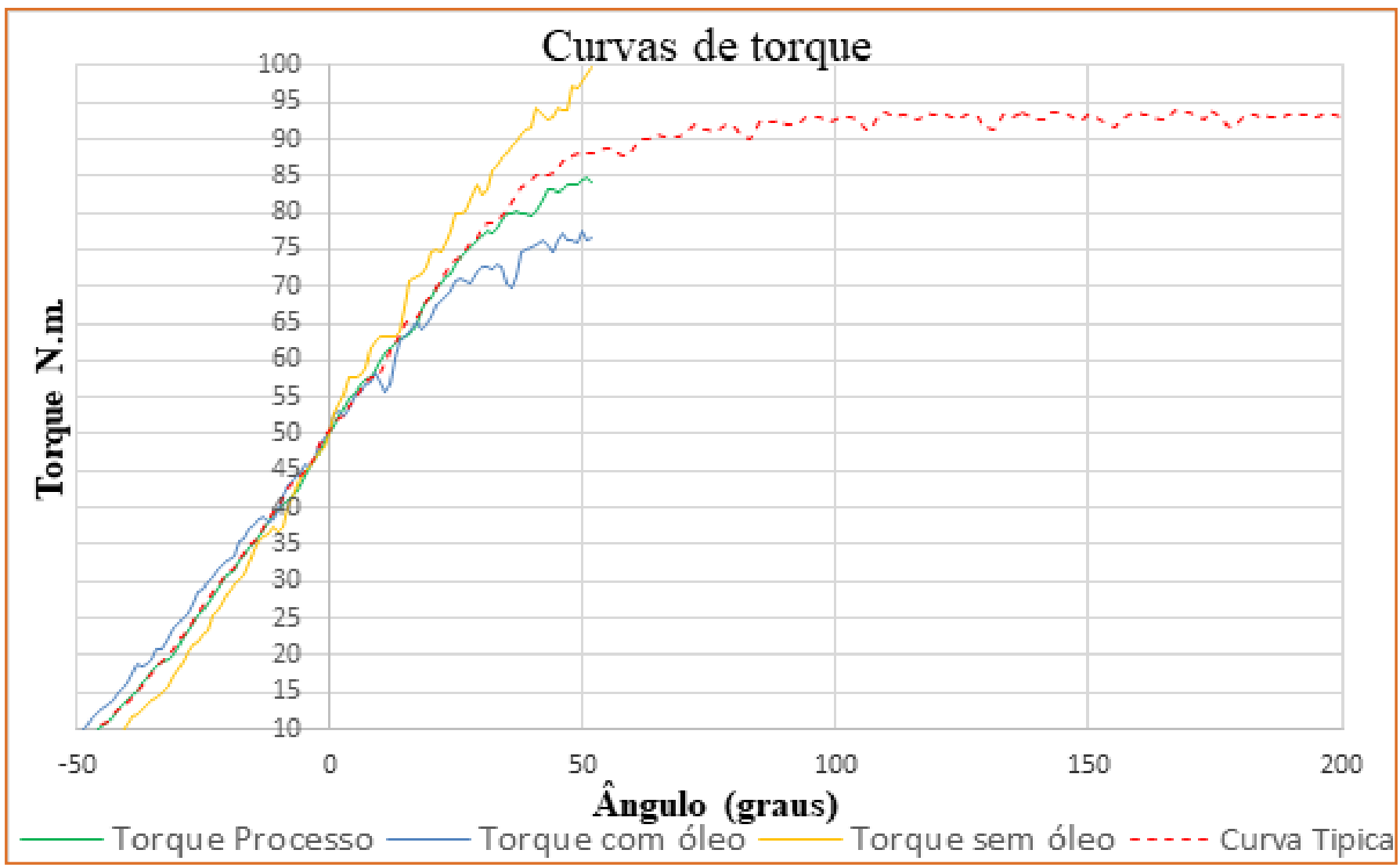

Utilizando a curva típica como base para o estudo, foi definido um torque nominal de 88 N.m. (gráfico 7), que é a faixa de torque em que a curva típica entrou no limite elastoplástico. A realização do torque sem o monitoramento do ângulo funciona da seguinte forma: a máquina irá torquear o parafuso até chegar em sua faixa definida que no caso do estudo foi de 88 N., ou seja, a máquina só irá parar quando chegar nessa faixa. Analisando o gráfico foi visto que a curva de torque com excesso de óleo não vai chegar no torque específico pois, analisando sua curva ela chega no seu limite elastoplástico com $76 \mathrm{~N}$ a partir desta faixa inicia a tensão plástica e seu torque não irá aumentar significativamente, oscilando até sua ruptura.

O parafuso sem óleo por sua vez irá chegar aos $88 \mathrm{~N}$, porém verifica-se que o torque ainda está crescente não chegando a iniciar a curva indicando que o parafuso está na região elastoplástica, ou seja, a região em que o torque parou é a elástica, isso faz com que o parafuso não realize uma fixação total na peça.

\section{CONCLUSÃO}

O estudo comparativo do torque e ângulo com o torque simples, visou demonstrar suas características singulares e os resultados em dois casos, um foi o torque no parafuso sem óleo e o outro com excesso de óleo, a fim de demonstrar na prática, como o atrito influência diretamente no parafusamento, podendo ocasionar um problema grave no processo.

Com os dados em um gráfico (gráfico 6), foi possível analisar melhor a diferença entre os testes realizados. No teste do parafuso sem óleo, percebeu-se que no momento do ajuste por ângulo, que no caso a apertadeira gira em um ângulo nominal de $52^{\circ}$, a apertadeira aplicou mais torque, o que ocasionou no parafuso, uma deformação plástica, chegando a um torque de $100 \mathrm{~N}$.m. e consequentemente inviabilizando a peça já que em uma condição normal o parafuso estaria entrando na condição plástica em torno de 100 N.m.

Ao contrário disso, foi possível analisar que nos testes dos parafusos com excesso de óleo, o torque foi mais 
baixo para atingir o ângulo, mas sem ficar fora da tolerância, tornando o processo viável.

Para a análise do torque simples utilizamos o mesmo gráfico, porém sem considerar o o ângulo. Verificamos que, definindo um torque, que no caso foi definido em 88 N.m. dependendo da condição do parafuso, este pode nem chegar ao torque especificado atingindo sua ruptura devido a máquina entender que só vai parar quando chegar a 88 N.m. e se diminuir o torque limite poderia ocorrer de estar trabalhando com parafusos na região elástica, não garantindo o grampeamento da junta.

Desta forma, com este estudo concluiu-se que, com as variações de atrito no processo o torque simples, pode gerar um grave problema na montagem dos mancais, pois em alguns casos, o parafuso pode não chegar ao torque nominal, levando a sua ruptura e em outros casos, o parafuso pode não chegar a sua tensão elastoplástica.

Concluiu-se também que a utilização do torque simples no parafuso do mancal é um método arriscado e com uma ampla tendência ao erro.

Baseado nos resultados dos testes, percebe-se que o torque e ângulo é a forma mais eficiente de fixação, visto isso, deve-se ampliar a pesquisa de sua utilização em outros tipos de equipamentos que utilizem torque considerável e que a falta de torque ou rompimento do parafuso gere risco ou custo elevado de manutenção, além de motores automotivos, garantindo a qualidade e a padronização do processo.

\section{REFERÊNCIAS}

[1] ATLAS COPCO. Tecnologia de Aperto - Guia de Bolso. Disponível em: < http://www.valona.com.br/downloads/ Tecnologiadeaperto.pdf>. Acesso em: 15 de março de 2016.

[2] BOELLHOFF. Hexalobular/Torx®. Disponível em: <http:// www.boellhoff.com/en/de/fasteners/additional_assortments/ hexalobular-torx.php>. Acesso em: 13 de março de 2016.
[3] BREGANON, Rogério. Comportamento tribológico do aço inoxidável martensítico CA-6NM nitretado por plasma em ensaio de riscamento linear. 2015. 115f. Dissertação (Mestrado) - Universidade Federal do Paraná

[4] BUDYNAS, Richard G.; NISBETT, J. Keith. Elementos de Máquinas de Shigley. Projeto de engenharia mecânica. 8a ed. Porto Alegre: AMGH, 2011.

[5] COLLINS, Jack A. Projeto mecânico de elementos de máquinas: uma perspectiva de prevenção de falha. Rio de Janeiro: LTC, 2006

[6] GARCIA, Roberto. Conceitos Gerais sobre Torque e Processos de Torque. Conceitos Relevantes sobre Coeficiente de Atrito. Disponível em: http://www.metaltork. com.br/i_prot/biblioteca/Cartilha_RobertoGarcia.pdf. Acesso em: 28 de mar. de 2016.

[7] GRAY, GARY L.; COSTANZO, FRANCESCO; PLESHA, MICHAEL E. Mecânica para engenharia: Dinâmica. Porto Alegre: Bookman, 2014.

[8] NORTON, RobertL. Projeto de máquinas: umaabordagem integrada. Tradução: Konstantinos DimitriouStavropoulos et al. 4를 ed. Porto Alegre: Bookman, 2013.

[9] PIZZIO, Éverton. Avaliação da vida em fadiga de uniões parafusadas - Estudo de caso. 2005. 120p. Dissertação (Pós-graduação) - Universidade Federal do Rio Grande do Sul.

[10] RODRIGUES, Carlan Ribeiro. Avaliação do comportamento mecânico e tribológico de parafusos da classe 10.9 para emprego estrutural. 2015. 120f. Dissertação (Mestrado em Engenharia e Ciência dos Materiais) Universidade Estadual do Norte Fluminense Darcy Ribeiro.

[11] SENAI/CST. Noções Básicas de Elementos de Máquinas. Vitória: Senai, 1996.

[12] TORK FORT. Classes de parafusos. Disponível em: <http://www.torkfort.com.br/2010/12/classe-de-parafusos/>. Acesso em: 22 de junho de 2016

[13] THOME, Éderson. Proposta de alteração do processo de produção do parafuso de roda mantendo as propriedades de montagem. 2015. 61f. Monografia (Graduação em Engenharia Mecânica) - Centro Universitário Univates. Lajeado.

[14] VISINTIN, Rodrigo Sudá de Forton Bousquet. Investigação sobre o desgaste prematuro dos parafusos de fixação do bocal de exaustão externo de motores aeronáuticos GE CF680C2. 2016. 63 p. Monografia (Graduação) - Universidade Federal do Rio de Janeiro. 
Gráfico2: Tensão de ruptura do parafuso do mancal

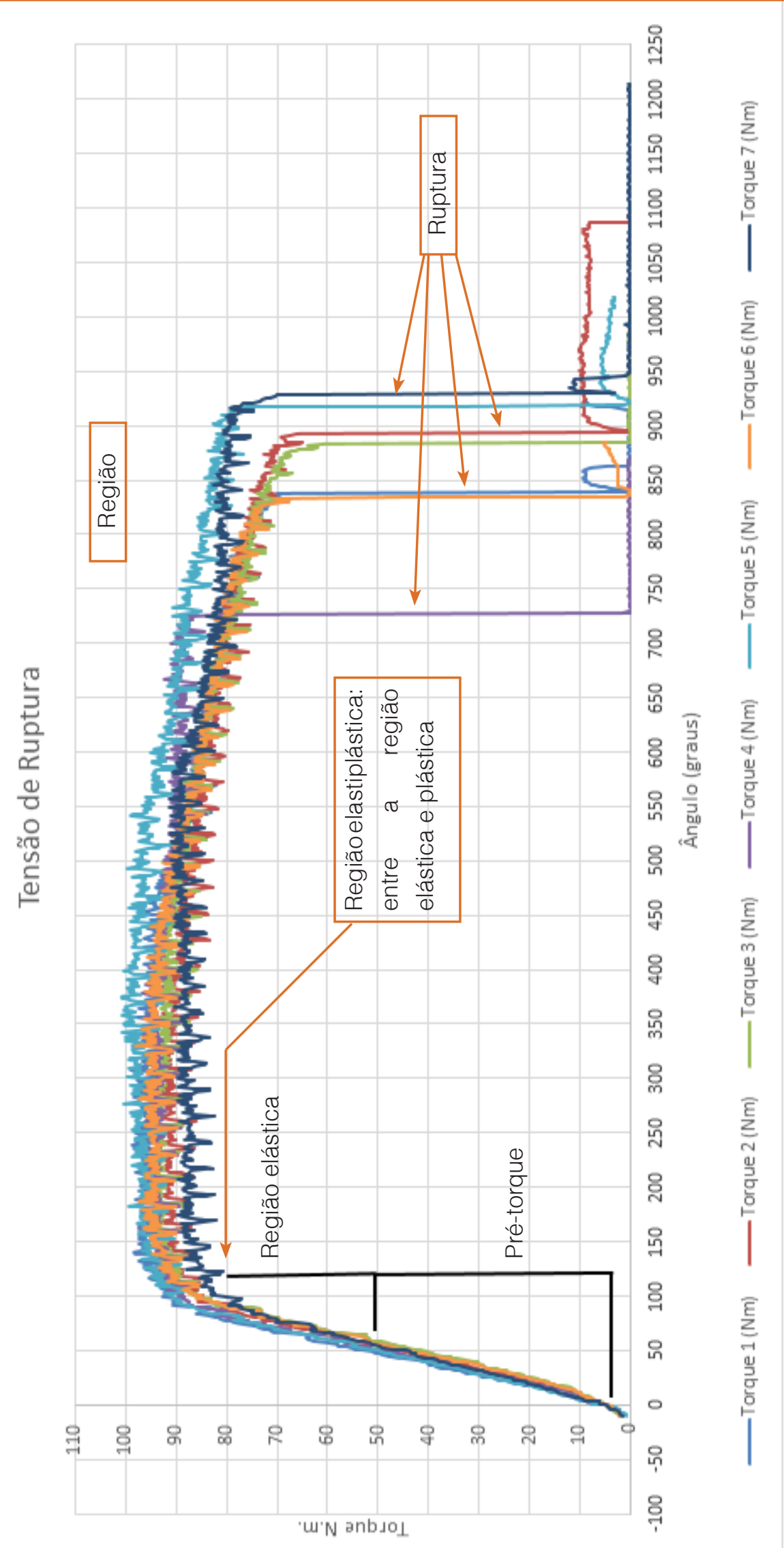




\title{
CAPÍTULO 2
}

\section{ANÁlise de MANifestaÇões Patológicas em PASSARELA DE CONCRETO ARMADO NA REGIÃO CENTRO-SUL DE MANAUS}

\author{
Daniela Oliveira De Lima \\ Janiely Lima De Almeida \\ Rennan Silva Italiano \\ Wesley Gomes Feitosa \\ José Roberto De Queiroz Abreu
}

Resumo: A indústria da construção civil passou por grandes avanços tecnológicos no decorrer dos anos, aumentando a concorrência entre as empresas e consequentemente havendo a necessidade de executar obras em prazos cada vez menores, porém é bastante comum observar uma grande incidência de manifestações patológicas nas edificações, frequentemente causada pela falha de planejamento, aliado a falta de mão de obra qualificada e a ausência de manutenções preventivas. O objetivo deste trabalho é realizar a análise visual de uma passarela em concreto armado, a fim de identificar as possíveis causas que proporcionaram o surgimento das anomalias e especificar manutenções corretivas. A passarela escolhida para análise encontra-se na Avenida Desembargador João Machado, região Centro-Sul de Manaus. Para realizar o levantamento adequado das manifestações patológicas primeiramente realizou-se a pesquisa bibliográfica, a fim de adquirir conhecimento teórico necessário com base em livros, artigos e normas técnicas, em seguida fez-se a visita in loco para coletar dados e fazer os registros fotográficos, durante a avaliação da passarela constatou-se uma quantidade significativa de anomalias onde foram detectadas fissuras, trincas, exposição de armaduras, deterioração nas juntas, entre outros. Neste contexto observa-se que os danos poderiam ter sido minimizados com a realização de manutenções periódicas, para prevenir e corrigir quaisquer problemas, evitando o comprometimento da funcionalidade, operacionalidade e a segurança dos usuários.

Palavras chave: Manifestações Patológicas, Patologias no Concreto Armado, Inspeção Visual. 


\section{INTRODUÇÃO}

O setor da construção civil é um dos mais importantes alicerces econômicos do país, passando por grande evolução da tecnologia dos materiais de construção e das técnicas de projeto e execução, tantas inovações estão contribuindo para o surgimento de manifestações patológicas nas estruturas, por isso é necessário entender-se do que se trata a patologia. Segundo Helene (1992, p. 19), "a patologia pode ser entendida como a parte da engenharia que estuda os sintomas, os mecanismos, as causas e as origens dos efeitos das construções civis, ou seja, é o estudo das partes que compõe o diagnóstico do problema".

Um dos elementos mais utilizados na construção civil é o concreto armado, este é amplamente empregado devido à facilidade de se conseguir moldar diversas formas geométricas e o seu relativo custo de produção. Sabendo-se da necessidade em entender sobre as patologias buscou-se identificar estruturas que são utilizadas constantemente para avaliar as anomalias, assim averiguar os possíveis motivos que colaboraram para o desenvolvimento do problema.

Para fazer a avaliação das manifestações patológicas escolheu-se uma passarela de concreto armado localizada em Manaus - Amazonas, região CentroSul da cidade. A mesma encontra-se na Avenida Desembargador João Machado em frente ao Terminal Rodoviário Huascar Angelim, como demonstrado na Figura 1, possuindo latitude (3.0752714) e longitude $(-60.0260012)$.

Figura 1- Localização da passarela.

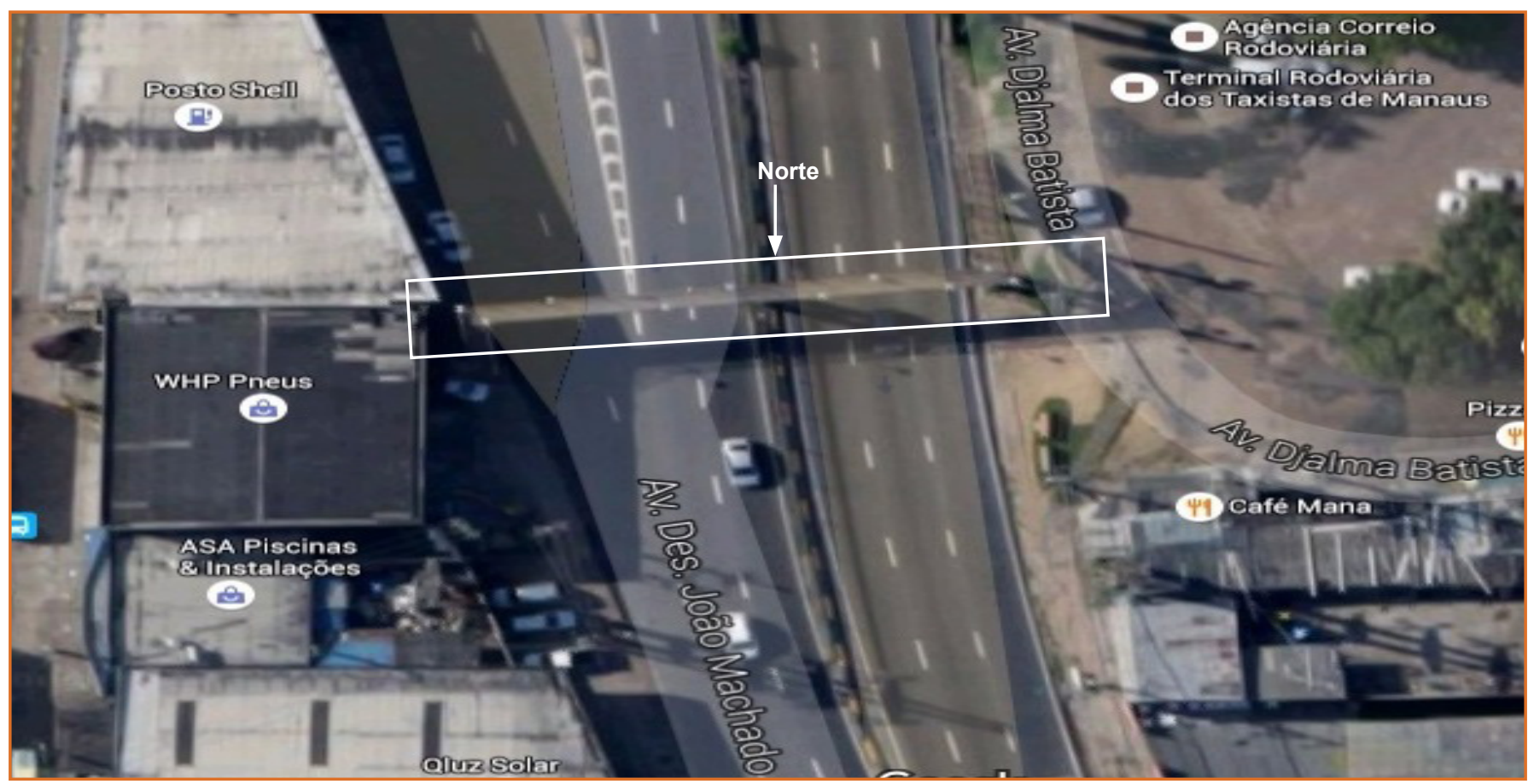

Fonte: Google Maps, 2016.

O motivo da escolha desta estrutura está relacionado com a quantidade significativa de anomalias encontradas que podem comprometer a funcionalidade e durabilidade, além de colocarem em risco a segurança de seus usuários, pois há um fluxo constante de pessoas que utilizam a passarela para fazer a travessia da avenida. gerar nas estruturas percebe-se a importância da prevenção, a fim de minimizar ou eliminar as anomalias, para isso é necessário manter o controle da qualidade nas etapas do processo construtivo. Além de realizar manutenções preventivas nas edificações para assegurar a conservação da estrutura (OLIVEIRA, 2013). 
técnicas construtivas é comum o aparecimento das manifestações patológicas, podendo apresentar-se de diversos tipos, porém os problemas mais comuns e de maior efeito no concreto, são as eflorescências, as fissuras, as flechas excessivas, a corrosão das armaduras, manchas no concreto aparente e ninhos de concretagem, o conhecimento e identificação dessas anomalias são importantes correção e prevenção de problemas ainda maiores na estrutura (MONTEIRO, 2005 apud BARBOSA, 2009).

É possível resolver os problemas patológicos simples sem ter conhecimento especializado, porém, para os problemas patológicos mais complexos é necessário um conhecimento mais profundo das patologias da estrutura, utilizando outros mecanismos além da inspeção convencional (Souza e Ripper, 1998).

A fim de conhecer a natureza e extensão do problema patológico na edificação, é necessário fazer uma inspeção técnica na estrutura. Geralmente, o trabalho de inspeção compreende em duas etapas, sendo a primeira uma inspeção preliminar e a segunda a inspeção detalhada. A preliminar tem como característica uma avaliação visual e se necessário o uso de alguns ensaios. A detalhada por sua vez, é uma avaliação mais abrangente da edificação, com ensaios mais complexos, visando identificar-se a extensão das manifestações patológicas nas estruturas (ANDRADE, 1992 apud OLIVEIRA, 2013,).

\section{INFRAESTRUTURA DA PASSARELA}

Inicialmente, buscou-se uma passarela em concreto armado na região Centro-Sul de Manaus que pudesse ser considerada padrão, assim poderia fornecer de forma eficaz, dados que representassem o estado de deterioração das outras passarelas. Para a escolha dessa estrutura, primeiramente, percorreu-se outras passarelas na mesma região, visualizando e analisando a estrutura como um todo. Todas as passarelas visitadas da região Centro-Sul apresentaram independentemente do grau de degradação, algum tipo de manifestação patológica.

Tratando-se da estrutura, procurou-se primeiramente caracterizar a mesma, através de características construtivas, como o tipo de agressividade do ambiente, ano de execução, mesmo que de forma aproximada, entre outras. A seguir, informações que ajudam na caracterização da estrutura.

a. nome da edificação: não possui nome oficial;

b. local: em frente ao Terminal Rodoviário Huascar Angelim;

c. endereço: Avenida Desembargador João Machado;

d. ano de execução: década de 2000;

e. tipo de estrutura: passarela;

f. agressividade ambiental: moderada, conforme NBR 6118 (2014, p. 16);

g. concepção do projeto: pilares, vigas e lajes em concreto pré-moldado e escada feita in loco.

Durante a coleta de informações sobre a passarela não foi possivel obter dados geométricos e das condições gerais da obra. Porém procurou-se observar minuciosamente a estrutura para a identificação de erros de projeto, execução ou por falta de manutenções preventivas. A Figura 2 mostra a vista frontal da passarela escolhida para inspeção.

Figura 2: Vista Frontal da Passarela.

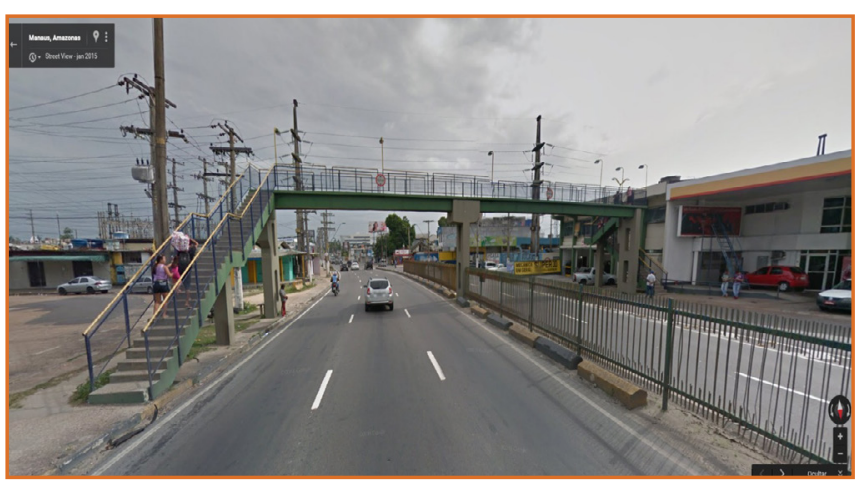

Fonte: Google Maps, 2016.

Durante a inspeção observou-se uma quantidade significativa de manifestações patológicas, pode-se diagnosticar os seguintes problemas:

a. Descascamento da pintura;

b. Desplacamento do cobrimento por corrosão da armadura; 
c. Desplacamento do revestimento da laje;

d. Deterioração da junta;

e. Exposição de armaduras por falta de cobrimento adequado;

f. Exposição da armadura por ação mecânica;

g. Expulsão parcial do cobrimento;

h. Falhas por ação mecânica;

i. Fiação exposta;

j. Fissuras;

k. Fungos;

I. Trincas.

Para auxiliar na inspeção foram utilizados alguns materiais, como lupa, trena e régua, além da máquina fotográfica para fazer o registro das manifestações patológicas detectadas na estrutura. Com os dados coletados buscou-se fazer a avaliação das patologias para diagnosticar as possíveis causas que levaram a ocasionar as deteriorações na passarela e, assim especificar manutenções específicas para cada causa, para isso fez-se tabelas e gráficos, que poderão ver vistos a seguir nos resultados.

\section{RESULTADOS E DISCUSSÃO}

Durante a inspeção visual fez-se o levantamento das manifestações patológicas, através do material fotográfico, indicando sua respectiva localização, observando-se que muitos trechos da passarela apresentam algum tipo de anomalia, variando entre processos fissuratórios, expulsão do cobrimento da armadura, deterioração nas juntas, entre outros. Sendo essas patologias distribuídas ao longo de toda estrutura, possuindo elementos estruturais em estado avançado e outros com pouquíssimos indícios de deterioração. No Quadro 1, é apresentado a relação dos elementos estruturais e as manifestações patológicas.

Quadro 1: Distribuição das manifestações patológicas.

\begin{tabular}{|c|c|c|c|}
\hline Manifestação Patológica & Pilar & Escada & Laje \\
\hline Descascamento da pintura & $x$ & & \\
\hline Desplacamento do cobrimento por corrosão da armadura & & $x$ & \\
\hline Desplacamento do revestimento da laje & & & $x$ \\
\hline Deterioração da junta & & & $x$ \\
\hline Exposição de armaduras por falta de cobrimento adequado & $x$ & $x$ & $x$ \\
\hline Exposição da armadura por ação mecânica & & $x$ & \\
\hline Expulsão parcial do cobrimento & $x$ & $x$ & \\
\hline Falhas por ação mecânica & $x$ & & \\
\hline \multicolumn{4}{|l|}{ Fiação exposta } \\
\hline Fissuras & & $x$ & \\
\hline Fungos & & $x$ & \\
\hline Trincas & & $x$ & \\
\hline
\end{tabular}

Fonte: Próprio autor.

Observou-se que o único elemento estrutural ausente de manifestações patológicas foram as vigas, por isso elas não se encontram presentes na Tabela 1. A seguir serão apresentadas algumas das anomalias encontradas na estrutura. $\mathrm{Na}$ inspeção dos pilares foram constatados poucos processos patológicos como apresentado na Figura $3(a, b, c)$ onde foram identificados apenas descascamento da pintura, falhas nos encontros do pilar causados por ação mecânica e fiação exposta e danificada. É importante mencionar que os problemas observados na estrutura tem caráter não somente referente à falta de manutenção, mas também de caráter construtivo. 
Figura 3: Descascamento da pintura (a); Falhas por ação mecânica (b); Fiação exposta (c).

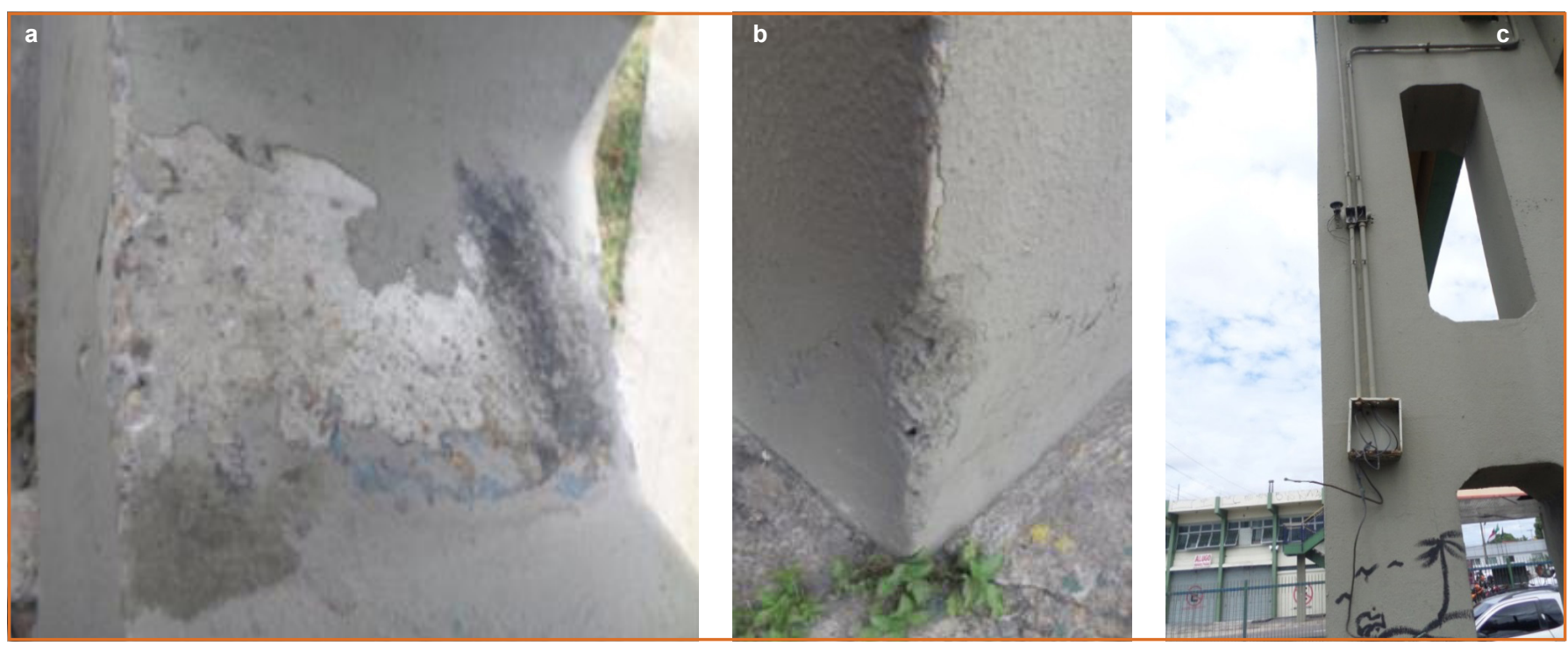

Fonte: Próprio autor, 2016.

O descasamento da pintura pode-se desenvolver por diversos fatores, dentre eles a película se destaca da superfície quando há resíduos de pó na superfície antes da aplicação da tinta, este pó que pode ser proveniente de uma superfície de reboco mal preparada (CINCOTTO, 1983 apud VELOSO et al., 2016). Porém, se tratando de uma repintura, observou-se que o problema se desenvolveu devido a uma camada muito antiga de tinta calcinada, já descascando. Para solucionar este problema é necessário fazer a remoção de todas as partes soltas ou mal aderidas da superfície com o auxílio de uma espátula ou escova de aço. Uma vez eliminados as partes soltas, deve-se proceder à correção e repintura.

Se tratando das falhas nos encontros no pilar percebeuse que foram ocasionadas por uma ação mecânica, ou seja, possivelmente houve um atrito que encadeou esta falha, ou mesmo durante o transporte e/ou montagem do elemento pré-moldado. Os serviços de reparo para esta falha é simples e de fácil procedimento, basta utilizar uma argamassa a base de cimento, areia e água e aplicá-la no local, dando acabamento para que fique uniforme, assim estará corrigido o problema, porém se o procedimento não for realizado ou feito de forma adequada à falha continuará servindo como uma entrada para agentes agressivos, podendo ocasionar outras manifestações patológicas, como por exemplo, a corrosão da armadura.

Ainda durante a inspeção dos pilares foi possível constatar a presença de fiação exposta e danificada, possivelmente a depreciação foi ocasionada por terceiros, aliado a falta de manutenções preventivas. Pode-se observar durante as visitas in loco que em nenhum momento apareceu pessoas responsáveis para fazer $\mathrm{O}$ isolamento desses fios, o mesmo encontrasse ao alcance de adultos e crianças podendo gerar acidentes. Para sanar o problema deve-se fazer a substituição dos fios e componentes danificados. Segundo a NBR (5410/2004) os componentes escolhidos segundo suas características de potência devem ser adequados às condições normais de serviço, considerando os regimes de carga que possam ocorrer. 
Figura 4: Armadura exposta por ação mecânica.

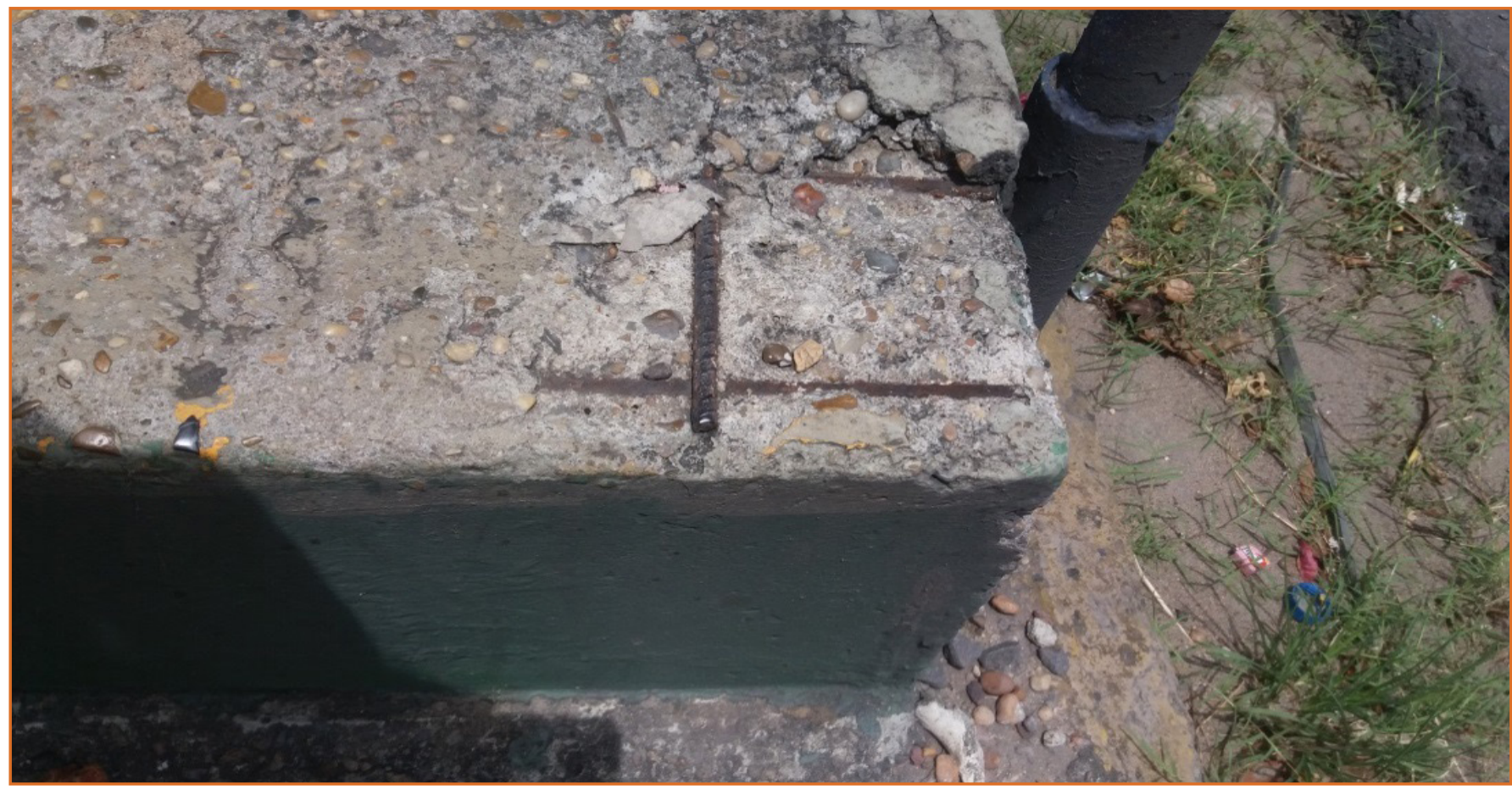

Fonte: Próprio autor, 2016.

Inspecionando as escadas verificaram-se vários degraus com armaduras expostas com indícios de corrosão, conforme apresentado na Figura 4. A manifestação patológica se desenvolveu por uma ação mecânica gerada pelo fluxo constante de pessoas que utilizam a passarela. $O$ atrito gerou um desgaste no revestimento, onde com o passar do tempo desencadeou a degradação da escada. Outro fator importante e de grande significância que colaborou para o desenvolvimento desta anomalia foi o cobrimento inadequado da armadura que não obedece às especificações da NBR 6118:2014, deixando aberturas para a entrada de agentes agressivos, responsáveis pela corrosão presente nas armaduras expostas.

Para solucionar este problema primeiramente devese fazer a limpeza do local para que o aço fique totalmente descoberto em toda área que está oxidado, é muito importante neste momento averiguando o grau de deterioração das armaduras para saber se houve perda de seção do aço, e assim evitar problemas futuros. Para fazer a melhor limpeza pode-se utilizar um jato de sílica, que é indispensável para a limpeza da ferrugem. Outro modo de tratamento é utilizar inibidor de ferrugem que, aplicado sobre a ferrugem do aço, transformada em fosfato de ferro e incorpora-Ihe uma fina película de asfalto. Os aços que pouco diminuem de espessura e que se encontram enferrujados, devem ser tratados com uma imprimação de inibidor de ferrugem, que tem propriedade fosfatizante, permitindo, dessa maneira, uma proteção antioxidante, do tipo pintura, sobre a qual o concreto novo tem uma boa aderência (LOTTERMANN, 2013).

Para finalizar faz-se o cobrimento da armadura através do uso de epóxi. Após o tratamento das corrosões é importante refazer o revestimento em toda extensão da escada para compensar o erro do cobrimento inadequado, este procedimento pode ser feito utilizando argamassas comuns contanto que a espessura seja suficiente para evitar novos problemas, além disso, devem-se adotar manutenções periódicas para controlar quaisquer novas anomalias para evitar maiores custos e riscos.

O elemento da passarela que mais apresenta problemas patológicos são as escadas, nelas encontraram-se expulsão parcial do cobrimento, desplacamento do cobrimento da armadura por corrosão da armadura, fissuras e trincas ocasionadas devido a expansão da armadura e fungos, como mostrado na Figura 5(a, b, 
c).

Figura 5: Face inferior das escadas (a, b, c).

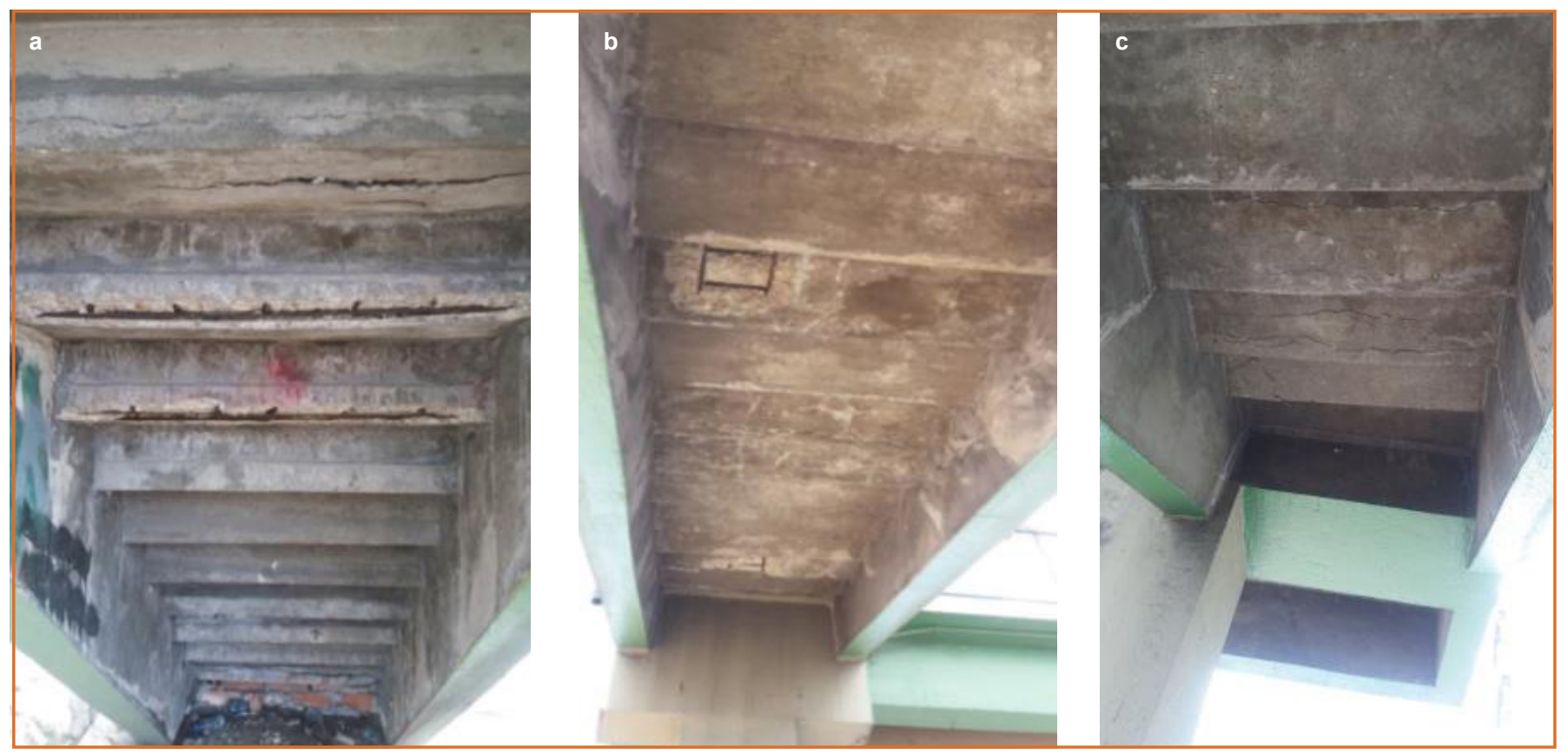

Fonte: Próprio autor, 2016.

Nas escadas observaram-se vários problemas patológicos, como a corrosão da armadura, durante a inspeção pode-se constatar que o cobrimento da armadura estava inadequado para a classe ambiental a qual está relacionada, pois de acordo com a NBR 6118:2014 para a classe ambiental moderada (urbana) a qual a passarela se encontra, o cobrimento da amadura deveria ser no mínimo de $25 \mathrm{~mm}$, porém ficou evidente a deficiência do cobrimento que era apenas de 20 mm, além da falta de espaçadores, estes que são dispositivos usados para garantir o posicionamento adequado da armadura consequentemente obter o cobrimento mínimo exigido pela NBR 6118:2014, esses erros podem estar relacionados tanto por falha de projeto quanto de execução. Muitas vezes os espaçadores são ignorados, fazendo com que o cobrimento fique inadequado ou deixe a armadura exposta, e consequentemente, poderá ocasionar a corrosão das armaduras com o passar do tempo, podendo assim comprometer a funcionalidade da estrutura.

Avaliando os problemas deste local pode-se afirmar que tais problemas foram ocasionados tanto pela má execução, quanto a ação de agentes agressivos do meio ambiente. Porém, além das falhas humanas, constatou a presença de urina no local, esta que possui elementos ácidos agressivos para o concreto, principalmente aos componentes cálcicos do cimento. O lado mais deteriorado da escada estava com odores mais fortes de urina, consequentemente era o lado com a deterioração mais generalizada, podendo este ser um fator colaborativo para a deterioração.

O erro ocasionado pelo não segmento das normas foi crucial para desencadear uma série de manifestações patológicas, observou-se que tanto as trincas quanto as fissuras são derivadas do processo corrosivo generalizado na escada, onde a armadura está em processo de expansão, ocasionando essas anomalias, além de desenvolver a expulsão e desplacamento o cobrimento da armadura.

Um dos principais motivos que podem ter desenvolvido a presença dos fungos nos degraus das escadas pode estar relacionado ao aumento da umidade no local, ocasionado pela a existência de água nos componentes internos, gerados pelos próprios materiais utilizados durante a construção, ou externos provenientes da condensação do solo, formando manchas escuras 
indesejáveis em tonalidades preta e marrom. Os fungos podem provocar alterações na superfície, exigindo na maioria das vezes a recuperação ou até mesmo a necessidade de se refazer revestimentos, gerando gastos dispendiosos (SOUZA, 2008). Para eliminar esse tipo de manifestação patológica é necessário primeiramente identificar a fonte da umidade.

Para realizar a manutenção corretiva deve-se primeiramente fazer a limpeza do local para fazer a verificação do grau de deterioração da armadura, para obter um diagnóstico mais preciso e analisar se há alguma perda de seção daarmadura. Os procedimentos para correção da corrosão das armaduras segue o mesmo procedimento já explanado anteriormente. É necessário realizar também as devidas manutenções quanto aos fungos, para isso é necessário umedecer a área para evitar que os esporos do fungo sejam espalhados, em seguida pode-se escovar a superfície utilizando uma escova de cerdas duras com uma solução de fosfato de trissódico (30 g Na3PO4 em 1 I de água) ou uma solução de hipoclorito de sódio (4\% a $6 \%$ de cloro ativo) e em seguida enxaguar com água abundante.

Embora essas anomalias sejam tratadas é importante fazer a recuperação do cobrimento mínimo da armadura para evitar que novas anomalias ressurjam depois de um determinado tempo, para isso, pode-se adotar uma argamassa auto-adensáveis ou "grautes" (como também são conhecidas), é necessário também a realização de um plano de manutenções corretivas para detectar as anomalias antes mesmo que elas possam gerar grandes danos.

A laje éo elemento estrutural da passarela que apresenta a maior degradação, embora as escadas possuam uma quantidade mais expressiva de manifestações patológicas, pois a laje dispõe do comprometimento total da junta. Nas imagens abaixo é possível observar a degradação que estende-se por todo o tabuleiro, exposição de armaduras, desplacamento do revestimento da laje juntamente com fissuras, além da fenda ocasionada pela deterioração da junta da laje, como observa-se na Figura 6.
Figura 6: Deterioração da laje (a, b).
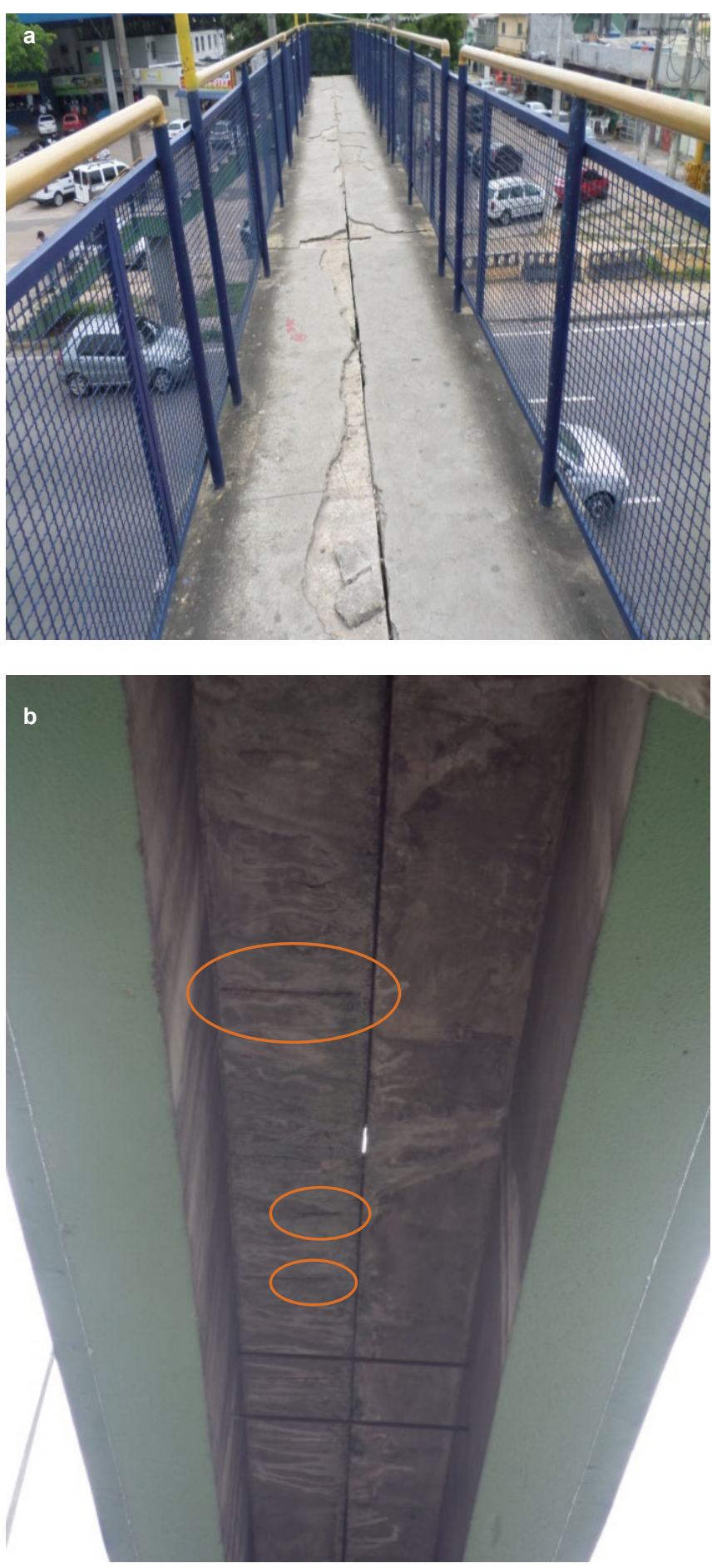

Fonte: Próprio autor, 2016.

A laje da passarela é constituída por placas prémoldadas as quais são unidas por argamassa simples e uma borracha para fazer a junta de dilatação entre as placas. Diagnosticou-se que essa junta está em processo de separação promovendo o aparecimento de fendas as quais é perceptível observar a rua através 
dela, esse problema gera aflição e desconforto aos seus usuários. As possíveis causas podem ser entre falhas construtivas, dimensionamento incorreto, não se prevendo adequadamente possíveis expansões ou retrações do concreto, além do desgaste natural ou ausência do material da junta, originados por uma má conservação.

O revestimento da laje também apresenta processos de deterioração, o mesmo está desplacando por toda sua extensão e possui várias fissuras resultadas da falta de manutenção. Na face inferior da laje também foi possível constatar a falta de cobrimento adequado onde as armaduras estão expostas e já em processo de corrosão.

Para realizar as devidas manutenções primeiramente tem de se tratar os processos corrosivos de acordo como explicado anteriormente, em seguida deve-se fazer a retirada de todo revestimento, pois o mesmo já se encontra muito degradado, então para obter bons resultados recomenda-se a retirada completa do revestimento, em seguida é importante ver o grau de comprometimento das juntas, sugere-se neste caso a realização de análises mais precisas para detectar os reais motivos do desenvolvimento do problema. Após o diagnóstico e a recuperação da junta, pode-se seguir realizando a construção de um novo revestimento que sirva proteção para as lajes pré-moldadas.

De forma geral pode-se perceber que vários dos problemas poderiam ter sido minimizados com manutenções periódicas. Pelo grau de deterioração presente na estrutura afirma-se que desde sua construção a mesma não recebeu manutenções, além da pintura. O descaso é evidente, e deixa as pessoas inseguras e com medo na hora de fazer a travessia na passarela.

Os dados recolhidos nas inspeções deram embasamento para realizar o levantamento quantitativo das incidências das manifestações patológicas. A Tabela 1 mostra a quantidade de cada anomalia encontrada na passarela.

Tabela 1: Quantitativo de manifestações patológicas na passarela.

\begin{tabular}{|l|l|}
\hline Manifestação Patológica & 4 \\
\hline Descascamento da pintura & 4 \\
\hline $\begin{array}{l}\text { Desplacamento do cobrimento } \\
\text { por corrosão da armadura de Anomalias }\end{array}$ & 1 \\
\hline $\begin{array}{l}\text { Desplacamento do revestimento } \\
\text { da laje }\end{array}$ & 1 \\
\hline Deterioração da junta & 9 \\
\hline $\begin{array}{l}\text { Exposição de armaduras por falta } \\
\text { de cobrimento adequado }\end{array}$ & 9 \\
\hline $\begin{array}{l}\text { Exposição da armadura por ação } \\
\text { mecânica }\end{array}$ & 6 \\
\hline Expulsão parcial do cobrimento & 9 \\
\hline Falhas por ação mecânica & 3 \\
\hline Fiação exposta & 1 \\
\hline Fissuras & 6 \\
\hline Fungos & 7 \\
\hline Trincas & 11 \\
\hline Total & 62 \\
\hline
\end{tabular}

Fonte: Próprio autor

O tipo de patologia que apresentou maior incidência na passarela foi às trincas ocasionadas pelo processo de corrosão (18\%), conforme respectivamente no Gráfico 1. 


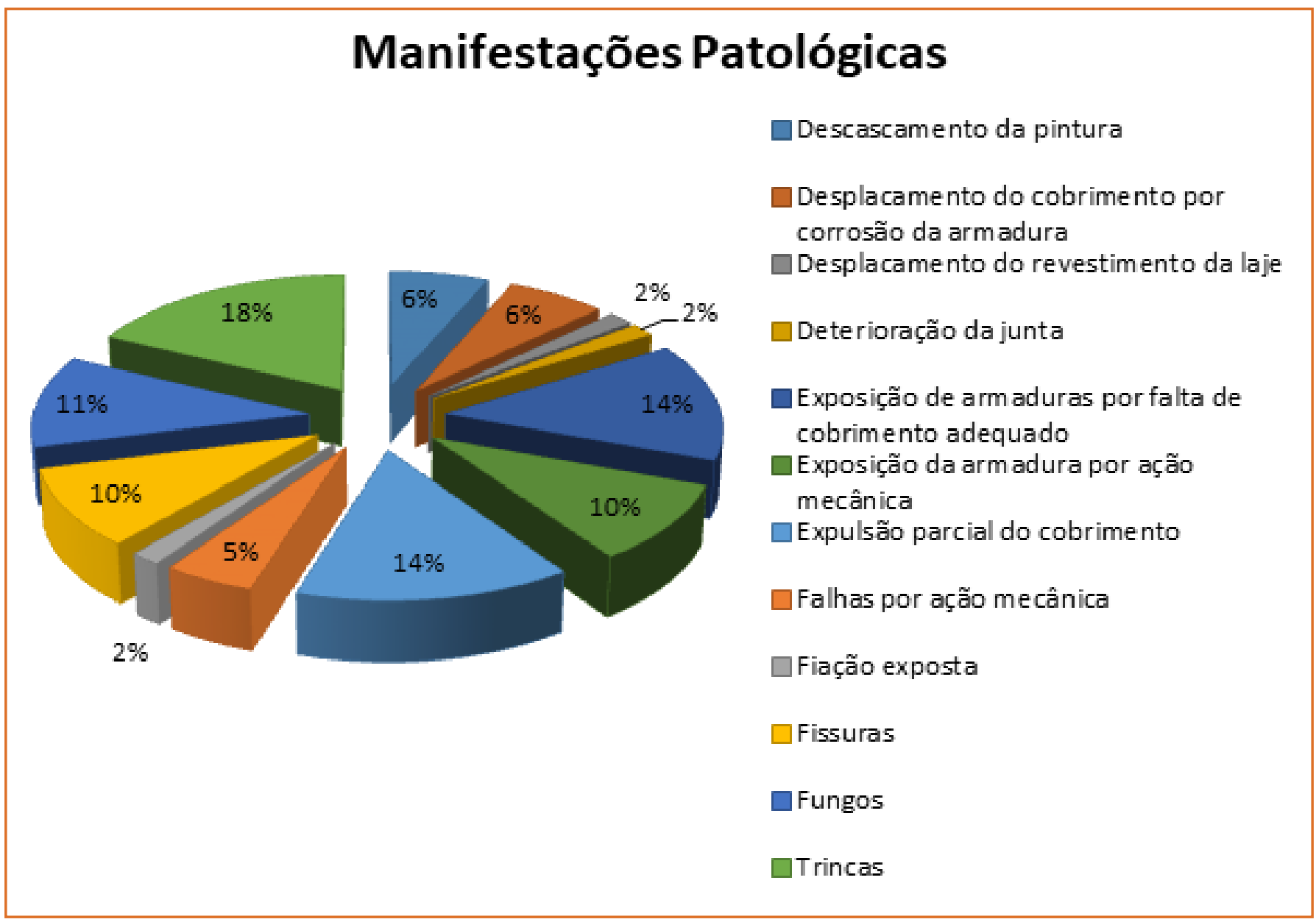

Fonte: Próprio autor

\section{CONCLUSÃO}

Mediante os resultados obtidos foi possível constatar que os problemas encontrados durante a inspeção técnica estão diretamente relacionados aos erros de execução aliados a falta de manutenções preventivas. Foi possível averiguar que a maioria das manifestações patológicas estão diretamente ligados a processos corrosivos que foram ocasionados pela falta de cobrimento adequado.

A estrutura de concreto armado não foi dimensionada de acordo com os padrões de exigências da NBR (6118:2014), sendo que ficou evidente que os problemas poderiam ter sido evitados ou minimizados se tivesse obedecido às especificações das normas técnicas, utilizando o cobrimento da armadura adequado, pois este erro deixou aberturas para agentes agressivos.

Diante das anomalias encontradas na passarela fica evidente a necessidade urgente de reparo e caso necessário reforços na estrutura, para evitar problemas ainda maiores que possam comprometer a funcionalidade, durabilidade e vida útil da estrutura.

\section{REFERÊNCIAS}

[1] ASSOCIAÇÃO BRASILEIRA DE NORMAS TÉCNICAS. NBR 6118: projeto de estruturas de concreto - procedimentos. Rio de Janeiro, 2014.

[2] ASSOCIAÇÃO BRASILEIRA DE NORMAS TÉCNICAS. NBR 5410: Instalações elétricas de baixa tensão. Rio de Janeiro, 2004. 
[3] BARBOSA, M. C. Estimativa da vida útil de estrutura de concreto armado imediatamente após sua execução. 2009. 170f. Dissertação (Mestrado) - Programa de Pós-Graduação de Engenharia Civil, Universidade Federal de Uberlândia, 2009.

[4] HELENE, P. R. L. Manual para reparo, reforço e proteção de estruturas de concreto. 2. Ed. São Paulo: Pini, 1992.

[5] LOTTERMANN, A. F. Patologia em estruturas de concreto: Estudo de caso. 2013. 66f. Trabalho de Conclusão de Curso (Graduação em Engenharia Civil) - Universidade Regional do Nordeste do Estado do Rio Grande do Sul, ljuí, 2013.

[6] OLIVEIRA, F. S. Manifestações patológicas: análise de fissuras em passarelas no campus do vale/ UFRGS. 2013. 115f. Trabalho de conclusão (Graduação em Engenharia Civil) - Curso de Graduação em Engenharia Civil, Universidade Federal do Rio Grande do Sul, Porto Alegre, 2013.
[7] SOUZA. M. F. Patologias ocasionadas pela umidade nas edificações. 2008. 64f. Monografia (Especialização) Curso de Especialização em Construção Civil, Universidade Federal de Minas Gerais, Belo Horizonte, 2008.

[8] SOUZA, V. C. M. de; RIPPER. T. Patologia, recuperação e reforço de estruturas de concreto. 1. Ed. São Paulo: Pini, 1998.

[9] VELOSO, C. et al. Análise das manifestações patológicas existentes nas fachadas das edificações localizadas no bairro de Recife/PE. Seminário de Patologia e Recuperação Estrutural (I SEMIPAR) - Universidade de Pernambuco, Recife, 2016. 


\section{CAPÍTULO 3}

\section{VIABILIDADE DA SUBSTITUIÇÃO DE CALDEIRAS DE ACORDO COM A UTILIZAÇÃo DE DIFERENTES TIPOS DE COMBUSTÍVEIS}

\section{Luciana Cristina de Carvalho Ramos}

\section{Alexandra Maria Sandy}

Luciene Vanessa Maia da Rocha Judice

\section{Gustavo Henrique Judice}

\section{Diego Henrique de Almeida}

Resumo: A questão ambiental tem sido uma grande preocupação das empresas no mundo atual, em especial das indústrias. Isso ocorre devido às pressões advindas dos governos, da sociedade e, principalmente, do próprio mercado econômico, no qual ser sustentável tornou-se item de competitividade e, portanto, de sobrevivência. Diante disto, este artigo tem como objetivo apresentar as vantagens econômicas e ambientais da utilização de biomassa em substituição a combustíveis fósseis em Sistemas de Caldeiras, através de um estudo de caso realizado em uma indústria do Sul de Minas Gerais. Foram estudados os resultados obtidos da substituição de caldeiras que utilizavam como combustível o óleo BPF, por outra que utilizava biomassa. Como conclusão, a troca entre os tipos de caldeiras foi viável, apresentando resultados satisfatórios, do ponto de vista econômico e ambiental.

Palavras chave: Biomassa, Combustíveis Fósseis, Caldeiras. 


\section{INTRODUÇÃO}

O relatório emitido pelo Painel Intergovernamental de Mudanças Climáticas (IPCC), em 27 de setembro de 2013, traz informações de que, a concentração de dióxido de carbono $\left(\mathrm{CO}_{2}\right)$ na atmosfera aumentou $40 \%$ desde a era pré-industrial em razão das emissões oriundas da queima de combustíveis fósseis (NETTO, 2013).

Tendo em vista que o principal gás responsável pelo efeito estufa e, consequentemente pelo aquecimento global, é o $\mathrm{CO}_{2}$, e que, a queima de combustíveis fósseis é a principal fonte de produção deste gás, surge a necessidade de buscar fontes alternativas de energia, ou seja, utilização de combustíveis mais limpos e renováveis.

Diante desse contexto, a preocupação com o meio ambiente é cada vez maior no setor industrial. As empresas vêm buscando diminuir índices de agressão ao ambiente e economia de recursos, para tanto, é necessário elaborar novas estratégias que combine crescimento econômico, desenvolvimento social e preservação ambiental.

As caldeiras, muito utilizadas nas indústrias para a produção de vapor são grandes fontes poluidoras, principalmente aquelas movidas a combustíveis fósseis, pois, ao queimar tais combustíveis, liberam gases e partículas na atmosfera. Tendo em vista esta grande fonte poluidora que é a Caldeira, uma indústria do Sul de Minas Gerais, que utiliza vapor em grande parte de seus processos, buscou uma maneira de reduzir suas emissões de $\mathrm{CO}_{2}$ na atmosfera, através do projeto de substituição de matriz energética.

Diante destas questões, o problema a ser abordado por este trabalho é a redução das emissões de $\mathrm{CO}_{2}$ provocadas pela queima de combustíveis fósseis em caldeiras e, ao mesmo tempo reduzir custos.

\section{INDUSTRIALIZAÇÃO VERSUS USO DE COMBUSTÍVEIS FÓSSEIS}

Segundo Pereira (2014), a Revolução Industrial provocou transformações em diversas áreas, sobretudo na economia, na tecnologia, na sociedade e no meio ambiente. Uma dessas transformações foi com relação ao uso intenso da energia proveniente da queima de combustíveis fósseis. Com o advento da máquina a vapor, o carvão mineral passou a ser o principal combustível utilizado na época. Posteriormente, derivados do petróleo passaram a ser utilizados como fonte energética para iluminação através de sua combustão em lampiões e, um pouco mais adiante, como combustíveis em motores a combustão, juntamente com o gás natural. O uso destes combustíveis foi se diversificando juntamente com o processo de industrialização.

Para Seiffert (2009) apud Silva Junior (2011), o uso desequilibrado dos recursos naturais não renováveis durante a Revolução Industrial, contribuiu, por um lado, para o aumento da qualidade de vida e dos padrões de consumo, mas por outro, intensificou a poluição e provocou o aumento das emissões de gases de efeito estufa, os principais vilões do aquecimento global. Com isso, pode-se dizer que a Revolução Industrial, teve grande influência no desencadeamento da crise ambiental vivida nos dias atuais.

Pearce (2002) apud Meneguello e Castro (2007) também afirma que a queima dos combustíveis fósseis teve grande aumento após a Revolução Industrial, se intensificando ainda mais após a década de 1970, o que resultou em um aumento significativo na concentração de dióxido de carbono na atmosfera. Segundo ele, este aumento na concentração de $\mathrm{CO}_{2}$, juntamente com outros gases tem intensificado o fenômeno do efeito estufa.

De acordo com o Ministério de Minas e Energia (2007) três objetivos devem ser alcançados para levar a um desenvolvimento energético sustentável:

- Acessibilidade: Há que se considerar a necessidade não somente a quantidade de energia a ser disponibilizada, mas em quais regiões existem maior demanda, ofertando assim o acesso aqueles economicamente menos favorecidos.

- Disponibilidade: as atuais reservas energéticas disponíveis são relativamente modestas e estão cada vez mais baixas havendo a necessidade de complexas políticas energéticas, haja visto 
que o setor depende também de investimentos privados. Espera alcançar tais objetivos optandose prioritariamente por opções renováveis.

- Aceitabilidade: ações necessárias com a capacidade de proporcionar ganhos significativos frente aos grandes desafios, exigindo grande ação do poder público alocando bens e recursos para que possa ser possível a inserção da variável socioambiental no processo decisório na formulação de políticas públicas neste sentido.

\subsection{SUSTENTABILIDADE E ECOEFICIÊNCIA}

Para Noro et al. (2012), atualmente muitas empresas estão buscando uma maneira de serem de fato sustentáveis, e, para tanto, é essencial que as mesmas busquem a ecoeficiência em todas as suas ações, decisões e, inclusive, em todos os seus processos produtivos. Ser ecoeficiente, segundo Zambon e Ricco (2011), é oferecer bens e serviços que satisfaçam as necessidades, gerando impactos ecológicos mínimos e capazes de serem absorvidos pela natureza.

Conforme afirmado pelo Conselho Empresarial Brasileiro para o Desenvolvimento Sustentável (2007) apud Sisinno e Moreira (2007), a ecoeficiência é obtida perante o fornecimento de bens e serviços a preços competitivos, que satisfaçam as necessidades humanas; proporcionem qualidade de vida; reduzam progressivamente, ao longo do ciclo de vida, o impacto ambiental e o consumo de recursos, até um nível que seja, no mínimo, equivalente à capacidade estimada da Terra.

Segundo Sisinno e Moreira (2007) são consideradas empresas ecoeficientes aquelas que conseguem obter benefícios econômicos ao mesmo tempo em que alcançam benefícios ambientais por meio da redução de emissões atmosféricas, efluentes líquidos, resíduos sólidos, entre outros.

Na concepção de Zambon e Ricco (2011), empresas ecoeficientes não passarão a existir num simples piscar de olhos. Afinal, uma nova postura voltada para a conservação ambiental exige, sobretudo, mudança, além ainda de muito esforço e inovação. Pressupõe- se que este novo cenário de ecoeficiência se torne, em breve, condição essencial para que as empresas sobrevivam no mercado. Para tal, é necessário quebrar paradigmas e procurar novas estratégias empresariais, que combine crescimento econômico com desenvolvimento social e preservação ambiental (ZAMBON; RICCO, 2011; SANDY, 2014).

Segundo Noro et al. (2012), a questão ambiental tem sido utilizada por muitas empresas como estratégia norteadora de seus negócios. Pois, ao reduzir os impactos ambientais de suas atividades e tornar seus processos os mais ecologicamente corretos possíveis, além de obter melhorias nos seus resultados e contribuir para a sustentabilidade, a empresa ainda ganha credibilidade diante da sociedade, melhorando sua imagem organizacional.

\section{CALDEIRAS}

\subsection{CONCEITUAÇÃO}

Segundo a Norma Regulamentadora 13 (NR-13:2008) "Caldeiras a vapor são equipamentos destinados a produzir e acumular vapor sob pressão superior à atmosférica, utilizando qualquer fonte de energia". Para Macintyre (2012), caldeiras são equipamentos cuja função é alterar o estado da água, do líquido para o vapor, para ser utilizado em aquecimento, processos industriais, esterilização, acionamento de máquinas motrizes, entre outros.

\subsection{CLASSIFICAÇÃO}

Segundo a NR-13:2008, as caldeiras são classificadas em três categorias, são elas:

- Caldeiras da categoria A, cuja pressão de operação é igual ou superior a $1960 \mathrm{kPa}\left(19,98 \mathrm{kgf} / \mathrm{cm}^{2}\right)$;

- Caldeiras da categoria "C", cuja pressão de operação é igual ou inferior a 588 kPa $(5,99$ kgf/ $\mathrm{cm}^{2}$ ) e o volume interno é igual ou inferior a 100 litros; Caldeiras da categoria "B", que não se enquadram nas categorias anteriores.

As caldeiras, segundo Macintyre (2012), também podem ser classificadas conforme o modo de 
transferência de calor para vaporizar a água, podendo ser: flamotubuladores ou aquatubulares. Nas caldeiras flamotubulares os gases quentes da combustão circulam no interior de tubos envoltos pela água a ser evaporada. Esses gases podem passar uma, duas ou até três vezes pelos tubos aquecedores.

Nas caldeiras aquatubulares o aquecimento ocorre externamente a um feixe de tubos contendo água e em comunicação com um ou mais reservatórios (tambores). Em geral são fabricadas para grandes produções de vapor, podendo produzir $50000 \mathrm{kgf} / \mathrm{h}$ ou valores até bem maiores (MACINTYRE, 2012).

\subsection{COMBUSTÍVEIS}

São muitas as opções de combustíveis que podem ser utilizados em caldeira, entre eles estão: gás natural, gás liquefeito de petróleo (GPL), óleos pesados como os de baixo ponto de fluidez (BPF) e biomassas.

Os óleos BPF's são aqueles produzidos a partir de frações pesadas resultante do processo de craqueamento do petróleo. Eles são constituídos de hidrocarbonetos e possuem uma elevada massa molecular, representados pela família das parafinas, naftênicos e aromáticos (MUTIRÃO PETRÓLEO, 2014).

Entre as biomassas há ainda uma grande variedade de tipos: lenha em tora, bagaço de cana de açúcar, cavaco de madeira, briquetes e pellets de vários tipos de resíduos, entre outros. Para Lippel (2014), os cavacos de madeira são pequenos pedaços de madeira oriundos da picagem ou destroçamento, com um comprimento variável entre 5 e $50 \mathrm{~mm}$. A qualidade do cavaco depende da matéria-prima e da tecnologia utilizada na sua produção.

\subsection{BIOMASSA}

Segundo a Agência Nacional de Energia Elétrica (ANAEEL) (2014), biomassa é todo recurso renovável proveniente de matéria orgânica (de origem animal ou vegetal) que pode ser aproveitada na produção de energia. A substituição do uso de combustíveis fósseis por energias alternativas renováveis tem sido interesse de muitos países, desenvolvidos ou não. Segundo Rosillo-Calle et al. (2005) isso ocorre, sobretudo, pelas preocupações com as mudanças climáticas, e também em virtude dos choques no preço do petróleo ocorridos na década de 1970.

Para Cortez et al. (2008), a motivação para essa mudança de postura se deve, principalmente, pela necessidade de reduzir a dependência energética em relação aos países exportadores de petróleo. $\mathrm{Na}$ percepção dos autores, a biomassa apresentase como uma ótima alternativa em substituição aos combustíveis fósseis, uma vez que, ela enquadrase perfeitamente no conceito do desenvolvimento sustentável, pois além de propiciar a criação de empregos, dinamizar as atividades econômicas, reduzir custos relacionados à distribuição de energia, se utilizada de modo sustentável, pode apresentar nulas as emissões de carbono, não causando impactos no meio-ambiente.

Uma das principais vantagens da biomassa é que, embora de eficiência reduzida, seu aproveitamento pode ser feito diretamente, por intermédio da combustão em fornos, caldeiras, etc. A fim de aumentar a eficiência do processo e reduzir os impactos socioambientais, novas tecnologias estão sendo desenvolvidas, como por exemplo, a gaseificação e a pirólise (ANEEL, 2014).

\section{MATERIAIS E MÉTODOS}

O projeto estudado neste trabalho, teve como objetivo a substituição de três caldeiras alimentadas a petróleo de baixa influência (óleo BPF) por uma caldeira alimentada por biomassa (cavaco de eucalipto), em uma indústria no sul de Minas Gerais.

Antes de realizar a substituição das caldeiras foi realizado um estudo exploratório, buscando todas as informações necessárias para análise de viabilidade do projeto, levando em conta os diferentes aspectos relativos aos combustíveis, como: custos, emissões atmosféricas, agressão ao meio ambiente e produção de energia. 
Tabela 1 - Características técnicas das caldeiras de óleo BPF

\begin{tabular}{|c|c|c|c|c|}
\hline Características & Caldeira 1 & Caldeira 2 & Caldeira 3 & Caldeira 3 \\
\hline Fabricante & ATA & ATA & Steammaster & HBremer \\
\hline Modelo & MP-813 & MP-812 & - & HBFR-4 \\
\hline Combustível & BPF & BPF & BPF & Biomassa \\
\hline Capacidade (t/h) & 10 & 8,5 & 15 & 20 \\
\hline Ano de Fabricação & 1979 & 1987 & 2008 & 2011 \\
\hline Temperatura de água & \multirow{2}{*}{90} & \multirow{2}{*}{90} & \multirow[t]{2}{*}{90} & \\
\hline de Alimentação (90 ㄷ) & & & & 90 \\
\hline Pressão Máxima de & \multirow{2}{*}{12} & \multirow{2}{*}{12} & \multirow{2}{*}{12} & 12 \\
\hline Trabalho Admitida $\left(\mathrm{kgf} / \mathrm{cm}^{2}\right)$ & & & & \\
\hline Tipo & Flamotubular & Flamotubular & Flamotubular & $\begin{array}{c}\text { Mista (fornalha aquatubular } \\
\text { e gerador flamotubular) }\end{array}$ \\
\hline
\end{tabular}

Fonte: Ramos (2014)

Os combustíveis utilizados neste estudo foram o óleo BPF e a biomassa (cavaco de eucalipto). O estudo do custo, disponibilidade e eficiência energética destes combustíveis foi a base para a análise de viabilidade do projeto.

O preço do óleo BPF foi extraído das contas pagas pela empresa no ano de 2010, e não sofreu grandes alterações durante este período. O preço do cavaco, utilizado nos cálculos, é a média dos preços praticados pelos fornecedores da região.

Foram levantados os dados referentes ao consumo médio de vapor da fábrica durante um ano, com base nas medições da água de alimentação da caldeira, considerando uma razão de 1:1 entre o volume de água que entra na caldeira e o volume de vapor que sai da mesma.

Para cálculo das emissões de gases na atmosfera a empresa utilizou a metodologia GHG Protocol. O GHG Protocol é uma ferramenta com o objetivo de entender, quantificar e gerenciar emissões de gases de efeito estufa.

\subsection{CÁLCULO DO CONSUMO DOS COMBUSTÍVEIS}

Para cálculo dos consumos de combustíveis realizouse o balanço de massa (Equação 1) e os dados da Tabela 2

$$
Q_{c}=\frac{Q_{v} \cdot\left(h_{v}-h_{a}\right)}{\eta \cdot P C I}
$$

Em que:

$\mathrm{Q}_{\mathrm{c}}=$ quantidade de combustível (óleo BPF ou cavaco de eucalipto), $\mathrm{kg}$

$\mathrm{Q}_{\mathrm{v}}=$ quantidade de vapor, $\mathrm{kg}$

$h_{v}=$ entalpia do vapor em função da pressão e temperatura, $\mathrm{kcal} / \mathrm{kg}$

$h_{\mathrm{a}}=$ entalpia da água em função da temperatura, kcal/ $\mathrm{kg}$

$\eta=$ rendimento $(\%)$

$\mathrm{PCl}=$ Poder Calorífico Inferior, $\mathrm{kcal} / \mathrm{kg}$ 
Tabela 2 - Dados utilizados para cálculo do consumo de combustível

\begin{tabular}{|l|l|}
\hline Características & Valores \\
\hline Regime de operação da caldeira (horas/dia) & 24 \\
\hline Quantidade de Vapor (kg/h) & 11030 \\
\hline Temperatura do Vapor $\left({ }^{\circ} \mathrm{C}\right)$ & 183,2 \\
\hline Pressão de Vapor $\left(\mathrm{kgf} / \mathrm{cm}^{2}\right)$ & 9 \\
\hline Temperatura de Água de Alimentação (ํㅜ) & 90 \\
\hline Entalpia do Vapor (kcal/kg) & 664,1 \\
\hline Entalpia da Água a 90 ํ $(\mathrm{kcal} / \mathrm{kg})$ & 90,02 \\
\hline Rendimento da Caldeira de óleo BPF (\%) & 86,17 \\
\hline Rendimento da Caldeira de biomassa (\%) & 85,72 \\
\hline PCl do óleo BPF (kcal/kg) & 9750 \\
\hline PCl do cavaco de eucalipto (kcal/kg) & 2600 \\
\hline Umidade do cavaco de eucalipto (\%) & 35 \\
\hline
\end{tabular}

Fonte: Ramos (2014)

\section{RESULTADOS E DISCUSSÃO}

O projeto foi impulsionado pelo aumento da demanda de vapor da fábrica e, ao mesmo tempo, pela necessidade de se eliminar as caldeiras mais antigas (uma delas com vida útil de 30 anos), que, além de terem reduzido em muito seu desempenho, acabavam por contribuir com o aumento das emissões de poluentes, além de apresentarem um maior risco de segurança. Porém, mesmo com a instalação de uma nova caldeira, as três caldeiras antigas permaneceram instaladas, para serem utilizadas como backup, principalmente durante paradas para manutenção da Caldeira à biomassa.

A empresa optou pela utilização da biomassa, uma vez que a mesma demonstrou ser uma opção viável economicamente e a empresa trocaria uma matriz energética insustentável baseada na utilização de combustíveis fósseis por uma sustentável, tendo significativos ganhos ambientais.

Na região de instalação da empresa foi constatada uma lista com 21 possíveis fornecedores de biomassa, na qual constava, entre diversos fatores: tipo de biomassa, local onde se encontra, quantidade disponível, qualidade e preço. O bagaço de cana de açúcar foi uma opção descartada devido, sobretudo, à inconsistência do setor sucroalcooleiro e também por gerar grande volume de fuligens durante sua queima, necessitando de um avançado sistema de filtragem.

Entre as biomassas da madeira, a lenha em tora também se mostrou inviável do ponto de vista operacional, pois além de exigir uma grande quantidade de mão de obra, demanda um trabalho brutal com grande risco de acidentes. Sem falar da grande quantidade de pragas, cobra e escorpião que podem ser encontradas na lenha. Diante das pesquisas realizadas concluiuse que, a alternativa mais viável seria a utilização de cavacos de madeira de reflorestamentos e resíduos industriais, devido a seu menor custo, facilidade de operação e disponibilidade.

Tal disponibilidade é confirmada por Neutzling e Palmeira (2007), que asseguram que, o país possui, hoje, vários estados produtores de madeira, tendo como destaque o estado de Minas Gerais, maior produtor individual, no que diz respeito às florestas plantadas. Ainda com relação à disponibilidade da madeira, segundo informações da Associação Brasileira de Produtores de Florestas Plantadas (ABRAF, 2006), o estado de Minas Gerais possui a maior área individual com florestas plantadas, compreendendo 1.216.744 hectares (sendo 13\% com pinus e $87 \%$ com eucaliptos).

Depois de decidido o tipo de biomassa, iniciou-se uma pesquisa junto aos fornecedores de caldeira, buscando as melhores alternativas e modelos que atendessem todas as necessidades do projeto em questão. Para tanto, foram levantados todos os custos necessários, bem como, o consumo de combustível para a nova opção, informação esta extremamente relevante para o cálculo de viabilidade do projeto.

A partir dos dados da empresa, referente à produção de vapor em 2010, calculou-se a produção média de vapor por hora, cujo resultado foi de $11030 \mathrm{~kg} / \mathrm{h}$. Com base neste valor, foram calculados os valores de produção por dia, mês e ano, considerando os seguintes fatores: 24 horas por dia, 30 dias no mês e 7920 horas no ano. Utilizando a Equação 1 calculouse a quantidade necessária de cavaco de eucalipto $(2841,14$ kg) e óleo BPF $(753,68 \mathrm{~kg})$ para produzir 
$11030 \mathrm{~kg}$ de vapor por hora, considerando as caraterísticas apresentadas na Tabela 2.

Os preços por tonelada de combustível no ano de 2010 eram de $R \$ 1002,00$ e $R \$ 143,50$, para o óleo BPF e para o cavaco de eucalipto, respectivamente.

A partir do estudo comparativo entre os combustíveis chegou-se a uma economia de $\mathrm{R} \$ 2.752 .071,46$, o que corresponde a uma redução de aproximadamente $46 \%$ em relação aos custos com óleo BPF registrados em 2010.

A partir do estudo comparativo entre os combustíveis, considerando os preços de 2014, verificou-se que a substituição do óleo BPF por cavaco de eucalipto resultou em uma economia de $\mathrm{R} \$ 6.222 .858,92$, o que corresponde a uma redução de aproximadamente $64 \%$ nos custos com combustíveis. A economia de combustível no decorrer dos anos tem demonstrado a eficiência e eficácia do projeto, dentro de sua viabilidade econômica e ambiental já verificada em 2010 na troca dos combustíveis da caldeira.

\section{CONSIDERAÇÕES FINAIS}

O estudo referente à substituição das caldeiras de óleo BPF por uma de cavaco de madeira resulta em grandes benefícios à empresa, tanto no âmbito econômico, quanto no ambiental. No âmbito econômico, percebeuse que a empresa conseguiu uma redução de custos superior a 40\% no valor do combustível, considerando os preços de 2010), a redução de custo seria de aproximadamente $64 \%$.

No âmbito ambiental, a redução nas emissões de gases de efeito estufa foi comprovada e registrada através dos inventários de emissões publicados pela empresa. Verificou-se que uma das dificuldades encontradas em projetos de substituição de matriz energética está na seleção entre as fontes renováveis de energia (devido à grande diversidade de opções, sobretudo na geração de vapor).

Tendo em vista a grande preocupação com as questões ambientais, principalmente ao que se refere às alterações do clima, cuja uma das principais causas é a queima de combustíveis fósseis pelas indústrias, conclui-se que projetos como o apresentado neste trabalho, que objetivam a substituição de uma matriz energética não renovável por uma renovável, são uma boa estratégia para as empresas que buscam uma melhor posição no mercado, pois, além de trazerem benefícios econômicos e ambientais, melhoram a imagem da empresa com relação à sustentabilidade, tema este de fundamental importância para a competitividade das empresas.

\section{REFERÊNCIAS}

[1] ANAEEL. Biomassa. ANEEL. Disponível em: <http://www.aneel.gov.br/aplicacoes/atlas/pdf/05Biomassa(2).pdf>. Acesso em: 01 jun. 2014.

[2] CORTEZ, L. A. B.; LORA, E. E. S.; GÓMEZ, E. O. Biomassa para energia. Campinas: Editora da UNICAMP, 2008.

[3] IPCC. Contribuição do Grupo de Trabalho I ao Quarto Relatório de Avaliação do Painel Intergovernamental sobre Mudança do Clima. IPCC. Set.2013. Disponível em:<http:// www.ipcc.ch/pdf/reports-nonUN-translations/portuguese/ ar4-wg1-spm.pdf>. Acesso em: 25 mai. 2014.

[4] LIPPEL. Cavacos de madeira. Lippel. Disponível em:<http://www.lippel.com.br/br/sustentabilidade/cavacosde-madeira\#.VITJp9LF-Jp>. Acesso em: 25 nov. 2014.

[5] MACINTYRE, A. J. Equipamentos industriais e de processo. Rio de Janeiro: LTC, 2012.

[6] MENEGuello, L. A.; CAStRO, M. C. A. A. O Protocolo de Kyoto e a geração de energia elétrica pela biomassa da cana-de-açúcar como mecanismo de desenvolvimento limpo. Revista Internacional de Desenvolvimento Local. v. 8, n.1, p. 33-43, 2007.

[7] MINISTÉRIO DE MINAS E ENERGIA. Resenha energética 2007. Brasília, 2007.

[8] MUTIRÃO PETRÓLEO. BPF-A1.Mutirão Petróleo. Disponivel em: <http://www.mutiraopetroleo.com.br/ produtos_bpf_a1.php>. Acesso em: 25 nov. 2014.

[9] NETTO, A. Concentração de dióxido de carbono no ar bate recorde de 800 mil anos. Estadão. 28 set. 2013. Disponível em: <http://saopaulo.estadao.com.br/ noticias/geral,concentracao-de-dioxido-de-carbono-no-arbaterecorde-de-800-mil-anos-imp-,1079653>. Acesso em: 4 mai. 2014. 
[10] NORO, G. B. et al. A ecoeficiência e a gestão sustentável: um estudo de caso. In: IX SIMPÓSIO DE EXCELÊNCIA EM GESTÃO E TECNOLOGIA. Alagoas, 2012. Disponível em: http://www.aedb.br/seget/artigos12/981662.pdf>. Acesso em: 4 mai. 2014.

[11] NEUTZLING, F.C.; PALMEIRA, E. M. A competitividade das exportações brasileiras de cavaco de madeira. In: Observatorio de la Economía Latinoamericana, Número 77, 2007. Disponível em: http://www.eumed.net/cursecon/ ecolat/br/07/nmp.htm>. Acesso em: 07 dez. 2014.

[12] NR13. NORMA REGULAMENTADORA 13 DO MINISTÉRIO DO TRABALHO E EMPREGO. Manual técnico de caldeiras e vasos de pressão. 2008. Disponível em: <http://www.mte.gov.br>. Acesso em: 01 jun. 2014.

[13] PEREIRA, A. S. Mudança climática e energias renováveis. Com ciência. Disponível em: <http://www.comciencia.br/ reportagens/clima/clima12.htm>. Acesso em: 25 mai. 2014.

[14] RAMOS, L. C. C. Estudo do custo-benefício para substituição de óleo BPF por biomassa de madeira em caldeiras a partir de dados de indústria alimentícia de Poços de Caldas. 2015. 80 f. Trabalho de Conclusão de Curso (Graduação em Engenharia de Produção), Faculdade Pitágoras, Campus Poços de Caldas, Poços de Caldas, 2014.
[15] ROSILLO-CALLE, F.; BAJAY, S. V.; ROTHMAN, H. Uso da biomassa para produção de energia na indústria brasileira. Campinas: Editora da UNICAMP, 2005.

[16] SANDY, A. M. Análise da viabilidade do mercado de créditos de carbono como contribuição para a eficiência energética no Brasil. 98 f. 2015. Monografia (Trabalho de Conclusão de Curso em Engenharia de Produção), Faculdade Pitágoras, Campus Poços de Caldas, Poços de Caldas, 2015.

[17] SILVA JUNIOR, A. C. Projetos de mecanismo de desenvolvimento limpo (MDL): promotores de transferência de tecnologia e tecnologias mais limpas no Brasil. 2011. 204 f. Tese (Doutorado em Engenharia Industrial) - PEI, Escola Politécnica, Universidade Federal da Bahia, Salvador, 2011.

[18] SISINNO, C. L. S.; MOREIRA, J. C. Ecoeficiência: um instrumento para a redução da geração de resíduos e desperdícios em estabelecimentos de saúde. Cad. Saúde Pública, v. 21, n. 6, p. 1893-1900, 2007

[19] ZAMBON, B. P.; RICCO, A. S. Sustentabilidade empresarial: uma oportunidade para novos negócios. 2011. Disponível em: <http://amauridomakoski.com.br/tegf_6. pdf>. Acesso em: 25 mai. 2014. 


\section{CAPÍTULO 4}

\section{ESTUDO DOS EFEITOS DA FILTRAÇÃ̃O DE EFLUENTE DE LATICÍNIO NA REDUÇÃo do FLUXO PERMEAdo E NA COLMATAÇÃ̃o DE MEMBRANAS DE MICROFILTRAÇÃO E ULTRAFILTRAÇÃO}

\section{Douglas Felipe Galvão}

Eliane Rodrigues dos Santos Gomes

Resumo: As indústrias de laticínios utilizam volume substancial de água para a realização dos processos produtivos, especialmente para a manutenção de condições de higiene e limpeza. Com isso, ocorre a geração de volume considerável de efluentes que demandam tratamento para atendimento dos padrões de lançamento, antes de serem descartados. Os processos de separação por membranas têm destaque na geração de efluentes tratados de boa qualidade. Desse modo, a presente pesquisa teve como objetivo verificar a permeabilidade de membranas com a água destilada e com efluente de laticínio e estudar os efeitos do efluente na redução do fluxo permeado e na colmatação das membranas. Para isso, foi realizada a circulação tanto de água destilada quanto de amostra de efluente de uma indústria de laticínios da região Oeste do Estado do Paraná, em membranas de microfiltração (MF) e ultrafiltração (UF). Os processos de MF e UF foram realizados variandose as condições de pressão aplicadas, realizando-se a avaliação do comportamento das membranas durante os experimentos.

Palavras chave: Leite. Separação. Retenção. Fluxo. 


\section{INTRODUÇÃO}

Os efluentes de laticínios são caracterizados pelas altas taxas de matéria orgânica, sabões e constituintes do leite oriundos dos processos produtivos. Há elevado consumo de água em indústrias de laticínios, especialmente para manter as condições sanitárias e de higiene neste tipo de indústria e, consequentemente, há elevada geração de efluentes, (MAGANHA, 2008).

Os processos de separação por membranas têm ganhado relevância no tratamento de efluentes de laticínios e geração de efluente tratado de elevada qualidade, o que possibilita o seu reúso em processos industriais.

A utilização dos processos de separação por membranas no tratamento de efluentes pode ser limitada pela redução do fluxo de permeado das membranas no decorrer do tempo de filtração. Esse fenômeno, denominado de colmatação ou fouling, é causado, especialmente, pelo acúmulo de partículas na superfície e dentro dos poros das membranas (SONG, 1998; HABERT et al., 2006).

Habert, Borges e Nobrega (2006) indicam como principais causadores do decaimento do fluxo, a deformação mecânica da membrana (quando ocorre o seu inchamento), a interação do solvente com o material da membrana, ou então pela presença de impurezas no solvente que causa o entupimento dos poros.

Schneider e Tsutyia (2001) citam que, o fluxo do líquido através da membrana é dependente de alguns fatores, como diâmetro dos poros; porosidade da membrana (fração da área de membrana ocupada por poros); espessura da membrana; camada de concentração e polarização; tortas de filtro (material retido); fouling químico (sais precipitados ou géis); e biofilmes.

Um dos piores problemas citados pelos autores durante a operação dos sistemas de membranas é o decaimento do fluxo com o tempo. Esse fenômeno é denominado de fouling ou colmatação da membrana (LAUTENSCHLAGER; FILHO; PEREIRA; 2009; HASAN, et al., 2013; GIACOBBO et al., 2010; SONG, 1998; VIDAL; CAMPOS; 2009).
O fouling acaba aumentando a complexidade de operação dos sistemas de separação por membranas, pois, o sistema precisa ser parado frequentemente para restabelecimento do fluxo através da retrolavagem, resultando em aumento dos custos econômicos e tornando menos viáveis a utilização de sistemas de UF e MF para muitos processos (SONG, 1998).

Nesse sentido, o presente estudo teve como objetivo estudar a permeabilidade de membranas de microfiltração (MF) e ultrafiltração (UF) com água destilada e com efluente de laticínios, e estudar os efeitos do efluente de uma indústria na colmatação das membranas e na redução do fluxo permeado no decorrer do tempo.

\section{MATERIAIS E MÉTODOS}

\subsection{DESCRIÇÃO DO LOCAL DE COLETA DE AMOSTRAS}

O efluente utilizado na presente pesquisa foi obtido em uma Unidade de Laticínios situada na região oeste do Estado do Paraná, que produz iogurtes de diversas linhas de produção, bebidas lácteas e creme de leite. O efluente foi coletado na Estação de Tratamento de Efluentes, após o tratamento secundário (AATS).

Foram coletados, em cada um dos lotes de amostras, 30 litros de efluente para a realização dos ensaios. Para a coleta da amostra foram seguidas as normas brasileiras NBR 9897 (planejamento de amostragem de efluentes líquidos e corpos receptores) e NBR 9898 (preservação e técnicas de amostragem de efluentes líquidos e corpos receptores) (ABNT, 1987a; ABNT, 1987b)

\subsection{UNIDADE EXPERIMENTAL DE SEPARAÇÃO POR MEMBRANAS}

Os processos de separação por membranas foram realizados através de um módulo de bancada existente no Laboratório de Águas e Efluentes da Universidade Tecnológica Federal do Paraná (UTFPR Câmpus Medianeira), conforme foto ilustrativa na Figura 1. 
Figura 1 - Módulo de Tratamento por membranas de bancada.

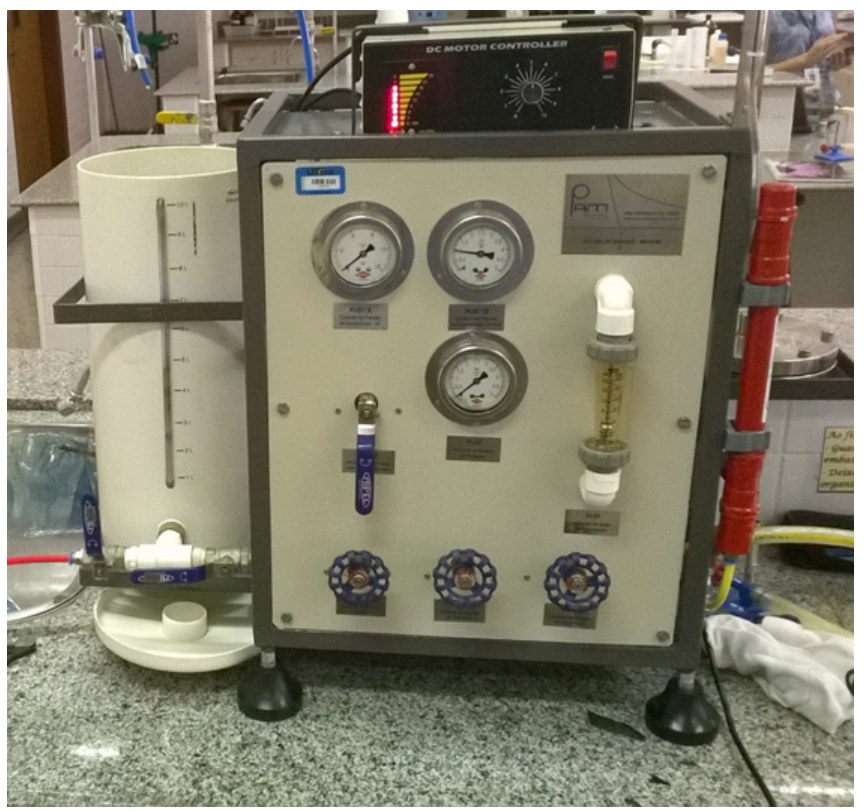

Os módulos utilizados no estudo foram de Microfiltração e Ultrafiltração (MF 158 e UF 257), adquiridos da Pam-Membranas Seletivas. As duas membranas são de geometria fibra-oca, sendo a de microfiltração com porosidade de 0,4 $\mu \mathrm{m}$ e material de produção polieterimida e a de Ultrafiltração de polietersulfona, com retenção molar de 50 kDa (PAM-MEMBRANAS, 2012).

\subsection{EXPERIMENTOS DE FILTRAÇÃO POR MEMBRANAS}

No módulo de bancada foram monitoradas as seguintes variáveis: vazão do permeado $(L \quad h-1)$; vazão do concentrado ( $L$ min-1); rotação da bomba (RPM); pressão de permeado, de recirculação e de alimentação (bar); e o volume de alimentação (L).

Para cada ensaio foram utilizados 5 litros de efluente oriundos do sistema de tratamento da indústria. Em todos os ensaios ocorre o retorno do concentrado para o tanque de armazenamento, caracterizando-se em um processo em batelada. A Tabela 1 apresenta as condições experimentais estabelecidas.
Tabela 1 - Condições experimentais estabelecidas para os processos de separação por membranas.

\begin{tabular}{|l|l|l|l|}
\hline Tratamento & Membrana & \multicolumn{1}{c|}{$\begin{array}{l}\text { Pressão } \\
\text { (Bar) }\end{array}$} & \multicolumn{1}{l|}{$\begin{array}{l}\text { Ponto de } \\
\text { coleta }\end{array}$} \\
\hline E1 & $\begin{array}{l}\text { Pressurização/ } \\
\text { Despressurização } \\
\text { MF 158 }\end{array}$ & $0,50-1,50$ & Água Destilada \\
\hline E3 & $\begin{array}{l}\text { Pressurização/ } \\
\text { Despressurização } \\
\text { MF 158 }\end{array}$ & $0,50-1,75$ & AATS \\
\hline E4 & $\begin{array}{l}\text { Pressurização/ } \\
\text { Despressurização } \\
\text { UF 257 }\end{array}$ & $0,50-1,75$ & Água Destilada \\
\hline E5 & $\begin{array}{l}\text { Pressurização/ } \\
\text { Despressurização } \\
\text { UF 257 }\end{array}$ & $0,50-1,75$ & AATS \\
\hline E6 & $\begin{array}{l}\text { Cálculo } \\
\text { Coeficiente de } \\
\text { Colmatação MF } \\
\text { 158 }\end{array}$ & $0,50,0,75$ e & AATS \\
\hline & $\begin{array}{l}\text { Cálculo } \\
\text { Coeficiente de } \\
\text { Colmatação UF } \\
\text { 257 }\end{array}$ & $0,50,1,00$ e & AATS \\
\hline
\end{tabular}

(MF 158 = Membrana Microfiltração série 158; UF 257 = Ultrafiltração série 257; AATS = Amostra Após Tratamento Secundário).

Os 4 experimentos (E1 a E4) foram realizados com o objetivo de verificar a permeabilidade das membranas para a água destilada e para o efluente de laticínio e verificar os efeitos de histerese, compactação e entupimento dos poros para as membranas de MF e UF.

Nos experimentos E5 e E6, buscou-se analisar o comportamento do fluxo permeado das membranas de MF e UF e o efeito da comatação nas duas membranas, que corresponde a concentração de partículas na superfície das membranas e consequente redução no fluxo permeado, no decorrer do tempo.

Para verificar a permeabilidade das membranas de MF e UF, foi realizada, primeiramente, a análise da permeabilidade destas com água destilada e com efluente de laticínios, através da pressurização e despressurização do módulo. O diferencial de pressão transmembrana aplicado foi de 0,5 bar a 1,5 bar (pressurização) para a membrana de microfiltração (MF 158) com água destilada e de 0,5 a 1,75 bar com efluente de laticínio; para a membrana de UF foi de 
0,5 a 1,75 bar tanto para água destilada quanto para o efluente de laticínio.

A elevação da pressão para as duas membranas ocorreu em intervalos de 0,25 bar, retornando a pressão para 0,5 bar (despressurização) em intervalos de 0,25 bar, em seguida. O fluxo da água destilada foi medido de 5 em 5 minutos durante 60 minutos, para cada pressão.

O cálculo do coeficiente de colmatação (CC) foi realizado conforme a equação 3. Para o cálculo, inicialmente, ocorreu durante 60 minutos (estabilização do fluxo permeado), a passagem de água destilada pelo módulo. Em seguida, ocorreu a filtração de efluente de laticínio durante 60 minutos, até a estabilização do fluxo permeado. Por fim, ocorreu uma nova circulação, por 60 minutos, de água destilada. O fluxo foi medido de 5 em 5 minutos, e realizou-se as corridas para 3 pressões diferentes para a MF $(0,5,0,75$ e 1,0 bar) e para a UF (0,5, 1,0 e 1,5 bar $)$, calculando-se o coeficiente de colmatação para cada pressão conforme Rao (2002).

As membranas foram avaliadas quanto aos parâmetros de processo:

a) Efeito da pressão - Pressão Transmembrana ( $\square P$ );

b) Fluxo em função do tempo. O fluxo permeado (J) foi determinado pela equação:

$$
J=V p / A x t
$$

Na equação 1, Vp é o volume permeado, A é a área de filtração da membrana e t é o tempo.

c) Coeficiente de Colmatação que refere-se a mensuração da incrustação na superfície da membrana após a realização dos ensaios. O valor do coeficiente varia de 0 (sem colmatação) até 1,0 (membrana completamente colmatada). O cálculo do Coeficiente foi realizado de acordo com Rao (2002):

$\mathrm{CC}=$ Fluxo de água destilada após filtração com efluente / Fluxo de água com a membrana limpa

\subsection{LIMPEZA DAS MEMBRANAS}

Após os ensaios realizados com efluente de laticínio (Experimentos 2 e 4 da Tabela 1), realizou-se a limpeza dasmembranas conformerecomendação do fabricante. A limpeza é realizada até que a membrana apresente o fluxo permeado de água destilada encontrado nos ensaios de pressurização e despressurização das membranas de MF e UF, tolerando-se valores de fluxo inferiores ou superiores a $20 \%$, conforme orientações do fabricante das membranas.

Utilizou-se os seguintes métodos para limpeza das membranas de MFe de UF: limpeza física(retrolavagem) que consiste na passagem de água no sentido oposto ao da filtração, com o objetivo de desobstruir os poros da membrana; e limpeza química (limpeza oxidante) utilizando-se como oxidante o Hipoclorito de Sódio (500 mg/L). Circulou-se, no módulo, 1 litro da solução durante um período não superior a duas horas.

\section{RESULTADOS E DISCUSSÃO}

\subsection{PRESSURIZAÇÃO E DESPRESSURIZAÇÃO DAS MEMBRANAS COM ÁGUA DESTILADA E COM EFLUENTE DE LATICÍNIO}

Nas Figuras 2 e 3 tem-se a variação do fluxo das membranas de MF e de UF, respectivamente, utilizando água destilada. 
Figura 2 - Fluxo permeado no decorrer do tempo e à variação da pressão (pressurização e despressurização) da membrana MF 158, com água destilada.

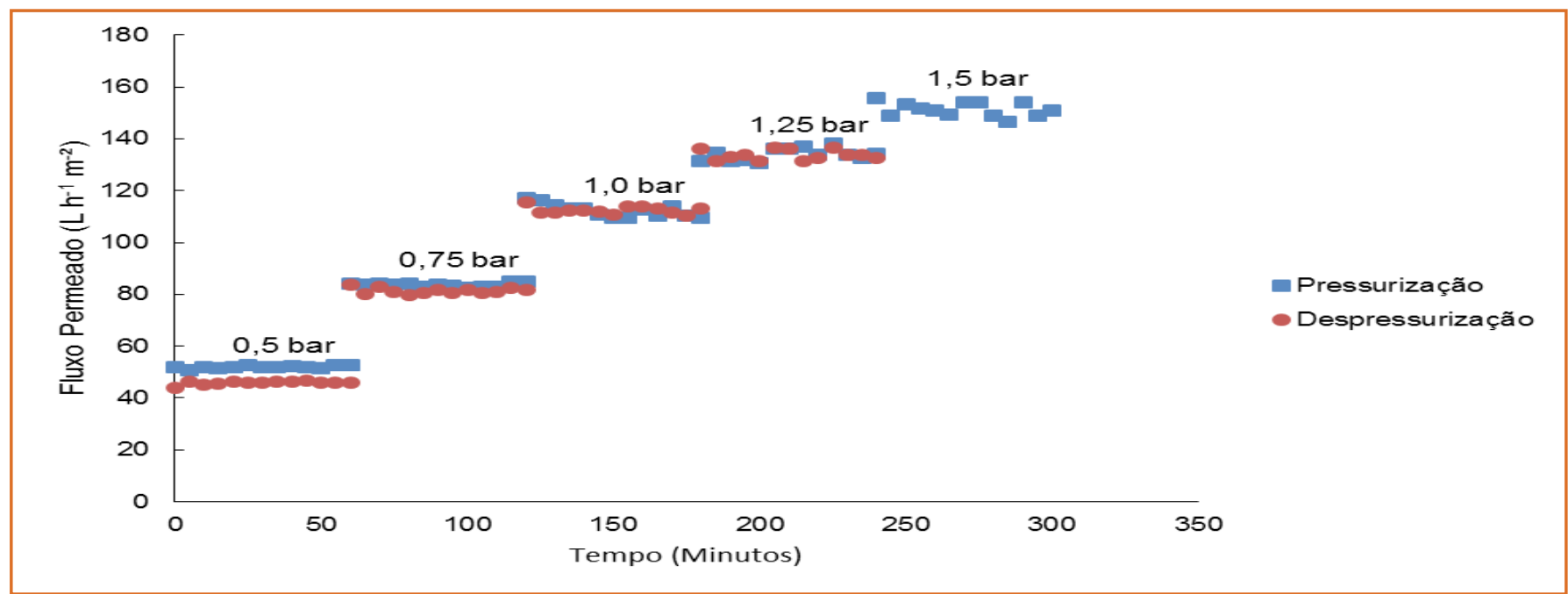

Figura 3 - Fluxo permeado no decorrer do tempo e à variação da pressão (pressurização e despressurização) da membrana UF 257, com água destilada.

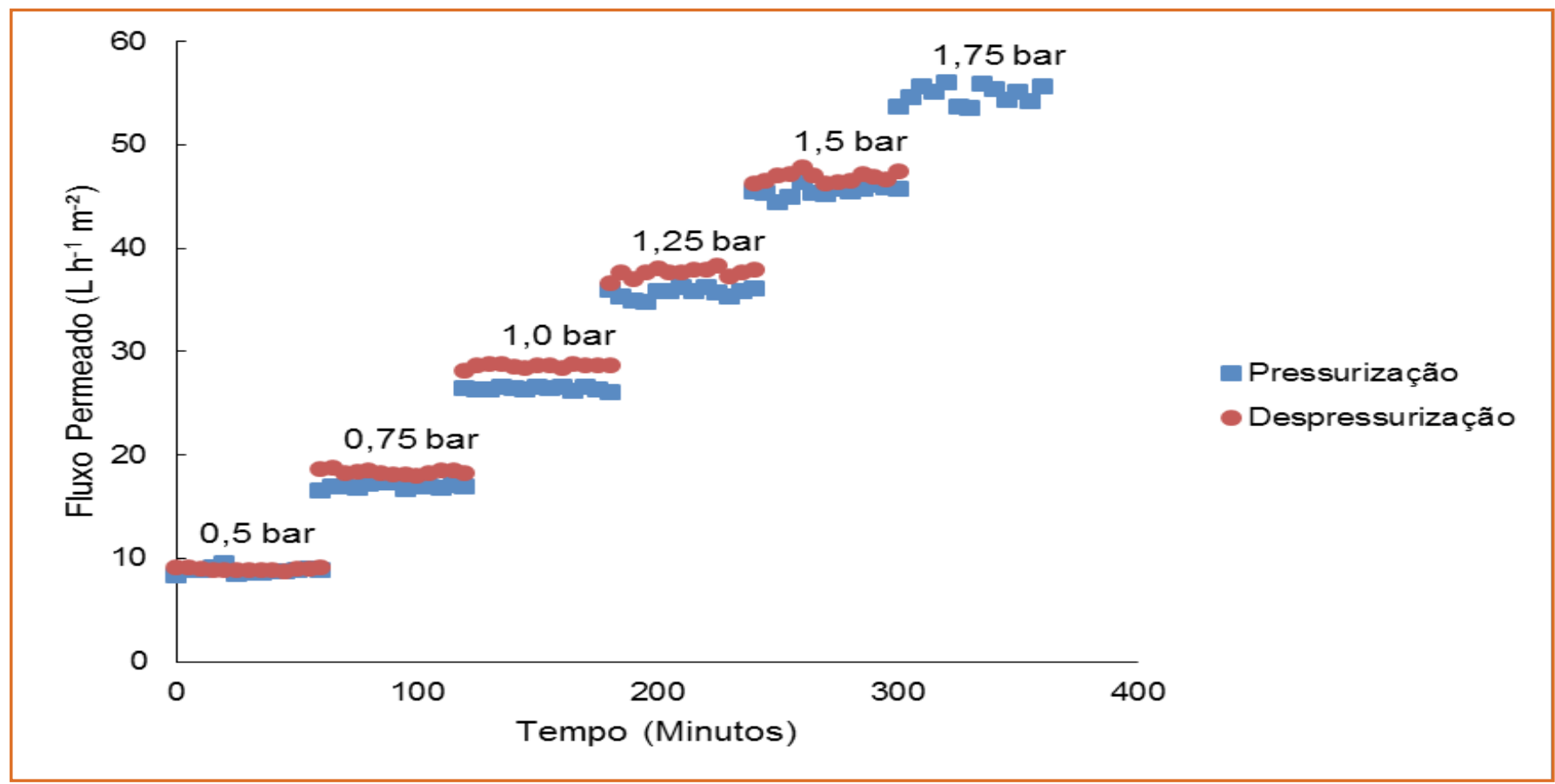

Através da pressurização e da despressurização do módulo das membranas de MF e UF é possível verificar o fenômeno de compactação dos poros, ou histerese, que modifica o comportamento da membrana com relação a seletividade e fluxo (SARMENTO, 2007).

Nas Figuras 2 e 3, verifica-se pouca diminuição do fluxo das membranas na despressurização do módulo, ocorrendo pouca compactação e entupimento dos poros quando realizadas os ensaios com água destilada. Tal fenômeno fica mais evidente somente na membrana de MF a pressões mais baixas $(0,5 \mathrm{e}$ 0,75 bar), quando há queda no fluxo permeado na despressurização.

Para a membrana de ultrafiltração, quando da despressurização, observa-se que houve aumento do fluxo permeado nas diferentes pressões. A alteração 
na estrutura dos poros do polímero da membrana pode ter contribuído para esse aumento do fluxo.

Nas Figuras 4 e 5 estão ilustradas a variação da permeabilidade hidráulica das membranas de microfiltração e ultrafiltração, respectivamente, com relação a água destilada e a variação de pressão, pressurização e despressurização, aplicadas as membranas.

É possível observar a linearidade do comportamento do fluxo com relação ao aumento da pressão e o aumento do fluxo quando da despressurização, especialmente na membrana de ultrafiltração. Para água destilada houve boa reversibilidade do fluxo às condições iniciais do processo.

Figura 4 - Permeabilidade para água destilada da membrana de MF 158.

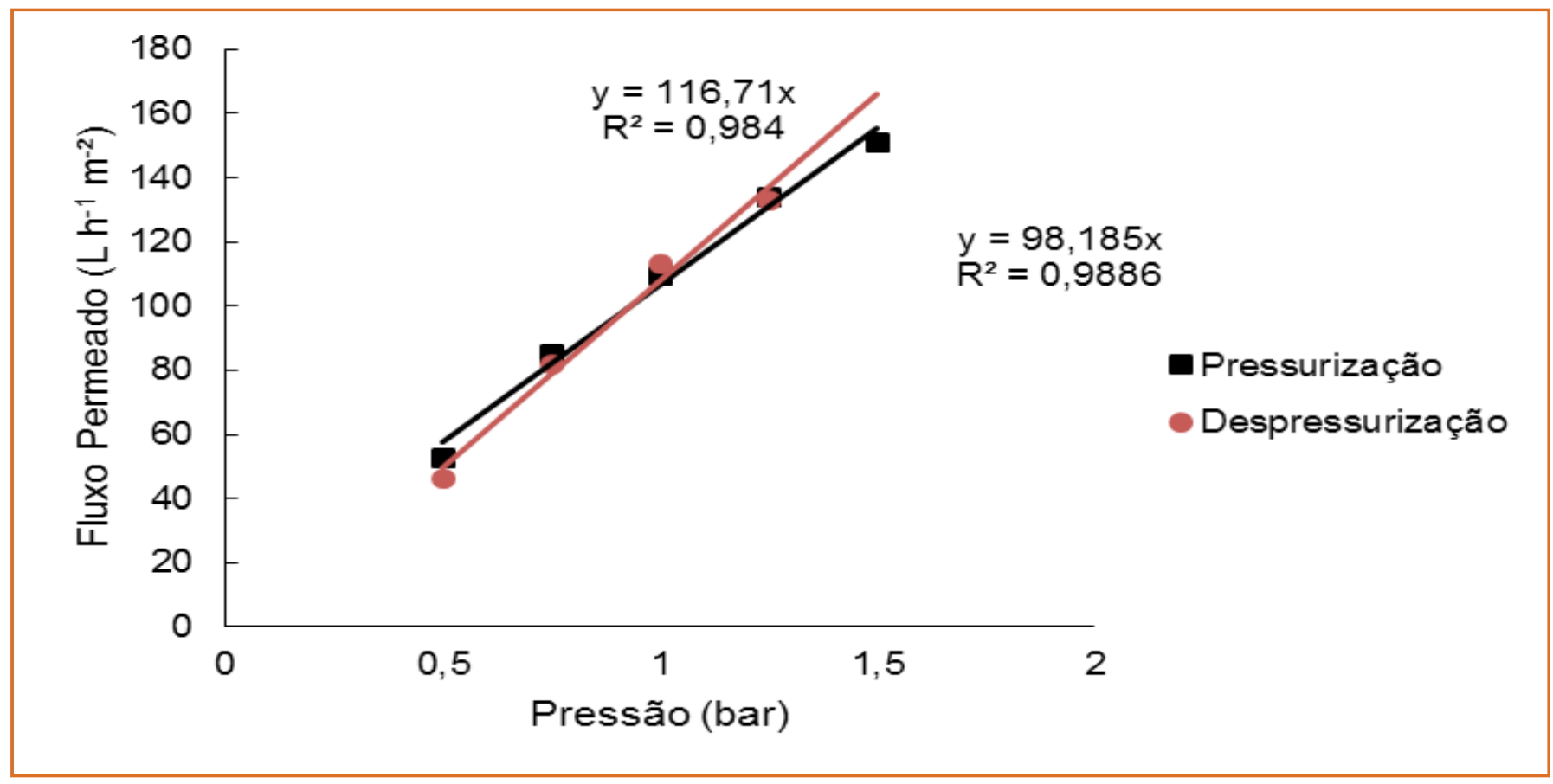

Figura 5 - Permeabilidade para água destilada da membrana de UF 257.

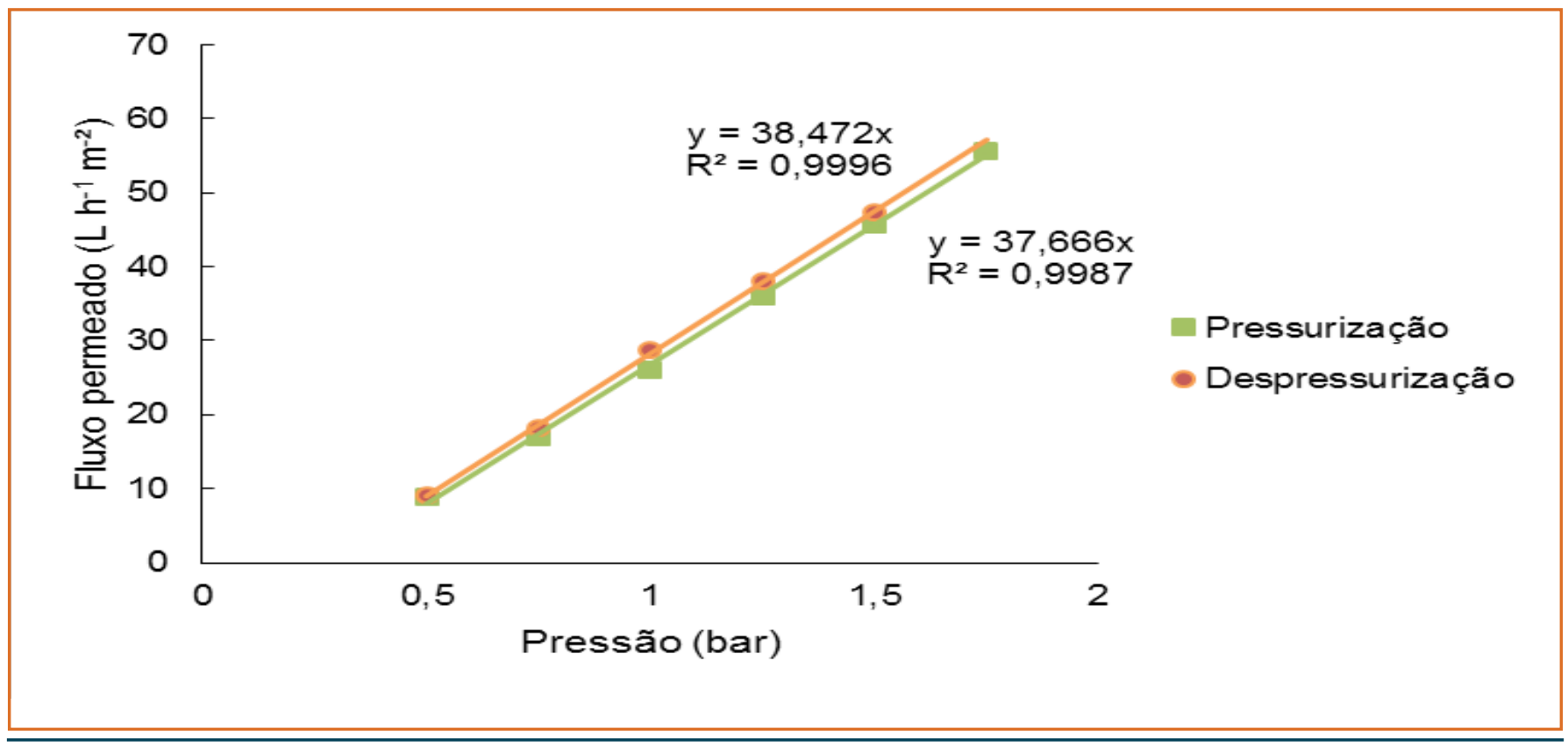


Os fluxos permeados encontrados nos ensaios de pressurização e despressurização (MF: 109,47 L h-1 m-2 bar-1; UF: 26,07 L h-1 m-2 bar-1), estão acima dos estabelecidos no manual de operação do módulo (PAM MEMBRANAS, 2012) e dispostos no Quadro 1 (MF: 99,7 L h-1 m-2 bar-1; UF: 25,37 L h-1 m-2 bar-1). Porém, as condições de realização foram diferentes. No manual, para a membrana de microfiltração, os ensaios foram realizados com água previamente microfiltrada. Para a membrana de ultrafiltração, os dados disponibilizados no manual informam que os ensaios foram realizados com água da concessionária de abastecimento público. Nos ensaios dispostos nas
Figuras 4 e 5 foi utilizado água destilada.

Os dados de pressurização e despressurização foram utilizados para estabelecer a permeabilidade das membranas de MF e UF com água destilada, padronizando tais valores, para o restabelecimento do fluxo permeado após a limpeza das membranas.

Nas Figuras 6 e 7, estão dispostos os fluxos encontrados para a pressurização e despressurização dos módulos de microfiltração e ultrafiltração, quando realizados com efluente de laticínio coletado após a lagoa aerada (AATS).

Figura 6 - Fluxo permeado no decorrer do tempo e à variação da pressão (pressurização e despressurização) da membrana de microfiltração (MF 158) com efluente de laticínio.

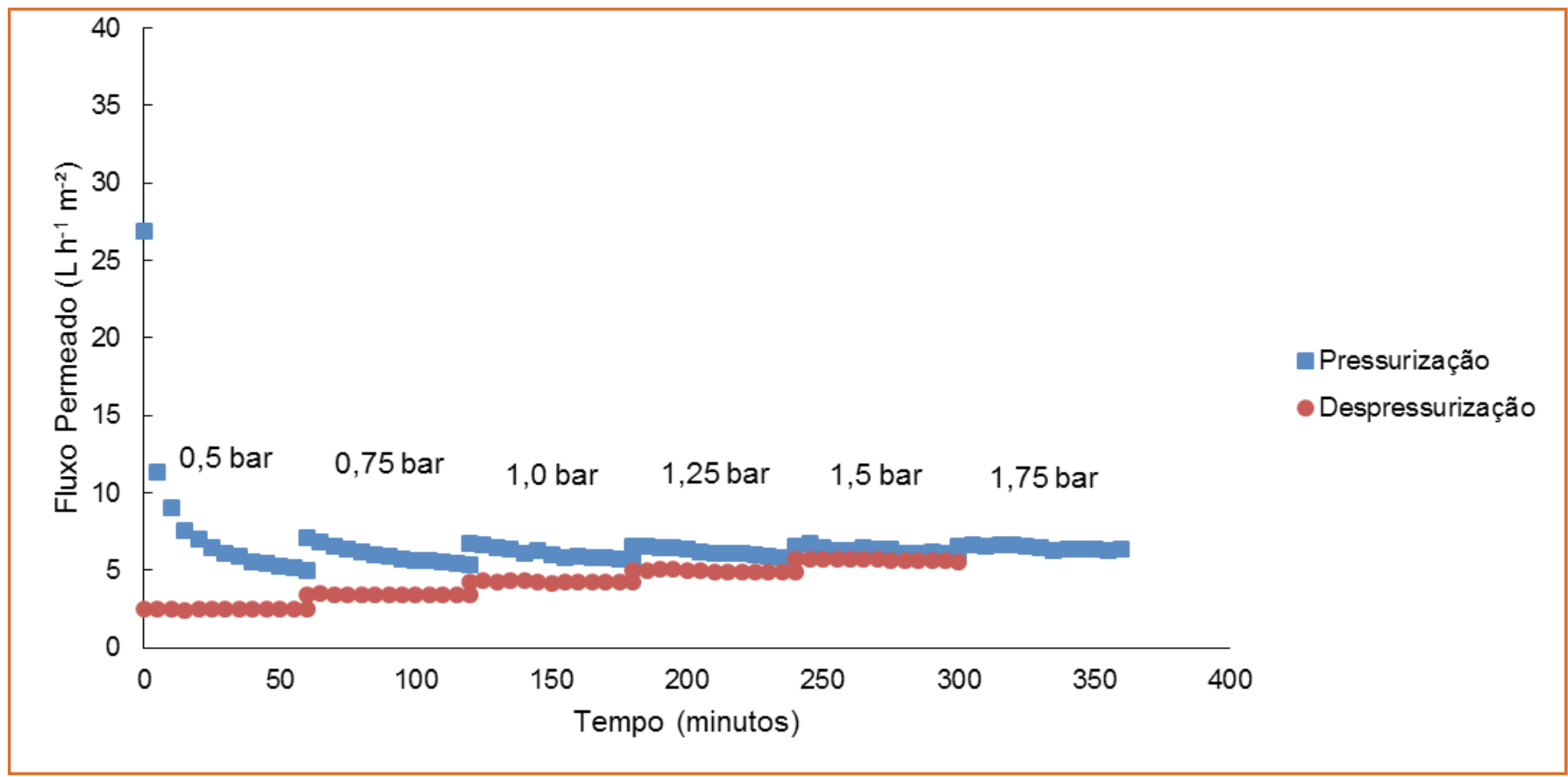


Figura 7 - Fluxo permeado no decorrer do tempo e à variação da pressão (pressurização e despressurização) da membrana de ultrafiltração (UF 257) com efluente de laticínio.

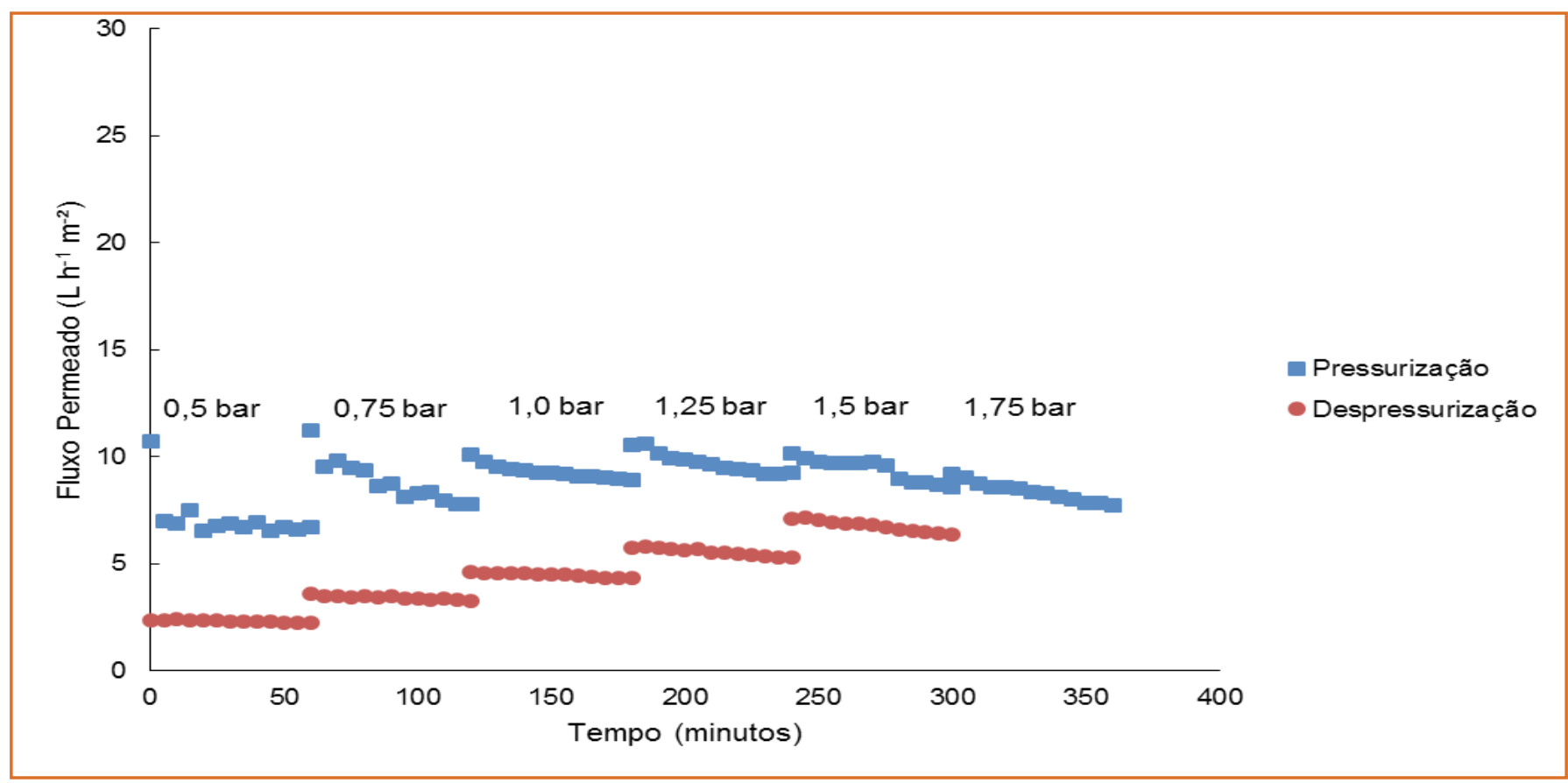

Para os ensaios com a utilização do efluente de laticínio, é mais evidente o fenômeno de histerese de ambas as membranas quando comparadas com o fluxo encontrado quando da passagem de água. Para todas as pressões das duas membranas, houve queda do fluxo na despressurização, evidenciando o entupimento dos poros e a influência da compactação destes na redução do fluxo permeado.

A queda do fluxo foi mais evidente para as pressões menores, em ambas as membranas. Essa redução indica que, o efluente oriundo do tratamento secundário da indústria, favorece a formação de incrustação na superfície da membrana, aumentando o entupimento do poro e, consequentemente, os fenômenos de colmatação e polarização de concentração.
Resultados semelhantes ao do presente estudo foram também encontrados por Fappi (2015), que estudou membranas de MF e UF, da PamMembranas Seletivas, semelhantes às utilizadas no presente trabalho, e encontrou diminuição do fluxo na pressurização e despressurização usando efluente de matadouro frigorífico e estabelecendo metodologia depressurização e despressurização semelhante a aplicada no presente estudo.

As Figuras 8 e 9, expõem a linearidade referente ao fluxo permeado das membranas de micro e ultrafiltração para a água destilada e para o efluente, de acordo com as pressões aplicadas. Observa-se que a permeabilidade das membranas para o efluente de laticínio é menor. 
Figura 8 - Comportamento do fluxo permeado de água destilada em função do diferencial de pressão aplicado à membrana de microfiltração (MF 158) e de ultrafiltração (UF 257).

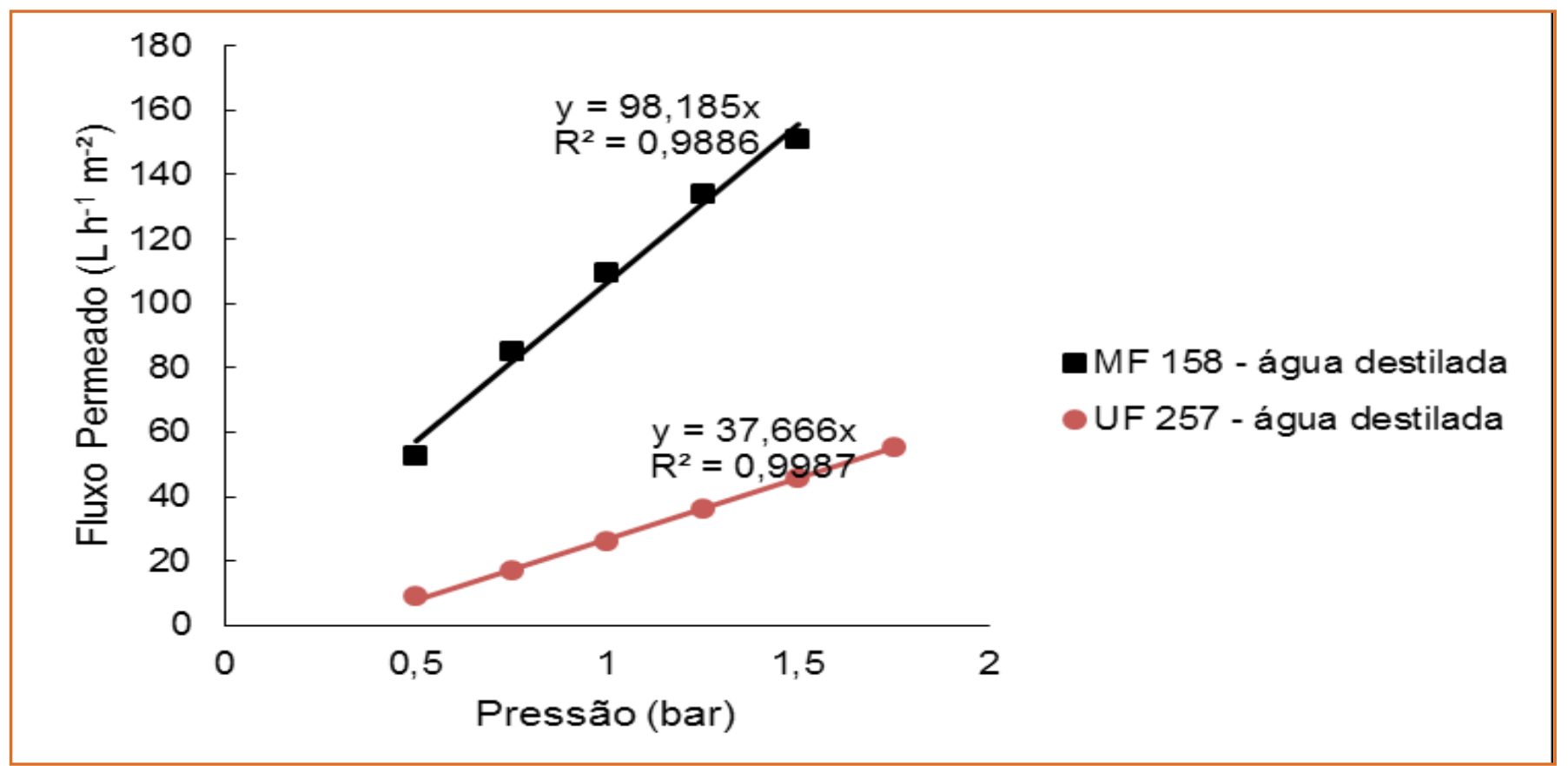

Figura 9 - Comportamento do fluxo permeado de amostra de efluente após o tratamento secundário (AATS) em função do diferencial de pressão aplicado às membranas de microfiltração (MF 158) e ultrafiltração (UF 257).

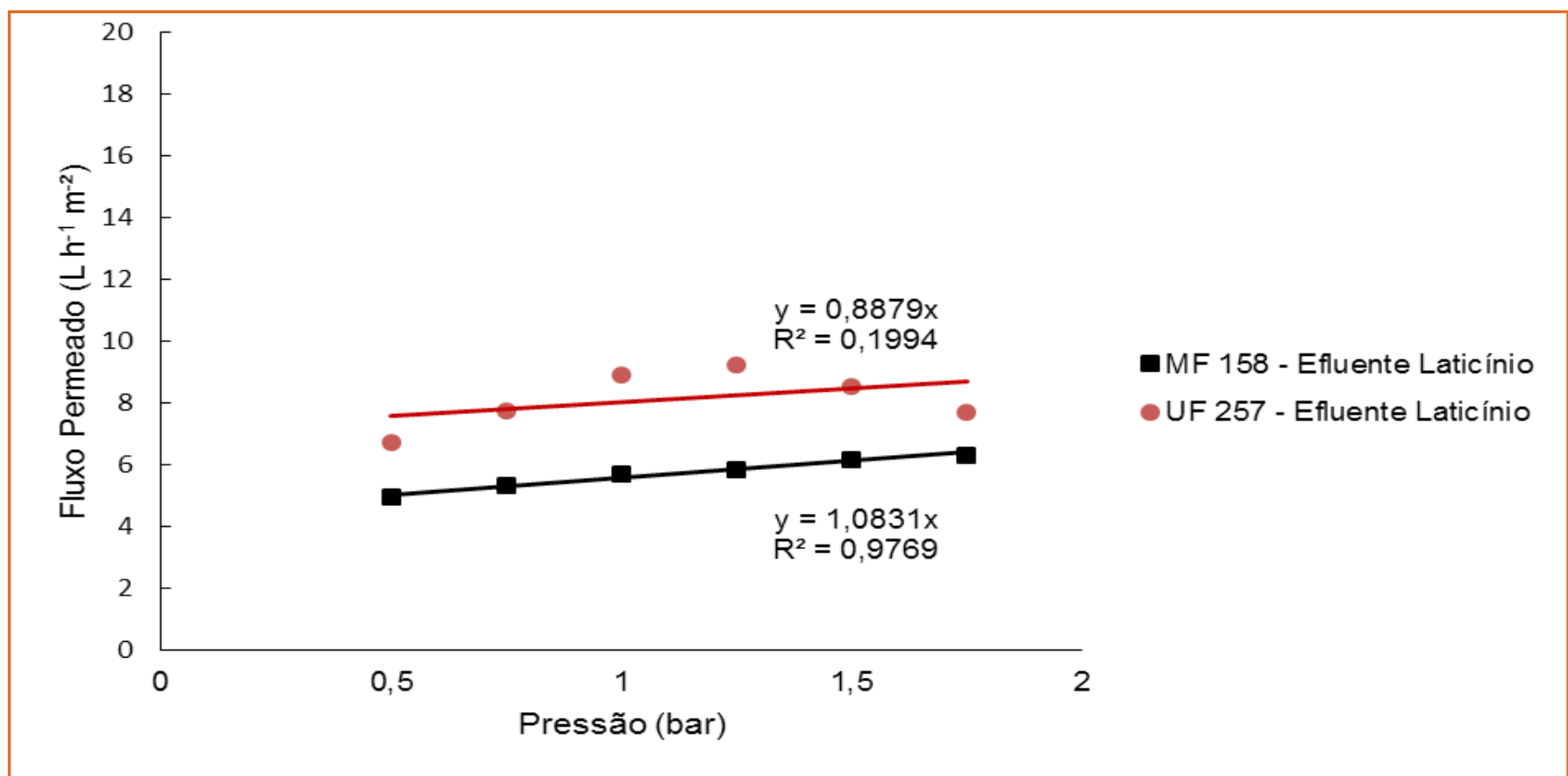

O aumento no fluxo permeado de água destilada das membranas de MF e UF fica visível com o aumento da pressão. Entretanto, a permeabilidade das membranas de MF e UF para o efluente de laticínio é menor que para água destilada, e a visualização do aumento do volume de permeado com o aumento da pressão fica pouco visível.

A linearidade do fluxo permeado com o aumento da pressão ocorre, para a membrana de MF, tanto com água destilada quanto para o efluente de laticínio (Figuras 8 e 9). Já para a membrana de UF, 
a linearidade ocorre apenas para a água destilada. Quando ocorreu a filtração de efluente de laticínio, a partir do aumento da pressão de 1,25 para 1,5 e em seguida para 1,75 bar, o fluxo permeado apresentou um pequeno decréscimo (Figura 9). A não linearidade do fluxo permeado com o aumento da pressão pode indicar o acúmulo de partículas na superfície da membrana

É possível perceber que a colmatação afeta ambas as membranas quando há permeação de efluente oriundo de laticínio. A diferença nos fluxos permeados já era esperada, comparando-se com os resultados obtidos em outros estudos (AMARAL et al., 2013; FAPPI, 2015; ANDRADE et al., 2001)

Pode-se atribuir a não linearidade e a queda do fluxo no decorrer do tempo ao entupimento dos poros e formação de incrustação na superfície da membrana, o que amplia a resistência à permeabilidade do fluxo, quando da existência de poluentes na solução que é permeada (HABERT et al., 2006).

\subsection{COEFICIENTE DE COLMATAÇÃo PARA AS MEMBRANAS DE MICROFILTRAÇÃO E ULTRAFILTRAÇÃO}

De acordo com Rao (2002), o coeficiente de colmatação indica o acúmulo de partículas na superfície da membrana, que diminuem a passagem do líquido a ser permeado pelos poros. Na Tabela 2 estão dispostos os valores para os coeficientes de colmatação das membranas de MF e UF, para as diferentes pressões utilizadas, e nos tempos de 30 e 60 minutos.
Tabela 2 - Coeficiente de Colmatação das membranas de MF e UF, nas diferentes pressões e nos tempos de 30 e 60 minutos

\begin{tabular}{|c|c|c|c|c|c|c|}
\hline \multirow[b]{2}{*}{ Pressão (bar) } & \multicolumn{3}{|c|}{$\begin{array}{l}\text { Membrana de } \\
\text { Microfiltração }\end{array}$} & \multicolumn{3}{|c|}{$\begin{array}{l}\text { Membrana de } \\
\text { Ultrafiltração }\end{array}$} \\
\hline & 0,5 & 0,75 & 1,0 & 0,5 & 1,0 & 1,5 \\
\hline Tempo (minuto) & 30 & 30 & 30 & 30 & 30 & 30 \\
\hline $\begin{array}{l}\text { Coeficiente de } \\
\text { Colmatação (CC) }\end{array}$ & 0,76 & 0,75 & 0,89 & 0,10 & 0,21 & 0,41 \\
\hline Tempo (minuto) & 60 & 60 & 60 & 60 & 60 & 60 \\
\hline $\begin{array}{l}\text { Coeficiente de } \\
\text { Colmatação (CC) }\end{array}$ & 0,79 & 0,78 & 0,89 & 0,14 & 0,17 & 0,44 \\
\hline
\end{tabular}

A membrana de MF apresentou valores altos de CC para todas as pressões e nos tempos de 30 e 60 minutos. Os CC foram bem superiores aos de UF em todas as pressões. À pressão de 0,75 bar apresentou os menores CC, 0,75 e 0,78, nos tempos de 30 e 60 minutos, respectivamente, valores semelhantes aos da pressão de 0,5 bar que foram de 0,76 e 0,79, nos tempos de 30 e 60 minutos, respectivamente. Os maiores valores do CC foram à pressão de 1,0 bar, 0,89 nos tempos de 30 e 60 minutos, chegando-se próximo ao entupimento da membrana.

A membrana de UF apresentou CC menores, principalmente comparando-se com a membrana de MF. Para as pressões de 0,5 e 1,0 bar, aos 60 minutos, o CC foi de 0,14 e 0,17, respectivamente.

Os valores elevados de colmatação para a membrana de UF ocorreram à pressão mais alta, sendo maiores principalmente na pressão de 1,5 bar, na qual, no tempo de 60 minutos, chegou a 0,44.

Conforme afirmam Vidal e Campos (2009), a fração coloidal presente nos efluentes que são microfiltrados, a qual compreende a faixa de partícula próxima do diâmetro dos poros da membrana de microfiltração, é a mais relevante na colmatação dessas membranas, causando na maior parte das vezes, obstrução interna dos poros. Mesmo a retrolavagem e o escoamento tangencial pela membrana não são suficientes para a remoção destas partículas nas membranas.

O fouling aliado a concentração de polarização representam as maiores limitações para a aplicação de 
membranas no tratamento de efluentes (RAO, 2002). Verifica-se através dos valores de CC encontrados que a membrana de MF tem maior acúmulo de partículas em sua superfície se comparada com a membrana de UF. Isso pode significar que a aplicação de tal membrana pode ser limitada para o efluente oriundo de laticínio. A membrana de UF sofre menor influência dos fenômenos de fouling.

\section{CONSIDERAÇÕES FINAIS}

As membranas de microfiltração e ultrafiltração, com relação a permeação de água destilada, praticamente não apresentaram redução de fluxo e influência dos fatores de polarização da concentração, colmatação, incrustação na superfície da membrana e entupimento de poros, sendo pouco sensíveis à histerese e/ou compactação do polímero da membrana, devido à reversibilidade das condições iniciais de fluxo, quando da pressurização e despressurização do módulo.

Com a permeação de efluente pela membrana, contrariamente, houve influência dos fatores de polarização da concentração, colmatação, incrustação na superfície da membrana e entupimento de poros, o que causou a redução do fluxo permeado e entupimento das membranas de microfiltração e ultrafiltração.

O fluxo de água destilada aumenta linearmente com o aumento da pressão aplicada a membrana de microfiltração e ultrafiltração, ou seja, quanto maior a pressão aplicada a membrana, maior o fluxo permeado. Quando emprega-se as mesmas condições operacionais, ocorre uma diferença significativa nos fluxos permeados utilizando amostras de água destilada e efluentes. Tanto para a microfiltração, quanto para a ultrafiltração, o fluxo de água destilada foi superior ao fluxo permeado das amostras de efluentes.

O cálculo do coeficiente de colmatação para a membrana de MF e UF nas diferentes pressões $(0,5$, 0,75 e 1,0 bar para MF e 0,5, 1,0 e 1,5 bar para UF), demonstrou que as duas membranas sofrem com 0 acúmulo de partículas na superfície da membrana, porém, a membrana de MF apresentou maior efeito de colmatação, o que pode comprometer o seu uso no tratamento de efluente de laticínio após o tratamento secundário por lagoa aerada de mistura completa.

\section{REFERÊNCIAS}

[1] ABNT - ASSOCIAÇÃO BRASILEIRA DE NORMAS TÉCNICAS. Planejamento de amostragem de efluentes líquidos e corpos receptores. Procedimento. NBR 9897. Rio de Janeiro, 1987a.

[2] Rio de Janeiro: Preservação e técnicas de amostragem de efluentes líquidos e corpos receptores. Procedimento. NBR 9898. Rio de Janeiro: 1987b.

[3] AMARAL, M. C. S. ANDRADE, L. H. de. LANGE, L. C. BORGES, C. P. Avaliação do emprego de microfiltração para remoção de fibras do efluente de branqueamento de polpa celulósica. Revista de Engenharia Sanitária e Ambiental. V. 18, n. 1, p. 65-74. Jan-mar 2013.

[4] AMERICAN PUBLIC HEALTH ASSOCIATION - APHA; AMERICAN WATER WORKS ASSOCIATION - AWWA; WATER ENVIROMENT FEDERATION - WEF. Standard methods for the examination of water and wastewater. 22 ed., Washington, DC: APHA, 2012.

[5] ANDRADE, J. F. ELIAS, R. J. WOLF, D. B. COSTA, R. H. R. LAPOLLI, F. R. Microfiltração de efluente sanitário tratado através do processo de lodos ativados. In: 21ํㅡㄹ Congresso Brasileiro de Engenharia Sanitária e Ambiental. 2001.

[6] BEZERRA, L. F. MATSUMOTO, T. Avaliação da remoção da matéria orgânica carbonácea e nitrogenada de águas residuárias em biorreator de membranas. Revista de Engenharia Sanitária e Ambiental. V.15, n. 13, p. 253-260, Jul/set 2011.

[7] CONSTANZI, R. N. Tratamento de efluentes domésticos por sistemas integrados de lodos ativados e membranas de ultrafiltração visando o reúso de água. 2007. 200 f. Tese (Doutorado em Engenharia Hidráulica e Sanitária) Escola Politécnica de São Paulo. São Paulo, 2007.

[8] CONSELHO ESTADUAL DO MEIO AMBIENTE. Resolução no 70, de 1 de outubro de 2009 - Condições e padrões de lançamento de efluentes líquidos industriais.

[9] DACANAL, M. BEAL, L. L. Filtro anaeróbio associado à membrana de microfiltração tratando lixiviado de aterro sanitário. Revista Sanitária e Ambiental. V. 15, n. 1. Jan-Mar 2010, p. 11-18.

[10] FAPPI, Devanir André. Micro e ultrafiltração como pós-tratamento para o reúso de efluentes de abatedouro e frigorífico de suínos. 2015. 126 p. Dissertação (Mestrado em Tecnologias Ambientais). Universidade Tecnológica Federal do Paraná. Medianeira, 2015. 
[11] GIACOBBO, A. RODRIGUES, M. A. S. BERNARDES, A M. FERREIRA, J. Z. MENEGUZZI, A. Microfiltração aplicada ao tratamento de efluentes de curtume. In: VII Simpósio Internacional de Qualidade Ambiental. Porto Alegre, Rio Grande do Sul, 2010.

[12] HABERT, A. C.; BORGES, C. P.; NOBREGA, R. Processos de separação por membranas. Rio de Janeiro: E-papers, 2006.

[13] MAGANHA, M. F. B. (Elab.). Guia técnico ambiental da indústria de produtos lácteos - Série $\mathrm{P}+\mathrm{L}$. São Paulo: CETESB, 2008.

[14] MIERZWA, J. C.; HESPANHOL, I. Água na indústria: uso racional e reúso. São Paulo: Oficina de Textos, 2005.
[15] PAM MEMBRANAS. Manual de instalação, operação e manutenção. Unidade de MF/UF/NF de bancada, 2012.

[16] RAO, R. H. G. Mechanisms of flux decline during ultrafiltration of dairy products and influence of $\mathrm{pH}$ on flux rates of whey and buttermilk. Desalination. Amsterdan, v. 144, n. 1-3, p. 319-324, 2002.

[17] SARMENTO, L. A. V. Obtenção e separação de polifenóis de sementes de cacau por extração supercrítica associada a membranas. 2007. 103 p. Tese (Doutorado em Engenharia Química). Universidade Federal de Santa Catarina, Florianópolis, 2007. 


\title{
CAPÍTULO 5
}

\section{ORANGE COUNTY E A REDE DE PRODUTOS AGRÍCOLAS DO SLOW FOOD}

\author{
Franciele Lourenço \\ Luciane Cristina Ribeiro dos Santos \\ Osíris Canciglieri Junior \\ Liliane Cristina Schlemer Alcântara
}

Resumo: O objetivo deste artigo foi analisar o movimento slow food de Orange County a fim de identificar a sua capacidade de organização frente ao movimento slow food. Metodologicamente, utilizou-se de instrumentos metodológicos, de ordem qualitativa com caráter exploratório. Dessa forma, foi reconstruída a trajetória e a difusão de um dos casos do movimento Slow Food, localizado em Orange County, Califórnia, Estados Unidos da América. Tal projeto é uma organização composta por um grupo diversificado de amantes da boa culinária, que conta com variados tipos de membros, os quais buscam novas formas de agricultura e, construir uma rede de feiras agrícolas baseadas nos princípios do Slow Food. Percebeu-se que o movimento slow food de Orange County possui uma capacidade de organização, principalmente no que se refere aos produtores ruais. Sobretudo, algumas formas do movimento auxiliam e protegem os produtores locais em dificuldades conectandoos com mercados alternativos, por meio da construção de relações, prezando a proteção dos produtos tradicionais e locais e qualidade de vida.

Palavras chave: Slow food, Agricultura, Orange County. 


\section{INTRODUÇÃO}

O indivíduo moderno adotou um estilo de vida muito diferente de seus antepassados, onde nem mesmo as crianças sabem a origem de animais, comidas ou até mesmo como é brincar ou passar as férias no campo. São tradições e fatores que escapam ao controle das pessoas, devido ao ritmo acelerado da vida. Dessa forma, o dinheiro, o tempo e os interesses se tornam mais importantes, enquanto outras escolhas e alternativas vão ficando para trás.

A dinâmica da vida moderna nas cidades passou a moldar e a dar sentido as 'coisas', tanto na evolução das necessidades quanto a dos hábitos, os quais se solidificaram na busca pela praticidade, conforto e comodidade.

Por isso, em meio ao stress e a correria do dia a dia vivido nas grandes cidades, as pessoas se tornam protagonistas da ascensão das comidas industriais e das cadeias de fast food, que crescem de maneira desordenada, assim como sua adesão, o que preocupa, pois além deste tipo de comida não ser saudável, vem colaborando para o grande aumento de pessoas com problemas de diabetes, doenças cardiovasculares, obesidade, etc.

Contudo, as pessoas ficam a 'mercê' dos alimentos, sem nem ao menos saberem sua procedência e, é neste sentido que na década de 1970, o italiano Carlo Petrini iniciou um movimento chamado de slow food (Slow Food de County Orange, 2009), como uma organização internacional sem fins lucrativos, cujo objetivo é difundir a cultura alimentar, para desenvolver a educação sensorial e de bom gosto, protegendo a biodiversidade e promovendo a qualidade dos alimentos, do ambiente e da vida social.

É importante lembrar que, o slow food surgiu a partir do ambiente político e social turbulento da Itália, em meio aos movimentos e protestos do operariado em relação a industrialização e globalização da produção. Mas foi somente em 1989, que o conceito se internacionalizou e, a partir daí várias tecnologias surgiram, tais como os Organismos Geneticamente Modificados (OGM) - usados na agricultura industrial, o quê preocupa e muito os ambientalistas, dado que ainda não se possui muitos estudos a longo prazo sobre o assunto; ameaçando a biodiversidade e as economias agrícolas locais.

A partir deste contexto, questionou-se quais são as políticas e estratégias de desenvolvimento adotadas pelo governo e pelos agricultores do movimento slow food de Orange County, Califórnia, EUA. O objetivo geral foi analisar o movimento slow food de Orange County a fim de identificar a sua capacidade de organização frente ao movimento slow food.

Paratanto, foramaplicadosinstrumentosmetodológicos, de ordem qualitativa de caráter exploratório, utilizando como base de avaliação os princípios de atuação que se apresentou no documento do Comitê de Orange County.

O trabalho foi estruturado à partir da Introdução. $\mathrm{Na}$ sequência foi apresentado o conceito de slow food; suas características e interesses; políticas e estratégias de desenvolvimento; técnicas e processo produtivo. O terceiro capítulo dispõe do caso do slow food de Orange County, Califórnia, EUA e, por fim as considerações finais e referências.

\section{SLOW FOODS}

Esse movimento foi criado na Itália no final dos anos 1980, seu surgimento se deu em resposta aos problemas vividos naquela época, principalmente pelo modo de vida e ao consumismo. Entre os problemas destacam-se: o uso excessivo de antibióticos no gado e outros animais, agrotóxicos nas plantações e outros componentes prejudiciais a saúde. O movimento preza que as pessoas precisam ter um tempo para se alimentar de forma que possam saborear o alimento a fim de sentir prazer com esse momento. Que o alimento consumível seja o mais natural possível, livre de agrotóxicos ou geneticamente modificado.

Gentile (2008) ainda complementa que foi um movimento, que se iniciou especificamente em 1989, na cidade de Bra na região de Piemonte, adotando como símbolo o caracol. O evento que motivou sua criação foi a mobilização em resposta a abertura de um Mc Donalds na Piazza Di Spagna, em Roma. 
Figura 1: Símbolo do Slow Food

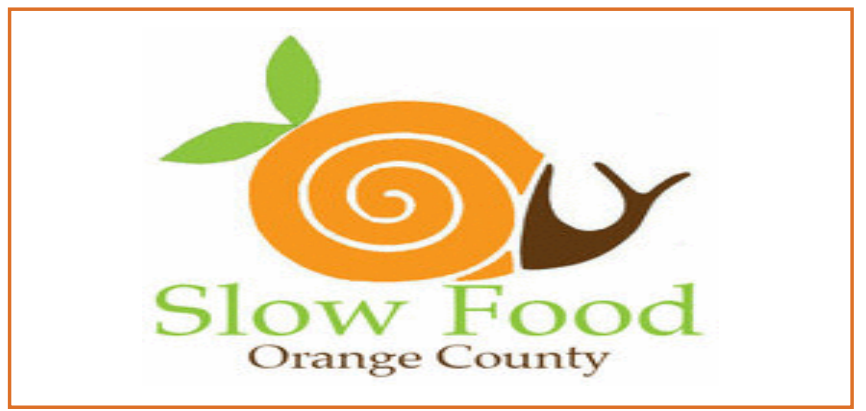

Fonte: Manual do Slow Food (2005)

O termo slow food ou comida sem pressa, é uma expressão que passou a circular há pouco toda essa 'revolta' diz respeito a vida moderna nas cidades, que acaba por não oferecer tanta opção, no que diz respeito à alimentação saudável, impossibilitando as pessoas de fazerem uma refeição completa, de qualidade e o mais importante, com tempo de apreciação. Então, o empenho do movimento é o de defesa de uma vida tranquila, se opondo a vida corrida do meio urbano.

Segundo o Manual do Slow Food (2005), através dos seus conhecimentos gastronômicos relacionados com a política, agricultura e ambiente, o Slow Food tornou-se uma voz ativa na agricultura e na ecologia; conjugando prazer e alimentação com consciência e responsabilidade.

Todos os acontecimentos da Terceira Revolução Industrial promoveram o crescimento da coordenação política; crescente utilização dos recursos naturais, promoção e ampliação do incremento da produtividade e mais ainda, difusão de inovações econômicas.

Tão logo, o que ficou de lado neste processo foi a preocupação com a produção de alimentos; a agressão ao ecossistema e aos seres vivos.

Portanto, o que se nota é que Homem e Natureza estão vivenciando momentos de tensão, pois antigamente $\mathrm{o}$ homem respeitava a natureza, mas hoje há uma desconexão muito grande, a exemplo do desmatamento, uso de agrotóxico nas plantações que contamina o meio ambiente entre outros pontos (SANTOS, 1992).
Ademais, o 'comer' ficou distanciado do nosso dia a dia e a preocupação é uma alimentação rápida e sem a preocupação de como foram produzidos os alimentos; de onde vieram ou sua qualidade. Saber o que está escolhendo e entender se aquilo está em extinção, possui agrotóxicos ou se faz bem a saúde, etc., para alguns já não faz tanta diferença.

De outro lado, o slow food é considerado um movimento amplo e com uma proposta diferente de aproximação de produtores e consumidores; defesa da biodiversidade e da alimentação tornaram-se princípios deste movimento, que acredita na defesa de uma boa e responsável alimentação, além da tradições e culturas culinárias. Este movimento é interessante porque passa desde o processo de transformação do meio ambiente até o prato do consumidor final.

Os três pré requisitos para um alimento de qualidade são: bom (de sabor e qualidade); justo (preço justo para produtor e consumidor final em relação ao processo produtivo) e; limpo (além de ser ecológico, não ser poluente). Tudo isso servirá de resposta ao modo de viver das pessoas, focando no resultado (gosto) e preço. Estas duas premissas estando satisfeitas nada mais importará.

O Manual do Slow Food (2005) ainda diz que, "num mundo onde os prazeres do gosto nem sempre se apreendem durante refeições alegres em volta duma mesa animada, deve-se fazer um esforço consciente por explorar, questionar e experimentar. Este é o objetivo das iniciativas de educação do gosto do Slow Food".

É preciso resgatar a alimentação correta, os sabores e a procedência para que não se diminua o papel central que exercem em nossas vidas. Logo, a conscientização e o reconhecimento da vida tumultuada em que vivemos são necessárias e, uma das formas é o movimento das slow cities.

O slow cities, conceito que também nasceu na Itália em conjunto com a ideia do slow foods, no entanto, no ano de 1999, aconteceu pelo fato de os moradores de pequenas cidades italianas estarem cansados do rápido ritmo das metrópoles. 
"Devagar", como princípio de toda uma campanha por qualidade de vida, naturalmente chegou às cidades. De acordo com o Movimento Conviva, o "slow cities" quer priorizar, pela sua iniciativa, atitudes que desacelerem o ritmo das cidades e suas principais e velozes características - incluindo o trânsito.

E, para que o objetivo do Movimento do Slow Cities realmente fosse aplicado, o Movimento Conviva passou a aplicar a metodologia de que a cidade não pode ter mais de 50 mil habitantes. Há uma carta de princípios, o manifesto das "cidades lentas", que os candidatos devem seguir ao pé da letra. Eles estão divididos em categorias como estrutura, política de meio ambiente, qualidade das vias urbanas e encorajamento ao uso e produção de bens localmente.

Assim, a poluição sonora, os engarrafamentos e o próprio stress seriam amenizados, já que o tráfego seria reduzido, as cidades seriam mais "lentas" e principalmente a poluição sonora diminuiria.

Percebe-se que um dos problemas está relacionado a caracterização das cidades, tendo em vista que já se vive em um processo que parece não ter mais volta; sendo assim, a implantação não é dependente do tamanho da cidade, logo, não seria tão difícil, desde que os princípios fossem atendidos.

\subsection{POLÍTICAS E ESTRATÉGIAS DESENVOLVIMENTO DO SLOW FOOD}

As políticas e estratégias de desenvolvimento vivem pressionadas pelo consumismo, que faz com que a economia cresça aceleradamente, proporcionando um processo produtivo que se reproduz mediante as incessantes e ilimitadas necessidades humanas. Este processo invoca um modelo de vida que necessita de uma reavaliação, pois o apetite pela ânsia; a pressa pelo consumo e a correria da vida moderna transformaram os homens em 'escravos do excedente econômico'.

O direito de cada homem de buscar a coerência de um projeto existencial no emprego do seu próprio tempo, ou ainda, de ganhar consciência e autonomia implica que as suas singularidades naturais e individuais conseguirão gerar uma criatura original ou irredutível. Nessa perspectiva, os homens são atores sociais - cada um conservando sua singularidade - que assumem funções distintas na sociedade, conforme suas ansiedades e possibildades (SAMPAIO, 2011)

Ademais, o slow food torna-se importante por propor o emprego do tempo e por ser uma alternativa organizada, que preza tanto o aspecto individual quanto o coletivo, pois as pessoas estão fazendo o bem para si mesmas e promovendo a participação de um conjunto de pessoas.

Rico em sua organização, o movimento propõe modos originais de agrupar pessoas, saberes e fazeres em torno do que talvez pudéssemos chamar de uma ecologia da alimentação [...]. As formas de luta vão dos manifestos às redes de produtores e feiras de gastronomia (GENTILI, 2008). Apesar das evidentes expressões e das iniciativas de Carlo Petrini sobre os aspectos culturais; de promoção das tradições e das questões políticas e de democracia.

O movimento fundado por Petrini contestava a base ética daquela que era definida "vida veloz", que criticava a confusão entre eficiência e frenesi e exaltava as virtudes de uma vida lenta, baseada nos valores e nos prazeres dos sentidos e da sabedoria (ANDREWS, 2008).

Mas o movimento não ficou limitado apenas a alimentação, ele tomou proporções internacionais, as quais incorporaram novas agendas políticas, novas questões e novas lutas para novos contextos, bem como a realização de eventos e de projetos voltados à redescoberta e valorização de produtos típicos, biodiversidade (sementes e espécies nativas), sociodiversidade (saberes e práticas agrícolas tradicionais) e de processos produtivos atentos ao equilíbrio ecológico (GENTILLE, 2008).

O mais interessante do movimento é que ele aceita os 
mais variados tipos de membros e a preocupação é, em aspecto social, ou seja, todos fazem a sua parte em prol de um objetivo comum. O que os tornam coprodutores e não simples consumidores, isso faz com que o processo de produção seja feito por meio de uma parceria entre produtores e consumidores.

Portanto, é uma associação democrática aberta a todos, qualquer pessoa pode se associar, o mais interessante é a diversidade dos seus associados, o que contribui a tornando forte.

Para se cadastrar basta preencher um formulário de adesão e contactar o chamado líder do Convivium local ou inscrever-se através do site internacional (www.slowfood.com) - a inscrição é anual e renovável.

Os envolvidos podem delegar um convivium ou abrir um novo convivium, organizando eventos ou participando de atividades voltadas ao slow food.

O Manual do Slow Food conceitua o 'convivium' como uma palavra Latina que significa 'um festim, entretenimento, um banquete', e o slow food usa este nome muito adequado para designar as suas células locais. Os convivia são representantes locais da filosofia do Slow Food, além disso, existem cerca de 1.000 convivia espalhados pelo mundo formando uma rede de movimento.

A função dos convivia também é a de construir relações com os produtores, prezar pela proteção dos produtos tradicionais e locais e a qualidade de vida. O que também surpreende é a capacidade de organização, de ajuda e de proteção que os produtos locais em dificuldades encontram em mercados alternativos.

A grande disseminação das informações acerca desse movimento e o grande grupo de relacionamentos, por meio de mercados alternativos cresce a cada dia, assim como a própria conscientização do governo, mercado e população em geral, o que colabora para a proteção de todos em relação a seus objetivos.

Logo, a promoção e as políticas de desenvolvimento do slow food estão pautadas na participação da população e nas iniciativas de educação alimentar e ação social e ao apoio aos pequenos agricultores.

\subsection{TÉCNICAS AGRÍCOLAS E DO PROCESSO PRODUTIVO}

A participação no slow food tem colaborado com as técnicas dos processos agrícolas, pois estão trazendo melhores resultados, no que diz respeito à participação e capacitação dos envolvidos.

O slow food entrou em estreita
sinergia com lutas altermundistas
pelo comércio justo, bem como com
as lutas socioambientais por modos
de produção, produtos, produtores e
consumidores ecológicos. Além disto,
o slow promete uma interessante fusão
da dimensão prazerosa e sofisticada
da ecogastronomia com os ideais de
solidariedade e de convívio preconizado
pelos defensores de uma vida simples ou
"simplicidade voluntária", como caminho
para uma existência ecologicamente
orientada (CARVALHO, 2008, p. 2).

Para que isso fosse possível, o movimento do slow food criou um programa chamado Terra Madre ou Mãe Terra, o qual teve o objetivo de criar 1.000 hortas em todo o continente - reunindo desta forma, uma rede internacional de 2.000 comunidades de alimentos, entre eles os produtores de alimentos e representantes de comunidades locais, cozinheiros, acadêmicos e jovens de 160 países, com vistas a estabelecer uma produção de alimentos bons, limpos, justos e que respeitem o nosso planeta (MANUAL DO SLOW FOOD, 2005).

Essas mil hortas são modelos concretos de agricultura sustentável, que interessa às escolas, a comunidade e/ou famílias. As hortas além de servirem de alimento; colaboram para que a população entre em contato com a natureza, participe da sua manutenção e promova conhecimentos (MANUAL DO SLOW FOOD, 2005). 
Chef de Culinária Natural, membro do Slow Food e proprietária do Espaço Zym, várias e fáceis são as alternativas as quais podemos inserir em nosso dia a dia, o que colabora para uma vida de maior qualidade:

I. Construir uma horta em casa;

II. Conhecer melhor o alimento que vai pra sua mesa;

III. Comprar alimentos de produtores locais;

IV. Proteger os alimentos nacionais para que não entrem em extinção;

V. Procurar ambientes tranquilos para realizar suas refeições e;

VI. Cultivar relacionamentos e companhias agradáveis.

Portanto, percebe-se que 'coisas' simples podem fazer a diferença e trazer um novo modo de vida, o que colabora para uma vida menos agitada e estressante e, que pode tentar garantir que a escassez ou até mesmo a extinção sejam repensadas e até mesmo sanadas.

\section{OCASODEORANGECOUNTY:CARACTERIZAÇÃO E A CAPACIDADE DE ORGANIZAÇÃO FRENTE AO MOVIMENTO SLOW FOOD}

Orange County está localizado a 40km de Manhattan, ou seja, ao sul da Califórnia, nos Estados Unidos da Améria - EUA, conforme mapa à seguir:

Figura 2 : Condado de Orange County, Califórnia, EUA

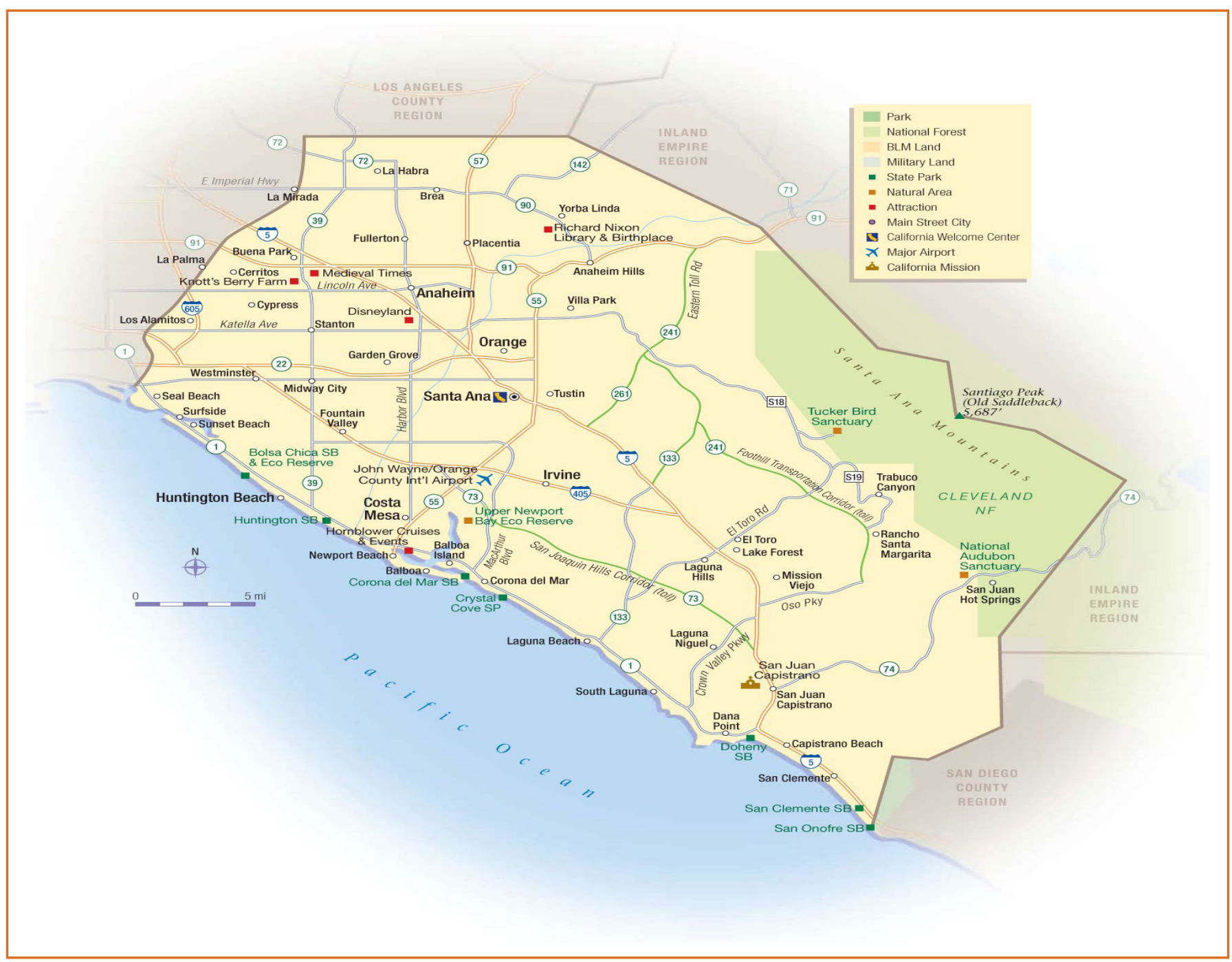

Fonte: http://mapsof.net/map/california-orange-county-map 
É um local que enfatiza o bem-estar e a qualidade de vida, principalmente pelos serviços disponibilizados à população.

Segundo o site do Condado de Orange, a chamada Orange County, foi criada em 1693 como um dos Condados originais da Província de Nova Iorque. O nome do município foi derivado do rei Willian III da Inglaterra, que era um príncipe da Casa de Orange. Portanto, é um dos 58 condados do estado americano da Califórnia, sendo fundado em 11 de março de 1889, ao se separar do vizinho Condado de Los Angeles e recebeu seu nome do cultivo da laranja e outros frutos cítricos que eram cultivados na região.

Orange County possui uma população estimada, de acordo com os dados de 2013 e 2010, respectivamente, da Census Bureau, de 3.114.363 pessoas e um área de 790,57 milhas quadradas, enquanto Califórnia possui 38.332.521 e 155,779.22 milhas quadradas.

Sendo assim, é um local que possui habitação com preços acessíveis; excelentes sistemas escolares, de transporte rodoviário, ferroviário e aéreo; baixos índices de criminalidade e uma vasta gama de atividades recreativas e de negócios.

Por isso, o caso de Orange County demonstra claramente a necessidade de que temos que pensar na sustentabilidade dos recursos e no nosso bem-estar - qualidade de vida aliada a longevidade. É preciso de forma diferente, governar nossas vidas e recursos, de tal forma que tenhamos novas alternativas de tornar nossa alimentação justa, boa e limpa.

Logo, a governança poderia colaborar para que os movimentos voltados pra este tipo de alternativa (slow food), sejam ainda melhores aproveitados e disseminados, de tal forma que não se restrinja à apenas um movimento ou grupo, mas sim o fortalecimento de uma política mais ampla.

Para isso, foi necessário entender a importância de se ampliar os movimentos sociais e a mudança de postura em relação a "independência" das áreas, o que na verdade não é real, a começar pelo julgamento que era feito sobre ecologia e economia, que até então eram consideradas áreas incompatíveis. A criação de alguns conselhos voltados ao diálogo e a promoção da cidadania, igualdade, democracia, conservação, etc foram de tal importância, já que colaboraram para que parte da sociedade assimilasse a importância em se politizar os riscos e de garantir a sustentabilidade (JACOBI, 2000).

O sistema alimentar mundial é atualmente controlado pela agricultura industrializada e pela globalização. Isto levou a distribuição desigual de alimentos, a falta de cultura e de um sistema alimentar ecologicamente insustentável.

Odesenvolvimentosustentávelapresentase como uma questão imperativa para criar condições de sobrevivência para a espécie humana. Embora o objetivo seja focado na preservação do ser humano, em condições satisfatórias de vida, a interconexão dos sistemas viventes exige uma regulação do sistema humano, na sua relação com o meio ambiente. As evidências deixam claro que, para viabilizar a permanência da espécie humana no planeta, garantindo qualidade de vida, é inviável manter a exploração acelerada e continuada dos recursos naturais e seu conseqüente esgotamento (PAULISTA et al, 2008, p. 1)

Logo, o desenvolvimento sustentável se torna a premissa básica deste movimento fortalecendo a ideia de sobrevivência dos recursos e da própria raça humana.

Por isso, em 2010 o Slow Food de Orange County (SFOC) foi criado como uma missão local do Slow Food EUA, que teve como premissa criar uma mudança duradoura no sistema alimentar, buscando reconectar pessoas, tradições e o ecossistema como um todo.

No entanto, seu objetivo era o de criar uma mudança 
duradoura no sistema alimentar local para assegurar a equidade, sustentabilidade e prazer na comida. Parcerias, publicações e eventos sociais são organizados constantemente, para que se possa aumentar a consciência pública à respeito dos problemas desarmônicos da vida cotidiana.

Conforme o Comitê de Orange County, os Princípios de Atuação são:

- Trabalhar em conjunto com o Slow Food EUA, aceitar e respeitar as Estatuto Nacional do Slow Food USA e os Protocolos financeiros;

- Estar consciente das dívidas organizacionais e de seus históricos;

- Alterar e melhorar as técnicas e práticas de liderança;

- Honrar e valorizar os produtos advindos da terra e os animais e;

- Fazer eventos abertos, acessíveis e sem custos para os participantes.
Segundo o SFOC, esta é uma associação aberta a todos e sua adesão é oficial, uma vez que um indivíduo tenha pago a sua quota anual ao Slow Food EUA, sendo encerrada uma vez que o indivíduo não renovar sua filiação ou pedir para ser retirado das funções de associação. Portanto, necessita-se de um Comitê Gestor, que é formado por voluntários não-remunerados - para garantir a continuidade e o funcionamento eficaz deste é necessária a participação em ao menos - das reuniões durante um ano, para que seja feita a decisão quanto a utilização dos fundos a serem gastos e o cumprimento das metas e responsabilidades. Quanto à Política de interesse, a confiança do público é fundamental, por isso cada membro do comitê deve divulgar seu interesse pessoal.

O Comitê é dividido em 07 (sete) áreas, conforme organograma à seguir, sendo 06 (seis) subordinadas a presidência.

Figura 3: Comitê diretivo da Slow Food - Orange County, Califórnia, EUA

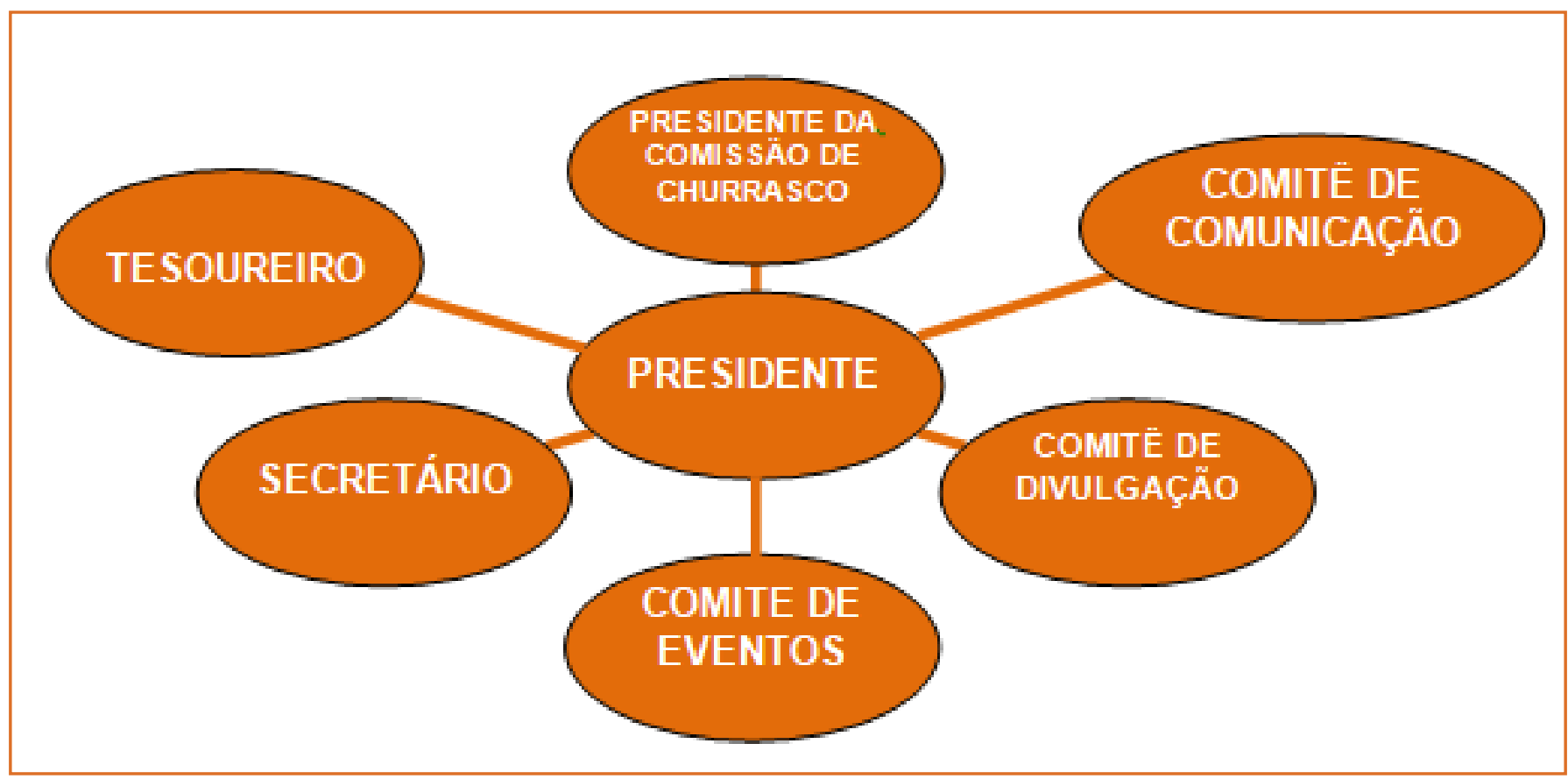

FONTE: adaptado de Manual do Slow Food (2005).

As funções pertinentes aos cargos são: o Presidente organiza as reuniões e a política e direção definida; o Tesoureiro mantém a organização dos livros; o
Secretário é responsável pelas atas das reuniãos; o Comitê de eventos cria eventos para angariar fundos para as instituições de caridade e de atividades 
associativas do Slow Food; o Comitê de divulgação entrelaça a política e os aspectos sociais, informando ao público à respeito do movimento e as atividades entre os agricultores e chefs; o Comitê de comunicação garante que a adesão seja ampla (notícias, anúncios de e-mail e boletins mensais regulares) e o Presidente da Comissão de Churrasco, que planeja e implementa - maior evento anual de angariação de fundos provenientes do churrasco.

O movimento conta com vários programas, um deles é o Programa Microgrant Food que distribui pequenos prêmios em dinheiro para os grupos locais da comunidade, organizações e empresas cujos programas e produtos visam promover os valores fundamentais da Slow Food.

Sendo assim, percebe-se que o Slow Food de Orange County é um movimento arquitetado e executado de maneira voluntária por uma organização sem fins lucrativos, cuja sobrevivência depende de um orçamento proveniente de recursos, eventos locais e de um valor limitado de microfinanciamentos (valores podem variar entre UU\$200 a UU\$ 1000). Mas, que apesar disso, ajuda a fortalecer a cultura alimentar local.

Segundo o Relatório Econômico de Orange County (2013), a cidade é considerada uma parceira ideal para o comércio internacional com as vantagens de proximidade com os portos de Long Beach e de Los Angeles, uma rodovia com um bom sistema viário para o transporte de frota e linhas ferroviárias que fornecem ligações comerciais.

Orange County também possui suas preocupações voltadas para a tecnologia verde, o que considerase mais um ponto positivo, diante do movimento slow food, o que colabora para o crescimento da economia, já que, segundo o Relatório Econômico (2013) a cidade encontra-se em progresso de recuperação, buscando assim, atingir os seus níveis de emprego, a ascensão de turismo e comércio, bem como a melhoria da produção global, dado que as indústrias e as profissões são considerados pontos fortes de Orange County, o que Ihe dá em 2014, se comparado a 2013, um resultado de crescimento do Produto Interno Bruto - PIB de
$2,5 \%$. Por isso, o movimento também colabora para a recuperação das atividades econômicas de Orange County e para o re-estabelecimento da qualidade de vida da população.

Além disso, a própria relação entre ser humano e natureza começa por uma simples iniciativa a ser controlada, a fim de se pensar no futuro e em seu próprio desenvolvimento.

\subsection{ESTRATÉGIAS ADOTADAS PELO ORANGE COUNTY DE AUXILIO E PROTEÇÃO AOS PRODUTORES LOCAIS}

Entre as estratégias de auxilio e proteção aos produtores locais de Orange County adotadas pelo movimento foi de garantir que haja a conectividade com mercados alternativos, por meio da construção de relações, prezando a proteção dos produtos tradicionais e locais e a qualidade de vida.

No entanto, para que isso aconteça essa relação deve ter a participação do governo e da própria população, a fim de promover a disseminação de informações, a conscientização à respeito das técnicas agrícolas e dos processos produtivos, mantendo-os o mais próximos do usual e garantindo sua sobrevivência.

Pois, os envolvidos entendendo a proteção de comércio e da sua própria vida, acabam, de forma automática, a aderir ao programa, tendo em vista seus objetivos em comum.

Quanto as políticas e estratégias de desenvolvimento, percebeu-se que um novo pensar em relação as incessantes e ilimitadas necessidades humanas, processo que demanda por uma nova avaliação, pois a correria da vida moderna transformou a sociedade dependentes do "excedente econômico".

E foi a partir desta "dependência" que deu início a esse movimento - que propõe uma alternativa organizada, que preza por questões e participações, tanto de produtores quanto de consumidores, individuais ou de forma coletiva, buscando a ecologia da alimentação. De forma geral, o movimento, conforme o Manual do Slow Food (2005) tomou proporções internacionais 
em busca da redescoberta e valorização de produtos típicos, biodiversidade (sementes e espécies nativas), sociodiversidade (saberes e práticas agrícolas tradicionais) e de processos produtivos atentos ao equilíbrio ecológico.

Vale ressaltar que o movimento possui objetivos comuns entre os produtores e consumidores: i) promover a redução do ritmo de vida contemporâneo; ii) apreciação da comida; iii) melhorar a qualidade das refeições e; iv) produção que valorize o produto, o produtor e o meio ambiente. Assim, o movimento constrói a cada dia grandes relações com os produtores e consumidores, prezando pela proteção dos produtos tradicionais e locais e a qualidade de vida. O mesmo cresce por meio da conscientização do governo, do mercado e da população em geral.

A conscientização por uma vida mais saudável e que aproveita os alimentos colabora para a proteção de todos em relação a seus objetivos, tendo em vista que o slow food preza pelas iniciativas de educação alimentar, ação social e ao apoio aos pequenos agricultores, a fim de capacitar os envolvidos, ter um comércio justo, modos de produção, produtos, produtores e consumidores ecológicos e uma vida simples.

\section{CONCLUSÕES FINAIS}

A partir dos elementos de problemática de pesquisa e objetivo geral, foi possível perceber que o Slow Food apresenta-se com capacidade de organização a partir dos objetivos do movimento slow, além de bom aproveitamento por parte da população, o que pode trazer muitos benefícios para a saúde tanto física e psicológica, quanto econômica da cidade.

Sendo assim, o movimento propõe modos originais de agrupar pessoas, saberes e fazeres em torno do que talvez pudesse ser chamado de uma ecologia da alimentação, impondo três pré-requisitos para um alimento de qualidade: bom, justo e limpo, os quais servirão como parte do resultado proposto, ou seja, a aproximação entre consumidores e produtores, ajudando assim a proteger os produtores de uma queda bruta no consumo, por conta de seus demandantes aderirem a um novo formato de vida, mas puro e sustentável e, também acaba ajudando aos consumidores a obterem produtos de qualidade, selecionados e aprovados por eles mesmos, o que garante a comercialização.

Assim, percebeu-se também, grande empenho do movimento em auxiliar e proteger os produtores locais em dificuldades conectando-os com mercados alternativos, por meio da construção de relações, prezando a proteção dos produtos tradicionais e locais e a qualidade de vida. O que também surpreende é o relacionamento com os mercados alternativos, favorecido pelo governo e pela própria população, que acaba por disseminar informações e a conscientização à respeito. Dando assim uma boa utilização de técnicas agrícolas e do processo produtivo, mantendo-os o mais próximo do usual e garatindo sua sobrevivência.

Por isso, que a capacidade de organização do movimento se dá pelos princípios de atuação, os quais envolvem toda a comunidade, por exemplo: Trabalhar em conjunto com o Slow Food EUA, aceitar e respeitar as Estatuto Nacional do Slow Food USA e os Protocolos financeiros; Estar consciente das dívidas organizacionais e de seus históricos; Alterar e melhorar as técnicas e práticas de liderança; Honrar e valorizar os produtos advindos da terra e os animais e; Fazer eventos abertos, acessíveis e sem custos para os participantes.

Por fim, é um movimento que preserva antes do seu individual, a coletividade; fazendo com que ninguém saia lesado dessa relação.

\section{REFERÊNCIAS}

[1] ANDREWS, G. (2008). The Slow Food Story. Politics and Pleasure. London: Pluto Press.

[2] BARRETO, Gabriela Muniz. Slow food: origem e benefícios. Disponível em: http://namu.com.br/palestras/ slow-food-origem-e-beneficios. Acesso em: 01 dez. 2014

[3] BEM VINDOS AO NOSSO MUNDO: o manual. Disponível em: http://www.slowfoodbrasil.com/documentos/manual-doslowfood-2013.pdf. Acesso em: 15 nov. 2014. 
[4] Carvalho, Isabel Cristina Moura. Slow food e a educação do gosto: um movimento social sem pressa Revista Prâksis - Educação e Meio Ambiente, Ano 5, Volume I ISSN 18071112, 2008.

[5] CONDADO DE ORANGE. Disponível em: http://WWW. CO.ORANGE.NY.US/CONTENT/1156/DEFAULT.ASPX. Acesso em: 01 dez. 2014.

[6] GENTILE, Chiara. Os Mercados da Terra Slow Food: entre modelos antigos e novas demandas: experiências locais de troca e consumo alimentar. Disponível em: http://actacientifica.servicioit.cl/biblioteca/gt/GT15/GT15_ ChGentile.pdf. Acesso em: 25 out. 2014.

[7] MANUAL DO SLOW FOOD (2005). Disponível em: http:// www.dhnet.org.br/direitos/novosdireitos/slowfood/manual_ slow_food.pdf. Acesso em 10 nov. 2014.

[8] MOVIMENTO CONVIVA. Slow city: ritmo lento e agradável. Disponível em: http://movimentoconviva.com.br/ slow-city-ritmo-lento-e-agradavel-nas-cidades/. Acesso em: 29 out. 2014.
[9] PAULISTA, Geralda; VARVAKIS, Gregório; MONTIBELLER FILHO, Gilberto. Espaço emocional e indicadores de sustentabilidade. Revista Ambiente \& Sociedade, Campinas, v. XI, n. 1, p. 185-200, jan.-jun. 2008.

[10] RELATÓRIO ECONÔMICO DE ORANGE COUNT (2013), disponível em: http://economy.scag.ca.gov/economy\%20 site\%20document\%20library/2013economicsummit_report_ orangecounty.pdf. Acesso em: 01 dez. 2014.

[11] SAMPAIO, Carlos Alberto C. Gestão que privilegia uma outra economia: ecossocioeconomia das organizações. SC: Edifurb, 2011.

[12] SANTOS, Milton. 1992: a redescoberta da natureza. Estudos Avançados, v.6. p.95-106, 1992.

[13] SLOW FOOD: até as origens do gosto. Disponível em: http://www.slowfood.com/education/filemanager/resources/ Origini_Gusto_por.pdf. Acesso em 15 out. 2014.

[14] Slow Food de County Orange. Disponível em: http:// www.slowfoodoc.org/index.php. Acesso em 02 dez. 2014. 


\title{
CAPÍTULO 6
}

\section{O DESIGN E OS SISTEMAS PRODUTO-SERVIÇO NA ECONOMIA DA FUNCIONALIDADE: UMA ANÁLISE BIBLIOMÉTRICA}

\author{
Manuela Gortz \\ Décio Estevão do Nascimento
}

Resumo: O objetivo deste artigo é mostrar o status de publicações e da produção científica na relação entre o design, os sistemas produto-serviço e a economia da funcionalidade, com o foco no desenvolvimento sustentável. Quanto aos procedimentos metodológicos, trabalhou-se com pesquisa bibliométrica, a qual permitiu um levantamento de portfólio bruto de referências, seguida de análise sistêmica inicial, para se chegar a um portfólio potencial de artigos sobre a relação entre os temas. A pesquisa permitiu identificar quais os autores e periódicos de maior relevância, além de apresentar um panorama do status de publicações. Os resultados apontam que a relação entre design e sistemas produto-serviço já é mais discutida, bem como sua relação com a sustentabilidade. Porém, pouco se explora sobre a economia da funcionalidade e sua relação com o design.

Palavras chave: Economia da funcionalidade, Sistemas produto-serviço, Design, Desenvolvimento sustentável. 


\section{INTRODUÇÃO}

A globalização e as demandas crescentes dos consumidores impõem um novo desafio para a indústria e os sistemas produtivos tradicionais, impelindoos a se tornarem mais sustentáveis (VASANTHA et al., 2012). Vezzoli et al. (2015) apontam que nas últimas décadas foram criadas diversas propostas de reação aos problemas de sustentabilidade, como soluções produtivas mais limpas, end-of-pipe e estratégias de design ecológico ou verde. Porém, apesar destas implementações serem necessárias, os resultados ainda são pequenos e não dão conta de uma população com taxas de consumo cada vez mais altas. Por esta razão, entende-se ser necessário abordar novos padrões de consumo e estilo de vida (VEZZOLI et al., 2015).

Stahel (1997) considera como questão chave a mudança de uma economia de base industrial, com valor centrado na troca de produtos e com crescimento influenciado pelo consumo de recursos, para uma economia da funcionalidade, em que os produtos são vistos apenas como meios de fornecer funções e satisfações. Tal economia orienta-se a satisfazer os consumidores pela otimização do uso e entrega de funções ao invés de produtos, com o objetivo de criar o maior valor de uso possível, pelo maior tempo possível, consumindo a menor quantidade possível de recursos e energia (STAHEL, 1997).

Dentro dessa nova economia, considera-se promissora a estratégia dos Sistemas Produto-Serviço (SPS), proposta de valor orientada a providenciar a satisfação aos consumidores pela entrega de um sistema integrado de produtos e serviços, oferecendo incentivos econômicos e competitivos para que os atores envolvidos continuamente adotem práticas sustentáveis da gestão dos recursos (VEZZOLI et al., 2012). Assim, o conceito de SPS pode ser relacionado com a economia da funcionalidade, por ser caracterizado como uma estratégia de design também com foco na provisão de funções pela combinação de produtos e serviços que permitem a redução do consumo de recursos materiais, visando assim a uma sociedade mais sustentável (AFSHAR; WANG, 2011).

Uma vez que a economia da funcionalidade objetiva substituir a prática tradicional da troca de bens materiais entre fornecedor e consumidor com a entrega de funções que apresentam menos recursos materiais, ela pode ser considerada mais sustentável ou desmaterializada que a economia presente, a qual foca na produção como o principal meio de criar riqueza e fluxo material (AFSHAR; WANG, 2011). Goedkoop et al. (1999) destacam também a importância dos Sistemas Produto-Serviço como estratégias de design voltadas à sustentabilidade. Ao envolver uma seleção de variáveis integradas em um sistema funcional, as alternativas competitivas são avaliadas com os objetivos e desenvolvimento nas três dimensões: vantagens econômicas, impacto social e ambiental, o que caracteriza o tripé da sustentabilidade (GOEDKOOP et al., 1999).

Por ser considerada uma estratégia de design que objetiva uma nova economia, os SPS implicam em mudanças nos sistemas tradicionais de produção e na lógica convencional de projetos de produtos (DILL; BOHN; BIRKHOFER, 2012). No entanto, muitos designers ainda não possuem experiência em como estender a vida dos produtos, seja projetando produtos mais duráveis, remodelados, remanufaturados ou reciclados (BAKKER et al., 2014). Para tanto, Stahel (1997) considera que o novo desafio aos engenheiros e designers está em considerar a capacidade de adaptação dos produtos existentes e futuros para as mudanças nas necessidades dos usuários (para produtos rentáveis) e ao progresso tecnológico (para mantê-los atualizados com o progresso tecnológico). Demyttenaere, Dewit e Jacoby (2016) também indicam que o estudo da propriedade e das características de posse entre consumidores e produtos no contexto de SPS pode direcionar futuras pesquisas no aprofundamento de casos existentes, o que pode resultar em um conjunto de orientações para designers, facilitando o processo da transição para um design sustentável.

Entende-se, portanto, que a relação da economia da funcionalidade e dos SPS com o design e o desenvolvimento sustentável é fundamental, uma vez que tais propostas desafiam não apenas a indústria e as companhias, mas também a atuação de designers de projeto de produtos e a formação que recebem (ERICSON; WENNGREN, 2012). 
Para verificar a validade destas afirmativas $e$ aprofundar os estudos na área, foi realizada uma pesquisa bibliométrica a fim de verificar qual o status da produção científica na relação entre design, economia da funcionalidade, sistemas produtoserviço e sustentabilidade. Entende-se que por ser considerada uma estratégia de design, os sistemas produto-serviço podem apresentar maior relação com o termo design, porém o mesmo já não ocorre com a economia da funcionalidade.

\section{METODOLOGIA}

A pesquisa bibliométrica constitui-se de um processo utilizado para a seleção de artigos relevantes, cujos resultados obtidos podem contribuir com a pesquisa de um tema de interesse, por conta do processo estruturado, tendo como instrumento teórico de intervenção o Knowledge Development Process Constructivist (Proknow-C) (ENSSLIN; ENSSLIN; PINTO; 2013). Além de gerar como resultado um referencial teórico sobre o tema de interesse de pesquisa, o processo permite identificar os periódicos que mais se destacam quanto ao número de publicações, e revelar quais os autores com mais contribuições na área (LACERDA; ENSSLIN; ENSSLIN, 2012). A Figura 1 apresenta as 8 etapas estabelecidas e desenvolvidas no processo de pesquisa bibliométrica.

Figura 1 - Etapas da pesquisa bibliométrica

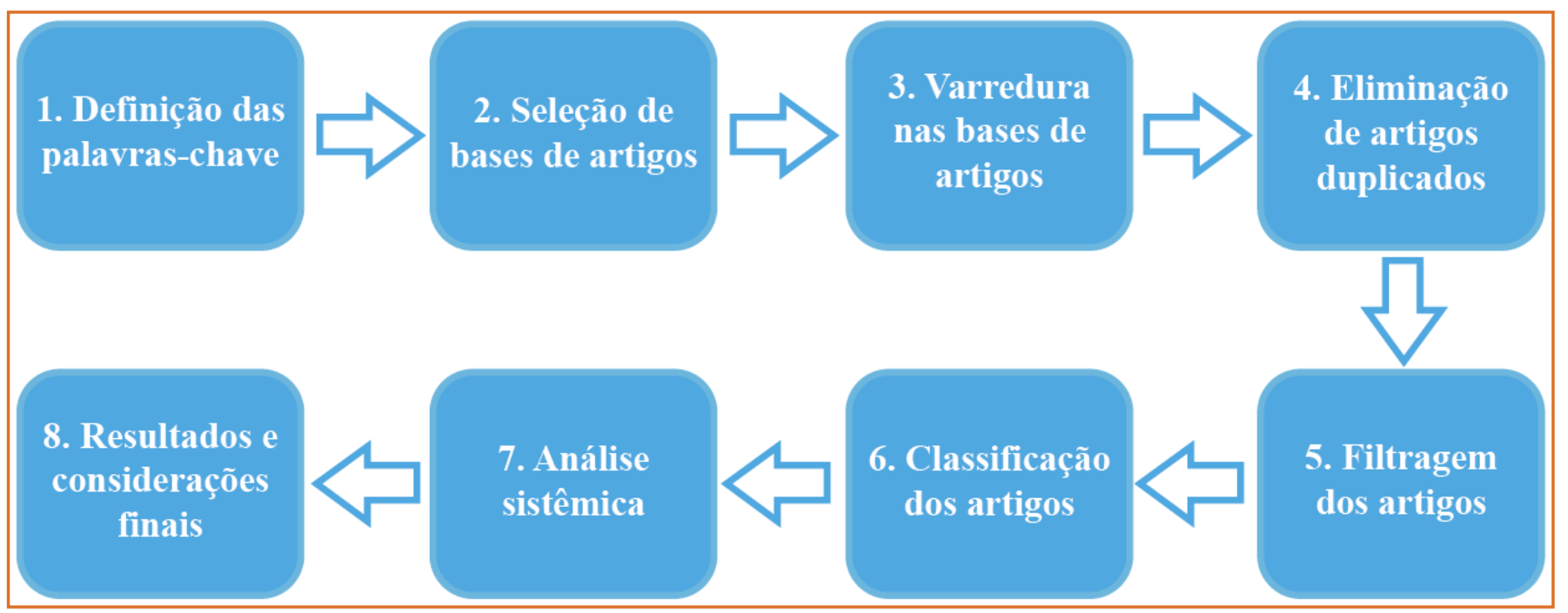

Fonte: Adaptado de Lacerda, Ensslin e Ensslin (2012)

Os procedimentos metodológicos que orientaram esta pesquisa foram realizados em setembro de 2016. Como palavras-chave, definiram-se os termos: design, economia da funcionalidade, sistemas produtoserviço e sustentabilidade, com suas possíveis combinações, utilizando operadores booleanos para otimizar as buscas. A investigação foi feita nas bases internacionais da SciVerse - Science Direct, Scopus e a base do Institute for Scientific Information - Web of Science. Estas foram escolhidas de acordo com sua relevância frente ao tema pesquisado. Nacionalmente, utilizou-se a base do Instituto Brasileiro de Informação em Ciência e Tecnologia (IBICT) - Oasisbr, a qual, além de concentrar um volume considerável das publicações nacionais, também constituiu um banco de testes e dissertações da língua portuguesa. A pesquisa levantou as publicações dos últimos cinco anos, período compreendido entre os anos de 2012 a 2016. Em um primeiro momento, encontrou-se um total de 1,508 referências (sem a eliminação de artigos duplicados). Os resultados iniciais obtidos encontramse na Tabela 1. 
Tabela 1 - Resultados de buscas por palavra-chave

\begin{tabular}{|l|l|}
\hline Palavras-chave & Resultados \\
\hline Product-Service Systems design & 103 \\
\hline Functional economy & 30 \\
\hline Design + Product-Service Systems & 1.131 \\
\hline Design + Functional economy & 8 \\
\hline $\begin{array}{l}\text { Design + Product-Service Systems + } \\
\text { Sustainable }\end{array}$ & 233 \\
\hline $\begin{array}{l}\text { Design + Functional economy + } \\
\text { Sustainable }\end{array}$ & 3 \\
\hline TOTAL & 1.508 \\
\hline
\end{tabular}

Fonte: Autoria própria (2016).

É possível observar, somente pela busca inicial, como o termo product-service systems, e a sua relação com a palavra design e sustainable apresenta uma quantidade relativamente maior de publicações, se comparada com o termo functional economy e suas combinações.

Em seguida, foram eliminados os artigos duplicados do portfólio bruto de artigos. As duplicações ocorreram principalmente pela replicação na mesma base de dados, em bases diferentes, ou por variações na grafia de nomes dos autores. Foram identificados 709 artigos duplicados, resultando em 799 publicações não duplicadas.

Na sequência deu-se início à filtragem das referências, verificando o alinhamento dos elementos título, palavras-chave, resumo com o objetivo da pesquisa. Das 799 referências não-duplicadas, 217 foram descartadas por não apresentarem alinhamento. Das 582 restantes, realizou-se novo filtro a fim de identificar apenas os artigos que apresentassem relação direta com o design, no sentido de disciplina de projeto de produto. Este filtro foi aplicado visto que muitos artigos continham a palavra design apenas para designar a metodologia utilizada no artigo (no sentido do delineamento do artigo), e não com o objetivo aqui proposto. Deste modo, 438 referências abordam o tema de sistemas produto-serviço, mas sem relação direta com o design, restando assim 144 para o portfólio potencial (Tabela 2).
Tabela 2 - Resultados após filtragem

\begin{tabular}{|l|l|}
\hline Artigos & Quantidade \\
\hline Quantidade inicial de artigos & 1.508 \\
\hline Artigos duplicados (eliminados) & 709 \\
\hline Artigos não-duplicados & 799 \\
\hline Artigos não alinhados ao tema (eliminados) & 217 \\
\hline $\begin{array}{l}\text { Artigos sobre SPS de forma geral } \\
\text { (desconsiderados) }\end{array}$ & 438 \\
\hline $\begin{array}{l}\text { Artigos alinhados ao tema (Portfólio } \\
\text { potencial) }\end{array}$ & 144 \\
\hline
\end{tabular}

Fonte: Autoria própria (2016).

A próxima etapa foi classificar os artigos de acordo com seu tema central, com base na leitura especialmente do resumo. Isto permitiu verificar qual a quantidade real de artigos resgatados que aborda os temas de interesse da pesquisa. Os quatro temas definidos, bem com a respectiva quantidade de artigos, encontram-se na Tabela 3.

Tabela 3 - Classificação dos artigos quanto ao tema central

\begin{tabular}{|c|c|}
\hline Classificação & $\begin{array}{l}\text { Quantidade de } \\
\text { Artigos }\end{array}$ \\
\hline Design and Product Service-Systems & 103 \\
\hline $\begin{array}{l}\text { Design and Product Service-Systems and } \\
\text { Sustainability }\end{array}$ & 28 \\
\hline Functional Economy and Fuctional Produtcs & 11 \\
\hline Design and Functional Economy & 3 \\
\hline TOTAL & 144 \\
\hline
\end{tabular}

Fonte: Autoria própria (2016).

Percebe-se, portanto, como a relação entre os temas design e sistemas produto-serviço apresenta quantidade maior de publicações, mas artigos que abordam a sua relação com sustentabilidade é menor, talvez pelo fato de sistemas produto-serviço já serem vistos como estratégias implícitas de sustentabilidade. Por outro lado, a abordagem da economia da funcionalidade é perceptivelmente menor, e a sua relação com o design é ainda mais reduzida.

Por fim, realizou-se uma análise sistêmica inicial dos artigos que constituem o portfólio em potencial. $\mathrm{O}$ objetivo foi verificar a quantidade de publicações por 
ano e por país de origem dos autores, quais os tipos de publicação predominantes e quais periódicos tiveram mais destaque, além de verificar a relevância dos autores pelas quantidade de citações. Os resultados são apresentados na próxima seção.

\section{RESULTADOS}

\subsection{QUANTIDADE DE ARTIGOS POR ANO DE PUBLICAÇÃO}

A quantidade de artigos classificada de acordo com o ano de publicação encontra-se na Figura 2 abaixo.

Figura 2 - Quantidade de artigos por ano da publicação

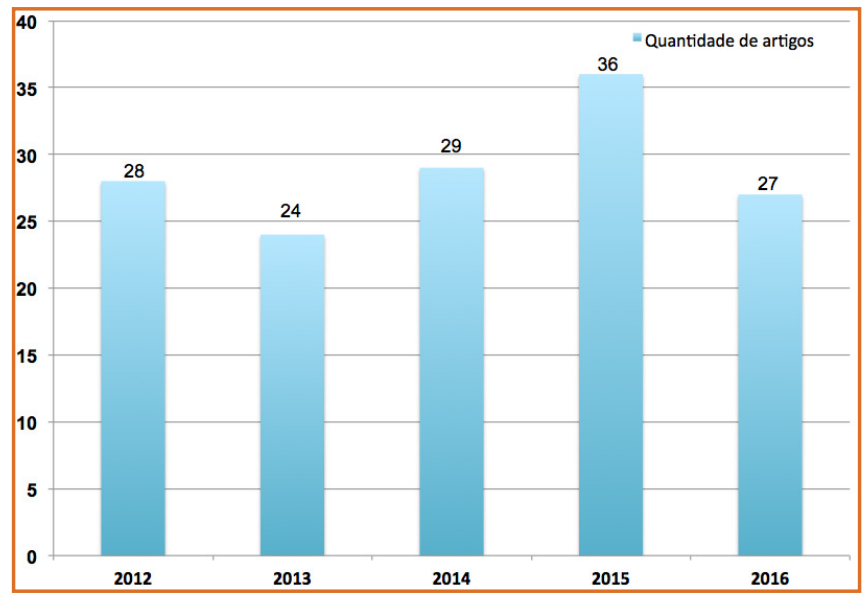

Fonte: Autoria própria (2016)

Percebe-se que do intervalo de 2012 para 2013, houve uma queda na quantidade de publicações, porém também houve um crescimento a partir de 2013 até 2015. Como o ano de 2016 ainda não foi concluído, essas informações podem representar uma tendência de aumento das publicações nestas temas.

\subsection{QUANTIDADE DE ARTIGOS POR PAÍS DE AUTORIA}

A Figura 3 a seguir apresenta a relação dos principais países das publicações, considerados de acordo com o país de origem do autor principal.
Figura 3 - Quantidade de artigos por país de origem do(s) autor(es)

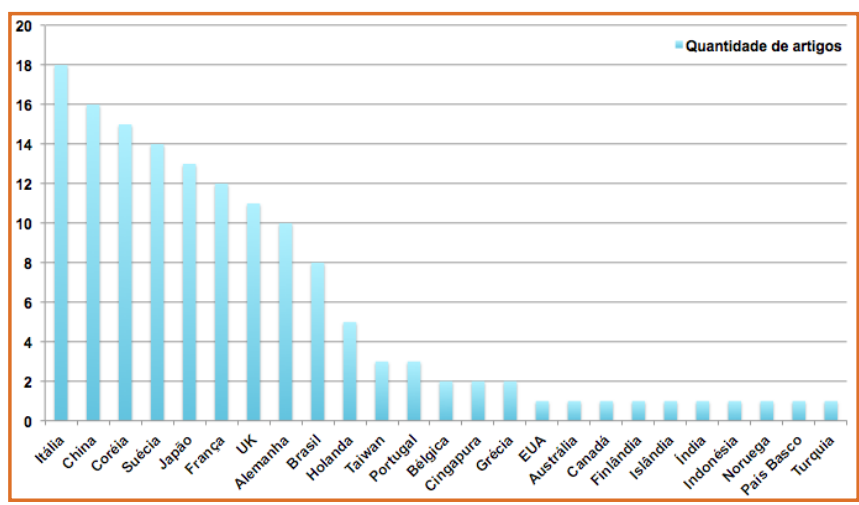

Fonte: Autoria própria (2016)

Destaca-se a relevância dos países europeus e asiáticos, com maior quantidade de publicações. Isso pode-se dar ao fato de que grande parte das experiências pioneiras de sistemas produtoserviço surgiram nestes locais, portanto muitas das publicações tratam de estudos de caso de sistemas já em funcionamento. O Brasil também apresenta quantidade razoável de publicações, sendo que destas, metade são dissertações de mestrado.

\subsection{QUANTIDADE DE ARTIGOS POR TIPO DE PUBLICAÇÃO}

Quanto ao tipo de publicação, a relação pode ser verificada na Figura 4 abaixo.

Figura 4 - Quantidade de artigos por tipo de publicação

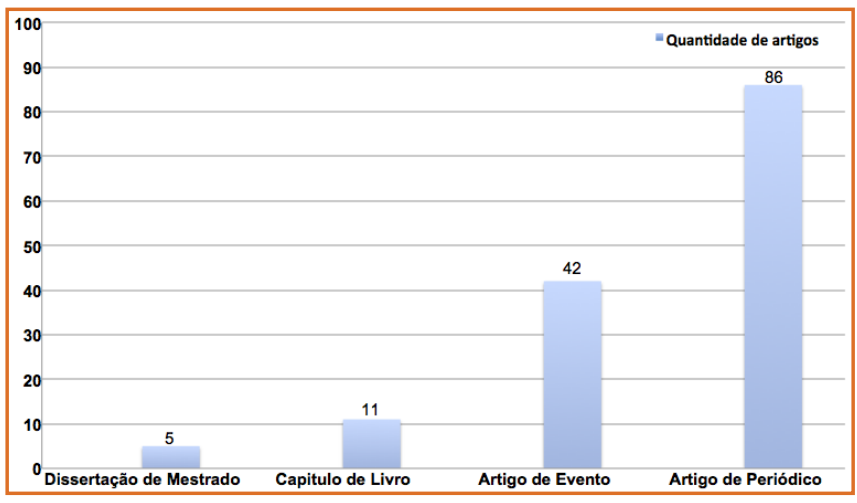

Fonte: Autoria própria (2016)

Verifica-se uma quantidade razoável de artigos publicados em anais de eventos, o que indica que os 
temas estão sendo tratados em conferências científicas recentes. A maior quantidade de publicações encontra-se em artigos de periódicos, o que traz certa credibilidade e relevância para os temas.

\subsection{QUANTIDADE DE ARTIGOS POR PERIÓDICO}

Dos 86 artigos publicados em periódicos, a classificação encontra-se na Tabela 4 abaixo.

Tabela 4 - Quantidade de artigos por periódico

\begin{tabular}{|c|c|}
\hline Periódico & $\begin{array}{l}\text { Quantidade } \\
\text { de Artigos }\end{array}$ \\
\hline Procedia CIRP & 27 \\
\hline Journal of Cleaner Production & 15 \\
\hline Computers in Industry & 6 \\
\hline Journal of Engineering Design & 3 \\
\hline CIRP Annals - Manufacturing Technology & 2 \\
\hline $\begin{array}{l}\text { CIRP Journal of Manufacturing Science and } \\
\text { Technology }\end{array}$ & 2 \\
\hline Computers \& Industrial Engineering & 2 \\
\hline Expert Systems with Applications & 2 \\
\hline Journal of Computational Design and Engineering & 2 \\
\hline Simulation Modelling Practice and Theory & 2 \\
\hline Advanced Engineering Informatics & 1 \\
\hline Advanced Materials Research & 1 \\
\hline Advances in Mechanical Engineering & 1 \\
\hline Benchmarking & 1 \\
\hline Clean Technologies and Environmental Policy & 1 \\
\hline Design Journal & 1 \\
\hline Design Studies & 1 \\
\hline Intelligent Decision Technologies & 1 \\
\hline $\begin{array}{l}\text { International Journal of Advanced Manufacturing } \\
\text { Technology }\end{array}$ & 1 \\
\hline $\begin{array}{l}\text { International Journal of Agile Systems and } \\
\text { Management }\end{array}$ & 1 \\
\hline $\begin{array}{l}\text { International Journal of Energy, Environment and } \\
\text { Economics }\end{array}$ & 1 \\
\hline $\begin{array}{l}\text { International Journal of Technology, Knowledge } \\
\text { and Society }\end{array}$ & 1 \\
\hline Journal of Chemical and Pharmaceutical Research & 1 \\
\hline Journal of Design Research & 1 \\
\hline $\begin{array}{l}\text { Journal of Manufacturing Technology } \\
\text { Management }\end{array}$ & 1 \\
\hline Journal of Strategic Marketing & 1 \\
\hline Journal of the Indian Institute of Science & 1 \\
\hline
\end{tabular}

\begin{tabular}{|l|c|}
\hline Mechatronics & 1 \\
\hline Procedia Manufacturing & 1 \\
\hline $\begin{array}{l}\text { SpringerBriefs in Applied Sciences and } \\
\text { Technology }\end{array}$ & 1 \\
\hline Sustainability & 1 \\
\hline Technovation & 1 \\
\hline Universia Business Review & 1 \\
\hline TOTAL & 86 \\
\hline
\end{tabular}

Fonte: Autoria própria (2016).

Dentre os periódicos encontrados, destaca-se o Procedia CIRP, por apresentar a maior quantidade de artigos, o Journal of Cleaner Production, Computers in Industry e Journal of Engineering Design, os quais, além de apresentarem maior quantidade de artigos, apresentam também artigos dos autores que foram mais citados, conforme mostra a Tabela 5 a seguir.

\subsection{QUANTIDADE DE CITAÇÕES POR AUTOR E PERIÓDICO}

A Tabela 5 a seguir mostra a relação dos principais autores, classificando-os pela ordem decrescente de quantidade de citações, além de mostrar o título da publicação, o ano e o periódico. 
Tabela 5 - Relevância dos autores por quantidade de citações

\begin{tabular}{|c|c|c|c|c|}
\hline Autor & Título & Ano & Periódico & $\mathbf{N}^{\circ}$ de Citações \\
\hline $\begin{array}{l}\text { Vasantha, G. V. A.; Roy, R.; Lelah, } \\
\text { A.; Brissaud, D. }\end{array}$ & $\begin{array}{l}\text { A review of product-service systems design } \\
\text { methodologies }\end{array}$ & 2012 & $\begin{array}{l}\text { Journal of Engineering } \\
\text { Design }\end{array}$ & 122 \\
\hline Boehm, Matthias; Thomas, Oliver & $\begin{array}{l}\text { Looking beyond the rim of one's teacup: a } \\
\text { multidisciplinary literature review of Product- } \\
\text { Service Systems in Information Systems, } \\
\text { Business Management, and Engineering \& } \\
\text { Design }\end{array}$ & 2013 & $\begin{array}{l}\text { Journal of Cleaner } \\
\text { Production }\end{array}$ & 83 \\
\hline Yoon, B.; Kim, S.; Rhee, J. & $\begin{array}{l}\text { An evaluation method for designing a new } \\
\text { product-service system }\end{array}$ & 2012 & $\begin{array}{l}\text { Expert Systems with } \\
\text { Applications }\end{array}$ & 58 \\
\hline Garetti, M.; Rosa, P.; Terzi, S. & $\begin{array}{l}\text { Life Cycle Simulation for the design of Product- } \\
\text { Service Systems }\end{array}$ & 2012 & Computers in Industry & 46 \\
\hline Geng, Xiuli; Chu, Xuening & $\begin{array}{l}\text { A new importance-performance analysis } \\
\text { approach for customer satisfaction evaluation } \\
\text { supporting PSS design }\end{array}$ & 2012 & $\begin{array}{l}\text { Expert Systems with } \\
\text { Applications }\end{array}$ & 46 \\
\hline $\begin{array}{l}\text { Vezzoli, Carlo; Ceschin, Fabrizio; } \\
\text { Diehl, Jan Carel; Kohtala, Cindy }\end{array}$ & $\begin{array}{l}\text { New design challenges to widely implement } \\
\text { 'Sustainable Product-Service Systems' }\end{array}$ & 2015 & $\begin{array}{l}\text { Journal of Cleaner } \\
\text { Production }\end{array}$ & 45 \\
\hline Zhang, D.; Hu, D.; Xu, Y.; Zhang, H. & $\begin{array}{l}\text { A framework for design knowledge management } \\
\text { and reuse for Product-Service Systems in } \\
\text { construction machinery industry }\end{array}$ & 2012 & Computers in Industry & 45 \\
\hline $\begin{array}{l}\text { Bakker, Conny; Wang, Feng; } \\
\text { Huisman, Jaco; den Hollander, } \\
\text { Marcel }\end{array}$ & $\begin{array}{l}\text { Products that go round: exploring product life } \\
\text { extension through design }\end{array}$ & 2014 & $\begin{array}{l}\text { Journal of Cleaner } \\
\text { Production }\end{array}$ & 41 \\
\hline $\begin{array}{l}\text { Van Ostaeyen, J.; Van Horenbeek, } \\
\text { A.; Pintelon, L.; Duflou, J. R. }\end{array}$ & $\begin{array}{l}\text { A refined typology of product-service systems } \\
\text { based on functional hierarchy modeling }\end{array}$ & 2013 & $\begin{array}{l}\text { Journal of Cleaner } \\
\text { Production }\end{array}$ & 31 \\
\hline Sakao, T.; Lindahl, M. & $\begin{array}{l}\text { A value based evaluation method for Product/ } \\
\text { Service System using design information }\end{array}$ & 2012 & $\begin{array}{l}\text { CIRP Annals - } \\
\text { Manufacturing } \\
\text { Technology }\end{array}$ & 28 \\
\hline $\begin{array}{l}\text { Akasaka, F.; Nemoto, Y.; Kimita, K.; } \\
\text { Shimomura, Y. }\end{array}$ & $\begin{array}{l}\text { Development of a knowledge-based design } \\
\text { support system for Product-Service Systems }\end{array}$ & 2012 & Computers in Industry & 26 \\
\hline $\begin{array}{l}\text { Clayton, R. J.; Backhouse, C. J.; } \\
\text { Dani, S. }\end{array}$ & $\begin{array}{l}\text { Evaluating existing approaches to product- } \\
\text { service system design: A comparison with } \\
\text { industrial practice }\end{array}$ & 2012 & $\begin{array}{l}\text { Journal of } \\
\text { Manufacturing } \\
\text { Technology } \\
\text { Management }\end{array}$ & 26 \\
\hline $\begin{array}{l}\text { Vezzoli, C.; Ceschin, F.; Diehl, J. C.; } \\
\text { Kohtala, C. }\end{array}$ & $\begin{array}{l}\text { Why have 'Sustainable Product-Service } \\
\text { Systems' not been widely implemented? } \\
\text { Meeting new design challenges to achieve } \\
\text { societal sustainability }\end{array}$ & 2012 & $\begin{array}{l}\text { Journal of Cleaner } \\
\text { Production }\end{array}$ & 25 \\
\hline $\begin{array}{l}\text { Bertoni, A.; Bertoni, M.; Isaksson, } \\
\text { O. }\end{array}$ & $\begin{array}{l}\text { Value visualization in Product Service Systems } \\
\text { preliminary design }\end{array}$ & 2013 & $\begin{array}{l}\text { Journal of Cleaner } \\
\text { Production }\end{array}$ & 18 \\
\hline Peruzzini, M.; Germani, M. & $\begin{array}{l}\text { Design for sustainability of product-service } \\
\text { systems }\end{array}$ & 2014 & $\begin{array}{l}\text { International Journal } \\
\text { of Agile Systems and } \\
\text { Management }\end{array}$ & 17 \\
\hline $\begin{array}{l}\text { Carreira, R.; Patricio, L.; Jorge, R. } \\
\text { N.; Magee, C. L. }\end{array}$ & $\begin{array}{l}\text { Development of an extended Kansei } \\
\text { engineering method to incorporate experience } \\
\text { requirements in product-service system design }\end{array}$ & 2013 & $\begin{array}{l}\text { Journal of Engineering } \\
\text { Design }\end{array}$ & 16 \\
\hline Tran, Tuan A.; Park, Joon Y. & $\begin{array}{l}\text { Development of integrated design methodology } \\
\text { for various types of product - service systems }\end{array}$ & 2014 & $\begin{array}{l}\text { Journal of } \\
\text { Computational Design } \\
\text { and Engineering }\end{array}$ & 16 \\
\hline Geng, X.; Chu, X.; Zhang, Z. & $\begin{array}{l}\text { An association rule mining and maintaining } \\
\text { approach in dynamic database for aiding } \\
\text { product-service system conceptual design }\end{array}$ & 2012 & $\begin{array}{l}\text { International Journal } \\
\text { of Advanced } \\
\text { Manufacturing } \\
\text { Technology }\end{array}$ & 15 \\
\hline
\end{tabular}




\begin{tabular}{|c|c|c|c|c|}
\hline Autor & Título & Ano & Periódico & $\mathbf{N}^{\circ}$ de Citações \\
\hline $\begin{array}{l}\text { Amaya, J.; Lelah, A.; } \\
\text { Zwolinski, P. }\end{array}$ & $\begin{array}{l}\text { Design for intensified use in product- } \\
\text { service systems using life-cycle } \\
\text { analysis }\end{array}$ & 2014 & $\begin{array}{l}\text { Journal of } \\
\text { Engineering } \\
\text { Design }\end{array}$ & 14 \\
\hline $\begin{array}{l}\text { Pezzotta, G.; Pirola, F.; } \\
\text { Pinto, R.; Akasaka, F.; } \\
\text { Shimomura, Y. }\end{array}$ & $\begin{array}{l}\text { A Service Engineering framework } \\
\text { to design and assess an integrated } \\
\text { product-service }\end{array}$ & 2015 & Mechatronics & 12 \\
\hline $\begin{array}{l}\text { Qu, M.; Yu, S. H.; Chen, D. } \\
\text { K.; Chu, J. J.; Tian, B. Z. }\end{array}$ & $\begin{array}{l}\text { State-of-the-art of design, evaluation, } \\
\text { and operation methodologies in } \\
\text { product service systems }\end{array}$ & 2016 & $\begin{array}{l}\text { Computers in } \\
\text { Industry }\end{array}$ & 11 \\
\hline $\begin{array}{l}\text { Favi, C.; Peruzzini, M.; } \\
\text { Germani, M. }\end{array}$ & $\begin{array}{l}\text { A lifecycle design approach to } \\
\text { analyze the eco-sustainability of } \\
\text { industrial products and product- } \\
\text { service systems }\end{array}$ & 2012 & $\begin{array}{l}\text { Proceedings } \\
\text { of International } \\
\text { Design } \\
\text { Conference, } \\
\text { DESIGN }\end{array}$ & 11 \\
\hline Gaziulusoy, A. I. & $\begin{array}{l}\text { A critical review of approaches } \\
\text { available for design and innovation } \\
\text { teams through the perspective of } \\
\text { sustainability science and system } \\
\text { innovation theories }\end{array}$ & 2015 & $\begin{array}{c}\text { Journal of Cleaner } \\
\text { Production }\end{array}$ & 11 \\
\hline $\begin{array}{l}\text { Borgianni, Yuri; Cascini, } \\
\text { Gaetano; Pucillo, } \\
\text { Francesco; Rotini, Federico }\end{array}$ & $\begin{array}{l}\text { Supporting product design by } \\
\text { anticipating the success chances of } \\
\text { new value profiles }\end{array}$ & 2013 & $\begin{array}{l}\text { Computers in } \\
\text { Industry }\end{array}$ & 10 \\
\hline $\begin{array}{l}\text { de Pauw, Ingrid C.; Karana, } \\
\text { Elvin; Kandachar, Prabhu; } \\
\text { Poppelaars, Flora }\end{array}$ & $\begin{array}{l}\text { Comparing Biomimicry and Cradle to } \\
\text { Cradle with Ecodesign: a case study } \\
\text { of student design projects }\end{array}$ & 2014 & $\begin{array}{c}\text { Journal of Cleaner } \\
\text { Production }\end{array}$ & 10 \\
\hline
\end{tabular}

Fonte: Autoria própria (2016).

Apesar de se considerar que artigos publicados em 2016 ainda não puderam ser citados, a tabela limitouse a apresentar os autores com 10 citações ou mais, de modo a mostrar a relação entre esta quantidade, o autor e o periódico vinculado. Assim, é possível perceber que os autores com maior relevância no portfólio em potencial selecionado também publicam em periódicos de relevância internacional.

Por fim, salienta-se que neste artigo foi apresentada uma análise sistêmica inicial, considerando apenas alguns dos principais aspectos encontrados. A próxima etapa pode consistir em uma análise das referências utilizadas por estes autores mais citados, bem como uma análise de conteúdo para identificar categorias em comum nos artigos do portfólio potencial.

\section{CONSIDERAÇÕES FINAIS}

Inovações eco-eficientes como a proposta de Sistemas Produto-Serviço representam uma abordagem promissora rumo à sustentabilidade (CESCHIN, 2013). Como visto nos resultados da pesquisa desenvolvida, diversas pesquisas (DILL; BOHN; BIRKHOFER, 2012; BAKKER et al., 2014; VEZOLLI et al., 2015) já foram desenvolvidas neste campo nos últimos anos, o que permite aumentar o entendimento sobre as potenciais vantagens, diretrizes e barreiras para o desenvolvimento de diferentes métodos de design e ferramentas capazes de aumentar o alcance dos SPS implementados globalmente (VEZZOLI et al, 2012).

Porém, Vezzoli et al. (2012) também apontam que apesar da experiência já acumulada, a aplicação dos 
SPS ainda é muito limitada, uma vez que normalmente são consideradas "inovações radicais" por desafiarem os atuais hábitos de consumo, as estruturas organizacionais empresarias e regulamentações vigentes, e por isso requerem mudanças fundamentais no comportamento e práticas de indivíduos, grupos, comunidades executivas, atores políticos e a sociedade como um todo. (VEZOLLI et al., 2012; CHESCHIN, 2013).

O desafio não está apenas em conceber conceitos eco-eficientes de SPS, mas também em compreender as condições do contexto que facilitam o engajamento da sociedade, para traçar as estratégias e caminhos mais apropriados (CHESCHIN, 2013). A necessidade urgente não é apenas visar os processos de produção e provisão de produtos e serviços, mas sim redefinir os padrões de consumo e estilos de vida (VEZZOLI et $\mathrm{al}, 2012)$. Entende-se, portanto, que a proposta da economia da funcionalidade, por ser vista mais como uma mudança de comportamento ao propor uma nova economia, pode contribuir nesta troca de paradigmas. E neste sentido, a relação da economia da funcionalidade com o design é de grande relevância.

Destaca-se, portanto, a importância da necessidade de novas pesquisas abordando a relação entre os temas, em especial abordando a economia da funcionalidade. Ressalta-se também que a pesquisa aqui descrita trata-se de um panorama geral e de uma busca inicial, a qual ainda será continuada e refinada em etapas futuras.

\section{REFERÊNCIAS}

[1] AFSHAR, M.; WANG, D. Systems Thinking for Designing Sustainable Product Service Systems: A Case Study Using a System Dynamics Approach. Design Principles And Practices: AN INTERNATIONAL JOURNAL, Champaign, v. 4, n. 6, p.259-274, jan. 2011.

[2] BAKKER, C.; WANG, F.; HUISMAN, J.; DEN HOLLANDER, M. Products that go round: exploring product life extension through design. Journal of Cleaner Production, v. 69, p. 10-16, 2014. ISSN 0959-6526.
[3] CESCHIN, Fabrizio. Critical factors for implementing and diffusing sustainable product-Service systems: insights from innovation studies and companies' experiences. Journal Of Cleaner Production, [s.I.], v. 45, p.74-88, abr. 2013. Elsevier BV.

[4] EMYTTENAERE, K.; DEWIT, I.; JACOBY, A. The Influence of Ownership on the Sustainable Use of Product-service Systems - A Literature Review. Procedia Cirp, [s.I.], Elsevier BV., v. 47, p.180-185, 2016.

[5] DILL, A. K.; BOHN, A.; BIRKHOFER, H. From product designer to PSS designer - How to educate engineers to become PSS designers. Proceedings of the 14th International Conference on Engineering and Product Design Education: Design Education for Future Wellbeing, EPDE 2012, 2012. p.807-812.

[6] ENSSLIN, L.; ENSSLIN, S. R.; PINTO, H. de M. Processo de investigação e Análise bibliométrica: Avaliação da Qualidade dos Serviços Bancários. RAC - Revista de Administração Contemporânea; v.17, n. 3, p. 325-349, 2013.

[7] ERICSON, A.; WENNGREN, J. A change in design knowledge: From stand-alone products to service offerings. International Journal of Technology, Knowledge and Society, v. 8, n. 2, p. 51-63, 2012

[8] GOEDKOOP, M. J.; VAN HALEN, C. J.G.; TE RIELE, H.R.M.; ROMMENS, P.J.M. Product Service Systems, ecological and economic basics. Report No. 1999/36, submitted for Dutch Ministries of Environment (VROM) and Economic Affairs (EZ), 1999.

[9] LACERDA, R. T. O.; ENSSLIN, L.; ENSSLIN, S. R. Uma análise bibliométrica da literatura sobre estratégia e avaliação de desempenho. Revista Gestão \& Produção, São Carlos, v. 19, n. 1, p. 59-78, 2012.

[10] STAHEL, W. R. The functional economy: cultural and organizational change. In: Richards (Ed.), The Industrial Green Game. National Academy Press, Washington DC, 1997.

[11] VASANTHA, G. V. A.; ROY, R.; CORNEY, J. R. A review of product-service systems design methodologies. Journal of Engineering Design, v. 23, n. 9, p. 635-659, 2012.

[12] VEZZOLI, C.; CHESCHIN, F.; DIEHL, J. C.; KOHTALA, C. Why have 'Sustainable Product-Service Systems' not been widely implemented? Journal Of Cleaner Production, [s.I.], Elsevier BV., p.288-290, nov. 2012.

[13] VEZZOLI, C.; CHESCHIN, F.; DIEHL, J. C.; KOHTALA, C. New design challenges to widely implement 'Sustainable Product-Service Systems'. Journal of Cleaner Production, v. 97, p. 1-12, 2015. ISSN 0959-6526. 


\section{CAPÍTULO 7}

\section{políticas públicas Na CAdeia PRodutiva de ENERgia ELÉTRICA E A INFLUÊNCIA NAS PERDAS DE ENERGIA}

\section{Marcos Roberto Lopomo}

Kátia Madruga

Resumo: O objetivo deste artigo é identificar as políticas públicas estabelecidas para a cadeia produtiva de energia elétrica orientadas para a redução das perdas, bem como seus principais atores e suas responsabilidades, a fim de discutir as possíveis formas de compensação ou mitigação dessas perdas. O estudo de caráter qualitativo e exploratório foi realizado por meio de revisão bibliográfica e documental. Entre os principais resultados destacam-se: a concentração da formulação de políticas públicas em poucos atores e a não consideração das perdas de energia como fator relevante na formulação das políticas do setor elétrico, o que leva a uma trajetória de perdas na cadeia de energia elétrica.

Palavras chave: Perdas, energia, políticas públicas, atores. 


\section{INTRODUÇÃO}

A exploração dos serviços e instalações de energia elétrica está estabelecida na Constituição Federal, que prevê a realização direta pelo Governo Federal ou indireta por meio da outorga de concessões, permissões ou autorizações. Durante as duas últimas décadas foram adotadas medidas legislativas para aumentar o investimento privado, eliminando barreiras para capital estrangeiro em busca da concorrência do setor. (PIMENTA,2009)

Para conceber este modelo foram criados diversos atores responsáveis pela estratégia, planejamento, operação, contabilização, fiscalização e monitoramento setorial. Um aspecto relevante no processo de produção, distribuição e consumo de energia é o esforço para a redução de perdas na cadeia. Este esforço remete a busca da eficiência energética, racionalidade econômica e da sustentabilidade socioambiental. Neste cenário, as políticas públicas desempenham um papel importante para apoiar este esforço importante já que diminuirá a necessidade de investimentos na expansão da geração de energia por determinadas fontes e os impactos ambientais e sociais negativos relacionados.

Considerando estes aspectos, o objetivo deste artigo é identificar as políticas públicas estabelecidas para a cadeia produtiva de energia elétrica orientadas para a redução das perdas, bem como seus principais atores e suas responsabilidades, a fim de discutir as possíveis formas de compensação ou mitigação dessas perdas.

Este trabalho, de caráter qualitativo e exploratório foi realizado por meio de revisão bibliográfica e documental. A revisão inclui trabalhos acadêmicos e documentos publicados por organizações do setor de energia.

Os temas tratados foram: políticas públicas e atores no processo, o sistema produtivo de energia elétrica, as políticas públicas voltadas ao setor de energia elétrica, perdas de energia. A partir da revisão foi realizada a discussão e análise do impacto das políticas públicas do setor de energia elétrica na evolução das perdas de energia.

\section{POLÍTICAS PÚBLICAS E ATORES NO PROCESSO DE FORMULAÇÃO}

Dworkin(2002) designou 'política' como aquele tipo de padrão que estabelece um objetivo a ser alcançado, o qual em geral é visto como uma melhoria em determinados aspectos econômicos, políticos ou sociais da comunidade. Fabio Comparato(1997) identifica política inicialmente como uma atividade, como um conjunto organizado de normas e atos tendentes à realização de um objetivo determinado. Lahera (2004) descreve as políticas públicas como sendo as soluções específicas de como manejar os assuntos públicos.

Dias e Matos (2012) consideram que o conceito de política pública pressupõe que há uma área ou domínio da vida que não é privada ou somente individual, mas que existe em comum com outros, sendo assim denominada propriedade pública, controlada pelo governo para propósitos públicos e não pertencente a ninguém em particular. Também indica que as políticas públicas podem ser agrupadas de acordo com as arenas decisórias, finalidades e alcance das ações. As arenas decisórias podem ser distribuídas em quatro tipos (regulatória, distributiva, redistributiva e constitutiva), sendo a regulatória aquela que nasce de interesses claramente opostos, tornando-a de maior conflito.

Dias e Matos (2012) denomina atores aos inúmeros indivíduos, grupos, movimentos, organizações e partidos que influenciam as políticas públicas, subdividindo-os na seguinte tipologia de atores:

- formais (definidos pela Constituição Federal, Assembléias Legislativas ou Leis Orgânicas Municipais) e informais (movimentos sociais , empresas, sindicatos, imprensa); ou,

- individuais (políticos, formadores de opinião, etc) e coletivos (partidos políticos, organizações da sociedade civil, movimentos sociais); ou,

- públicos (que compõem o sistema político exercendo função pública) e privados (sem vínculo com a estrutura administrativa do estado). 
Quanto aos papéis e funções desempenhados pelos atores no que diz respeito às políticas públicas, podese concluir da literatura de Dias e Matos (2012):

- Atores Fundamentais (políticos eleitos e alta administração), Partidos Políticos e Equipes de Governo são aqueles responsáveis por formular e executar as políticas públicas, respondendo pela acomodação dos interesses da coletividade;

- Corpo Técnico (funcionários de carreira do governo) atua como auxiliar na elaboração e execução das políticas públicas, de forma imparcial e profissional;

- Judiciário possui o papel de árbitro imparcial e representante da sociedade com poder de veto, fiscalizador e mediador das políticas;

- Mídia aparece como fornecedor de informações à sociedade, criando uma opinião pública sobre determinados temas;

- Grupos específicos atuam com o papel de defender políticas públicas de interesses coletivos internos (ex: sindicatos e associações profissionais, grupos de pressão, movimentos sociais, associações comunitárias);

- Institutos vinculados a partidos políticos defendem interesses vinculados ao seu eleitorado;

- Grupos de interesse coletivo externo como ONG's, atores de conhecimento, organismos internacionais e centros de pesquisa prestam ajuda na formulação de políticas públicas;

- Empresas e suas unidades de pesquisas atuam com interesse no oferecimento de produtos e serviços vinculados às políticas públicas.

Ainda com extrema relevância, não obstante a identificação dos atores e seus papéis, Dias e Matos (2012) promovem a discussão quanto à participação política ser essencial na gestão pública. Em outras palavras, "envolve os destinatários diretos das ações governamentais, que têm interesse em melhorá-las. ... promovendo uma melhor utilização dos recursos; os serviços podem ser melhorados...".

\section{ATORES DO SETOR ELÉTRICO NO BRASIL}

Especialmente voltado à formulação de políticas do setor de energia elétrica no Brasil, figuram os seguintes atores (MME,2016):

- MME - Ministério de Minas e Energia: é o órgão da administração federal direta, representa a União como Poder Concedente e formulador de políticas públicas, bem como indutor e supervisor da implementação dessas políticas nos segmentos de recursos energéticos, aproveitamento da energia hidráulica, petróleo, combustível e energia elétrica, inclusive nuclear, entre outros. Cabe, ainda, as mesmas para: energização rural, agroenergia, inclusive eletrificação rural, quando custeada com recursos vinculados ao Sistema Elétrico Nacional; e zelar pelo equilíbrio conjuntural e estrutural entre a oferta e a demanda de recursos energéticos no País.

- CNPE-Conselho Nacional de Política Energética: órgão de assessoramento do Presidente da República para formulação de politicas e diretrizes de energia e presidido pelo Ministro de Estado de Minas e Energia;

- EPE - Empresa de Pesquisa Energética: vinculado ao MME, tem como finalidade a prestação de serviços na área de estudos e pesquisas destinadas a subsidiar o planejamento do setor energético.

\section{SISTEMA PRODUTIVO DE ENERGIA ELÉTRICA}

O sistema produtivo de energia elétrica é composto por diversos agentes que podem ser definidos por suas participações ativas na oferta e demanda de energia, conforme exposto na ilustração, a seguir: 
Figura 1: Ilustração dos sistemas elétricos de potência

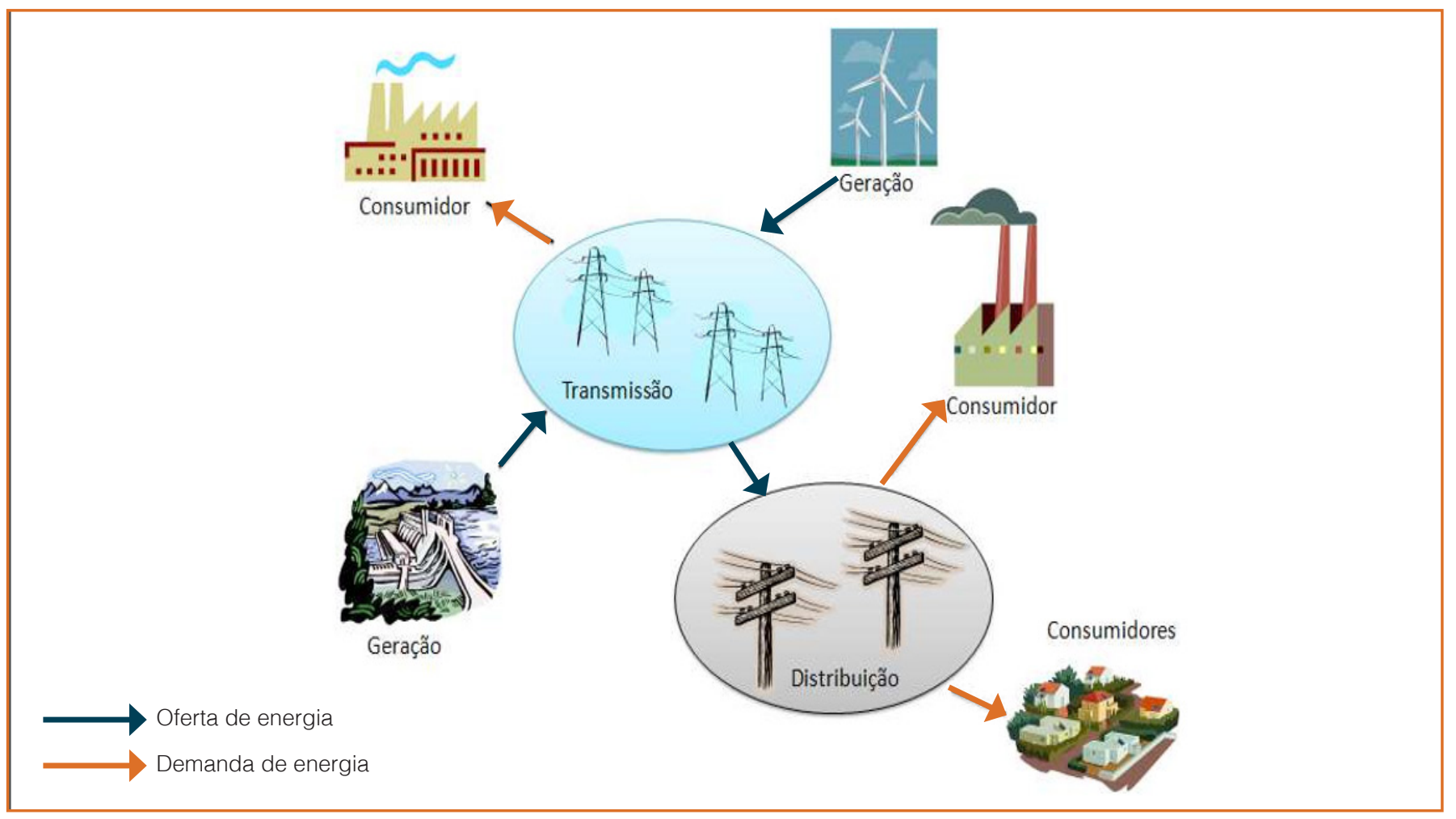

Fonte: adaptado de (Queiroz 2010)

\subsection{GERAÇÃO DE ENERGIA ELÉTRICA:}

A transformação de uma fonte de energia em energia elétrica é atualmente o melhor vetor energético disponível, ou seja, a forma que que a energia pode ser transmitida de um local a outro e pode ser transformado em outra forma de energia. As principais fontes de energia elétrica no Brasil são denominadas renováveis, principalmente em razão da grande base hidráulica e ainda em menor proporção, mas crescente, das energias eólica e térmica a biomassa. No entanto, considerando os impactos e dificuldades ambientais de grandes reservatórios para o crescimento da geração firme de energia por fonte hídrica, há também uma previsão de continuidade no crescimento de fontes de energia não renováveis provenientes de combustíveis fósseis, como o gás natural. (POMILIO, 2013)

A seguir, é identificada a composição da matriz energética para fins de energia elétrica:
Figura 2: Matriz Energética para fins de Energia Elétrica

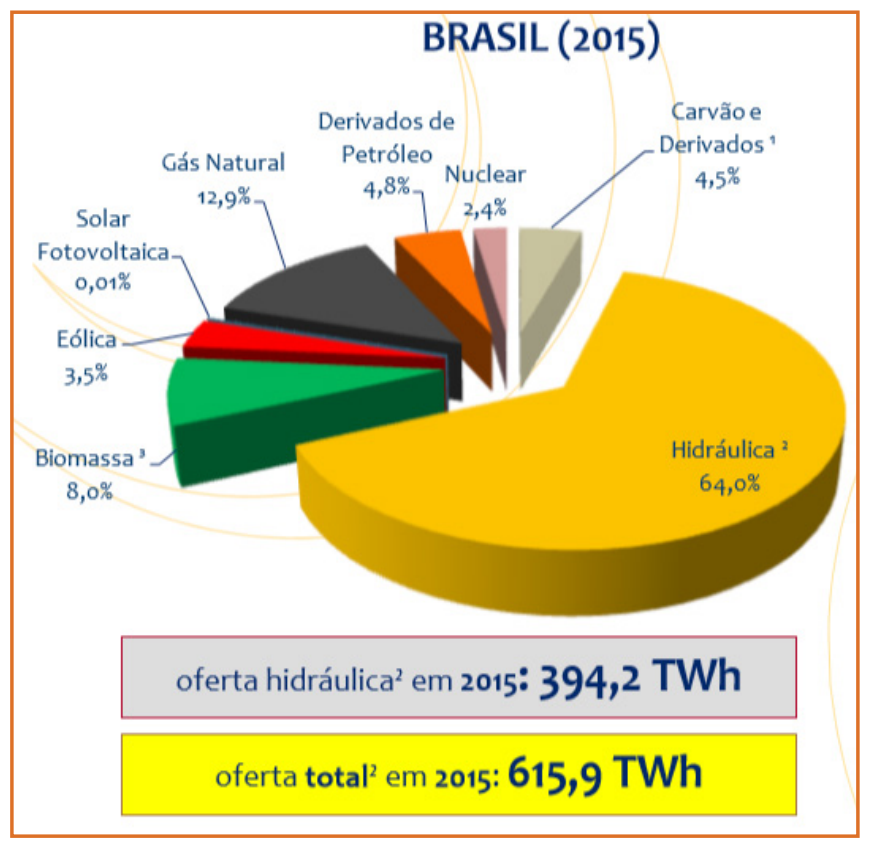

Fonte: Balanço Energético Nacional, ano base 2015

\subsection{TRANSMISSÃO DE ENERGIA ELÉTRICA:}

As linhas de transmissão no Brasil normalmente são 
extensas, uma vez que as grandes usinas geradoras de energia estão geralmente situadas a distâncias consideráveis dos centros consumidores de energia, e composta por fios condutores, transformadores e equipamentos diversos de medição, controle e proteção das redes elétricas e no Brasil é constituída por um grande sistema integrado, também denominado Rede Básica - utilizando-se de uma rede de linhas de transmissão e subestações em tensão igual ou superior a $230 \mathrm{kV}$ ou abaixo - denominadas DIT's (demais instalações de transmissão) e que trabalham em tensão inferior a $230 \mathrm{kV}$ mas que por sua estratégica localização elétrica compõem a rede básica - e sistemas isolados o abastecimento é feito por pequenas usinas termelétricas ou por usinas hidrelétricas situadas próximas às áreas de carga. Estas linhas são de propriedade estatal ou privada, mas são operadas pelo ONS - Operador Nacional do Sistema Elétrico, que gerencia o despacho otimizado das grandes unidades geradoras de energia elétrica, e qualquer agente que produza ou consuma energia elétrica tem direito de acesso. (ATLAS DA ENERGIA ELÉTRICA, 2008)

A vantagem de um grande sistema interligado de energia elétrica é a troca de energia entre regiões, quando uma delas apresenta queda no nível dos reservatórios, considerando a grande dependência hidráulica como fonte de energia no Brasil. Como o regime de chuvas é diferente nas regiões Sul, Sudeste, Norte e Nordeste, as linhas de transmissão possibilitam que os pontos com produção insuficiente de energia sejam abastecidos por centros de geração em situação favorável. (ATLAS DA ENERGIA ELÉTRICA, 2008)

\subsection{DISTRIBUIÇÃO DE ENERGIA ELÉTRICA:}

A conexão, o atendimento e a entrega efetiva de energia elétrica a maior parte dos consumidores ocorrem por parte das distribuidoras de energia e pode ser por meio de rede aérea (suportada por postes) ou de tipo subterrânea (com cabos ou fios localizados sob o solo, dentro de dutos subterrâneos). A distribuição é composta por fios condutores, transformadores e equipamentos diversos de medição, controle e proteção das redes elétricas, mas diferente do sistema de transmissão, é muito mais extenso em razão de sua ramificação, chegando a cada domicílio. (ABRADEE, 2016)

Podem operar com tensão entre 69 kV e 138 kV (subtransmissão), 2,3 kV a 44 kV (média tensão) e entre 110 e $440 \mathrm{~V}$ (baixa tensão). As redes de baixa tensão levam energia elétrica até as residências e pequenos comércios/indústrias por meio dos chamados ramais de ligação. Os supermercados, comércios e indústrias de médio porte adquirem energia elétrica diretamente das redes de média tensão, devendo transformá-la internamente para níveis de tensão menores, sob sua responsabilidade. (ABRADEE, 2016)

Também existe no Brasil a distribuição da energia realizada por Cooperativas de eletrificação rural, que contidas nas áreas de concessão das distribuidoras, devem figurar como Permissionárias ou Autorizadas para a realização da prestação do serviço. (PELEGRINI, RIBEIRO, PAZZINI, 2004)

\subsection{COMERCIALIZAÇÃO DE ENERGIA ELÉTRICA:}

A comercialização da Energia Elétrica é a etapa onde estão inseridos os agentes de comercialização de energia (Geradores, Distribuidores e Comercializadores) e os usuários/consumidores finais. Essa etapa está basicamente dividida em mercado regulado (usuários cativos) e mercado livre de energia elétrica (consumidores livre ou especiais). A comercialização de energia elétrica passou a contar com dois ambientes de negociação a partir de 2004: o Ambiente de Contratação Regulada ACR, entre agentes de geração e de distribuição de energia (estes repassando tais custos aos usuários cativos); e o Ambiente de Contratação Livre - ACL, entre geradores, distribuidores, comercializadores, importadores e exportadores, além dos consumidores livres e especiais - sendo que estes devem possuir grandes volumes de contratação de energia, entre outras características, para exercer esta opção de compra de energia desvinculada da distribuidora. Há ainda o mercado de curto prazo, também conhecido como mercado de diferenças, no qual se promove o ajuste entre os volumes contratados e os volumes 
efetivamente medidos de energia, mas basicamente destinado aos integrantes do ambiente de contratação livre. (CCEE 2016)

Esta configuração integra 0 modelo setorial vigente, implantado em 2004 e fruto de um aprimoramento ao modelo originado em 1998, oriundo do Projeto de Reestruturação do Setor Elétrico Brasileiro - Projeto RE-SEB. Com a implantação do modelo atualizado em 2004, que objetivou alcançar a modicidade tarifária, foram instituídos no modelo atual os leilões de energia - que funcionam como instrumento de compra de energia elétrica pelas distribuidoras no ambiente regulado. Os leilões são realizados pela Câmara de Comercialização de Energia Elétrica - CCEE, por delegação da ANEEL, e utilizam o critério de menor tarifa, visando a redução do custo de aquisição da energia elétrica a ser repassada aos consumidores cativos. Entre estes leilões figuram os de energia nova, onde se busca garantir o abastecimento relacionado ao crescimento de mercado. O modelo em vigor exige a contratação de totalidade da demanda por parte das distribuidoras e dos consumidores livres; nova metodologia de cálculo do lastro para venda de geração; contratação de usinas hidrelétricas e termelétricas em proporções que assegurem melhor equilíbrio entre garantia e custo de suprimento, bem como o monitoramento permanente da segurança de suprimento. Este modelo foi implantado por meio das Leis $n^{\circ} 10.847$ e 10.848, de 15 de março de 2004, e pelo Decreto ㄲo 5.163, de 30 de julho de 2004. (CCEE 2016)

\section{PERDAS DE ENERGIA NOS PRINCIPAIS SEGMENTOS}

As perdas de energia elétrica ocorrem basicamente nos segmentos que possuem participação ativa na disponibilidade e consumo de energia elétrica, ou seja, nas etapas de Transmissão, Distribuição. As perdas atribuídas às questões técnicas são inerentes ao transporte da energia elétrica na rede, relacionadas à transformação de energia elétrica em energia térmica nos condutores (efeito Joule), perdas nos núcleos dos transformadores (Histerese) ou perdas dielétricas. Em outras palavras, trata-se do consumo dos equipamentos responsáveis pela transmissão e distribuição de energia. (MAHMOOD;SHIVAN;KUMAR;KRISHNAM, 2012)

As perdas na etapa da cadeia de Transmissão de Energia Elétrica, também denominada Rede Básica são apuradas mensalmente pela Câmara de Comercialização de Energia Elétrica - CCEE. A metodologia de cálculo das perdas técnicas é estabelecida pela Agência Nacional de Energia Elétrica nos Procedimentos de Distribuição de Energia Elétrica no Sistema Elétrico Nacional - PRODIST, em seu Módulo 7 - Cálculo de Perdas na Distribuição. (ANEEL, 2016)

As perdas não técnicas, também denominadas perdas comerciais, são estimadas considerando a diferença entre as perdas totais e as perdas técnicas, e considera as demais perdas associadas à distribuição de energia elétrica. Essas perdas decorrem de furtos de energia, erros de medição, erros no processo de faturamento, fornecimento sem equipamento de medição, entre outros.(MAHMOOD;SHIVAN;KUMAR;KRISHNAM, 2012)

Não definida como perda, mas importante como aproveitamento da energia está o conceito de eficiência energética, que corresponde à relação entre "a energia aproveitada por aparelhos, equipamentos e instalações e a energia a eles suprida. Há medidas que comparam PIB com intensidade energética e também consumo específico de equipamentos em alguns setores selecionados. Entretanto, a primeira medida traz grande dependência do peso de diversos setores na economia bem como o comportamento das pessoas, enquanto a segunda medida não apresentou ganhos sensíveis e generalizados no princípio do século XXI. (LEITE, 2013) 
Figura 3: Perdas na cadeia produtiva de energia elétrica.

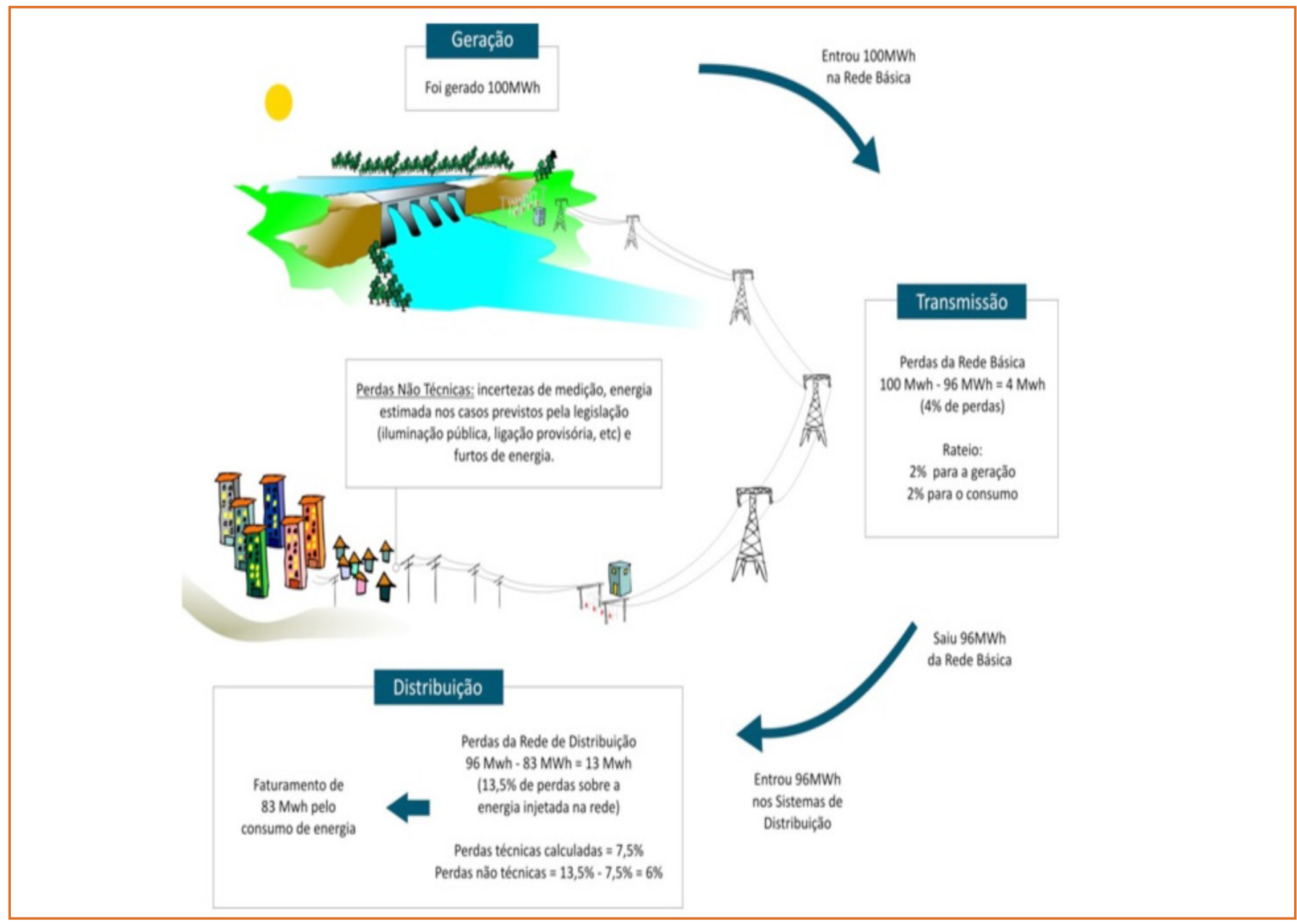

Fonte (ANEEL)

Gráfico 1 - Evolução das perdas em relação à energia injetada no sistema global das distribuidoras.

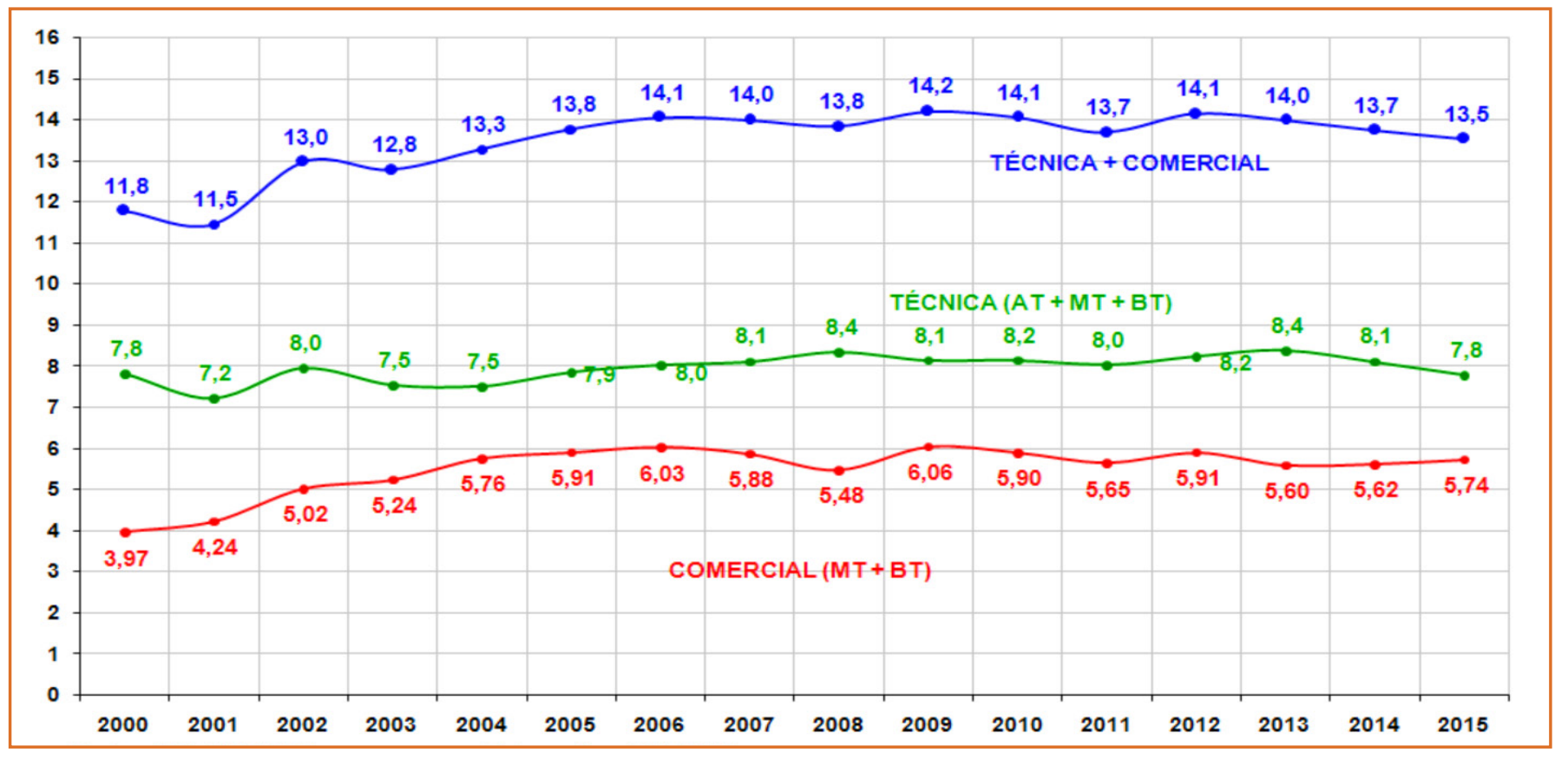

Fonte: (ABRADEE, 2016) 
1. 6. Políticas públicas na cadeia de energia elétrica A partir da revisão foram identificadas as políticas públicas relacionadas à redução das perdas na cadeia de produção.

\subsection{POLÍTICAS PÚBLICAS PARA A GERAÇÃO DISTRIBUÍDA}

O programa de desenvolvimento da geração distribuída de energia elétrica - ProGD foi lançado pelo Ministério de Minas e Energia em 2015 e objetiva ampliar e aprofundar as ações de estímulo à geração de energia pelos próprios consumidores, com base nas fontes renováveis de energia (em especial a solar fotovoltaica).A geração distribuída traz benefícios para o consumidor e para o setor elétrico uma vez que estará no centro de consumo, o que reduz a necessidade de estrutura de transmissão elétrica e evita perdas. A previsão é de que até 2030, 2,7 milhões de unidades consumidoras poderão ter energia gerada por elas mesmas, entre residência, comércios, indústrias e no setor agrícola, o que pode resultar em 23.500 MW (48 TWh produzidos) de energia limpa e renovável, o equivalente à metade da geração da Usina Hidrelétrica de Itaipu. Com isso, o Brasil pode evitar que sejam emitidos 29 milhões de toneladas de CO2 na atmosfera.

As ações correspondentes são:

a. Criação dos créditos de energia entre consumidor-gerador e distribuidora, com prazo de 36 meses para utilizá-la, possibilidade de usar crédito em outras unidades de mesma titularidade ou por meio de condomínios ou consórcios;

b. Isenção de ICMS regulamentada pelo Conselho Nacional de Política Fazendária - CONFAZ, permitindo a adesão de estados interessados;

c. Isenção de PIS/Cofins, formalizada por lei específica;

d. Redução do Imposto de Importação sobre bens de capital destinados à produção de equipamentos de geração solar fotovoltaica;

e. Apoio do Banco Nacional de Desenvolvimento Econômico e Social (BNDES) com recursos a taxas diferenciadas para projetos de eficiência energética e de geração distribuída por fontes renováveis em escolas e hospitais públicos.

(Fonte: MME, 2016)

\subsection{POLÍTICA PÚBLICA PARA GERAÇÃO DE ENERGIA POR FONTES ALTERNATIVAS}

O Programa de Incentivo às Fontes Alternativas de Energia Elétrica (Proinfa), foi instituído com o objetivo de aumentar a participação da energia elétrica produzida por empreendimentos concebidos com base em fontes eólica, biomassa e pequenas centrais hidrelétricas ( $\mathrm{PCH}$ ) no Sistema Elétrico Interligado Nacional (SIN), iniciado em 2010 e estabelecido que o valor pago pela energia elétrica adquirida, além dos custos administrativos, financeiros e encargos tributários incorridos pela Eletrobrás na contratação desses empreendimento, fossem rateados entre todas as classes de consumidores finais atendidas pelo SIN, com exceção dos consumidores classificados na Subclasse Residencial Baixa Renda (consumo igual ou inferior a $80 \mathrm{kWh} / \mathrm{mês}$ ). O Programa prevê a implantação de 144 usinas, totalizando 3.299,40 MW de capacidade instalada, sendo 1.191,24 MW provenientes de $63 \mathrm{PCHs}, 1.422,92 \mathrm{MW}$ de 54 usinas eólicas, e 685,24 MW de 27 usinas a base de biomassa. Toda essa energia tem garantia de contratação por 20 anos pela Centrais Elétricas Brasileiras S.A. (Eletrobrás). (Fonte: MME, 2016)

\subsection{POLÍTICAS PÚBLICAS PARA A EXPANSÃO E UNIVERSALIZAÇÃO DO FORNECIMENTO DE ENERGIA ELÉTRICA}

O Governo Federal criou em novembro de 2003 o Programa Luz para Todos, por meio do decreto lei no 4.873, de 11 de novembro de 2003 e prorrogado pelo Decreto $\mathrm{n}-6.442$, de 25 de abril de 2008 . O objetivo era levar energia elétrica de forma gratuita a 10 milhões de moradores, com o principal objetivo de promover o acesso à energia elétrica para famílias de baixa renda, residentes no meio rural, bem como também atender às demandas da comunidade como escolas, postos de saúde e sistemas de bombeamento de água. Para 
o atendimento dessa população, o Governo Federal destina recursos provenientes de fundos setoriais de energia - a Conta de Desenvolvimento Energético (CDE) e a Reserva Global de Reversão (RGR), verba de governos estaduais e investimentos das empresas distribuidoras de energia elétrica. Os investimentos chegam a $R \$ 20$ bilhões, dos quais $R \$ 14,5$ bilhões são do Governo Federal. As metas iniciais foram cumpridas em 2009 e em 2012 ultrapassaram 14,4 milhões de ligações. (Fonte: Espíndula, 2013)

\subsection{POLÍTICAS PÚBLICAS PARA O USO EFICIENTE DE ENERGIA ELÉTRICA E PESQUISA E DESENVOLVIMENTO}

\subsubsection{P\&D E PEE}

Os programas de Pesquisa \& Desenvolvimento (P\&D) e Eficiência Energética (PEE) para as empresas de energia elétrica vigoram desde o ano 2000. As obrigações de investimentos equivalem a $1 \%$ da receita operacional líquida das empresas sendo, no caso das empresas de distribuição, 0,75 \% destinam-se a P\&D e 0,25\% a eficiência energética. No caso das empresas de geração e transmissão exclusivamente para programas de P\&D. Dos recursos de P\&D, 40 \% são destinados ao Fundo Nacional de Desenvolvimento Científico e Tecnológico, a cargo do Ministério das Ciências, Tecnologia, Inovações e Comunicações, 40 \% em projetos das próprias empresas e supervisionados pela ANEEL e 20\% recolhido ao MME.(Fonte: Leite,A.D, 2013)

\subsubsection{PROCEL}

O Programa Nacional de Conservação de Energia Elétrica (Procel), criado em 1985 para promover o uso eficiente da energia elétrica, combatendo o desperdício e reduzindo os custos e os investimentos setoriais foi criado pelo governo federal em 1985, e é executado pela Eletrobras, com recursos da empresa, da Reserva Global de Reversão (RGR) e de entidades internacionais. Em 2015, o Procel contribuiu para uma economia de 11,7 bilhões de quilowatts-hora (kWh), o equivalente a $2,5 \%$ de todo o consumo nacional de energia elétrica naquele ano, redução nas emissões de gases de efeito estufa alcançando 1,453 milhão de toneladas de $\mathrm{CO} 2$ equivalentes, o que corresponde às emissões de 499 mil veículos em um ano. Instituído em 1993, o Selo Procel de Economia de Energia indica ao consumidor, no ato da compra, os equipamentos que apresentam os melhores níveis de eficiência energética dentro de cada categoria. O objetivo é estimular a fabricação e a comercialização de produtos mais eficientes, contribuindo para o desenvolvimento tecnológico e a preservação do meio ambiente. $O$ Procel conta com os seguintes subprogramas:

a. Procel GEM - Gestão Energética Municipal;

b. Procel Sanear - Eficiência Energética no Saneamento Ambiental;

c. Procel Educação - Informação e Cidadania;

d. Procel Indústria - Eficiência Energética Industrial;

e. Procel Edifica - Eficiência Energética em Edificações;

f. Procel EPP - Eficiência Energética nos Prédios Públicos;

g. Procel Reluz - Eficiência Energética na lluminação Pública e Sinalização Semafórica;

h. Selo Procel - Eficiência Energética em Equipamentos;

i. Procel Info - Centro Brasileiro de Informação de Eficiência Energética.

(Fonte: Eletrobrás, 2016)

\subsection{POLÍTICAS PÚBLICAS DE SUBVENÇÃO TARIFÁRIA PARA USUÁRIOS DE BAIXA RENDA}

Estabelecida por Lei, a Tarifa Social de Energia Elétrica (TSEE) introduziu inovações para o enquadramento de consumidores que poderão ser beneficiários de desconto na conta de energia elétrica. Caracterizada por descontos incidentes sobre a tarifa aplicável à classe residencial das distribuidoras de energia elétrica, é calculada de modo cumulativo, em descontos que variam entre $10 \%$ e $65 \%$ do valor da fatura de energia elétrica, atendendo critérios de renda e consumo, com o uso da Conta de Desenvolvimento EnergéticoCDE para atendimento à subvenção econômica destinada à modicidade da tarifa de fornecimento aos consumidores beneficiários.(Fonte: MME, 2016) 


\section{ANÁLISE E COMENTÁRIOS FINAIS}

Conforme proposto inicialmente o objetivo deste artigo foi identificar as políticas públicas estabelecidas para a cadeia produtiva de energia elétrica orientadas para a redução das perdas, bem como seus principais atores e suas responsabilidades, a fim de discutir as possíveis formas de compensação ou mitigação dessas perdas.

De acordo com a pesquisa realizada foram identificados como principais atores voltados para a formatação e implementação das políticas públicas o MME, o CNPE e a EPE. Com base na tipologia dos atores realizada por Dias e Matos, este grupo responsável pelas políticas públicas no setor de energia elétrica está basicamente formado por: atores fundamentais, equipe de governo e corpo técnico.

Como funções principais, os atores fundamentais são constituídos por figuras políticas eletivas e sua equipe administrativa, com a função de responder pela acomodação dos interesses da coletividade. A equipe de governo refletirá um quadro de servidores indicado pelos próprios governantes. Já o corpo técnico é contratado diretamente pelo estado cujo papel deve ser imparcial e profissional. Embora tais atores tenham sido identificados entre aqueles elencados por Dias e Matos para a formulação das políticas mencionadas, a não inclusão do tema perdas na formulação destas políticas sugere que outros relevantes atores em políticas públicas não foram inseridos no processo de formulação, como os denominados "atores de conhecimento" (por ex. centros de pesquisas), associações profissionais ou grupos de pressão específicos (neste caso aqueles que poderiam defender políticas de maior eficiência energética).

As principais políticas públicas referenciadas neste estudo estão voltadas para a ampliação do uso de energia elétrica, de forma eficiente e com o uso de fontes alternativas de energia elétrica de origem renovável. Com relação ao resultado observado nas perdas da cadeia de produção de energia elétrica, conforme identificado pela ABRADE(2016), há uma clara estabilização das perdas na distribuição em relação à energia injetada, seja de origem técnica ou comercial.

Em que pese muitas dessas iniciativas indiretamente beneficiarem a redução de perdas de energia (P\&D; PEE; PROCEL; TSEE), ou mesmo sua mitigação (ProGD), o que se verifica nos resultados estáveis de perdas é que tais políticas públicas não corroboram com uma resposta no potencial necessário para o atender plenamente o que deveria ser uma premissa de redução de perdas. No entanto, deve-se destacar que as políticas públicas voltadas para a expansão do atendimento e fomento no uso de fontes alternativas (Luz para Todos e PROINFA) foram muito incentivadas, conforme apresentado por Espíndula e MME. Como para atingir os objetivos de expansão de tais programas é necessária a implementação de redes de energia normalmente distantes dos principais centros de consumo há, consequentemente, o incremento das perdas técnicas.

Assim, considerando as políticas públicas estabelecidas e identificadas no presente trabalho para a cadeia produtiva de energia elétrica, os principais atores envolvidos na formulação dessas políticas (MME, CNPE e EPE) poderiam estabelecer como premissa dos programas instituídos a busca de uma trajetória de redução das perdas de energia elétrica decorrentes de tais políticas. Desta forma, - componente de redução seria um fator a ser considerado nos resultados.

Dias e Matos destacam que a participação da sociedade é essencial na gestão pública pois poderia colaborar quanto às suas necessidades e consequente promoção da utilização dos recursos. O resultado da trajetória de perdas nos permite afirmar que este componente não vem sendo priorizada pelas políticas públicas existentes. Assim, em linha com a tese de Dias e Matos, uma maior participação da sociedade nas políticas públicas existentes poderia prever a preocupação com a trajetória de perdas de energia no sistema elétrico e assim ser inserida como mais um indicador para a verificação do êxito das políticas formuladas.

Alternativamente, como não foi identificada na pesquisa realizada nenhuma política específica com 
o foco na redução das perdas na cadeia produtiva do setor de energia elétrica também poderia ser promovida uma política pública orientada para a compensação e mitigação das perdas nas instâncias intermediárias da cadeia de produção de energia. Isto significaria a implementação de uma política de incentivo à geração distribuída pelos próprios agentes de distribuição e transmissão, especificamente para compensação e mitigação das perdas na sua parcela do processo produtivo, reduzindo assim a necessidade de expansão da geração por meio de grandes usinas para suprir as perdas de energia existentes.

\section{REFERÊNCIAS}

[1] AGÊNCIA NACIONAL DE ENERGIA ELÉTRICA-ANEEL. Atlas de energia elétrica do Brasil.3. ed. - Brasília : Aneel, 2008, pgs 28 a 33 .

[2] AGÊNCIA NACIONAL DE ENERGIA ELÉTRICAANEEL. Perdas de energia elétrica. Disponível em $<h t t p: / / w w w . a n e e l . g \quad$ ov.br/busca?p_p_id=101\&p_p_ lifecycle $=0 \& p \_p \_s t a t e=$ maximized\&p_p_mode $=v i e w \& \_101$ struts_action=\%2Fasset_publisher\%2Fview_content\&_10 1_returnToFullPageURL = \% 2Fweb\%2Fguest $\% 2$ Fbusca\&_101_assetEntryld $=14485421 \& \_101$ type $=$ content\&_101_groupld $=654800 \& \_101 \_$ur $\mid$Tit| e=perdas\&_101_redirect $=$ http $\% 3 A \% 2 F \% 2 F w w w$. aneel.gov.br\%2Fbusca\%3Fp_p_id\%3D3\%26p_p_ lifecycle\%3D0\%26p_p_state\%3Dmaximized\%26p_p _mode\%3Dview\%26_3_groupld\%3D0\%26_3 keywords\%3 Dperda\%26_3_search.x\% 3 D $0 \% 26$ _ 3_search.y\%3D0\%26_3_struts _ action \% 3D\%252Fsearch\%252Fsearch\%26 3 redirect\%3D\%252Fweb\% $252 \mathrm{Fguest} \% 252 \mathrm{Fb}$ usca\&inheritRedirect=true> Acesso em 30/07/2016

[3] CÂMARA DE COMPENSAÇÃO DE ENERGIA ELÉTRICA-CCEE. Disponível em<https://www.ccee. org.br/portal/faces/pages_publico/onde-atuamos/ setor_eletrico?_afrLoop=135357596956599\#\%40\%3F_ afrLoop\%3D135357596956599\%26_adf.ctrl-stat e\%3D19yc9veydo_4> Acesso em 30/07/2016.

[4] COMPARATO, F. Ensaio sobre o juízo de constitucionalidade de Políticas Públicas, Revista dos Tribunais, março de 1997, pg 17-18.

[5] DIAS, R. e MATOS F. Políticas Públicas-Princípios, Propósitos e Processos. Editora Atlas, 2012, pg.11,42-44, 161.

[6] DWORKIN, R. Levando os Direitos a Sério, Ed.Martins Fontes, 2002, pg.36.

[7] ELETROBRÁS. PROCEL. Disponível em:<https://www. eletrobras.com/elb/data/Pages/LUMIS0389BBA8PTBRIE. htm> Acesso em 26/08/2016
[8] EMPRESA DE PESQUISA ENERGÉTICA-EPE. BALANÇO ENERGÉTICO NACIONAL-RELATÓRIO SÍNTESE, ANO BASE 2015, RIO DE JANEIRO, RJ, junho de 2016, pg.34.

[9] ESPínDULA, D.C.F. Políticas Públicas no Setor de Energia Elétrica: Uma análise do Programa Luz para Todos. Trabalho de Graduação UniCEUB/NPM, 2013

[10] LAHERA, E.P. Políticas y Políticas Públicas. Santiago de Chile: Cepal, 2004.(Série Políticas Sociales, 95).

[11] LEITE, A.D. Eficiência e Desperdício da Energia no Brasil, 2013, pgs 81-83 e 87-88.

[12] MAHMOOS,M.; SHIVAN,O.;KUMAR,P. Real Time Study on Technical Losses in Distribution System, 2014; International Journal of Advanced Research in Electrical, Electronics and Instrumentation Engineering, Vol. 3, Special Issue 1, February 2014

[13] MINISTÉRIO DE MINAS E ENERGIA-MME. ProGDDisponível em <http://www.mme.gov.br/we b/guest/ pagina-inicial?p_p_auth $=0 \mathrm{OcPrDfO} \&$ p_p_id $=101 \&$ p_p_ lifecycle $=0 \& p \_p \_s t a t e=$ maximized\&p_p_mode $=v i e w \& \_101$ struts_act ion=\%2Fasset_publisher\% 2Fview_content\&_101_ returnToFullPageURL=\%2F\& _101_assetEntryld $=3094745 \&$ _101_type =content\&_101_uriTitle=programa - de geracao-distribuida-preve-movimentar-r-100-bi-eminvestimentos-ate-2030\&redirect $=$ http $\% 3 \mathrm{~A} \% 2 \mathrm{~F} \% 2 \mathrm{Fwww}$. mme.gov.br\% 2 Fweb\% 2 F guest $\% 2 F$ paginainicial\%3Fp_p_id\%3D3\%26p_p_lifecycle\%3D0\%26p_p_ state\%3Dma ximized\%26p_p_mode\%3Dview\% 26_3 groupld\%3D0\%26_3_keywords\%3Dprograma\%2Bde\%2 B g e r a \% 25 C $3 \% 25$ A $7 \% 25$ C $3 \% 25$ A 3 0\%2Bdistribuida\%2Bpreve\%2Bmovimen tar\%26_3_struts actio n\%3D\%252Fsearch\%252Fsearch\%26_3_redirect\%3D \%252F\&inheritRedirect=true> Acesso em 26/08/2016

[14] Competências dos órgãos- Disponível em < http://www. mme.gov.br/web/guest/acesso-a-informacao/institucional/ competencias $>;<$ http://mme.gov.br/web/guest/entidadesvinculadas-e-afins/epe $>$ e,,$<$ http://mme.gov.br/web/guest/ conselhos-e-comites/cnpe> Acesso em 30/08/2016.

[15] MINISTÉRIO DE MINAS E ENERGIA-MME. Proinfa. Disponível em < http://www.mme.gov.br/web/guest/acessoa-informacao/acoes-e-programas/programas/proinfa> Acesso em 26/08/2016

[16] MINISTÉRIO DE MINAS E ENERGIA-MME. Tarifa Social. Disponível em < http://www.mme.gov.br/web/guest/acessoa-informacao/acoes-e-programas/acoes/energia-eletrica/ tarifa-social-de-energia-eletrica> Acesso em 26/08/2016

[17] OPERADOR NACIONAL DO SISTEMA ELÉTRICO -ONS. O Novo Modelo do Setor Elétrico. Disponível em < http://www.ons.org.br/institucional_linguas/relacionamentos. aspx>. Acesso em 30/07/2016.

[18] PIMENTA, A.P.A. Serviços de Energia Elétrica Explorados em Regime Jurídico de Dlreito Privado, de 15 de jan2009.Disponível em <http://www2.aneel.gov.br/biblioteca/ trabalhos/trabalhos/Patrus_Andre_Servicos.pdf> Acesso em 04/08/2016. 
[19] POMILIO, J.A. Eletrônica de Potência para Geração, Transmissão e Distribuição de Energia Elétrica, 2013. Disponível em < http://www.dsce.fee.unicamp.br/ antenor/ pdffiles/it744/introdu\%e7\%e3o.pdf> e <http://www.dsce.fee. unicamp.br/ antenor/pdffiles/it744/CAP1.pdf>

[20] QUEIROZ, L. Estimação e Análise das Perdas Técnicas na Distribuição de Energia Elétrica, Tese de Doutorado UNICAMP, 2010.
[21] TEIXEIRA, E.C. O Papel das Políticas Públicas no Desenvolvimento Local e na Transformação da Realidade, 2002. Disponível em: <http://www.dhnet.org.br/dados/ cursos/aatr2/a_pdf/03_aatr_pp_papel.pdf>. Acesso em 26/08/2016 


\title{
CAPÍTULO 8
}

\section{A IMPORTÂNCIA DA ADEQUADA SEPARAÇÃo DE RESÍDUOS SÓLIDOS NA CONSTRUÇÃ̃ CIVIL}

\author{
Rodrigo Vielmo Moura \\ Maiara Baldissarelli \\ Jamile Pereira da Silva \\ DiegoWillian Nascimento Machado \\ Mario Fernando de Mello
}

Resumo: Os impactos ambientais causados pelo armazenamento incorreto dos resíduos sólidos são vários e podem comprometer os recursos naturais, assim como a sobrevivência humana. O objetivo deste artigo é a compreensão da importância da separação de resíduos sólidos na construção civil, pois com uma gestão de qualidade pode-se evitar custos, desperdício de materiais e principalmente diminuir o impacto ambiental do planeta. O presente estudo foi dividido em três etapas. A primeira consistiu em um entendimento das leis e decretos do Brasil e da cidade de Santa Maria, Rio Grande do Sul; a segunda numa revisão bibliográfica envolvendo o tema; e, na última etapa procederam-se algumas inspeções visuais em três obras a fim de analisar a produção e armazenamento dos resíduos gerados na construção civil. Através de uma visita numa empresa especializada em coleta e reciclagem de resíduos sólidos, consegui-se acompanhar e compreender todos os processos que a empresa se responsabiliza, como as demolições, coleta de entulho, reciclagem da madeira, gesso e ferro. Durante inspeções visuais feitas em obras, com o objetivo de observar e avaliar se estão sendo seguidos as resoluções e os decretos de lei, sobre os resíduos sólidos da construção civil. As obras, em sua grande maioria, apresentaram bons resultados, uma vez que utilizavam as resoluções e decretos previstos em quase todas as etapas dos resíduos das obras, somente em alguns casos observou-se irregularidades.

Palavras chave: Impacto ambiental, Resíduos Sólidos na Construção Civil, Leis e decretos, Gestão de Resíduos. 


\section{INTRODUÇÃO}

Entre os diversos setores da indústria, a construção civil é uma das maiores geradoras de resíduos, superando até mesmo a geração de resíduos domiciliares por habitante. Segundo John (2010) a porcentagem de resíduos da construção civil varia entre 40\% e 70\% do total de resíduos sólidos de cidades de médio e grande porte.

Conforme John (2010) a preocupação em diminuir a geração de resíduos, e consequentemente as perdas, deve começar na concepção do empreendimento, seguido pela execução e utilização de produtos que geram resíduos. A importância de ter uma preocupação com a diminuição de resíduos está diretamente ligada ao meio ambiente, como também à sustentabilidade. A geração desenfreada de resíduos sólidos sem conscientização acarreta em grandes impactos ambientais, afetando bastante as gerações futuras. Além disso, Assis (2012) apresenta a reciclagem dos resíduos sólidos como uma solução viável para resolver os problemas dos resíduos dos pontos de vista econômico, ambiental e social, contribuindo para a sustentabilidade do setor da Construção Civil.

A Resolução 307 do CONAMA exige dos geradores de resíduos sólidos uma proposta para gestão dos resíduos, gerenciar a quantidade de resíduos gerados visando a sua diminuição é um grande desafio, uma vez que o seu número hoje é muito grande. Segundo Jadovski (2008), poucas são as iniciativas praticadas e implantadas no país que visam a reciclagem como forma de aproveitar os resíduos da construção civil e diminuir a quantidade direcionada para os aterros sanitários e locais inadequados.

Sendo assim, o objetivo geral deste trabalho é avaliar a separação e a organização do armazenamento dos resíduos sólidos da construção civil em obras localizadas na cidade de Santa Maria-RS, dentro das resoluções do CONAMA e os decretos de lei da cidade.

\section{REFERENCIAL TEÓRICO}

Neste capítulo serão descritos os principais conceitos estudados relacionados aos resíduos sólidos da construção civil, com objetivo de compreender melhor o assunto com estudos já existentes.

\subsection{RESÍDUOS SÓLIDOS NA CONSTRUÇÃO CIVIL}

A construção civil é um setor da economia formado por uma enorme quantidade de atividades, com isso gera uma grande quantidade de empregos. Entretanto, constitui uma atividade desanimadora que é a geração de impactos ambientais com os resíduos que concebe. Conforme John (2010), os resíduos da construção civil são definidos como entulhos e tecnicamente são determinados como todo resíduo de material usado na realização de etapas de obras em atividades de construção civil, podendo ser provenientes de obras de infraestrutura, demolições, reformas, restaurações, reparos, etc.

Segundo Jadovski (2008) a composição dos resíduos da construção civil brasileira gerados em uma obra é, basicamente, constituída por argamassa, concreto e blocos de concreto, além de madeiras, plásticos, papel e papelão. Entretanto, também podem ser gerados resíduos classificados como perigosos e não inertes. Os resíduos perigosos apresentam riscos à saúde pública e ao meio ambiente em função das suas características de inflamabilidade, corrosividade, reatividade, toxicidade e patogenicidade. Resíduos não inertes não apresentam riscos, são basicamente resíduos domésticos. Na figura 1 há uma porcentagem de cada tipo de resíduo que é gerado em maiores quantidades na construção civil. 
Figura 1- Porcentagem de tipos de resíduos

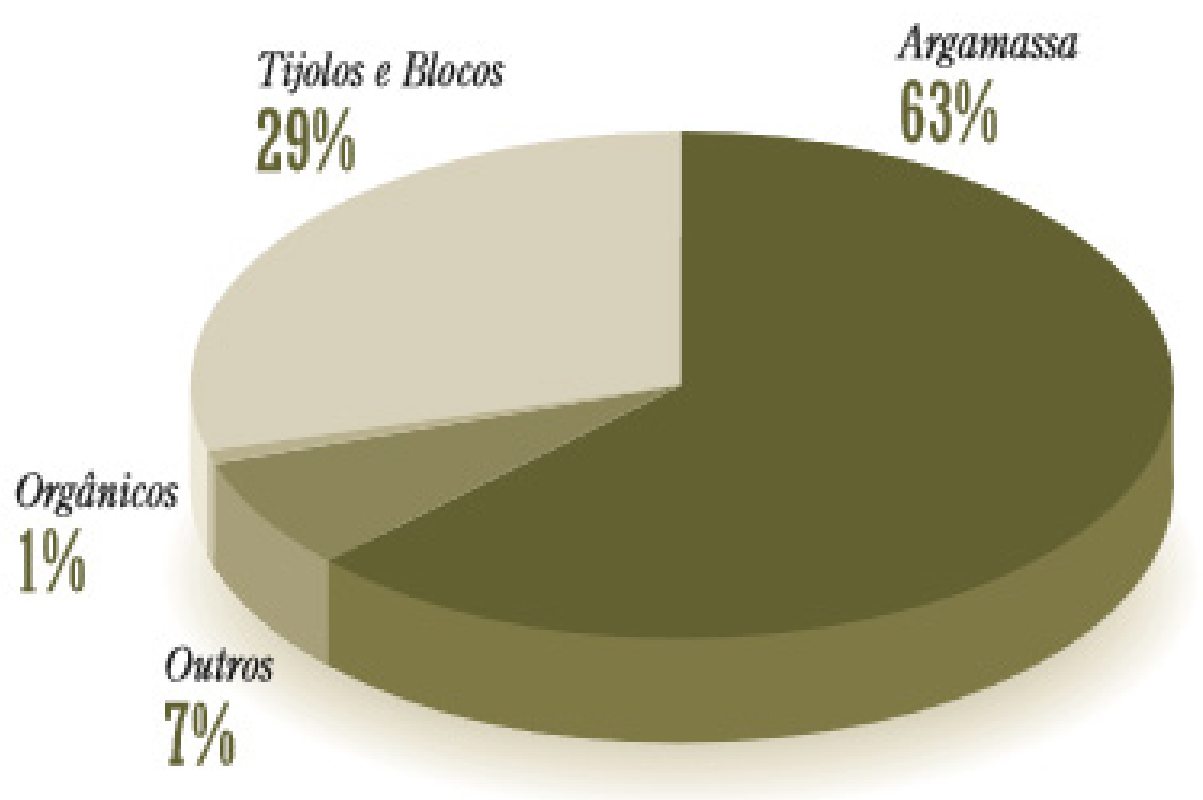

Fonte: Blumenschein, 2004

Segundo Blumenschein (2004) os resíduos sólidos provenientes de canteiros de obras, particularmente os resíduos classe $A$ e classe $B$ de acordo com a resolução 307 do Conama são os resíduos que são possíveis de serem absorvidos pelos processos de reciclagem.

\subsection{GESTÃO DE RESÍDUOS DA CONSTRUÇÃO CIVIL}

Segundo Costa (2010), a falta de gerenciamento adequado dos resíduos de construção e demolição acarreta sua disposição indevida, sendo que muitas vezes eles são jogados em terrenos baldios, em beiras de estradas, córregos e, quando dispostos em lixões e aterros, pelo seu alto volume, acabam por saturar rapidamente a capacidade do local.

$\mathrm{Na}$ concepção de um projeto, deve ser pensado o sistema que será utilizado para a execução da obra, como a possibilidade do cliente optar pelo acabamento de seus produtos à seu gosto, evitando "quebradeiras" e rasgos desnecessários, buscando uma menor taxa gerada de resíduos sólidos. Mas para isso, é necessário que se tenha uma mão-de-obra qualificada pois a qualidade deste serviço oferecido pode potencializar ou minimizar a geração de resíduos em canteiros de obras.

Conforme Donat (2008) o governo brasileiro criou uma série de medidas como uma tentativa de amenizar a situação decorrente dos grandes volumes de entulhos.

\subsection{CONSELHO NACIONAL DO MEIO AMBIENTE - CONAMA}

Conama é o Conselho Nacional do Meio Ambiente, órgão consultivo e deliberativo do Sistema Nacional do Meio Ambiente-SISNAMA, criado pela Política Nacional do Meio Ambiente. Ele não é um lugar físico, mas sim um ambiente vivido por reuniões como as Câmaras Técnicas, Grupos de Trabalho e as Plenárias, as quais se reúnem os Conselheiros.

O Conselho pode produzir diversos atos, sendo que seu principal e mais conhecido instrumento são as suas Resoluções. Por meio desses dispositivos são 
estabelecidas normas, critérios e padrões relativos ao controle e à manutenção da qualidade do meio ambiente, com vistas ao uso racional dos recursos ambientais. O processo se inicia mediante proposta de seus Conselheiros, que segue para ser analisado pelo Ministério do Meio Ambiente -MMA e entidades vinculadas (Ibama, SFB, ANA e ICMBio), no que couber, e segue de acordo com a estrutura de trabalho pré-determinada por seu Regimento Interno.

As principais competências da Conama são: estabelecer normas e critérios para o licenciamento de atividades efetiva ou potencialmente poluidoras; determinar a necessidade de realização de estudos das alternativas e das possíveis consequências ambientais de projetos públicos ou privados; decisão, em última instância administrativa, sobre as multas e outras penalidades impostas pelo IBAMA; estabelecer normas e padrões nacionais de controle da poluição causada por veículos automotores, aeronaves e embarcações; estabelecer normas, critérios e padrões relativos ao controle e à manutenção da qualidade do meio ambiente, com vistas ao uso racional dos recursos ambientais, principalmente os hídricos; e a deliberação, sob a forma de resoluções, proposições, recomendações e moções, que visam cumprir os objetivos da Política Nacional de Meio Ambiente.

\subsubsection{RESOLUÇÃO 307 CONAMA}

A resolução estabelecer diretrizes, critérios e procedimentos para a gestão dos resíduos da construção civil, disciplinando as ações necessárias de forma a minimizar os impactos ambientais. Portanto, para efeito desta Resolução são adotadas as seguintes definições:

I - Resíduos da construção civil: são os provenientes de construções, reformas, reparos e demolições de obras de construção civil, e os resultantes da preparação e da escavação de terrenos, tais como: tijolos, blocos cerâmicos, concreto em geral, solos, rochas, metais, resinas, colas, tintas, madeiras e compensados, forros, argamassa, gesso, telhas, pavimento asfáltico, vidros, plásticos, tubulações, fiação elétrica etc., comumente chamados de entulhos de obras, caliça ou metralha;

II - Geradores: são pessoas, físicas ou jurídicas, públicas ou privadas, responsáveis por atividades ou empreendimentos que gerem os resíduos definidos nesta Resolução;

III - Transportadores: são as pessoas, físicas ou jurídicas, encarregadas da coleta e do transporte dos resíduos entre as fontes geradoras e as áreas de destinação;

IV - Agregado reciclado: é o material granular proveniente do beneficiamento de resíduos de construção que apresentem características técnicas para a aplicação em obras de edificação, de infraestrutura, em aterros sanitários ou outras obras de engenharia;

V - Gerenciamento de resíduos: é o sistema de gestão que visa reduzir, reutilizar ou reciclar resíduos, incluindo planejamento, responsabilidades, práticas, procedimentos e recursos para desenvolver e implementar as ações necessárias ao cumprimento das etapas previstas em programas e planos;

VI - Reutilização: é o processo de reaplicação de um resíduo, sem transformação do mesmo;

VII - Reciclagem: é o processo de reaproveitamento de um resíduo, após ter sido submetido à transformação;

VIII - Beneficiamento: é o ato de submeter um resíduo à operações e/ou processos que tenham por objetivo dotá-los de condições que permitam que sejam utilizados como matéria-prima ou produto;

IX - Aterro de resíduos classe A de reservação de material para usos futuros: é a área tecnicamente adequada onde serão empregadas técnicas de destinação de resíduos da construção civil classe A no solo, visando a reservação de materiais segregados de forma a possibilitar seu uso futuro ou futura utilização da área, utilizando princípios de engenharia para confiná-los ao menor volume possível, sem causar danos à saúde pública e ao meio ambiente e devidamente licenciado pelo órgão ambiental competente; (nova redação dada pela Resolução 448/12) 
$X$ - Área de transbordo e triagem de resíduos da construção civil e resíduos volumosos (ATT): área destinada ao recebimento de resíduos da construção civil e resíduos volumosos, para triagem, armazenamento temporário dos materiais segregados, eventual transformação e posterior remoção para destinação adequada, observando normas operacionais específicas de modo a evitar danos ou riscos a saúde pública e a segurança e a minimizar os impactos ambientais adversos; (nova redação dada pela Resolução 448/12)

XI - Gerenciamento de resíduos sólidos: conjunto de ações exercidas, direta ou indiretamente, nas etapas de coleta, transporte, transbordo, tratamento e destinação final ambientalmente adequada dos resíduos sólidos e disposição final ambientalmente adequada dos rejeitos, de acordo com plano municipal de gestão integrada de resíduos sólidos ou com plano de gerenciamento de resíduos sólidos, exigidos na forma da Lei no 12.305, de 2 de agosto de 2010; (nova redação dada pela Resolução 448/12)

XII - Gestão integrada de resíduos sólidos: conjunto de ações voltadas para a busca de soluções para os resíduos sólidos, de forma a considerar as dimensões política, econômica, ambiental, cultural e social, com controle social e sob a premissa do desenvolvimento sustentável. (nova redação dada pela Resolução 448/12)

Além disso os geradores deverão ter como objetivo prioritário a não geração de resíduos e, secundariamente, a redução, a reutilização, a reciclagem, o tratamento dos resíduos sólidos e a disposição final ambientalmente adequada dos rejeitos. Planos de Gerenciamento de Resíduos da Construção Civil serão elaborados e implementados pelos grandes geradores e terão como objetivo estabelecer os procedimentos necessários para o manejo e destinação ambientalmente adequados dos resíduos.

\subsection{DECRETO 146/2009PIGRCC}

Esse decreto aprova o Plano Integrado de Gerenciamento dos resíduos da construção civil de Santa Maria, estabelecendo diretrizes, critérios e procedimentos para a gestão sustentável dos resíduos da construção civil gerados no município.

No Plano Integrado de Gerenciamento de Resíduos da Construção Civil de Santa Maria (PIGRCC/SM) os resíduos devem ser, preferencialmente, segregados na origem e transportados de forma diferenciada para o reaproveitamento, tratamento ou destino final. Com o plano de gestão implantado, os resíduos da construção civil serão encaminhados a locais onde possam ser dispostos de forma adequada, evitando, assim, que estes materiais sejam descartados em locais impróprios no município ou encaminhados para os aterros sanitários.

Gerador é responsável pelo gerenciamento dos seus resíduos, segregando, preferencialmente, na origem, utilizando transporte licenciado e adequado e realizando a disposição final em locais devidamente licenciados pelo município. O pequeno gerador, abrangido pelo Programa Municipal de Gerenciamento de Resíduos da Construção Civil, terá facultado o transporte de pequenos volumes, até $3,5 \mathrm{~m}^{3}$ por obra, em veículos próprios ou terceirizados, não licenciados encaminhando os resíduos para as áreas licenciadas pelo município. O transportador de resíduos da construção civil é diretamente responsável pela correta operação, obrigando-se ao licenciamento de sua atividade. Os operadores, públicos ou privados, das áreas de recebimentos de resíduos da construção civil, são responsáveis pela utilização e disposição dos mesmos nas áreas licenciadas, assim, como, pelos danos ambientais que por ventura derem causa. Fica facultado ao gerador, independente do porte, a doação ou venda dos resíduos classe A que possam ser reutilizados (tijolos, telhas, pisos), bem como resíduos classe B (madeira, papel, papelão, e outros.). Na figura 2 está descrito como é estabelecida a classificação dos grupo de resíduos. 
Figura 2- Tabela de classificação dos resíduos

\begin{tabular}{|c|c|}
\hline Classifícação & Tipologia \\
\hline Classe A & $\begin{array}{l}\text { São os resíduos reutilizáveis ou recicláveis como agregados, tais como: solos } \\
\text { provenientes de terraplanagem, tijolos, blocos, telhas, placas de revestimento, argamassa } \\
\text { e concreto, peças pré moldadas em concreto (blocos, tubos, meios-fios); }\end{array}$ \\
\hline Classe B & $\begin{array}{l}\text { São os resíduos recicláveis para outras destinações, tais como: plásticos,papel, papelão, } \\
\text { metais, vidros, madeiras e gesso; }\end{array}$ \\
\hline Classe C & $\begin{array}{l}\text { São os resíduos para os quais não foram desenvolvidas tecnologias ou aplicações } \\
\text { economicamente viáveis que permitam a sua reciclagem/recuperação, tais como: manta } \\
\text { asfáltica e lã de vidro; }\end{array}$ \\
\hline Classe D & $\begin{array}{l}\text { São resíduos perigosos oriundos do processo de construção, tais como tintas, solventes, } \\
\text { óleos, reparos de clínicas radiológicas, instalações industriais e materiais que contenham } \\
\text { amianto; }\end{array}$ \\
\hline
\end{tabular}

Fonte: GR2 Resíduos, 2016.

\subsection{PLANO NACIONAL DE RESÍDUOS SÓLIDOS}

A Lei no 12.305/10, que institui a Política Nacional de Resíduos Sólidos (PNRS) é bastante atual e contém instrumentos importantes para permitir o avanço necessário ao País no enfrentamento dos principais problemas ambientais, sociais e econômicos decorrentes do manejo inadequado dos resíduos sólidos.

Prevê a prevenção e a redução na geração de resíduos, tendo como proposta a prática de hábitos de consumo sustentável e um conjunto de instrumentos para propiciar o aumento da reciclagem e da reutilização dos resíduos sólidos (aquilo que tem valor econômico e pode ser reciclado ou reaproveitado) e a destinação ambientalmente adequada dos rejeitos (aquilo que não pode ser reciclado ou reutilizado).
Institui a responsabilidade compartilhada dos geradores de resíduos: dos fabricantes, importadores, distribuidores, comerciantes, o cidadão e titulares de serviços de manejo dos resíduos sólidos urbanos na Logística Reversa dos resíduos e embalagens pósconsumo e pós-consumo.

Cria metas importantes que irão contribuir para a eliminação dos lixões e institui instrumentos de planejamento nos níveis nacional, estadual, micro regional, intermunicipal e metropolitano e municipal; além de impor que os particulares elaborem seus Planos de Gerenciamento de Resíduos Sólidos.

Também coloca o Brasil em patamar de igualdade aos principais países desenvolvidos no que concerne ao marco legal e inova com a inclusão de catadoras e catadores de materiais recicláveis e reutilizáveis, tanto na Logística Reversa quando na Coleta Seletiva. 
Além disso, os instrumentos da PNRS ajudaram o Brasil a atingir uma das metas do Plano Nacional sobre Mudança do Clima, que foi alcançar o índice de reciclagem de resíduos de 20\% em 2015.

\subsection{SUSTENTABILIDADE}

A sustentabilidade pode ser descrita como o modo que o ser humano se relaciona com o mundo, preservando o meio ambiente para não comprometer os recursos naturais. Nesse conceito é preciso respeitar o ser humano, para que este possa respeitar a natureza.

A construção é um dos maiores responsáveis pela geração de resíduos sólidos. Dados levantados por Schneider (2004) sobre a geração dos resíduos da construção civil mostram que essa questão é mundialmente reconhecida. O processo de controle desses resíduos deveria ser um dos quesitos principais de debate nas empresas, evitando custos, desperdício de materiais para a sustentabilidade do planeta. Os sistemas construtivos como steel frame, wood frame e alvenaria estrutural estão entre os que geram menos resíduos na construção civil, pois são sistemas que visam a sustentabilidade e racionalidade, porém dificilmente as empresas terão uma taxa mínima de resíduos sólidos. Segundo Thomaz (2001) tudo isso está relacionado à eficiência da forma de construir. Visando esse desperdício de materiais que se torna incômodo, pode ser transformado numa redução de custos, por meio da venda desses resíduos para empresas de reciclagem especializadas.

O principal destino dos resíduos sólidos da construção civil deve ser pensado de forma que se tenha o total controle e conhecimento do início ao término no canteiro de obras, gerenciados pelas etapas de manuseio, armazenamento, coleta, transporte, reutilização, reciclagem, tratamento e disposição final.

\section{METODOLOGIA}

Quanto aos objetivos esta pesquisa é do tipo exploratória que segundo Gil (2008) proporciona maior familiaridade com o problema ao mesmo tempo em que pode explicita-lo. É também uma pesquisa explicativa, pois identifica fatores que determinam ou que contribuem para a ocorrência dos fenômenos. Ainda segundo Gil (2008), este tipo de pesquisa aprofunda o conhecimento da realidade porque explica a razão e o porquê das coisas.

O presente estudo foi dividido em três etapas. A primeira consistiu em um entendimento nas leis e decretos do Brasil e da cidade de Santa Maria, no Rio Grande do Sul, a segunda numa revisão bibliográfica envolvendo o tema. Na terceira etapa procedeu-se algumas inspeções visuais em três obras à fim de analisar a produção e armazenamento dos resíduos gerados na construção civil. O estudo foi realizado durante os meses de Julho, Agosto e Setembro de 2016.

\section{RESULTADOS}

\subsection{VISITA EM EMPRESA ESPECIALIZADA EM RESÍDUOS SÓLIDOS, NA CIDADE DE SANTA MARIA NO RIO GRANDE DO SUL}

Através de uma visita numa empresa especializada em coleta e reciclagem de resíduos sólidos na cidade de Santa Maria, no Rio Grande do Sul, conseguimos acompanhar e compreender todos os processos que a empresa se responsabiliza como as demolições, coleta de entulho, reciclagem da madeira, gesso e ferro. Nesta empresa a preservação e sustentabilidade do meio ambiente é o ponto chave, oferecendo serviços que minimizam os impactos da construção civil no meio ambiente.

Dentro dos métodos de reciclagem da empresa está a transformação da madeira em cavacos de alta qualidade, utilizando como combustíveis em caldeiras e fornalhas de indústrias, ou ainda a madeira pode ser reutilizada na obra se não estiver suja e danificada. No caso do gesso, a coleta seletiva melhora a qualidade do resíduo a ser enviado para a reciclagem, tornando-a mais fácil, sendo limpo pode ser utilizado novamente na cadeia produtiva.

Pode-se observar também que o ferro é separado dentro do entulho e enviado numa caçamba para siderúrgica, onde é reutilizado, contemplando assim 
os princípios da sustentabilidade como geração de economia e proteção ambiental. As demolições estão entre o processo com mais preocupação enfrentado pela empresa especializada em reciclagem, pois gera uma grande quantidade de resíduos da construção civil com a demolição resultando em grandes transtornos para população e o meio ambiente.

\subsection{VISITA EM OBRAS LOCALIZADAS NA CIDADE DE SANTA MARIA, NO RIO GRANDE DO SUL}

Durante inspeções visuais feitas em obras localizadas na cidade de Santa Maria, Rio Grande do Sul, tivemos o objetivo de observar e avaliar se estão sendo seguidos as resoluções e os decretos de lei, citados anteriormente, sobre os resíduos sólidos da construção civil.

As obras, em sua grande maioria, apresentaram bons resultados, uma vez que utilizavam as resoluções e decretos previstos. Nas etapas visualizadas, em casos específicos foram observadas irregularidades.

Nas figuras 3 e 4 , pode-se observar, na primeira imagem estão dispostos diversos tipos de resíduos juntos, tornando impossível realizar uma reciclagem deste material, na segunda imagem observa-se também a irregularidade da disposição dos blocos, tornando-os sem utilidades futuras na obra.
Figura 3 - Acondicionamento irregular de diversos resíduos

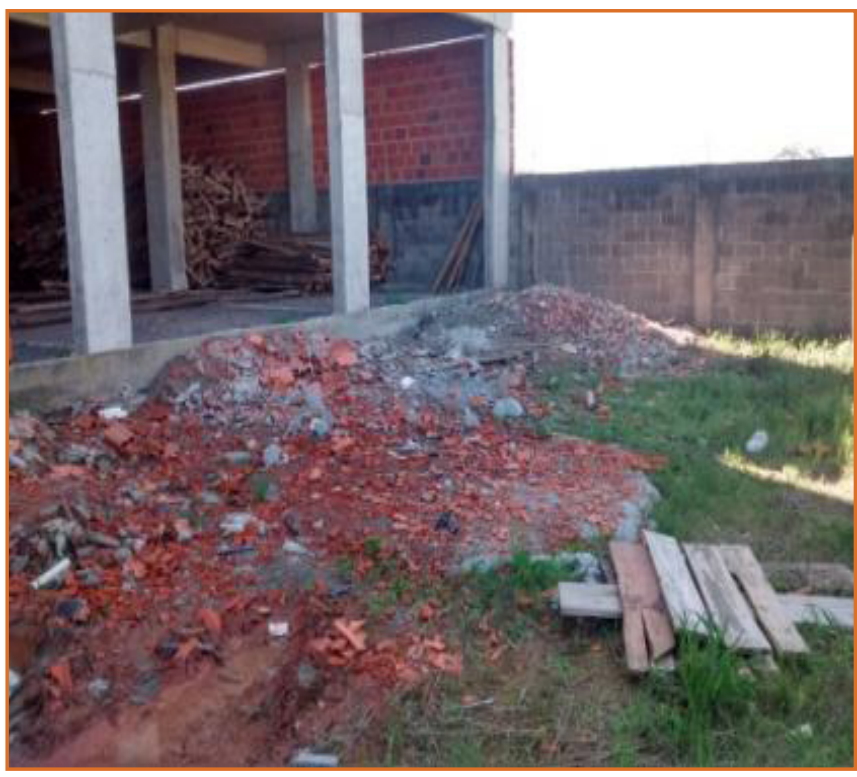

Fonte: Autores

Figura 4 - Acondicionamento irregular de blocos de concreto celular

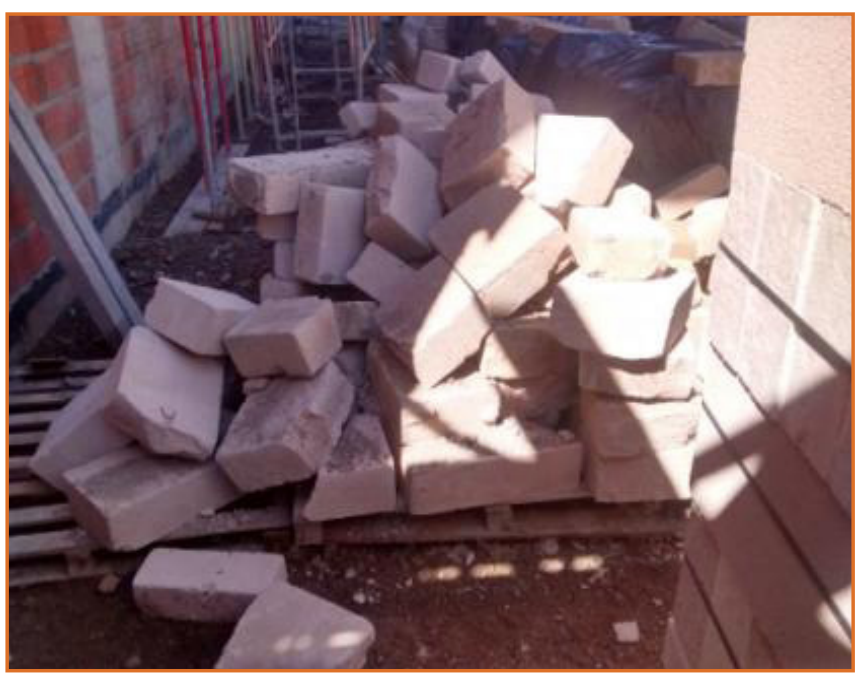

Fonte: Autores

$\mathrm{Na}$ figura 5 percebe-se que $\mathrm{O}$ acondicionamento dos resíduos está executado de forma correta. Há a colocação em cima de estribos e também existe uma separação por categorias de resíduos. Desta forma, neste caso, houve o cuidado para seguir o que determina a legislação. 
Figura 5 - Acondicionamento dos estribos

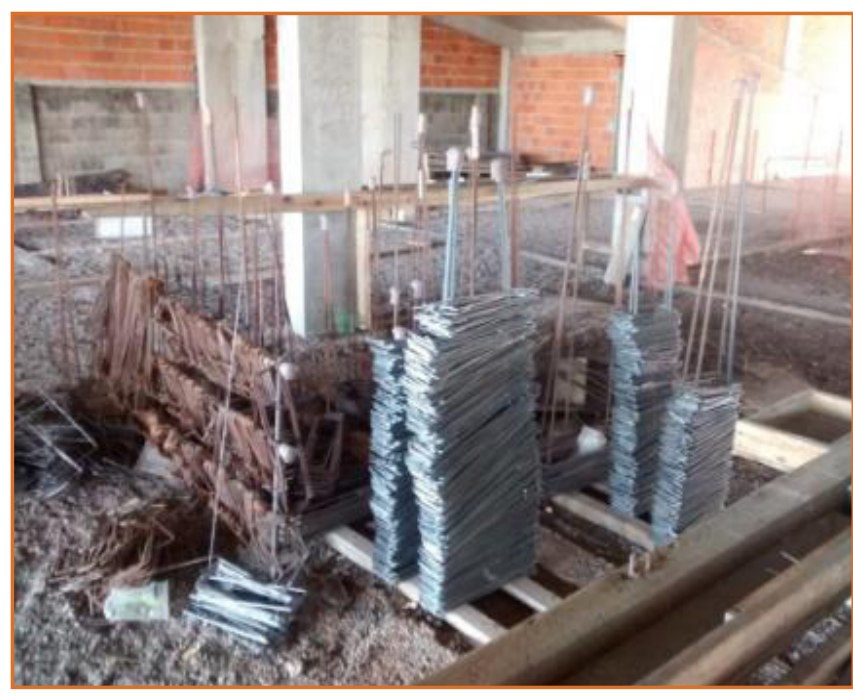

Fonte: Autores

Na figura 6 está demonstrado o acondicionamento de madeiras utilizadas para escoras de andaimes ou de outra atividade na obra. Percebe-se, também, a separação por categorias uma vez que as mesmas são de tamanhos e utilizações diferentes.

Figura 6 - Acondicionamento das madeiras de escoras

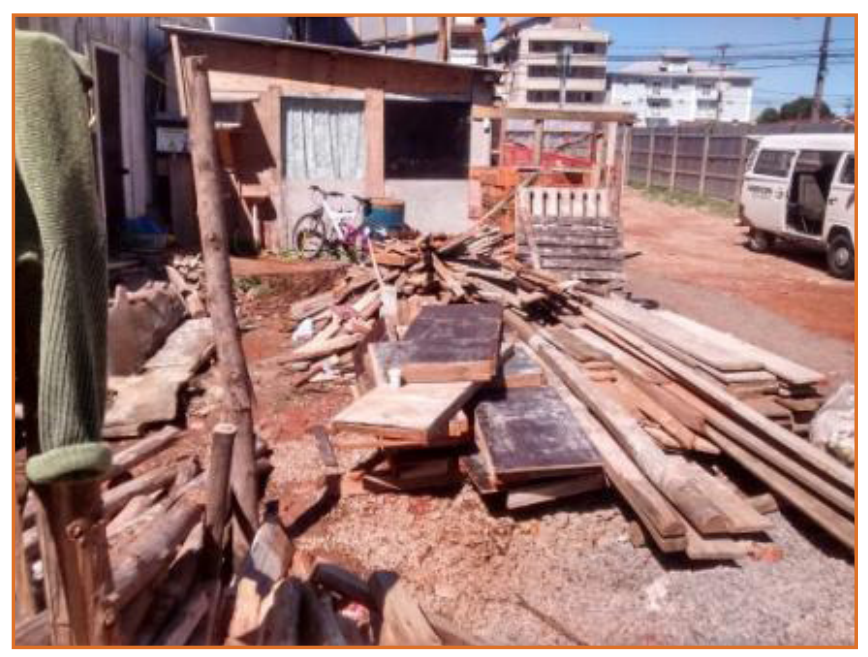

Fonte: Autores

\section{CONSIDERAÇÕES FINAIS}

Ao término da elaboração deste trabalho, conforme pesquisas coletadas e inspeções visuais feitas, conclui-se que a separação adequada dos resíduos sólidos na construção civil é de inteira importância em todas as etapas de uma obra.
As inspeções feitas buscavam analisar se estava acontecendo a adequada separação de resíduos na construção civil, e se as resoluções do CONAMA e decretos de lei de resíduos estavam sendo seguidos. Foi apresentado que a grande maioria dos resíduos das obras visitadas não estavam sendo separados corretamente. Os resíduos que não estavam armazenados corretamente, como no caso onde foram colocados vários tipos de resíduos juntos, estes inviabilizaram a reciclagem, acarretando impactos ambientais, afetando não somente os recursos naturais como também a vida humana.

Partindo-se da premissa que o desenvolvimento sustentável implica trabalho consciente, isto é planejamento baseado nas leis de resíduos sólidos, neste caso, é importante que ações estratégicas na área da construção civil sejam concebidas a partir de uma prévia elaboração de diagnóstico, avaliação e análise dos impactos relativos aos resíduos. Neste contexto, tratar adequadamente os resíduos sólidos não pode mais ser negligenciado pelas empresas da construção civil.

Por fim, mesmo considerando que houve limitações no trabalho, acredita-se que o mesmo traz importantes contribuições sobre a redução de resíduos na construção civil. Esta redução é imprescindível, uma vez que com ela os recursos naturais e o meio ambiente em geral sofrerão menos impactos.

\section{REFERÊNCIAS}

[1] ASSIS, C. S. Modelo de Gerenciamento Integrado de Resíduos Sólidos Urbanos: Uma Contribuição ao Planejamento Urbano, 2012, Rio Claro, Dissertação de Mestrado - Universidade Estadual Paulista, Instituto de Geociências e Ciências Exatas, 2012.

[2] BLUMENSCHEIN, R. N. A Sustentabilidade da Cadeia Produtiva da Indústria da Construção, (Tese de Doutorado). Centro de Desenvolvimento Sustentável, Universidade de Brasília, Brasília, 2004.

[3] CONAMA - Resolução 307, de 5 de julho de 2002; Disponivel em : < http://www.mma.gov.br/port/conama/ legiabre.cfm?codlegi=307 >. Acesso em 12 Setembro de 2016. 
[4] COSTA, N. A. A. A Reciclagem do Resíduo da Construção e Demolição: Uma Aplicação da Análise Multivariada. Florianópolis, 2010. 188 p. Tese (Doutorado) -Universidade Federal de Santa Catarina, Programa de Pós-graduação em Engenharia de Produção, 2010.

[5] DECRETO EXECUTIVO № 146, DE 29 DE OUTUBRO DE 2009 Disponível em: < https://www.santamaria. rs.gov.br/inc/view_do c.php?arquivo_dir=2015\&arquivo_ nome $=$ doc_20150515-1391.pdf $>$. Acesso em 18 de Setembro de 2016.

[6] DONAT, L.M.; BECK, M.H.; TOEBE, D. Diagnóstico de Resíduos de Construção e Demolição do Município de Foz do Iguaçu. In:I Encontro Latino Americano de Universidades Sustentáveis (ELAUS), Passo Fundo, 2008. Anais...Passo Fundo, 2008.

[7] GIL, A.C. Como elaborar projetos de pesquisa. 4.ed. São Paulo: Atlas, 2008.

[8] GR2 RESÍDUOS. Disponível em: <http://gr2residuos. com.br/ProdutoseServico>. Acesso em 12 de Setembro de 2016.

[9] JADOVSKI, I. Diretrizes Técnicas e Econômicas para Usinas de Reciclagem de Resíduos de Construção e Demolição. Porto Alegre, 2008. Dissertação de Mestrado - Universidade Federal do Rio Grande do Sul, Escola de Engenharia, Curso de Mestrado Profissionalizante em Engenharia, 2008.
[10] JOHN, V. M. Reciclagem de resíduos na construção civil - contribuição à metodologia de pesquisa e desenvolvimento. São Paulo, 2010. 102p.Tese (livre docência) - Escola Politécnica, Universidade de São Paulo, 2010.

[11] LEI № 12.305, DE 2 DE AGOSTO DE 2010; Disponível em:<http://www.mma.gov.br/port/conama/legiab re.cfm?codlegi=636 > . Acesso em 12 Setembro de 2016.

[12] MINISTÉRIO DO MEIO AMBIENTE. Disponível em : <http://www.mma.gov.br/>. Acesso em 12 Setembro de 2016.

[13] MISSIAGGIA, R.R; Dissertação de mestrado: Gestão de resíduos sólidos industriais, defendida em 2002 no PPGA/ Universidade Federal do Rio Grande do Sul, 2002.

[14] SCHNEIDER, D.M.; PHILIPPI, A.JR. Public management of construction and demolition waste in the city of São Paulo. Ambiente construído, Porto Alegre, 2004.

[15] PREFEITURA MUNICIPAL DE SANTA MARIA. Disponível em: <http://www.santamaria.rs.gov.br/>. Acesso em 12 de Setembro de 2016

[16] THOMAZ, E. Tecnologia, gerenciamento e qualidade na construção. São Paulo: Editora Pini, 2001. 


\title{
CAPÍTULO 9
}

\section{ESTUDO DE TEMPOS E MOVIMENTOS: UM ESTUDO DE CASO EM UMA EMPRESA PRODUTORA DE PICOLÉS NA CIDADE DE BELÉM/PA}

\author{
Ana Elaje Azevedo Simões da Mota \\ Bárbara Heliodora Negreiros Salomão \\ Matheus Amaral Damasceno \\ Renato Augusto Pereira Archer \\ André Clementino de Oliveira Santos
}

Resumo: Em um contexto onde a concorrência alcança níveis globais, a otimização da produção e redução de custos são fatores que se tornaram essenciais atualmente. A fim de aumentar a capacidade produtiva e identificar os gargalos para posteriores tomadas de decisão, foi aplicado um estudo de caso através do estudo de tempos e movimentos, por meio do qual foi possível tratar os dados, calcular os parâmetros utilizados e identificar e tratar os outliers, caso existissem. Desse modo, foram analisados os diversos gráficos e tabelas com o objetivo de identificar qual atividade, dentre as quatro necessárias para a produção de picolés, era o gargalo da produção que não permitia o aumento de sua capacidade produtiva. Assim, pôde-se concluir que o estudo apresentou uma tendência à padronização, além de que o gargalo encontra-se na atividade 02 , no processo de enformação e, caso fosse investido naquela atividade, a capacidade aumentaria, fazendo do processo palitagem o novo gargalo. Além disso, foi observada uma ociosidade que poderia ser produtiva em outras áreas da sorveteria, já que picolé não é seu único produto vendido.

Palavras chave: Estudo de Tempos e Movimentos, Capacidade Produtiva, Picolé. 


\section{INTRODUÇÃO}

Devido aos diversos desafios encontrados atualmente no mercado globalizado e à necessidade de minimizar o custo para manter-se competitivo, o bom planejamento e a otimização dos processos se tornou a meta de muitas empresas. Desta forma, diversas técnicas surgiram com o intuito de analisar detalhadamente as operações envolvidas nas prestações de serviços ou produção de bens, entre elas, a Engenharia de Métodos. Dentro desta técnica e a partir do uso do estudo de tempos e movimentos, busca-se a aplicação de métodos que identifiquem gargalos na produção, o que pode conduzir a uma maior produtividade (SILVA FILHO, 2015).

Nesse contexto e em resposta ao grande tempo ocioso identificado na empresa estudada, este artigo busca a aplicação do estudo de tempos e movimentos em uma fábrica de picolés e sorvetes, embora a análise seja restringida apenas ao setor de produção de picolé. Esta, situa-se na cidade de Belém no Estado do Pará, a qual possui produção média mensal de 130.000 picolés. O processo produtivo deste produto é majoritariamente manual, onde as etapas de operação do produto são altamente dependentes, possuindo entre elas diferentes capacidades produtivas diárias. Ao decorrer do estudo realizado, foram encontrados nesta empresa alguns problemas como a falta de planejamento da produção, a ausência de padronização na quantidade produzida e nos dias de produção, fatores que geram custos elevados.

À vista disso, o objeto de pesquisa desse artigo foi determinar a capacidade produtiva mensal de picolé a fim de descobrir o gargalo da produção e a prioridade de invesimentos da fábrica estudada, caso queira aumentar a produção. Por meio do estudo de mensuração de tempo, foi possível determinar o tempo necessário para a execução das etapas de produção, consequentemente, estimando a capacidade produtiva de cada processo. Assim, permitiu-se que a empresa estudada possua informações importantes para a gestão de toda a cadeia de produção, o que possibilita a tomada de decisões.

$\mathrm{Na}$ realização do artigo, primeiramente, foram cronometrados os tempos de produção de cada etapa durante 5 dias. Posteriormente, foi possível calcular diversas variáveis como o tempo normal, o tempo padrão e a capacidade produtiva. A partir dos valores calculados, foi possível identificar a etapa que possui maior /capacidade produtiva e o gargalo do processo. Desta maneira, os resultados obtidos no artigo possibilitam a função de auxiliar na tomada de decisão para futuros investimentos no processo produtivo ou no aprimoramento da mão de obra utilizada.

\section{ESTUDO DE TEMPOS E MOVIMENTOS}

Esse estudo possui várias aplicações práticas e recebeu diversas leituras desde sua origem. Para Barnes (2008), o estudo de tempos e movimentos é uma ferramenta baseada na observação e análise dos movimentos executados por um operário na realização de uma atividade, objetivando otimizar estes movimentos por meio de promoções de melhorias a fim de possibilitar uma execução em um tempo menor e com um mínimo de esforço. Ao longo do tempo, essa ferramenta aumentou sua aplicabilidade ao ser uma das mais eficazes em relação a determinação da eficiência do trabalho. Assim, o autor caracteriza este estudo como sistemático dos sistemas de trabalho, possuindo como principais objetivos: desenvolver o sistema e o método preferido, usualmente aquele de menor custo; padronizar esse sistema e método; determinar o tempo gasto por uma pessoa qualificada e devidamente treinada; e orientar o treinamento do trabalhador no método preferido.

Oliveira (2009) também define o estudo de tempo, o qual seria uma quantificação do trabalho por meio da estatística como ferramenta para alcançar os valores exatos de tempo de execução das tarefas. Sendo assim, objetiva a proposição de métodos de aperfeiçoamento na realização das tarefas, buscando a padronização necessária para o balanceamento do processo produtivo e determinação da capacidade produtiva da empresa.

Atualmente, muitas das grandes empresas enfrentam problemas causados por operários que executam a mesma tarefa de forma diferente. Nesse caso, padronizar os processos, definir e discutir a melhor forma de realizar esses processos, treinar os operários 
e assegurar a execução das tarefas conforme o definido é o melhor método para aumentar a produtividade de cada funcionário, o que eliminaria das operações as possíveis perdas. A padronização das atividades é a base para o planejamento e controle da produção, que tem o objetivo de atender a uma demanda determinada e, simultaneamente, de maximizar o lucro da empresa (CASTRO, 2012).

\section{O ESTUDO DE CASO}

As operações da empresa estudada foram divididas em quatro atividades. A primeira consiste na palitagem, a segunda atividade constitui a enformação, a terceira é a desenformação e a quarta atividade consiste na embalagem, como apresenta a figura 01.

Figura 01 - Gráfico de fluxo de processos

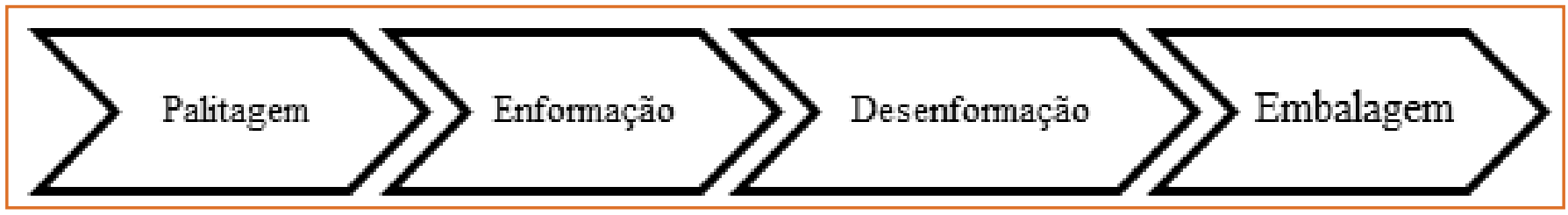

Fonte: Autores (2016)

O processo se inicia com a palitagem, onde, em um gabarito, são dispostos os palitos de picolé de forma que encaixem nos suportes, com posterior trava e armazenagem dos suportes preenchidos com 28 palitos. Posteriormente, na enformação, a calda pronta é despejada nas fôrmas de 28 compartimentos e manuseada de forma que reste o mínimo excesso nas bordas. Essas fôrmas são colocadas, depois de tampadas com os suportes previamente palitados e armazenados, uma a uma, na máquina de endurecer picolé, onde permanecem por um tempo. Em seguida, essas fôrmas são suspensas por alguns segundos, até que, ao desenformar, sofrem choque térmico em água quente e o suporte com os picolés é retirado da fôrma. Em uma bandeja, são colocados seis desses suportes e levados ao freezer. Esse processo se repete até que todos os suportes sejam desenformados.

Já na embalagem, o operador retira os suportes do freezer e os coloca na máquina de embalar, onde os picolés são separados do suporte e saem como produto final, pronto para ser estocado. A realização de todas as etapas apresentadas na figura 01 ocorrem no mesmo espaço físico, o qual está representado graficamente na figura 02. 
Figura 02 - Esquema e cotas do espaço físico em metros

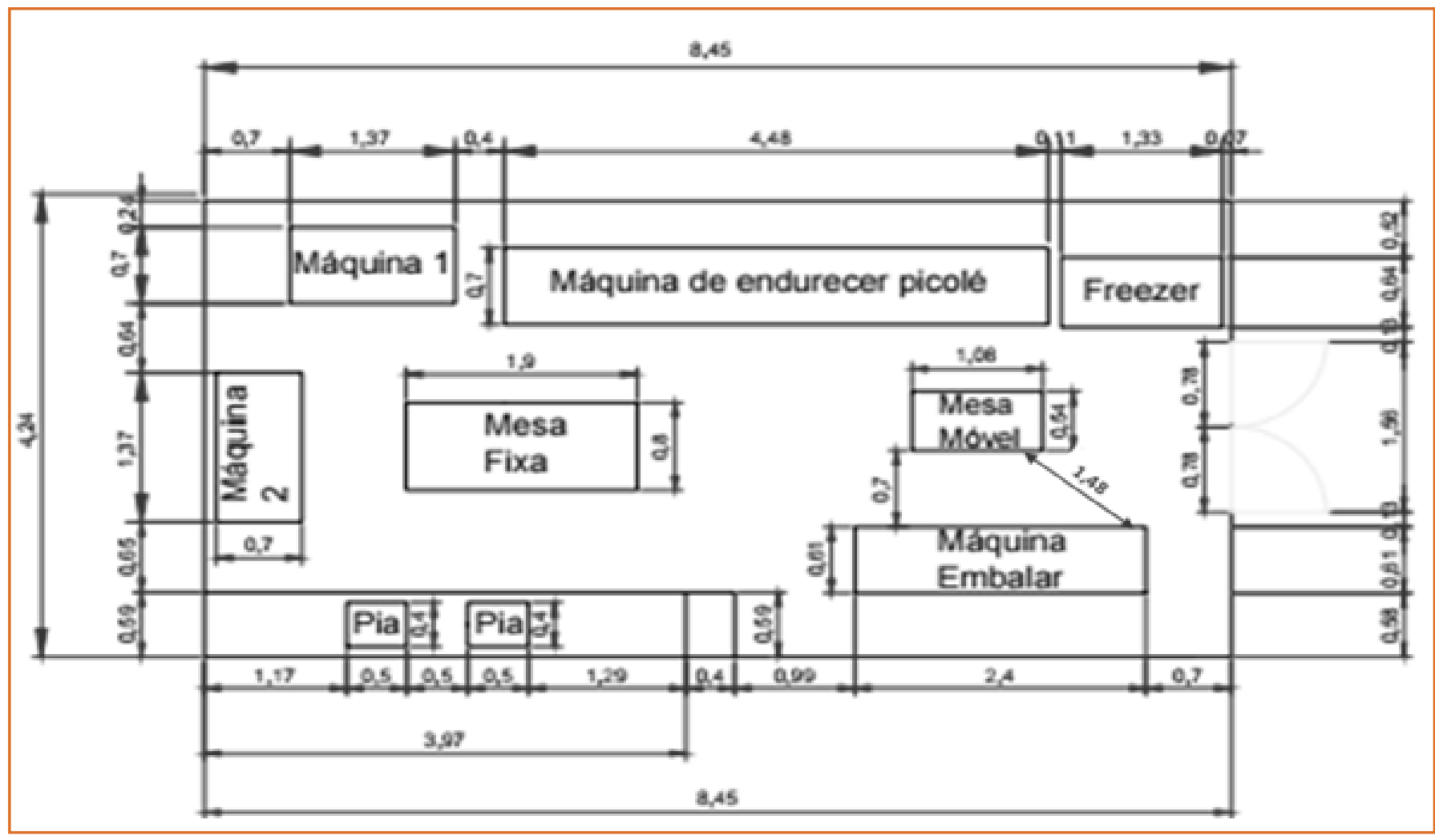

Fonte: Autores (2016)

\section{COLETA DE DADOS}

A coleta de dados na empresa realizou-se por meio de cinco cronometragens de cada atividade por dia, ao longo de cinco dias. Esses dados foram organizados e calculou-se a média e amplitude por processo, como mostra a tabela 01 . O mesmo procedimento foi aplicado aos outros dias.

Tabela 01 - Cronometragens, média e amplitude no primeiro dia

\begin{tabular}{|c|c|c|c|c|c|c|c|}
\hline Processo & Atividade & Tempo 1 & Tempo 2 & Tempo 3 & Tempo 4 & Tempo 5 & Média \\
\hline Palitagem & Arrumar Palito & 33,63 & 41,17 & 39,01 & 38,85 & 40,88 & 38,708 \\
\hline \multirow{2}{*}{ Enformação } & Arrumar molde & 51,646 & 48,516 & 48,846 & 48,656 & 44,466 & \multirow{2}{*}{101,997} \\
\hline & Gap (endurecimento) & 53,5713 & 53,5713 & 53,5713 & 53,5713 & 53,5713 & \\
\hline Desenformação & Desenformar na máquina & 11,635 & 10,965 & 10,845 & 9,905 & 10,915 & 10,853 \\
\hline \multirow{2}{*}{ Embalagem } & Reposição da máquina & 10,84 & 11,84 & 10,6 & 10,3 & 11,62 & \multirow{2}{*}{25,72} \\
\hline & GAP (embalagem) & 14,68 & 14,68 & 14,68 & 14,68 & 14,68 & \\
\hline
\end{tabular}

Fonte: Autores (2016)

\section{NÚMERO DE CICLOS A SER CRONOMETRADO}

Segundo Barnes (2008), por mais que a empresa possua boas condições de trabalho e operadores qualificados que trabalhem em ritmo constante, que os equipamentos estejam em boas situações e que as atividades sejam altamente padronizadas, ainda existiria uma variabilidade de tempo demandado, mesmo que ligeiramente, a cada ciclo. Dessa forma, as oscilações de duração podem comprometer os ciclos subsequentes, uma vez que é possível resultar em variações nas cronometragens feitas, caso ocorra 
possíveis diferenças na determinação do local definido de finalização da atividade, onde a leitura deve ser feita.

Ainda segundo o autor, o tamanho da amostragem é de suma importância para o estudo de tempos e movimentos, já que quanto maior o número de ciclos cronometrado, maior será o nível de confiabilidade e contribuirá para resultados mais satisfatórios. Dessa maneira, para cronometragens com maiores variações de tempo, maior terá de ser o número de observações para que se alcance a precisão esperada.

Assim, segundo Martins e Laugeni (2005), o número de ciclos a serem cronometrados () pode ser calculado a partir da Formula 1, onde é o coeficiente de ciclos da distribuição normal padrão para uma probabilidade desejada; representa a amplitude da amostra, é o erro relativo; é o coeficiente em função do número de cronometragens realizadas preliminarmente e é a média da amostra.

$$
N_{c}=\left(\frac{Z \cdot R}{E_{r} \cdot d_{2} \cdot \bar{x}}\right)^{2} \quad(\text { Fórmula 1) }
$$

Como era desejado um nível de confiança de 90\% e consequente erro relativo $10 \%$, adotou-se 1,28 para $Z$, já que é o valor, na tabela de distribuição normal, correspondente a porcentagem desejada. Dessa forma, foi calculado o número de ciclos por dia e por processo, como mostra a tabela 02. Os mesmos cálculos foram repetidos para os outros dias.

Tabela 02 - Número de cronometragem dos processos no primeiro dia

\begin{tabular}{cc|c|c|c|c|c|} 
Processo & $\mathbf{E}_{\mathrm{r}}$ & $\mathbf{Z}$ & $\mathbf{R}$ & $\overline{\mathbf{X}}$ & $\mathbf{d}_{\mathbf{2}}$ & $\mathbf{N}_{\mathbf{c}}$ \\
Palitagem & 0,1 & 1,28 & 7,54 & 38,708 & 2,326 & 2 \\
\hline Enformar & 0,1 & 1,28 & 7,18 & 101,99728 & 2,326 & 2 \\
Desenformar & 0,1 & 1,28 & 1,73 & 10,853 & 2,326 & 2 \\
Embalagem & 0,1 & 1,28 & 1,54 & 25,72 & 2,326 & 2 \\
\hline
\end{tabular}

Fonte: Autores (2016)

\subsection{CONSTRUÇÃO DOS GRÁFICOS DE CONTROLE}

Com o intuito de assegurar a consistência das cronometragens realizadas, são construídos os gráficos de controle, os quais buscam detectar os valores que se destoam dos demais e encontram-se fora do limite permitido baseados na amplitude e na média de cada atividade (BARNES, 2008). Desse modo, para cada dia, foi construído um gráfico baseado na média das contagens de tempo para as etapas de produção, assim como foi para construção do gráfico de controle da amplitude, que foi produzido fundamentado na amplitude de cada dia das atividades.

A obtenção dos limites superiores (LSC) e inferiores (LIC) dos gráficos de controle da amplitude se dão da seguinte forma:

$$
\begin{array}{ll}
L S C=D_{4} \times \bar{R} & (\text { Fórmula 2) } \\
L I C=D_{3} \times \bar{R} & (\text { Fórmula 3) }
\end{array}
$$

Onde, e são coeficientes tabelados de acordo com o maior número de cronometragens ocorrido em cada processo, e é a média das amplitudes dos dias.

Como o maior número de cronometragens () encontrado nos 5 dias estudados desta atividade foi 3 , os valores tabelados foram de acordo com essa variável. O mesmo procedimento foi utilizado nas demais atividades e os resultados foram organizados

\begin{tabular}{|c|c|c|c|c|c|c|}
\hline Atividade & $\overline{\mathbf{R}}$ & MaiorN $_{c}$ & $D_{3}$ & $\mathbf{D}_{4}$ & LSC & LIC \\
\hline Palitagem & 7,185 & 3 & 0 & 2,574 & 18,4942 & 0 \\
\hline Enformar & 5,766 & 2 & 0 & 3,268 & 18,8433 & 0 \\
\hline Desenformar & 2,02972 & 4 & 0 & 2,282 & 4,63182 & 0 \\
\hline Embalagem & 2,274 & 2 & 0 & 3,268 & 7,4314 & 0 \\
\hline
\end{tabular}
na tabela 03.

Tabela 03 - Limites superior e inferior de cada atividade

Fonte: Autores (2016)

Para ajudar na visualização dos pontos da a primeira atividade, a palitagem, foi construído o gráfico mostrado na figura 03. 
Figura 03 - Controle de amplitude dos dias para a primeira atividade

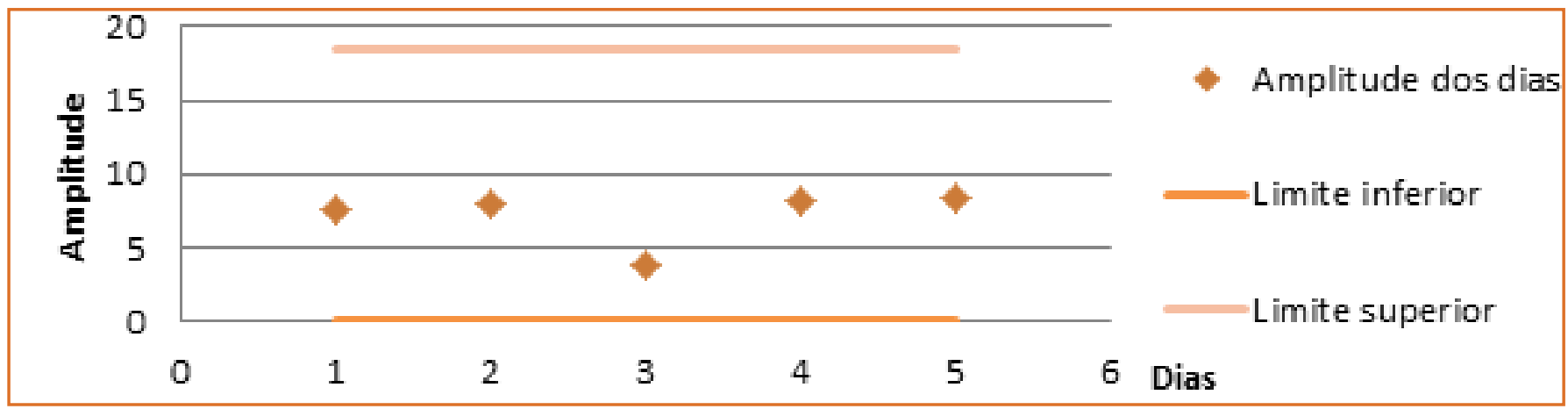

Fonte: Autores (2016)

A partir da análise dos gráficos, verificou-se que todos os valores de todas as atividades estão dentro dos limites de controle permitidos.

Para a construção dos gráficos de controle da média, os limites superiores (LSC) e inferiores (LIC) são calculados da seguinte forma:

$$
\begin{aligned}
& L I C=\bar{X}-A \times R(\text { Fórmula 4) } \\
& L S C=\bar{X}+A \times R(\text { Fórmula 5) }
\end{aligned}
$$

Onde representa a média das medições no determinado dia, $\mathrm{R}$ a amplitude diária e $\mathrm{A}$ é um valor tabelado de acordo com o número de cronometragens $\left(N_{c}\right)$.
$\mathrm{Na}$ tabela 04, são apresentados os dados relativos ao primeiro dia da primeira atividade. Embora esses dados tenham sido calculados para todos os dias, escolheu-se um para o exemplo.

Tabela 04 - Limites superior e inferior do primeiro dia de palitagem

\begin{tabular}{|c|c|c|c|c|c|}
\hline $\mathbf{R}$ & $\mathbf{X}$ & $\mathbf{N}_{\mathbf{c}}$ & $\mathbf{A}$ & \multicolumn{1}{c|}{ LIC } & LSC \\
\hline 7,54 & 38,708 & 2 & 1,880 & 24,5328 & 52,8832 \\
\hline
\end{tabular}

Fonte: Autores (2016)

Na figura 04, é apresentado o gráfico de controle de média do primeiro dia da palitagem, o qual foi repetido para os outros dias. Nessa atividade, os valores obtidos se mantiveram dentro dos limites de controle.

Figura 04 - Controle da média do dia 1 para a primeira atividade

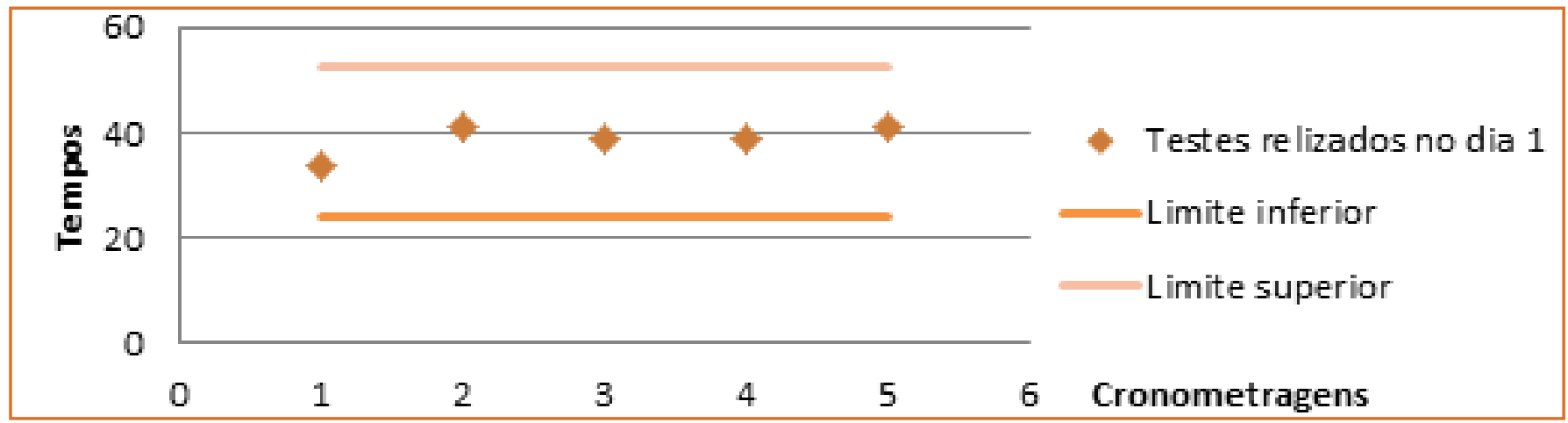

Fonte: Autores (2016)

Na tabela 05, constam os dados do primeiro dia da segunda atividade, sendo também um modelo de como foi calculado para todos os outros dias. 
Tabela 05 - Limites superior e inferior do primeiro dia de enformação

\begin{tabular}{|c|c|c|c|c|c|}
\hline $\mathbf{R}$ & $-\boldsymbol{*}$ & $\mathbf{N}_{\mathrm{c}}$ & $\mathbf{A}$ & LIC & LSC \\
\hline 7,18 & 101,99728 & 2 & 1,880 & 88,4989 & 115,496 \\
\hline
\end{tabular}

Fonte: Autores (2016)
Na figura 05, é apresentado o gráfico de controle de média do primeiro dia da enformação, o qual foi repetido para os outros dias. Nessa atividade os valores obtidos mantiveram dentro dos limites de controle, com nenhum ponto outlier.

Figura 05 - Controle da média do dia 1 para a segunda atividade

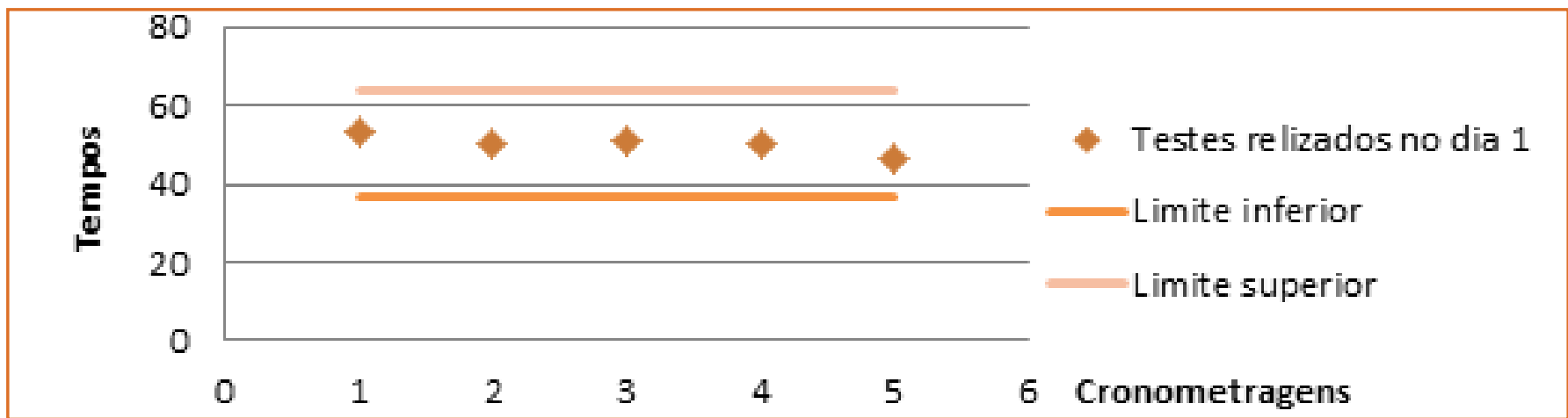

Fonte: Autores (2016)

Na tabela 06, organizam-se os dados do primeiro dia da terceira atividade, calculados da mesma forma para os outros dias.

Tabela 06 - Limites superior e inferior do primeiro dia de desenformar

\begin{tabular}{|c|c|c|c|c|c|}
\hline $\mathbf{R}$ & $\mathbf{X}$ & $\mathbf{N}_{\mathbf{c}}$ & \multicolumn{1}{c}{$\mathbf{A}$} & \multicolumn{1}{c|}{ LIC } & LSC \\
\hline 1,73 & 10,853 & 2 & 1,880 & 7,6006 & 14,1054 \\
\hline
\end{tabular}

Fonte: Autores (2016)

Figura 06 - Controle da média do dia 1 para a terceira atividade

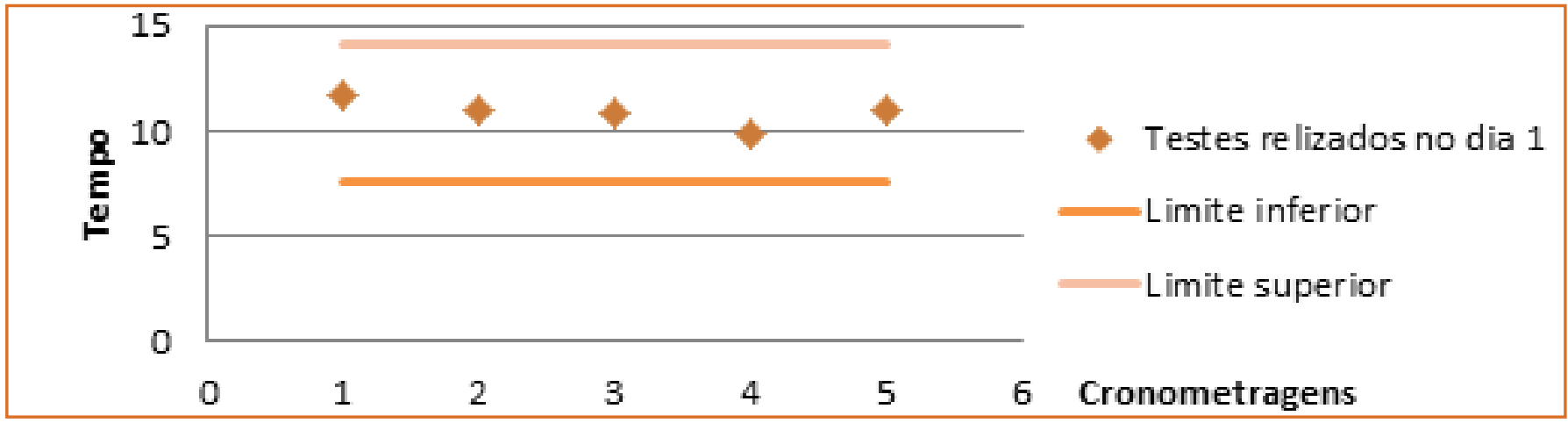

Fonte: Autores (2016)

Na tabela 07, listam-se os dados do primeiro dia da quarta atividade, calculados também aos outros dias. 
Tabela 07 - Limites superior e inferior do primeiro dia de embalagem

\begin{tabular}{|c|c|c|c|c|c|}
\hline $\mathbf{R}$ & $\mathbf{X}$ & $\mathbf{N}_{\mathbf{c}}$ & \multicolumn{1}{c|}{$\mathbf{A}$} & \multicolumn{1}{c|}{ LIC } & LSC \\
\hline 1,54 & 25,72 & 2 & 1,880 & 22,8248 & 28,6152 \\
\hline
\end{tabular}

Fonte: Autores (2016)
A figura 07 mostra o gráfico de controle de média do primeiro dia da embalagem, que foi repetido para os outros dias. Nessa atividade, os valores obtidos mantiveram dentro dos limites de controle desejados.

Figura 07 - Controle da média do dia 1 para a quarta atividade

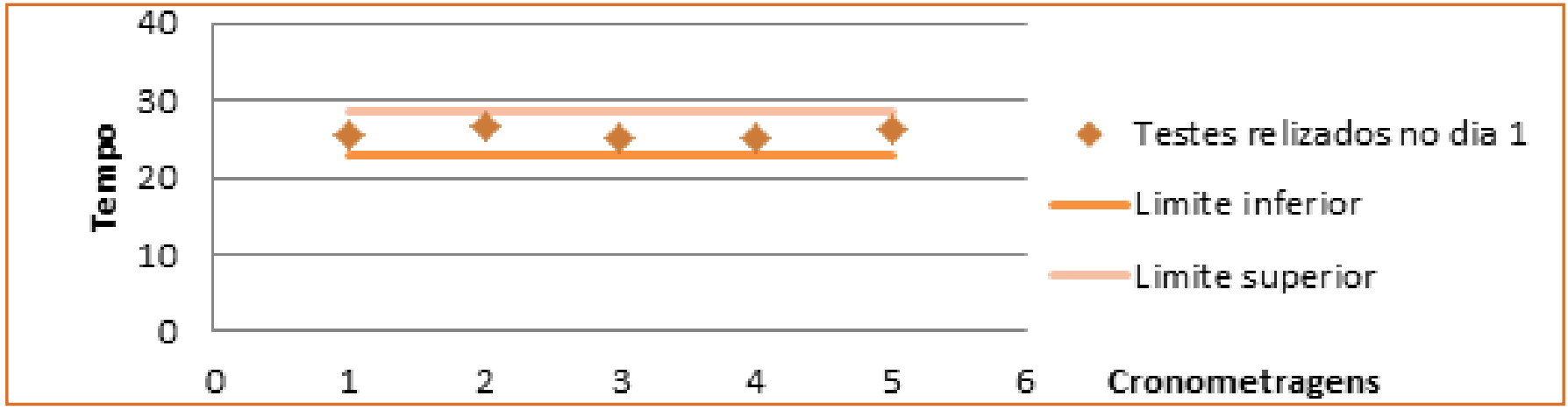

Fonte: Autores (2016)

De modo geral, todos os valores de todas as atividades se submeteram aos limites superior e inferior calculados.

\subsection{TEMPO NORMAL}

O tempo normal é o tempo que o operador executa seu trabalho operando em regime normal, em um ambiente adequado e desconsiderando as tolerâncias existentes. O cálculo desta variável envolve duas incógnitas, o tempo médio das cronometragens válidas () e o fator de ritmo (V) (BARNES, 2008).

$$
T_{n}=T_{C V} \times V \quad \text { (Fórmula 6) }
$$

Apesar disso, nesta pesquisa, o fator de ritmo foi tido como máximo, assumindo valor de 100\%. Dessa forma, o tempo normal foi considerado igual ao tempo médio das cronometragens válidas de cada atividade e, já que não houve nenhuma cronometragem outlier nas quatro atividades, não foi necessário um novo cálculo da média dos tempos. Esses valores considerados são expostos na tabela 08.
Tabela 08 - Tempo normal de cada atividade

\begin{tabular}{|c|c|}
\hline Atividade & Tempo Normal (s) \\
\hline Palitagem & 33,9878 \\
\hline Enformação & 100,3949 \\
\hline Desenformação & 10,5788 \\
\hline Embalagem & 26,8233 \\
\hline
\end{tabular}

Fonte: Autores (2016)

\subsection{DETERMINAÇÃO DAS TOLERÂNCIAS}

Peinaldo e Graeml (2007) afirmam que os operadores devem ter um tempo previsto para suas necessidades pessoais e para proporcionar descanso, evitando a fadiga excessiva. Essas interrupções na jornada de trabalho são denominadas tolerâncias e a soma do tempo dessas tolerâncias é chamado tempo permissivo $\left(T_{p}\right)$. O cálculo do Fator de Tolerância leva em consideração o tempo permissivo e o tempo total da jornada de trabalho $\left(T_{t}\right)$, resultando num valor entre 1 e 1,5. Este valor é interpretado em conjunto com as condições de trabalho e avaliação do ambiente. Caso este seja agressivo, é indicado um fator de tolerância alto e, caso seja considerado leve, um fator de tolerância baixo é suficiente para o ritmo de trabalho. 
A empresa em questão permite aos funcionários uma flexibilidade de até 20 minutos nos horários de entrada e saída, 25 minutos para necessidades pessoais e mais 25 minutos para descanso, sendo a jornada de trabalho de 8 horas. Como o fator de tolerância é dado pela fórmula a seguir, sendo possível calcular o fator de tolerância da empresa.

$$
\begin{gathered}
F_{t}=\frac{1}{1-\frac{T_{p}}{T_{t}}} \quad \text { (Fórmula 7) } \\
F_{t}=\frac{1}{1-\frac{90}{480}} \\
F_{t}=\frac{1}{1-0,1875} \\
F_{t}=\frac{1}{0,8125} \\
F_{t}=1,23
\end{gathered}
$$

\subsection{TEMPO PADRÃO}

Conforme Picanco et al. (2011), o tempo padrão é o tempo utilizado para determinar a capacidade produtiva da empresa, elaborar programas de produção e determinar o valor da mão de obra direta no cálculo do custo do produto, dentre outras aplicações. O tempo padrão engloba a determinação da velocidade de trabalho do operador e aplica fatores de tolerância para atendimento às necessidades pessoais, alívio de fadiga e tempo de espera.

O cálculo do tempo padrão (TP) relaciona o tempo normal $\left(T_{n}\right)$ com o fator de tolerância $(F T)$, como mostrado na formula abaixo:

$$
T P=T_{N} x F T \quad(\text { Fórmula 8) }
$$

Foi realizado o cálculo para cada atividade e os resultados são apresentados na tabela 09.
Tabela 09 - Tempo padrão de cada atividade

\begin{tabular}{|c|c|}
\hline Atividade & Tempo Padrão(s) \\
\hline Palitagem & 41,8312 \\
\hline Enformação & 123,5630 \\
\hline Desenformção & 13,0201 \\
\hline Embalagem & 33,0133 \\
\hline
\end{tabular}

Fonte: Autores (2016)

\subsection{CAPACIDADE PRODUTIVA}

A partir da mensuração dos tempos padrões cronometrados, foi possível determinar a capacidade produtiva de cada etapa do processo produtivo estudado. Considerando a carga horária diária de trabalho de 8 horas, a capacidade produtiva obtida pode ser mensurada como mostrado na fórmula 9.

$$
C_{p}=\frac{\text { Tempo Total de Produção (segundos) }}{\text { Tempo Padrão da Atividade (segundos) }} \quad(\text { Fórmula 9) }
$$

Visando saber a capacidade produtiva para a identificação de gargalos, foi calculada a capacidade produtiva de cada atividade, conforme tabela 10.

Tabela 10 - Capacidade produtiva de cada atividade

\begin{tabular}{|c|c|}
\hline Capacidade produtiva & Formas/dia \\
\hline Palitagem & 688,4813 \\
\hline Enformação & 233,0795 \\
\hline Desenformação & 2211,9612 \\
\hline Embalagem & 872,3760 \\
\hline
\end{tabular}

Fonte: Autores (2016)

Após análise da tabela, identificou-se que capacidade produtiva da empresa é de 233 formas/dia, apresentado na atividade 2 , visto que se deve levar em consideração o menor valor, pois todas as atividades ocorrem simultaneamente. Essa quantidade gera um valor de 6524 picolés/dia.

\section{ESTUDO DE MICRO MOVIMENTOS}

A fim de determinar a tendência à padronização ou não padronização do processo, escolheu-se uma 
atividade na qual foi desenvolvido um estudo dos tempos sintéticos, com consequente determinação de seus micromovimentos. Para o estudo, foi utilizada a embalagem, a qual é apresentada na tabela 11.

Tabela 11 - Estudo de micromovimentos para atividade de embalagem

\begin{tabular}{|c|c|c|c|}
\hline Micromovimento & Classificação & Distância & TMU \\
\hline Alcançar suporte & Tipo E & $58,13 \mathrm{pol}$ & 49 TMU \\
\hline $\begin{array}{l}\text { Agarrar um } \\
\text { suporte }\end{array}$ & $1^{\underline{a}}$ & - & $2 \mathrm{TMU}$ \\
\hline $\begin{array}{l}\text { Movimentar } \\
\text { suporte à } \\
\text { máquina }\end{array}$ & Tipo C & $58,13 \mathrm{pol}$ & $64 \mathrm{TMU}$ \\
\hline $\begin{array}{l}\text { Posicionar } \\
\text { suporte na } \\
\text { máquina }\end{array}$ & Justo & & $22 \mathrm{TMU}$ \\
\hline $\begin{array}{l}\text { Movimentar } \\
\text { suporte vazio até } \\
\text { o carrinho }\end{array}$ & Tipo B & $58,13 \mathrm{pol}$ & $53 \mathrm{TMU}$ \\
\hline $\begin{array}{c}\text { Posicionar } \\
\text { suporte vazio no } \\
\text { carrinho }\end{array}$ & Frouxo & & $11 \mathrm{TMU}$ \\
\hline Soltar suporte & Normal & & $2 \mathrm{TMU}$ \\
\hline $\begin{array}{c}\text { Alcançar a } \\
\text { maquina }\end{array}$ & Tipo B & $58,13 \mathrm{pol}$ & $54 \mathrm{TMU}$ \\
\hline $\begin{array}{l}\text { Tempo de } \\
\text { máquina }\end{array}$ & & & $\begin{array}{c}14,16 \\
\text { segundos }\end{array}$ \\
\hline TOTAL & \multicolumn{3}{|c|}{$257 \mathrm{TMU}+14,16$ segundos } \\
\hline
\end{tabular}

Fonte: Autores (2016)

Sendo esses valores calculados para a produção de 1 fôrma, como $T_{\text {sintético }}=(257 \times 60 \times 0,0006)+14,16$, o $T_{\text {sintético }}=9,252+1402=23,452$ segundos.

\section{DETERMINAÇÃO DE CONVERGÊNCIA E DIVERGÊNCIA}

Para a determinação da convergência ou divergência da atividade, realiza-se um cálculo comparando o tempo real com o tempo sintético. Caso haja uma disparidade superior a $20 \%$, constata-se que a atividade diverge e tende a não padronização. Nos casos com disparidade de $20 \%$ ou inferior, a atividade converge e, portanto, tende à padronização. Desse modo, foi usado o tempo médio das cronometragens válidas a fim de calcular a diferença entre o resultado e o tempo sintético, além do percentual dessa diferença em relação ao tempo sintético. Sendo assim, tem-se

$$
\begin{gathered}
\overline{\boldsymbol{x}}=\frac{25,72+28,293+25,266+27,494+27,3434}{5}=26,82328 \text { segundos } \\
\Delta=26,82328-23,452=3,37128 \\
3,37128=\frac{x}{100} \times 23,452 \rightarrow x=14,375 \%
\end{gathered}
$$

Observou-se, portanto, que a atividade embalagem é convergente, tendendo à padronização.

\section{CONCLUSÃO}

Por meio deste estudo, foi possível observar que o gargalo da produção reside na segunda atividade, a de enformação, já que esta apresenta a menor capacidade produtiva da operação. Nesta, são produzidas 233 fôrmas de picolé por dia, valor que quantifica o número máximo de picolés que podem ser produzidos. Para aumentar sua capacidade produtiva, a empresa deve investir na padronização da atividade gargalo, ação que aumentaria a produção para 688 fôrmas, devido ao novo gargalo, a palitagem.

Através da análise dos resultados, verificou-se uma convergência entre os valores aferidos por cronometragens, durante o estudo, e os resultados dos tempos sintéticos, com o estudo de micro movimentos. Este fato se dá pelo valor da diferença entre os dois ser inferior a $20 \%$ do tempo sintético, indicando que o processo produtivo tende à padronização.

Embora padronizado, o processo produtivo poderia ser mais bem aproveitado se o fator de tolerância fosse inferior a 1,23, visto que esse processo possui muitos tempos de máquina (gaps) e não exige um esforço físico elevado. Para um trabalho leve, onde o operador trabalha 8 horas por dia sem períodos de descanso préestabelecidos, o trabalhador médio usará 2 a 5 \% (10 a 24 minutos) por dia. Caso o tempo de permissividade fosse diminuído, a produtividade aumentaria sem causar fadiga excessiva nos funcionários, já que, devido aos gaps, foi observado um alto nível de ociosidade em várias partes do processo.

Caso contrário, esse tempo de gap poderia ser aproveitado em outras etapas do processo como a produção da calda ou a preparação do sorvete, atividades que, embora não tenham sido considerados 
nesse estudo, são um potencial para estudos futuros, a fim de complementar o presente artigo e trazer resultados ainda melhores à empresa, a fim de fazer ela se destacar no mercado competitivo e globalizado.

\section{REFERÊNCIAS}

[1] BARNES, R. M. Estudo de movimentos e de tempos: projeto e medida do trabalho. 6. Ed. São Paulo: Edgar Blücher, 2008.

[2] CASTRO, D; RAMOS, M; COSTA, D. Estudo de Tempos e Movimentos no Processo de Flow Rack em uma Empresa de Distribuição. In: ENCONTRO NACIONAL DE ENGENHARIA DE PRÓDUÇÃO, 32., 2012. Bento Gonçalves. Anais eletrônicos... Bento Gonçalves: ABEPRO, 2012. Disponível em: <http://www.abepro.org.br/biblioteca/enegep2012_TN_ STP_157_913_19678.pdf>. Acesso em: 20 mar. 2016.

[3] MARTINS, P. G; LAUGENI, F. P. Administração da Produção. 2. Ed. São Paulo: Saraiva, 562 p. 2005.
[4] OLIVEIRA, C.L.P.A. Análise e Controle da Produção em Empresa Têxtil, Através da Cronoanálise. 2009. 46 f. Trabalho de conclusão de curso (Graduação em Engenharia de Produção) - Centro Universitário de Formiga, Formiga, 2009.

[5] PEINADO, J; GRAEML A. R. Administração da Produção (Operações Industriais e de Serviços). Curitiba: Unicemp, 2007.

[6] PICANCO A. R. S; FRANCA F. S. A; CRUZ L. D. F; SANTOS L. F. Estudo de padronização e definição da capacidade produtiva de uma indústria de bebidas visando um controle mais eficiente do processo produtivo. In: ENCONTRO NACIONAL DE ENGENHARIA DE PRODUÇÃO, 31., 2011. Belo Horizonte. Anais eletrônicos... Belo Horizonte: ABEPRO, 2011. Disponível em: <http://www.abepro.org. br/biblioteca/enegep2011_TN_STO_135_861_17977.pdf > . Acesso em: 20 mar. 2016.

[7] SILVA FILHO, S. O. Estudo de Tempos e Métodos no Setor de Montagem de Estrutura ortopédica de uma Empresa de Colchões Magnéticos. 2015. 68 f. Trabalho de Conclusão de Curso (Graduação em Engenharia de Produção) - Centro de Tecnologia, Universidade Estadual de Maringá, Maringá, 2015. 


\title{
CAPÍTULO 10
}

\section{DETERMINAÇÃO DA CAPACIDADE PRODUTIVA EM UMA INDÚSTRIA DE FARINHA DE TAPIOCA NO NORDESTE DO PARÁ: UMA APLICAÇÃ̃O DA ENGENHARIA DE MÉTODOS}

\author{
Antonio Andrei Braga \\ Denilson Ricardo de Lucena Nunes \\ Edullis Garcia Rodrigues \\ Igor Santos Costa \\ Jonathas Sampaio dos Santos
}

Resumo: Este artigo tem por objetivo, por meio da aplicação de ferramentas da engenharia de métodos, com foco no estudo de tempos, obter conhecimento da capacidade produtiva de uma indústria de farinha de tapioca e propor melhorias para o processo produtivo. Para tal, foram determinados fluxogramas, tempo padrão da operação e a capacidade produtiva. Posteriormente, os resultados adquiridos foram analisados e, baseado nestes, propostas de possíveis melhorias foram feitas, em busca do aumento da produtividade e da eficiência no processo.

Palavras chave: Engenharia de métodos, Estudo de tempos, Capacidade produtiva, Farinha de tapioca 


\section{INTRODUÇÃO}

Atualmente, a empresa que deseja sobreviver no mercado e apresentar resultados positivos, precisa ter uma gestão consistente e conhecer, sobretudo, os seus processos produtivos. No entanto, ainda existem organizações em que a forma como se dá sua gestão fabril é muito empírica e arcaica, e este tipo de visão acaba prejudicando a própria organização, pois tal postura pode acarretar em decisões equívocas que, em alguns casos, levarão ao declínio da empresa.

Para se manter constantemente competitivo em um mercado que é crescentemente concorrido, se faz necessário o uso de ferramentas que dão aos gestores da organização uma visão mais abrangente do que se passa no seu chão de fábrica. Baseado nisso, as organizações estão cada vez mais interessadas na apropriação e utilização de tais ferramentas da administração da produção, para que satisfaçam as necessidades dos clientes e mantenha seu lugar no mercado.

Nessa visão, a aplicação de ferramentas da engenharia de métodos, como estudo de tempos e a determinação da capacidade produtiva se apresentam como uma excelente alternativa, visto que essas proporcionarão aos gestores da organização o fluxo detalhado das atividades, os tempos padrões de cada operação e a capacidade produtiva da empresa. Esse tipo de conhecimento permitirá um melhor planejamento da fábrica para que a mesma utilize com eficácia os recursos disponíveis.

Segundo Barnes (1977), os principais impulsos para o desenvolvimento dos estudos de tempos partiram de Frederick Taylor, em 1881 na usina de Midvale Steel Company. Taylor organizou o estudo de tempos cronometrados com o propósito de medir a eficiência individual de um operador (MARTINS; LAUGENI, 2005).

O objetivo deste trabalho foi analisar as operações do processo de fabricação de uma empresa de farinha de tapioca, aplicar o estudo de tempos e movimentos, determinar a capacidade produtiva de cada operação e buscar possíveis melhorias para a empresa.

O interesse de estudo a cerca desse produto se deu devido a sua natureza regional e a pouca exploração científica. A farinha de tapioca é derivada da mandioca, sendo esta uma importante geradora de renda para a economia do Pará, fazendo com que o estado seja o maior produtor nacional desta raiz, com participação de $22 \%$ da produção brasileira (GROXKO, 2013). Ela faz parte da cultura gastronômica da região.

\section{REFERENCIAL TEÓRICO}

Nesta seção é apresentado o referencial teórico com o objetivo de dar suporte ao estudo realizado, salientando as ferramentas da engenharia de métodos, como o estudo de tempos e a capacidade produtiva, e caracterizando brevemente o conceito de ergonomia.

\subsection{FLUXOGRAMA}

Fluxograma é uma ferramenta representada graficamente que ajuda o gestor a visualizar e mapear os processos no seu fluxo e em sua forma organizacional, tanto administrativa quanto abstrata. Serve também para auxiliar nos padrões de atividades (PARANHOS FILHO, 2007).

Barnes (1977) relata que em 1947 a American Society Mechanical Engenieers (ASME) padronizou cinco símbolos para representação de um processo, conforme apresenta o quadro 1.

O fluxograma vertical é o mais utilizado em pesquisas científicas, pois ele permite uma visualização definida sobre o processo e uma melhor possibilidade de melhoramento, devido a clareza que essa ferramenta proporciona na apresentação e leitura da operação. 


\begin{tabular}{|c|c|c|c|}
\hline Símbolo & Operação & $\begin{array}{l}\text { Definição da Operação } \\
\text { Uma operação existe quando um objeto é modificado } \\
\text { intencionalmente numa ou mais das suas características. }\end{array}$ \\
\hline Operação & $\begin{array}{l}\text { A operação é a fase mais importante no processo e, } \\
\text { geralmente, é realizada numa máquina ou estação de } \\
\text { trabalho. }\end{array}$ \\
\hline Transporte & $\begin{array}{l}\text { Um transporte ocorre quando um objeto é deslocado } \\
\text { de um lugar para outro, exceto quando o movimento é } \\
\text { parte integral de uma operação ou inspeção. }\end{array}$ \\
\hline Inspeção & $\begin{array}{l}\text { Uma inspeção ocorre quando um objeto é examinado } \\
\text { para identificação ou comparado com um padrão de } \\
\text { quantidade ou qualidade. }\end{array}$ \\
\hline Espera & $\begin{array}{l}\text { Uma espera ocorre quando a execução da próxima } \\
\text { ação planejada não é efetuada. }\end{array}$ \\
\hline Armazenamento & $\begin{array}{l}\text { Um armazenamento ocorre quando um objeto é } \\
\text { mantido sob controle, e a sua retirada requer uma } \\
\text { autorização. }\end{array}$ \\
\hline
\end{tabular}

Fonte: Banes (1977)

\subsection{ESTUDO DE TEMPOS}

O estudo de tempos é uma das ferramentas mais usadas na engenharia quando o objetivo é determinar a eficiência no trabalho e padrões de operação, com consequência na redução dos custos da mesma (OLIVEIRA et al; 2012).

O estudo de tempos é utilizado para determinar o tempo necessário que uma pessoa bem instruída e capacitada, trabalhando em um ritmo normal, utiliza para executar um trabalho específico. Dentre as finalidades que essa análise leva estão o cálculo do tempo padrão, capacidade produtiva, melhor planejamento do trabalho, preparo de orçamentos, estimação do custo do produto, determinação da eficiência das máquinas e os fatores que interferem na produção (BARNES, 1977).
Barnes (1977), Martins e Laugeni (2005) afirmam que o procedimento a ser seguido na execução do estudo de tempos possui alguns passos necessários:

a. Coleta de dados;

b. Divisão da operação em elementos;

c. Determinação do número de ciclos a serem cronometrados;

d. Avaliação de ritmo do operador;

e. Determinação do tempo normal;

f. Determinação das tolerâncias;

g. Determinação do tempo-padrão para a operação.

\subsubsection{DIVISÃO DA OPERAÇÃO EM ELEMENTOS}

Segundo Barnes (1997), a cronometragem de uma operação inteira em um único elemento, na maioria das vezes, é insatisfatória. A operação total, portanto, deve ser dividida em partes (elementos) menores 
para que os resultados do estudo de tempos sejam precisos. Entretanto, torna-se necessário o cuidado de não dividir a operação em excessivamente muitos ou demasiadamente poucos elementos (GRAEML e PEINADO, 2007).

\subsubsection{DETERMINAÇÃO DO NÚMERO DE CICLOS A SEREM CRONOMETRADOS}

Peinado e Graeml (2007) sugerem que a quantidade de ciclos pode ser obtida por meio de uma equação geral, onde quem está realizando o estudo, por meio de análise subjetiva, pode identificar o nível de confiança e aplica-lo, obtendo por meio da tabela de distribuição normal. Segue a equação 1.

$$
n=\left(\frac{z \cdot R}{E_{r} \cdot d_{2} \cdot \bar{X}}\right)^{2}
$$

Em que:

a. n: número de ciclos a serem cronometrados;

b. z: coeficiente de distribuição normal;

c. R: amplitude da amostra;

d. Er: erro relativo;

e. d2: coeficiente em função do número de cronometragens realizada preliminarmente;

f. X: média das observações.

\subsubsection{AVALIAÇÃO DE RITMO DO OPERADOR}

Segundo Peinado e Graeml (2007), a avaliação da velocidade do operador é o processo no qual o cronometrista compara o ritmo do operário em observação com o seu próprio conceito de ritmo normal.

A avaliação da velocidade ou ritmo com o qual o operador trabalha é uma das análises mais importantes e que exige maior grau de atenção do avaliador no estudo de tempos, pois ela pode apresentar caráter subjetivo (PEINADO e GRAEML, 2007).
Existe também a possibilidade de o avaliador se apropriar de métodos mais quantitativos para a avaliação do ritmo. Destes, frequentemente se utiliza o método das cartas, que consiste em repartir um baralho em quatro pilhas idênticas e cronometrar o tempo em que o operador realiza esta atividade (BARNES, 1977). O tempo ideal para esta distribuição é de 30 segundos, sendo o ritmo (V) do operador a razão entre o tempo ideal e a média dos tempos cronometrados, como descreve a equação 2 .

$$
\mathrm{V}=\frac{30}{\text { Tempo cronometrado }}
$$

\subsubsection{DETERMINAÇÃO DO TEMPO NORMAL}

Após a avaliação do ritmo do operador, é possível calcular o tempo normal. Para Slack, Chambers e Johnston (2009), este é o tempo levado por um operador qualificado executar um determinado trabalho com desempenho padrão. O tempo normal é obtido por meio da equação 3 .

$$
\mathrm{TN}=\mathrm{TC} \times \mathrm{V}
$$

Em que:

a) TN: tempo normal;

b) TC: tempo cronometrado;

c) V: velocidade do operador.

\subsubsection{DETERMINAÇÃO DAS TOLERÂNCIAS}

Não se pode contar com a execução de tarefas initerruptamente por um operador durante todo o período de produção. O operador pode dispender seu trabalho descansando, aguardando o tempo de uma máquina ou por motivos fora de controle, e tudo isso consome um tempo onde não há operações que agregam valor ao produto. Essas interrupções são chamadas de tolerâncias (BARNES, 1977). 
Segundo Peinado e Graeml (2007) existem três principais tipos de tolerâncias. Estas são:

a. Tolerância para atendimento às necessidades pessoais;

b. Tolerância para alívio da fadiga;

c. Tolerância para espera.

As tolerâncias são avaliadas subjetivamente pelas pessoas que estão realizando o estudo, por meio de uma análise do local e da forma com que o trabalho é executado. Os fatores destes são descritos no quadro 2.

$$
F T=\frac{1}{1-p}
$$

Depois de efetuada a somatória de todas as tolerâncias, a equação 4 é utilizada para determinação do fator de tolerância:

Em que:

a) FT: fator de tolerância;

b) p: tempo de intervalo dado dividido pelo tempo de trabalho.

Quadro 2 - Tolerâncias de trabalho

\begin{tabular}{|c|c|c|c|}
\hline DESCRIÇĀO & $\%$ & DESCRIÇĀO & $\%$ \\
\hline A Tolerâncias invariáveis: & & 4. Iluminaçao deficiente: & \\
\hline $\begin{array}{l}\text { 1. Tolerâncias para necessidades pes- } \\
\text { soats }\end{array}$ & 5 & a. ligeiramente abatxo do recomendado & 0 \\
\hline 2. Tolerâncias básicas para fadiga & 4 & b. bem abaixo do recomendado & $\overline{2}$ \\
\hline B. Tolerâncias variáveis: & & c. mutto fnadequada & 5 \\
\hline 1. Tolerâncla para ficar em pé & 2 & 5. Condiçoes atmosfëricas & $0-10$ \\
\hline 2. Tolerância quanto à postura & & (calor e umidade) - variavels & \\
\hline a. ligeiramente desajeitada & 0 & 6. Atenção cuidadosa & \\
\hline b. desajeitada (recurvada) & $\overline{2}$ & a. trabalho razoavelmente fino & 0 \\
\hline c. muito desajettada (dettada, esticada) & 7 & b. trabalho fino ou de prectsão & 2 \\
\hline 3. Uso de forca ou energla muscular & & c. trabalho fino ou de grande prectsao & 5 \\
\hline (erguer, puxar ou levantar) & & 7. Nivel de ruido: & \\
\hline Peso levantado em quilos & & a. continuo & 0 \\
\hline 2,5 & 0 & b. Intermitente - volume alto & 2 \\
\hline 5,0 & 2 & c. intermitente - volume muito alto & 5 \\
\hline 7,5 & 2 & d. timbre elevado - volume alto & 5 \\
\hline 10,0 & 3 & 8. Estresse mental & \\
\hline 12,5 & 4 & a. processo razoavelmente complexo & 1 \\
\hline 15,0 & 5 & $\begin{array}{l}\text { b. processo complexo, atenção } \\
\text { abrangente }\end{array}$ & 4 \\
\hline 17,5 & 7 & c. processo muito complexo & 8 \\
\hline 20,0 & 9 & 9. Monotonta: & \\
\hline 22,5 & 11 & a. batxa & 0 \\
\hline 25,0 & 13 & b. média & 1 \\
\hline 27.5 & 17 & c. elevada & 4 \\
\hline \multirow[t]{4}{*}{30,0} & 22 & 10. Grau de tédio & \\
\hline & & a. um tanto tedioso & 0 \\
\hline & & b. tedioso & 2 \\
\hline & & c. muito tedioso & 5 \\
\hline
\end{tabular}

Fonte: Stevenson (2001)

2.2.7 DETERMINAÇÃO DO TEMPO PADRÃO PARA A OPERAÇÃO
O tempo padrão para um elemento é uma extensão do tempo normal. Ele leva em consideração as tolerâncias 
para pausas e descansos (SLACK; CHAMBERS; JOHNSTON, 2009). Para obtê-lo, efetua-se o produto entre o tempo normal e o fator de tolerância (GRAEML e PEINADO, 2007). Segue a equação 5, do tempo padrão.

\section{$\mathrm{TP}=\mathrm{TN} \times \mathrm{FT} \quad(5)$}

\subsection{ERGONOMIA}

Ergonomia pode ser definida como o estudo das interações entre os seres humanos e outros elementos ou sistemas, e à aplicação de teorias, princípios, dados e métodos a projetos a fim de se otimizar o bem-estar humano e o desempenho global do sistema (IEA, 2000).

Pode-se afirmar então que a aplicação desses conceitos em processos produtivos dos mais diversos aspectos, em decorrência de um maior conforto do trabalhador, maiores adequações do sistema ao homem e redução de execução de movimento desnecessário, acarreta de fora significativa o aumento na eficiência do processo.

\subsection{CAPACIDADE PRODUTIVA}

A capacidade produtiva de uma operação é o máximo nível de atividade de valor adicionado em um determinado período de tempo que o processo pode realizar sob condições normais de operação (SLACK; CHAMBERS; JOHNSTON, 2009). A capacidade produtiva é determinada de acordo com a equação 6 .

$$
\mathrm{CP}=\frac{\mathrm{TD}}{\mathrm{TP}}
$$

Em que: a) CP: capacidade produtiva;

b) TD: tempo disponível de trabalho;

c) TP: tempo padrão.

\section{O ESTUDO DE CASO}

A empresa escolhida para o presente estudo foi uma fábrica de tapioca localizada no nordeste paraense, município de Santa Isabel do Pará, na vila de Americano. A localização da empresa é importante para o grande número de vendas da farinha, por estar próxima de grandes centros consumidores da região, como Belém, Ananindeua e Castanhal. Ela também não apresenta processo totalmente padronizado e é conduzida por uma gerência que possui apenas conhecimentos empíricos sobre suas atividades.

A vila de Americano é o maior centro produtor de Farinha de Tapioca do Brasil, com uma produção de, aproximadamente, 2 milhões de litros mensais (Portal G1, 2015). Porém, os casos de indústrias que possuem uma planta organizada e instalações adequadas para a produção ainda são minoria na região, fator que contribui para que a quantidade de farinha produzida não seja maior.

\subsection{APLICAÇÃO DO ESTUDO DE TEMPOS}

O estudo de tempos foi aplicado somente nos 4 ultimos elementos do processo de produção da farinha de tapioca de tamanho médio.

Primeiramente, foram coletadas informações das operações necessárias para a produção de farinha de tapioca. A partir disso, foi possível construir o fluxograma das operações do processo, representado no quadro 3. 
Quadro 3 - Fluxograma do processo

\begin{tabular}{|c|c|l|}
\hline Etapa & Símbolo & \multicolumn{1}{|c|}{ Descrição das ope rações } \\
\hline 1 & & Transportar grãos para máquina de separação de grãos \\
\hline 2 & $\bigcirc$ & Efetuar processo de separação de grãos \\
\hline 3 & $\Rightarrow$ & Transportar grãos separados para o armazem de grãos \\
\hline 4 & $\checkmark$ & Armazenar grãos separados em um tanque \\
\hline 5 & $\Rightarrow$ & Transportar grãos separados para o forno de espocamento \\
\hline 6 & $\bigcirc$ & Efetuar processo de espocamento dos grãos separados \\
\hline 7 & $\checkmark$ & Armazenar grãos separados espocados(farinha de tapioca) \\
\hline 8 & $\Rightarrow$ & Transportar farinha de tapioca para máquina de separação de farinha de tapioca \\
\hline 9 & $\bigcirc$ & Efetuar processo de separação de farinha de tapioca \\
\hline 10 & $\checkmark$ & Armazenar farinha de tapioca \\
\hline 11 & $\bigcirc$ & Empacotamento da farinha de tapioca \\
\hline 12 & 0 & Expedição \\
\hline
\end{tabular}

Fonte: Autores (2016)

\subsubsection{DIVISÃO DA OPERAÇÃO EM ELEMENTOS}

Utilizando o segundo passo do procedimento, fezse necessário dividir as operações em elementos, formando assim um fluxograma mais enxuto, o que ,posteriormente, facilitaria no processo de cronometragem e traria resultados mais condizentes com a realidade. A descrição destes elementos está descrita no quadro 4.

Quadro 4 - Elementos do processo

\begin{tabular}{|c|c|l|}
\hline Etapa & Símbolo & \\
\hline 1 & $\bigcirc$ & Separação de grãos \\
\hline 2 & $\bigcirc$ & Espocamento \\
\hline 3 & $\bigcirc$ & Separão dos elementos \\
\hline 4 & $\bigcirc$ & Empaco da farinha de tapioca \\
\hline
\end{tabular}

Fonte: Autores (2016)

3.1.2 DETERMINAÇÃO DO NÚMERO DE CICLOS A SEREM CRONOMETRADOS

O terceiro passo do procedimento consistiu na determinação do número de ciclos a serem cronometrados. Devido ao baixo grau de padronização do processo produtivo, utilizou-se para o cálculo do N um erro relativo de $10 \%$ e grau de confiabilidade igual 
a 90\%. A tabela 1 mostra as cronometragens, a média das cronometragens e o valor resultante de $\mathrm{N}$ para cada elemento. ao número de cronometragens (8), concluiu-se que o número de cronometragens seria suficiente para o prosseguimento do estudo de tempos.

Como o valor de $\mathrm{N}$ em todos os elementos foi inferior

Tabela 1 - Médias das cronometragens e número de ciclos

\begin{tabular}{|c|c|c|c|c|c|c|c|c|c|c|c|}
\hline \multirow{3}{*}{\multicolumn{2}{|c|}{ Elementos }} & \multicolumn{8}{|c|}{ Cronometragens (minutos) } & \multirow{3}{*}{$\begin{array}{c}\text { Média das } \\
\text { cronometragens } \\
\text { (minutos) }\end{array}$} & \multirow{3}{*}{$\mathbf{N}$} \\
\hline & & \multicolumn{4}{|c|}{ Amostra 01} & \multicolumn{4}{|c|}{ Amostra 02} & & \\
\hline & & $\mathbf{1}^{\mathrm{a}}$ & $2^{\mathrm{a}}$ & $3^{\mathbf{a}}$ & $4^{\mathrm{a}}$ & $5^{a}$ & $\mathbf{6}^{\mathbf{a}}$ & $7^{\mathrm{a}}$ & $8^{\mathbf{a}}$ & & \\
\hline $1^{\circ}$ & Separação de grãos & 7,87 & 8,12 & 8,75 & 9,23 & 6,25 & 7,37 & 7,25 & 7,32 & 7,77 & 4,95 \\
\hline $2^{\circ}$ & Espocamento & 27,17 & 29,05 & 25,07 & 20,00 & 22,83 & 23,78 & 19,90 & 22,05 & 23,73 & 4,99 \\
\hline $3^{\circ}$ & Separação da farinha de tapioca & 16,72 & 15,22 & 12,07 & 13,23 & 14,07 & 16,95 & 15,28 & 18,90 & 15,30 & 6,70 \\
\hline $4^{\circ}$ & Empacotamento & 1,17 & 1,13 & 1,08 & 1,02 & 0,83 & 1,20 & 1,13 & 0,87 & 1,05 & 4,06 \\
\hline
\end{tabular}

Fonte: Autores (2016)

\subsubsection{AVALIAÇÃO DE RITMO DO OPERADOR}

Para amedição dos ritmos dos operadores responsáveis pelo processo produtivo, utilizou-se a metodologia das cartas de baralho. O teste foi realizado 5 vezes para a cada operador. Posteriormente, calculou-se a média das cronometragens dos testes para cada um deles. Após isso, foi possível encontrar o ritmo de cada operador por meio da divisão do tempo ideal pela média das cronometragens. Os dados estão descritos na tabela 2.

Tabela 2 - Média das cronometragens e Avaliação de Ritmo

\begin{tabular}{|c|c|c|c|c|c|c|c|}
\hline \multirow{2}{*}{ Operador } & \multicolumn{5}{|c|}{ Cronometragens (segundos) } & \multirow{2}{*}{$\begin{array}{c}\text { Média das cronometragens } \\
\text { (s egundos) }\end{array}$} & \multirow{2}{*}{$V(\%)$} \\
\hline & $\mathbf{1}^{\mathrm{a}}$ & $2^{\mathrm{a}}$ & $3^{a}$ & $4^{a}$ & $5^{a}$ & & \\
\hline Operador 01 & 28,05 & 28,44 & 27,27 & 28,18 & 28,21 & 28,03 & 107,03 \\
\hline Operador 02 & 25,88 & 26,74 & 28,39 & 26,29 & 28,81 & 27,22 & 110,20 \\
\hline
\end{tabular}

Fonte: Autores (2016)

\subsubsection{DETERMINAÇÃO DO TEMPO NORMAL}

Com os valores de ritmo de cada operador, obtiveramse os tempos normais para cada elemento. Vale ressaltar que $\circ 1^{\circ}, 3^{\circ}$ e $\circ 4^{\circ}$ e elemento são realizados pelo operador 02 , enquanto que $\circ 2^{\circ}$ elemento é realizado pelo operador 01 . Os resultados dos tempos normais estão descritos na tabela 3. 
Tabela 3 - Tempo Normal

\begin{tabular}{|llccc|}
\hline \multicolumn{1}{|c}{ Elementos } & $\begin{array}{c}\text { Média das } \\
\text { cronometragens (minutos) }\end{array}$ & V (\%) & $\begin{array}{c}\text { Tempo normal } \\
\text { (minutos) }\end{array}$ \\
\hline $1^{\mathbf{o}}$ & Separação de grãos & 7,77 & 110,20 & 8,56 \\
$2^{\text {o }}$ & Espocamento & 23,73 & 107,03 & 25,40 \\
$3^{\text {o }}$ & Separação da farinha de tapioca & 15,30 & 110,20 & 16,87 \\
$4^{\text {o }}$ & Empacotamento & 1,05 & 110,20 & 1,16 \\
\hline
\end{tabular}

Fonte: Autores (2016)

\subsubsection{DETERMINAÇÃO DAS TOLERÂNCIAS}

Para determinar as tolerâncias de cada operador, a equipe que estava realizando o estudo analisou de maneira conjunta as variáveis de tolerância. Utilizou-se como auxilio o quadro de tolerâncias do trabalho. Os resultados das tolerâncias para cada operador estão descritos na tabela 4.

Tabela 4 - Tolerâncias

\begin{tabular}{|cc|}
\hline Operador & $\begin{array}{c}\text { Fator Tolerância } \\
(\%)\end{array}$ \\
\hline Operador 01 & 25 \\
Operador 02 & 24 \\
\hline
\end{tabular}

Pontua-se que o fator tolerância igual a 25 do operador 01 é devido, principalmente, a estrutura precária de trabalho referente as condições atmosféricas (calor e umidade) na qual este é exposto no $2^{\circ}$ elemento. Já o fator de tolerância igual a 24 do operador 02 pode ser explicado devido ao uso excessivo da força no $1^{\circ}$ e $4^{\circ}$ elemento.

\subsubsection{DETERMINAÇÃO DO TEMPO-PADRÃO}

Com o valores do fator tolerância de cada operador, foi possível obter os tempos padrões para cada elemento descritos na tabela 5 .

Fonte: Autores (2016) 
Tabela 5 - Tempo Padrão das Operações

\begin{tabular}{|llccc|}
\hline \multicolumn{1}{|c}{ Elementos } & $\begin{array}{c}\text { Tempo normal } \\
\text { (minutos) }\end{array}$ & $\begin{array}{c}\text { Fator } \\
\text { Tolerância (\%) }\end{array}$ & $\begin{array}{c}\text { Tempo padrão } \\
\text { (minutos) }\end{array}$ \\
\hline $1^{\circ}$ Separação de grãos & 8,56 & 24 & 10,62 \\
$2^{\circ}$ & Espocamento & 25,40 & 25 & 31,75 \\
$3^{\circ}$ & Separação da farinha de tapioca & 16,87 & 24 & 20,91 \\
$4^{\circ}$ & Empacotamento & 1,16 & 24 & 1,44 \\
\hline
\end{tabular}

Fonte: Autores (2016)

\subsection{DETERMINAÇÃO DA CAPACIDADE PRODUTIVA}

Para o cálculo da capacidade produtiva, é necessário a escolha de uma unidade para o tempo padrão. O tempo padrão calculado no quadro acima está na unidade minutos por elemento. No entanto, com a escolha desta unidade, a capacidade produtiva seria resultada em elemento por dia. Porém, não se buscava a capacidade produtiva em elemento por dia, mas em saca por dia. Portanto, antes da determinação da capacidade, fez-se necessário a conversão da unidade de tempo padrão para minutos por saca. Os resultados estão descritos na tabela 6 .

Tabela 6 - Determinação da Capacidade Produtiva

\begin{tabular}{|lccc|}
\hline \multicolumn{1}{|c}{ Elementos } & $\begin{array}{c}\text { Tempo padrão } \\
\text { (minutos/elemento) }\end{array}$ & $\begin{array}{c}\text { Unidade de conversão } \\
\text { (elemento/s aca) }\end{array}$ & $\begin{array}{c}\text { Tempo padrão } \\
\text { (minutos/s aca) }\end{array}$ \\
\hline $1^{\circ}$ Separação de grãos & 10,62 & 2,54 & 26,93 \\
$2^{\circ}$ Espocamento & 31,75 & 0,30 & 9,43 \\
$3^{\circ}$ Separação da farinha de tapioca & 20,91 & 0,10 & 2,07 \\
$4^{\circ} \quad$ Empacotamento & 1,44 & 1,00 & 1,44 \\
\hline
\end{tabular}

Fonte: Autores (2016)

A unidade de conversão utilizada foi elemento por saca. Essa unidade foi obtida a partir da análise da proporção de quantos elementos eram necessários para começar um outro elemento.

Posteriormente, continuou-se com o procedimento de determinação da capacidade produtiva. Sabendo que os operadores trabalham 8,8 horas (528 minutos) diárias, foi possível calcular a capacidade produtiva de cada elemento. Os resultados estão descritos na tabela 7 . 


\begin{tabular}{|c|c|c|c|}
\hline Elementos & $\begin{array}{l}\text { Tempo padrão } \\
\text { (minutos) }\end{array}$ & $\begin{array}{r}\text { Tempo padrão } \\
\text { (minutos/saca) }\end{array}$ & $\begin{array}{c}\text { Capacidade Produtiva } \\
\text { (s aca/dia) }\end{array}$ \\
\hline $1^{\circ}$ Separação de grãos & 10,62 & 26,93 & 19,61 \\
\hline $2^{\circ}$ Espocamento & 31,75 & 9,43 & 55,99 \\
\hline $3^{\circ}$ Separação da farinha de tapioca & 20,91 & 2,07 & 254,99 \\
\hline $4^{\circ}$ Empacotamento & 1,44 & 1,44 & 366,52 \\
\hline
\end{tabular}

Fonte: Autores (2016)

Reintera-se que o presente estudo se refere somente a produção de farinha de tapioca média. O grão que será utilizado na produção desse tipo de farinha de tapioca é separado no $1^{\circ}$ elemento (separação de grãos). Entretanto, simultaneamente à separação dos grãos médios, também são separados mais 3 tipos de grãos. Caso fosse considerado os 4 tipos de grãos separados, a capacidade produtiva da separação de grãos aumentaria consideravelmente. Já os 3 últimos elementos não sofreriam alterações significativas quanto a capacidade produtiva, visto que o tempo para a realização dos 3 últimos elementos para os 4 tipos de farinha de tapioca são, praticamente, os mesmos.

Em vista disso e de posse dos resultados da capacidade produtiva, pôde-se concluir que $\mathrm{O}^{2} 2^{\circ}$ elemento (espocamento) apresenta uma capacidade produtiva consideravelmente inferior à dos outros elementos. Em consequência, os 2 últimos elementos não conseguem atingir nem $25 \%$ da sua capacidade produtiva total.

A demanda por farinha de tapioca no estado do Pará é bem expressiva. Vale ressaltar que a indústria estudada apresenta um sistema de produção empurrado e que segundo informações repassadas pela empresa, tudo que é produzido é vendido rapidamente. Portanto, a aquisição de mais um forno de espocamente e a contração de um operador aumentaria a produção da empresa em quase cem por cento.

Uma outra sugestão, refere-se a melhorias quanto as condições de trabalho (fatores ergonômicos).
Por conta das operações envolverem fornos e o ambiente de trabalho apresentar poucas saídas de ar, o espaço se torna extremamente quente e abafado, afetando diretamente na capacidade produtiva da empresa. Portanto, a implantação de algumas saídas de ar tornaria o espaço mais arejado e amenizaria significativamente a alta temperatura.

\section{CONSIDERAÇÕES FINAIS}

Com os resultados obtidos por meio da metodologia aplicada, foi possível observar a importância das informações que o estudo de Engenharia de Métodos gerou para a empresa. Os resultados e os dados apresentados - fluxograma, capacidade produtiva dão à gerência uma visão mais ampla do processo e possibilitam o maior domínio de informações sobre suas próprias operações, o que a empresa possuía somente de maneira empírica. Foi possível também aferir a eficiência de cada elemento, comparando o que é produzido com a capacidade total das operações.

Estudos realizados com foco na produção da Farinha de Tapioca ainda são bastante escassos. Neste contexto, esse trabalho também tem grande importância, podendo trazer para os produtores de farinha, discentes ou engenheiros uma referência para futuros estudos ou para o conhecimento dos processos produtivos. É visível que a falta de estudos desse produto de natureza regional tem como consequência o baixo desenvolvimento tecnológico e estrutural desse setor produtivo. 
Portanto, com o auxílio dos resultados obtidos e das sugestões de melhorias, pretende-se que estas possam influenciar positivamente a empresa estudada, resultando em um aumento da produtividade e nas melhorias das condições de trabalho.

\section{REFERÊNCIAS}

[1] BARNES, R. M. Estudo de movimentos e de tempos: Projeto e medida do trabalho. São Paulo: Edgard Blucher, 1977.

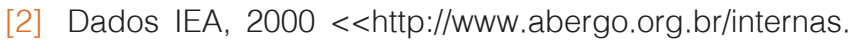
php?pg=o_que_e_ergonomia $>>$ acesso em 12/09/2016.

[3] Dados farinha de tapioca em americano, $2015<<$ http:// g1.globo.com/pa/para/noticia/2015/07/vila-de-americanopa-comemora-producao-da-farinha-de-tapioca.html>> acesso em 09/09/2016.

[4] FONSECA, R.C. Metodologia do trabalho. Curitiba: IESDE Brasil S.A, 2009.
[5] FILHO, Paranhos. Gestão da produção industrial. 20 ed. Curitiba: Ibpex, 2007

[6] GROXKO, M. Mandiocultura. Paraná: Secretaria de Estado da Agricultura e do Abastecimento, Departamento de Economia Rural, 2013. Disponível em:< http://www. agricultura.pr.gov.br/arquivos/File/deral/Prognosticos/ mandiocultura_2013_14.pdf>.

Acesso em 16/09/2016.

[7] MARTINS, P; LAUGENI, F. Administração da produção. São Paulo: Saraiva, 2005.

[8] OLIVEIRA, C; FONTENELLE, N; BEZERRA, W. Projeto de engenharia de métodos em uma indústria de sorvetes: um estudo de caso. Mossoró, 2012.

[9] PEINADO, J; GRAEML, A. R. Administração da produção: operações industriais e de serviços. Curitiba: Unicenp, 2007.

[10] SLACK, N.; CHAMBERS, S. JOHNSTON, R. Administração da produção. 3ํㅡㄹ ed. São Paulo: Atlas, 2009. 


\title{
CAPÍTULO 11
}

\section{O USO dO Plano Mestre de PRODUÇÃo COM SUPORTE NA GESTÃO DE SUPRIMENTOS EM UM EMPREENDIMENTO COMERCIAL}

\author{
Antônio Caio Cézar Costa dos Santos \\ Ana Paula Souza de Freitas \\ Ayllan Cesar de Sousa Galvão \\ Aiury Daniele Correa da Silva \\ Leony Luis Lopes Negrão
}

Resumo: O presente trabalho tem por objetivo aplicar o MPS (Master Production Schedule) para analisar a quantidade necessária de produtos a serem repostos para atender efetivamente a demanda da família de itens mais relevante, economicamente, para o empreendimento estudado, melhorando assim as atividades de suprimentos. Identificou-se a família de bebidas como a mais rentável e foi utilizado o método de suavização exponencial simples para estabelecer a quantidade de produtos a serem adquiridos semanalmente pela responsável do estabelecimento, adotando uma serie de critérios como acompanhamento de demanda, lote mínimo e estoque de segurança. De posse dos MPS's foi possível estabelecer uma melhor política de gestão de estoque por meio de decisões melhoradas quanto ao nível de manutenção dos itens em estoque, compras assertivas em termos de itens, quantidade e período.

Palavras chave: MPS, Estoque, Demanda. 


\section{INTRODUÇÃO}

Com o crescente desenvolvimento organizacional, principalmente de pequenas e médias empresas, torna-se crucial tomadas de decisões que sejam rápidas e precisas além de um maior planejamento e controle das atividades produtivas de uma empresa. É importante que as organizações se preparem para possíveis mudanças no mercado, a partir do comportamento das estimativas de demanda. Nesse contexto, é necessário que as empresas planejem a sua produção de forma eficiente.

De acordo com Lustosa et al. (2008), o Planejamento e Controle da Produção (PCP) surgiu no início do século XX, tendo como um de seus pioneiros Henry Gantt, que desenvolvia cálculos manuais baseados no tempo e na capacidade de produção. Desde aquela época, o PCP vem evoluindo constantemente na busca por melhorias capazes de suprir o avanço do setor produtivo, em especial na área de suprimentos de materiais

Toda organização precisa saber como dimensionar suas capacidades produtivas da forma que estas se adequem de modo preciso às demandas, evitando assim possíveis desperdícios de tempo, energia, material ou falta de produtos para atender o mercado. O PCP pode ser um elo importante entre as estratégias da empresa e o seu sistema produtivo. De acordo com Slack et al. (2002), o propósito do planejamento e controle é garantir que os processos da produção ocorram eficaz e eficientemente e que produzam bens e serviços conforme requeridos pelos consumidores.

De acordo com o Serviço Brasileiro de Apoio às Micro e Pequenas Empresas - SEBRAE (2014), os pequenos negócios respondem por mais de um quarto do Produto Interno Bruto (PIB) brasileiro. Juntas, cerca de nove milhões de micro e pequenas empresas no País representam $27 \%$ do PIB, um resultado que vem crescendo nos últimos anos. Portanto faz-se necessário que esses empreendimentos adotem algumas medidas para o planejamento de suas produções adquirindo certa posição de prestigio em relação às demais microempresas.

Conforme Slack (2002), o Planejamento Mestre da Produção (MPS) tem como principal atividade a gestão de pedidos, que através de uma verificação da capacidade durante o processo de entrada de pedido e da disponibilidade de materiais, possibilita saber se a empresa é capaz ou não de cumprir o prazo estipulado pelo cliente, visando garantir o atendimento do pedido desde o processo de venda.

Para Martins e Laugeni (2005), o MPS trata-se de uma demonstração do planejamento de vendas e operações em bens produzíveis com suas quantidades e momentos determinados. O papel principal do MPS é especificar o mix e o volume de produção. Frente a isso, o objetivo do presente trabalho foi aplicar o MPS para analisar a quantidade necessária de produtos a serem repostos para atender efetivamente a demanda da família de itens mais relevante, economicamente, para o empreendimento estudado, melhorando assim as atividades de suprimentos.

\section{REFERENCIAL TEÓRICO}

A inserção do PCP em um micro empreendimento baseia-se em conjunto de decisões que visam atingir desempenho em critérios competitivos alinhados aos ideais da empresa, de forma a assegurar que objetivos ocorram de forma eficiente e segura.

\subsection{PLANEJAMENTO E CONTROLE DA PRODUÇÃO}

Segundo Fernandes e Godinho (2010), o Planejamento e Controle da Produção (PCP) envolve uma série de decisões sobre o que, quanto e quando produzir e comprar, tanto para os produtos finais, quanto para os componentes e matérias-primas desses.

Para Slack, Chambers e Johnston (2009), planejamento e controle da produção é a tarefa de determinar a capacidade efetiva da operação produtiva, de forma que ela possa responder à demanda. Isso normalmente significa decidir como a operação deve reagir a flutuações na demanda.

Para planejar e controlar a produção são necessários vários tipos de conhecimento, a saber: conhecimentos a respeito dos produtos e processos inseridos no 
sistema cujas atividades de deseja planejar e controlar; conhecimentos conceituais a respeito do próprio PCP; conhecimentos em computação e conhecimentos em matemática (FERNADES; GODINHO, 2010).

Segundo Martins e Laugeni (2015), o sistema de PCP (planejamento e controle da produção) deve informar corretamente a situação corrente dos recursos, o que envolve, pessoas, equipamentos, instalações, materiais e das ordens de compra e de produção, além de ser capaz de reagir de forma eficaz. A informação deve estar disponível e atualizada para que seja possível oferecer aos clientes uma ampla variedade de serviços, melhorar o planejamento, a programação e o controle em um ambiente de negócios internacionalizado; e que a habilidade da empresa nesses aspectos possa ser o diferencial para que se torne de classe mundial, acrescentando que a informação deve estar disponível também no chão de fábrica.

\subsection{PREVISÃO DE DEMANDA}

No atual ambiente competitivo é inegável que as previsões têm um papel fundamental, servindo como guia para o planejamento estratégico da produção, finanças e vendas de uma empresa. No âmbito do PCP, a previsão também é importante, uma vez que ela é um dos principais dados de entrada para várias funções e decisões do PCP (FERNANDES; GODINHO, 2010).

Segundo Corrêa e Corrêa (2012), previsões são, em geral, o resultado de um processo, um encadeamento de ativdades que inclui: a coleta de informações relevantes; o tratamento destas informações; a busca de padrões de comportamento, muitas vezes fazendo uso de métodos quantitativos de tratamento de séries temporais de dados do passado; a consideração de fatores qualitativos relevantes; a projeção de padrões de comportamento; a estimativa de erros da previsão, entre outros.

A projeção de demanda é importante para utilizar as máquinas de maneira adequada, realizar a reposição dos materiais no momento e na quantidade certos, e para que todas as demais atividades necessárias ao processo industrial sejam programadas de forma apropriada. Apesar de as previsões serem importantes e úteis para o planejamento de atividades, elas apresentam erros em suas estimativas, devendose ser cuidadoso tanto na coleta de dados quanto na escolha do modelo de previsão para diminuir os erros (MARTINS; LAUGENI, 2015).

As previsões dentro do PCP costumam ser classificadas de acordo com o horizonte de planejamento (longo, médio e curto prazo) a que se destina. No longo prazo, as previsões são importantes para o PCP para o planejamento de novas instalações, de novos produtos, gastos de capital, dentre outros. No médio prazo, as previsões servem como base para o planejamento agregado da produção e análises de capacidade agregadas. Já no curto prazo, as previsões auxiliam na programação da força de trabalho, na programação de compras, nas análises de capacidade de curto prazo, dentre outras (FERNANDES; GODINHO, 2010).

\subsubsection{ABORDAGEM BASEADA EM SÉRIES TEMPORAIS}

De acordo com Fernandes e Godinho (2010), o pressuposto da previsão utilizando séries temporais é que o futuro pode ser previsto com base no histórico de dados passados; em outras palavras, a utilização de séries temporais acredita que os fatores que influenciarão o futuro são os mesmos que influenciaram o passado.

A abordagem de séries temporais requer que inicialmente seja reconhecido o padrão de comportamento da série temporal, para que dessa forma os métodos de previsão dentro dessa abordagem (média móvel simples, padrão com tendência, sazonalidades) possam ser escolhidos.

\subsubsection{MÉTODO DA SUAVIZAÇÃO EXPONENCIAL SIMPLES}

De acordo com Fernandes e Godinho (2010), o método da suavização exponencial simples é um método similar ao método da média móvel ponderada, com a diferença de que os pesos decrescem 
exponencialmente do tempo presente em direção ao passado.

O método da suavização exponencial simples advém da minimização da somatória dos desvios ao quadrado devidamente ponderados por fatores que exponencialmente dão maior peso aos dados mais recentes. De maneira mais simplificada, o método da suavização exponencial fornece a previsão para o próximo período como sendo a previsão para o período atual, corrigida pelo erro ocorrido no período atual

\subsubsection{ERROS DE PREVISÃO}

O sistema de previsão deve ser controlado a fim de se determinarem os erros que estão ocorrendo nas previsões. O erro de previsão em um período () pode ser definido como a diferença entre a demanda real nesse período e a previsão no período (FERNANDES; GODINHO, 2010).

\subsubsection{DESVIO ABSOLUTO MÉDIO}

O Desvio absoluto médio (DAM) mede a dispersão dos erros. Portanto, se o DAM for pequeno a previsão estará próxima à demanda real. Valores altos do DAM indicam problemas com o método da previsão empregado ou com os parâmetros utilizados. O DAM é muito utilizado na escolha de métodos e parâmetros da previsão (FERNANDES; GODINHO, 2010).

\subsection{PROGRAMA MESTRE DA PRODUÇÃO - MPS}

O programa mestre de produção (MPS - master production schedule) é a fase mais importante do planejamento e controle de uma empresa. O MPS contém uma declaração da quantidade e momento em que os produtos finais devem ser produzidos; esse programa direciona toda operação em termos do que é montado, manufaturado e comprado (SLACK; CHAMBERS; JOHNSTON, 2009).

Segundo Corrêa e Corrêa (2012), o planejamento mestre de produção, coordena a demanda do mercado com os recursos internos da empresa de forma a programar taxas adequadas de produção de produtos finais, principalmente aqueles que têm sua demanda independente.

O planejamento mestre de produção, colabora com a melhora do processo de promessa de datas e quantidades de produtos para clientes, com uma melhor gestão de estoques dos produtos acabados, melhor uso e gestão da capacidade produtiva e melhor integração na tomada de decisão entre funções, permitindo que as decisões multifuncionais, muitas vezes envolvendo interesses conflitantes entre funções, possam ser tomadas com base objetiva, suporta por dados e não por opiniões não fundamentas, ou como isso é chamado em muitas organizações, apenas por feeling (intuição) (CORRÊA; CORRÊA, 2012).

O programa mestre de produção é constituído de registro com escala de tempo que contêm, para cada produto final, as informações de demanda e estoque disponível atual. Usando essa informação, o estoque disponível é projetado à frente no tempo. Quando não há estoque suficiente para satisfazer à demanda futura, quantidades de pedido são inseridas na linha do programa-mestre (SLACK; CHAMBERS; JOHNSTON, 2009).

\section{MÉTODO DE PESQUISA}

Inicialmente, foi realizada uma coleta de dados, dirigindo-se até o local a ser implantado o protejo. Após o recolhimento dos dados sobre a compra e venda dos produtos fornecidas pela responsável do estabelecimento, foi realizada uma análise para organizar os dados obtidos e decidir o que deveria ser feito para planejar e controlar a produção, de forma que não houvesse falta de produtos, garantindo assim a satisfação do cliente e a minimização dos custos com gastos de estoque, excesso de produtos ou a falta dos mesmos.

As etapas que serão descritas abaixo, foram realizadas na família de produtos que mais destacouse economicamente para o local, a família de bebidas, o qual engloba refrigerantes, lacticínios, sucos e etc. Tal afirmação foi tomada como verídica segundo informações fornecidas pela própria responsável do 
estabelecimento.

Com a obtenção dos dados, foi iniciado o estudo para identificar quais métodos do planejamento e controle da produção poderiam ser utilizados para o objetivo proposto. As abordagens causais foram descartas do projeto, pelo estudo do t-student que ao computar os dados de compra o valor deu acima de $5 \%$, ou seja, rejeita-se a hipótese nula.

Com a não possibilidade do uso das abordagens Causais, foi proposto o estudo acerca das abordagens baseadas em series temporais, o qual foram aplicados os métodos propostos pelos estudos para cada uma das famílias do estabelecimento, com o objetivo de identificar qual o melhor método de previsão de demanda a ser utilizado. Ao ser realizado os cálculos observou-se que o método de suavização simples, utilizando alfa igual a 0,3 apresentou melhor previsão de demanda. Ao realizar o cálculo do erro utilizando a diferença entre a demanda real e a prevista, e logo em seguida o Desvio médio absoluto, foi possível identifica que dentre os outros métodos das series temporais, o que apresentou menor erro foi o do método de suavização simples com um valor de aproximadamente 0,14 .

Após as etapas descritas acima, foi iniciado os estudos dos dados utilizando-se do Programa Mestre da Produção (MPS) com o objetivo de estabelecer a quantidade de produtos a serem adquiridos semanalmente pela responsável do estabelecimento, adotando uma serie de critérios como acompanhamento de demanda, lote mínimo e estoque de segurança. Para cada produto foi feito um (MPS) estabelecendo cada um dos critérios descritos anteriormente.

\section{RESULTADOS}

Durante a entrevista com a proprietária da empresa e com os dados históricos identificou-se que a família de produtos de bebidas é responsável pelo maior fluxo saída e faturamento da empresa. Este produto tem sua demanda influenciada por uma série de fatores que se estendem desde as condições macroeconômicas até as questões operacionais, como a disponibilidade do produto e preço no ponto de venda. Logo, conforme o histórico de vendas obtido foi possível testar os métodos de previsão de demanda e utilizando o Desvio Médio Absoluto (DAM) verificou-se que a Suavização Exponencial Simples apresentou um menor erro para prever a demanda semanal para o próximo mês, conforme resultados que constam na Tabela 1.

TABELA 1 - Escolha do método de previsão para os itens da Família de Bebidas

\begin{tabular}{|l|l|}
\hline \multicolumn{1}{|c|}{ MÉTODOS DE PREVISÃO DE DEMANDA } \\
$\alpha$ Média Móvel & \multicolumn{1}{|c|}{18,11} \\
\hline Média Ponderada $(0,4 ; 0,3 ; 0,3)$ & 11,38 \\
\hline Previsão Suavizada Simples ( =0,1) $\alpha$ & 13,17 \\
\hline Previsão Suavizada Simples ( =0,2) $\alpha$ & 2,86 \\
\hline Previsão Suavizada Simples ( =0,3) $\alpha$ & 2,25 \\
\hline Previsão Suavizada Dupla com Tendência $(=0,1)$ & 189,55 \\
\hline Previsão Suavizada Dupla com Tendência $(=0,2)$ & 62,62 \\
\hline Previsão Suavizada Dupla com Tendência $(=0,3)$ & 4,43 \\
\hline
\end{tabular}

Fonte: Autores (2016)

A previsão de demanda semanal foi desagregada em 15 itens individuais da família de produtos estudada para elaboração do Programa Mestre de Produção (MPS) de cada item da mesma família. Na Tabela 2 constam as previsões do mês de maio das bebidas 
com maior saída que o estabelecimento dispõe para atender os clientes. Essas previsões, serviram como base para que se pudesse elaborar o MPS.

TABELA 2 - Previsão para maio de 2016

\begin{tabular}{|l|l|}
\hline Produto & Previsão \\
\hline Bebida láctea sache & 25 \\
\hline Coca Cola lata & 21 \\
\hline Danette & 16 \\
\hline Tuchaua 2l & 15 \\
\hline Coca Cola 2L & 14 \\
\hline Cerveja Antarctica lata & 13 \\
\hline Activia & 10 \\
\hline Danoninho & 10 \\
\hline Fanta laranja & 7 \\
\hline Coca Cola 600 & 6 \\
\hline Kaiser lata & 6 \\
\hline Skol 1I & 5 \\
\hline Tuchaua 600 & 5 \\
\hline Coca Cola 1L & 4 \\
\hline logurte garrafa & 4 \\
\hline
\end{tabular}

Fonte: Autores (2016)

As previsões serviram como base para que se pudesse elaborar o MPS dos produtos. Na Tabela 3 visualizase o MPS para o produto Bebida Láctea Sache. A programação foi feita considerando um estoque de no mínimo quatro produtos para se atender a demanda, e um lote mínimo de seis produtos. Com base nessas políticas de restrições do estabelecimento, obtevese os resultados conforme constam na Tabela 3. Para primeira e segunda semana deve se adquirir 12 produtos para atender a demanda, sendo que na terceira e quarta semana do mês de maio deve-se obter seis produtos.
TABELA 3 - Programa Mestre de Produção (Bebida Láctea Sache)

\begin{tabular}{|c|c|c|c|c|c|}
\hline \multirow{2}{*}{$\begin{array}{l}\text { PRODUTO: BEB } \\
\text { LACTEA SACHE }\end{array}$} & \multicolumn{5}{|c|}{ Períodos } \\
\hline & 0 & 1 & 2 & 3 & 4 \\
\hline $\begin{array}{l}\text { Previsao de demanda } \\
\text { independente }\end{array}$ & & 7 & 7 & 7 & 7 \\
\hline Demanda & & 7 & 7 & 7 & 7 \\
\hline Estoque & 4 & 9 & 14 & 13 & 12 \\
\hline $\begin{array}{c}\text { Programa Mestre de } \\
\text { produção }\end{array}$ & & 12 & 12 & 6 & 6 \\
\hline Estoque de segurança & 4 & & & & \\
\hline Lote mínimo & 6 & & & & \\
\hline
\end{tabular}

Fonte: Autores (2016).

O Programa Mestre de Produção da Coca Cola Lata que constam da tabela 4 foram feitos considerando um estoque de no mínimo três produtos, e um lote mínimo de 12 produtos. Com base nessas políticas do estabelecimento, obteve-se o seguinte planejamento. Para primeira, segunda e quarta semana deve ser adquirido 12 produtos pelo empreendimento, sendo que na terceira semana do mês não é necessário a compra de produto.

TABELA 4 - Programa Mestre de Produção (Coca Cola Lata)

\begin{tabular}{|c|c|c|c|c|c|}
\hline \multirow{2}{*}{$\begin{array}{l}\text { PRODUTO: COCA } \\
\text { COLA LATA }\end{array}$} & \multicolumn{5}{|c|}{ Períodos } \\
\hline & 0 & 1 & 2 & 3 & 4 \\
\hline $\begin{array}{l}\text { Previsao de demanda } \\
\text { independente }\end{array}$ & & 6 & 6 & 6 & 6 \\
\hline Demanda & & 6 & 6 & 6 & 6 \\
\hline Estoque & 3 & 9 & 15 & 9 & 15 \\
\hline $\begin{array}{c}\text { Programa Mestre de } \\
\text { produção }\end{array}$ & & 12 & 12 & 0 & 12 \\
\hline Estoque de segurança & 3 & & & & \\
\hline Lote mínimo & 12 & & & & \\
\hline
\end{tabular}

Fonte: Autores (2016). 
A programação mestre de produção dos outros constam na Tabela 5. produtos da família de bebidas do estabelecimento,

Tabela 5 - MPS dos 13 itens restantes

\begin{tabular}{|c|c|c|c|c|c|c|c|c|c|c|c|}
\hline \multirow{2}{*}{ PRODUTO: ANTARCTICA PILSEN LATA } & \multicolumn{5}{|c|}{ Períodos } & \multirow{2}{*}{ PRODUTO: ACTIVIA BJ } & \multicolumn{5}{|c|}{ Períodos } \\
\hline & 0 & 1 & 2 & 3 & 4 & & 0 & 1 & 2 & 3 & 4 \\
\hline Previsão de demanda independente & & 4 & 4 & 4 & 4 & Previsão de demanda independente & & 3 & 3 & 3 & 3 \\
\hline Demanda & & 4 & 4 & 4 & 4 & Demanda & & 3 & 3 & 3 & 3 \\
\hline Estoque & 2 & 10 & 6 & 14 & 10 & Estoque & 2 & 7 & 8 & 5 & 6 \\
\hline Programa Mestre de produção & & 12 & 0 & 12 & 0 & Programa Mestre de produção & & 8 & 4 & 0 & 4 \\
\hline Estoque de segurança & 2 & & & & & Estoque de segurança & 2 & & & & \\
\hline Lote mínimo & 12 & & & & & Lote mínimo & 4 & & & & \\
\hline PRODUTO: COCA COLA 2L & \multicolumn{4}{|c|}{ Períodos } & 4 & PRODUTO: TUCHAUA CHAMP 2L & \multicolumn{4}{|c|}{ Períodos } & 4 \\
\hline Previsão de demanda independente & & 4 & 4 & 4 & 4 & Previsão de demanda independente & & 4 & 4 & 4 & 4 \\
\hline Demanda & & 4 & 4 & 4 & 4 & Demanda & & 4 & 4 & 4 & 4 \\
\hline Estoque & 2 & 10 & 6 & 8 & 10 & Estoque & 2 & 10 & 6 & 8 & 10 \\
\hline Programa Mestre de produção & & 12 & 0 & 6 & 6 & Programa Mestre de produção & & 12 & 0 & 6 & 6 \\
\hline Estoque de segurança & 2 & & & & & Estoque de segurança & 2 & & & & \\
\hline Lote mínimo & 6 & & & & & Lote mínimo & 6 & & & & \\
\hline \multirow{2}{*}{ PRODUTO: DANETTE-ACHOCOLATADO } & \multicolumn{4}{|c|}{ Períodos } & & \multirow{2}{*}{ PRODUTO: DANONINHO } & \multicolumn{5}{|c|}{ Períodos } \\
\hline & 0 & 1 & 2 & 3 & 4 & & 0 & 1 & 2 & 3 & 4 \\
\hline Previsão de demanda independente & & 4 & 4 & 4 & 4 & Previsão de demanda independente & & 3 & 3 & 3 & 3 \\
\hline Demanda & & 4 & 4 & 4 & 4 & Demanda & & 3 & 3 & 3 & 3 \\
\hline Estoque & 2 & 4 & 6 & 8 & 7 & Estoque & 3 & 8 & 13 & 10 & 7 \\
\hline Programa Mestre de produção & & 6 & 6 & 6 & 3 & Programa Mestre de produção & & 8 & 8 & 0 & 0 \\
\hline Estoque de segurança & 2 & & & & & Estoque de segurança & 3 & & & & \\
\hline Lote mínimo & 3 & & & & & Lote mínimo & 8 & & & & \\
\hline PRODUTO: COCA COLA 600 & \multicolumn{5}{|c|}{ Períodos } & PRODUTO: KAISER PILSEN LATA & \multicolumn{5}{|c|}{ Períodos } \\
\hline & $\mathbf{0}$ & 1 & 2 & 3 & 4 & 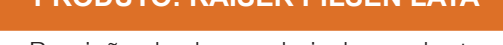 & 0 & 1 & 2 & 3 & 4 \\
\hline Previsão de demanda independente & & 2 & 2 & 2 & 2 & Previsão de demanda independente & & 2 & 2 & 2 & 2 \\
\hline Demanda & & 2 & 2 & 2 & 2 & Demanda & & 2 & 2 & 2 & 2 \\
\hline Estoque & 2 & 12 & 10 & 8 & 6 & Estoque & 2 & 12 & 10 & 8 & 6 \\
\hline Programa Mestre de produção & & 12 & 0 & 0 & 0 & Programa Mestre de produção & & 12 & 0 & 0 & 0 \\
\hline Estoque de segurança & 2 & & & & & Estoque de segurança & 2 & & & & \\
\hline Lote mínimo & 12 & & & & & Lote mínimo & 12 & & & & \\
\hline PRODUTO: SKOL GFA 1L & \multicolumn{5}{|c|}{ Períodos } & PRODUTO: FANTA LARANJA/PEPSI & \multicolumn{5}{|c|}{ Períodos } \\
\hline PRODUIO: SKOL GFA 1L & 0 & 1 & 2 & 3 & 4 & SUKITA 2L & 0 & 1 & 2 & 3 & 4 \\
\hline Previsão de demanda independente & & 2 & 2 & 2 & 2 & Previsão de demanda independente & & 2 & 2 & 2 & 2 \\
\hline Demanda & & 2 & 2 & 2 & 2 & Demanda & & 2 & 2 & 2 & 2 \\
\hline Estoque & 2 & 12 & 10 & 8 & 6 & Estoque & 2 & 6 & 4 & 8 & 6 \\
\hline Programa Mestre de produção & & 12 & 0 & 0 & 0 & Programa Mestre de produção & & 6 & 0 & 6 & 0 \\
\hline Estoque de segurança & 2 & & & & & Estoque de segurança & 2 & & & & \\
\hline Lote mínimo & 12 & & & & & Lote mínimo & 6 & & & & \\
\hline PRODUTO: TUCHAUA CHAMP 600 & \multicolumn{5}{|c|}{ Períodos } & PRODUTO: IOGURTE GARRAFA & 0 & ${ }_{1}^{P}$ & $\begin{aligned} \text { ríod } \\
2\end{aligned}$ & s & 4 \\
\hline Previsão de demanda independente & & 2 & 2 & 2 & 2 & Previsão de demanda independente & & 2 & 2 & 2 & 2 \\
\hline Demanda & & 2 & 2 & 2 & 2 & Demanda & & 2 & 2 & 2 & 2 \\
\hline Estoque & 2 & 12 & 10 & 8 & 6 & Estoque & 1 & 3 & 3 & 3 & 3 \\
\hline Programa Mestre de produção & & 12 & 0 & 0 & 0 & Programa Mestre de produção & & 4 & 2 & 2 & 2 \\
\hline Estoque de segurança & 2 & & & & & Estoque de segurança & 1 & & & & \\
\hline Lote mínimo & 12 & & & & & Lote mínimo & 1 & & & & \\
\hline PRODUTO: COCA COLA 1L & 0 & ${ }_{1}^{P}$ & $\begin{array}{l}\text { ríod } \\
2\end{array}$ & s 3 & 4 & & & & & & \\
\hline Previsão de demanda independente & & 2 & 2 & 2 & 2 & & & & & & \\
\hline Demanda & & 2 & 2 & 2 & 2 & & & & & & \\
\hline Estoque & 1 & 5 & 3 & 7 & 5 & & & & & & \\
\hline Programa Mestre de produção & & 6 & 0 & 6 & 0 & & & & & & \\
\hline Estoque de segurança & 1 & & & & & & & & & & \\
\hline Lote mínimo & 6 & & & & & & & & & & \\
\hline
\end{tabular}


De posse dos MPS's foi possível estabelecer uma melhor política de gestão de estoque por meio de decisões melhoradas quanto ao nível de manutenção dos itens em estoque, compras assertivas em termos de itens, quantidade e período. Essas iniciativas possibilitaram à empresa uma adequada alocação de recursos financeiros, humanos e de espaço, melhorando sua rentabilidade.

Observa-se que o emprego do MPS possibilitou à empresa uma organização e um planejamento adequado de gestão de suprimento dos itens que mais agregam valor para a sustentabilidade do empreendimento. O uso desta ferramenta para os 15 itens da família de produtos de bebidas, reúne informações importantes que possam melhora a tomada de decisão dos gestores por meio da gestão adequado dos itens em estoque.

\section{CONCLUSÕES E SUGESTÕES}

\section{A crescente concorrência pelos mercados} consumidores tem levado as empresas a reconsiderarem seus processos produtivos e a forma como os mesmos são gerenciados. Nas médias e pequenas empresas, as atividades do PCP ganharam destaque e passaram a ser o diferencial entre as empresas, tendo em vista os benefícios e os resultados satisfatórios que proporcionam às mesmas. Ressalta-se que a utilização de tais atividades no empreendimento comercial em estudo é particularmente inovador visto que suas principais características perfaz a variabilidade da demanda, variedade de produtos, distância dos principais fornecedores e concorrência cada vez mais agressiva.

Os resultados obtidos quanto a definição do método de previsão, o cálculo da previsão de demanda e a elaboração do MPS, possibilitou à empresa a identificação dos itens que mais contribuem para o faturamento da mesma e o gerenciamento melhorado de tais itens quanto a redução do nível de estoque, reposição de itens em lotes menores e o emprego efetivo dos recursos empresariais.

O estudo poderia ser mais bem explorado caso houvesse dados históricos suficientes dos produtos analisados assim como de outros produtos. Isso possibilitaria uma ampliação das análises discorridas e dos resultados relacionados aos indicadores operacionais. Dessa forma, infere-se como uma oportunidade de estudo futuro a ampliação deste para todos os produtos da referida empresa. Outra sugestão é o detalhamento da gestão de estoques para os produtos em questão, visando a formulação de uma política gerencial do estoque dos itens da empresa.

\section{REFERENCIAS}

[1] COELHO, L. C. Utilização de modelos de suavização exponencial para previsão de demanda com gráficos de controles combinados Shewhart-CUSUM. Dissertação (Mestrado) - Universidade Federal de Santa Catarina, Programa de Pós-Graduação em Engenharia de Produção, 2008.

[2] CONSUL, F. B.; WERNER, L. Avaliação de Técnicas de Previsão de Demanda Utilizadas por um Software de Gerenciamento de Estoques no Setor Farmacêutico - XXX Encontro Nacional de Engenharia de Produção, 2010.

[3] CORRÊA, H.; CORRÊA, C.. Administração de produção e operações. 3. Ed. São Paulo: Atlas, 2012.

[4] FERNANDES, F.; GODINHO FILHO, M. Planejamento e Controle da Produção: do essencial à prática. 1. ed. São Paulo: Atlas, 2010.

[5] LUSTOSA, L. et al. Planejamento e Controle da Produção. 4.Ed. Rio de Janeiro: Elsevier, 2008.

[6] MARTINS, P.; LAUGENI, F. Administração da Produção. 3. Ed. São Paulo: Saraiva, 2015.

[7] MARTINS, P. G.; LAUGENI, F. P. Administração da Produção. $2^{2}$ edição. São Paulo: Saraiva, 2005.

[8] MENEZES, G. Tecnicas de planejamento e controle da cadeia de suprimentos utilizadas nas empresas de pequeno porte em Itabira-MG, BA, 2013.

[9] SEBRAE. Disponível em: < http://www.sebrae.com. $\mathrm{br} / \mathrm{sites} /$ PortalSebrae/ufs/mt/noticias/micro-e-pequenasempresas-geram-27-do-pib-do-brasil>. Acesso em: 18/05/2016

[10] SLACK, N.; CHAMBERS, S.; JOHNSTON, R. Administração da Produção. 3. Ed. São Paulo: Atlas, 2009.

[11] SLACK, $\quad$ N.; $\quad$ CHAMBERS,S.; JOHNSTON,R. Administração da Produção. $2^{\underline{a}}$ edição. São Paulo: Editora Atlas, 2002. 


\title{
CAPÍTULO 12
}

\section{TROCA RÁPIDA DE FERRAMENTAS (TRF): ANÁLISE DA \\ LITERATURA PARA IDENTIFICAÇÃO DE \\ OPORTUNIDADE DE PESQUISA}

\author{
Edimar Nunes Dias \\ Claudilaine Caldas de Oliveira \\ Rony Peterson da Rocha \\ Tânia Maria Coelho \\ Márcia de Fátima Morais
}

Resumo: O mercado está em constante mudança e para que as empresas se mantenham competitivas são necessárias melhorias em seus processos produtivos, buscando aprimoramento da qualidade, por meio da padronização de suas operações e aumento da produtividade e da flexibilidade de produção. Uma das metodologias da Produção Enxuta que vem ao encontro com essas necessidades é a Troca Rápida de Ferramentas, ela busca diminuir os tempos de setups (tempo de trocas de ferramentas e maquinários) no processo produtivo das organizações. O presente estudo teve como objetivo desenvolver o mapeamento sobre a metodologia de Troca Rápida de Ferramentas a partir da seleção e análise de um conjunto de estudos científicos sobre o tema, denominado como portifólio bibliográfico. Utilizou-se o método de abordagem quali-quantitativo. A pesquisa classificase, quanto aos fins, como exploratória, descritiva, e, quanto aos meios, com bibliográfica. Realizaram-se pesquisas nas bases de dados da SCOPUS, Google, web of Science e SCIELO. A partir disso, foi possível obter um portifólio de trabalhos sobre a metodologia TRF quantificando: a quantidade de citação dos artigos; as palavras-chave encontradas; os eventos em que foram publicados; os fatores de impacto da Qualis da Capes; quais são "estudos de revisão" e quais são "estudo de caso"; e as principais melhorias encontradas nos trabalhos pesquisados. A pesquisa evidencia a importância da realização do levantamento do Portifólio Bibliográfico, aumentando os conhecimentos a respeito do tema de interesse, considerando que essa área de conhecimento configura-se como um campo a ser explorado.

Palavras chave: Análise Sistêmica, Análise Bibliométrica, Troca Rápida de Ferramentas, Levantamento Bibliográfico. 


\section{INTRODUÇÃO}

A metodologia de Troca Rápida de Ferramentas (TRF) tem como principal objetivo reduzir estoques e materiais em processo (HOFRICHTER, 2010). Para que a TRF tenha bons resultados, deve ser realizado um Estudo de Tempos e Movimentos.

O Estudo de Tempos e Movimento, uma das atividades da Engenharia de Métodos, subárea de Conhecimento de Engenharia de Produção (ABEPRO, 2008), é um assunto bastante pesquisado em todo o mundo. Isto ocorre pois busca garantir a maior eficiência na utilização de recursos, resultando em maior produtividade e menores danos ao trabalhador.

A partir disso, este artigo objetivou desenvolver o mapeamento da literatura sobre a metodologia de Troca Rápida de Ferramentas a partir da seleção e análise de um conjunto de estudos científicos sobre o tema, denominado como Portifólio Bibliográfico (PB). Assim realizaram-se análises (bibliométrica e sistêmica) das publicações encontradas, com o intuito de adquirir melhor o conhecimento e verificar pesquisas que tratam do tema em que se tem interesse.

Este artigo está estruturado em 6 seções. Na primeira seção apresenta-se uma breve contextualização sobre o assunto e o objetivo da pesquisa. Em seguida, apresenta-se a fundamentação teórica. $\mathrm{Na}$ terceira seção apresenta-se a metodologia utilizada. Na quarta seção, encontra-se os resultados e discussões. Por fim, apresentam-se as considerações finais e referências.

\section{A Metodologia de Troca Rápida de Ferramentas} (TRF)

A Troca Rápida de Ferramentas (TRF) é uma metodologia do Sistema Toyota de Produção, que tem por objetivo reduzir o tempo de preparação ou setup de equipamentos, minimizando períodos nãoprodutivos no chão-de-fábrica e, consequentemente, aumentar a capacidade produtiva dos equipamentos (RODRIGUES e BILHAR, 2014).

O tempo de setup pode ser definido como o tempo necessário para preparar os operadores e os equipamentos para a fabricação de outro produto pertencente à produção (DALCOL, 2008). A diminuição do tempo de setup contribui para a agilidade no processo e para a redução dos custos de produção.

A TRF permite alterações de determinado produto em uma linha de produção de forma rápida e eficiente (MOTA, 2007).

Os benefícios da aplicação da TRF não se restringem apenas a redução no tamanho do lote de produção, mas junto a isso têm-se a redução do tempo de setup, que é de tamanha importância, pois permite maior capacidade de adaptação pelas organizações devido às variações da demanda. Juntamente temos ainda a redução dos estoques, que geram custos para a empresa, assim como o envolvimento dos colaborados, afinal sem eles o TRF não acontece (PEREIRA, 2008).

A referência da metodologia TRF é Shingo (2000), ele divide a TRF em quatro estágios: levantar as operações de setups; classificá-las em setups internos e externos; transformar setups internos em externos; racionalizar as demais operações de setups. Juntamente a metodologia de Shingo (2000) será utilizada a metodologia Rodrigues; Bilhar (2014), nela os tempos de troca de ferramentas são divididos em: Estratégico, Preparatório, Operacional e de Consolidação. Assim, os tópicos a seguir apresentaram uma combinação das duas metodologias.

- Fase Estratégica: inicia-se com o convencimento da alta gerência, pois é ela quem toma as decisões estratégicas da organização. O próximo passo é registrar os tempos atuais de setup, em seguida define-se a meta, ou seja, qual a porcentagem de diminuição de setup a ser alcançado (RODRIGUES e BILHAR, 2014). Em seguida, deve-se definir um cronograma de realização das atividades, o qual deve estar bem elaborado e com os respectivos responsáveis por implantar cada uma dessas etapas, sendo que devem ser suficientemente bons para liderar e treinar sua equipe. Na equipe de trabalho, devem estar pessoas que realmente conheçam o processo e então poderão atuar, verificar possíveis falhas e propor melhorias, mas isso só será possível se seu responsável realmente explicar sobre a TRF, seus benéficos e exemplos 
de sucesso (SHINGO, 2000).

- Fase Preparatória: deve-se definir em qual produto a TRF será aplicada, pode ser aquele que apresenta a maior demanda, ou aquele com maior valor agregado, ou ainda a combinação do dois (SHINGO, 2000). Sendo assim, deve-se construir uma curva $A B C$ e priorizar os produtos que apresentarem os maiores valores, geralmente os classificados na classe $A$, visto que a redução do tempo de setup obtida nesses itens terá maior impacto financeiro na empresa (RODRIGUES e BILHAR, 2014). Após definir o produto, deve-se definir qual a parte do processo será estudada e começar por uma operação específica, geralmente o gargalo, se conseguirmos diminuí-lo o tempo de processamento como um todo diminuirá (SHINGO, 2000).

- Fase Operacional: de acordo com Shingo (2000) relata que o método deve ser aplicado em quatro estágios, são eles:

- Estágio Preliminar - setup interno e externo não se distinguem: nessa etapa, primeiramente é feita a descrição de todas as atividades, com seus respectivos tempos de processamento e os responsáveis por cada uma delas. Após isso, faz-se a separação das atividades internas e as externas do setup (SUGAl et al., 2007). O Estágio Inicial é como a empresa realmente está produzindo, assim, deve-se inicialmente fazer um levantamento dos tempos gastos em cada fase do setup. Para sua realização deve-se utilizar a cronoanálise, que não se baseia apenas na coleta de dados por cronômetros, mas também pela utilização de filmadoras (em operações mais complexas) (PEREIRA, 2008).

- Estágio 1 - Separando o setup interno e externo: é feita uma avaliação das operações internas ao setup e aquelas que se classificam como externas, essa diferenciação pode ser feita com a utilização de checklists (SUGAl et al., 2007). Um exemplo de checklist está presente em Anexo. Operações internas são aquelas que só podem ser realizadas com a máquina parada, enquanto que operações externas podem e devem ser realizadas com a máquina em funcionamento (MOTA, 2007).

- Estágio 2 - Convertendo setup interno em externo: procura-se transformar os setups internos em externos, isso é feito por meio da padronização das operações e do ferramental utilizado, buscando maximizar o número de tarefas a serem executadas (PEREIRA, 2008). A padronização irá garantir maior agilidade produtiva, já que elimina desperdícios e busca aproveitar os recursos com máxima eficiência. Vale lembrar que caso algum setup interno não possa ser convertido em externo, mas que mesmo assim acabe influenciando muito no processo, uma alternativa pode ser automatizálo, devendo fazer toda uma análise de custo e benefício (SUGAl et al., 2007). Sabe-se que a classificação em setups internos e externos acaba diminuindo o tempo em até 30\% (MOTA, 2007).

- Estágio 3 - Racionalizando todos os aspectos da operação de setup: No terceiro estágio as operações internas já foram convertidas em externas, o objetivo agora é diminuir o tempo das operações externas, essa redução no tempo das atividades pode ser feita basicamente buscando maneiras mais rápidas e fáceis de executar a operação (MOTA, 2007). Porém, nem todas as operações internas podem ser convertidas em externas, para isso existem algumas técnicas como: realizar as operações em paralelo; fixar as bases, eliminar desregulagens; padronizar procedimento de setup; eliminar ajustes através da utilização de dispositivos de posicionamento rápido, e ainda; aprimorar a gestão visual para o sistema produtivo (SHINGO, 2000). A Figura 1 mostra o funcionamento de cada um dos estágios da metodologia TRF. 
Figura 1 - Esquema dos vários estágios da metodologia TRF

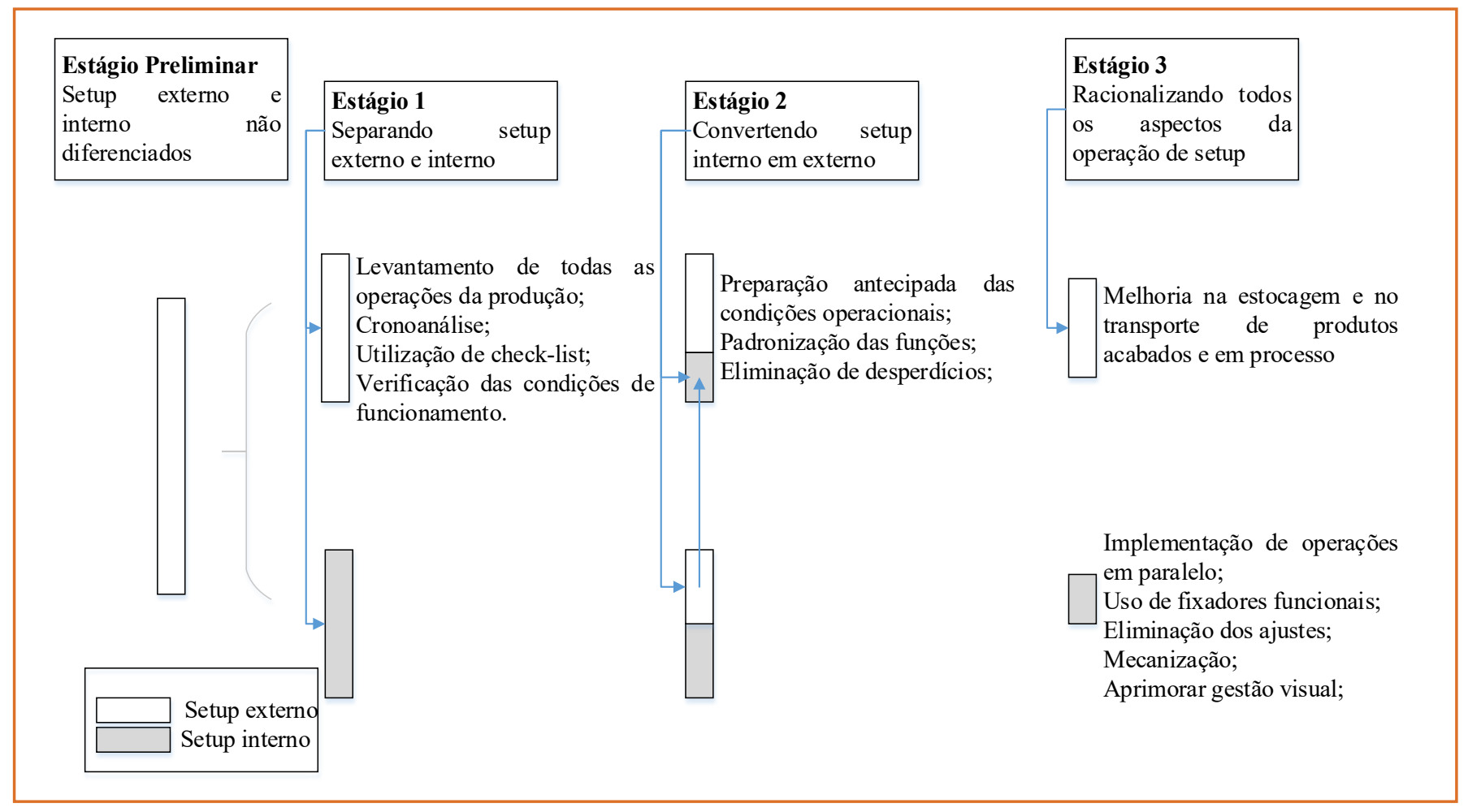

Fonte: Adaptado de Shingo (2000)

- Estágio de Consolidação: nesse estágio os resultados são realmente avaliados e contabilizados. Analisa-se o tempo reduzido do setup, e consequentemente os ganhos com mãode-obra e ganhos com aumento de produtividade. Deve-se então, buscar avançar a TRF para outros setores da organização, e implantar a metodologia em todos os envolvidos, para que os resultados de diminuição no tempo de setup sejam satisfatórios no processo produtivo como um todo (FOGLIATTO; FAGUNDES, 2003).

\section{METODOLOGIA}

O método de abordagem utilizado no presente trabalho foi o quali-quantitativo. Qualitativo pois realizou-se a busca sobre a metodologia de Troca Rápida de Ferramentas (TRF) e por ter sido feito o levantamento de um Portifólio Bibliográfico (PB) sobre o assunto.

A abordagem quantitativa foi feita por meio de um estudo bibliométrico e sistêmico, utilizando de gráficos comparativos, assim, levantaram-se diferentes resultados de aplicação da metodologia TRF.

A pesquisa quanto aos fins é classificada como exploratória e descritiva. A pesquisa é considerada exploratória uma vez que foram realizadas buscas sobre as metodologias e aplicações da TRF, almejando assim identificar diferentes trabalhos sobre o assunto, contribuindo para a construção do PB.

Descritiva, uma vez que foram descritas todas as etapas para a implantação da metodologia TRF, bem como os pontos principais de cada trabalho pesquisado.

Quanto aos meios, a pesquisa classifica-se como bibliográfica, pois foram utilizados livros, artigos científicos, trabalhos de graduação, dissertações e teses sobre a aplicação da metodologia TRF, auxiliando assim, na elaboração deste trabalho.

A pesquisa consistiu na construção de um PB, para isso realizaram-se buscas nas bases de dados da 
SCOPUS, Google acadêmico, Web of Science, SCIELO e eventos de Engenharia de Produção utilizando as palavras chave: Troca rápida de ferramentas; TRF; Single Minute Exchange of Die; SMED, e; diminuição do tempo de setup. Assim, realizaram-se leitura dos trabalhos brutos identificados e filtragem.

\section{RESULTADOS E DISCUSSÕES}

Foram selecionados 30 trabalhos alinhados com o tema que compõem o Portfólio Bibliográfico (PB), dos quais são classificados em: 16 artigos científicos em âmbito nacional e internacional publicados em eventos e periódicos, seis trabalhos de conclusão de curso e oito dissertações. Estes trabalhos estão apresentados no Quadro 1 e 2 ao qual foram atribuídos códigos à cada um dos trabalhos e localização de publicação.

Quadro 1 - Artigos que compõe o Portfólio Bibliográfico

\begin{tabular}{|c|c|c|c|}
\hline Código & Autores & Título & Periódico/Evento \\
\hline A & $\begin{array}{l}\text { Fogliatto e Fagundes } \\
\qquad(2003)\end{array}$ & Troca rápida de ferramentas: proposta metodológica e estudo de caso & Revista Gestão \& Produção \\
\hline B & $\begin{array}{l}\text { Neumann e Ribeiro } \\
\text { (2004) }\end{array}$ & $\begin{array}{l}\text { Desenvolvimento de fornecedores: um estudo de caso utilizando a troca } \\
\text { rápida de ferramentas }\end{array}$ & Revista Produção \\
\hline $\mathrm{C}$ & $\begin{array}{l}\text { Satolo e Calarge } \\
\text { (2008) }\end{array}$ & $\begin{array}{l}\text { Troca Rápida de Ferramentas: estudo de casos em diferentes } \\
\text { segmentos industriais }\end{array}$ & Revista Exacta \\
\hline $\mathrm{D}$ & Conceição et al. (2009) & $\begin{array}{l}\text { Desenvolvimento e implementação de uma metodologia para troca } \\
\text { rápida de ferramentas em ambientes de manufatura contratada }\end{array}$ & Revista Gestão \& Produção \\
\hline $\mathrm{E}$ & Sugai et al. (2007) & Metodologia de Shigeo Shingo (SMED): análise crítica e estudo de caso & Revista Gestão \& Produção \\
\hline $\mathrm{F}$ & Leão e Santos (2009) & $\begin{array}{c}\text { Aplicação da troca rápida de ferramentas (TRF) em intervenções de } \\
\text { manutenção preventiva }\end{array}$ & Revista Produção \\
\hline G & Lopes et al. (2007) & $\begin{array}{l}\text { Estudo de caso de implementação de troca rápida de ferramenta em } \\
\text { uma empresa calçadista }\end{array}$ & Enegep \\
\hline $\mathrm{H}$ & Avi Júnior et al. (2010) & $\begin{array}{l}\text { Troca rápida de ferramenta: redução do tempo de setup de uma linha } \\
\text { de montagem de braço de controle }\end{array}$ & Revista Ciências Exatas \\
\hline I & $\begin{array}{l}\text { Monteiro e Menezes } \\
\quad(1995)\end{array}$ & $\begin{array}{l}\text { Produtividade fabril III - método para rápido aumento da produtividade } \\
\text { fabril: redução de tempos inativos e do tempo de espera do material em } \\
\text { processo }\end{array}$ & Revista Gestão \& Produção \\
\hline J & $\begin{array}{l}\text { Monteiro e Menezes } \\
\text { (2005) }\end{array}$ & $\begin{array}{l}\text { Troca rápida de ferramentas aplicada a uma indústria siderúrgica do rio } \\
\text { de janeiro: um estudo de caso }\end{array}$ & Simpoi \\
\hline K & Méndez et al. (2015) & $\begin{array}{l}\text { Um estudo de caso: metodologias SMED \& JIT para desenvolver fluxo } \\
\text { contínuo de peças estampadas em linha de montagem de desconexão } \\
\text { AC na Schneider Electric Tlaxcala Planta }\end{array}$ & IFAC-PapersOnLine \\
\hline L & $\begin{array}{l}\text { Ferradás e Salonitis } \\
\qquad(2013)\end{array}$ & $\begin{array}{l}\text { Melhorando o tempo de mudança: uma abordagem SMED sob medida } \\
\text { para as células de soldagem }\end{array}$ & Procedia CIRP \\
\hline M & $\begin{array}{l}\text { Azizia e Manoharanb } \\
\qquad(2015)\end{array}$ & $\begin{array}{l}\text { Projetando um Mapeamento Futuro do Fluxo de Valor para reduzir o } \\
\text { tempo de entrega usando SMED-Um Estudo de Caso }\end{array}$ & Procedia Manufacturing \\
\hline $\mathrm{N}$ & $\begin{array}{l}\text { Simões e Tenera } \\
(2010)\end{array}$ & $\begin{array}{c}\text { Melhorar o tempo de configuração em uma linha Press - Aplicação da } \\
\text { metodologia SMED }\end{array}$ & IFAC Proceedings Volumes \\
\hline $\mathrm{O}$ & Karasu et al. (2013) & $\begin{array}{c}\text { Melhoramento de tempos de troca através de Taguchi com } \\
\text { aprimoramentos do SMED/ estudo de caso sobre a produção de } \\
\text { moldagem por injeção }\end{array}$ & Measurement \\
\hline$P$ & Almomani et al. (2013) & $\begin{array}{c}\text { Uma abordagem proposta para a redução de tempo de configuração } \\
\text { através da integração método SMED convencional com múltiplos } \\
\text { critérios de técnicas de tomada de decisão }\end{array}$ & $\begin{array}{l}\text { Computers \& Industrial } \\
\text { Engineering }\end{array}$ \\
\hline
\end{tabular}


Quadro 2 - Trabalhos que compõe o Portfólio Bibliográfico

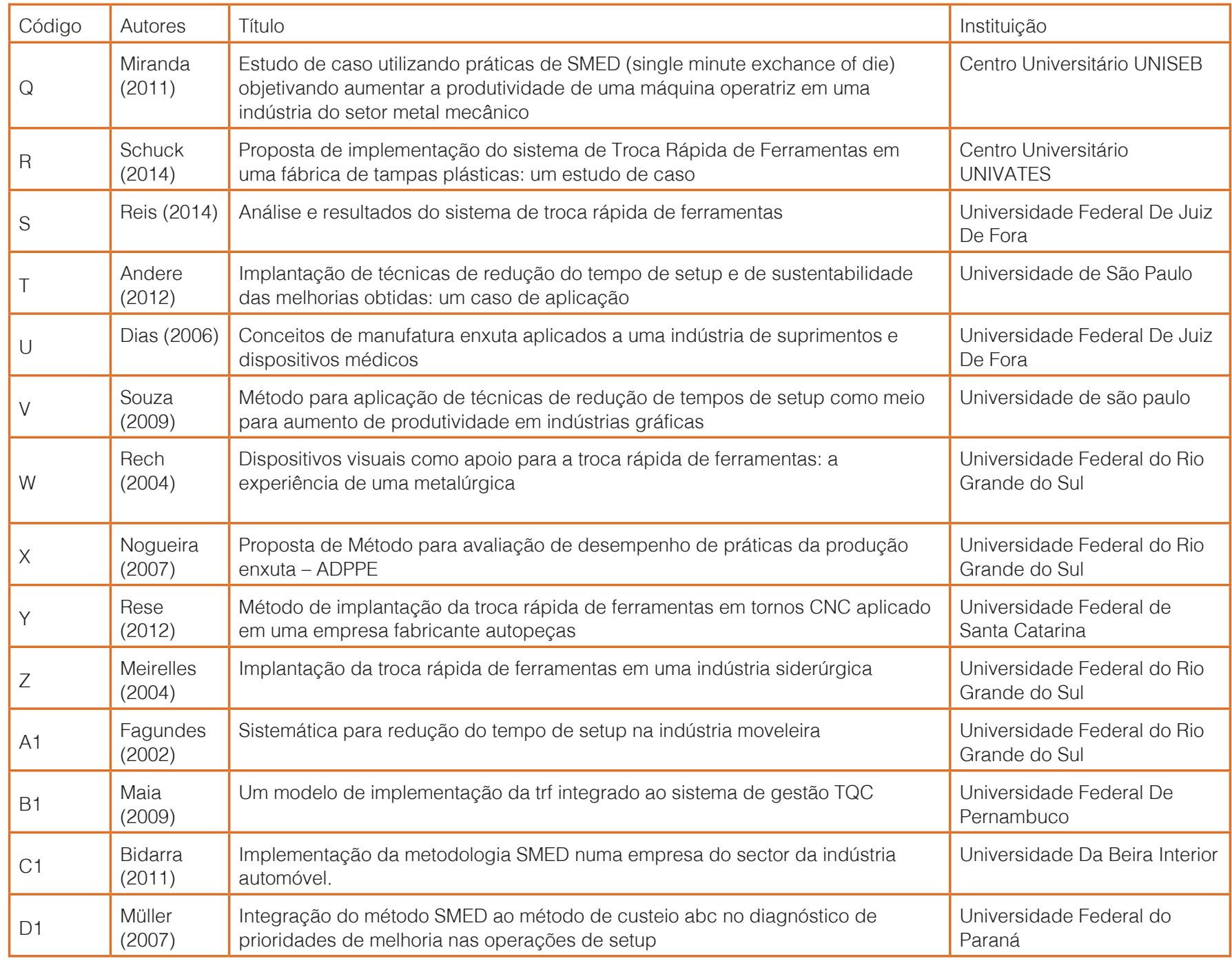

A partir da seleção dos trabalhos fez-se uma análise bibliométrica e sistêmica.

\subsection{ANÁLISE BIBLIOMÉTRICA}

A análise bibliométrica identifica os autores, suas relações, o crescimento e tendências do conhecimento em uma área (SPINAK, 1996). Neste contexto, a análise no presente estudo apresentam-se os resultados do perfil das publicações do PB: (i) reconhecimento científicos dos trabalhos; (ii) palavras chave de maior destaque; (iii) local de publicação, e; (iv) fator de impacto dos periódicos do PB.
O reconhecimento científico (Figura 2) foi identificado de cada trabalho do PB baseado no número de vezes que o trabalho foi citado em outras pesquisas científicas por meio do Google Acadêmico. Ressalta-se que os trabalhos que não foram apresentados na Figura 2 é porque não foram citados por outros trabalhos.

Figura 2 - Relevância dos trabalhos do Portfólio Bibliográfico

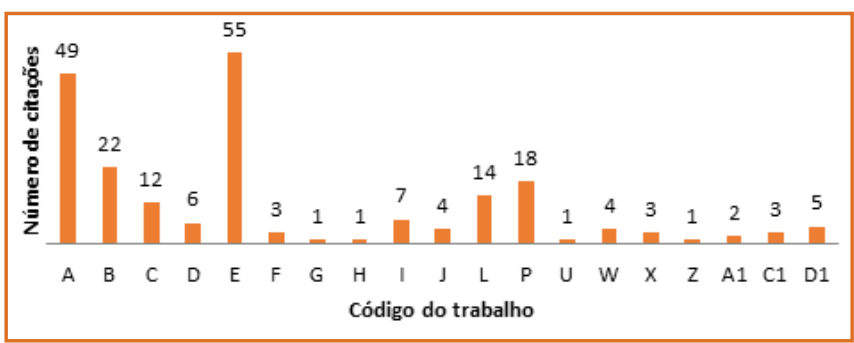


Nota-se (Figura 2) que o artigo (código E) intitulado "Metodologia de Shigeo Shingo (SMED): análise crítica e estudo de caso" de Sugai et al. (2007) publicado na Revista Gestão \& Produção foi a pesquisa que representou maior reconhecimento científico, sendo citado 55 vezes por outros trabalhos, seu objetivo era analisar criticamente a Troca Rápida de Ferramentas revelando as lacunas da metodologia

Destacou-se também, o artigo (código A) "Troca rápida de ferramentas: proposta metodológica e estudo de caso" com 49 citações de Fogliatto e Fagundes (2003), desenvolver uma proposta metodológica para a TRF, constituída dos seguintes passos: definição do projeto, planejamento das atividades, treinamento da equipe de implantação, implantação propriamente dita, acompanhamento e consolidação.

As palavras-chave são fatores importantes a serem pesquisadas, visto que evidenciam a efetividade do mapeamento da literatura. Assim, elaborou-se a figura 3 , comparando a quantidade de artigos que tinham as mesmas palavras-chave das utilizadas pelos autores dessa pesquisa.

Figura 3 - Relevância das palavras-chave do Portfólio Bibliográfico

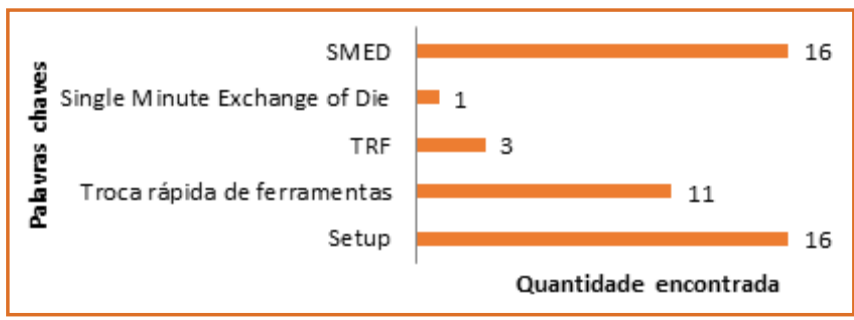

Verifica-se (Figura 3) que as palavras SMED e setup são as mais relevantes, que aparecem 16 vezes, respectivamente. Pondendo, assim constatar que a representatividade destas palavras permite confirmar que as palavras-chave utilizadas no processo de busca para formar o PB foram acertiva, uma vez que as palavras-chave utilizadas para realização da busca dos trabalhos foram: SMED; Single Minute Exchange of Die; TRF; Troca Rápida de Ferramentas e setup.

A partir dos dados do Quadro 1, elaborou-se o gráfico que apresenta os locais de publicação dos artigos e a quantidade encontrada em cada evento/periódico (Figura 4).

Figura 4 - Relevância dos Periódicos e Eventos do Portfólio Bibliográfico

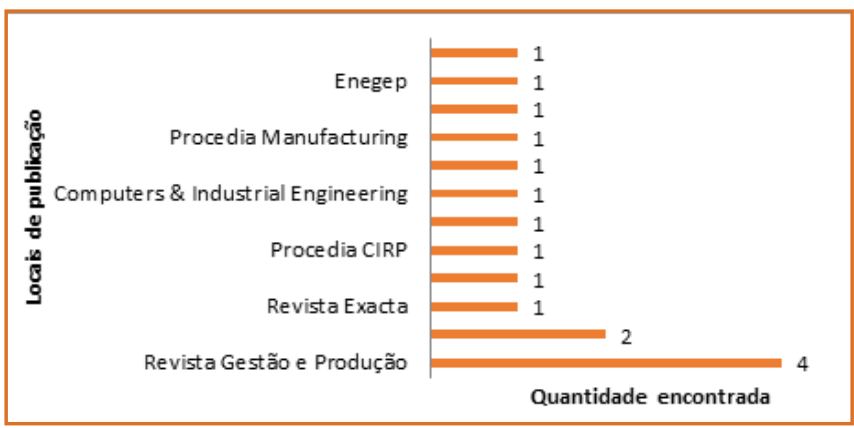

Quanto aos 16 trabalhos do portifólio que foram publicados, nota-se que 11 (68,75\%) foram publicados em periódicos e cinco $(31,25 \%)$ foram publicados em eventos.

Dos publicados em periódicos 25\% deles foram publicados na Revista Gestão \& Produção.

Outra análise realizada relação aos periódicos que os artigos que compõe o PB baseado na Qualis, sendo este um sistema de avaliação de periódicos pela Coordenação de Aperfeiçoamento de Pessoal de Nível Superio (CAPES) na área de Engenharias III a qual a Engenharia de Produção se inclui (Figura 5).

Figura 5 - Qualis da CAPES dos periódicos do Portfólio Bibliográfico

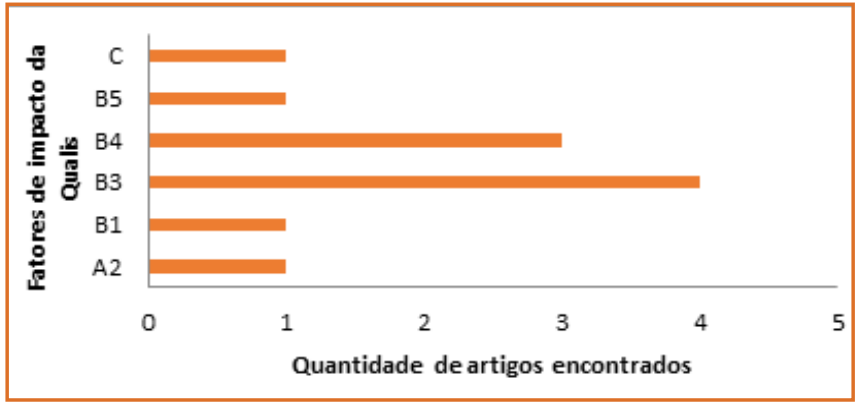

Observa-se que dentre os trabalhos publicados em periódico 36,36\% enquadravam-se na categoria B3.

\subsection{Análise Sistêmica}

Após a realização da análise bibliométrica, iniciou-se uma abordagem sistêmica para análise do conteúdo dos trabalhos. 
Foi verificado que a maioria dos estudos, 77\% (23 estudos) realizaram estudo de caso (práticos), enquanto que $23 \%$ (sete trabalhos) eram teóricos, visto que realizaram revisão da literatura. Isso mostra que o estudo em trabalhos de revisão que tratam do tema de Troca Rápida de Ferramentas é baixo se comparado aos trabalhos aplicados.

Foi invesigado as principais melhorias que os trabalhos do PB obtiveram com a implementação da metodologia de Troca Rápida de Ferramentas (TRF) conforme a Figura 6.

Figura 6 - Principais benefícios da implementação da metodologia de Troca Rápida de Ferramentas (TRF)

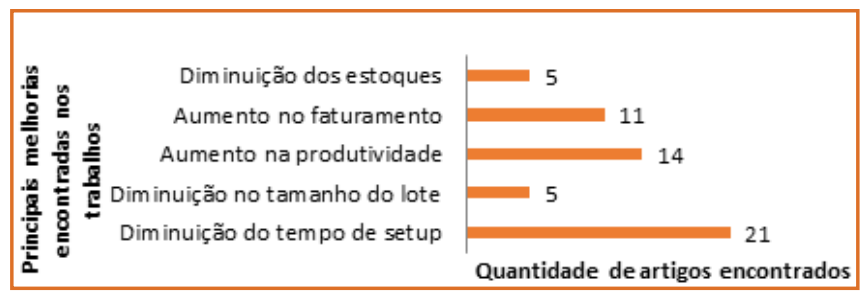

Em um contexto geral, pode-se observar que dentre todas as melhorias proporcionadas pela Troca Rápida de Ferramentas, 21 delas tiveram diminuição do tempo de setup, representando 37,5\% do total. Também, nota-se grande relevância da TRF para o aumento da produtividade da empresa, na qual obtiveram-se 14 melhorias, representando $25 \%$ e para o aumento do faturamento, representando 11 melhorias (19,64\%). Realizaram-se também, outras abordagens sistêmicas:

No estudo de Neumann e Ribeiro (2004) o foco foi utilizar a metodologia TRF para os fornecedores da matéria-prima e não na linha de produção da empresa como foi o caso dos demais trabalhos encontrados;

Já Satolo e Calarge (2008) observaram que as empresas estão usando apenas parte dos benefícios da metodologia TRF (apenas a diminuição do tempo de setup) e acabam não dando importância para outros aspectos como o aumento do lucro ou da produtividade;

Sugai et al. (2007) propõe não seguir a metodologia de Shingo (2000) tal como descrita, ela é apenas uma base e deve ser adaptada para a realidade de cada empresa;

Méndez et al. (2015) em seu estudo criaram uma equipe de pit-stop, que foi responsável pelo funcionamento da TRF, ou seja, eles quem faziam a gestão visual;

A metodologia TRF para Ferradás e Salonitis (2013) só funciona em sua integridade quando existem poucas pessoas envolvidas no processo (no máximo 5);

Os autores Azizia e Manoharanb (2015) sugerem a utilização da metodologia TRF com a Mapeamento do Fluxo de Valor, afirmam proporcionar maior visibilidade e entendimentos dos ganhos atuais e futuros e ainda tiveram melhorias com a diminuição no tamanho dos lotes e sugeriu que futuramente a produção por batelada fosse substituída por um fluxo contínuo de produção;

O trabalho de Karasu et al. (2013) foi o único dentre os encontrados que relacionou a metodologia TRF com a metodologia Taguchi, buscando encontrar onde está a maior parte dos desperdíceos;

Outra sugestão encontrada foi no trabalho de Schuck (2014), propõe que trabalhos futuros relacionem a metodologia TRF com a análise PERT/CPM;

Fagundes (2002) fez uma relação do layout e da Manutenção Produtiva Total (do inglês Total Productive Manegement - TPM) na implantação de uma sistemática de TRF;

Müller (2007) quer criar uma metodologia de aplicação que integra a curva $\mathrm{ABC}$ e a metodologia TRF;

Leão e Santos (2009) propõem implantar a metodologia TRF seguindo os mesmos passos de implementação do ciclo PDCA;

Por fim, a única abordagem não satisfatória, encontrada no trabalho de Andere (2012), o qual cita que os resultados da aplicação da metodologia TRF foram negativos. 


\section{CONSIDERAÇÕES FINAIS}

Com a elaboração desta pesquisa foi possível obter um PB de trabalhos sobre a metodologia TRF e realizar um mapeamento da literatura sobre o tema a ser estudado, adquirindo assim, o conhecimento e informações relevantes para se realizar uma análise sistêmica e bibliométrica, análises essas que auxiliaram na identificação de oportunidade para futuras pesquisas sobre o respectivo tema.

Nas análises sistêmicas e bibliométricas quantificaramse as quantidades de vezes que os artigos do portifólio foram citados em outros trabalhos, sendo o artigo Metodologia de Shigeo Shingo (SMED): análise crítica e estudo de caso de Sugai et al. (2007) publicado na Revista Gestão \& Produção o mais citado dentre todos os trabalhos.

Também, identificaram-se as palavras-chave mais encontradas nos trabalhos e que também foram utilizadas como palavras-chave para a busca do portifólio, setup e SMED. Além ainda dos fatores de impacto da Qualis da Capes para Engenharias III, sendo que a maioria enquadra-se no fator B3, outro resultado discutido foi que a maior parte das publicações sobre TRF foi encontrada na Revista Gestão \& Produção.

A pesquisa mostra a importância da implantação da metodologia de TRF nas empresas, visto que seu foco é reduzir estoques e material em processo por meio do aprimoramento no tempo de setup e melhoria do método de execução da troca de ferramentas.

Dessa forma, evidencia-se que essa área de conhecimento configura-se como um campo a ser explorado, visto que a maioria dos trabalhos encontrados alcançaram apenas um ou no máximo dois dos benefícios que a TRF permite: diminuição dos estoques; aumento no faturamento; aumento na produtividade; diminuição no tamanho do lote; e, diminuição do tempo de setup.

Assim, observa-se uma lacuna de oportunidade para trabalhos futuros, almejando aplicar a metodologia TRF no segmento industrial com uma quantidade maior de benefícios.

\section{REFERÊNCIAS}

[1] AlMOMANI, M. A.; AlADEEMY, M.; ABDELHADI, A.; MUMANI, A. A proposed approach for setup time reduction through integrating conventional SMED method with multiple criteria decision-making techniques. Computers \& Industrial Engineering, Vol. 66, n.2, p. 461-469, 2013.

[2] ANDERE, G. Implantação de técnicas de redução do tempo de setup e de sustentabilidade das melhorias obtidas: um caso de aplicação. 76 f. TCC (curso de engenharia de produção mecânica) - Universidade de São Paulo. São Carlos, 2012

[3] ASSOCIAÇÃO BRASILEIRA DE ENGENHARIA DE PRODUÇÃO - ABEPRO. Áreas e Subáreas da Engenharia de Produção. 2008. Disponível em: < http://www.abepro.org. br/interna. $a s p ? p=399 \& m=424 \& s s=1 \& c=362>$. Acesso em 21 de abril de 2016

[4] AVI JUNIOR, E.; ARAÚJO, D. G. \& RIBEIRO, D. G. Troca rápida de ferramenta: redução do tempo de setup de uma linha de montagem de braço de controle. Revista ciências exatas Vol. 16, n. 1, p. 22-32, 2010.

[5] AZIZI, A.; MANOHARANB, T. A. P. Designing a Future Value Stream Mapping to Reduce Lead Time using SMED-A Case Study. Procedia Manufacturing. Vol. 2, p. 153-158, 2015

[6] BIDARRA, T. F. T. Implementação da metodologia SMED numa empresa do sector da indústria automóvel. 92 f. Dissertação (Mestrado em Engenharia e Gestão Industrial) - Universidade da Beira Interior. Covilhã, 2011.

[7] CONCEIÇÃO, S.V.; RODRIGUES, I.A.; AZEVEDO, A.A.; ALMEIDA, J.F.; FERREIRA, F.; MORAIS, A. Desenvolvimento e implementação de uma metodologia para troca rápida de ferramentas em ambientes de manufatura contratada. Gestão \& produção Vol. 16, n. 3, p. 357-369, 2009.

[8] DALCOL, R. S. Estudo da Aplicação da Logística Enxuta na Linha de Compressores a Parafuso da Empresa Alfa. 74 f. Dissertação (Graduação em Engenharia de Produção e Sistemas). Universidade do Estado de Santa Catarina. Joinville, 2008.

[9] DIAS, R. L. T. Conceitos de manufatura enxuta aplicados a uma indústria de suprimentos e dispositivos médicos. 43 f. TCC (Graduação em Engenharia de Produção) Universidade Federal de Juiz De Fora. Juiz de Fora, 2006.

[10] FAGUNDES, P. R. M. Sistema para redução do tempo de setup na indústria moveleira. 128 f. Dissertação (Mestrado Profissionalizante em Engenharia) - Universidade Federal do Rio Grande do Sul. Porto Alegre, 2002.

[11] FERRADÁS, P. G.; SALONITIS, K. Improving changeover time: a tailored SMED approach for welding cells. Procedia CIRP. Vol. 7, n.2, p. 598-603, 2013.

[12] FOGLIATTO, F. S.; FAGUNDES, P. R. M. Troca Rápida de Ferramentas: Proposta Metodológica e Estudo de Caso. Gestão \& Produção. Vol.10, n.2, p.163-181, 2003 
[13] HOFRICHTER, M. SMED - Single Minute Exchange of Die, 2010. Recuperado em 21 de Abril de 2016, de http:// www.artigonal.com/gestao-artigos/smed-simgle-minuteexchange-of-die-3881605.html

[14] KARASU, M. K.; CAKMAKCI, M.; CAKIROGLU, M. B.; AYVA, E. \& DEMIREL-ORTABAS, N. Improvement of changeover times via Taguchi empowered SMED/case study on injection molding production. Measurement, Vol. 47, p. 741-748, 2014.

[15] LEÃO, S. R. D. C \& SANTOS, M. J. Aplicação da troca rápida de ferramentas (trf) em intervenções de manutenção preventiva. Produção on line. Vol. 9, n. 1, p. 167-1901, 2009.

[16] LOPES, P. F.; MORAES, F. A. \& LOPES, P. S. Estudo de caso de implementação de troca rápida de ferramenta em uma empresa calçadista. Enegep, foz do iguaçu, pr, brasil, 09 a 11 de outubro de 2007.

[17] MAIA, A. F. Um modelo de implementação da trf integrado ao sistema de gestão TQC. 119 f. Dissertação (Mestrado em Engenharia de Produção) - Universidade Federal de Pernambuco. Recife, 2009

[18] MEIRELLES, F. M. Implantação da troca rápida de ferramentas em uma indústria siderúrgica. 87 f. Dissertação (Mestrado Profissionalizante em Engenharia) - Universidade Federal do Rio Grande do Sul. Porto Alegre, 2004.

[19] MÉNDEZ, R. R.; PARTIDA, D. S.; MARTÍNEZ-FLORES, J. L. \& ARVIZU-BARRÓN, E. A case study: SMED \& JIT methodologies to develop continuous flow of stamped parts into AC disconnect assembly line in Schneider Electric Tlaxcala Plant. IFAC-PapersOnLine. Vol. 48, n. 3, p. 13991404, 2015.

[20] MIRANDA, R. T. D. Estudo de caso utilizando práticas de smed (single minute exchance of die) objetivando aumentar a produtividade de uma máquina operatriz em uma indústria do setor metal mecânico. 20 f. TCC (Graduação em Engenharia de Produção) - Centro Universitário Uniseb. Ribeirão Preto, 2011.

[21] MONTEIRO, A. MENEZES, J. O. Troca rápida de ferramentas aplicada a uma indústria siderúrgica do rio de janeiro: um estudo de caso. In: VIII simpósio de administração da produção, logística e operações internacionais - simpoi 2005 - tema: operações: inovações e tendências. Anais... Realizado na fgv-eaesp em 30, 31 de agosto e 01 de setembro de 2005.

[22] MOTA, P. M. P. Estudo e implementação da metodologia SMED e o seu impacto numa linha de produção. Dissertação de Mestrado, Mestrado em Engenharia Mecânica, Instituto Superior Técnico da Universidade Técnica de Lisboa, Lisboa, Portugal, 2007.

[23] MÜLLER, R. M. Integração do método SMED ao método de custeio abc no diagnóstico de prioridades de melhoria nas operações de setup. 133 f. Dissertação (Mestrado em Engenharia Mecânica) - Universidade Federal do Paraná. Curitiba, 2007.
[24] NEUMANN, C. S. R. \& RIBEIRO, J. L. D. Desenvolvimento de fornecedores: um estudo de caso utilizando a troca rápida de ferramentas. Revista produção. V. 14 n. 1, p. 44-53, 2004.

[25] NOGUEIRA, M. G. S. Proposta de método para avaliação de desempenho de práticas da produção enxuta - ADPPE. 116 f. Dissertação (Mestrado em Engenharia de Produção) - Universidade Federal Do Rio Grande Do Sul. Porto Alegre, 2007.

[26] PEREIRA, M. A. Estudo de caso da metodologia SMED: Questões Operacionais para implantação em tornos CNC. Anais do Encontro Nacional de Engenharia de Produção, Rio de Janeiro, Rio de Janeiro, Brasil, 2008.

[27] PINCERATO, N. F. Treinamento Lean Manufacturing "Compartilhando conhecimento para um alto desempenho". [Apostila do Treinamento de Lean Manufacturing]. São Paulo: RL \& Associados, 2014.

[28] RECH, G. C. Dispositivos visuais como apoio para a troca rápida de ferramentas: a experiência de uma metalúrgica. 107 f. Dissertação (Mestrado Profissionalizante em Engenharia) - Universidade Federal do Rio Grande do Sul. Porto Alegre, 2004.

[29] REIS, J. A. Análise e resultados do sistema de troca rápida de ferramentas. 40 f. TCC (Curso de Graduação em Engenharia de Produção) - Universidade Federal de Juiz de Fora. Juiz de Fora, 2014.

[30] RESE, S. C. C. Método de implantação da troca rápida de ferramentas em tornos cnc aplicado em uma empresa fabricante autopeças. 95 f. Dissertação (Mestrado em Engenharia Mecânica) - Universidade Federal de Santa Catarina. Florianópolis, 2012.

[31] RODRIGUES, A. S. \& BILHAR, B. M. A. Troca Rápida de Ferramentas: Objetivos e Implantação. Recuperado em 20 de maio de 2016, de: http://www.techoje.com.br/site/techoje/ categoria/detalhe_artigo/2059.

[32] SATOLO, G. E. \& CALARGE, A.F. Troca rápida de ferramentas: estudo de casos em diferentes segmentos industriais. Exacta. Vol. 6, n. 2, p. 283-296, 2008.

[33] SCHUCK, D. C. Proposta de implementação do sistema de troca rápida de ferramentas em uma fábrica de tampas plásticas: um estudo de caso. 99 f. TCC (Curso de Engenharia de Produção) - Centro Universitário Univates. Lageado, 2004.

[34] SHINGO, S. Sistema de Troca Rápida de Ferramenta: uma revolução nos sistemas produtivos. Porto Alegre: Bookman, 2000.

[35] SIMÕES, A. \& TENERA, A. Improving setup time in a Press Line - Application of the SMED methodology. IFAC Proceedings Volumes. Vol. 43, n. 17, p. 297-302, 2010. 
[36] SOUZA, R. V. B. Método para aplicação de técnicas de redução de tempos de setup como meio para aumento de produtividade em indústrias gráficas. 86f. TCC (Graduação em Engenharia de Produção) - Universidade de São Paulo. São Carlos, 2009.

[37] SPINAK, E. Dicionário enciclopédico de bibliometría, cienciometría e informetría. Montevideo. P. 245, 1996.
[38] SUGAI, M.; MCINTOSH, R. I. \& NOVASKI, O. Metodologia de shigeo shingo (smed): análise crítica e estudo de caso. Gestão \& produção, São Carlos, Vol. 14, n. 2, p. 323-335, 2007. 


\title{
CAPÍTULO 13
}

\section{PARAMETRIZAÇÃO DO MRP E IMPLANTAÇÃO DE TEMPO DE SEGURANÇA NO SETOR DE PROGRAMAÇÃO DE MATERIAIS EM UMA EMPRESA MULTINACIONAL DO SETOR AERONÁUTICO}

\author{
Ferdinand Van Run
}

Resumo: $O$ aumento de concorrência entre as empresas e a formação de alianças entre fornecedores e empresas tem influenciado a estabilidade do sistema de Planejamento das Necessidades de Materiais - Material Requirements Planning (MRP) das indústrias e este é fundamental para o cumprimento de prazos. Com relação ao planejamento de materiais dois conceitos se destacam para esse trabalho que são: os tempos de segurança (que se refere ao tempo incorporado ao lead time dos itens que é calculado pela média de dias atrasados de cada fornecedor) e a parametrização do sistema (que se refere à antecipação da verificação de disponibilidade de materiais para ordens planejadas, ou seja, vinculadas a aeronaves que ainda não estão em execução). Desta forma, o objetivo deste trabalho foi implantar tempos de segurança no Planejamento das Necessidades de Materiais (MRP) para melhorar o desempenho do setor de programação de materiais em uma empresa aeronáutica de grande porte. O trabalho foi desenvolvido por meio de pesquisa bibliográfica para sustentar uma pesquisa-ação na empresa do estudo. O tratamento dos dados foi qualiquantitativo. Os principais resultados foram o aumento na confiabilidade dos resultados, melhora no gerenciamento das faltas de materiais e a redução do número de falta de materiais.

Palavras chave: Tempo de Segurança, Ordem Planejada, Parametrização MRP, Fornecedores. 


\section{INTRODUÇÃO}

Diante do aumento na competitividade e expansão de grandes empresas, estratégias envolvendo a formação de alianças, fusões, aquisições e parcerias com a finalidade de aumentar suas chances de sucesso no mercado tornaram-se comuns. Em muitos segmentos empresariais como aeronáutica e automobilística, essas estratégias contribuíram para 0 aumento da concentração na medida em que os grandes competidores atingiram maiores parcelas de mercado. (MINTZBERG e QUINN, 2001).

Segundo Carvalho (2008) esta nova forma de relacionamento provoca uma hierarquização na estrutura de suprimentos da matéria-prima, reduzindo o número de fornecedores e torna-se importante a localização destes com relação à proximidade das indústrias.

Os sistemas de planejamento e controle da produção (SPCP) são sistemas responsáveis por prover informações utilizadas para um gerenciamento eficaz do fluxo de materiais, determinação da cargacapacidade, coordenação das atividades internas relacionadas a fornecedores e distribuidores, além da comunicação e da interface com os clientes, referente à necessidades operacionais (CORRÊA e GIANESI, 1996).

Para Zonta et al. (2010), o sistema Planejamento das Necessidades de Materiais - Material Requirements Planning (MRP) é uma ótima ferramenta utilizada na gestão dos estoques, pois é capaz de integrar diversas áreas e analisar informações essenciais para a gestão da produção. Porém a integração deve ir além do fato de estar operando o mesmo sistema, ela deve ser considerada pelo impacto que cada variável ajustada no MRP tem em todos os demais departamentos da empresa. Desta maneira o Planejamento das Necessidades de Materiais se mostra como uma ferramenta ideal para empresas que possuam como objetivo estratégico a redução de estoques e o cumprimento de prazos. Mas para alcançar estes objetivos não é fácil, pois deverão ser tratados diversos problemas enfrentados pelos usuários do MRP, como as falhas na parametrização do sistema, abordagem de capacidade infinita com a qual estes sistemas trabalham e a instabilidade do sistema, propiciando resultados satisfatórios (CORRÊA \& GIANESI, 1996).

A parametrização do MRP permite informar ao Planejamento e Controle da Produção (PCP) possíveis restrições e características da realidade consideradas pelo sistema; como o nível de confiança de um fornecedor, o que torna possível reagir à sua baixa eficiência com a criação de um pequeno nível de estoque de segurança frente a esta incerteza, adaptando o cálculo do MRP às necessidades especificas da organização (CORRÊA, GIANESI \& CAON, 2001).

Nesse cenário esse trabalho tem como norteador a seguinte questão: como parametrizar o planejamento da necessidade de materiais a fim de aumentar sua eficiência perante a falha de fornecedores com relação a prazo de entrega?

Um conceito importante para o trabalho é o de tempo de segurança que segundo Corrêa, Gianesi e Caon (2001) é uma variante lógica frente às incertezas dos fornecedores com relação ao tempo de entrega é equivalente a criação de estoques de segurança em uma empresa. A visualização dos tempos de segurança permitem a reprogramação das ordens planejadas, impedindo que o atraso do fornecedor se propague por todas as etapas de planejamento e produção da empresa.

Quanto ao termo parametrizar nesse trabalho referese a antecipar a verificação de disponibilidade de materiais relacionados a ordens de produção indicadas no sistema ERP com o status planejada e a determinação de tempos de segurança para cada fornecedor, por meio do cálculo da média de atrasos, tendo como parâmetro o tipo de material.

Uma correta parametrização do sistema juntamente a uma abordagem do MRP no curto prazo, levam a uma redução do system nervousness e, conseqüentemente, melhoria no desempenho do sistema, como a redução dos estoques e o cumprimento dos prazos. Ressaltando desta maneira a aplicabilidade em indústrias de diversos setores, visto que foram feitas as adaptações necessárias para a obtenção de resultados promissores (GODINHO FILHO e FERNANDES, 2005). 
O objetivo deste trabalho foi implantar tempos de segurança no Planejamento das Necessidades de Materiais (MRP) para melhorar o desempenho do setor de programação de materiais em uma empresa aeronáutica de grande porte.

Os sistemas que possuem baixos níveis de incerteza necessitam de baixos níveis de estoque de segurança, pois as incertezas de fornecimento devem ser eliminadas com o desenvolvimento dos fornecedores, tornando-os mais confiáveis e deste modo tornar a empresa e suas alianças mais competitivas diante do mercado (CORRÊA, GIANESI \& CAON, 2001).

Nesta pesquisa a empresa estudada será denominada empresa Beta, sendo esta uma indústria de forte concorrência no mercado aeronáutico, tendo comércio disponível em grande parte do mundo e todo o território brasileiro, com aumento crescente em seu mercado. Tendo em vista o aumento na competitividade da empresa, a estratégia foi reduzir o lead time de entrega do produto acabado, com o auxilio dos programadores de materiais.

\section{REVISÃO BIBLIOGRÁFICA}

\subsection{O SISTEMA DE PARAMETRIZAÇÃO DO MRP}

Analisando-se o fluxo de materiais é possível perceber que para ocorrer a execução das operações de montagem, cada ordem de produção deve possuir um conjunto especifico de materiais a serem utilizados, denominado de Lista de Materiais, ou em inglês "Bill of Material" (BOM), sendo classificados em matériasprimas, componentes e produtos semiacabados; os quais podem ser obtidos por meio de diferentes tipos de fornecedores e diferentes modos: externamente ou através de fabricação própria, (VOLLMANN et al., 1997).

Orliky (1975 apud LAURINDO e MESQUITA, 2000) relata que a demanda de materiais na produção de maneira intermitente tende a ser irregular ("lumpy"), devido a uma irregularidade no plano mestre de produção e da política de formação de lotes, sendo o modelo MRP uma solução por permitir calcular as necessidades destes materiais ao longo do tempo e gerar uma redução dos níveis de estoque.
Pozo (2004) define o MRP como um sistema responsável por simplificar a gestão de estoques, de modo que o fator principal do sistema é ajudar o administrador ou o comprador a comprar e produzir o necessário e no momento correto, a fim de eliminar a criação de estoques.

Quanto à demanda, esta pode ser classificada em dependente e independente. A demanda dependente está relacionada às matérias-primas, submontagens e montagens que compõem os produtos finais, já a demanda independente está voltada para os produtos acabados e está ligada diretamente às condições de mercado. O MRP faz o calculo para a demanda dependente, considerando os tempos de compra e de produção (lead time), determinando as quantidades e os instantes em que deverão ser produzidos ou comprados os produtos.

A parametrização é a forma pela qual se faz uma adaptação no cálculo do MRP, tomando por base as necessidades específicas de cada organização; uma vez que estas necessidades e características estão em constante mudança, torna-se necessário que haja a revisão da parametrização periodicamente, de modo a refletir fielmente a realidade da organização (CORRÊA, GIANESI e CAON, 2001).

Segundo Slack, Chambers e Johnston (2002), o MRP só consegue calcular corretamente as necessidades de materiais ou as quantidades a serem produzidas pela empresa, se além do tempo de produção, a empresa mantiver os dados atualizados em seus sistemas. Conhecida como system nervousness, a instabilidade do sistema MRP, uma das dificuldades mais enfrentadas por usuários do sistema, é definida como sendo a modificação de datas e quantidades de ordens planejadas que causam uma mudança no planejamento de prioridades das mesmas, sendo quanto maior a incidência de reprogramação maior será a instabilidade do MRP (HO \& HO, 1999).

\subsection{PARAMETRIZAÇÃO DO MRP E TEMPO DE SEGURANÇA}

Segundo Corrêa, Gianesi e Caon (2001) os "tempos de segurança", possuem uma influencia positiva a 
respeito da instabilidade do MRP, sendo estes os períodos arbitrariamente adicionados ao lead time dos materiais, de modo a calcular a abertura de ordens planejadas com um tempo de antecedência, relacionado ao tempo médio, de modo que se não houver atrasos por parte do fornecedor, terá como impacto a formação de um estoque temporário, do contrário o atraso do fornecedor não se propagará, sendo este dentro do tempo de segurança.

Godinho Filho e Fernandes (2005), afirmam que a correta parametrização do MRP leva a uma redução da instabilidade do sistema, e consequentemente leva a melhorias no desempenho do mesmo; como a redução dos estoques e o cumprimento dos prazos. Ressaltando desta maneira a aplicabilidade em indústrias de diversos setores, dado que sejam feitas as adaptações necessárias permitindo a obtenção de resultados promissores.

\section{MÉTODO DA PESQUISA}

Esta pesquisa foi realizada por meio de uma pesquisa bibliográfica e pesquisa-ação em uma empresa do setor aeronáutico, mais especificamente, envolvendo o setor de programação de materiais.

A pesquisa bibliográfica trata- se de um estudo exploratório ou uma pesquisa ideológica, com analise de diferentes opiniões sobre um tema, no qual se baseia em um material já elaborado, constituído normalmente por livros e artigos científicos (GIL, 2008).
Segundo Thiollent (1986), desde a década de 40 a pesquisa-ação é um método eficaz para conhecer e modificar a organização, sendo este um tipo de pesquisa social com base empírica que é realizada por meio de uma ação ou a resolução de um problema coletivo de modo que todos os participantes envolvidos estejam se relacionando de maneira cooperativa e participativa. Tripp (2005), apresenta que a pesquisaação pode ser dividida em quatro partes, como pode ser observado na Figura 1.

Figura 1- Representação em quatro etapas do ciclo de Pesquisa-Ação

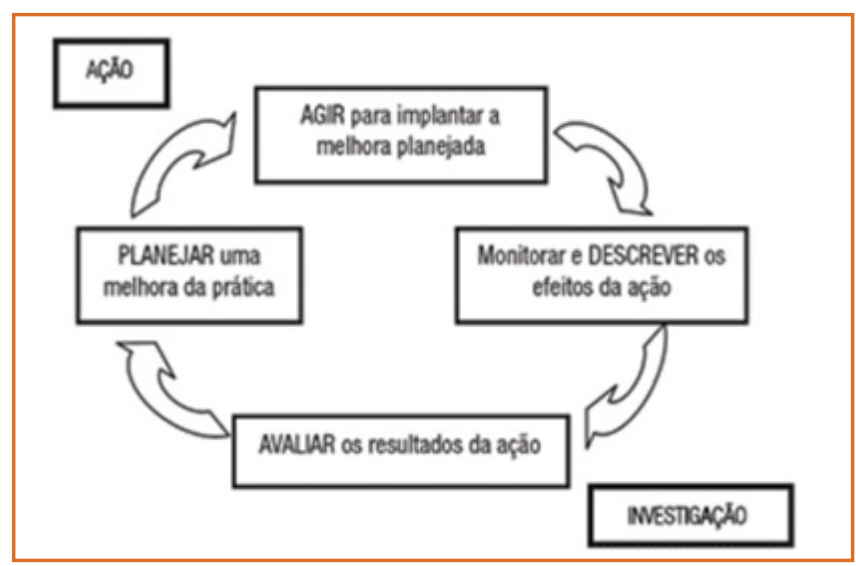

Fonte: Tripp (2005, p.4)

As quatro etapas definidas por Tripp (2005) podem ser vistas no quadro 1 , neste se pode visualizar a fundamentação teórica do método com a aplicação no cenário abordado por esse trabalho.

Quadro 1 - Descrição das quatro etapas do ciclo de Pesquisa-Ação e descrição no ambiente da pesquisa

\begin{tabular}{|l|l|l|}
\hline Fases & Definição & Fases da Pesquisa-Ação dentro do ambiente de pesquisa \\
\hline \multirow{5}{*}{ Planejar } & $\begin{array}{l}\text { De acordo com Thiollent (1997), a } \\
\text { fase de planejamento é explicada } \\
\text { como exploratória na qual se efetua } \\
\text { a análise do cenário, o modo de } \\
\text { coleta de dados, de monitoramento, } \\
\text { e como serão determinadas as ações } \\
\text { corretivas. }\end{array}$ & $\begin{array}{l}\text { Foi elaborada uma análise da empresa Beta, no setor de } \\
\text { Programação de Materiais, no qual se pretende definir } \\
\text { qual a base de dados e a ferramenta de apoio a ser } \\
\text { utilizada para apontar a atual eficiência do setor. Com esse } \\
\text { levantamento, deseja-se determinar as quantidades de } \\
\text { pendencias e faltas de cada fornecedor por tipo de material, } \\
\text { permitindo a elaboração dos planos de ação. }\end{array}$ \\
\hline Agir & $\begin{array}{l}\text { A fase da ação trata-se de implantar } \\
\text { cços corretivas, estabelecidas } \\
\text { na fase de planejamento e dos } \\
\text { problemas levantados no momento } \\
\text { de análise, de modo a apresentar } \\
\text { os objetivos e as propostas. Estas } \\
\text { originarão as ações de mudanças } \\
\text { que serão iniciadas após aprovação } \\
\text { (THIOLLENT, 1997) }\end{array}$ & $\begin{array}{l}\text { Por meio de reuniões com a supervão foi possível o } \\
\text { desenvolvimento de planos de ação que permitiram a } \\
\text { implantação dos tempos de segurança e o replanejamento } \\
\text { de ordens Planejadas. } \\
\text { As ações passaram a ser executadas e analisadas pelos } \\
\text { responsáveis do projeto; ações estas que serão detalhadas } \\
\text { na Pesquisa da Empresa no processo de implantação. }\end{array}$ \\
\hline
\end{tabular}




\begin{tabular}{|l|l|l|}
\hline Fases & Definição & Fases da Pesquisa-Ação dentro do ambiente de pesquisa \\
\hline Monitorar & $\begin{array}{l}\text { Avaliar os parâmetros das melhorias } \\
\text { implantadas e analisar os indicadores } \\
\text { de controle de desenvolvimento da } \\
\text { eficiência das respectivas melhorias } \\
\text { implantadas (TRIPP, 2005) }\end{array}$ & $\begin{array}{l}\text { O monitoramento foi algo essencial no projeto, pois é } \\
\text { necessário controlar os dados e certificar-se de que } \\
\text { não estão sendo considerados dados discrepantes e } \\
\text { problemáticos, que possam interferir nas mudanças diárias } \\
\text { e no resultado. }\end{array}$ \\
\hline Avaliar & $\begin{array}{l}\text { Segundo Thiollent (1997), após } \\
\text { implantada as melhorias e decorrido } \\
\text { um determinado período de tempo, } \\
\text { analisar a efetividade das melhorias } \\
\text { e a situação do senário final. }\end{array}$ & $\begin{array}{l}\text { Por fim, a equipe envolvida no projeto avaliará através de } \\
\text { uma gestão visual a ser elaborada durante a implantação, } \\
\text { processo, no qual pretende-se identificar quais foram as } \\
\text { melhorias alcançadas durante e após os planos de ação da } \\
\text { implantação. }\end{array}$ \\
\hline
\end{tabular}

Fonte: O próprio autor.

\section{PESQUISA NA EMPRESA}

\subsection{PLANEJAR}

Com o crescimento da empresa e a disseminação da filosofia Lean Manufacturing em diversos de seus setores além da busca pela excelência, foram identificados alguns setores com oportunidades de melhorias, nesse trabalho será abordado o setor de Programação de Materiais, que possui uma necessidade de parametrização do sistema MRP.

A empresa tratada neste artigo não possuía tempos de segurança relacionados a cada um de seus fornecedores além de não haver uma tratativa de faltas relacionadas a ordens planejadas, ficando em função dos Programadores de Materiais a responsabilidade de manter a eficiência dos fornecedores referente às faltas efetivas.

Partindo deste principio, foi identificada a necessidade de antecipar a verificação de disponibilidade de materiais ou $\mathrm{O}$ andamento das requisições dos mesmos para ordens planejadas no ERP, ou seja, ordens que ainda não entraram em execução, além de melhorar o indicador de falta de materiais, que é um indicador-chave de desempenho conhecido por Key Performance Indicator ou KPI, pois o mesmo permitia a visualização da eficiência do Planejamento das Necessidades de Materiais (MRPI) de cada linha produtiva, porém não de maneira diária.

Por isso foi discutido juntamente à supervisão a necessidade de criar um banco de dados no Microsoft Office Access, que fizesse o download do sistema SAP e armazenasse todas as faltas cometidas por fornecedores e que estivessem devidamente descritas no ERP em um histórico anual e de maneira diária.

Sendo de suma importância a atualização dos dados e o startup automático das macros, além da elaboração de uma interface prática, exibindo por meio de gráficos a eficiência das linhas produtivas e a confiabilidade de cada fornecedor juntamente de seu tempo de segurança, que serão acrescidos aos prazos estabelecidos pelos programadores de materiais acordado com os fornecedores.

\subsection{AGIR}

Por meio de uma análise detalhada do painel de faltas por parte da supervisão, foi possível a distribuição da carga-capacidade das linhas produtivas entre os programadores, com o objetivo de aumentar suas respectivas capacidades produtivas de modo a incorporar as Ordens Planejadas antecipadas em suas rotinas de trabalho evitando gerar hora-extra, ou novas contratações.

Para que houvesse o perfeito funcionamento das macros criadas no Microsoft Office Access foi preciso estabelecer junto aos programadores de materiais quais seriam as diretrizes a serem consideradas ou desconsideradas, permitindo o uso de dados confiáveis.

O conhecimento de programação Visual Basic for Applications (VBA) foi de extrema relevância entre os implantadores do aplicativo em Access, para que fosse possível a criação de uma "frontend" (interface) mais prática e a atualização automática dos dados de maneira diária e por meio de macros acionadas através do Task Scheduler em períodos fixos definidos 
durante o turno de trabalho.

Para se calcular os tempos de segurança, os dados foram agrupados de acordo com seus respectivos planejadores MRP e filtrados apenas os materiais que se encontravam com prazos vencidos, contando-se a quantidade de dias de cada atraso comparando a data estabelecida pelo fornecedor como prazo e a data de atualização do banco de dados.

Sendo estabelecidos suas respectivas médias e desvios padrão, tornando os dados mais confiáveis por meio do escore padronizado de cada dado, utilizando a formula 1 .

$$
Z=(\text { valor }- \text { media) / desvio padrão }
$$

Onde:

- Valor - quantidade de dias de atraso referente a cada fornecedor;

- Média - valor da media aritmética da quantidade de dias de atraso de toda a amostra;

- Desvio-padrão - desvio padrão calculado sobre toda a amostra;

- Z > ou igual a 3 em valor absoluto, considerado um outlier e retirado dos cálculos, gerando uma tabela normalizada.

Calculados as novas médias e os novos desvios padrões sobre os dados da tabela normalizada, utilizase as informações na fórmula 2.

$$
\mathrm{T}=(\text { Fator } \times \text { Desvio Padrão) }+ \text { Média }
$$

Onde:

- - T - quantidade de dias a ser utilizado como tempo de segurança.

- Fator - valor fixo encontrado na tabela de distribuição normal, de acordo com o nível de confiança desejado.

Porém por se tratar de períodos de atraso, não se pode desconsiderar totalmente os outliers, pois ainda assim continuam impactando de forma grave o processo, sendo necessária a sua tratativa separada.

\subsection{MONITORAR}

Os dados são controlados periodicamente, para verificar a confiabilidade da informação e verificar se não foram alteradas ou acrescentadas novas diretrizes em cada linha produtiva, além de retirar dados equivocados gerados por algum erro sistêmico do SAP.

Semanalmente a eficiência do Key Performance Indicator (KPI) de faltas é apresentado para todo o PCP e discutido de modo a explicar os motivos de alguns atrasos e o posicionamento do fornecedor, justificando também a eficiência do setor de programação de materiais, que influencia positivamente ou não sobre a eficiência de toda a célula, gerando cobranças por parte da supervisão.

Por sua vez a eficiência do KPI de Faltas é controlado diariamente pelos programadores de materiais e utilizado juntamente com o nível de confiabilidade de cada fornecedor em reuniões denominadas "Pregões", para cobrar dos fornecedores um posicionamento e um maior comprometimento no momento de cumprir os prazos de entrega.

\subsection{AVALIAR}

Por meio de uma visão mais global e detalhada foi possível identificar os pontos críticos e impactantes no processo, e foram tomadas as ações corretivas sobre as causas raízes, tratando das ordens planejadas de modo eficiente, gerando por sua vez visibilidade diária e resultados positivos, como o aumento na eficiência do setor de programação de materiais e de toda a célula além da determinação dos tempos de segurança de maneira dinâmica.

\section{RESULTADOS E DISCUSSÕES}

Com a criação de um software que não depende de operadores para fazer o download dos dados do sistema ERP e processar estes dados, de modo a efetuar uma atualização automática do indicador de falta de materiais, foi possível aumentar a confiabilidade das informações resultantes, pois reduziu o intervalo entre as atualizações dos dados, consolidou todas 
as informações em um único local e não permitiu mais alterações pelo usuário, evitando resultados tendenciosos.

Esse novo indicador permitiu uma melhor gerencia por parte do supervisor por possuir uma interface prática, com visões dinâmicas e comparativas entre as linhas produtivas, é possível identificar a quantidade de faltas e suas respectivas informações cadastrais do ERP.

Sendo possível iniciar a tratativa das ordens planejadas e a implantação dos tempos de segurança nos prazos dos fornecedores, identificando as reais melhorias no painel de faltas, como a redução na quantidade de faltas sem prazo e vencidas, mesmo com um aumento na quantidade total de faltas, resultante do aumento da demanda.

Como se pode observar na Tabela 1, comparando o período de 2015, no qual não havia a antecipação da verificação de disponibilidade de materiais das ordens planejadas, com 2016 quando se iniciou a parametrização, obteve-se uma redução significativa na quantidade de faltas de materiais que estavam sem prazo e com status vencido, ou seja, materiais que eram para estar no estoque, mas o fornecedor ainda não efetuou a entrega.

Tabela 1 - Comparação da quantidade de faltas de matérias no período entre 2015 - 2016

\begin{tabular}{|c|c|c|c|}
\hline Mês & Status & 2015 & 2016 \\
\hline Ago & No Prazo & 1054 & 2964 \\
\hline Ago & Sem Prazo & 107 & 63 \\
\hline Ago & Vencido & 34 & 5 \\
\hline
\end{tabular}

Fonte: O próprio autor.

O gráfico 1 apresenta a eficiência geral do setor de programação de materiais, nota-se em 2016 uma queda no percentual devido a um erro de duplicidade ocorrido no ERP somado a inclusão de novas aeronaves no painel de faltas, que aumentou o numero de faltas efetivas e planejadas.

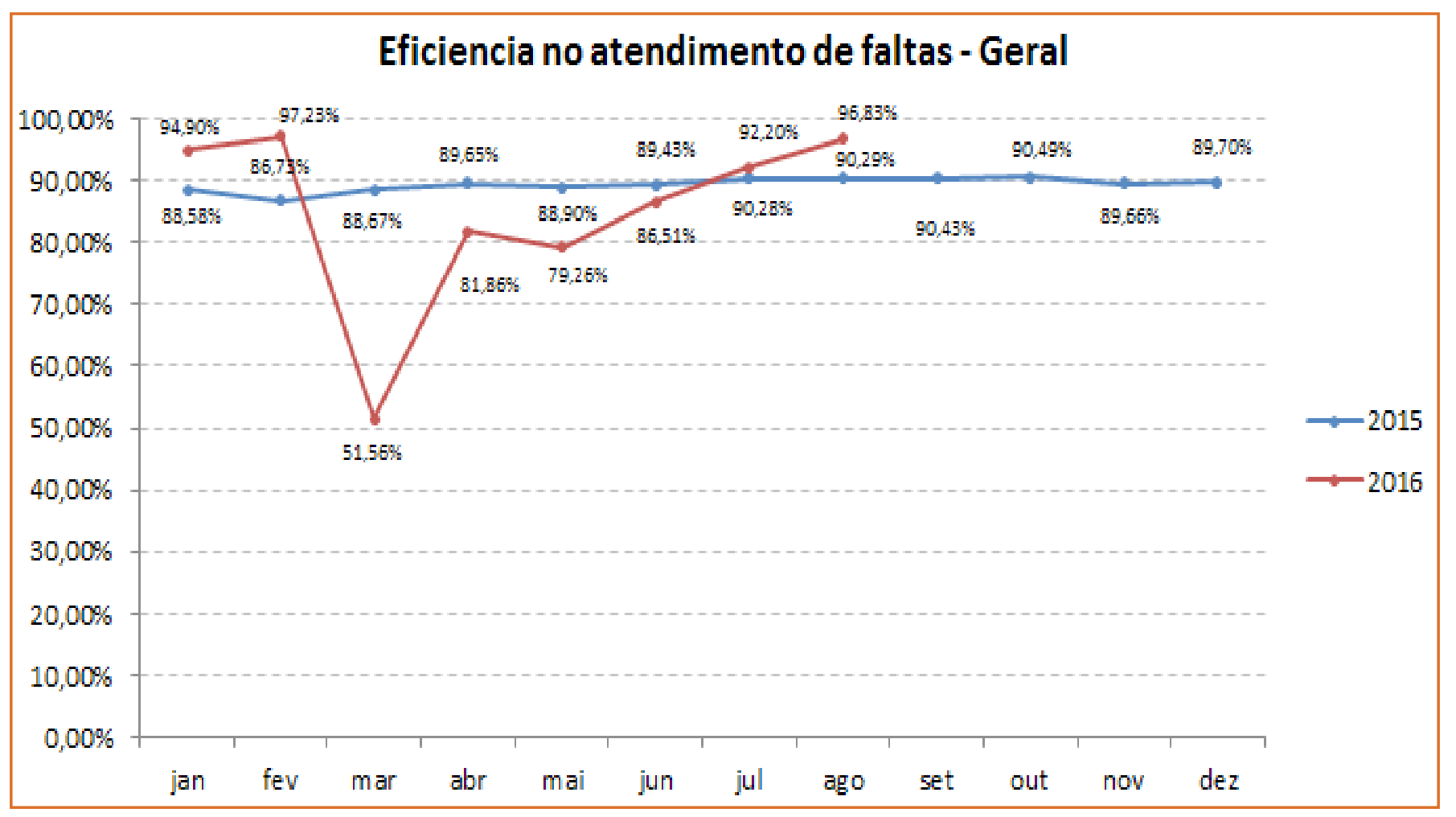

Fonte: O próprio autor. 


\section{CONCLUSÕES}

Com a parametrização do sistema ERP por meio da implantação dos tempos de segurança e a antecipação da verificação e acompanhamento das ordens de compra de materiais relacionadas às ordens de produção com status de planejada no sistema ERP, ou seja, de aeronaves que ainda não entraram na linha de produção, pode-se concluir que anteriormente os programadores de materiais possuíam uma alta responsabilidade em atender os prazos produtivos e garantir o material em estoque, contudo sem um poder de ação sobre os fornecedores e as imprevisões, porém por meio do novo indicador de faltas e a parametrização do ERP, a empresa adquiriu um maior controle e robustez no setor de programação de materiais, por deixar de depender diretamente da confiabilidade dos fornecedores para atender aos prazos de entrega dos materiais e possuir uma melhor e mais rápida tomada de decisão sobre as faltas críticas.

Um dos resultados foi a redução no número de falta de materiais, deixando de impactar no andamento da linha produtiva, ou seja, na postergação das datas de mudança de fase produtiva (movimentação da aeronave para uma próxima montagem, uma vez que o sistema produtivo adotado é através de montagem em doca) e na acurácia da carga-capacidade, melhorando a eficiência do PCP.

Destaca-se a importância da participação de todos os setores envolvidos no processo, de modo a elaborar um sistema prático, eficiente, que seja robusto permitindo uma melhor supervisão da gerência e contribuindo para uma maior competitividade da empresa no mercado.

\section{REFERÊNCIAS}

[1] CARVALHO, E.G. Inovação tecnológica na indústria automobilística: características e evolução recente. Economia e Sociedade v. 17, n. 3 (34), p. 429-461, 2008.
[2] CORRÊA, H.L.; GIANESI, I.G.N.Just in Time, MRP II e OPT- Um enfoque estratégico. Ed. Atlas, 2. ed. 1996.

[3] CORRÊA, H.L.; GIANESI, I.G.N.; CAON, M. Planejamento, Programação e Controle da Produção. 4. ed. São Paulo: Editora Atlas, 2001.

[4] GODINHO FILHO, M.; FERNANDES, F.C.F. Redução da instabilidade e melhoria de desempenho do sistema MRP. Produção v. 16 n. 1, 2005.

[5] GIL, A.C. Como elaborar projetos de pesquisa.4. ed. São Paulo: Atlas, 2008.

[6] $\mathrm{HO}, \mathrm{C}$; $\mathrm{HO}$, S.J.K. Evaluating the effectiveness of using lot- sizing rules to cope with MRP system nervousness. Production Planning and Control, v. 10, n. 2, p. 150-161, 1999.

[7] LAURINDO, F.J.B.; MESQUITA, M.A. Material Requirements Planning: 25 Anos de História - Uma revisão do passado e prospecção do futuro. Gestão \& Produção, São Paulo, v.7, n.3, p.320-337, dez. 2000.

[8] MINTZBERG, H.; QUINN, J.B. O processo da estratégia. 3. ed. Porto Alegre: Bookman, 2001.

[9] ORLICKY, J.A. Material Requirements Planning: the new way of life in Production and Inventory Management. McGraw-Hill, 1975.

[10] POZO, H. Administração de recursos materiais e patrimoniais: uma abordagem logística. 3 ed. São Paulo: Atlas 2004

[11] SLACK, N.; CHAMBERS, S.; JOHNSTON, R. Administração da Produção. 2. ed. São Paulo: Atlas, 2002.

[12] TRIPP, D. Pesquisa ação: Uma introdução metodológica. Educação e Pesquisa, São Paulo, v. 31, n. 3, set./dez. 2005, pp. 443-466.

[13] THIOLLENT, M. Metodologia da Pesquisa-ação. 2. ed. São Paulo: Cortez, 1986.

[14] THIOLLENT, M. Pesquisa-ação nas Organizações. São Paulo: Atlas, 1997. 164p.

[15] VOLLMANN et al. Manufacturing Planning and Control Systems.4ed, McGraw-Hill, 1997.

[16] ZONTA, L; BIANCHINI, V. K; MOTTA, G. A; TRULHA, L. C. Sistemas MRP, MRPII e ERP: Parametrização correta e acurácia nos dados. Revista Ingepro, 2010. 


\section{CAPÍTULO 14}

\section{ESTUDO DE MOVIMENTOS E TEMPOS: EXEMPLIFICAÇÃO A PARTIR DE UM PROCESSO DO COTIDIANO DOMICILIAR}

\section{Jackson de Sousa Silva}

Thalasso Bezerra Bispo

Jair Paulino de Sales

Cássia Taisy Alencar de Andrade

Resumo: Na atualidade, se manter no mesmo patamar já não é sinônimo de sucesso, é necessário mais que isso. A competitividade mercadológica requer que as empresas sejam cada vez mais enxutas, dinâmicas e mais cíclicas e as conduz a adotar estratégias de manufatura para elevar suas receitas e, consequentemente, seus lucros. Levando em consideração que a produtividade é apenas um fim, são necessários meios para promovêla. Destarte, diante de tais premissas, a presente produção cientifica objetiva evidenciar a ampla aplicação dos métodos pertinentes ao aumento de produtividade, através do estudo de movimentos e tempos, a ser incorporado em um processo do cotidiano domiciliar. A investigação, de caráter exploratório, se fundamentará, a priori, no método DMAIC para definição de processos geradores de problema e se mediará a partir do desenvolvimento de um estudo de caso. Após a aplicação e análise quantitativa do método proposto, tornase perceptível a elevada redução no tempo padrão de execução do processo com base no método anterior. Já no que remete à eficiência produtiva, constatou-se um aumento de $7 \%$. Tais informações, por fim, instigam a aplicação deste estudo em processos cada vez mais cíclicos, que acabam por tender a consolidar resultados ainda mais promissores.

Palavras chave: Competitividade, Métodos, Produtividade. 


\section{INTRODUÇÃO}

$\mathrm{Na}$ atualidade, se manter no mesmo patamar já não é sinônimo de sucesso, é necessário mais que isso (CHIROLI; NUNES; LEAL, 2010). A competitividade mercadológica requer que as empresas sejam cada vez mais enxutas e objetivas (BARBOZA; PORTELA, 2014). Esta nova dinâmica as conduz a adotar estratégias de manufatura para elevar suas receitas e, consequentemente, seus lucros (PEREIRA, 2010).

Segundo Chiroli, Nunes e Leal (2010), o controle da produtividade e o melhor gerenciamento dos recursos são as atividades chaves para um futuro em que ser 0 expoente é o foco de qualquer empresa. Pereira (2010) destaca que a adoção da promoção da qualidade em tudo o que a organização faz, dos produtos até suas operações rotineiras, contribui para que estas atinjam seus objetivos estratégicos.

Nada obstante, para Deming (1993), a melhoria da qualidade substitui o desperdício de horas de trabalho, tanto de mão-de-obra quanto de máquinas, pela fabricação de produtos bem acabados ou pela prestação de melhores serviços. O resultado é uma reação em cadeia: custos menores, maior competitividade e colaboradores satisfeitos.

Barboza e Portela (2014), por outro lado, afirmam que, em muitos casos, o custo operacional pode ser reduzido no próprio processo de fabricação dos produtos através de uma melhor distribuição das atividades e, assim, aumentando o aproveitamento dos recursos da produção.

Santos e Martins (2008), por sua vez, enfatizam que o pensamento e os métodos estatísticos devem ser valorizados como meios vitais para atingir os objetivos estratégicos organizacionais, tendo o alinhamento estratégico como catalisador.

Em contrapartida, Campos (2004), relata que as organizações humanas são constituídas em três elementos básicos: hardware (equipamentos e materiais), software (métodos) e humanware (ser humano). Para que se possa melhorar o hardware é necessária uma aquisição de capital a fim de adquirir equipamentos mais avançados, no software, o que não é tão fácil, porque sozinho não conseguirá melhorias, sendo que sua ligação está diretamente relacionada às pessoas, ou seja, ao humanware. Para progredir no humanware é necessário um aporte de capital de conhecimento. Portanto, para obter um aumento na produtividade os dois itens primordiais para tal conquista são o aporte de capital e aporte de conhecimento. E, neste caso, utiliza-se como base o humanware através do estudo de movimentos e tempos, o qual tem como centro a padronização dos métodos de trabalho.

Barners (1977) explica que o estudo de movimentos e de tempos é a avaliação dos sistemas de trabalho com os objetivos de desenvolver o melhor método, padronizar o sistema escolhido, determinar os tempos de operações em ritmo normal, orientar e treinar. Por conseguinte, segundo os ideais de Frederick Taylor, estes tornam possível a transferência da habilidade da administração da empresa para os funcionários (CHIROLI; NUNES; LEAL, 2010).

Isto posto, é notório que a melhoria da produtividade nos processos de fabricação tornou-se também uma busca constante das empresas. Pereira (2010) enfatiza que, levando em consideração que a produtividade é apenas um fim, são necessários meios para promovêla.

Destarte, diante de tais premissas, a presente produção cientifica objetiva evidenciar a ampla aplicação dos métodos pertinentes ao aumento de produtividade, através do estudo de movimentos e tempos, a ser incorporado em um processo do cotidiano domiciliar.

\section{REVISÃO TEÓRICA}

\subsection{CONSIDERAÇÕES SOBRE OS TERMOS UTILIZADOS}

A Literatura disponível sobre trabalhos realizados com o tema proposto é ampla (PEREIRA, 2010), o que pode ser facilmente constatado pelas referências bibliográficas, no entanto, a fartura de publicações acabou acarretando uma série de indagações sobre a maneira correta de designar os termos relacionados ao tema.

De acordo com o dicionário da linga portuguesa da Academia Brasileira de Letras (1998), os significados 
são os seguintes:

- Diagrama, s.f. 1. Representação gráfica, por meio de figuras geométricas, de fatos, fenômenos, grandezas, ou das relações entre eles; desenho que mostra esquematicamente o plano de uma estrutura, com a posição e relação de suas partes.

- Método, s.m. 1. Conjunto dos meios dispostos convenientemente para chegar a um fim que se deseja; modo ordenado de proceder para se alcançar um resultado determinado; arranjo ordenado e sistemático; maneira de fazer as coisas.

- Metodologia, s.f. 1. Disciplina que tem por objeto o estabelecimento e a sistematização dos procedimentos e princípios gerais pertinentes à produção do conhecimento científico.

- Operação, s.f. 1. Ato, processo ou modo de operar; ato ou efeito de executar, realizar; processo ou série de atos desempenhados na obtenção de certo resultado.

- Produtividade, s.f. 1. Qualidade ou estado de produtivo; eficiência no esforço de produzir; relação entre uma produção e os fatores econômicos empregados na mesma.

Por outro lado, Contador (1998) define processo como sendo uma sequência organizada de atividades, que transforma as entradas dos fornecedores em saídas para os clientes, com um valor agregado gerado pela unidade. Além disso, segundo o mesmo autor, processo também é um conjunto de causas que geram um ou mais efeitos.

Ao mais, utilizaremos a definição de tempo padrão, segundo Barnes (1977), como o tempo gasto por uma pessoa qualificada e devidamente treinada, trabalhando em ritmo normal, para executar uma tarefa ou operação especifica. Por fim, conceituaremos elemento da operação como um ou vários movimentos combinados numa determinada sequência para alcançar certo resultado (MICHELINO, 1964).

\subsection{MÉTODO DMAIC}

Segundo Harry e Schoroeder (2000), o método DMAIC é utilizado para melhorar processos existentes. De acordo com Eckes (2001), cada etapa da metodologia significa uma ação:

- definir (D): definição clara e objetiva do escopo do projeto, identificando o processo gerador do problema e definindo uma meta global;

- medir (M): analisar quantitativamente os dados, avaliar as causas potenciais no processo mapeado e definir os focos do projeto;

- analisar (A): identificar as causas prioritárias do problema com fatos e dados;

- melhorar (M): propor soluções, avaliar o risco de implementação, elaborar e executar o plano de ação que eliminem, atenuem ou minimizem as causas do problema;

- controlar (C): garantir que as melhorias se sustentem ao longo do tempo.

\subsection{DIAGRAMAS DE PROCESSOS}

Segundo Anis (2010), a decomposição de operações possibilita eliminar movimentos inúteis e ainda simplificar, racionar ou fundir os movimentos úteis proporcionando economia de tempos e esforços do operário. De fato, estudar o tempo de operações em seu conjunto, nada adiantaria. Michelino (1964) afirma que dividindo uma operação em elementos, a padronização de métodos fica mais próxima à realidade e os gargalos e tempos de espera ficam mais visíveis.

Desta forma, a fim de representar as ações executadas e os diversos passos ou eventos que ocorrem durante um procedimento específico, foram propostos uma simbologia composta de cinco figuras pela American Society of the Mechanical Engineering (ASME) que traduzem os efeitos relativos aos processos de operação, transporte, armazenagem, inspeção e espera (CORREA; ALMEIDA, 2002). 
Figura 1 - Simbologia ASME.

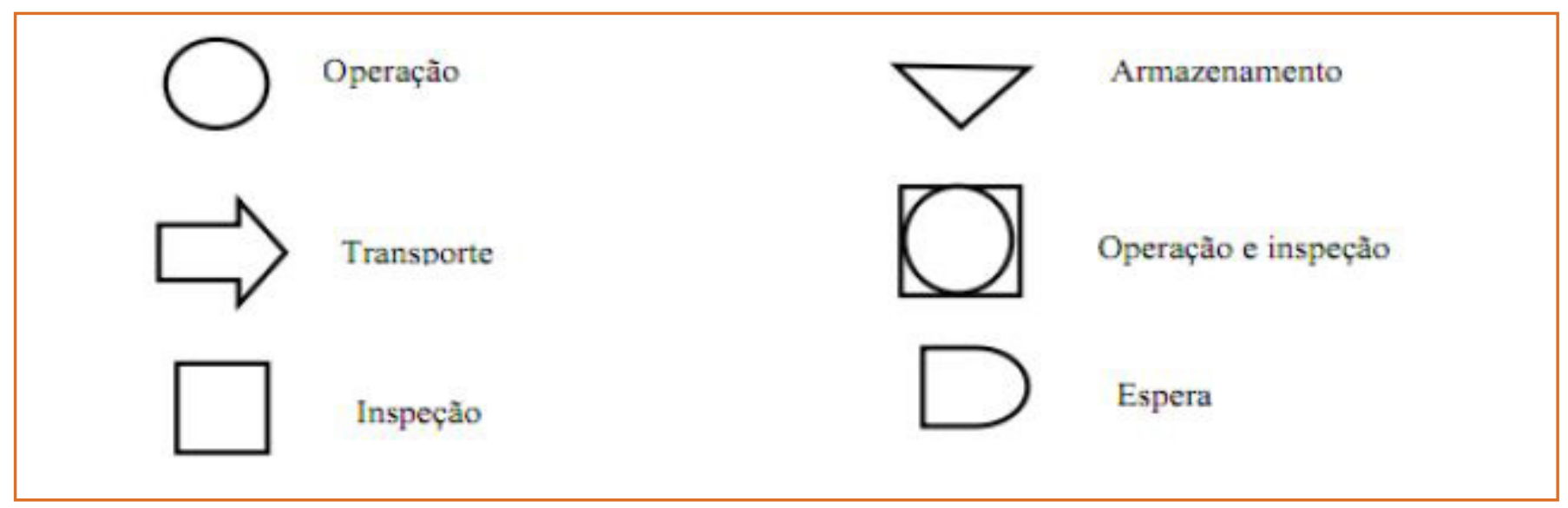

Fonte: Adaptado de Correa e Almeida (2002)

Nesta linha de raciocínio, para que se possam dimensionar processos, estes, deverãosermensuráveis e conter limites, a fim de alcançar resultados. E, logo após, novos métodos, procedimentos, processos e tempos surgem melhores resultados, devendo assim, serem colocados em prática, alcançando um patamar maior (CONTADOR, 1998).

Diante desta perspectiva, quando se faz um estudo dos métodos de trabalho, é evidente a importância de se apresentar, de forma clara e lógica, a informação relacionada com o processo. Para tal, um dos instrumentos mais importantes são, segundo Peinado e Graeml (2007), os diagramas de processos, dos quais abordaremos e destacaremos:

- Diagrama de Fluxo do Processo: representação gráfica de forma parcial ou total do processo ou parte do processo em estudo, com a apresentação das distâncias, quantidades e tempo de cada atividade do processo;

- Diagrama de Duas Mãos: representa, basicamente, uma lista do trabalho que executam simultaneamente a mão direita e a mão esquerda do operário na realização de um trabalho especifico.

\section{MATERIAIS E MÉTODOS}

Segundo Ruiz (1990), o método confere segurança na pesquisa, no estudo e na aprendizagem, estabelecido e aprimorado pela contribuição dos antepassados, não devendo ser ignorada hoje, em seus delineamentos gerais, sob pena de insucesso.

Esta pesquisa, de caráter exploratório-qualitativo, fundamenta-se no método DMAIC, com exclusão da fase controlar, para definição de processos geradores de problema e se mediará a partir da aplicação em uma atividade cotidiana. Para tal, é desenvolvido um estudo de caso, no qual se busca avaliar o processo de montagem e disposição de um ambiente de estudos domiciliar constituído de um banco e uma mesa plástica desmontável.

O trabalho será dividido em duas etapas: (1) serão adotados o método DMAIC e o Diagrama de Duas Mãos com o objetivo de evidenciar as possibilidades de melhorias para o processo analisado; (2) posteriormente avaliar-se-ão as atividades agregadoras de valor com o intuito de aperfeiçoar o processo.

A utilização de diagramas de processos guiará o desenvolvimento da análise das operações e, com base no estudo de movimentos e tempos, serão propostas possíveis intervenções nos métodos atuais. Ulteriormente, se buscará confrontar os resultados obtidos com o levantamento contextual/teórico introduzido.

\section{RESULTADOS E DISCUSSÃO 4.1 FASE DEFINIR (D)}

Frente à ampla aplicabilidade do estudo de movimentos 
e tempos, até então apresentados, está presente produção cientifica busca evidenciar sua aplicação em atividades do cotidiano que demandam baixo índice de complexidade, visto a eminente identificação de pontos peculiares, e posterior confronto com possibilidades em alta escala.
Deste modo, a problemática em questão se limita à busca do aumento de eficiência no processo de montagem e disposição de objetos que irão, futuramente, compor um ambiente de estudos domiciliar (figura 2). Este, por sua vez, é composto por um banco plástico e uma mesa quadrada, plástica e desmontável.

Figura 2 - Disposição inicial/final dos objetos. Fonte: Dados da pesquisa

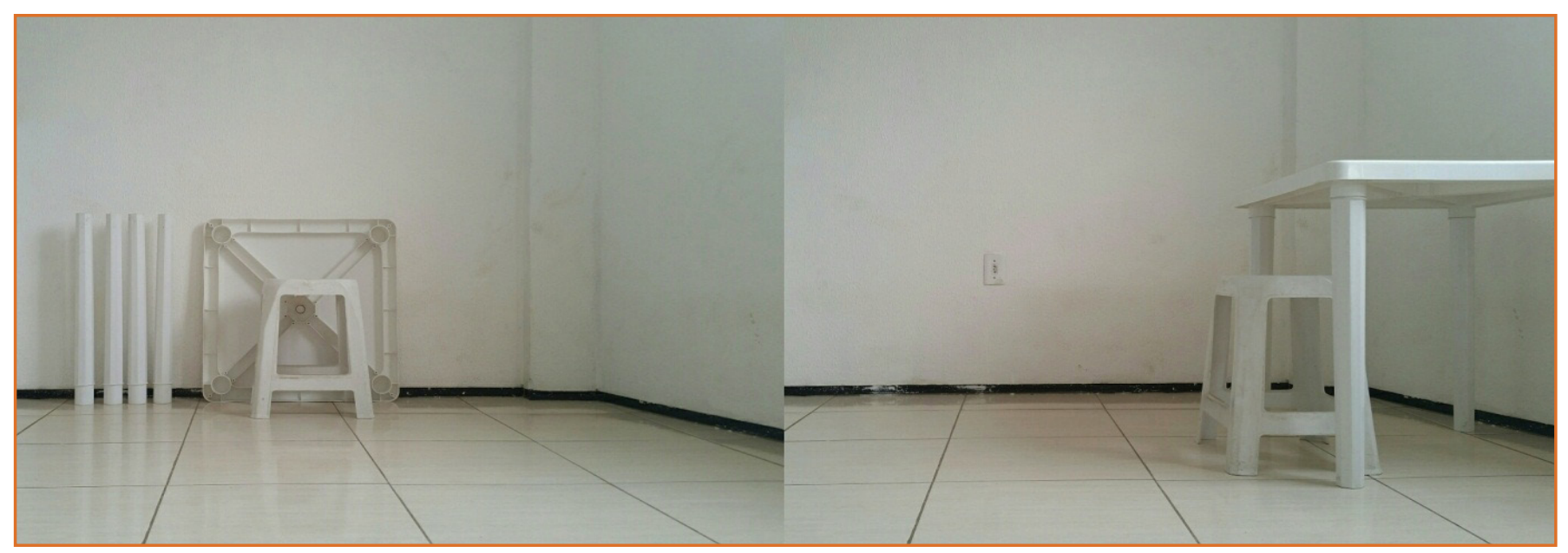

\subsection{FASE MEDIR (M)}

Definido o processo a ser estudado, nesta etapa se pretendem analisar quantitativamente o processo em questão. Para isso, à medida que se desprezará as distâncias pela sua baixa relevância, são utilizadas a cronometragem para medição e registro das atividades, o qual, por meio da filmagem direta, é possível se identificar um padrão nos atuais procedimentos.

Assim, partindo desta perspectiva, o processo foi executado e registrado nove vezes a fim de se extrair um tempo padrão de execução que, ao fim, se definiu em 57" e se apresenta de acordo com a figura 3. 
Figura 3 - Diagrama do fluxo do processo (atual).

\begin{tabular}{|c|c|c|c|c|}
\hline \multicolumn{2}{|c|}{ PROCESSO: Montagem e disposição de objetos } & \multicolumn{3}{|c|}{ LOCAL: Residência } \\
\hline \multicolumn{2}{|c|}{ PRODUTO: Ambiente de estudos domiciliar } & \multicolumn{3}{|c|}{ ANALISTA: Jackson Sousa } \\
\hline $\mathrm{N}^{\mathbf{0}}$ & DESCRIÇÃO DA ATIVIDADE & DURAÇÃO & TIPO & \\
\hline 1 & Caminhar para o local de montagem & $2 "$ & & \\
\hline 2 & Posicionar a tábua da mesa & $5 "$ & & \\
\hline 3 & Encaixar o primeiro pé & 7" & & \\
\hline 4 & Inspecionar o encaixe & & & \\
\hline 5 & Rotacionar verticalmente a tábua em $90^{\circ}$ & $4 "$ & & \\
\hline 6 & Encaixar o segundo pé & 7" & & \\
\hline 7 & Inspecionar o encaixe & & & \\
\hline 8 & Rotacionar verticalmente a tábua em $90^{\circ}$ & $4 "$ & & \\
\hline 9 & Encaixar o terceiro pé & $5 "$ & & \\
\hline 10 & Inspecionar o encaixe & & & \\
\hline 11 & Rotacionar verticalmente a tábua em $90^{\circ}$ & $4 "$ & & \\
\hline 12 & Encaixar o quarto pé & 7" & & \\
\hline 13 & Inspecionar o encaixe & & & \\
\hline 14 & Rotacionar horizontalmente a mesa em $90^{\circ}$ & $2 "$ & & \\
\hline 15 & Posicionar a mesa no local final & $3 "$ & & \\
\hline 16 & Inspecionar a disposição da mesa & & & \\
\hline 17 & Posicionar o banco no local final & $5 "$ & & \\
\hline 18 & Inspecionar a disposição do banco & & & \\
\hline 19 & Retornar ao local inicial & $2 "$ & & \\
\hline
\end{tabular}

Fonte: Dados da pesquisa

Por outro lado, a fim de se possibilitar a geração mais detalhada, em particular, da montagem da mesa, também se é medido e listado as atividades executadas simultaneamente pela mão direita e esquerda (figura

4).

Figura 4 - Diagrama de duas mãos (atual).

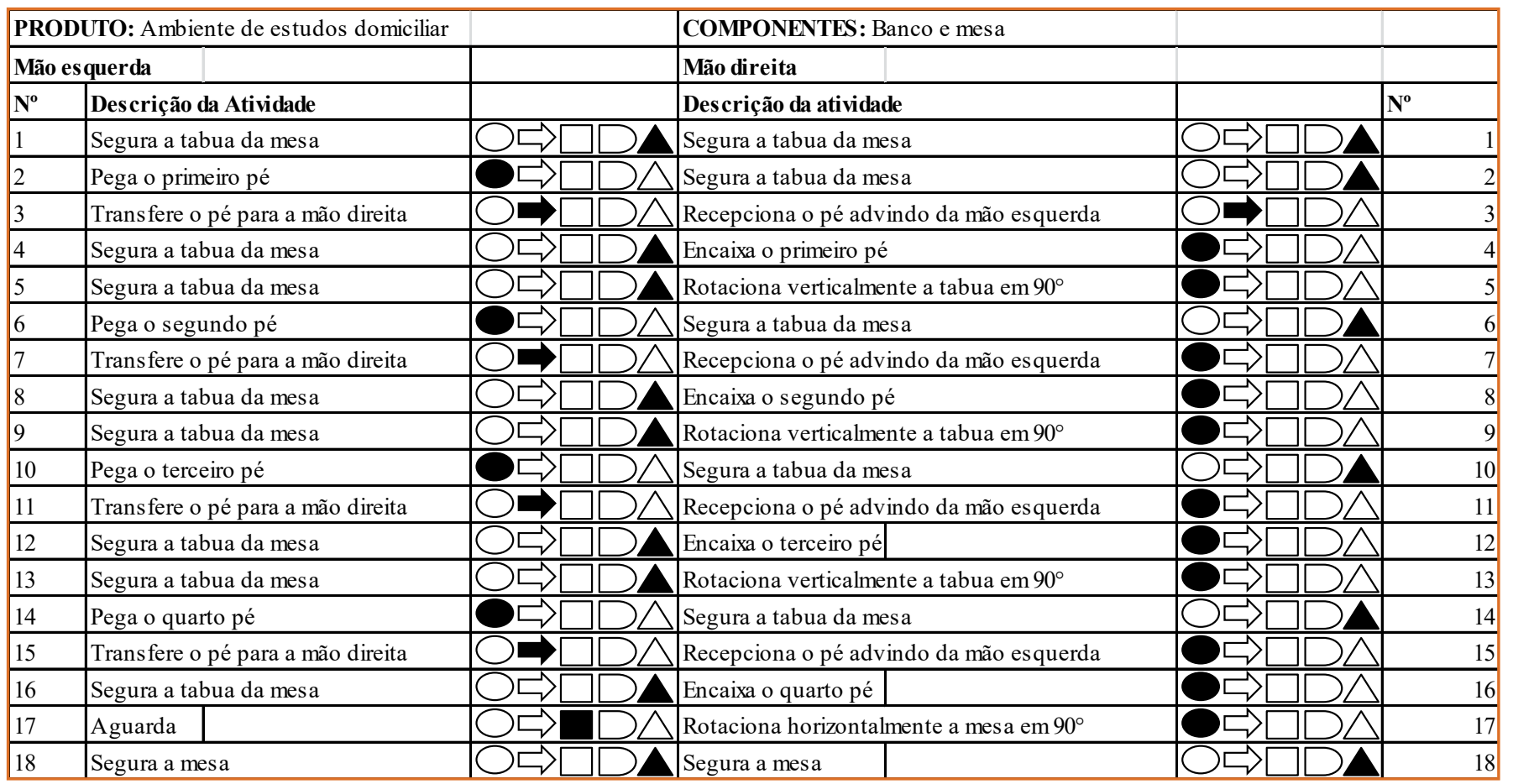




\subsection{FASE ANALISAR (A)}

Em primeira instância, é notório destacar a anomalia presente na atividade 9 , onde se foi executado com 2" a mais de rapidez, decorrente de folga no encaixe da tábua. Nada obstante, a partir da separação das atividades que agregam valor, ou não, se tem um índice de 68\% de eficiência no processo (figura 5).

Figura 5 - Eficiência do processo (atual).

\begin{tabular}{|l|c|}
\hline ATIVIDADES & TEMPO(S) \\
\hline$\sum$ Atividades que agregram valor & $39^{\prime \prime}$ \\
\hline$\sum$ Atividades que não agregram valor & $18^{\prime \prime}$ \\
\hline EFICIÊNCIA & $68 \%$ \\
\hline
\end{tabular}

Fonte: Dados da pesquisa

O Diagrama do Fluxo do Processo, por sua vez, viabiliza a percepção de excessivas realizações de operações repetitivas que acabam por poder ser reagrupadas e executadas em conjunto. Por fim, a análise em decorrência do Diagrama de Duas Mãos nos permite perceber a quantidade de folgas e "inatividade", por parte da mão esquerda, que se totalizam em maior significância do que a própria realização das operações.

\subsection{FASE MELHORAR (I)}

Posto os detalhamentos e análises até então apresentados, à priori, se é proposto uma reorganização do método de execução das atividades frente aos pontos peculiares citados anteriormente. Com base no estudo de movimentos realizados no processo, a redução de atividades que não agregam valor, de fato se torna possível, a partir da execução simultânea de operações (figura 6).

Figura 6 - Diagrama do fluxo do processo (proposto).

\begin{tabular}{|c|c|c|c|c|}
\hline \multicolumn{2}{|c|}{ PROCESSO: Montagem e disposição de objetos } & \multicolumn{3}{|c|}{ LOCAL: Residência } \\
\hline \multicolumn{2}{|c|}{ PRODUTO: Ambiente de estudos domiciliar } & \multicolumn{3}{|c|}{ ANALISTA: Jacks on Sousa } \\
\hline $\mathbf{N}^{\mathbf{0}}$ & DESCRIÇÃO DA ATIVIDADE & DURAÇÃO & TIPO & \\
\hline 1 & Caminhar para o local de montagem & $2 "$ & & $\triangle$ \\
\hline 2 & Posicionar o banco & $3 "$ & & \\
\hline 3 & Posicionar a tabua sobre o banco & 7" & & \\
\hline 4 & Encaixar o primeiro e o segundo pé & $9 "$ & & \\
\hline 5 & Inspecionar os encaixes & & & \\
\hline 6 & Rotacionar horizontamente a tábua em $180^{\circ}$ & $5 "$ & & \\
\hline 7 & Encaixar o terceiro e o quarto pé & $9 "$ & & \\
\hline 8 & Inspecionar os encaixes & & & \\
\hline 9 & Rotacionar verticalmente a mesa em $90^{\circ}$ & $2^{\prime \prime}$ & & \\
\hline 10 & Posicionar a mesa no local final & $3 "$ & & \\
\hline 11 & Posicionar o banco no local final & $2^{\prime \prime}$ & & 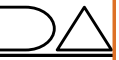 \\
\hline 12 & Retornar ao local inicial & $2^{\prime \prime}$ & & $\triangle$ \\
\hline
\end{tabular}

Fonte: Dados da pesquisa

A redução de "inatividade", em especial por parte da mão esquerda, a partir das percepções e replanejamento do Diagrama de Duas Mãos, enfim, tornam viável o aumento significativo do percentual de operações (figura 7). 
Figura 7 - Diagrama de duas mãos (proposto).

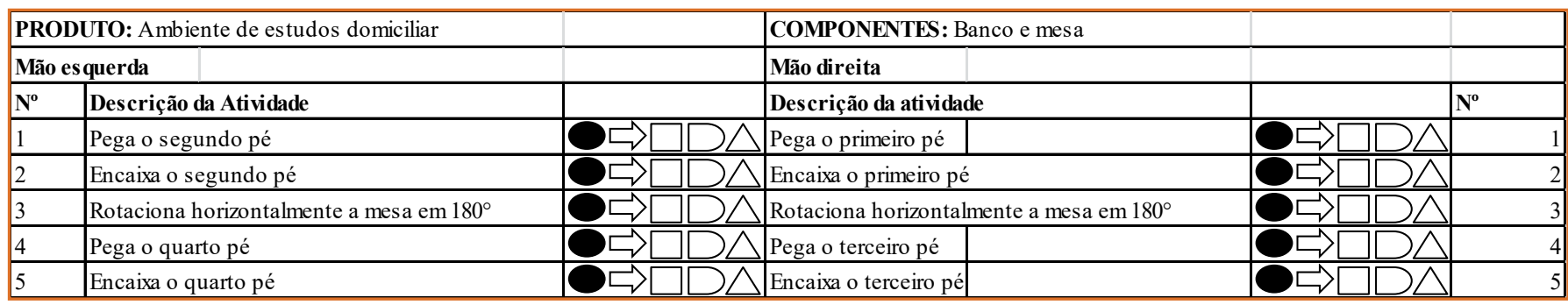

Fonte: Dados da pesquisa

Como resultado, após a aplicação e análise quantitativa do método proposto, é notório destacar a elevada redução no tempo padrão de execução do processo: após nove registros, identificou-se que este passará a ser finalizado, em média, em 44" os quais representam uma melhoria de 13" com base no método anterior. Já no que remete à eficiência, constatou-se um aumento de $7 \%$, ou seja, foi-se atingindo um nível de $75 \%$ de eficiência no processo.

\section{CONSIDERAÇÕES FINAIS}

Tendo em vista o objetivo inicial proposto, esta produção científica vai de encontro a uma ampla e evidente possibilidade de melhoria de processos, quer sejam estes de baixa, média ou alta complexidade. Contudo, de fato, o estudo de caso apresentado, contribui de forma expressiva para a identificação dos ganhos em eficiência produtiva agregados com alterações que demandam baixo investimento econômico e propiciam alto retorno em produtividade.

Todavia, a aplicação deste estudo em processos cada vez mais cíclicos tende a consolidar resultados ainda mais promissores. Cada redução, seja está à mínima possível, no tempo padrão de execução de uma atividade especifica, analisada a partir da ótica de uma jornada de trabalho integral e/ou mensal, certamente entrega ganhos cada vez mais impactantes à medida que se é realizado em repetitividade e se busca cotidianamente elevação da produtividade como prérequisito primordial mercadológico.

Destarte, esta discussão evidência a expressiva relevância dos levantamentos destacados à medida que se é potencializada pelo estudo de caso em questão. Como proposta de trabalhos futuros, instigase o aprofundamento das concepções apresentadas introdutoriamente aliada a uma aplicação prática dos estudos de movimentos e tempos em um processo de larga escala do setor industrial/empresarial a fim de se mensurar os ganhos, em produtividade, oriundos desta adesão.

\section{REFERÊNCIAS}

[1] ACADEMIA BRASILEIRA DE LETRAS. Dicionário escolar da língua portuguesa. Rio de Janeiro: Bloch Ed., 1988.

[2] ANIS, G. C. A importância dos estudos de tempos e métodos para controle da produtividade e qualidade. MBA em Qualidade e Produtividade, 2010.

[3] BARBOZA, P. S. S.; PORTELA, R. A. Cronoanálise com foco em melhor aproveitamento da mão de obra no pólo calçadista de Jáu. 3o Jornada Científica e Tecnologica do FATEC de Botucatu, Botucatu - SP, 2014.

[4] BARNES, R. M. Estudo de movimentos e tempos: projeto a medida do trabalho. 6. Ed. São Paulo: Edgard Blucher, 1977, $635 \mathrm{p}$.

[5] CAMPOS, V. F. TQC Controle da Qualidade Total. 2. Ed. Nova Lima: Indg Tecnologia e Serviços Ltda, 2004, 256 p.

[6] CHIROLI, D. M. G.; NUNES, P. V. N.; LEAL, G. C. L. O uso da cronoanálise para implantação do plano mestre de produção em uma empresa avícola. XXV Encontro Nacional de Engenharia de Produção, São Carlos - SP, 2010.

[7] CONTADOR, J. C. Gestão de operações: A engenharia de Produção a serviço da modernização da empresa. São Paulo: Edgard Blucher, Fundação Vanzolini, 1998.

[8] CORREA, K. S. A.; ALMEIDA, D. A. Aplicação da técnica de mapeamento de fluxo do processo no diagnóstico do fluxo de informações da cadeia cliente-fornecedor. Disponível em: <http://www.abepro.org.br/biblioteca/ENEGEP2002_ TR11_0553.pdf>. Acesso em: 01jun.2016. 
[9] DEMING, W, E. Saia da crise: as 14 lições definitivas para controle da qualidade. Tradução de Marcelo Alves Mendes. São Paulo: Editora Futura, 1993.

[10] ECKES, G. A. A revolução Seis Sigma: o método que levou a GE e outras empresas a transformar processos em lucros. Rio de Janeiro: Campos, 2001.

[11] HARRY, M.; SCHOROEDER, R. Six sigma: the breakthrough management strategy revolutionizing the world's top corporations. Currency: New York, 2000.

[12] MICHELINO, G. Estudo de tempos e supervisores. 2. Ed. São Paulo: Publicações Educacionais Limitada, 1964, 204 p.
[13] PEINADO, J.; GRAEML, A. R. Administração da produção: operações industriais e de serviços. Curitiba: UnicenP, 2007.

[14] PEREIRA, M. A. Estudo multicaso de práticas de implantação do método SMED. Dissertação (Mestrado em Engenharia de Produção), Universidade Federal de São Carlos, São Carlos, 2010.

[15] RUIZ, J. A. Metodologia científica: guia para eficiência nos estudos. São Paulo: Atlas, 1990

[16] SANTOS, A. B.; MARTINS, M. F. Modelo de referência para estruturar o Seis Sigma nas organizações. Rev. Gest. Prod., São Carlos, v.15, n.1, p.43-56, jan.-abr. 2008. 


\title{
CAPÍTULO 15
}

\section{INTRODUÇÃo da CURVA ABC NO PROCESSO DE ANÁlise DA DEMANDA EM UMA EMPRESA DO SEGMENTO METALOMECÂNICO}

\author{
Juan Pablo Silva Moreira \\ Jaqueline Luisa Silva \\ Igor Caetano Silva \\ Felipe Augusto da Silva \\ Janser Queiroz Oliveira
}

Resumo: O processo de globalização tem impulsionado um ritmo cada vez mais competitivo e acelerado entre as organizações que, seguem em busca por posições satisfatórias para acompanhar a nova demanda de cenário atual. Assim, o presente trabalho tem o objetivo de realizar uma otimização no gerenciamento e controle da demanda, identificando os sidecars mais rentáveis e lucrativos para a empresa ômega, desta forma, foi utilizada a aplicação da curva abc na organização analisada. Portanto, com o propósito de obter uma visão mais clara da problemática em evidencia, utilizou-se a aplicação de questionários de maneira descritiva e qualitativa, pois essas abordagens de pesquisa permitem maior interação com o cotidiano empresarial sem que os pesquisadores interfiram na linha de produção. O resultado apontado através desta pesquisa mostra que através da aplicação desta metodologia, foi possível evidenciar os produtos que são menos comercializados e quais são os produtos mais adquiridos pelos clientes da organização.

Palavras chave: Custeio ABC. Atividades. Custos. Recursos. Serviços. 


\section{INTRODUÇÃO}

O processo de globalização tem impulsionado um ritmo cada vez mais competitivo e acelerado entre as organizações que, seguem em busca por posições satisfatórias para acompanhar a nova demanda de cenário atual. Segundo Pires (2009) a sobrevivência dos empreendimentos depende de como são realizadas as atividades de planejamento e a execução que auxiliarão a alcançar os níveis de qualidade estipulados pelo mercado.

Em virtude disso, com o processo de inovações tecnológicas, se tornou muito importante que os empreendimentos desenvolvam periodicamente a implantação de procedimentos que auxiliem a dar um direcionamento ao processo de tomada de decisão, garantindo, que seus produtos não entrem em declínio. Tidd et al. (2008) afirma que a era da tecnologia se refere às novas formas de planejar, organizar e coordenar os fatores que são julgados essenciais para desenvolver métodos mais rentáveis de se obter um aumento da lucratividade desejada pelo empreendimento.

Os modelos de sidecars (dispositivo preso ao lado da motocicleta) utilizados a princípio para transportar militares durante as disputas territoriais europeias, atualmente foram ajustados para transportar diversos produtos, dando maior comodidade ao cotidiano da sociedade. Segundo Miranda (2012) os primeiros modelos de sidecars foram desenvolvidos pelo exército alemão no período da Segunda Guerra Mundial com a finalidade de possibilitar que os veículos da época pudessem transportar uma quantidade maior de soldados do Eixo para combater nas linhas de frente contra o exército Aliado.

A empresa em análise, que por questão de confidencialidade será considerada como Empresa Ômega, organização que se localiza na cidade Patos de Minas, no estado de Minas Gerais, tem como nicho de mercado a fabricação de modelos de sidecars. Segundo Moreira et al. (2015) este produto conquistou seu espaço no mercado devido ao crescimento da demanda por um equipamento mais prático e que pudesse transportar mercadorias por locais estreitos sem maiores dificuldades.

Contudo, com em decorrência do aprimoramento realizado nos processos de fabricação de produtos, alguns pesquisadores desenvolveram novas ferramentas que tinham a finalidade de evidenciar quais são os produtos mais rentáveis para as organizações. Foi então que no início dos anos de __ surgiu, a curva $A B C$, uma metodologia que auxilia os gestores na análise por produtos que sejam mais rentáveis e que garantam a lucratividade da empresa. Pozo (2010) informa que a curva ABC, é uma metodologia de Gerenciamento da Demanda, que se fundamenta em demonstrar, através de aspectos quantitativos, o estoque de produtos acabados, a quantidade vendas e a demanda dos clientes por um determinado produto desenvolvido pelo empreendimento.

Para Chopra e Meindl (2011) a Gestão Demanda (do inglês Demand Chain Management - DCM) não se resumem unicamente à previsão de vendas, ela também tem interação com as atividades relacionadas ao planejamento, comunicação, influência e determinação das prioridades que influenciam direta ou indiretamente no processo de gerenciamento da demanda.

Assim, o presente trabalho tem o objetivo de realizar uma otimização no gerenciamento e controle da demanda, identificando os sidecars mais rentáveis e lucrativos para a Empresa Ômega, desta forma, será utilizada a aplicação da curva ABC na organização analisada, pois de acordo com Castiglioni (2009), a curva ABC permite que os gestores analisem os itens que devem ser tratados com mais atenção, possibilitando assim, a obtenção de uma maior lucratividade no processo produtivo do empreendimento.

Para tanto, a fim de analisar o tema abordado com uma maior eficiência, desenvolveu-se um estudo mediante o estudo sistemático dos conteúdos disponíveis em métodos, técnicas e ou procedimentos de caráter cientifico. Assim, quanto aos objetivos, esta pesquisa foi caracterizada como descritiva, pois para Gil (2002) a pesquisa descritiva é "a descrição das características de determinada população ou fenômeno, ou, então, o estabelecimento de relação entre as variáveis". Rampazzo (2005) salienta que a análise descritiva "observa, registra, analisa e correlaciona os fatos e fenômenos, sem manipula-los", permitindo assim, uma análise sem que o pesquisador interfira nos resultados 
da pesquisa.

A fim de que se analisasse melhor a qualidade dos sidecars desenvolvidos pela Empresa Ômega, os autores deste trabalho, fizeram uso de uma abordagem quantitativa Essa abordagem possibilita uma traduzir através de dados numéricos a relação direta existente entre o mundo real e o assunto pesquisado, pois permite a estes analisar, questionar e interpretar determinado acontecimento utilizando unicamente os recursos quantitativos e estatísticos. Para as autoras Silva e Menezes (2005) essa abordagem permite a percepção de um fato relacionado à lucratividade, probabilidade ou análise gráfica.

E por fim, os autores deste trabalho fazem uso de um questionário estruturado, a aplicação de questionários para a obtenção de informações pode ser caracterizada pela elaboração de questões abertas ou fechadas que tem como finalidade realizar observações para se compreender os fenômenos que serão estudados na elaboração de trabalhos científicos (HILL; HILL, 2012). Marconi e Lakatos (2004) acrescentam que o questionário é um eficiente método de pesquisa, porque se trata de um instrumento de coleta de dados constituído por uma série ordenada de perguntas, que devem ser respondidas por escrito e sem a presença do entrevistador. Deste modo, a elaboração de questionários é fundamental como forma de se obter dados estatísticos, qualitativos e quantitativos sobre o assunto abordado nesta pesquisa.

\section{GESTÃO DE ESTOQUES}

O estoque é uma parte de vital importância para que se possa garantir um bom funcionamento da organização, pois através dele é possível realizar uma representação de todos os ativos da empresa e a partir dele que são adquiridos todos os lucros para ela se manter no mercado. Para Slack et al. (1997) a definição de estoque passou a ser difundido quando as organizações "compreenderam a importância de integrar o fluxo de materiais a suas funções de suporte, tanto por meio do negócio, como por meio do fornecimento aos clientes imediatos".

Deste modo, a gestão de estoque pode interpretada como uma atividade que envolve o gerenciamento de recursos ociosos e que tem a função estratégica de suprir as necessidades da organização (VENDRAME, 2008). Viana (2002) salienta que "a gestão de estoques visa ao gerenciamento dos estoques por meio de técnicas que permitam manter o equilíbrio com o consumo, definindo parâmetros e níveis de suprimento e acompanhamento à sua evolução".

O gerenciamento de estoque é o procedimento operacional em que são analisadas todas às políticas de estocagem da empresa e a cadeia de valor adquiridas a partir da relação existente entre estoque e produção. De acordo com Bowersox e Closs (2001), nessa análise também é importante se levar em conta a variação à demanda e o lugar destinado à armazenagem desses produtos e, por isso, deve-se elaborar um planejamento que irá projetar uma movimentação de forma eficiente com o objetivo de otimizar a utilização desses produtos.

Logo, gerir estoques que vise uma de maneira enxuta e econômica, consiste essencialmente na busca por um ponto de equilíbrio entre consumo, de tal maneira que se atenda as necessidades efetivas de seus consumidores, sem comprometer a qualidade e o custo do produto final (VIANA, 2002). Assim, na gestão do estoque se faz necessário o desenvolvimento de um gerenciamento quando a demanda de produção, pois só assim, será possível garantir que os produtos que serão adquiridos pela empresa estarão conforme as exigências estipuladas pelos clientes finais.

\section{GESTÃO DA DEMANDA}

As empresas têm buscado se identificar cada vez analisar as percepções de valor percebidas pelo consumidor final e como transformadas em ofertas. Dentre as funções de produção, sistemas de planejamento e controle de mercado, a Demand Chain Management (DCM) ou traduzida para o português como Gerenciamento da Demanda se torna fundamental para compreender as atividades de previsão de demanda, descrever os pedidos dos clientes e equilibrar a oferta e a demanda (VOLLMANN et al., 2004). 
Favaretto (2001) salienta ainda que a Gestão da Demanda, é desenvolvida através da integração entre clientes e organização, já que os colaboradores responsáveis por realizar planejamento a gestão da demanda, é a integração entre cliente e empresa, sendo responsável pelo planejamento adequado de todas as demandas geradas, externa ou internamente, a fim de se obter um equilíbrio entre o que o mercado requer e o que a produção pode fornecer.

Para alcançar uma efetiva DCM, o caminho inicial é a compreensão do cenário interno e externo, pois ele influenciará diretamente nas atividades estratégicas e operacionais, demonstrando o trajeto para que 0 planejamento seja concretizado. Também é necessário possuir equipes multifuncionais, já que este grupo de profissionais permite obter uma ampla compreensão do mercado e dos setores da organização, além evidenciar fornecedores e clientes, que são os representantes estratégicos da cadeia. (HILLETOFTH et al., 2009; JUTTNER et al., 2007; MENTZER; MOON, 2004; RAINBIRD, 2004).

As autoras Melo e Alcântara (2010) salientam que a capacidade da empresa e as necessidades dos clientes devem estar em equilíbrio, pois isso faz com que haja uma minimização das incertezas da oferta e da demanda, além de melhorar consideravelmente, a qualidade dos serviços prestados ao cliente, provocar uma redução dos níveis de e melhorar a utilização dos ativos e na disponibilidade do produto no mercado. A figura 1 representa a estrutura conceitual para um processo eficiente da Gestão da Demanda.

Figura 1 - Estrutura conceitual para um processo efetivo de Gestão da Demanda

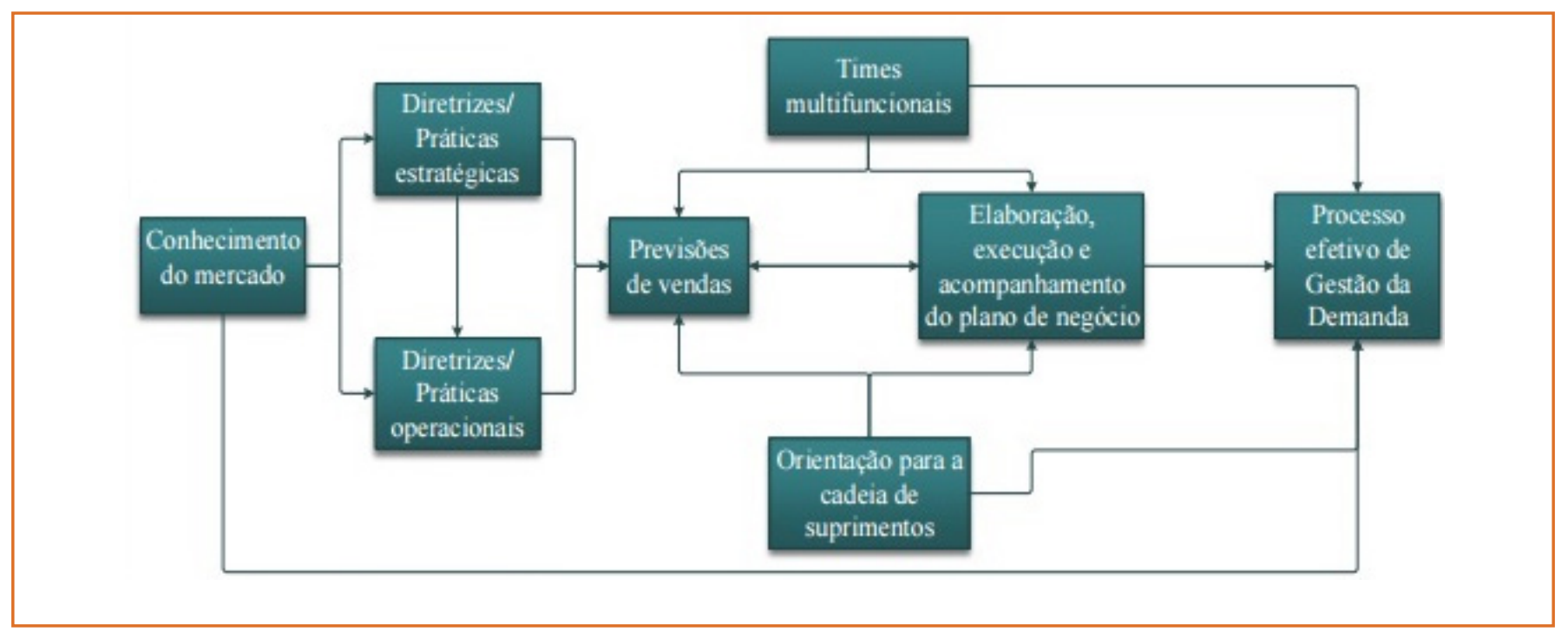

Fonte: Adaptado de Melo e Alcântara (2010)

E possível identificar que todas os fatores organizacionais se interligam, isto demonstra que para que haja uma Gestão da Demanda eficiente, devese possuir um conhecimento apurado do mercado, pois só conhecendo o funcionamento do mercado, é possível realizar um levantamento de como os clientes irão consumir o produto naquele período de tempo. Os times multifuncionais se tornam importantes para desenvolver um planejamento estratégico para garantir a lucratividade da empresa. Assim, com essas etapas em sintonia, é possível estabelece um processo efetivo de demanda.

\subsection{CURVA ABC}

Para Bowersox, Closs e Cooper (2007), o objetivo da classificação $A B C$ é determinar, por meio de uma classificação que agrupa produtos, mercados ou clientes, os esforços de gerenciamento de estoque. Para o desenvolvimento desse processo de classificação são considerados apenas os produtos 
que tem as mesmas características e relevância perante o mercado.

Gaither e Frazier (2002) salienta que a classificação pode se baseada em uma variedade de medidas, sendo as mais comuns: vendas, contribuição para a lucratividade, valor do estoque, taxa de uso e natureza do item. Segundo o mesmo autor, o procedimento mais utilizado para desenvolver esta classificação é organizar, em ordem decrescente, em um mesmo grupo os produtos que possuem características semelhantes de acordo com o volume de vendar ou de comercialização.

Segundo Lambert, Stock e Ellram (1998), a lógica por trás da classificação eficiente da curva $A B C$ é que $20 \%$ (vinte por cento) dos consumidores ou produtos da empresa representam 80\% (oitenta por cento) das vendas e, em alguns casos, pode representar uma porcentagem dos lucros ainda mais representativa.

Depois que os itens são devidamente classificados e agrupados, é comum rotular cada categoria com um código ou descrição que os diferencia das demais classificações. Produtos com alto poder de rotatividade e volume elevado, por exemplo, são normalmente são considerados como itens $A$. Itens com volume moderado são denominados itens $B$, e os de baixo volume ou de baixo poder de rotatividade são conhecidos como C. Para os autores Bowersox; Box; Cooper, (2007) "o agrupamento dos produtos semelhantes facilita os esforços gerenciais e possibilita o estabelecer estratégias de estoque concentradas para segmentos específicos de produtos". Por exemplo, produtos com alto de volume ou que possuem alta rotatividade, normalmente são utilizados com mais frequências na linha de produção níveis mais altos de utilização. Isso faz com que os itens de alta rotatividade possuam um estoque de estoque de segurança mais elevado. Em contrapartida, para reduzir os níveis gerais de estoque, itens de baixa rotatividade podem ter possuir um índice menor de estoque de segurança, resultando em níveis mais baixos de utilização.

De acordo com Gaither e Frazier (2002), essa classificação estimula que os gestores desenvolvam um planejamento eficiente da linha de produção, já que quanto maior o valor de estoque de um material, mais este material deve sofrer rotatividade para não perder lucratividade com estoque parado. O mesmo autor relata ainda que, em geral, os materiais Classe $A$ são amplamente verificados, e os materiais Classe C são analisados com mais frequência.

\section{METODOLOGIA}

Inicialmente, foi realizado um estudo bibliográfico sobre a utilização da curva ABC como fator determinante da gestão de demanda em uma empresa que é fabricante de sidecars nomeada como Empresa Ômega. Para que fosse possível desenvolver esse relato foram desenvolvidos dois questionários, composto por questões abertas e fechadas, aplicados aos treze (13) colaboradores do empreendimento, sendo três (3) gestores e dez (10) funcionários. Para a eficiência desta análise foi necessário que todos os funcionários e gestores respondessem aos questionários, pois a melhoria no controle e gerenciamento da demanda influencia em todos os setores da organização em que ele é implantado, seja no setor operacional, logístico ou de vendas. As informações secundárias da pesquisa foram obtidas através de verificação em sites, artigos de caráter técnico-científicos, livros, monografias, teses e dissertações de mestrado e doutorado.

As questões contidas nos questionários tinham o objetivo de adquirir informações quanto ao planejamento estratégico a curto, médio e longo prazo da empresa bem como, a organização estratégica de trabalho, os processos utilizados na fabricação dos equipamentos, a missão, a visão e os objetivos da empresa. Além disso, as indagações ajudaram na identificação de quais os modelos de sidecars mais vendidos e qual a lucratividade que estes produtos trazem para a organização.

\section{ANÁLISE DOS RESULTADOS}

Com base nas informações identificadas foi desenvolvido um planejamento com instruções de como implantar a Curva ABC na Empresa Ômega. A primeira atividade proposta para a implantação desta modelagem foi à realização de uma reunião com gestores e colaboradores para se pudesse explicar a 
os envolvidos sobre a importância de uma filosofia que avalia a demanda e determina a lucratividade de cada um dos produtos fabricados pelo empreendimento. Pires (2007) relata que haja a execução eficiente de uma melhoria que envolva o processo operacional do empreendimento, é necessário que todos os colaboradores entendam quais são os benefícios de melhorar o processo produtivo e como esta melhoria será benéfica para a organização.

Desta forma, com base nas opiniões adquiridas pelos funcionários foi possível desenvolver uma metodologia de análise que estivesse de acordo com a missão, a visão e os valores organizacionais desenvolvidos pela
Empresa Ômega.

Após a conclusão desta etapa, foi definida a equipe responsável por analisar todas as informações referentes ao controle de demanda, ao faturamento mensal e anual da organização, esta etapa foi de fundamental importância, pois através dela, foi possível determinar a lucratividade anual e mensal dos sidecars vendidos nos anos de 2014 e 2015, de acordo com os estados brasileiros (tabela 1). Nesta relação foi possível evidenciar que houve um acréscimo de 1,3\% de vendas no ano de 2014 em comparação com o de 2015.

TABELA 1 - Planilha de Faturamento Anual da Empresa Ômega

\begin{tabular}{|c|c|c|c|c|c|c|c|}
\hline Estados & Fatı & imento 2014 & Share \%2014 & Fatu & mento 2015 & Share \% 2015 & $\Delta \%$ \\
\hline AM & $\mathrm{R} \$$ & $3.210,00$ & $0,2 \%$ & $\mathrm{R} \$$ & - & $0,0 \%$ & $-100,0 \%$ \\
\hline $\mathrm{AL}$ & $\mathrm{RS}$ & - & $0,0 \%$ & $\mathrm{RS}$ & $2.750,00$ & $0,2 \%$ & - \\
\hline BA & $\mathrm{R} \$$ & $24.337,50$ & $1,7 \%$ & $\mathrm{R} \$$ & $28.627,93$ & $1,9 \%$ & $17,6 \%$ \\
\hline $\mathrm{CE}$ & $\mathrm{RS}$ & - & $0,0 \%$ & $\mathrm{RS}$ & $3.755,00$ & $0,3 \%$ & - \\
\hline DF & $\mathrm{R} \$$ & $24.274,00$ & $1,7 \%$ & $\mathrm{RS}$ & $20.380,00$ & $1,4 \%$ & $-16,0 \%$ \\
\hline ES & $\mathrm{R} \$$ & $34.747,00$ & $2,4 \%$ & $R \$$ & $20.428,00$ & $1,4 \%$ & $-41,2 \%$ \\
\hline GO & $\mathrm{R} \$$ & $33.290,00$ & $2,3 \%$ & $\mathrm{R} \$$ & $165.077,20$ & $11,1 \%$ & $395,9 \%$ \\
\hline MA & $\mathrm{R} \$$ & 115,00 & $0,0 \%$ & $\mathrm{R} \$$ & $22.750,00$ & $1,5 \%$ & $19682,6 \%$ \\
\hline MG & $\mathrm{R} \$$ & $1.073 .519,78$ & $73,3 \%$ & $\mathrm{R} \$$ & $975.352,55$ & $65,7 \%$ & $-9,1 \%$ \\
\hline MS & $\mathrm{R} \$$ & - & $0,0 \%$ & $\mathrm{RS}$ & $6.730,00$ & $0,5 \%$ & - \\
\hline MT & $\mathrm{R} \$$ & $24.780,00$ & $1,7 \%$ & $R \$$ & $27.145,00$ & $1,8 \%$ & $9,5 \%$ \\
\hline PA & $\mathrm{RS}$ & $18.150,00$ & $1,2 \%$ & $\mathrm{RS}$ & $47.440,00$ & $3,2 \%$ & $161,4 \%$ \\
\hline PB & $\mathrm{R} \$$ & $6.630,00$ & $0,5 \%$ & $\mathrm{R} \$$ & - & $0,0 \%$ & $-100,0 \%$ \\
\hline PE & $\mathrm{R} \$$ & $6.020,00$ & $0,4 \%$ & $R \$$ & $17.684,60$ & $1,2 \%$ & $193,8 \%$ \\
\hline PR & $\mathrm{R} \$$ & $8.858,00$ & $0,6 \%$ & $\mathrm{RS}$ & $12.116,00$ & $0,8 \%$ & $36,8 \%$ \\
\hline RJ & $\mathrm{R} \$$ & $15.575,00$ & $1,1 \%$ & $\mathrm{R} \$$ & $15.950,00$ & $1,1 \%$ & $2,4 \%$ \\
\hline RO & $R \$$ & - & $0,0 \%$ & $R \$$ & $8.780,00$ & $0,6 \%$ & - \\
\hline RS & $\mathrm{R} \$$ & $11.863,00$ & $0,8 \%$ & $\mathrm{R} \$$ & $2.615,90$ & $0,2 \%$ & $-77,9 \%$ \\
\hline SC & $\mathrm{R} \$$ & $2.950,00$ & $0,2 \%$ & RS & $3.010,00$ & $0,2 \%$ & $2,0 \%$ \\
\hline SE & $\mathrm{R} \$$ & - & $0,0 \%$ & $\mathrm{R} \$$ & $2.850,00$ & $0,2 \%$ & - \\
\hline SP & $\mathrm{R} \$$ & $113.400,85$ & $7,7 \%$ & $\mathrm{RS}$ & $88.093,00$ & $5,9 \%$ & $-22,3 \%$ \\
\hline TO & $\mathrm{R} \$$ & $62.954,00$ & $4,3 \%$ & $\mathrm{RS}$ & $11.930,00$ & $0,8 \%$ & $-81,0 \%$ \\
\hline & $\mathrm{R} \$$ & $1.464 .674,13$ & $100,0 \%$ & $\mathrm{RS}$ & $1.483 .465,18$ & $100 \%$ & $1,3 \%$ \\
\hline
\end{tabular}

Porém, apesar da alta lucratividade obtida pelos produtos, através desta tabela não foi possível determinar a lucratividade de cada um dos produtos vendidos. Deste modo, foi desenvolvido um gráfico que demonstra a lucratividade anual obtida em cada um dos 11 modelos de sidecar (gás/água, multiuso, mercado aberto, pet shop, baú térmico, cadeirante, pranchão, manutenção, grade fechada e passageiro) comercializados pela organização. 
FIGURA 2 - Faturamento Anual da Empresa Ômega no período 2014- 2015

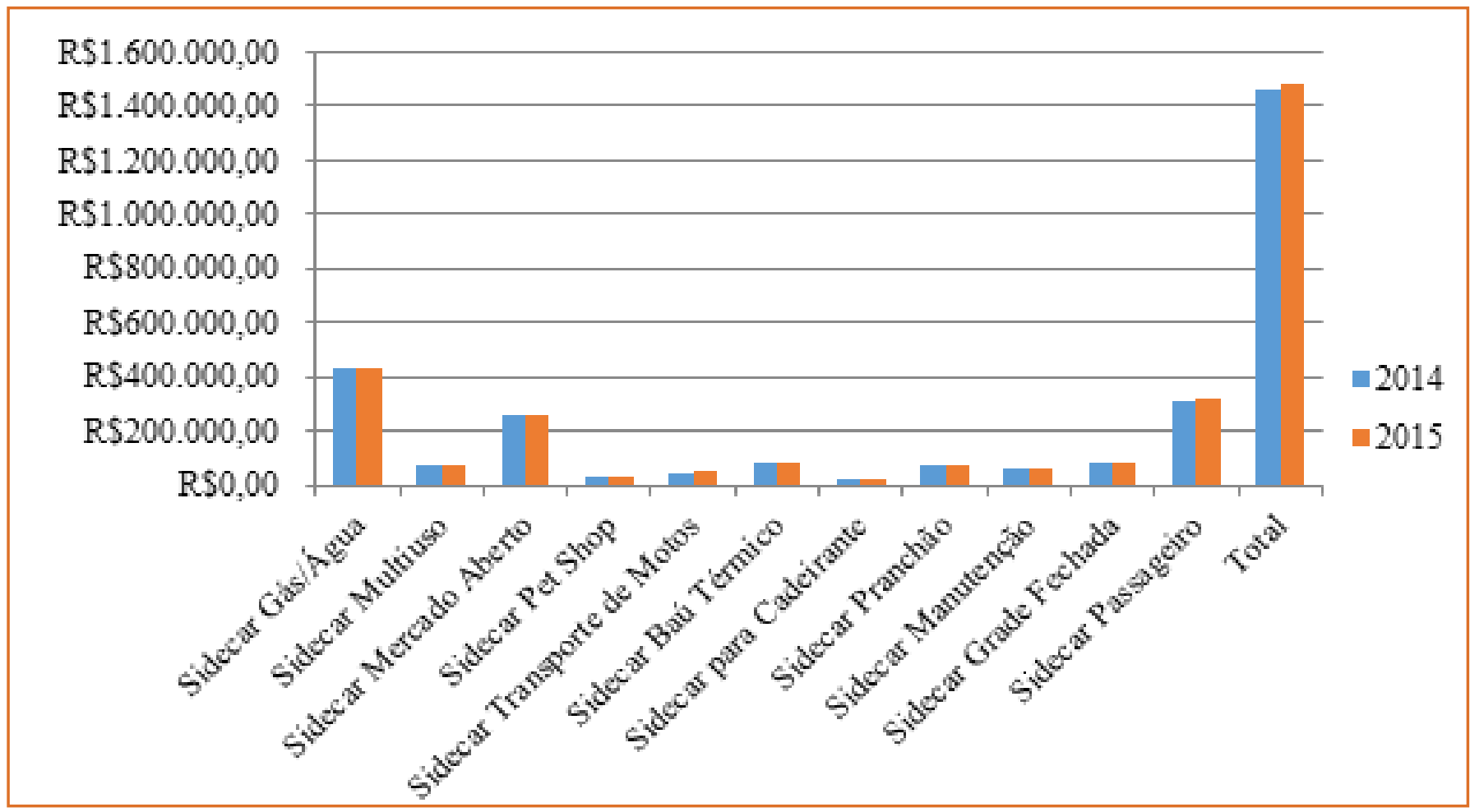

Todos os sidecars foram contabilizados de acordo com a lucratividade obtida nos dois anos analisados, então como não houve discrepância significativa neste levantamento, nas próximas etapas será considerado apenas o levantamento obtido no ano de 2015. Para a formulação da curva ABC considerou-se aproximadamente $75 \%$ das vendas para os produtos tipo A, aproximadamente $21 \%$ produtos tipo B e aproximadamente 5 para o tipo $\mathrm{C}$, como demonstra na tabela 2.

TABELA 2 - Critério para classificação da Curva ABC

\begin{tabular}{|l|l|}
\hline Classificação & \% de Vendas \\
\hline A & 74,22 \\
\hline B & 21,17 \\
\hline C & 4,43 \\
\hline
\end{tabular}

Deste modo, com base na lucratividade anual fornecida pela Empresa Ômega, foi possível classificar os produtos, levando em consideração a quantidade individual de vendas e o preço unitário dos produtos. A tabela 3 demonstra a relação obtida entre as Classes $\mathrm{A}, \mathrm{B}$ e $\mathrm{C}$, com seus respectivos percentuais de vendas, de produtos e valor total no adquirido no ano de 2015.
Pires (2009) relata que é possível identificar que uma quantidade considerável de produtos representa uma pequena margem de vendas nas organizações e uma quantidade reduzida de produtos representa um percentual elevado nas vendas.

TABELA 3 - Resultados da tabela ABC

Classificação \% de Vendas \%Total de Itens Venda Anual

\begin{tabular}{|l|l|l|l|}
\hline$A$ & 56,72 & 131 & $\mathrm{R} \$ 853.187,81$ \\
\hline $\mathrm{B}$ & 25,58 & 185 & $\mathrm{R} \$ 384.749,26$ \\
\hline $\mathrm{C}$ & 17,69 & 327 & $\mathrm{R} \$ 266.320,16$ \\
\hline
\end{tabular}

A classificação $A B C$, representada nas figuras 3 e 4 , relaciona o consumo anual acumulado (valor que corresponde ao total de produtos vendidos) com os diferentes tipos de produtos disponíveis no mercado. A classificação permitiu identificar uma quantidade de 327 itens como Classe (representando 17,69\% dos produtos), 185 itens como Classe B (25,58\% dos produtos), e 131 itens como classe C (56,72\% dos produtos). 
FIGURA 3 - Curva ABC da Empresa Ômega

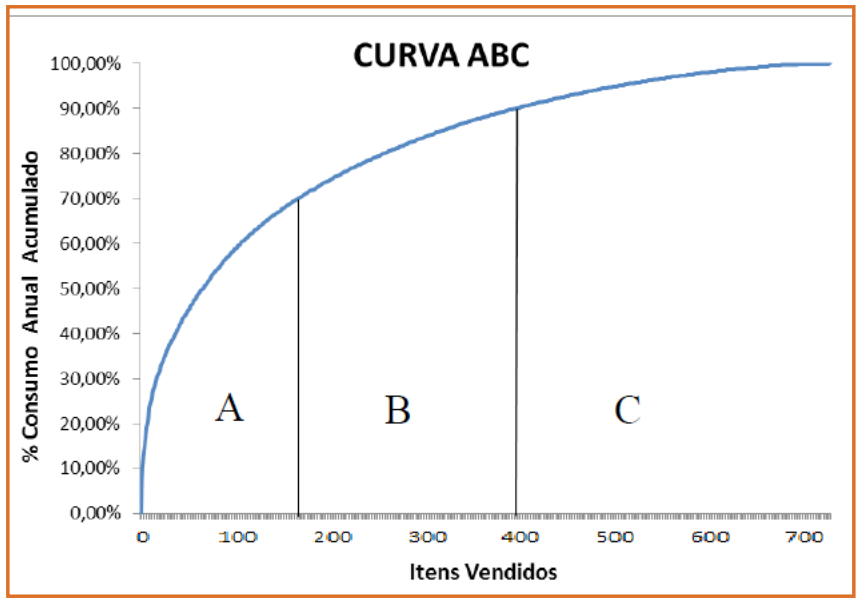

FIGURA 4 - Classificação dos produtos vendidos

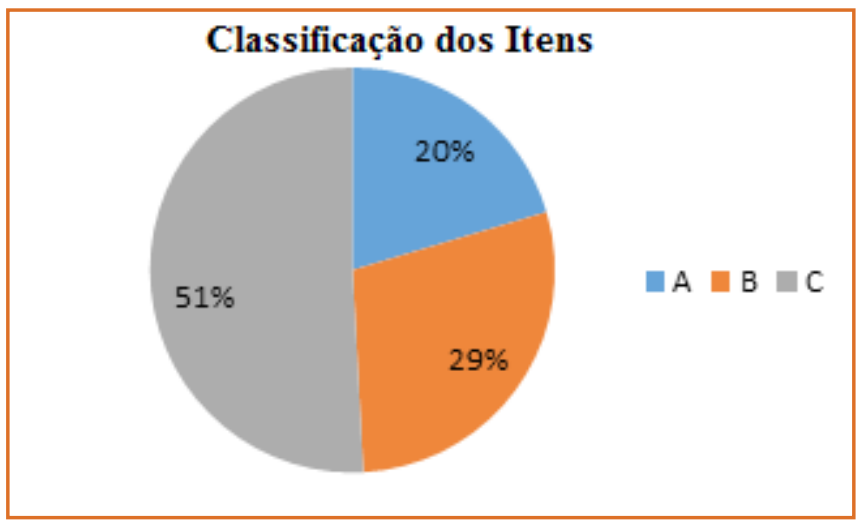

De acordo com as figuras 3 e 4 foi possível observar que há uma diferença significativa na diferença de lucratividade obtida entre os sidecars classificados como A e os classificados como B. Neste sentido, foi aconselhado aos gestores do empreendimento que criem um plano de ações que potencializem as vendas dos itens de nível $A$ (sidecars gás/agua e passageiro) e $\mathrm{B}$ (sidecars grade fechada, baú térmico e mercado aberto), e caso os itens de nível $\mathrm{C}$ (sidecars para cadeirante, pet shop, transporte de motos, manutenção, multiuso e pranchão) ofereçam perdas à lucratividade, foi aconselhado a retirar estes produtos de forma temporária ou definitiva do portfólio para que não ocorram problemas futuros com a qualidade dos outros produtos.

\section{CONSIDERAÇÕES FINAIS}

Pela análise desenvolvida ao longo deste estudo, podese verificar que o objetivo de aplicação da metodologia para diagnosticar a análise da demanda e da lucratividade obtida pela Empresa Ômega foi atingido, tendo em vista que esta análise evidenciou quais são os sidecars mais vendidos pela organização. Além disso, através da utilização da curva $A B C$ foi possível observar que este instrumento, de fácil utilização, possui uma alta confiabilidade no desenvolvimento e esclarecimento dos resultados desejados, já que demonstrou quais os produtos precisam sofrem ações potencializadoras para alavancar as vendas e, com isso aumentar a lucratividade, ou ainda, identificar quais os equipamentos reduzem a lucratividade da organização.

Outro benefício observado, é a partir dessa nova metodologia, foi possível analisar que os funcionários estão mais capacitados e preparados para continuar desenvolvendo uma análise quanto a lucratividade obtida por cada sidecar vendido, pois através desta nova forma de gerenciar a produção os gestores e colaboradores podem excluir temporariamente ou definitivamente determinado produto do portfólio sidecars oferecidos aos clientes, e com isso garantir a redução de gargalos com produtos fabricados com menos frequência.

\section{REFERÊNCIAS}

[1] BOWERSOX, Donald J.; CLOSS, David J. Logística empresarial. São Paulo Ed. Atlas S. A. 2001.

[2] BOWERSOX, Donald J.; CLOSS, David J.; COOPER, M. Bixby. Gestão da Cadeia de Suprimentos e Logística. Rio de Janeiro: Elsevier, 2007.

[3] CASTIGLIONI, José Antônio de Mattos. Logística Operacional. Guia Prático. 2. ed. São Paulo: Érica, 2009.

[4] CHOPRA, Sunil; MEINDL, Peter. Gestão da cadeia de suprimentos: Estratégia, Planejamento e Operações. 4 ed. São Paulo: Pearson, 2011.

[5] FAVARETTO, F. Uma Contribuição ao Processo de Gestão da Produção pelo uso da Coleta Automática de Dados de Chão de Fábrica. 2001. Tese (Doutorado em Engenharia Mecânica) - Escola de Engenharia, Universidade de São Paulo, São Carlos, 2001.

[6] GAITHER, Norman; FRAZIER, Greg. Administração da Produção e Operações. 8a ed. São Paulo: Thomson, 2002.

[7] GIL, Antônio Carlos. Técnicas de pesquisa em economia e elaboração de monografias. 4aㅡ ed. São Paulo: Atlas, 2002. 
[8] HILL, Manuela Magalhães; HILL, Andrew. Investigação por Questionário. Sílabo Ltda. Lisboa, 2012.

[9] HILLETOFTH, P.; ERICSSON, D.; CHRISTOPHER, M. Demand chain management: a Swedish industrial case study. Industrial Management \& Data Systems, v. 109, n. 9, p. 184-211, 2009

[10] JUTTNER, U.; CHRISTOPHER, M.; BAKER, S. Demand chain management-integrating marketing and supply chain management. Industrial Marketing Management, v. 36, p. 377-392, 2007.

[11] LAMBERT, Douglas M.; STOCK, James R.; ELLRAM, Lisa M. Fundamentals of Logistics Management. The United States of America: Irwin McGraw-Hill, 1998.

[12] MARCONI, M. A.; LAKATOS, E. M. Metodologia Científica. Ed. 4. São Paulo: Atlas, 2004.

[13] MELO, Daniela de Castro; ALCÂNTARA, Rosane Lúcia Chicarelli. A gestão da demanda em cadeias de suprimentos: uma abordagem além da previsão de vendas. Gestão \& Produção, São Carlos, v. 18, n. 4, p. 809- 824, 2011.

[14] MENTZER, J. T.; MOON, M. A. Understanding Demand. Supply Chain Management Review, v. 8, p. 38-45, 2004.

[15] MIRANDA, Francisco. As Motos e Sidecars - O princípio da Mobilidade da Guerra, 2012. Disponível em: <https:// chicomiranda. wordpress.com/2012/05/05/as-motos-esidecars-o-principio-da-mobilidade-da-guerra/>. Acesso em 28 de mar. de 2016.

[16] MOREIRA, J. P. S.; SILVA, I. C.; LOPES, C. A. Implantação das Metodologias MASP e 5S no almoxarifado de uma indústria de sidecar. In: Encontro Nacional de Engenharia de Produção, 2015, Fortaleza (CE). Anais ... Encontro Nacional de Engenharia de Produção (ENEGEP), Fortaleza (CE) ENEGEP, 2015.

[17] NOVAES, A. G. Logística e gerenciamento da cadeia de distribuição: estratégia, operação e avaliação. Rio de Janeiro: Campus, 2001.
[18] PIRES, S. R. I. Gestão da Cadeia de Suprimentos: conceitos, estratégias, práticas e casos. São Paulo: Atlas, 2007.

[19] _. Gestão da Cadeia de Suprimentos (Supply Chain Management): Conceitos, Estratégias, Práticas e Casos. 2 ed. São Paulo: Atlas, 2009.

[20] POZO, H. Administração de Recursos Materiais e Patrimoniais. Ed. Atlas, 2010.

[21] RAINBIRD, M. Demand and supply chains: the value catalyst. International Journal of Physical Distribution \& Logistics Management. v. 34, n. 3/4, p. 230-251, 2004

[22] RAMPAZZO, L. Metodologia científica. São Paulo: ed. Loyola, 2005.

[23] SILVA, E. L.; MENEZES, E. M. Metodologia da pesquisa e elaboração de dissertação. 4. ed. rev. atual. Florianópolis/ SC: Laboratório de Ensino a Distância da UFSC, 2005

[24] SLACK, N.; CHAMBERS, S.; HARLAND, C.; HARRISON, A.; JOHNSTON, R.; - Administração da Produção. 2ª ed. São Paulo, editora Atlas S.A.. 2002.

[25] TIDD, Joe et al. Gestão da Inovação. Porto Alegre: Bookman, 2008.

[26] VENDRAME, F. C. Administração de Recursos Materiais e Patrimoniais. Apostila da Disciplina de Administração, Faculdades Salesianas de Lins, 2008.

[27] VIANA, João José. Administração de materiais. São Paulo: Atlas S. A. 2002.

[28] VOLLMANN, T. E. et al., Manufacturing Planning and Control for Supply Chain Management. Boston: Mcgraw-Hill, 2004 


\title{
CAPÍTULO 16
}

\section{ANÁLISE DA VIABILIDADE DE APLICAÇÃO DA ESTRATÉGIA MAKE OR BUY NO PROCESSO DE USINAGEM EM UMA INDÚSTRIA DO SEGMENTO AUTOMOTIVO}

\author{
Juan Pablo Silva Moreira \\ Jaqueline Luisa Silva \\ Igor Caetano Silva \\ Felipe Augusto da Silva \\ Janaína Aparecida Pereira
}

Resumo: Neste mercado altamente globalizado e competitivo as empresas buscam constantemente por ferramentas e métodos para aperfeiçoarem seus processos produtivos. Umas das grandes indagações que as empresas enfrentam no seu dia-a-dia para se manter no mercado é a decisão, alinhada a seu posicionamento estratégico, de quais atividades e processos internalizar e quais terceirizar. Uma ferramenta que vem auxiliando as organizações na tomada de decisão é a análise make or buy, que tem por objetivo analisar a melhor alternativa para empresa, em termos de custos, entre comprar ou fabricar bens e serviços. Sendo assim, este artigo tem por objetivo realizar a análise make or buy no processo de usinagem de uma empresa de fabricação e montagem de triciclos de carga e propor soluções eficientes para redução de custos e tempo de processo. Através da pesquisa percebeu-se que será mais lucrativo para a empresa a terceirização do semieixo, peça na qual gera mais atrasos, assim estará produzindo com o menor custo, dentro do prazo estipulado e otimizando o processo produtivo. 


\section{INTRODUÇÃO}

Frente a um mercado cada vez mais competitivo, as empresas buscam constantemente por ferramentas e métodos para redução de custos em seu processo produtivo. Segundo Conte e Durski (2002) as transformações impostas pela modernidade têm se mostrando preponderantes para se estabelecer uma relação existente entre o trabalho, a gestão, a aprendizagem e a capacidade de as pessoas atuarem e colaborarem no crescimento dos empreendimentos. Nessa nova fase do mercado as organizações devem adotar uma visão mais proativa quanto às inovações que ocorrem na produção, e com isso ampliarem o seu nível de qualidade, reduzindo os custos e conseguindo uma situação de destaque para com seus concorrentes.

Com processo de inovações tecnológicas, se tornou muito importante que os empreendimentos desenvolvam periodicamente projetos inovadores que auxiliem na melhoria dos processos produtivos, e impeça que seus produtos entrem em declínio. Tidd et al.(2008) afirma que a era tecnológica se refere às novas formas de planejar, organizar e coordenar os fatores que são julgados essenciais para desenvolver métodos mais rentáveis de se obter um aumento da lucratividade desejada pelo empreendimento.

$\mathrm{Na}$ indústria de automóveis adaptados, a busca por uma inovação nos processos produtivos é bastante preocupante, uma vez que, por se tratar de um mercado menor boa parte de suas peças em estoques passam por processos de adaptação. Deste modo, um bom planejamento por parte dos gestores se torna indispensável, uma vez que as empresas buscam cada vez mais por uma produção enxuta e sem desperdícios.

Segundo Venkatesan (1992), um das grandes decisões que as empresas enfrentam para se manter no mercado é a decisão, alinhada a seu posicionamento estratégico, de quais atividades e processos internalizar e quais terceirizar. O mesmo autor comenta sobre a importância da identificação das atividades e processos, e sugere a externalização das atividades que estão ligados apenas indiretamente e não são essenciais ao processo produtivo. Nesse contexto, uma das alternativas mais eficientes é a
Análise Make or Buy, que tem como objetivo auxiliar na escolha de integrar ou terceirizar as atividades seja de modo parcial ou total. De forma que possa otimizar a capacidade de resposta do processo produtivo, a produtividade e redução dos custos e do lead time do produto.

O presente artigo descreve um estudo de caso realizado em um centro automotivo de fabricação, montagem e reparo de triciclos de carga na cidade de Patos de Minas (MG). O trabalho tem como objetivo a realização da Análise Make or Buy no processo de usinagem da empresa e propor alternativas para redução de custos e atrasos no processo produtivo.

A abordagem da pesquisa é investigativa e de caráter qualitativo que, segundo Hofstein e Lunetta (2003), implica em, entre outros aspectos, planejar investigações, usar montagens experimentais para coletar dados seguidos da respectiva interpretação e análise, além de comunicar os resultados.

\section{GESTÃO DA PRODUÇÃO}

Após a Revolução Industrial os sistemas produtivos das indústrias passaram por constantes modificações, devido à necessidade de se produzir de acordo com as especificações dos clientes e de reduzir os custos operacionais. No final do século XIX com Frederick W Taylor, surgiram várias técnicas e princípios que norteavam as indústrias a identificar e transformar métodos de trabalho que obtinham maior produtividade e menor custo de produção. (JUNIOR, 2012, p.15).

Devido às crescentes transformações mercadológicas e produtivas, as empresas se viram na necessidade de definirem uma política de gestão para aumentarem seus ganhos e conduzirem suas estratégias operacionais em um mercado altamente competitivo. Surgiu então, o termo "Gestão da Produção" que veio com o objetivo de organizar e gerenciar os recursos humanos, materiais, tecnológicos e de capital, proporcionando coordenação, responsabilidades e controles efetivos dentro da organização (JUNIOR, 2012, p. 18-20).

Um sistema de produção é composto por uma sequência de processos, e estes, transformam 
inputs em outputs agregando valor a cada etapa, para entregar para clientes produtos/serviços. Cabe a Gestão da Produção analisar quais recursos estão disponíveis e realizar um planejamento de todas as atividades desenvolvidas, definindo tempo, sequência, monitorando e controlando, para prevenir possíveis desvios e evitar falhas, de forma a tornar o processo mais eficiente.

Dentro dessa perspectiva, pode-se encontrar a gestão da produção em todas as áreas de atuação do ambiente organizacional, envolvendo desde a chefia aos operadores. É importante que toda a empresa esteja ciente dos seus objetivos e metas, para alcance dos indicadores de desempenho normalmente já estabelecidos, sendo estes: custo, qualidade, rapidez, flexibilidade, qualidade e confiabilidade (MOREIRA 2000; MARTINS E LAUGENI, 2002; SLACK; CHAMBERS E JOHNSTON, 2002).

\subsection{PROCESSO DE TERCEIRIZAÇÃO}

Com o desenvolvimento econômico mundial e com a globalização, as empresas passaram a buscar constantemente por técnicas que aumentassem a produtividade, diminuíssem os custos e garantissem a qualidade dos produtos. Logo, o processo de Outsourcing, também conhecido como terceirização, contribuiu para que as organizações pudessem agilizar e direcionar suas atividades empresariais para alcançarem estes objetivos.

Entende-se por terceirização do trabalho, o processo pelo qual uma empresa contrata o serviço de outra empresa para desempenhar uma atividade ou serviço em uma determinada área da organização. Este processo vem se consolidando no mundo inteiro, inclusive no Brasil, que já consta com $25 \%$ da mão de obra sendo terceirizada (HOLCOMB, 2007).

A terceirização possibilita redução de custos administrativos, maior flexibilidade, aumento na qualidade dos serviços, tornando-se uma ferramenta estratégica para as empresas que desejam alcançar suas metas organizacionais. Porém, é importante que as empresas não possuam extrema dependência com as empresas prestadoras dos serviços, pois qualquer falha pode comprometer o desenvolvimento dos processos atuais.

\subsection{ANÁLISE MAKE OR BUY}

O make or buy consiste basicamente em um estudo que tem o objetivo de auxiliar a organização na tomada de decisão entre a empresa comprar ou fabricar um determinado produto. A decisão de fazer ou comprar (make or buy) é um fator de grande influência para as operações produtivas, que são cada vez mais complexas por agruparem e organizarem um grande número de peças, itens ou componentes utilizados no processo de fabricação (AMATO NETO, 1995).

De acordo com Canéz et al. (2000), os fatores que influenciam no início da análise make or buy são: a redução de custos, a falta de maquinário especializado para produzir o pré-processo do produto, a redução de tempo para introduzir novos produtos ao mercado, o aumento da qualidade do produto, a falta de habilidades e/ou competências para desenvolver os processos que antecedem o produto final e o aumento no tempo de resposta.

É essencial que as empresas analisem todas as situações e possibilidades para uma correta tomada de decisão entre fazer ou comprar, é necessário que todas as despesas sejam consideradas tanto para a produção/fabricação interna tanto para compra direta com o fornecedor. O processo Make or Buy deve ser periodicamente avaliado pela organização, pois diferentes momentos da economia, necessidades de mercado e variações de demanda podem provocar mudanças significados nos custos e a empresa precisa estar ciente dos seus gastos operacionais.

\subsection{ANÁLISE MAKE OR BUY NO PROCESSO DE USINAGEM}

O setor de usinagem de peças da empresa em estudo é um setor de extrema importância dentro do processo produtivo de fabricação dos triciclos de carga, visto que muitas peças são fabricadas na usinagem e utilizadas por outros setores da empresa. A usinagem é um processo que tem por objetivo dar forma à matériaprima através de máquinas ou equipamentos, sendo 
comumente utilizados tornos mecânicos, onde o aço trefilado bruto se transforma em vários tipos de peças.

A usinagem é considerada um dos processos mais complexos e demorados dentro da empresa, pelo fato de fabricar peças muito finas e com vários detalhes. Além disso, este setor fica sobrecarregado, pois conta com apenas um funcionário que faz o acabamento em quase todas as peças necessárias para montar o tricargo, ou seja, ocorre grande acúmulo de trabalho e demanda de tempo, provocando paralizações no restante do processo.

Mediante isso, uma das soluções seria a compra pronta da peça que demanda mais tempo para ser usinada, assim o processo seria agilizado e uma possível diminuição de custos aconteceria. Para isso, foi utilizado a Análise make or buy com o objetivo de auxiliar a organização na tomada de decisão entre comprar ou fabricar a peça.

\section{MATERIAIS E MÉTODOS}

Inicialmente, foi realizado um levantamento junto aos colaboradores e gestores da Empresa Brazcar Veículos Especiais LTDA para avaliar o custo médio de fabricação de um triciclo. Optou-se, desta forma, pela realização de uma reunião com os gestores e colaboradores para analisar os custos necessários para fabricar o triciclo e como esse fato reflete na lucratividade da organização. Assim, após a reunião com os funcionários relatou as atividades que poderiam ser realizadas de forma terceirizada.

Deste modo, foi escolhido através desta reunião que a fabricação do semieixo poderia sofrer uma análise de terceirização, já que por conter várias etapas e necessitar de muitas peças se torna desgaste para os colaboradores da organização. Em virtude deste fato, para que os resultados fossem analisados fossem eficientes, o desenvolvimento da análise Make or Buy se deu exclusivamente pela elaboração de um formulário semiestruturado, composto por questões abertas e fechadas, aplicados aos colaboradores que participam efetivamente do processo de fabricação dos triciclos. Os dados posteriores utilizados para o desenvolvimento deste trabalho foram obtidos através de análise realizada em sites, livros, artigos acadêmicos/científicos, teses, monografias e dissertações.

As questões contidas no formulário tinham o objetivo de analisar os processos utilizados para fabricação do semieixo que da origem ao triciclo, bem como os tempos e os custos gastos para a fabricação do mesmo. Além disso, o formulário também tinha a finalidade de identificar os fatores que podem influenciar na tomada de decisão dos gestores e colaboradores da organização analisada.

\section{RESULTADOS E DISCUSSÃO}

Com base nas informações coletadas, foi desenvolvida uma proposta para a análise Make or Buy no processo de fabricação do semieixo do triciclo da Empresa Brazcar. O primeiro passo relatado nesta análise foi à realização de uma reunião para que gestores e colaboradores pudessem esclarecer as informações sobre o funcionamento do triciclo e como é a realizada a fabricação do semieixo da organização.

Desta forma, com base nos esclarecimentos adquiridos, foi possível definir os objetivos estratégicos para a elaboração de uma análise eficiente e que beneficiasse tanto colaboradores como os clientes que consomem os produtos do empreendimento analisado. Para Canéz et al. (2000) uma análise Make or Buy só se torna bem sucedida quando é considerado fatores que são vantajosos tanto para a organização (incluindo os colaboradores e os gestores) quanto para os clientes, pois nada adianta desenvolver um produto vantajoso para o empreendimento se os clientes não consumirem esses produtos.

Holcomb e Hitt (2007) a primeira medida a ser tomada para garantir a eficiência desta análise é a definição de uma equipe que deverá analisar todo o processo a fim de verificar todos os custos necessários para fabricar o produto internamente e quanto custará para uma empresa terceirizada fabricá-lo. Assim, foi definida a equipe que realizará o levantamento de todos os dados fundamentais para a análise de viabilizar o processo de terceirização do semieixo. 
Para melhor evidenciar o desenvolvimento de qualquer atividade no contexto organizacional, é importante demonstrar todos os procedimentos necessários para se compreender a sequência lógica das atividades que o compõem (GRIMALDI \& MANCUSO, 1994). Em virtude disso, a fim de realizar uma melhor análise desta metodologia, foi elaborado um mapeamento de processos que tem o objetivo de descrever as etapas essenciais para implementação da filosofia (Figura 1).

Figura 1 - Fluxograma da análise Make or Buy

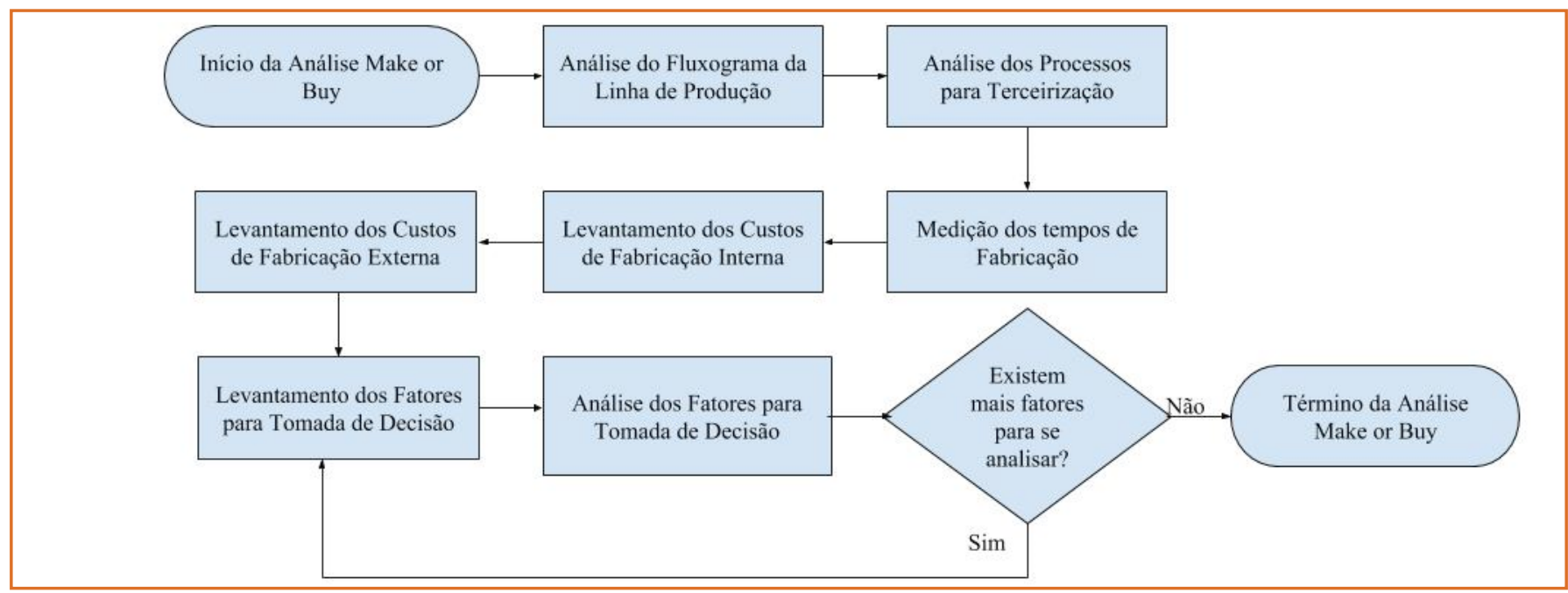

O início da análise ocorre com a verificação de todo o fluxograma do processo produtivo, nesta etapa são observadas todas as atividades que dão origem ao produto final. Posteriormente, é feito um levantamento de quais os processos podem ser realizados de forma terceirizada, para que se possa reduzir o custo final. Na sequência, são realizadas as medições do tempo gasto para a fabricação da peça ou equipamento identificada como foco do processo de terceirização.

Em seguida, são realizados os levantamentos de custos para a fabricação interna e externa à indústria. Após esta etapa é realizado um levantamento de todos os fatores que podem auxiliar no processo de decisão quanto à fabricação interna ou externa. Em alguns casos, pode haver a incidência de um fator não identificado imediatamente e que, posteriormente pode ser visto como um fator que influencia na decisão dos gestores. Neste caso, é realizada a criação de uma nota atividade que tem o objetivo de identificar os demais fatores e analisá-los juntamente aos demais.

Desta forma, o primeiro passado executado nesta pesquisa foi definir o fluxograma da linha de produção para se produzir um triciclo (figura 2). 
Figura 2 - Fluxograma da produção do semieixo do triciclo

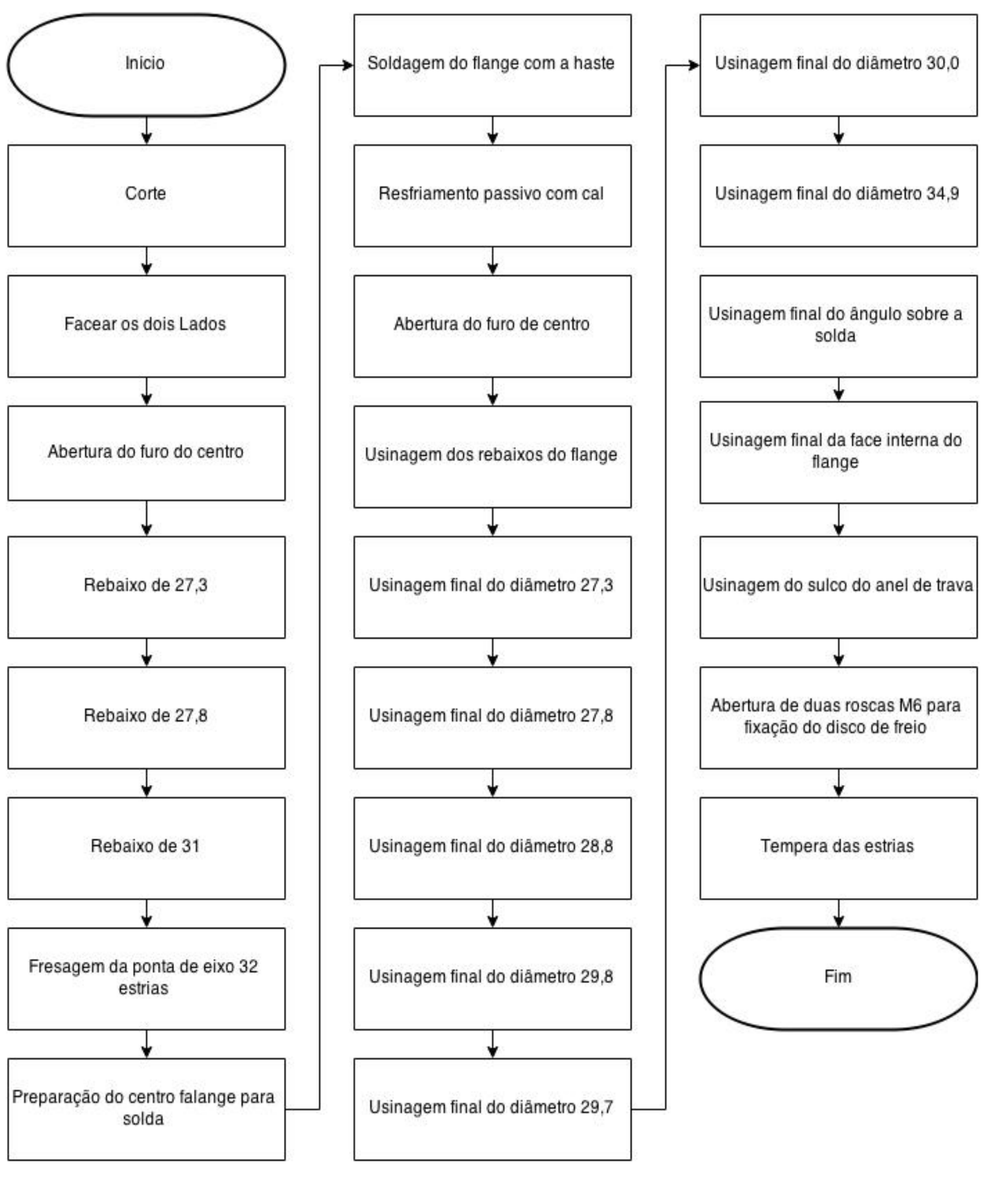

Apesar da variedade de atividades utilizadas para a fabricação do triciclo, optou-se por desenvolver um processo de terceirização das etapas de fabricação do semieixo, a escolha deste processo ocorreu devido ao tempo e a quantidade de etapas necessárias para se fabricar esta peça do triciclo. Assim, para melhor evidenciar o tempo e as etapas utilizadas para a fabricação do triciclo, foi desenvolvida uma medição destes tempos (Tabela 1). 
Tabela 1 - Etapas de Fabricação do semieixo

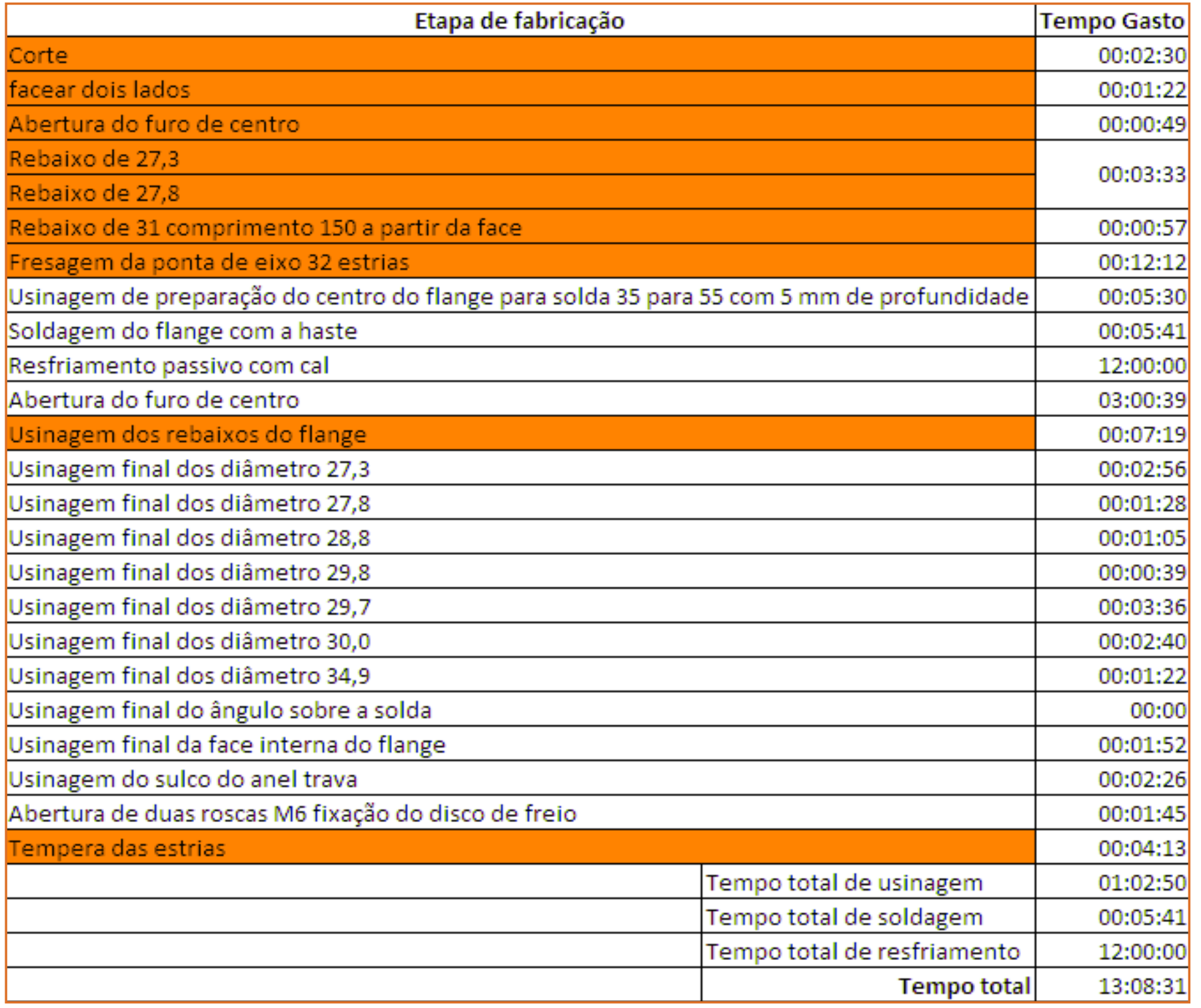

Fonte: Autores

Dando sequência ao processo de análise Make or Buy, foi realizado o levantamento dos custos para a fabricação interna e externa do semieixo na Empresa Brazcar (anexos A e B). Devido ao maior poder de compra das empresas terceirizadas, alguns produtos tem seu valor menor do que os adquiridos pela Empresa Brazcar, tornando-se mais rentável comprar os semieixos pré-fabricados. Assim, o custo médio de $R \$ 214,37$ para a fabricação interna do triciclo passa a custar $\mathrm{R} \$ 189,08$, sendo entregue em um prazo de dois dias, se fabricado por empresas terceirizadas, acarretando uma redução de aproximadamente 12\% por produto fabricado. Apesar do lead time do semieixo ser maior, é possível evidenciar que com menos atividades para desempenhar, os colaboradores poderão fabricar os triciclos com mais qualidade, reduzindo consequentemente, $\mathrm{O}$ índice de refugo e retrabalho por peças fabricadas pela Empresa Brazcar.

Foi aconselhado aos gestores do empreendimento que esse percentual de lucro fosse destinado a capacitação dos colaboradores, pois além de melhor a mão de obra profissional também aumenta a motivação dos colaboradores, fazendo com que eles desempenhem os produtos com mais qualidade. 


\section{CONCLUSÃO}

A partir desta pesquisa foi possível analisar e verificar os benefícios que a Análise Make or Buy traz para a organização em que é implantada. A Análise make or buy permite evidenciar variáveis que auxiliam tanto gestores quanto colaboradores na tomada de decisão referente à internalização ou terceirização da fabricação de determinada peça do processo produtivo do empreendimento.

Assim, pode-se perceber através desta pesquisa que será mais lucrativo para a Empresa Brazcar a fabricação terceirizada do semieixo do triciclo de carga, pois além do custo financeiro ser reduzido em $12 \%$, será possível analisar se a qualidade do produto irá aumentar de forma satisfatória, juntamente com a satisfação dos clientes em receber o produto dentro do prazo estipulado. Além disso, a redução dos custos fará com que os colaboradores passem por um processo de aperfeiçoamento e/ou capacitação, ampliando assim a possibilidade de outras melhorias no processo de fabricação dos triciclos.

\section{REFERÊNCIAS}

[1] AMATO NETO, João. Reestruturação Industrial, Terceirização e Redes de Sub-contratação. 1995. Disponível em: <http://www.rae.com.br/redirect.cfm?ID=485>. Acesso em: 27 mar. 2016.

[2] CÁNEZ, L. E; PLATTS, K. W; PROBERT, D. R. Developing a framework for make-or-buy decisions. International Journal of Operation \& Production Management. v. 20, n. 11, p. 13131330, 2000.
[3] CANEZ, L.E.. PROBERT, D.; PLATTZ, K. Developing a framework for make-or-buy decisions. International Journal of Operations and Productions Management. Bradford: vol. 20, issue 11, p. 1313. 2000.

[4] CONTE, Antônio Lázaro; DURSKI, Gislene Regina. Qualidade. In: MENDES, Judas Tadeu Grassi. Gestão empresarial. Curitiba: Editora Gazeta do Povo, 2002.

[5] GRIMALDI, R. e MANCUSO, J.H. Qualidade Total. Folha de SP e Sebrae, 6o e 7으 fascículos, 1994.

[6] HOFSTEIN, A.P. e LUNETTA, V. The laboratory science education: Foundation for the twenty-first century. Science Education, v. 88, p. 28-54, 2003.

[7] HOLCOMB, T. R.; HITT, M. A. Toward a model of strategic outsourcing. Journal of Operations Management, v. 25, n. 2, p. 464-481, 2007

[8] HOLCOMB, T. R.; HITT, M. A. Toward a model of strategic outsourcing. Journal of Operations Management, $v$. 25, p. 464-481, 2007

[9] JUNIOR, J. M. (2012). Administração da Produção. Curitiba: lesde Brasil.

[10] MARTINS, P. G; LOUGENI, F. P. Administração de produção. São Paulo: Editora Saraiva, 2002.

[11] MOREIRA, D. A. Administração da produção e operações. 5. ed. São Paulo: Pioneira, 2000

[12] SLACK, N.; CHAMBERS, S.; HARLAND, C.; HARRISON, A.; JOHNSTON, R.. Administração da produção. São Paulo: Editora Atlas SA, 2002.

[13] TIDD, Joe et al. Gestão da Inovação. Porto Alegre: Bookman, 2008.

[14] VENKATESAN, R.. Strategic sourcing: to make or not to make. Harvard Bussiness Review, v.70, n.6, p.98- 107, 1992. 
ANEXO A - A TABELA DEMONSTRA O CUSTO MÉDIO NECESSÁRIO PARA A AQUISIÇÃO DE UM SEMIEIXO FABRICADO PELA EMPRESA BRAZCAR.

\begin{tabular}{|c|c|c|c|}
\hline \multicolumn{4}{|l|}{ Fabricação Total do Semieixo na Brazcar } \\
\hline \multicolumn{4}{|c|}{ Custo da Mão de obra com encargos trabalhistas } \\
\hline Descrição & Valor em $\mathrm{R} \$$ & Quantidade & Valor total \\
\hline Custo Homem Hora torneiro mecânico & $\mathrm{R} \$ 31,25$ & 1,047 & $\mathrm{R} \$ 32,72$ \\
\hline Custo Homem Hora ajudante torneiro & $\mathrm{R} \$ 17,25$ & 1,047 & $\mathrm{R} \$ 18,06$ \\
\hline Custo Homem Hora Soldador & $R \$ 21,87$ & 0,1 & $\mathrm{R} \$ 2,19$ \\
\hline \multicolumn{4}{|l|}{ Custo da Matéria-Prima } \\
\hline Descrição & Valor em $\mathrm{R} \$$ & Quantidade & Valor total \\
\hline Aço trefilado 35 mm / kg com frete & $\mathrm{R} \$ 6,75$ & 5,5 & $R \$ 37,13$ \\
\hline Flange com corte laser com frete & $R \$ 52,72$ & 1 & $R \$ 52,72$ \\
\hline \multicolumn{4}{|l|}{ Custo das Ferramentas } \\
\hline Ferramentas de corte & Valor em $\mathrm{R} \$$ & Rendimento & Valor total \\
\hline Pastilha P30 & $\mathrm{R} \$ 9,50$ & 0,1 & $\mathrm{R} \$ 0,95$ \\
\hline Pastilha K10 & $\mathrm{R} \$ 9,30$ & 0,1 & $\mathrm{R} \$ 0,93$ \\
\hline Knux & $\mathrm{R} \$ 18,80$ & 0,05 & $R \$ 0,94$ \\
\hline Lâmina Serra & $\mathrm{R} \$ 48,80$ & 0,01 & $R \$ 0,49$ \\
\hline \multicolumn{4}{|c|}{$\begin{array}{l}\text { Custo com Depreciação do torno } \\
\text { (de acordo com a tabela da Receita Federal - NCM de referência 8458) }\end{array}$} \\
\hline Descrição & Valor em $\mathrm{R} \$$ & Rendimento & Valor Total \\
\hline Valor do Torno & $\mathrm{R} \$ 30.000,00$ & - & $\mathrm{R} \$ 30.000,00$ \\
\hline Depreciação anual (10\%) & $\mathrm{R} \$ 3.000,00$ & - & $\mathrm{R} \$ 3.000,00$ \\
\hline Depreciação por hora & $\mathrm{R} \$ 1,56$ & 1,047 & $\mathrm{R} \$ 1,63$ \\
\hline \multicolumn{4}{|c|}{$\begin{array}{l}\text { Custo com depreciação do aparelho de solda } \\
\text { (de acordo com a tabela da Receita Federal - NCM 8468) }\end{array}$} \\
\hline Descrição & Valor em $\mathrm{R} \$$ & Rendimento & Valor total \\
\hline Valor do aparelho de solda & $\mathrm{R} \$ 5.500,00$ & - & $\mathrm{R} \$ 5.500,00$ \\
\hline Depreciação anual (10\%) & $\mathrm{R} \$ 550,00$ & - & $\mathrm{R} \$ 550,00$ \\
\hline Depreciação por hora & $R \$ 0,29$ & 0,1 & $\mathrm{R} \$ 0,03$ \\
\hline \multicolumn{4}{|l|}{ Equipamentos Consumíveis } \\
\hline Descrição & Valor em $\mathrm{R} \$$ & Rendimento & Valor total \\
\hline Arame de solda & $\mathrm{R} \$ 8,44$ & 0,2 & $\mathrm{R} \$ 1,69$ \\
\hline Mistura de gases para soldagem MIG & $\mathrm{R} \$ 208,1$ & 0,01 & $\mathrm{R} \$ 2,08$ \\
\hline Bico de contato MIG & $R \$ 3,50$ & 0,02 & $R \$ 0,07$ \\
\hline Anti-respingo de solda & $\mathrm{R} \$ 11,85$ & 0,01 & $\mathrm{R} \$ 0,12$ \\
\hline GLP (Gás liquefeito de petróleo) & $R \$ 53,00$ & 0,05 & $\mathrm{R} \$ 2,65$ \\
\hline \multicolumn{4}{|l|}{ Custos Fixos e Administrativos } \\
\hline Descrição & Valor em $\mathrm{R} \$$ & Rendimento & Valor total \\
\hline Custo Administrativo/hora & $\mathrm{R} \$ 55,75$ & 1,047 & $\mathrm{R} \$ 58,37$ \\
\hline Custo fixo Aluguel / hora / área & $R \$ 5,50$ & 1,047 & $\mathrm{R} \$ 5,76$ \\
\hline \multicolumn{3}{|l|}{ Custo total final } & $\mathrm{R} \$ 214,37$ \\
\hline
\end{tabular}


ANEXO B - A TABELA DEMONSTRA O CUSTO MÉDIO NECESSÁRIO PARA A AQUISIÇÃO DE UM SEMIEIXO DE MANEIRA TERCEIRIZADA.

\begin{tabular}{|c|c|c|c|}
\hline \multicolumn{4}{|c|}{ Fabricação Terceirizada do Semieixo } \\
\hline \multicolumn{4}{|c|}{ Mão de obra com encargos trabalhistas } \\
\hline Descrição & Valor em $\mathrm{R} \$$ & Quantidade & Valor total \\
\hline Custo Homem Hora torneiro mecânico & $\mathrm{R} \$ 31,25$ & 0,18 & $\mathrm{R} \$ 5,63$ \\
\hline Custo Homem Hora Soldador & $\mathrm{R} \$ 21,87$ & 0,1 & $\mathrm{R} \$ 2,19$ \\
\hline \multicolumn{4}{|l|}{ Matéria-prima } \\
\hline Semieixo pré-fabricado c/ frete & $R \$ 114,00$ & 1 & $\mathrm{R} \$ 114,00$ \\
\hline Flange com corte laser $\mathrm{c} /$ frete & $\mathrm{R} \$ 50,72$ & 1 & $\mathrm{R} \$ 50,72$ \\
\hline \multicolumn{4}{|c|}{ Ferramentas } \\
\hline Ferramentas de corte & Valor em $\mathrm{R} \$$ & Rendimento & Valor total \\
\hline Pastilha P30 & $\mathrm{R} \$ 8,50$ & 0,02 & $\mathrm{R} \$ 0,17$ \\
\hline Pastilha K10 & $\mathrm{R} \$ 8,50$ & 0,02 & $R \$ 0,17$ \\
\hline Knux & $\mathrm{R} \$ 18,30$ & 0,05 & $\mathrm{R} \$ 0,92$ \\
\hline \multicolumn{4}{|c|}{ Depreciação do torno } \\
\hline \multicolumn{4}{|c|}{ (de acordo com a tabela da Receita Federal - NCM de referência 8458) } \\
\hline Descrição & Valor em $\mathrm{R} \$$ & Quantidade & Valor total \\
\hline Valor do Torno & $\mathrm{R} \$ 30.000,00$ & 1 & $\mathrm{R} \$ 30.000,00$ \\
\hline Depreciação anual (10\%) & $\mathrm{R} \$ 3.000,00$ & 1 & $\mathrm{R} \$ 3.000,00$ \\
\hline Depreciação por hora & $\mathrm{R} \$ 1,56$ & 0,18 & $\mathrm{R} \$ 0,28$ \\
\hline \multicolumn{4}{|c|}{ Depreciação do aparelho de solda } \\
\hline \multicolumn{4}{|c|}{ (de acordo com a tabela da Receita Federal - NCM 8468) } \\
\hline Descrição & Valor em $\mathrm{R} \$$ & Quantidade & Valor total \\
\hline Valor do aparelho de solda & $R \$ 5.500,00$ & 1 & $\mathrm{R} \$ 5.500,00$ \\
\hline Depreciação anual (10\%) & $\mathrm{R} \$ 550,00$ & 1 & $R \$ 550,00$ \\
\hline Depreciação por hora & $\mathrm{R} \$ 0,29$ & 0,1 & $\mathrm{R} \$ 0,03$ \\
\hline \multicolumn{4}{|c|}{ Consumíveis } \\
\hline Descrição & Valor em $\mathrm{R} \$$ & Rendimento & Valor total \\
\hline Arame de solda & $\mathrm{R} \$ \quad 8,44$ & 0,2 & $\mathrm{R} \$ 1,69$ \\
\hline Mistura de gases para soldagem MIG & $\mathrm{R} \$ 208,11$ & 0,01 & $\mathrm{R} \$ 2,08$ \\
\hline Bico de contato MIG & $\mathrm{R} \$ \quad 3,50$ & 0,02 & $\mathrm{R} \$ 0,07$ \\
\hline Anti-respingo de solda & $\mathrm{R} \$ 11,85$ & 0,01 & $\mathrm{R} \$ 0,12$ \\
\hline GLP (Gás liquefeito de petróleo) & - & - & - \\
\hline \multicolumn{4}{|c|}{ Custos Fixos e Administrativos } \\
\hline Descrição & Valor em $\mathrm{R} \$$ & Rendimento & Valor total \\
\hline Custo Administração/hora & $\mathrm{R} \$ 55,75$ & 0,18 & $\mathrm{R} \$ \quad 10,04$ \\
\hline Custo fixo Aluguel / hora / área & $\mathrm{R} \$ 5,50$ & 0,18 & $\mathrm{R} \$ \quad 0,99$ \\
\hline \multicolumn{3}{|c|}{ Custo Total final } & $\mathrm{R} \$ 189,08$ \\
\hline
\end{tabular}




\title{
CAPÍTULO 17
}

\section{A IMPORTÂNCIA DA REDUÇÃ̃O NA GERAÇÃO DE RESÍDUO LIMALHA DE AÇO PELA ALTERAÇÃo DAS ETAPAS DE UM PROCESSO DE FABRICAÇÃ̃O}

\author{
Mario Fernando Mello \\ Jéssica Citron Muneroli
}

Resumo: No mundo competitivo em que as empresas se encontram otimizar processos reduzindo desperdícios é um desafio a ser perseguido diariamente. O presente estudo foi desenvolvido em uma empresa de implementos agrícolas, localizada no norte do Estado do Rio Grande do Sul e tem por objetivo principal identificar perdas em um processo de estamparia bem como diminuir a contaminação do ambiente com o aço residual proveniente do processo de fabricação, promovendo as mudanças necessárias no referido processo. O trabalho foi realizado durante os meses de setembro a dezembro de 2015. Aumentar a produtividade e reduzir a contaminação ambiental em função de um resíduo chamado limalha de aço ficou comprovado ser possível através da mudança de um processo produtivo. Através das análises e as mudanças sugeridas no novo processo pode-se concluir que com as alterações nas etapas do processo de fabricação, os benefícios ocorreram tanto nas questões econômicas quanto nas questões ambientais.

Palavras chave: Resíduo; Eliminação de desperdícios; Processos Produtivos. 


\section{INTRODUÇÃO}

As empresas procuram cada vez padronizar seus processos e operações enfatizando a busca da melhoria contínua como uma importante ferramenta não só operacional, mas também motivacional. A implantação de métodos na administração da produção é importante para que a organização busque constantemente a melhoria de seus processos e com isso aumente sua competitividade no concorrido mercado atual.

A administração da produção está no centro de muitas mudanças que afetam o dia a dia das organizações e o uso de tecnologias e novos conceitos é sempre desafiador uma vez que muitas vezes a falta de investimento ou até mesmo de treinamento tornam as mudanças mais lentas e menos competitivas.

Desafios tecnológicos e ambientais estão cada vez mais presentes nos processos produtivos e em consequência estratégicos em sua perspectiva na questão de produção. Assim, segundo Slack et.al. (2009) a responsabilidade de qualquer equipe de produção é entender quais são seus objetivos implicando num desenvolvimento de visão clara sobre processos produtivos. Por isso é importante, para manter uma gestão eficiente que sejam integrados todos esses fatores em busca do bem comum que acaba se traduzindo em melhor produtividade e melhor rentabilidade da organização.

Nos paradigmas de melhoria de processos, segundo Antunes (2008), estabelece-se uma clara diferença entre os fins, que estão diretamente relacionados às melhorias nos processos e as consequências econômicas, que muitas vezes não estão relacionados às melhorias de operações, porém sempre tendo em vista a melhoria do processo como um todo.

O presente estudo foi desenvolvido em uma empresa de implementos agrícolas, localizada no norte do Estado do Rio Grande do Sul e tem por objetivo principal identificar perdas em um processo de estamparia bem como diminuir a contaminação do ambiente com o aço residual proveniente do processo de fabricação, promovendo as mudanças necessárias no referido processo. O trabalho foi realizado durante os meses de setembro a dezembro de 2015.

\section{REFERENCIAL TEÓRICO}

Neste capítulo serão descritos conceitos e práticas de autores consagrados no assunto em questão que irão embasar teoricamente o presente estudo.

\subsection{ENTENDIMENTO DE PROCESSOS}

Segundo Martins e Laugeni (2005), os processos, do mesmo modo que o conceito de qualidade podem ser determinado de maneiras distintas. Tal como um conjunto de ações por meio das quais os insumos se tornam bens ou serviços, além de um conjunto de recursos e atividades inter-relacionadas que tornam os insumos - entradas - em serviços ou produtos saídas, ou ainda o conjunto de ações correlacionadas e integradas que tornam os insumos recebidos em produtos ou serviços e agregam o valor aos usuários dos mesmos, ou o conjunto de recursos - humanos e materiais - direcionados às atividades necessárias à produção de um resultado final específico, independente de relacionamento hierárquico.

Correa et. al. (2001), por sua vez, explicam a existência dos macroprocessos, que consistem em um conjunto de processos que dizem respeito a uma função da empresa. Estes macroprocessos se encontram organizados em processos críticos e de apoio. De modo que o processo crítico consiste naquele de natureza estratégica para o êxito da instituição. Geralmente são denominados deste modo os principais processos críticos, ainda que alguns processos de apoio - ou processo-meio - possam classificar-se como críticos por conta da importância ou do impacto que causam nos resultados da empresa. Os autores explicam que um exemplo disso é o processo de pagamento de funcionários que incide de maneira direta no processofim para as empresas.

Estes conceitos do que significa qualidade e sua cultura devem atingir diretamente a organização e todos os membros envolvidos na gestão desta. Desde gestores até níveis operacionais da empresa devem estar alinhados e cientes de todos os passos e processos que fazem parte da busca por uma gestão de qualidade. Para que este modelo de gestão seja 
implantado e mantido durante todo o processo de gestão, é necessário que os gestores destaquem a importância da qualidade desde o início e mantenham o discurso durante todo o momento. Ou seja, o conceito de qualidade deve se manter imputado na política da organização.

Para Slack et.al. (2009), para que haja uma boa administração, toda a equipe, setores e processos da organização devem estar alinhados e buscar um mesmo conceito de qualidade. Ainda segundo os mesmo autores é preciso que a organização saiba identificar corretamente os tipos de seus processos uma vez que os mesmos apresentam muitas variantes. Ou seja, quando o processo em si apresenta alguma falha, ou até mesmo não está bem definido, mesmo que a equipe esteja focada e disposta, dificilmente conseguirá compensar esta carência. Quando as organizações conseguem executar processos contínuos e sem, ou com pouca interrupção, é provável que o mesmo torne-se repetitivo e em consequência o padrão está mais próximo de ser atingido.

\subsection{GESTÃO DA QUALIDADE}

O gerenciamento da rotina do dia-a-dia facilita 0 aperfeiçoamento das organizações em geral. Para Campos (2004) agregar valor a um produto é agregar valor ao seu cliente. Desta forma para atingir metas de melhoria é necessário estabelecer novos padrões ou modificar os padrões existentes. Assim gerenciar é estabelecer novos padrões, modificar os padrões existentes ou cumpri-los. Campos (2004) ressalta que a padronização é o cerne do gerenciamento.

Paladini (2011) corroborando com Campos (2004), diz que a necessidade pela qualidade de produtos e serviços passa pela decisão gerencial de produzir com qualidade alterando processos levando em conta a realidade de mercado buscando maior produtividade e lucratividade. É bem verdade, segundo Paladini (2011) que muitas vezes há equívocos na definição de qualidade e que no cotidiano existem muitos conceitos incorretos sendo que o aumento de custo para produzir com qualidade, normalmente é um deles. Por isso, neste contexto aliar qualidade com produtividade e custos, segundo Campos (2004) é o grande desafio que as organizações enfrentam.

Ainda para Campos (2004) se organização pensa em qualidade para melhorar seus resultados, deve acompanhar esses resultados sistematicamente por meio de itens de controle que garantam conduzir as mudanças que se fizerem necessárias em função do desempenho. Acompanhar os custos de produção e dos processos é fundamental na gestão da qualidade.

\subsection{MÉTODO DO CICLO PDCA}

Para Campos (2004) o método de melhorias, ou o Ciclo PDCA (Plan, Do, Check, Action), pode ser definido como uma metodologia de gestão de processos e de sistemas que consiste no caminho adequado para atingir as metas estipuladas sobre produtos de sistemas organizacionais. O método foi popularizado na década de 1950 com os conceitos de Gestão da Qualidade.

Os termos no Ciclo PDCA, segundo Campos (2004) têm o seguinte significado:

- Planejamento (P):

- Estabelece metas sobre os itens de controle;

- Estabelece a maneira, o caminho do método, para atingir as metas propostas.

- Execução (D):

- Execução das tarefas conforme previstas no plano e coleta de dados para verificação do processo.

- Verificação (C):

- A partir dos dados coletados na execução, compara-se o resultado alcançado com a meta planejada.

- Atuação corretiva (A):

- Esta é a etapa onde o usuário detectou desvios e atuará no sentido de fazer correções definitivas, de tal modo que o problema não volte a ocorrer. 
As etapas do Ciclo PDCA estão demonstradas na figura 1. Ainda segundo Campos (2004) o Ciclo PDCA é utilizado para a manutenção do nível de controle, ou cumprimento das diretrizes de controle, para quando um processo é repetitivo.

Figura 1 - Ciclo PDCA de controle de Processos

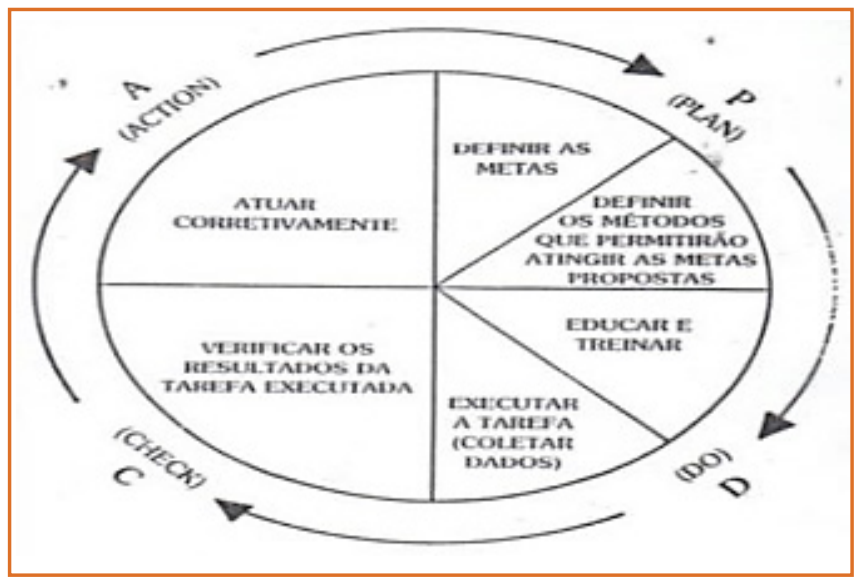

Fonte: Campos, 2004.

Paladini (2011) salienta que classificar defeitos faz sentido, pois de fato, o esforço em detectar, corrigir e, principalmente evitar defeitos é uma meta prioritária no esforço de produzir qualidade. Nesse sentido a utilização do Ciclo PDCA na prevenção de defeitos atua com uma visão de futuro, baseada em fatos passados, ajudando na própria definição básica de qualidade.

Campos (2004) ainda afirma que a utilização do PDCA se permeia de uma série de possibilidades, sendo que este pode ser utilizado a fim de estipular novas metas que visam à melhoria de processos, oriundas de diretrizes fornecidas pela alta administração de uma empresa, objetivando assim coordenar os esforços para um programa de qualidade que se perpetue. Neste ponto, ressalta-se também que cada um dos programas de melhoria deve ser iniciado por meio do planejamento atento que resultará na definição da meta e, posteriormente em ações efetivas, comprovando assim a eficácia das medidas para que seja possível, finalmente, obter os resultados da melhoria que se propôs e na consolidação da empresa.
O mesmo autor ainda ressalta que outra atribuição que pode ser dada ao ciclo é a resolução de problemas crônicos que as empresas enfrentam sobre seu desempenho. Essa interferências podem culminar em impactos negativos em seus resultados. Dessa forma, é possível compreender o dito ciclo de maneira que este se projeta a fim de ser utilizado de maneira dinâmica. Quando uma volta do ciclo se completa, o próximo ciclo começa a fluir e assim ocorre sucessivamente.

\subsection{MELHORIA CONTÍNUA}

Atualmente a busca da melhoria contínua é perseguida por uma grande parcela de organizações. A abordagem "enxuta", segundo Slack et.al. (2009), está sendo adotada fora de suas raízes automotivas tradicionais, manufatureiras e de alto volume. No entanto, onde quer que seja aplicada os princípios são os mesmos.

Ainda segundo Slack et.al. (2009) o princípio chave de operações enxutas é relativamente fácil e claro de entender. Significa mover-se na direção de eliminar todos os desperdícios de modo a desenvolver uma operação que seja mais rápida, mais confiável, produz produtos e serviços de mais alta qualidade e acima de tudo, opera com custo baixo.

Os mesmos autores definem que a parte mais significativa da filosofia enxuta é seu foco na eliminação de todas as formas de desperdício, que pode ser definido como qualquer atividade que não agregue valor ao produto ou serviço e que existem vários aspectos envolvidos em uma gestão que visa à melhoria contínua no sentido de reduzir os custos de operação e elevar a qualidade dos produtos e serviços oferecidos pela empresa. Assim, utilizar os princípios da gestão da qualidade é uma alternativa viável e necessária para a implementação da melhoria contínua na gestão da empresa.

Ainda, segundo Campos (2004) é possível verificar que, quando se atinge tamanho grau de comprometimento dos colaboradores, todos agem da mesma maneira, cuidando e zelando pelo que é seu no trabalho, um fator que tende a minimizar de maneira exponencial os custos 
com a operação, evitando manutenções, aquisições de materiais e equipamentos desnecessários, que podem ser evitados somente com a atitude de zelo e cuidado por parte dos colaboradores.

Para Shingo (1996) os processos podem ser melhorados de duas maneiras. A primeira consiste em melhorar o produto a partir da engenharia de valor. A segunda consiste em melhorar os métodos de fabricação do ponto de vista da engenharia de produção ou da tecnologia de fabricação. Nesse sentido este estudo buscou dentro desta filosofia de Shingo (1996) responder a questão de como a fabricação do produto pode ser melhorada. Ainda segundo o mesmo autor na busca da melhoria contínua é fundamental a análise básica do processo no qual se quer a mudança. Melhorias baseadas nos conceitos da engenharia de produção para descobrir, analisar e eliminar perdas são essenciais para a construção de sistemas produtivos mais eficientes e eficazes.

\subsection{PRODUÇÃO MAIS LIMPA}

Um dos aspectos mais importantes e relevantes na gestão empresarial nos últimos anos foi a gradativa compreensão de que a adoção de medidas que visam uma maior eficiência na prevenção da contaminação, segundo Dias (2011), é muito mais vantajosa não só do ponto de vista de se evitarem problemas ambientais, mas também porque resultam em aumento da competitividade.

A produção mais limpa, segundo Dias (2011) adota os seguintes procedimentos:

\section{a. Quanto aos processos de produção: conservando} as matérias-primas e a energia, eliminando aquelas que são tóxicas e reduzindo a quantidade e a toxidade de todas as emissões e resíduos;

b. Quanto aos produtos: reduzindo os impactos ambientais negativos ao longo do ciclo de vida dos produtos;

c. Quanto aos serviços: incorporando as preocupações ambientais no projeto e fornecimento dos serviços.
Ainda para Dias (2011) existem alguns fatores que afetam a adoção dos conceitos de produção mais limpa. Do ponto de vista das empresas é necessário identificar se existem fatores estruturais ou comerciais que não incentivem a mudança para romper a barreira de processos produtivos. Identificados, devem ser eliminados para que a empresa transforme o que normalmente é visto como um problema ambiental em novas oportunidades de negócio.

\section{METODOLOGIA}

O presente estudo foi dividido em três etapas. A primeira delas consistiu na busca de referencial teórico para embasar o trabalho de campo. A segunda etapa foi executada na empresa com a busca de dados e elementos de um processo produtivo visando sua melhoria. E por fim a terceira etapa foi a análise dos resultados, a sugestão de mudança no processo analisado e a comparação das atividades desenvolvidas.

O presente trabalho trata-se de um estudo de caso que segundo Yin (2010), é uma investigação empírica de um fenômeno contemporâneo em seu contexto de vida real onde o investigador enfrentará circunstâncias técnicas e distintas em função do fenômeno real. O mesmo autor ressalta que o estudo de caso evidenciase por meio de documentos, registros em arquivos, entrevistas, observações diretas, além de artefatos físicos.

O trabalho foi realizado em uma empresa de médio porte do setor de máquinas agrícolas que está localizada na região norte do estado do Rio Grande do Sul, durante os meses de setembro a dezembro de 2015.

Inicialmente foi feita uma reunião com o gerente administrativo para discutir sobre a empresa e seus processos para então definir a possível melhoria que seria aplicada. A melhoria sugerida e escolhida foi desenvolver uma solução para reduzir a geração de resíduos de aço, chamados de limalha, alterando seu processo de fabricação. 
Após debater e analisar a melhoria escolhida pôde-se perceber sua importância, pois reduzindo os resíduos de limalha, diminuirá a contaminação ao ambiente. O aço será melhor aproveitado e mudando o processo de fabricação, aumentará sua produtividade reduzindo o ferramental utilizado e reduzirá também sua mão de obra.

A coleta dos dados foi feita no setor de estamparia onde primeiramente foi analisado o processo antigo, anotado seus passos e o tempo para processo das peças. Depois de aplicado a melhoria escolhida, foi registrado seu novo passo a passo, fotografase e compara-se com o antigo processo para então demonstrar as melhorias obtidas.

\section{RESULTADOS}

Neste capítulo serão demonstrados os resultados do presente estudo.

\subsection{SITUAÇÃO INICIAL NO PROCESSO}

A empresa produz plantadeiras e semeadeiras, sendo a maioria das peças fabricadas por ela mesma e algumas terceirizadas. O processo escolhido para aplicar a melhoria foi na produção de peças com furos de $41 \mathrm{~mm}$ de diâmetro. A peça primeiramente passava por uma prensa para ser feito seu pré-furo e, em seguida, ia para a furadeira, onde se realizava a furação com várias brocas até chegar ao diâmetro $41 \mathrm{~mm}$. Esse processo levava em torno de 15 minutos para cada peça. No processo existem oito furadeiras.

$\mathrm{Na}$ figura 2 está demonstrado o equipamento, furadeira, onde é feito o processo do furo até chegar aos $41 \mathrm{~mm}$ de diâmetro, bem como o operador fazendo o processo de furação em uma chapa de aço.

Percebe-se ainda na figura 2, identificada pela seta, a quantidade de resíduos de aço acumulada no chão durante o processo. Esse resíduo chamado de limalha é o que sobra após a execução dos furos.
Figura 2 - Furadeira e resíduos limalha

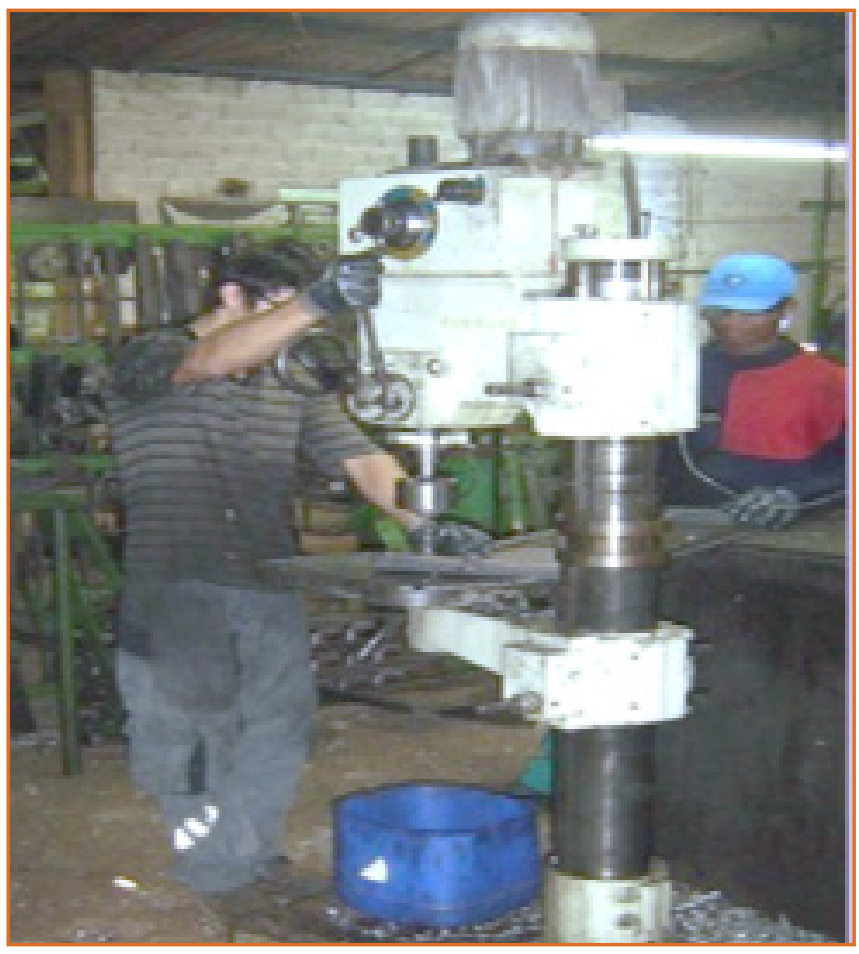

Já na figura 3 estão demonstrados exemplos de peças acabadas. Ou seja, peças que já passaram pela prensa para ser feito o pré-furo e também que já passaram pela furadeira onde foi feito o processo de furação de $41 \mathrm{~mm}$ de diâmetro em cada peça.

Figura 3 - Peças acabadas

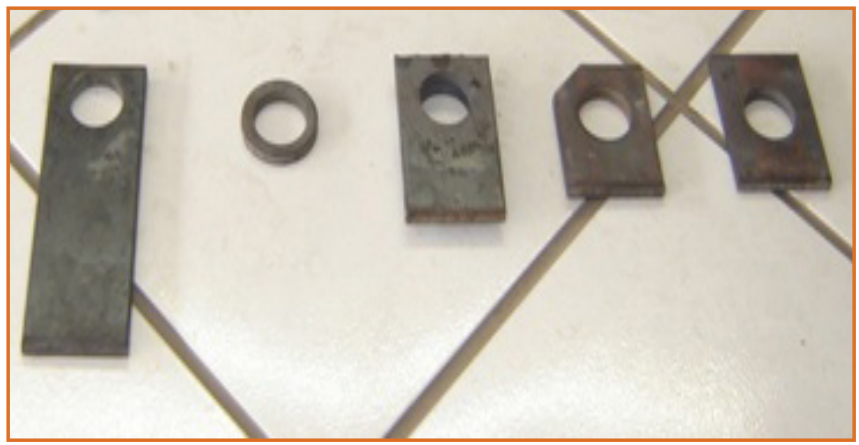

\subsubsection{FATORES IDENTIFICADOS COMO PREOCUPANTES}

Nesse processo pode-se notar/avaliar diversos fatores preocupantes: O tempo de furação para cada peça é demorado, pois a produção das mesmas é de grande demanda todos os dias. Pode-se perceber, na figura 
2, que o resíduo de limalha de aço que sai das peças na sua furação é alto, além de estar prejudicando o ambiente, é um custo elevado para a empresa também, pois o que sobra não possui reaproveitamento e é vendido por um preço muito baixo. O gasto com energia é alto, pois são oito furadeiras trabalhando e possui bastante mão de obra com elevado consumo de ferramentas.

\subsection{DESENVOLVIMENTO DA SOLUÇÃO}

Para obtenção dos resultados, foi utilizada a ferramenta PDCA, detalhando as etapas a serem executas, conforme mostra a figura 4.

Nesta etapa foram eleitas atividades necessárias à melhoria do processo em estudo e detalhadas adaptando-as ao Ciclo PDCA.

Figura 4 - Atividades adaptadas ao Ciclo PDCA

\begin{tabular}{|c|c|c|}
\hline \multirow{4}{*}{$\mathbf{P}$} & $\underline{\text { Identificação do Problema }}$ & $\begin{array}{l}\text { Elevadas sobras de resíduo maravalha prejudicando o ambiente e não possuindo } \\
\text { reaproveitamento das mesmas, além da demora para o processo das peças. }\end{array}$ \\
\hline & $\underline{\text { Observação }}$ & $\begin{array}{l}\text { Ao furar cada peça com a furadeira percebe-s,e que há muita geração de maravalha, } \\
\text { alto consumo de energia, alta mão de obra, alto consumo de ferramentas e os residuos } \\
\text { de maravalha não são utilizados para outros processos, sendo vendidos por um valor } \\
\text { muito baixo. }\end{array}$ \\
\hline & $\underline{\text { Análise }}$ & $\begin{array}{l}\text { Ao analisar pode-se perceber que o problema era a furadeira, ou seja, o problema } \\
\text { estava no processo. Deve-se alterar esta etapa do processo de fabricação para poder } \\
\text { otimizar o processo. }\end{array}$ \\
\hline & $\underline{\text { Plano de ação }}$ & $\begin{array}{l}\text { Investir e adquirir uma nova matriz (Prensa Excêntrica) no valor de R\$1.800,00 para } \\
\text { diminuir/eliminar a geração dos resíduos de maravalha. }\end{array}$ \\
\hline & $\underline{\text { Execução }}$ & $\begin{array}{l}\text { Nova matriz em funcionamento juntamente com a furadeira para compararmos se } \\
\text { realmente o processo é mais rápido, com alta qualidade e se irá reduzir/eliminar os } \\
\text { resíduos de maravalha. }\end{array}$ \\
\hline & $\underline{\text { Verificação }}$ & $\begin{array}{l}\text { A partir da estampagem direta no diâmetro necessário foi eliminado o processo de } \\
\text { furação, consequentemente, eliminou também a geração de resíduos maravalha e os } \\
\text { retalhos foram reaproveitados para produção do conjunto fuso. Verificando também a } \\
\text { redução de mão de obra, redução do consumo ferramental e redução no gasto com } \\
\text { energia. }\end{array}$ \\
\hline \multirow{2}{*}{$\mathbf{A}$} & $\underline{\text { Padronização }}$ & $\begin{array}{l}\text { Com o antigo processo, cada peça chegava a demorar, às vezes, em torno de } 15 \\
\text { minutos para ser feito o processo de furação, já com o novo processo em menos de um } \\
\text { minuto, as peças já estão prontas, então foram eliminados as furadeiras para este } \\
\text { processo, deixando apenas a matriz funcionando, pois apenas ela já produz o } \\
\text { necessário para a demanda estabelecida por dia. }\end{array}$ \\
\hline & $\underline{\text { Conclusão }}$ & $\begin{array}{l}\text { Além da eliminação de resíduos maravalha e melhor beneficio econômico, também } \\
\text { houve beneficios ambientais, pois reduziu o consumo de chapas, insumos e geração de } \\
\text { resíduos maravalhas que contaminam o ambiente. E benefícios no processo, pois } \\
\text { reduziu o tempo de fabricação do conjunto fuso por não precisar mais trabalhar com } \\
\text { chapas de aço. }\end{array}$ \\
\hline
\end{tabular}

\subsection{DETALHAMENTO DA SITUAÇÃO ATUAL}

\subsection{1 - AQUISIÇÃO DE NOVO EQUIPAMENTO PARA} MUDANÇA DO PROCESSO

Após a aquisição da matriz, as peças não precisam mais passar pela prensa para ser feito o pré-furo, pois a mesma realiza a estampagem na peça no diâmetro de $41 \mathrm{~mm}$. Foi adquirida uma prensa excêntrica para a execução das peças no novo processo. Assim, foi alterado o processo de fabricação onde o operador faz direto o furo sem precisar passar pela antiga prensa. 
Com esse novo processo o resíduo limalha de aço foi eliminado totalmente, restando apenas retalhos que podem ser usados em reaproveitamentos.

\subsubsection{RETALHOS APÓS O PROCESSO}

A partir da estampagem direta no diâmetro necessário foi eliminado o processo de furação, consequentemente, eliminou também a geração de resíduos limalha. Pois agora o que sobra da prensa são retalhos.

A figura 5 demonstra as peças acabadas no novo processo, e embaixo mostra os retalhos que sobram do processo, os quais podem ser reutilizados para outros processos. Obtendo agora os retalhos, não existem mais resíduos de limalha, que foram eliminados em $100 \%$.

Para que os retalhos não fossem esquecidos em um canto ou até mesmo vendidos, como acontecia com os resíduos de limalha, após analisar as demais peças produzidas na empresa, pôde-se notar que esse retalho poderia ser reaproveitado para produção do conjunto fuso demonstrado na figura 6. Desta forma não foi mais necessário comprar novas chapa para fazê-lo e também não era mais gasto com mão de obra. Apenas o que deve ser feito é realizar um pequeno furo no retalho e soldá-lo na peça.

Figura 5 - Peças acabadas e retalhos

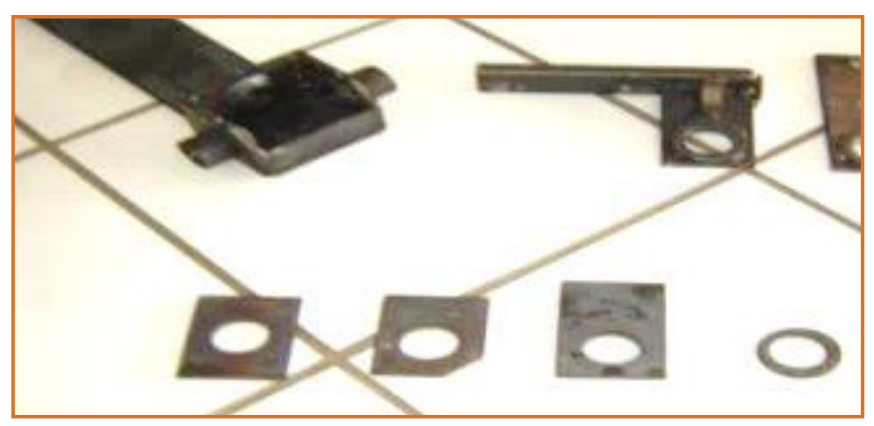

A figura 6 demonstra que o retalho que sobra no processo de estampagem é usado para produção do conjunto fuso, fazendo com que não precise mais ser feito a compra de chapas para a sua elaboração. No retalho é feito um pequeno furo para encaixar no fuso de regulagem, sobrando ainda um pequeno retalho que também poderá ser reaproveitado futuramente.

Figura 6 - Conjunto fuso

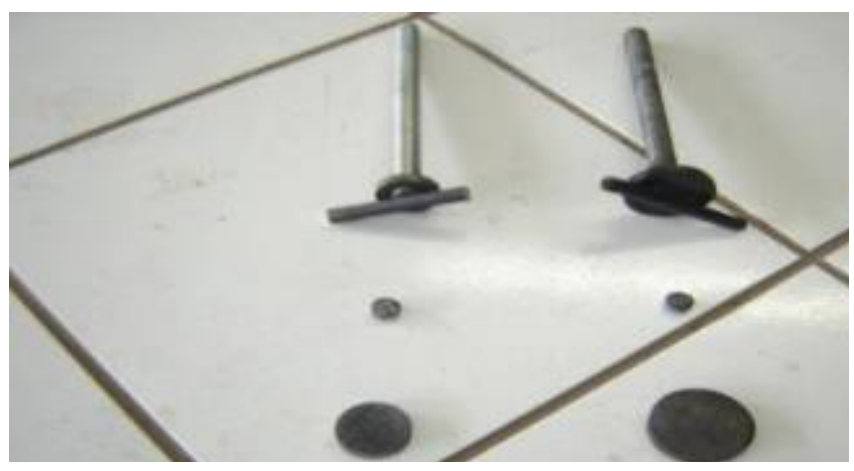

Após verificar-se que a mudança no processo trouxe várias vantagens, foram analisados também valores numéricos na redução de quilogramas de limalha, bem como com o reaproveitamento dos retalhos na confecção do conjunto fuso.

\subsubsection{REDUÇÃO DE LIMALHA DE AÇO}

Está demonstrado no quadro 1 que o resultado obtido foi excelente em comparação à execução do processo anterior. Não possui mais custo de furação na furadeira, pois esta não será mais utilizada para este processo. O valor de venda do retalho é maior em relação ao valor de venda da limalha. E o principal, o custo de fabricação da peça diminuiu $8 \%$ em relação ao custo anterior, além de diminuir em $100 \%$ o total de resíduos que era gerado, pois agora o retalho que sobra é reaproveitado para outras peças.

A redução total do resíduo limalha de aço foi de $246 \mathrm{~kg}$ num período de um mês. 


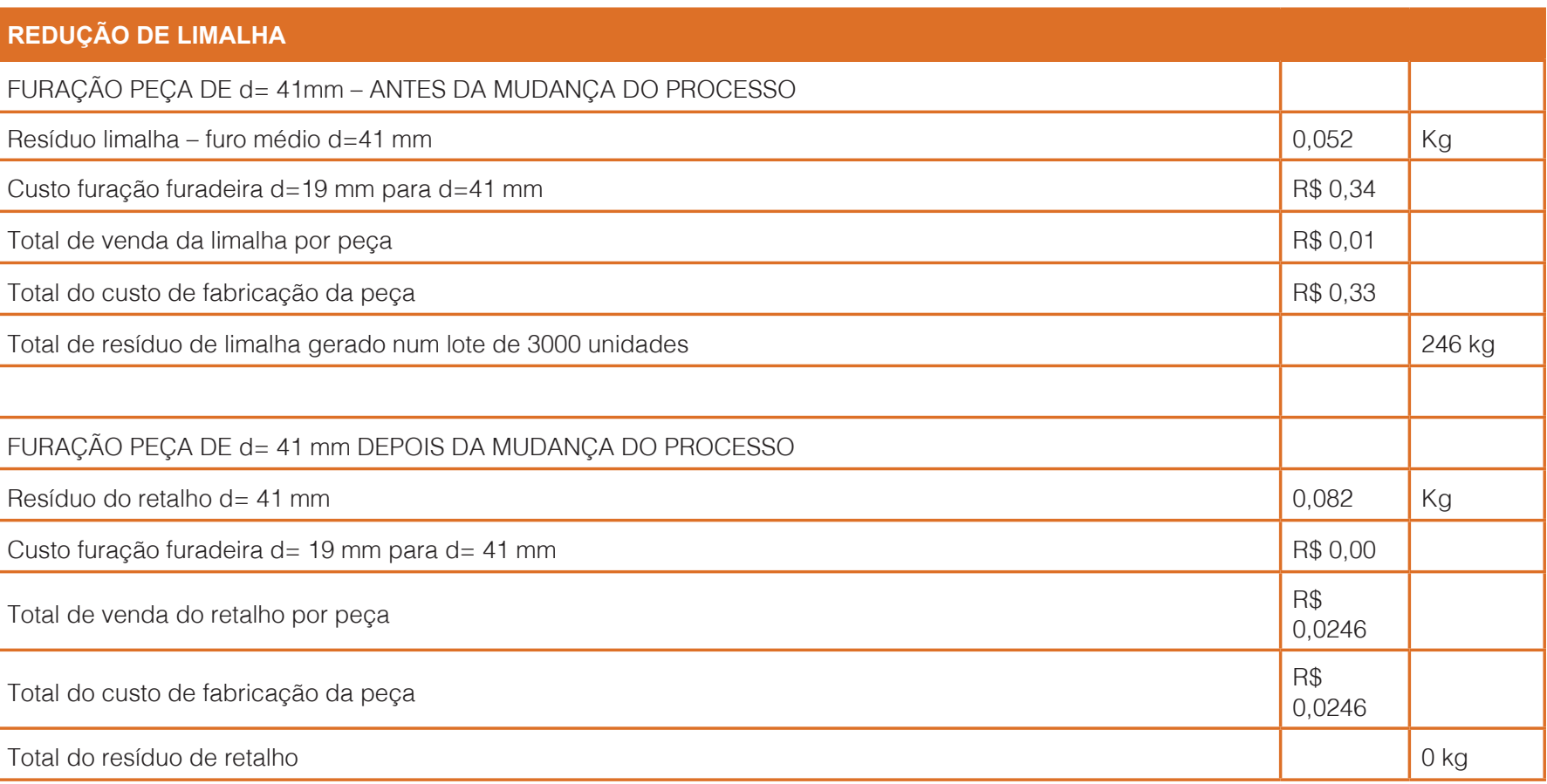

No quadro 2 está demonstrado o benefício do reaproveitamento dos retalhos que sobram do processo. Este reaproveitamento faz com que não seja necessário comprar chapas de aço para esta operação de fabricação do conjunto fuso.

Quadro 2 - Redução do consumo de chapa de aço

\begin{tabular}{|c|c|c|c|}
\hline \multicolumn{4}{|c|}{ Conjunto Fuso } \\
\hline \multicolumn{4}{|c|}{ Antes } \\
\hline Compra chapa 44x44 (146g) & $\mathrm{R} \$$ & 0,44 & \\
\hline Mão de obra & $\mathrm{R} \$$ & 0,34 & \\
\hline Custo total & $\mathrm{R} \$$ & 0,78 & \\
\hline Redução do consumo de chapa de aço & & 438 & $\mathbf{k g}$ \\
\hline \multicolumn{4}{|l|}{ Depois } \\
\hline Substituição da chapa por retalho $d=41 \mathrm{~mm}$ & $\mathrm{R} \$$ & 0,02 & \\
\hline Custo total & $\mathrm{R} \$$ & 0,02 & \\
\hline Benefício fabricação Conjunto fuso por peça & $\mathrm{R} \$$ & 0,75 & \\
\hline Quantidade produção conjunto fuso & & 3000 & unidades \\
\hline Benefício total fabricação conjunto fuso & $\mathbf{R} \$$ & & $2.260,20$ \\
\hline
\end{tabular}

Fonte: Empresa pesquisada

O quadro 3 demonstra o ganho obtido com a troca do processo. Como foi deixado de utilizar o processo de furação foi reduzido o valor de $\mathrm{R} \$ 0,34$ por unidade. A troca do processo furação por estampagem considerando uma quantidade de 6400 unidades proporcionou uma redução de $\mathrm{R} \$ 2.176,00$.
Quadro 3 - Redução de resíduos

\begin{tabular}{|l|r|c|}
\hline \multicolumn{3}{|c|}{ Redução de residuo } \\
\hline Peso do retalho d=41mm & 0,082 & $\mathrm{~kg}$ \\
\hline Total de retalho d=41mm & 9400 & unidades \\
\hline Total de retalho utilizado para fabricação do fuso & 3000 & unidades \\
\hline Total de resíduo de retalho d=41mm & \multicolumn{3}{|c|}{6400} & unidades \\
\hline Beneficio da troca de processo de furação por estampagem & \multicolumn{2}{|c|}{$\mathbf{R} 0,34$} \\
\hline Total do benefício com a troca de processo & $\mathbf{R} \$$ \\
\hline
\end{tabular}

Fonte: Empresa pesquisada

Por fim, analisando o quadro 4, nota-se que os benefícios não ocorreram apenas na eliminação de resíduos limalha e reaproveitamento dos resíduos de retalho, ou seja, não foram apenas benefícios econômicos, também ocorreram benefícios ambientais e no processo. Ambientais, pois houve redução no consumo chapas, de insumos e da geração do resíduo limalha que contamina o ambiente. E de processo, pois foi nítida a redução no tempo de fabricação do conjunto fuso após não precisar mais trabalhar com as chapas de aço, porque os retalhos de outro processo já vinham com a peça praticamente pronta para o acabamento. 
Quadro 4 - Totalização dos benefícios com a troca de processo

\begin{tabular}{|c|c|}
\hline \multicolumn{2}{|l|}{ Beneficios } \\
\hline \multicolumn{2}{|l|}{ Econôrricos } \\
\hline Utilzzacão do residuo de retalho $\mathrm{d}=41 \mathrm{~mm}$ para fabricacão do conjunto fuso & $\begin{array}{|ll|}\text { RS } & 2.260,20 \\
\end{array}$ \\
\hline Troca do processo de furacão pelo processo de Estampacem & RS $2.176,00$ \\
\hline Venda do residuo de retaho em subsituicão à limalha & \begin{tabular}{ll|} 
RS & 104,96 \\
\end{tabular} \\
\hline Total de Beneficio Econômico & RS $\quad 4.541,16$ \\
\hline \multicolumn{2}{|l|}{ Ambientais } \\
\hline Redução do consumo de MP de chapa de aço para fabricação do conjunto fuso & $438 \mathrm{~kg}$ \\
\hline \multicolumn{2}{|l|}{ Reducäo do consumo de Insumo - fuido de corte para furacäa } \\
\hline Reducão da geracäo do residuo de limalha contaminada & $770,8 \mathrm{~kg}$ \\
\hline Processo & \\
\hline
\end{tabular}

Fonte: Empresa pesquisada

\section{CONCLUSÃO}

Ficou evidenciado que a utilização de uma metodologia para resolução de problemas é o melhor caminho dentro dos vários processos produtivos empresariais. A gestão da qualidade e suas ferramentas fazem parte do processo de implementação de programas de melhorias e a padronização de atividades vem sendo cada vez mais importante para empresas que buscam excelência em seus negócios, com isso as empresas ganham em credibilidade, qualidade e consequentemente isso impacta diretamente, na produtividade e lucratividade.

O objetivo escolhido para aplicação do estudo fez com que todo um processo fosse modificado para reduzir/eliminar a geração de resíduos de limalha, que conforme foi demonstrado, obteve-se êxito no resultado final e beneficiando não só o processo em si, mas também o meio ambiente eliminando-se o resíduo.

Neste estudo, verificou-se que aplicação das ferramentas da qualidade pode auxiliar as organizações na identificação de problemas, na identificação das causas e no planejamento de ações para eliminá-las, através da melhoria contínua.

O objetivo proposto pelo presente estudo foi atingido, uma vez que foi identificado o problema, as causas deste problema e assim, feitas sugestões para a melhoria do processo de usinagem.

Por fim, mesmo considerando que o estudo traga importantes contribuições é necessário destacar que novas incursões em outros processos da empresa estudada podem ser feitas na busca de soluções de melhoria contínua.

\section{REFERÊNCIAS}

[1] ANTUNES, J. Sistemas de produção: conceitos e práticas para projeto e gestão da produção enxuta. Porto Alegre: Bookman, 2008.

[2] CAMPOS, V. F. Gerenciamento da rotina do trabalho do dia-a-dia. Nova Lima: INDG Tecnologia e Serviços Ltda., 2004

[3] CAMPOS, V. F. TQC - Controle da Qualidade Total (no estilo japonês). Nova Lima: INDG Tecnologia e Serviços Ltda., 2004.

[4] CORRÊA, H. L.; GIANESINI, I. G. N.; CAON, M. Planejamento, Programação e Controle da Produção: MRP II/ ERP: conceitos, uso e implantação. 4. ed. São Paulo: Atlas, 2001.

[5] DIAS, R. Gestão ambiental: responsabilidade social e sustentabilidade. - 2. ed. - São Paulo: Atlas, 2011.

MARTINS, P. G.; LAUGENI, F. P. Administração da Produção. 2. ed. São Paulo: Saraiva, 2005.

[6] PALADINI, E.P. Gestão da qualidade: teoria e prática. 2. ed. - 11. reimpr. - São Paulo: Atlas, 2011.

SHINGO, S. O Sistema Toyota de Produção do ponto de vista da Engenharia de Produção; tradução Eduardo Schaan. - 2. ed. - Porto Alegre: Bookman, 1996. 
[7] SLACK N. Administração da Produção / Nigel Slack, Stuart Chambers, Robert Johnston; tradução Maria Teresa Corrêa de Oliveira. - 3. ed. - São Paulo: Atlas, 2009.
[8] YIN, R. K. Estudo de caso: planejamento e métodos. - 4. ed. - Porto Alegre: Bookman, 2010. 


\title{
CAPÍTULO 18
}

\section{FABRICAÇÃO DE CARROCERIAS DE ÔNIBUS UTILIZANDO PROJETO ELÉTRICO MODULAR}

\author{
Alencar Silveira Roth \\ Jocarly Patrocínio de Souza
}

Resumo: O mercado de atuação das principais empresas brasileiras fabricantes de ônibus possui a característica de personalizar seus produtos de acordo com as necessidades de seus clientes. Esta prática acaba gerando diversos problemas no processo produtivo, dentro deles, a diversidade de sistemas elétricos dos ônibus. Para resolver estas dificuldades do sistema produtivo, as empresas estão investindo em novas tecnologias de software, projeto e processos de fabricação. Este trabalho apresenta um novo procedimento de projeto, fabricação e processo de montagem do sistema elétrico de suas carrocerias de ônibus, utilizando soluções de projetos modulares, explorando as características globais do sistema elétrico, para obter um processo de fabricação adequado às suas necessidades produtivas de larga escala, sem influenciar na caracterização individual do produto de cada cliente. $O$ novo processo fabril da carroceria apresenta nos seus resultados melhorias significativas nos projetos de engenharia, como precisão e tempo de projeto, redução de custo de fabricação e facilidade de manutenção das redes elétricas.

Palavras chave: sistema elétrico, projeto modular, ônibus. 


\section{INTRODUÇÃO}

O sistema elétrico das carrocerias de ônibus deve respeitar características construtivas conforme resoluções e normas nacionais e regionais, tais como - Conselho Nacional de Trânsito (Contran) e órgãos gestores público regional, que procuram estabelecer as melhores características de transporte para cada região do Brasil. No caso de exportação também se deve respeitar as normas e características construtivas do país de destino da carroceria. Além disso, os clientes, por sua vez, procuram incorporar características individuais de componentes e funcionalidades para aperfeiçoar seu produto, procurando identificar suas frotas com as necessidades de seus usuários.

Atualmente para atender estas necessidades específicas de construção das carrocerias são realizados projetos individuais para cada pedido ou frota, muitas vezes tendo de variar o projeto para o mesmo cliente, conforme alterações de chassis, comprimento, componentes eletrônicos, quantidade de portas, etc.

Projetos individuais ou especiais apresentam características que trazem impactos negativos no processo produtivo, como projetos elétricos pouco consistentes, redes elétricas não confiáveis, ausência de gabaritos para construção de redes elétricas, sistema de teste elétrico inadequado, metodologia de produção variável, matéria-prima distinta entre produtos e outros problemas produtivos em geral.

O sistema convencional de sistemas elétricos individuais por pedido, até então utilizado começa se ser questionado nos dias atuais em função dos novos lay-outs produtivos das empresas e também devido ao fato de apresentarem diversas falhas em todas as etapas de projeto e de fabricação. Assim, para atender esta nova demanda surge a necessidade de elaboração de um sistema elétrico consistente, incorporando as necessidades das diversas áreas das empresas, iniciando la no processo de venda do produto e finalizando na assistência técnica de pós-vendas. Este novo sistema deve trazer soluções eficientes aos pontos mais críticos do sistema elétrico, que são: o projeto elétrico, a fabricação das redes, a montagem elétrica da carroceria e a assistência técnica.

\section{O PROJETO MODULAR}

A modularidade definida por Baldwin e Clark (2000) é uma estratégia de organização de produtos e processos complexos de uma forma eficiente. O sistema modular é composto por unidades ou módulos que são concebidos de forma independente, mas funcionam de forma integrada como um todo. Para o autor, a modularidade é benéfica somente se as partições forem precisas, sem ambiguidades e completas.

O projeto para modularidade é apresentado por Back (2008) com o objetivo de ofertar produtos para uma ampla faixa de necessidades de uma forma mais racional e econômica. O termo de modularidade é adotado para descrever o uso de unidades comuns com o fim de criar uma variedade de produtos. O objetivo é identificar unidades independentes e normalizadas ou intercambiáveis para atender a uma variedade de funções.

Para Pahl et al. (2005) do ponto de vista técnico e econômico, um sistema modular sempre se apresentará como vantajoso em comparação com soluções específicas, desde que todas as variantes específicas do programa de um produto forem produzidas em quantidades pequenas e quando se consegue cobrir com a faixa exigida com um único ou com poucos blocos básicos auxiliares.

\subsection{SISTEMÁTICA DE PRODUTOS MODULARES}

A sistemática apresentada por Pahl et al. (2005) distingue-se entre blocos de função e blocos de produção. Blocos de função são definidos pelo critério do atendimento a funções técnicas, de modo a atendêlas por si próprio ou em combinação com outros blocos. Blocos de produção são aqueles que, independente da sua função, são definidos exclusivamente por critérios de tecnologia da produção.

Para organizar os blocos funcionais, o autor classificaos conforme sua utilização no sistema modular, em que o arranjo destas sub-funções atendem a diversas variações de funções globais. Essas funções são descritas a seguir: 
Funções básicas: são fundamentais, repetitivas e imprescindíveis. Basicamente não são variáveis. Para atendimento de variantes da função global, uma função básica pode comparecer solitária ou interligada a outras funções. Esses blocos básicos são contidos na estrutura do sistema modular como blocos obrigatórios.

Funções auxiliares: são ligantes e interligantes e, em geral, são atendidas por blocos auxiliares que se apresentam como elementos de ligação e interligação. Devem respeitar as características dos módulos básicos e demais blocos. Na maioria das estruturas de construção são obrigatórios.

Funções especiais: são funções isoladas, complementares, específicas de uma tarefa, que não se repetem em todas as variantes globais. São satisfeitas por blocos especiais, que representam uma complementação ou um acessório em relação ao básico e, por isso, são blocos opcionais.
Funções de adaptação: são necessárias para um ajuste aos outros sistemas e condições complementares. São concretizadas por blocos adaptativos com dimensões fixadas apenas parcialmente que, em casos especiais, necessitam de um ajuste das suas dimensões em razão da imprevisibilidade das condições de contorno. Blocos de adaptação ocorrem como blocos obrigatórios ou opcionais.

Funções específicas de um pedido, não previstas no sistema modular, sempre tornam a ocorrer, mesmo que o desenvolvimento do sistema modular tenha sido cuidadoso. Nestes casos podem ser utilizadas funções customizadas, onde apresenta solução para necessidades imprevisíveis no sistema modular, tornando o sistema misto.

A figura 1 apresenta a ilustração de uma ordem das funções a serem contempladas no sistema modular, assim como a agregação de funções customizadas tornando o sistema misto.

Figura 1 - Espécies de funções e módulos em sistemas modulares e mistos, Pahl et al., 2005

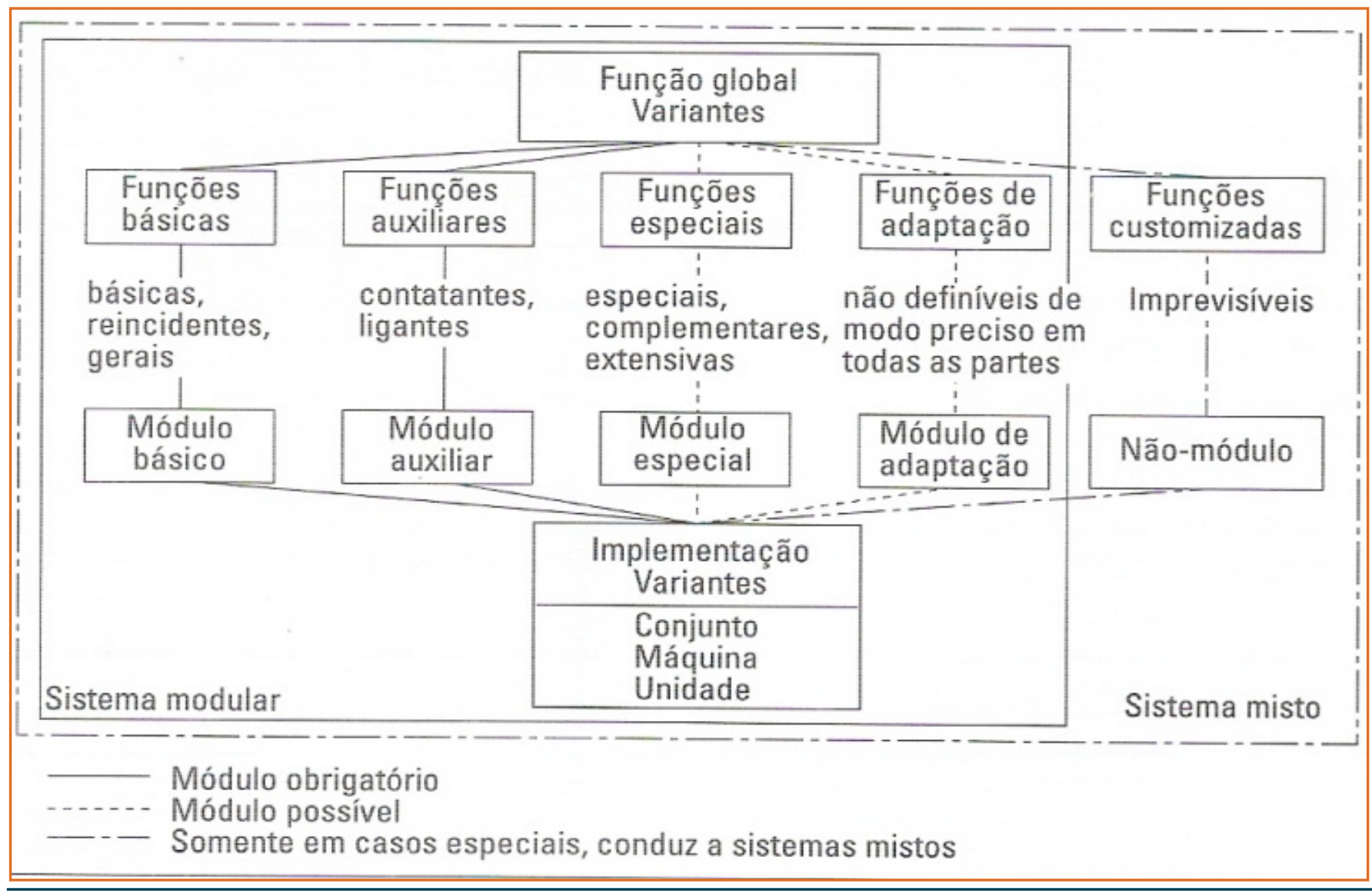


Oprojetomodular apresentavantagense desvantagens, sendo que para Back (2008) uma das vantagens está na fase de desenvolvimento do produto, pois o projeto modular apresenta a possibilidade de ser projetado e produzido paralelamente, tendo uma redução significativa no tempo de desenvolvimento do mesmo. A utilização de módulos proporciona um processo de fabricação mais avançado, apresentando vantagens como maior precisão na fabricação, racionalização de recursos, maior agilidade de atendimento aos usuários, facilidade de atualização tecnológica, diagnóstico de falhas, além da reposição e reparo de módulos.

\section{DESENVOLVIMENTO DO SISTEMA ELÉTRICO}

O novo sistema elétrico da carroceria não deverá ser um sistema exclusivo carro a carro, possibilitando a programação de fabricação das redes elétricas através do sistema Kanban, assim como, deve atender as necessidades descritas nas especificações do projeto, com o intuito de desenvolver um novo sistema que de acordo com Meybodi (2005) tenham poucas mudanças de projetos, menos tempo de desenvolvimento, menos custo de desenvolvimento e menos custo de fabricação.

\subsection{REQUISITOS DO SISTEMA ELÉTRICO}

A lista de requisitos do sistema elétrico inicia a partir das principais necessidades do sistema, conforme os itens abaixo:

- projeto do funcionamento do sistema elétrico;

- projeto de fabricação de redes elétricas;

- projeto de instalação das redes na carroceria;

- projeto de manutenção;

- toda documentação deve ser facilmente identificada;

- projeto único para todas as variações estruturais da carroceria;

- atender ao volume máximo de capacidade da planta de fabricação;

- atender a todas as variações de marcas e componentes eletrônicos embarcados;

- a instalação elétrica deve ter vida útil de acordo com o tempo de utilização da carroceria;
- o projeto deverá ser confiável e assertivo, contendo informações completas;

- deverá ter um curto prazo de tempo para a realização do projeto de cada carroceria.

O projeto do sistema elétrico de uma carroceria inicia-se nas primeiras etapas de elaboração das características do ônibus, que é o preenchimento do pedido junto ao cliente. Com as características construtivas e funcionais selecionáveis devidamente esclarecidas, objetivas e com linguagem acessível ao vendedor e ao cliente, cria-se um ambiente de venda mais seguro com relação ao que está sendo solicitado e ao que realmente será montado no ônibus. Finalizada a etapa comercial, o pedido entra na etapa de projeto de engenharia que, por sua vez, realiza a análise técnica das necessidades e transcreve as informações ao processo produtivo através de projetos claros, completos e objetivos.

\subsection{ESPECIFICAÇÕES DO SISTEMA ELÉTRICO}

O projeto elétrico, independente da característica da carroceria solicitada pelo cliente, deve ter informações totais sobre o sistema elétrico da carroceria e sua documentação deve contemplar o diagrama elétrico, que é a lógica de como a parte elétrica funciona. $\mathrm{O}$ projeto de pontos de passagem das redes elétricas, com as informações de seu posicionamento dentro da carroceria do ônibus e, por fim, o projeto de engenharia, que deve ser utilizado para fabricação das redes elétricas.

O volume de utilização das redes elétricas deve atender à capacidade total de fabricação de carrocerias de ônibus urbanos, partindo de um volume mínimo de uma unidade por dia e podendo chegar até quarenta, considerando todas as variações estruturais e componentes eletrônicos e chassis contemplados na tarefa de vendas da carroceria.

A qualidade da rede elétrica deverá ter vida útil conforme a carroceria do ônibus, sem que ocorram danos oriundos de infiltrações, superaquecimento, atritos, curto-circuito. O sistema de manutenção deve prever a identificação total do sistema elétrico, como a 
identificação e função de cada fio (diagrama elétrico de manutenção), identificação e posicionamento de cada conector na carroceria, ponto de passagem e identificação das redes elétricas. E por fim a reposição de peças do sistema elétrico, possibilitando a substituição parcial ou completa do sistema elétrico, incluindo as redes elétricas. Principais variações entre carrocerias e componentes:

Variações de portas: Além da variável de quantidade, tem-se ainda o posicionamento das portas, de acordo com a planta baixa (layout interno) e o comprimento da carroceria, ocorrendo variações de distância entre uma porta e outra. O sistema de acionamento da porta pode alternar entre acionamento elétrico, acionamento pneumático e acionamento eletro-pneumático e porta com ou sem elevador.

Variações de comprimento de carroceria: As variações de comprimento do sistema elétrico devem estar de acordo com a disponibilidade construtiva de cada modelo de carroceria, que pode iniciar com 10,5m e chegar ao máximo de $14 \mathrm{~m}$.

Variações de Chassi: O chassi é o conjunto que move o ônibus. Envolve toda a sustentação da carroceria, com suspensão, transmissão, motor, câmbio, sistema de freios, etc. Os principais fabricantes de chassis utilizados em ônibus urbanos são Mercedes Bens, Volkswagen (MAN), Volvo, Scania, Agrale e Iveco.

Legislação: Deve atender a todas as normas da legislação brasileira de construção de carrocerias de ônibus urbanos, como as normas NBR15570, NBR 15320, NBR14022, além das regionais de cada estado ou cidade, como por exemplo, o Departamento de Transportes Rodoviários do Rio de Janeiro (DETRO), e a Empresa Pública de Transporte e Circulação (EPTC) de Porto Alegre.

Variação de componentes: A quantidade de componentes utilizados nas carrocerias é variável e bastante complexa, devido ao fato de que cada cliente possui uma característica própria de utilização de componentes eletrônicos. Os componentes podem ser alterados quanto à sua utilização de diversas formas, desde a quantidade de componentes utilizados, funcionalidade, marcas e modelos e posicionamento na carroceria. Segue abaixo algumas variações comuns de componentes elétricos e eletrônicos utilizadas nas carrocerias.

Sistemas deacionamento de cargas: Ainterfaceutilizada entre o motorista e a carroceria define a arquitetura elétrica principal a ser utilizada na carroceria. Existem duas opções: sistema de acionamento de cargas por teclas convencionais, utilizando central elétrica com relés e fusíveis, e o sistema multiplexado, utilizando módulos eletrônicos programáveis, e acionamento de cargas através de semicondutores, com protocolo de comunicação serial síncrono (CAN) em que conforme Guimarães (2002), todos os módulos podem se tornar mestre em um determinado momento e escravo num outro.

Componentes eletrônicos gerais: Referente a componentes eletrônicos embarcados, existem diversas empresas com vastos portfólios de produtos, em que cada cliente se identifica com determinadas empresas ou produtos e solicita a utilização em suas carrocerias, sendo que cada produto eletrônico possui uma característica própria de instalação, tamanho físico e conexão elétrica com a carroceria.

Os principais componentes eletrônicos utilizados são os bloqueadores de portas, itinerários eletrônicos, validadores, elevadores, componentes de iluminação e sinalização, sistemas de áudio e vídeo. Para ter um sistema elétrico completo e eficiente, leva-se em consideração no momento da elaboração do projeto, todas as suas áreas influenciadoras. Para dividir o problema em diversas etapas, o projeto foi elaborado para os vários setores da empresa, onde foram encontradas dificuldades e soluções para cada área da organização.

\subsection{SETOR DE VENDAS}

Para ter um sistema elétrico eficiente é necessário ter um conhecimento prévio do que poderá ser utilizado na configuração da carroceria, portanto é de extrema importância que o setor trabalhe com tarefas conhecidas pela engenharia. Para que essa condição seja atendida, a tarefa de vendas deve ser elaborada 
juntamente pelo setor de engenharia e comercial.

$\mathrm{Na}$ tarefa de vendas constam todas as características de produtos disponíveis para fabricação, assim como as regras de utilização de cada atividade. Para facilitar a identificação de produtos disponíveis e necessidades novas de clientes, a tarefa é dividida da seguinte maneira:

Itens normais, opcionais, ou restritos: são itens já previstos pela engenharia, portanto já existe um projeto para atender a tarefa solicitada.
Itens especiais: são tarefas novas solicitadas pelos clientes. Este item é analisado tecnicamente e financeiramente quanto à sua viabilidade de utilização e, se necessário, é criado um projeto específico para o atendimento de sua necessidade. Conforme aumenta a demanda de solicitação do item, este pode vir a fazer parte de tarefas restritas, opcionais ou normais.

A figura 2 mostra a ilustração de um item restrito, e um normal ou opcional respectivamente, assim como a figura 3 representa solicitação de um elemento especial.

Figura 2 - llustração de item restrito + normal ou opcional

\begin{tabular}{|l|l|}
\hline & 184 - Instalação Elétrica \\
\hline 184.413 - Posição Do Validador & * DOIS, UM ANTES DA CATRACA LE (PD) E UM ANTES DA CATRACA LD (PD) \\
\hline 184.1081 - Sistema Multiplex & Sim ( Com Painel De Visualização) \\
\hline
\end{tabular}

Figura 3 - Ilustração de item especial

186 - Sinalização:

Observações:

186.515 - Campainha: Botoeiras Wi-Fi;

\subsection{SETOR DE ENGENHARIA}

Desde a entrada de uma nova solicitação até a entrega do produto final ao cliente existem diversas etapas informacionais a serem consideradas na elaboração de uma carroceria, nas quais grande parte delas têm relação direta com setor de engenharia.

\section{Principais etapas:}

- solicitação do cliente;

- interpretação da solicitação por parte do setor de vendas:

- descrição da solicitação por parte do setor de vendas;

- interpretação por parte da engenharia;

- desenvolvimento do projeto de engenharia;

- interpretação do projeto por parte dos setores de fabricação e montagem.

O setor de engenharia é o responsável pelo fluxo de informações desde a descrição da solicitação por parte do setor de vendas até a interpretação do projeto por parte dos setores de fabricação e montagem.Com o intuito de ter uma quantidade limitada de projetos por carro, aplica-se no conceito de projeto modular, em que se avalia cada função utilizada na carroceria através do conceito de produto modular. Os projetos foram divididos em quatro partes:

Projetos básicos: são utilizados em todos os carros. Apesar de demandar um esforço maior, no sentido de atender a todas as condições de utilização, sua programação é simples e basicamente não tem restrições quanto à sua utilização. Os projetos básicos compõem praticamente $40 \%$ dos projetos necessários na montagem de uma carroceria.

Projetos auxiliares: são as interligações utilizadas nas carrocerias. São elaborados para atender às variações construtivas da carroceria. Geralmente são utilizados em conjunto com os projetos básicos, direcionando estes para a aplicação desejada. São os projetos auxiliares os grandes responsáveis pelas diferenciações de funcionamento entre os itens 
opcionais.

Projetos adaptativos: são projetos complementares. Geralmente é o ponto final de um ramo da rede elétrica. Sua principal utilização é diferenciar algum detalhe de conexão entre os componentes finais. Normalmente são pequenos projetos de fácil elaboração e fabricação, e sua programação de utilização depende diretamente das marcas e modelos dos componentes a serem utilizados nas carrocerias.

Projetos especiais: são as aplicações pontuais solicitadas pelos clientes. Em um primeiro momento são utilizados somente para uma aplicação especial e são classificados como restritos a uma determinada condição ou cliente. Os tempos de projeto destes itens variam conforme o nível de complexidade da solicitação. O projeto especial pode ser desde um componente adicional a ser incorporado no sistema, como pode chegar a ser de uma carroceria completamente nova.

O projeto de engenharia parte do princípio estrutural de montagem das carrocerias, onde ocorrem cinco montagens interdependentes uma das outras. São basicamente: Teto, frente, traseira, laterais, e base. $\mathrm{O}$ arranjo de cada parte principal é formado por um conjunto de redes, onde este é formado por uma ou mais rede base, auxiliar, adaptativa ou especial. Segue na figura 4 o arranjo elétrico da frente é constituído pelas seguintes redes:

Rede da frente base: é uma rede padrão onde a mesma é utilizada para todos os modelos de carroceria.

Rede auxiliar ou adaptativa: faz a comunicação da rede da frente base com a central elétrica, ou interface com o chassi. Estas redes variam conforme a configuração do chassi a ser utilizado. Composição da ilustração:

- Rede base: sinalização dianteira (azul), Rede auxiliar: comunicação com a central elétrica (amarelo).
Figura 4 - Projeto elétrico Frente em 3D.

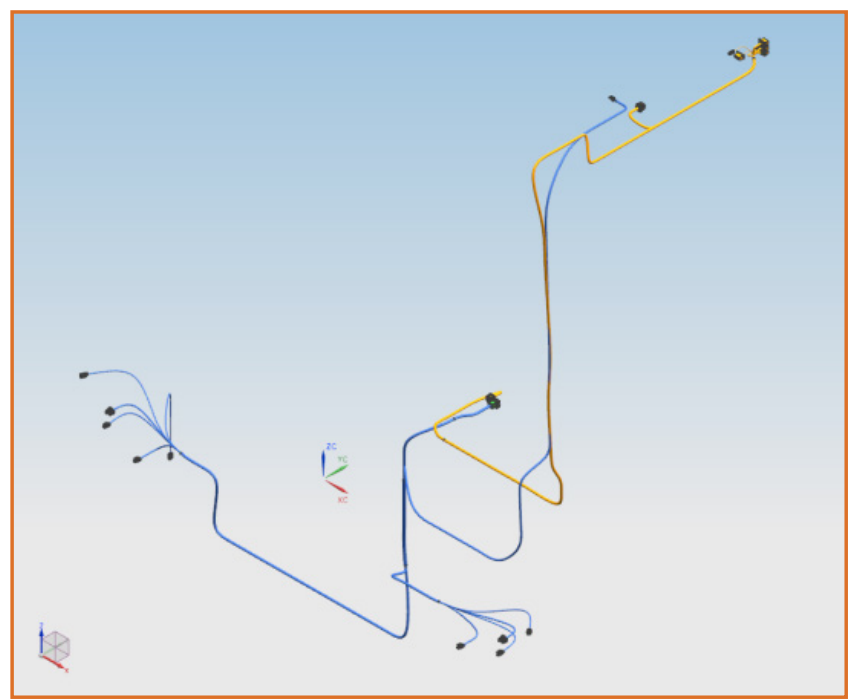

Os projetos elétricos, para apresentar uma estrutura adequada para a construção de uma carroceria de ônibus, necessitam ter basicamente as seguintes informações:

- lógica de ligação dos componentes da carroceria;

- projeto de fixação, pontos de passagem, e comprimento das redes elétricas;

- projeto de fabricação de redes elétricas.

Os diagramas elétricos são responsáveis por toda a lógica de ligação e o cálculo de dimensionamento de capacidade de corrente dos condutores. Contém informações de conectores (função, tipo, nomenclatura, quantidade de pinos utilizados), e condutores (seção, cor, identificação, função)

O projeto das redes elétricas utiliza as informações importadas dos diagramas elétricos na plataforma em 3D, como podemos verificar na figura 5. Os conectores são identificados e posicionados na carroceria conforme suas necessidades. São traçados os pontos de passagem por onde devem percorrer as redes elétricas e então realizado o roteamento dos fios. Neste momento tem-se o projeto tridimensional das redes elétricas com informações referentes aos pontos de passagem, fixação, volume de ocupação, quantidade, comprimento e características dos fios. 
Figura 5 - Projeto de rede elétrica utilizando o software Routing Electrical

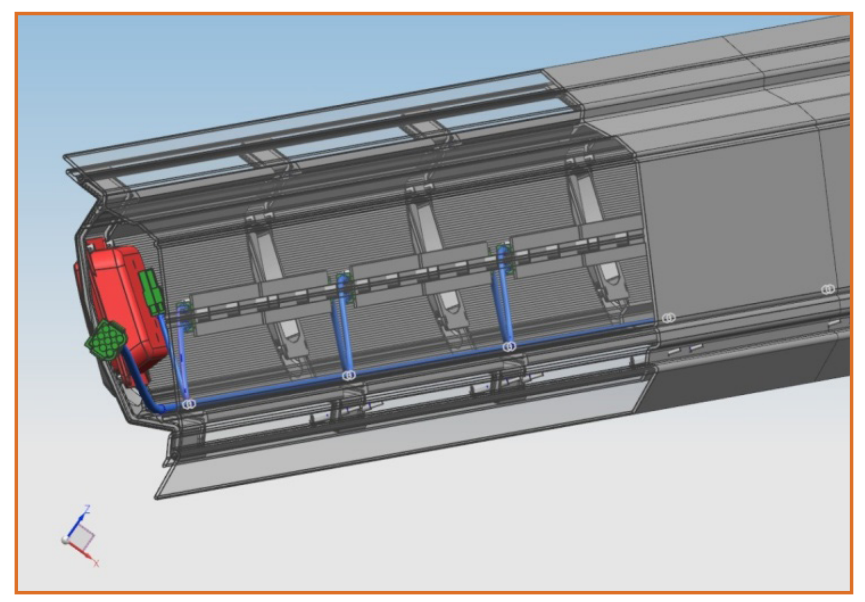

Para finalizar o projeto, a rede elétrica desenhada em 3D é planificada e expandida para o formato 2D, iniciando, assim, o processo de detalhamento. Nesta etapa são expostas as informações necessárias para a fabricação da rede elétrica, contendo todos os dados acumulados no diagrama elétrico e roteamento em 3D. (Figura 6).

Figura 6 - Detalhamento da rede elétrica utilizando o software Routing Electrical

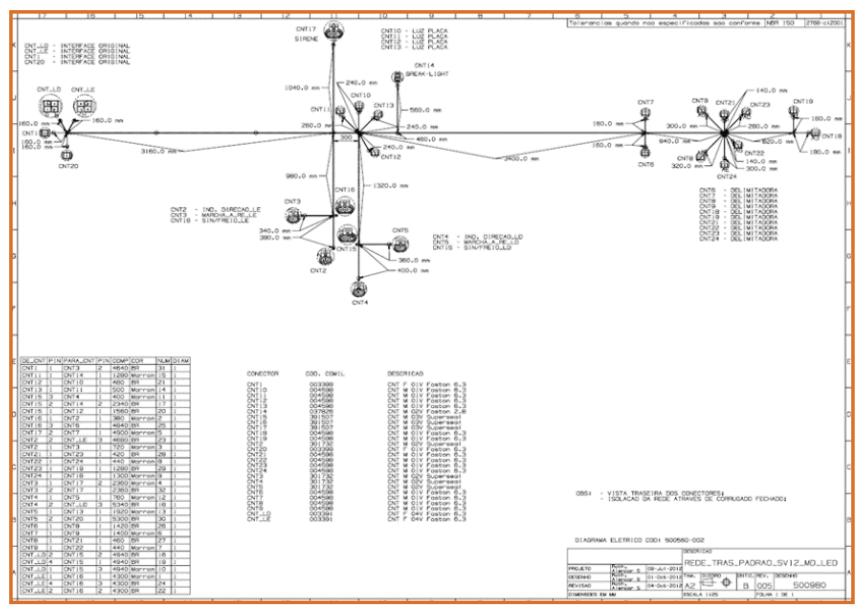

\subsection{SETOR DE FABRICAÇÃO E MONTAGEM}

O setor de fabricação é a primeira etapa de fabricação após liberado os projetos de engenharia, sendo este responsável pela fabricação das redes elétricas. Quando temos uma rede já desenvolvida, esta é cadastrada conforme seu volume de utilização, sendo essa classificada como padrão, variável e especial. No momento do pedido de fornecimento da rede, esta pode estar disponível para o fornecimento, como nos casos das redes padronizadas, ou poderá entrar no fluxo de produção, como nos casos de redes especiais. Segue na figura 7 o fluxo de organização do setor de fabricação de redes elétricas.

Figura 7 - Sistema de organização da fabricação de redes elétricas

\begin{tabular}{|c|}
\hline Finalização do Projeto de Engenharia \\
\hline Solicitação de Orçamento \\
\hline Projeto Industrial \\
\hline Fabricação de peça - Protótipo \\
\hline Aguarda Solicitação de Pedido \\
\hline Verificação de Estoque \\
\hline Gera Ordem de Fabricação ou Busca de Estoque Kanban \\
\hline Buffer Produção \\
\hline \\
Processo Produtivo \\
\hline Estoque Kanban \\
\hline Expedição \\
\hline
\end{tabular}

Para organizar a montagem das redes elétricas na carroceria é preciso um levantamento de todas as necessidades de montagem, juntamente com os postos de trabalho disponíveis para realização das tarefas.

Para direcionamento de realização das tarefas nos tempos e postos de trabalho corretos, foi elaborada uma matriz tarefa/dependência, sendo esta uma variação da matriz de interação entre módulos utilizada por Viero (2013), na qual relaciona-se as tarefas a serem realizadas com relação à dependência para início da mesma. A partir desta matriz foi possível analisar e ajustar as tarefas a serem realizadas ordenadamente, adiantando ao máximo o início de execução da mesma. A matriz tarefa/dependência é mostrada na tabela 1.

São listadas todas as tarefas a serem realizadas, tanto na coluna de tarefas, como na linha de dependências. A partir deste ponto podemos traçar uma linha nula 
entre as respectivas tarefas da coluna dependência e da linha tarefa. Este ponto vai diferenciar a tarefa que está adiantada e atrasada em relação à sua necessidade de montagem.

A numeração indicará qual dependência deve estar completa para a realização da tarefa. Temos como exemplo as tarefas de fabricação de redes, nas quais todas dependem exclusivamente de ter o projeto liberado para fabricação. Outro exemplo é a tarefa de montagem da central elétrica, que para iniciála é necessária a finalização das dependências de estar fabricada a rede da central elétrica e retirados/ armazenados os componentes originais do chassi.

Tendo todas as tarefas ordenadas e indicadas em sequência na planilha tarefa/dependência, posteriormente é realizado o planejamento da montagem nos postos de trabalho da linha de produção, levando em consideração em cada tarefa a condição física de execução em cada posto de trabalho.

Tabela 1 - Matriz tarefa-dependência

\begin{tabular}{|c|c|c|c|c|c|c|c|c|c|c|c|c|c|c|c|c|c|c|c|c|c|c|c|c|c|c|c|c|c|c|c|c|c|c|}
\hline DEPENDÊNCIA & 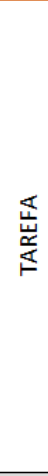 & 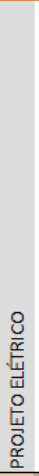 & 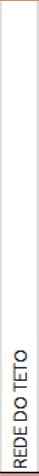 & 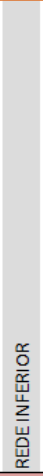 & 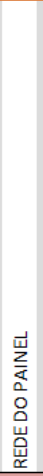 & 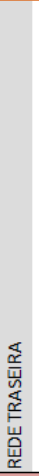 & 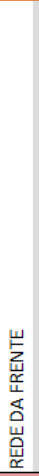 & 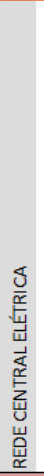 & 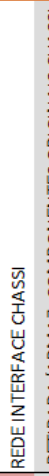 & 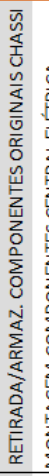 & 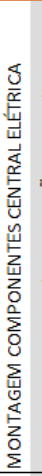 & 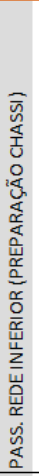 & 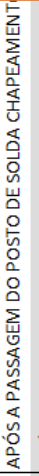 & 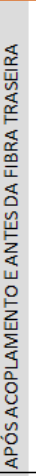 & 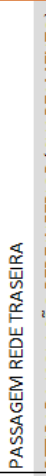 & 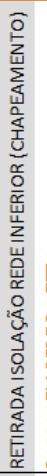 & & 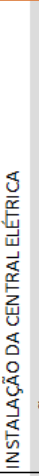 & 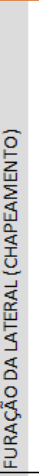 & 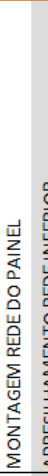 & 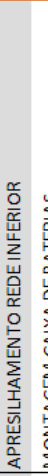 & 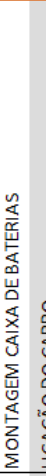 & 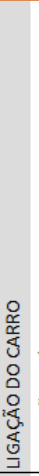 & 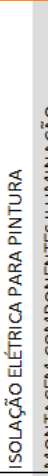 & 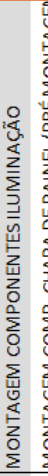 & 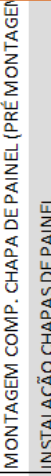 & 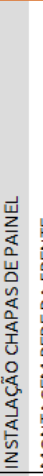 & 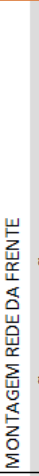 & 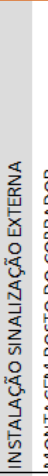 & 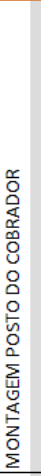 & 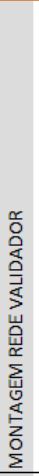 & 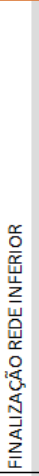 & 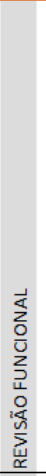 & \\
\hline PROJETO ELÉTRICO & & 0 & 1 & 2 & 3 & 4 & 5 & 6 & 7 & 0 & 0 & 0 & 0 & 0 & 0 & 0 & 0 & 0 & 0 & 0 & 0 & 0 & 0 & 0 & 0 & 0 & 0 & 0 & 0 & 0 & 0 & 0 & 0 & \\
\hline REDE DO TETO & & 0 & 0 & 0 & 0 & 0 & 0 & 0 & 0 & 0 & 0 & 0 & 0 & 0 & 0 & 0 & 15 & 0 & 0 & 0 & 0 & 0 & 0 & 0 & 0 & 0 & 0 & 0 & 0 & 0 & 0 & 0 & 0 & \\
\hline REDE INFERIOR & & 0 & 0 & 0 & 0 & 0 & 0 & 0 & 0 & 0 & 0 & 10 & 0 & 0 & 0 & 0 & 0 & 0 & 0 & 0 & 0 & 0 & 0 & 0 & 0 & 0 & 0 & 0 & 0 & 0 & 0 & 0 & 0 & 0 \\
\hline REDE DO PAINEL & & 0 & 0 & 0 & 0 & 0 & 0 & 0 & 0 & 0 & 0 & 0 & 0 & 0 & 0 & 0 & 0 & 0 & 0 & 18 & 0 & 0 & 0 & 0 & 0 & 0 & 0 & 0 & 0 & 0 & 0 & 0 & 0 & 0 \\
\hline REDE DA FRENTE & & 0 & 0 & 0 & 0 & 0 & 0 & 0 & 0 & 0 & 0 & 0 & 0 & 0 & 0 & 0 & 0 & 0 & 0 & 0 & 0 & 0 & 0 & 0 & 0 & 0 & 0 & 0 & 0 & 0 & 0 & 0 & 0 & 0 \\
\hline REDE CENTRAL ELÉTRICA & & 0 & 0 & 0 & 0 & 0 & 0 & 0 & 0 & 0 & 9 & 0 & 0 & 0 & 0 & 0 & 0 & 0 & 0 & 0 & 0 & 0 & 0 & 0 & 0 & 0 & 0 & 0 & 0 & 0 & 0 & 0 & 0 & 0 \\
\hline REDE INTERFACE CHASSI & & 0 & 0 & 0 & 0 & 0 & 0 & 0 & 0 & 0 & 0 & 0 & 0 & 0 & 0 & 0 & 0 & 0 & 0 & 0 & 0 & 0 & 0 & 0 & 0 & 0 & 0 & 0 & 0 & 0 & 0 & 0 & 0 & 0 \\
\hline RETIRADA/ARMAZ. COMPONENTES ORIGINAIS CHASSI & & 0 & 0 & 0 & 0 & 0 & 0 & 0 & 0 & 0 & 9 & 10 & 0 & 0 & 0 & 0 & 0 & 0 & 0 & 0 & & 20 & 0 & 0 & 0 & 24 & 0 & 0 & 0 & 0 & 0 & 0 & 0 & 0 \\
\hline MONTAGEM COMPONENTES CENTRAL ELÉTRICA & & 0 & 0 & 0 & 0 & 0 & 0 & 0 & 0 & 0 & 0 & 0 & 0 & 0 & 0 & 0 & 0 & 16 & 0 & 0 & 0 & 0 & 0 & 0 & 0 & 0 & 0 & 0 & 0 & 0 & 0 & 0 & 0 & 0 \\
\hline PASS. REDE INFERIOR (PREPARAÇÃO CHASSI) & & 0 & 0 & 0 & 0 & 0 & 0 & 0 & 0 & 0 & 0 & 0 & 0 & 0 & 0 & 14 & 0 & 0 & 0 & 0 & & 0 & 0 & 0 & 0 & 0 & 0 & 0 & 0 & 0 & 0 & 0 & 0 & 0 \\
\hline APÓS A PASSAGEM DO POSTO DE SOLDA CHAPEAMENTO & & 0 & 0 & 0 & 0 & 0 & 0 & 0 & 0 & 0 & 0 & 0 & 0 & 0 & 0 & 14 & 151 & 16 & 0 & 181 & 19 & 0 & 0 & 0 & 0 & 0 & 0 & 0 & 0 & 0 & 0 & 0 & 0 & 0 \\
\hline APÓS ACOPLAMENTO E ANTES DA FIBRA TRASEIRA & & 0 & 0 & 0 & 0 & 0 & 0 & 0 & 0 & 0 & 0 & 0 & 0 & 0 & 13 & 0 & 0 & 0 & 0 & 0 & 0 & 0 & 0 & 0 & 0 & 0 & 0 & 0 & 0 & 0 & 0 & 0 & 0 & 0 \\
\hline PASSAGEM REDE TRASEIRA & & 0 & 0 & 0 & 0 & 0 & 0 & 0 & 0 & 0 & 0 & 0 & 0 & 0 & 0 & 0 & 0 & 0 & 0 & 0 & 0 & 0 & 0 & 0 & 0 & 0 & 0 & 0 & 27 & 0 & 0 & 0 & 0 & 0 \\
\hline RETIRADA ISOLAÇÃ̃O REDE INFERIOR (CHAPEAMENTO) & & 0 & 0 & 0 & 0 & 0 & 0 & 0 & 0 & 0 & 0 & 0 & 0 & 0 & 0 & 0 & 0 & 0 & 17 & 181 & 192 & 20 & 0 & 0 & 0 & 0 & 0 & 0 & 0 & 0 & 0 & 0 & 0 & 0 \\
\hline PASSAGEM REDE DO TETO & & 0 & 0 & 0 & 0 & 0 & 0 & 0 & 0 & 0 & 0 & 0 & 0 & 0 & 0 & 0 & 0 & 0 & 0 & 0 & 0 & 0 & 0 & 0 & 23 & 0 & 0 & 0 & 0 & 0 & 0 & 0 & 0 & 0 \\
\hline INSTALAÇÃ̃o DA CENTRAL ELÉTRICA & & 0 & 0 & 0 & 0 & 0 & 0 & 0 & 0 & 0 & 0 & 0 & 0 & 0 & 0 & 0 & 0 & 0 & 0 & 18 & 0 & 0 & 21 & 0 & 0 & 0 & 0 & 0 & 0 & 0 & 0 & 0 & 0 & 0 \\
\hline FURAÇÃO DA LATERAL (CHAPEAMENTO) & & 0 & 0 & 0 & 0 & 0 & 0 & 0 & 0 & 0 & 0 & 0 & 0 & 0 & 0 & 0 & 0 & 0 & 0 & 0 & 19 & 0 & 0 & 0 & 0 & 0 & 0 & 0 & 27 & 0 & 0 & 0 & 0 & 0 \\
\hline MONTAGEM REDE DO PAINEL & & 0 & 0 & 0 & 0 & 0 & 0 & 0 & 0 & 0 & 0 & 0 & 0 & 0 & 0 & 0 & 0 & 0 & 0 & 0 & 0 & 0 & 21 & 0 & 0 & 0 & 25 & 0 & 0 & 0 & 0 & 0 & 0 & 0 \\
\hline APRESILHAMENTO REDE INFERIOR & & 0 & 0 & 0 & 0 & 0 & 0 & 0 & 0 & 0 & 0 & 0 & 0 & 0 & 0 & 0 & 0 & 0 & 0 & 0 & 0 & 20 & 21 & 0 & 0 & 0 & 0 & 0 & 0 & 0 & 0 & 0 & 0 & 0 \\
\hline MONTAGEM CAIXA DE BATERIAS & & 0 & 0 & 0 & 0 & 0 & 0 & 0 & 0 & 0 & 0 & 0 & 0 & 0 & 0 & 0 & 0 & 0 & 0 & 0 & 0 & 0 & 21 & 0 & 0 & 0 & 0 & 0 & 0 & 0 & 0 & 0 & 0 & 0 \\
\hline LIGAÇÃOO DO CARRO & & 0 & 0 & 0 & 0 & 0 & 0 & 0 & 0 & 0 & 0 & 0 & 0 & 0 & 0 & 0 & 0 & 0 & 0 & 0 & 0 & 0 & 0 & 22 & 0 & 0 & 25 & 0 & 0 & 0 & 0 & 0 & 31 & 0 \\
\hline ISOLAÇÃO ELÉTRICA PARA PINTURA & & 0 & 0 & 0 & 0 & 0 & 0 & 0 & 0 & 0 & 0 & 0 & 0 & 0 & 0 & 0 & 0 & 0 & 0 & 0 & 0 & 0 & 0 & 0 & 0 & 0 & 0 & 26 & 0 & 0 & 0 & 0 & 0 & 0 \\
\hline MONTAGEM COMPONENTES ILUMINAÇ̃̃O & & 0 & 0 & 0 & 0 & 0 & 0 & 0 & 0 & 0 & 0 & 0 & 0 & 0 & 0 & 0 & 0 & 0 & 0 & 0 & 0 & 0 & 0 & 0 & 0 & 0 & 0 & 0 & 0 & 0 & 0 & 0 & 31 & 0 \\
\hline INSTALAÇÃO SINALIZAÇÃO EXTERNA & & 0 & 0 & 0 & 0 & 0 & 0 & 0 & 0 & 0 & 0 & 0 & 0 & 0 & 0 & 0 & 0 & 0 & 0 & 0 & 0 & 0 & 0 & 0 & 0 & 0 & 0 & 0 & 0 & 0 & 0 & 30 & 31 & 0 \\
\hline MONTAGEM POSTO DO COBRADOR & & 0 & 0 & 0 & 0 & 0 & 0 & 0 & 0 & 0 & 0 & 0 & 0 & 0 & 0 & 0 & 0 & 0 & 0 & 0 & 0 & 0 & 0 & 0 & 0 & 0 & 0 & 0 & 0 & 0 & 29 & 0 & 0 & 0 \\
\hline MONTAGEM VALIDADOR & & 0 & 0 & 0 & 0 & 0 & 0 & 0 & 0 & 0 & 0 & 0 & 0 & 0 & 0 & 0 & 0 & 0 & 0 & 0 & 0 & 0 & 0 & 0 & 0 & 0 & 0 & 0 & 0 & 0 & 0 & 30 & 0 & 0 \\
\hline FINALIZAÇÃO REDE INFERIOR & & 0 & 0 & 0 & 0 & 0 & 0 & 0 & 0 & 0 & 0 & 0 & 0 & 0 & 0 & 0 & 0 & 0 & 0 & 0 & 0 & 0 & 0 & 0 & 0 & 0 & 0 & 0 & 0 & 0 & 0 & 0 & 31 & 0 \\
\hline FUNCIONAL & & 0 & 0 & 0 & 0 & 0 & 0 & 0 & 0 & 0 & 0 & 0 & 0 & 0 & 0 & 0 & 0 & 0 & 0 & 0 & 0 & U & 0 & 0 & 0 & 0 & 0 & 0 & 0 & 0 & 0 & 0 & 0 & \\
\hline & & 0 & 0 & 0 & & & & 0 & & & & & & & & & & & & & & & & & & & & & & & & & & \\
\hline
\end{tabular}

\subsection{RESULTADOS OBTIDOS E CONCLUSÃO}

Aplicando-se o conceito de projeto modular no processo de projeto, desenvolvimento e construção de carrocerias de ônibus urbano, pode-se observar os seguintes resultados quando comparados com o processo convencional: 
- Diminuição de estoques e desperdício de materiais

- Apresentação de custo real da rede elétrica

- Documentação do sistema elétrico

- Sistema elétrico padronizado, sendo utilizado como diferencial de vendas

- Baixo índice de problemas com as montadoras

- Aplicação do sistema Kanban na fabricação e montagem das redes elétricas

- Acertividade na elaboração de projetos de engenharia;

- Projeto de redes com componentes totalmente estruturados;

- Custo individual por carro;

- Redução de quantidade de códigos de componentes;

- Etiqueta de rastreabilidade da rede, indicando a data de fabricação, o código e revisão do projeto utilizado para fabricação da mesma;

- Reposição de peças na rede elétrica;

- Histórico individual completo do sistema elétrico utilizado em cada carroceria;

O conceito de projeto elétrico modular surpreendeu positivamente quanto ao seu desenvolvimento e aplicação, possibilitando utilizar informações completas da parte elétrica de cada carroceria. Os benefícios do projeto elétrico modular são evidenciados em diversos setores da empresa, como o de vendas, de engenharia, de custos, de produção, de pós-vendas, etc. Os clientes que já possuem o sistema instalado em suas carrocerias percebem maior maturidade do sistema elétrico da carroceria, vindo a solicitar o mesmo sistema em outros modelos de carrocerias.

\section{REFERÊNCIAS}

[1] BACK, NELSON; OGLIARI, ANDRÉ; DIAS, ACIARES; SILVA, JONNY C. DA.Projeto Integrado de Produtos: planejamento, concepção e modelagem. Barueri, SP: Editora Manole,2008.

[2] BALDWIN, CARLISSY.; CLARK, KIM B.Design Rules. The Power of Modularity. Massachusetts Institute of Technology, 2000.

[3] PAHL, GERHARD; BEITZ, WOLFGANG; FELDHUSEN, JORG; GROTE, KARL-HEINRICH.Projeto na engenharia: Fundamentos do desenvolvimento eficaz de produtos, métodos e aplicações. São Paulo: Edgard Blücher, 2005.

[4] MEYBODI, MOHAMMAD Z.The impact of just-in-time practices on new product development: a managerial perspective. School of Business, Indiana University Kokomo, USA, 2005.

[5] GUIMARÃES, A.A.O Protocolo CAN: Entendendo e Implementando uma Rede de Comunicação Serial de Dados baseada no Barramento "Controller Area Network". Universidade de São Paulo, 2002.

[6] VIERO, CARLOS F.Metodologia de Projeto para arranjo estrutural de Carroceria de Ônibus através de Sistemas Modulares: um estudo de caso. Universidade de Passo Fundo. Programa de Pós-Graduação em Projeto e Processos de Fabricação. Passo Fundo, 2013.

[7] ROTH, A. S. Projeto elétrico modular para construção de ônibus urbanos: Estudo de caso. Universidade de Passo Fundo. Programa de Pós-Graduação em Projeto e Processos de Fabricação. Passo Fundo, Brasil, 2014. 


\title{
CAPÍTULO 19
}

\section{ANÁLISE DAS FASES DE DESENVOLVIMENTO DE PRODUTOS APLICADAS NA CRIAÇÃ̃ DE UM MOBILIÁRIO URBANO}

\author{
Amanda Daniele de Carvalho \\ Rayane Ester Felício Santiago \\ Luciano Wallace Gonçalves Barbosa \\ Camila Gonçalves Castro
}

Resumo: Com referência nos modelos de desenvolvimento de produtos de Rozenfeld e Baxter, o trabalho presente teve como finalidade criar um objeto de mobiliário urbano seguindo as metodologias citadas e comparar a literatura para cada uma das fases seguidas no projeto. Para o lançamento de novos produtos deve-se primeiramente atender às necessidades do consumidor ou usuário, levando em consideração os seus requisitos como norteadores das fases do seu desenvolvimento. Ao projetar um novo assento para locais públicos, os pesquisadores buscaram levantar dados sobre possíveis soluções para o problema de limpeza, que em razão da pouca manutenção que possui e de estar localizado ao ar livre, o banco muitas vezes encontra-se sujo ou molhado. Por meio de pesquisas, entrevistas e estudos, no prosseguimento das fases de desenvolvimento de produtos buscou-se uma solução simples para o problema.

Palavras chave: Desenvolvimento de produtos, Público alvo, Engenharia do Produto, Projeto. 


\section{INTRODUÇÃO}

O desenvolvimento de produtos consiste na procura por soluções compatíveis com as necessidades analisadas. Este processo vem sendo desenvolvido descle a antiguidade. Na pré-história, os homens criavam instrumentos para ajudar na sua sobrevivência. Com a evolução da humanidade as necessidades foram se tornando cada vez mais complexas. Hoje em dia, um projetista deve considerar aspectos econômicos, ambientais e sociais, para suprir o desejo do consumidor (FILHO et al. 2011).

O processo de desenvolvimento de produtos (PDP) é um conjunto de atividades que determinam o projeto do produto e seu processo de produção, abrange desde conceito inicial e levantamento de informações no mercado até a difusão das informações obtidas nas demais áreas da empresa (ROZENFELD, 2006). O PDP possui ampla importância nas organizações, oferecendo grande contribuição na produção de produtos com qualidade, prazo e preço notáveis e interliga as necessidades do mercado com as tecnologias acessíveis. Diante disso, torna-se fundamental para competitividade no mercado e auxilia na tomada de decisões (SENHORAS et al., 2007).

Desenvolver produtos demanda de muitos estudos, recursos (humanos e financeiros) e conhecimentos, além de um prosseguimento de atividades predeterminadas. O objetivo principal deste artigo é ampliar a discussão teórica sobre cada fase do desenvolvimento de produto, apontando o caminho seguido para resolvê-las e as dificuldades enfrentadas, contribuindo para o enriquecimento da literatura sobre desenvolvimento de projetos.

A globalização tem provocado ao longo dos anos várias mudanças no cotidiano do ser humano. Em virtude da Revolução Industrial, o trabalhador que antes exercia uma atividade artesanal em casa, passou a executar funções em indústrias durante períodos maiores, dirigindo-se a locais públicos em maior constância. Hoje em dia, diante de grandes oportunidades de empregos, diversidade de estudos e melhores condições de trabalho, o tempo de permanência e a frequência de ida a locais públicos experimentaram um crescimento ainda maior.
Entretanto, os elementos citados não são os únicos motivos que levam as pessoas a frequentarem pontos populares, similarmente, a constante procura de diversão, distrações, comidas, bebidas, passeios, reuniões entre amigos, entre outros. Nesse grupo, há indivíduos de todas as idades, gênero, culturas e que possuem gostos diversificados, fatores que acarretam a dificuldade da satisfação de todos.

Diferenciando espaço público de espaço privado, Arendt (2004, apud FERRREIRA, 2007) afirma que no espaço privado o ser humano desfruta de suas relações intrínsecas e é onde procura satisfazer suas necessidades essenciais. No espaço público, ocorre o seu vínculo com o mundo, local onde as atividades sociais são realizadas. Já Hertzberger (1999), define que a área pública é aberta para qualquer um, seja qual for o momento e todos são responsáveis por sua conservação. A área privada é aquela cujo acesso é deliberado por um indivíduo ou um por um grupo pequeno, que tem a responsabilidade de conservá-la.

Uma vez que boa parte da população passa um tempo notável em lugares coletivos, é crucial que a estadia seja agradável, com o mínimo de contratempos. São muitos os problemas que atrapalham esta estância, contudo, um dos que mais aflige as pessoas é a impossibilidade de se sentar. Estando ao ar livre e em locais com pouca manutenção, o banco muitas vezes encontra-se sujo ou molhado.

Outro objetivo, portanto, é demonstrar de forma prática o PDP, por meio do desenvolvimento de um produto que resolva este problema, sendo vendável e satisfazendo o público alvo. Conforme Rozenfeld et al. (2006), os clientes estão paulatinamente exigentes, informados e com possibilidades de escolhas cada vez maiores e as empresas com competitividade global, frequentemente, lançam novos produtos que procuram atender constantemente às mudanças nas necessidades dos clientes, de melhor feitio e com maior número de funcionalidades tornando-os mais atrativos e criando no cliente o desejo de substituir o produto anterior.

Diante disso, é necessária uma atenção especial em relação ao cliente. Um produto para esse propósito 
deve ser de fácil acesso e manutenção, tendo em vista o custo de materiais e manutenção e a facilidade da mesma, também atentando sempre para a qualidade dos materiais que devem ser resistentes e duráveis para a segurança e conforto dos usuários.

\section{DESENVOLVIMENTO}

\subsection{REFERENCIAL TEÓRICO}

Projeto, conforme Maximiano (2010) pode ser definido por uma sequência de tarefas programadas, com a responsabilidade de fornecer um resultado que produz mudança. Segundo ele, os projetos criam inovações destinadas ao mercado, à sociedade ou processos de renovação interna das empresas, conduzindo ininterruptamente a novas situações, que geram novos projetos, gerando um ciclo repetitivo. Ensslin et al. (2010), afirma que, o processo de desenvolvimento de produtos envolve uma série de fases, tarefas e atividades que se complementam, variam entre simultâneas e sequenciais e apresentam suas especificidades de acordo com o produto a ser desenvolvido.

Segundo Lobach (2001), a partir do momento em que há conhecimento de um problema e intenção de resolvê-lo, acompanha-se uma meticulosa análise, podendo ser detalhada ou ampliada ao entorno do mesmo. É crucial recolher todas as informações possíveis, sem censuras e prepará-las para a fase posterior de avaliação. Todos os dados podem ser importantes para a base sobre a qual se construirá a solução.

No Planejamento do Projeto, as atividades devem executar esforços no sentido de identificar todas as ações, recursos e a melhor condição de integrálos para que o projeto siga adiante com o mínimo de erros. O Projeto Informacional tem por propósito o desenvolvimento de um conjunto mais completo possível de informações, dos quais orientam a geração de soluções ao passo que oferecem a base que serão montados os critérios de avaliação e de tomada de decisão empregados nas etapas posteriores do processo de desenvolvimento (ROZENFELD et al. 2006).
Para o Projeto Conceitual, é primordial que o benefício básico esteja bem estabelecido e as necessidades do consumidor e dos produtos concorrentes estejam bem compreendidos (BAXTER, 1998). Para o seu sucesso, faça o possível para gerar maior número possível de conceitos e selecione o melhor deles. Esta fase precisa de muita criatividade e é nela que muitas invenções são feitas. Rozenfeld et al. (2006) afirmam que, nesta fase, as tarefas da equipe de projeto está relacionada com a busca, criação, representação e seleção de soluções para o problema do projeto.

Após o desenvolvimento do projeto conceitual Roos et al. (2010) apresentam a fase de projeto detalhado, esta consiste em confeccionar um protótipo, com a finalidade de empreender testes mais aprimorados do que os realizados na fase anterior, detalhando-o de forma que todos os envolvidos no negócio aprovem seu desenvolvimento. Rozenfeld et al. (2006), afirmam que essa fase pode ser longa e demorada, variando de acordo com a complexidade das soluções que foram escolhidas para o projeto.

Tendo em vista os conceitos citados nesta seção, o prosseguimento e a obediência às etapas de PDP são imprescindíveis para a criação de um bom produto, assim sendo, consegue-se ao longo do projeto ideias cada vez melhores que obedecem a todos os requisitos necessários, entre eles, qualidade, beleza, praticidade, ergonomia, resistência, acessibilidade e maior custo-benefício.

\subsection{METODOLOGIA}

De acordo com Miguel (2012), o estudo de caso é uma metodologia de pesquisa amplamente utilizada na engenhara de produção. É um trabalho de caráter empírico que examina um problema real e efetua a análise do mesmo. Batalha et al. (2008) afirmam que para projetar, é imprescindível três tipos de conhecimentos básicos: conhecimentos para gerar ideias, para avaliar conceitos e para a estruturação do processo de projeto.

O projeto presente, fundamentou-se no modelo de desenvolvimento de produtos proposto por Rozenfeld 
et al. (2006), que segmenta o processo em seis fases: planejamento do projeto, projeto informacional, projeto conceitual, projeto detalhado, preparação da produção e lançamento do produto. Entretanto, a preparação da produção e o lançamento do produto não serão citados neste trabalho.

Inicialmente, foram realizadas pesquisas a respeito das limitações dos objetos coletivos, entrevistas com o público alvo e análises sobre a viabilidade do projeto, que proporcionaram a decisão do problema a ser resolvido: a impossibilidade da utilização de um assento em razão de não estar limpo ou seco. Com a finalidade de simplificar o problema, foram analisadas as tarefas e as funções que o produto deveria conter, subdividindo-o a seus elementos básicos.

Foram propostas cinco soluções, das quais uma foi escolhida, devido sua facilidade de uso e adaptação, podendo ser utilizada em várias ocasiões. A fase de detalhamento foi composta pela análise da arquitetura do produto, definindo todos os mecanismos presentes, design do produto, pela escolha do material para a produção e pela construção do modelo. O QFD e o FMEA foram utilizados como ferramentas de auxílio no desenvolvimento do projeto. Os detalhes de cada processo citado serão elucidados posteriormente.

\subsection{PLANEJAMENTO DO PROJETO}

São muitos os problemas enfrentados em locais públicos, escolher apenas um entre tantos outros com igual ou maior importância não foi uma tarefa simples. Para tal fim, foram necessárias muitas pesquisas e entrevistas como o público alvo para avaliar e decidir a melhor opção, sendo necessária também a análise das capacidades técnicas e tecnológicas disponíveis para projeto.

\subsection{PROJETO INFORMACIONAL}

Diante do embasamento teórico, destinadas ao projeto, foram realizadas pesquisas sobre o máximo de informações disponíveis sobre o problema, entrevistas e observações sobre o impacto que o mesmo produz no dia a dia. A entrevista direta foi executada com cem pessoas que frequentam locais públicos regularmente, de diferentes idades, grau de escolaridade e sexo, cidadãos das cidades de Belo Vale, Congonhas, Conselheiro Lafaiete e Ouro Branco - todas em Minas Gerais, objetivando o esclarecimento do problema maior: a impossibilidade de uso da cadeira ou da mesa.

Por intermédio do resultado geral, pôde-se concluir que o problema na cadeira produz um incômodo maior ao indivíduo, conquanto, o resultado da mesa possui muita significância para ser ignorada. É importante salientar a diferença entre os resultados, os indivíduos têm opiniões distintas, podendo ser ocasionada por desigualdade de idade, sexo, escolaridade, tornando impossível satisfazer por inteiro todos os integrantes do público alvo. Logo, o objetivo principal no desenvolvimento de um produto, é satisfazer o máximo de possíveis clientes e usuários. Portanto, o grupo tomou como objetivo principal a solução para cadeira e em segundo plano, a mesa.

Como uma fermenta de auxílio, utilizou-se o método de desdobramento da função qualidade (QFD), que conforme Cheng et al. (2007), pode ser definido como uma maneira de comunicar sistematicamente a informação, relacionando-a com os requisitos de qualidade do produto, objetivando alcançar o desenvolvimento de produto que atenda às necessidades dos clientes. Vergara et al. (2001), afirmam que o QFD é um método de desenvolvimento de produtos e processos que objetiva a garantia da introdução dos requisitos do cliente no projeto, sendo uma sistematização que envolve trabalho em equipe e utiliza diagramas para reunir grande quantidade de informações complexas de maneira sucinta. Portanto, de forma simplificada, o QFD tem o intuito de traduzir a "voz dos clientes" para a "voz dos engenheiros" (AKAO, 1990).

Para definir os requisitos do cliente, foram consideradas opiniões de vinte pessoas. O resultado final foi obtido por meio da média de todas as notas, utilizando o método de arredondamento. Os requisitos 
que obtiveram uma nota de menor importância (peso, conforto, volume e encosto) levaram em consideração a permanência breve do indivíduo no local e a questão do produto permanecer fixado em um lugar. Devido ao fato da cadeira ser destinada ao uso público, a fim de evitar furtos e propiciar menor possibilidade de erro no uso, a mobilidade não é recomendada. Desta forma, os principais requisitos a serem considerados são: praticidade, resistência, ergonomia, fácil manutenção e limpeza, estabilidade e acessibilidade.

Tabela 1- Diagrama do QFD do produto

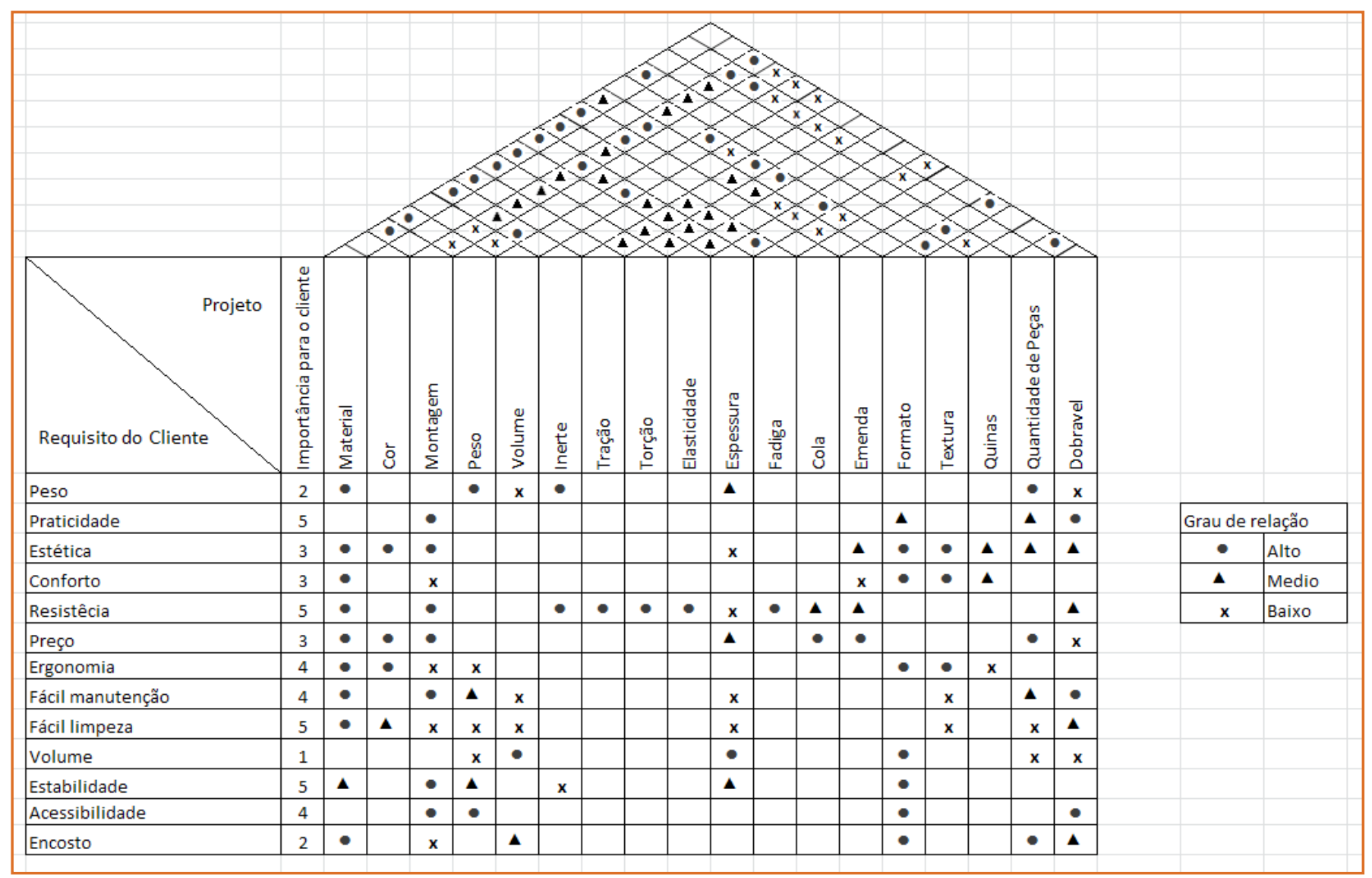

Fonte: Elaborado pelos autores com base na pesquisa realizada

\subsection{PROJETO CONCEITUAL}

Segundo Baxter (1998), a geração de conceitos auxilia no desenvolvimento do produto reduzindo o problema aos seus elementos básicos e empregando métodos estruturados de pensamento para analisar diferentes aspectos do projeto conceitual, gerando um grande número de alternativas possíveis para a solução do problema. Entre esses métodos está a análise das tarefas, onde ocorre a observação das pessoas utilizando os produtos. Ela cobre dois importantes aspectos do desenvolvimento de produtos: ergonomia e antropometria. A ergonomia usa os conhecimentos de anatomia, fisiologia e psicologia, aplicando-os ao projeto de objetos. A antropometria é a medida física das pessoas.

Em virtude das especificações necessárias para tornar o produto acessível a qualquer pessoa (pesos e tamanhos distintos), este método possuiu vital importância. Foram pesquisados padrões de altura e largura de bancos públicos, opiniões de pessoas com relação à finalidade principal do objeto e os complementos necessários para torná-lo mais agradável. O desempenho de uma cadeira comum não muda, sempre é colocado um peso para que ela sustente (podendo ser o próprio indivíduo sentado de 
modos diferentes ou uma bolsa apoiada no assento enquanto o dono executa alguma função) e não há variação de posição do uso (diferenças para canhotos e destros, cadeira de pés para o alto e assento para baixo, assento na vertical, entre outros).

Outro método de geração de conceitos é a análise de funções de um produto, que segundo Baxter (1998) é orientado diretamente para o consumidor. As funções do produto são demonstradas do modo que são percebidas e avaliadas pelo consumidor. Uma das ferramentas mais utilizadas para o sucesso desse método é o Mapa Mental, que conforme Buzan e Buzan (2003, apud WANDERLEY, 2012), é um diagrama que interliga palavras e ideias a um conteúdo central, permitindo a visualização, especificação e estruturação de conceitos, utilizado para se gerar novas ideias.

Figura 1 - Mapas metais
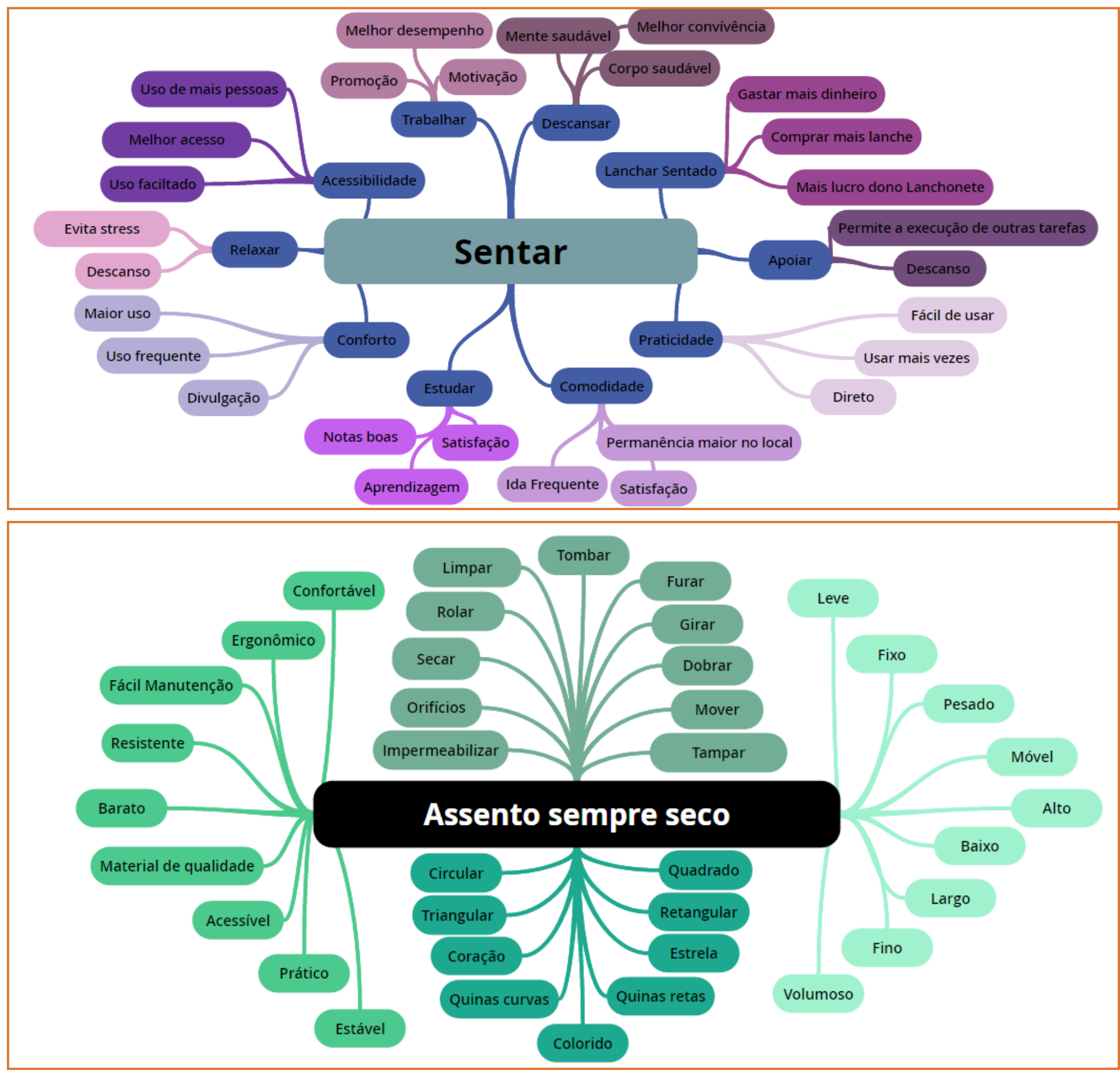

Fonte: Elaborado pelos autores com base na pesquisa realizada 
A execução de pesquisas sobre produtos que solucionam o problema teve por objetivo auxiliar na criação de novas alternativas. Buscou-se desde o mais simples (como por exemplo, uma toalha para secar o local) até os mais complexos (fabricação da cadeira com materiais impermeabilizados). Foram realizados testes com os mais acessiveis (tolha, tecidos impermeabilizantes, rodo, secador) para medir a eficiência e praticidade de cada um.

Foram propostas várias alternativas, no entanto, muitas impossíveis de construir. Todas as vezes que eram apresentadas novas ideias, na maioria delas, versões melhoradas das anteriores. Foram exibidas alternativas relacionadas ao mecanismo de funcionamento (dobrar, girar, encaixar, justapor, adaptar), ao formato (furos, ângulos) e ao material (impermeabilizante, que promove absorção), entretanto, diante da capacidade técnica e dos conhecimentos possuídos, decidiu-se focar na primeira questão.

Figura 2 - Soluções iniciais para o problema

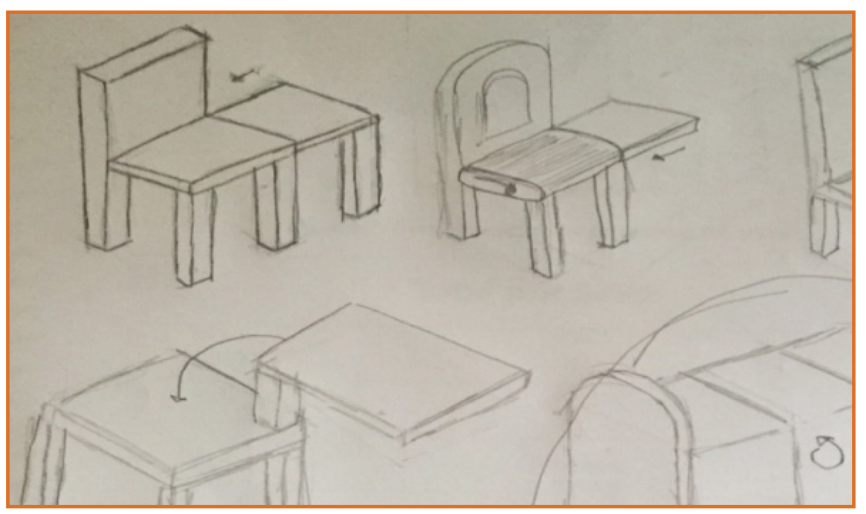

Fonte: Elaborado pelos autores com base na pesquisa realizada

Para assegurar o sucesso no desenvolvimento de um produto, Dreyfuss (1967, apud SÁ, 2009), afirmam que são necessárias cinco finalidades: maneabilidade, aparência, manutenção fácil, custo e comunicação. Diante das soluções iniciais, a elaboração do produto tornou-se mais fácil. Ao avaliar as opções, escolheu-se a mais adequada, aprovada por ser a mais prática e por possuir o mecanismo mais inteligente até aquele momento. O produto recebeu o nome de banco mágico.

Figura 3 - Banco Mágico

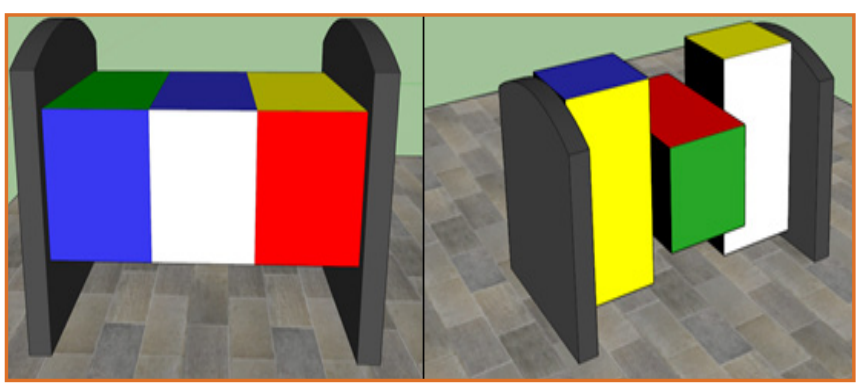

Fonte: Elaborado pelos autores com base na pesquisa realizada

O banco possui uma aparência que remete à de um cubo mágico (um quebra-cabeça tridimensional, que possui seis faces com cores diferentes divididas em nove partes, de modo que o brinquedo esteja subdividido em cinquenta e quatro faces menores), contém três partes que são os assentos que giram e torno de um eixo central, de modo que cada um possa ser colocado em quatro posições diferentes. Os assentos são prismas de bases retangulares, dependendo da posição escolhida, podem ser usados como mesa. Desta maneira, foram resolvidos dois problemas inicialmente questionados, o da cadeira e da mesa molhadas.

\subsection{PROJETO DETALHADO}

O banco mágico é constituído por três prismas que giram em torno de um eixo central (funcionam de mesa ou assento). Nas laterais estão os apoios que, ao mesmo tempo em que participa do sistema de sustentação, funciona como um descanso para o braço. O sistema possui dois tubos, o central que proporciona a rotação e o lateral que concede a trava. As cores podem sofrer modificações, entretanto, escolheram-se as similares de um cubo mágico, a fim de provocar no usuário uma associação entre os dois objetos. 
Figura 4 - Detalhamento do produto
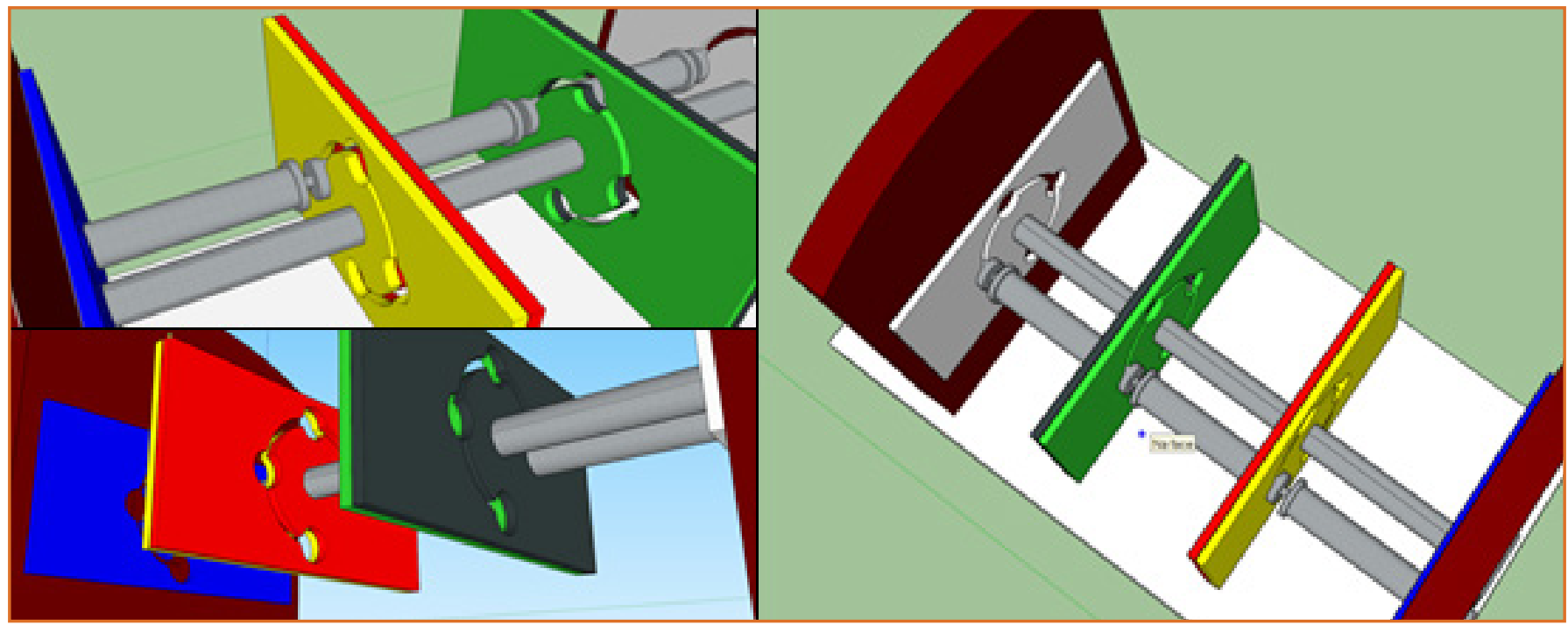

Fonte: Elaborado pelos autores com base na pesquisa realizada

O tubo central possui o mesmo diâmetro em toda a sua extensão e está fixado nas laterais do banco. O tubo que proporciona a trava possui diâmetros diferentes e realiza um movimento horizontal, da direita para a esquerda e da esquerda para a direita. As faces dos prismas voltadas para as laterais do produto detêm-se da configuração exposta na figura 5 , as demais são inteiras.

Figura 5 - Face lateral do prisma

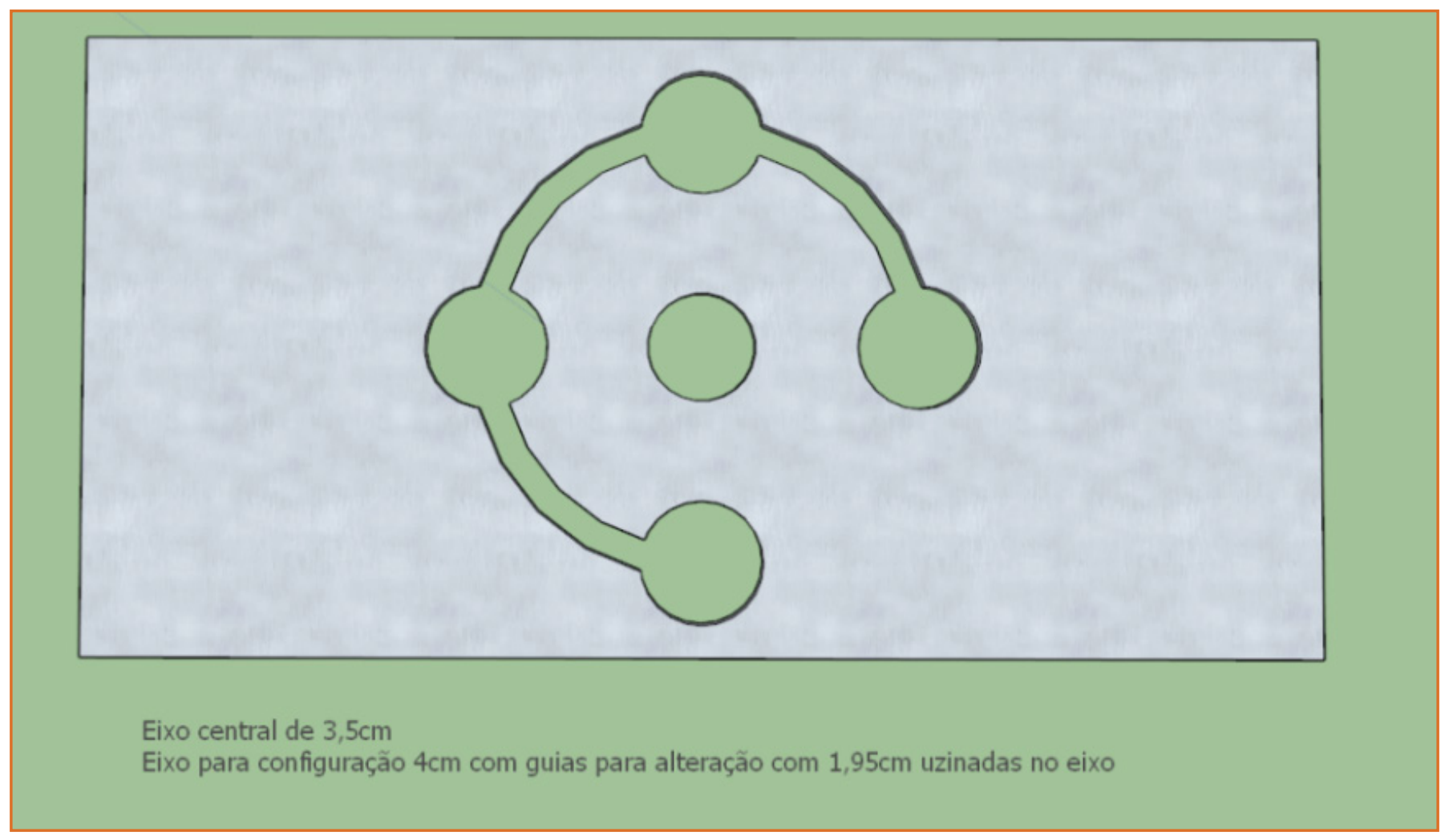

Fonte: Elaborado pelos autores com base na pesquisa realizada 
Inicialmente, o tubo móvel está em uma posição na qual o diâmetro maior encontra-se encaixado na face lateral do prisma. Para realizar a rotação é necessário puxar uma corda, localizada no descanso e conectada ao tubo, que o desloca, posicionando-o no diâmetro menor, proporcionando o movimento através da linha circular em torno do furo central. No momento em que as posições desejadas são alcançadas, deve-se empurrar o tubo para voltar à posição inicial.

A confiabilidade de um produto é uma característica muito importante para o consumidor. Segundo Maximiano (2010), o processo de administrar os riscos de um projeto consiste em antecipar o acontecimento de problemas, como base para o planejamento de respostas, monitorar e controlar a ocorrência de riscos durante $\mathrm{O}$ andamento do projeto. $\mathrm{O}$ trabalho presente utilizou o FMEA, que conforme Laurenti et al.(2012) é administrado em itens novos para a empresa com a finalidade de se descobrirem conexões entre funções e falhas, avaliar os riscos e determinar ações de melhoria.

Tabela 2- FMEA do produto

\begin{tabular}{|c|c|c|c|}
\hline Função & Falhas & Causa & Ação preventiva \\
\hline \multirow[t]{4}{*}{ Sentar } & $\begin{array}{c}\text { Quebra de um tubo ou } \\
\text { assento }\end{array}$ & $\begin{array}{l}\text { - Peso acima do suportado } \\
\text { - Material pouco resistente }\end{array}$ & $\begin{array}{l}\text { - Dimensionar o tubo a fim de amenizar concentração de } \\
\text { tensões } \\
\text { - Fabricar os tubos com um material mais resistente } \\
\text { - Demonstrar aos usuários o peso máximo suportado } \\
\text { - Fabricar os assentos com materiais resistentes à fadiga, às } \\
\text { condições climáticas e ao peso }\end{array}$ \\
\hline & $\begin{array}{l}\text { Assento molhado ou } \\
\text { sujo }\end{array}$ & $\begin{array}{c}\text { - Localização ao ar livre com } \\
\text { pouca manutenção }\end{array}$ & $\begin{array}{l}\text { - Mecanismo de rotação } \\
\text { - Limpar periodicamente } \\
\text { - Aumentar o número de manutenções }\end{array}$ \\
\hline & Falta de espaço & $\begin{array}{c}\text { - Ocupado } \\
\text { - Assento estreito }\end{array}$ & - Aumentar a largura do assento utilizando dois prismas \\
\hline & $\begin{array}{c}\text { Desconhecimento do } \\
\text { uso }\end{array}$ & - Falta de instrução & - Incluir placas ou adesivos de instrução \\
\hline \multirow{2}{*}{ Descansar } & Assento desconfortável & $\begin{array}{l}\text { - Material rígido } \\
\text { - Formato do assento }\end{array}$ & $\begin{array}{l}\text { - Proporcionar um assento menos rugoso, com material mais } \\
\text { macio na superfície }\end{array}$ \\
\hline & Rangidos & - Falta de lubrificação & - Promover a lubrificação \\
\hline Comer & $\begin{array}{l}\text { Local para objetos e } \\
\text { comida }\end{array}$ & - Falta de planejamento & - Utilizar um dos prismas na configuração mais alta \\
\hline
\end{tabular}

Fonte: Elaborado pelos autores com base na pesquisa realizada

Após a decisão do produto e o levantamento de possíveis falhas é necessário especificar o material de fabricação obedecendo a todas as restrições com um custo mais baixo. Produzindo um banco público com um custo muito elevado, os clientes não comprarão, uma vez que raramente serão os usuários, no entanto, não se deve economizar a ponto de interferir na qualidade do produto.

Segundo Callister (2006), existe certa dificuldade em selecionar um material dentre inúmeros disponíveis, para tal, deve-se definir algumas características. Entretanto, somente em ocasiões raras um material possuirá uma combinação máxima ou ideal de propriedades, tornando-se inevitável perder uma característica para obter outra, por exemplo, um material tendo uma alta resistência mecânica terá apenas uma limitada ductilidade. Pode-se encontrar um material que tenha um conjunto ideal de propriedades, mas certamente, possuirá um custo muito elevado. 
Para a construção dos assentos, determinou-se o Polipropileno (PP), que segundo as especificações determinadas por Montenegro et al. (1996) possui alta rigidez, baixo peso específico, boa claridade e resistência às altas temperaturas, propriedades mecânicas adequadas quando reforçado, e suficiente para competir, em várias aplicações, com polímeros de engenharia de maior custo. Suas propriedades permitem uma fácil moldagem por injeção e considerando o fator densidade, o polipropileno é um dos materiais mais econômicos.
Para a composição dos tubos e o sistema de sustentação, designou-se os aços-liga, que de acordo com Pannoni (2007), apresentam maior resistência mecânica que os aços de baixo carbono similares, mantendo a ductilidade e a fácil realização da solda, sendo destinados às estruturas onde a soldagem é um requisito importante do mesmo modo que a resistência. De forma geral, estes aços proporcionam uma grande economia de aço na estrutura, a um custo muito reduzido.

Figura 6 - Modelo construído

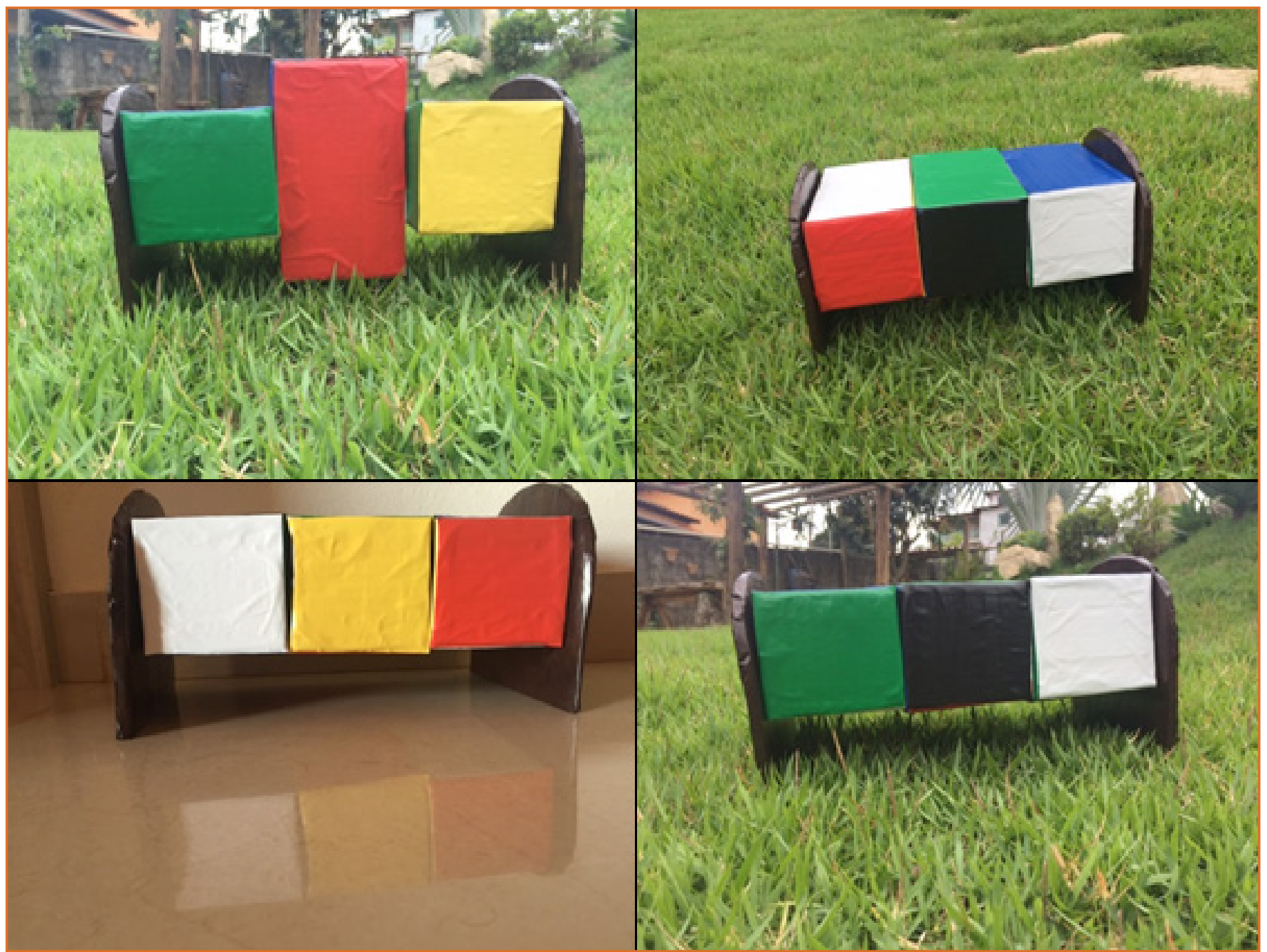

Fonte: Elaborado pelos autores com base na pesquisa realizada

\section{CONSIDERAÇÕES FINAIS}

Desenvolver produtos não é uma tarefa simples, são necessários inúmeros estudos, recursos, conhecimentos e em especial um fator quase escasso: tempo. Com os lançamentos frequentes de novos produtos, ao passo que as organizações estão com os prazos cada vez mais apertados, necessitam de investimentos crescentes em tecnologias de pesquisa e informação. 
A determinação do público alvo é muito importante, uma vez que, conhecido o consumidor ou o usuário que o produto será destinado, torna-se mais fácil saber o que se deseja, e consequentemente a probabilidade de se criar um objeto vendável é maior. Não especificado tal público, o produto não exerce identidade, não se torna popular e muitas vezes não executa as funções desejadas. Neste caso, os indivíduos que frequentam locais públicos foram o público alvo, devido a grande demanda e necessidade de melhora.

Os projetos consomem tempo e dinheiro, se realizados deformanegligente, concebem prejuízos consideráveis à empresa. É necessário o comprometimento de todos os envolvidos, a realização correta de todas as tarefas, a concreta coleta de dados, análises bem executadas e o processo de decisão tem por obrigação dispor do cuidado e do detalhamento de todas as escolhas, a fim de determinar a melhor opção para o mercado.

A sequência predeterminada de atividades é crucial para a criação de um produto criativo. Muitas ideias surgem por toda a extensão do projeto, muitas vezes relacionadas com as anteriores. No trabalho presente, a solução final para o problema baseou-se na primeira. A realização de estudos, pesquisas e análises ao longo do desenvolvimento, acarretaram à melhoria da proposta, tornando o produto mais adequado ao público pesquisado.

Por fim, o objetivo principal deste artigo conseguiu-se cumprir por meio da ampliação da discussão acerca das fases de desenvolvimento de produtos exibindo um problema real e discutindo cada fase onde foram levantados os caminhos seguidos e as dificuldades enfrentadas, cointribuindo para a literatura a respeito do tema.

\section{REFERÊNCIAS}

[1] AKAO, Y. Quality Function Deployment: Integrating Customer Requirements Into Product Design. Cambridge: Productivity, 369 p., 1990.

[2] BATALHA, M. et al. Introdução à engenharia de produção. Rio de Janeiro: Elsevier, 2008.
[3] BAXTER, M. Projeto de produto: guia prático para o design de novos produtos. 2. ed. São Paulo: Edgard Blücher, 1998.

[4] CALLISTER, W. D. Fundamentos da ciência e engenharia de materiais: uma abordagem integrada. Rio de Janeiro: LTC, 2006.

[5] CHENG, L. C.; MELOFILHO, L. D. R. QFD: desdobramento da função qualidade na gestão de desenvolvimento de produtos. São Paulo: Blucher, 2007.

[6] ENSSLIN, L., QUEIROZ, S. G., GRZEBIELUKAS, C., ENSSLIN, S. R., NICKEL, E., BUSON, M. A., \&

[7] BALBIM, A. J. I. Identificação das necessidades do consumidor no processo de desenvolvimento de produtos: uma proposta de inovação ilustrada para o segmento automotivo. Revista Produção. V.21, N.4, P 555-569, 2010.

[8] FILHO, E. R.; FERREIRA, C. V.; MIGUEL P. A. C.; GOUVINHAS, R. P.; NAVEIRA, R. .M.. Projeto do Produto. Rio de Janeiro: Elsevier: ABEPRO,2011.

[9] FERREIRA, P. E. B. A apropriação do espaço urbano e as políticas de intervenção urbana e habitacional no centro de São Paulo. 2007. 131f. Dissertação (Mestrado). Departamento de Arquitetura e Urbanismo, USP, São Paulo, 2007

[10] HERTZBERGER, H. Lições de Arquitetura. São Paulo: Editora Martins Fontes, 1999.

[11] LAURENTI, R.; ROZENFELD, H.; FRANIECK, E. K. Avaliação da Aplicação dos Métodos FMEA e DRBFM no Processo de Desenvolvimento de Produtos em uma Empresa de Autopeças. Revista Gestão e Produção. v.19, n.4, p. 841855. 2012.

[12] LÖBACH, B. Design industrial: bases para a configuração dos produtos industriais. s. I.: Edgar Blücher, 2001.

[13] MAXIMIANO, A. C. A. Administração de projetos: como transformar ideias em resultados. 4. ed. São Paulo: Atlas, 2010

[14] MIGUEL, P.A.C. Metodologia de Pesquisa em Engenharia de Produção e Gestão de Operações. Rio de Janeiro: Elsevier: ABEPRO, 2012.

[15] MONTENEGRO, R. S. P.; ZAPORSKI, J. A situação atual e futura da indústria de polipropileno. BNDES Setorial, Rio de Janeiro, 1996.

[16] PANNONI, F. D. Aços estruturais. Disponível em: <www. cbcaibs.org.br/downloads/apostilas/Aços_estruturais.pdf>. Acesso em: 10 fevereiro de 2016.

[17] ROOS, C.; BEUREN, F. H. ; BARBOSA, S. B. ; FERREIRA, M. G. G.. Método estruturado de design de produtos orientados aos sistemas produto-serviço: proposta e aplicação. Iberoamerican Journal of Industrial Engineering, v. 2, p. 44-69, 2010 
[18] ROZENFELD, H. et al. Gestão de desenvolvimento de produtos: uma referência para a melhoria do processo. São Paulo: Saraiva, 2006.

[19] SÁ, S. P. D. S. Design e desenvolvimento de novos produtos de mobiliário: aplicação e implementação de uma filosofia de desenvolvimento de produto. Dissertação (Mestrado em Design Industrial e de Produto). Universidade do Porto, Faculdade de Engenharia, Paços de Ferreira, Portugal, 2009.

[20] SENHORAS, E. M; TAKEUCHI, K. P; TAKEUCHI K. P. Gestão da Inovação no Desenvolvimento de Novos Produtos. In: IV Simpósio de Excelência em Gestão e Tecnologia. Anais..., Rio de Janeiro/RJ, 2007.
[21] VERGARA, L. G. L., GELSLEICHTER, B. D., ALMEIDA, M., \& DOS REIS, A. V. Processo de Desenvolvimento de Produto na concepção de utensílios de cozinha acopláveis. $8^{\circ}$ Congresso Brasileiro de Gestão e Desenvolvimento de Produto. Porto Alegre, RS, 2011.

[22] WANDERLEY, F. J. A.; SILVEIRA, D. S.. Transformando mapas mentais em modelos conceituais de informação. Revista Brasileira de Administração Científica, Aquidabã, v.3, n.2, p.105 $\square 122,2012$ 


\title{
CAPÍTULO 20
}

\section{ANÁLISE DA CADEIA DE SUPRIMENTOS SOB À LUZ DO LEAN LOGISTICS}

\author{
Ana Celia Vidolin \\ Christiane Wagner Mainardes Kraine \\ Jefferson Augusto Krainer \\ Cezar Augusto Romano
}

Resumo: O presente artigo tem por objetivo identificar com quais elementos a cadeia de suprimentos pode contribuir positivamente na aplicação do lean logistics. Foi realizada uma pesquisa aplicada, exploratória e qualitativa. Quanto aos procedimentos, utilizou-se da pesquisa bibliográfica feita a partir do levantamento de referências teóricas já analisadas e publicadas em meio físico e/ou eletrônico. Os resultados e discussões foram elaborados a partir do exame detalhado da pesquisa bibliográfica que conduziu a uma série de reflexões e conectividades a cerca dos temas lean manufacturing, gerenciamento da cadeia de suprimentos, logística empresarial e sales and operations planning. Os elementos de convergência da cadeia de suprimentos e do lean logistics identificados foram: coordenação, redes, informações, recursos, objetivos, insumos, processos, harmonia, alinhamento, planejamento, equilíbrio e integração. A integração da cadeia de suprimentos lastreada pela filosofia lean colaboram com o incremento da competitividade, da longevidade, do lucro, do atendimento as demandas do cliente, da redução dos desperdícios e dos custos. A aplicação da ferramenta S\&OP pode subsidiar a filosofia lean.

Palavras chave: Gestão da Cadeia de Suprimentos, Filosofia lean, Logística Empresarial, S\&OP. 


\section{INTRODUÇÃO}

$\mathrm{Na}$ estrutura logística que se relaciona à gestão da compra, à movimentação e armazenagem de materiais e aos canais de comercialização, está alicerçada a gestão da cadeia de suprimentos, a qual visa ter domínio na articulação e gestão de outros participantes como a própria organização, os fornecedores e os clientes (CHRISTOPHER, 2014). O foco da gestão da cadeia de suprimentos está na parceria, é "a gestão de relações a montante e a jusante com fornecedores e clientes, a fim de entregar ao cliente valor superior ao menor custo para toda a cadeia de suprimentos" (CHRISTOPHER, 2014, p.3).

Para que se produza mais com menos, a premissa é a redução de desperdícios. Na cultura lean manufacturing, ou produção enxuta, são identificados como desperdícios movimento, espera, transporte, correção, processamento, estoque, produção e falta de comunicação (PASCAL 2008). Aliás, as diretrizes do lean manufacturing foram elaboradas a partir da área fabril, porém têm sido aplicadas tanto nas áreas produtivas quanto nas áreas não produtivas, com resultados positivos (TURATI; MUSETTI, 2006).

Nessa linha de raciocínio, a aplicação do lean manufacturing, que tem como linha mestra a eliminação de desperdícios, em atividades logísticas tem sido chamada de lean logistics. De acordo com Bowersox et al. (2006, p.44) lean logistics é "a habilidade superior de projetar e administrar sistemas para controlar a movimentação e a localização geográfica de matérias primas, trabalhos em processo e inventários de produtos acabados ao menor custo possível". O lean logistics busca a otimização dos processos, produzindo mais com qualidade e com menos desperdícios.

A atividade logística é inseparável da gestão de suprimentos, logo o estudo das relações entre cadeias de suprimentos e logística se faz pertinente. A lean logistics tem como foco a idealização de processos simples e mais produtivos, de fluxos de informações mais eficientes, de respostas mais rápidas, de estoques reduzidos, de melhora contínua. Myerson (2012) ressalta que o lean logistics enfatiza a redução dos desperdícios dos recursos usados na cadeia de suprimentos, como: excesso de estoques e de produção, redução de erros, processamentos, movimentações, esperas e transportes desnecessários.

Nesta perspectiva, o presente artigo tem por objetivo identificar com quais elementos a cadeia de suprimentos pode contribuir positivamente na aplicação do lean logistics.

\section{REVISÃO BIBLIOGRÁFICA}

A disciplina e a cultura japonesas e o guerrear com o desperdício em vários níveis proporcionou um rearranjo do sistema produtivo definido primeiramente de Sistema Toyota de Produção, que veio a servir de alicerce posteriormente para o Sistema de Produção Enxuta (RODRIGUES, 2014). De acordo com Shimokawa; Fujimoto (2009), uma lição aprendida pela empresa Toyota no período pós-guerra foi de que não era suficiente apenas aumentar a produtividade, necessário, também, agregar valor à produção, manufaturando de acordo com a demanda, no tempo e na quantidade certa. Desta forma surgia o Modelo Toyota, base do Sistema Toyota de Produção.

A designação lean foi utilizada por Womack et al. (2004), ao analisar a indústria automobilística no mundo com base no Sistema Toyota de Produção, que resultava em eliminação dos desperdícios, ganhos em produtividade e qualidade. Com a implantação do Modelo Toyota, seguido da designação lean, tem-se então a criação do termo lean thinking ou mentalidade enxuta. O Lean thinking proporciona uma forma de produzir mais com menos; menos esforço humano, menos equipamento, menos tempo, menos tempo, menos espaço, aproximando-se mais e mais e oferecendo o que o cliente deseja (WOMACK et al., 2004). Cinco são os princípios básicos da mentalidade enxuta, segundo o referido autor: valor, cadeia de valor, fluxo, puxar e perfeição.

De acordo com Bowersox et al. (2006, p.22), o relacionamento entre as empresas de uma cadeia de suprimentos é caracterizado pelo fato de que nenhuma empresa "é autossuficiente a ponto de conduzir todos os seus negócios sozinha, esta estrutura é resultada das limitações de capacidade, informações, competências essenciais, capital e de restrição de 
recursos humanos das empresas integradas".

O gerenciamento da cadeia de suprimentos, segundo Davis et al. (2001), pode ser definido como um conjunto de empresas que fornecem todos os processos para a fabricação de um produto acabado; portanto o gerenciamento da cadeia de suprimentos pode ser tido como a aptidão de uma organização operar com seus provedores para receber insumos e partes com preços atrativos. Os fatores como incremento da competitividade, ciclo de vida dos produtos de menor duração, avanços tecnológicos e políticas de compartilhamento de riscos, são alguns aspectos que figuram na dinâmica do supply chain atualmente.

Para Lee (2004), o Supply Chain Management tem três características básicas: deve ser ágil para adaptar-se às variações das demandas do mercado; deve ser adaptável às alterações do mercado e deve, também, alinhar-se às demandas dos integrantes da cadeia de suprimentos. Para o autor, uma cadeia de suprimentos deve concatenar três elementos: adaptabilidade, agilidade e alinhamento.

Na visão de Gaither e Frazier (2002, p.427), uma cadeia de suprimentos "refere-se à maneira pela qual os materiais fluem através de diferentes organizações, iniciando com as matérias primas e encerrando com os produtos acabados entregues ao consumidor final". Por outro lado, a administração da cadeia de suprimentos "refere-se a todas as funções administrativas relacionadas ao fluxo de materiais dos fornecedores diretos da empresa até seus clientes diretos, inclusive os departamentos de compras, [...] e expedição e distribuição" (GAITHER; FRAIZER, 2002, p.429).

Tendo em vista uma e melhor administração e uma maior interação entre os membros da cadeia de suprimentos, surgiu o conceito de gestão integrada, no qual os agentes da cadeia, internos ou externos à organização, trabalham de forma unificada com objetivos em comum, na busca do menor custo total dos processos. Essa interação entre os membros da cadeia pode trazer, também, outros benefícios, como a melhoria na qualidade operacional e o destaque no mercado (BOWERSOX et al., 2014). Para Ballou (2006), devido à grande participação da cadeia de suprimentos dentro da organização e os efeitos causados pela sua correta ou incorreta administração, pode-se dizer que esta atividade tem grande potencial estratégico. A gestão da cadeia de suprimentos, continua o autor, pode gerar valor agregado ao produto ou serviço para o mercado, uma vez que suas necessidades de tempo e lugar sejam atendidas.

Com o incremento da complexidade do supply chain a logística desempenha um papel importante, devido a demanda de estratégias para movimentação dos insumos e produtos acabados para atendimento dos clientes por meio de parcerias com especialistas em transporte e logística e análises do custo de estoque em trânsito (DAVIS et al., 2001). Para Christopher (2014), o foco está nas relações intra cadeia, com busca no resultado positivo e lucrativo para todos os integrantes da cadeia. $\mathrm{O}$ autor ainda sugere duas adequações: a primeira, que a "gestão da cadeia de suprimentos" seja chamada de "gestão da cadeia de demanda", para indicar a demanda indicada pelo mercador e não mais pelos fornecedores; e a segunda, que a palavra "cadeia" seja substituída por "rede", em razão do desenho e da complexidade das estruturas (fornecedores dos fornecedores e clientes dos clientes).

Na mesma linha, Vivaldini e Pires (2010), afirmam que o crescente interesse no supply chain está relacionado com a reengenharia de projetos e com a melhoria contínua. Os autores defendem a hipótese de que a competição industrial ocorre entre as cadeias de suprimentos e não mais entre as empresas. Christopher (2014), acrescenta que a gestão de cadeia de suprimentos é uma extensão da logística; a gestão de logística atribui importância aos fluxos internos na organização, por outro lado, a gestão de cadeia de suprimentos observa que a integração interna não é suficiente, haja visto as questões estratégicas que a organização vivência como a concorrência, indústria globalizada, redução de preços e clientes com poder de decisão maior.

Christopher e Towill (2000) aduzem que, para ser ágil, o sistema de produção demandaria a utilização de mais recursos, o que comprometeria a performance enxuta 
da cadeia. Assim, continuam os autores, reduzir os desperdícios somente do lado do fornecedor, não é sinônimo de incremento de agilidade nos processos; a agilidade está relacionada com a forma de negociar e a qualidade da comunicação com esse fornecedor. Há, no entanto, mercados que não se exige sistemas produtivos ágeis.. A produção lean tem efeito melhor em ambientes de grande volume, baixa variedade de itens e demandas previsíveis (CHRISTOPHER; TOWILL, 2000). Os tipos de demandas, portanto, devem ser considerados quando do projeto da cadeia de suprimentos.

Na mesma linha de raciocínio, Harrison e Hoeck (2003) observam existir uma relação entre critérios enxuto e ágil na cadeia de suprimentos: quando se analisa sob o prisma enxuto, aspectos como ganho e qualidade são relevantes; todavia, quando se analisa agilidade, incremento na melhoria do serviço e do cliente são aspectos que devem ser considerados.

Para Harrison e Hoeck (2003), nas organizações em que o risco de obsolescência e/ou o custo da falta de estoque forem representativos em comparação com o custo de produção e distribuição, há que se analisar os custos totais do processo de entrega do produto (PDP - product delivery process), ou seja, o somatório dos custos de entrega do produto físico (custos de produção, mais distribuição, mais armazenagem), somado aos custos de atividade comercial (custos de obsolescência e falta de estoque). Advertem os autores que tanto na mentalidade enxuta, quanto na ágil, alto nível de qualidade e redução dos tempos de investida são requisitos; mesmo porque na mentalidade enxuta requer-se a eliminação do desperdício de tempo. O cerne da diferença entre ser enxuto e ágil, sob a análise do valor total ofertado ao cliente, reside, para aquele, no nível de serviço, ou seja, na disponibilidade, na compressão do tempo de investida, e para este, no custo (HARRISON; HOECK, 2003). Segundo Chopra e Meindl (2011, p.482): "o resultado da falta de coordenação de cadeia de suprimentos é o efeito chicote, em que as flutuações em pedidos aumentam à medida que elas sobem na cadeia de varejistas para atacadistas, de fabricantes para fornecedores". A coordenação, complementam os autores, deve ser na íntegra, de modo que cada nível da cadeia tenha ciência das consequências de suas ações; a informação, portanto, deve ser compartilhada ao longo da cadeia, evitando-se a ocorrência de distorções.

Apesar dos conflitos de objetivos entre suprimentos enxuto e ágil, é factível que em uma organização ambos coexistam. Em uma organização, por exemplo, é possível alinhar sistemas de informação, estruturas organizacionais, processos logísticos e mentalidades, ou seja, aplicar conhecimentos específicos para obter lucros em mercados voláteis, seja por ciclo de vida menor, maior variedade de opções ou capacidade de previsão da demanda. Distintas estratégias de logística (mentalidade ágil, enxuta ou combinação destas) podem ser adotadas levando-se em conta para tanto a análise do ambiente que se opera, particularidades da demanda do cliente final e a capacidade analítica para definir o tipo de demanda (HARRISON; HOECK, 2003).

Uma das ferramentas para obtenção de um fluxo mais equilibrado em termos de materiais e atendimento aos clientes é o Sales and Operations Planning ou Planejamento de Vendas e Operações (S\&OP), que visa a melhora nos processos de planejamento de vendas e produção, analisando o balanceamento entre demanda e oferta de produto no volume exato. O S\&OP trata-se da gestão integrada para ordenamento das funções da organização (CHING, 2010). Os objetivos do S\&OP são: dar sustentação ao planejamento estratégico do negócio; afiançar planos factíveis; gerir as mudanças de forma efetiva; gerir estoques de produtos acabados, carteira de novos pedidos e desempenho das entregas; e mensurar o desempenho e estender o trabalho em equipe (CORREA et al., 2014).

\section{METODOLOGIA}

Para a concretização do objetivo deste trabalho de identificar quais elementos da rede de suprimentos contribuem positivamente na aplicação do lean logistics foi realizada uma pesquisa aplicada, exploratória e qualitativa

A abordagem qualitativa, segundo Oliveira (2010, p. 60), "facilita a apresentação de resenhas, descrição detalhada dos fatos e fenômenos observados", e 
surge quando as informações sobre um determinado assunto não podem ser quantificadas, fazendo-se necessário a interpretação (TRIVIÑOS, 1987).

Quanto aos procedimentos, utilizou-se da pesquisa bibliográfica feita a partir do levantamento de referências teóricas já analisadas e publicadas em meio físico e/ou eletrônico.

A análise de dados que embasou essa pesquisa diz respeito a pesquisa bibliográfica, qualitativa com base em informações que não podem ser quantificados; aplicando-se então a interpretação. O artigo teve como fonte bibliografia consagrada, publicadas em bases de dados técnicos científicos, com indexações de periódicos de artigos, teses, livros, patentes, trabalhos de congressos, etc.

Para a busca do material bibliográfico foram definidas palavras chave que melhor representavam o tema abordado. Após pesquisa exploratória por meio de sondagem dos trabalhos com maior número de citações no Google Acadêmico, as palavras chave escolhidas foram: "lean", "lean manufacturing", "management supply chain", "business logistics", e "sales and operations planning". A escolha do Google Acadêmico se deu em função do alto grau de acessibilidade e abrangência aos periódicos científicos.

Na sequência, para a realização da pesquisa, foi consultado o "Portal de Periódicos CAPES" para acesso da base Web of Science do ISI (Institute for Scientific Information). A base Web of Science foi adotada em função de anexar volume elevado de periódicos de maior relevância sobre o tema abordado. Com o objetivo de garantir a qualidade dos resultados da pesquisa forma utilizadas palavras chave adequadas ao tema, um procedimento estruturado e uma análise sistematizada.

Assim a análise dos dados contou com dois momentos específicos: o primeiro a análise dos documentos técnicos, e o segundo da elaboração da interpretação dos mesmos e dos elementos em análise. Ao longo das apreciações dos temas, foi possível elaborar raciocínios a respeito da conectividade entre esses temas e seus reflexos, relações de causa e efeito em termos da gestão de uma organização.

\section{RESULTADOS E DISCUSSÕES}

Os resultados e discussões foram elaborados a partir do exame detalhado da pesquisa bibliográfica que conduziu a uma série de reflexões e conextividades a cerca dos temas lean manufacturing, gerenciamento da cadeia de suprimentos, logística empresarial e sales and operations planning.

Os elementos que contribuem sob forma positiva na aplicação do lean logistics foram elencados e apresentados em três etapas: análise dos elementos chaves da cadeia de suprimentos; correlação dos aspectos interfuncionais do lean manufacturing $e$ do lean logistics; e averiguação dos elementos de convergência da cadeia de suprimentos e do lean logistics.

\subsection{ANÁLISE DOS ELEMENTOS CHAVES DA CADEIA DE SUPRIMENTOS}

A cadeia de suprimentos engloba o planejamento, a gestão das atividades na definição de fontes de fornecimento, a compra, a transformação e/ou produção e a coordenação e/ou parceria com fornecedores, terceiros e clientes. A logística empresarial é um elemento fundamental com diversos processos responsáveis pela fluidez da operação, contribuindo sob a forma de um vetor dentro da cadeia.

O gerenciamento da cadeia de suprimentos visa a otimização do tempo, a melhora na comunicação e a redução dos custos. Outro aspecto que também merece destaque é a possibilidade da empresa tornar-se mais competitiva a partir da integração com fornecedores e clientes e por meio do desenvolvimento em conjunto de produtos e processos logísticos. Uma maior coordenação dos processos na cadeia de suprimentos auxilia na integração, principalmente, das áreas comercial, de marketing e de distribuição física da empresa.

A gestão da cadeia de suprimentos exerce papel importante na estrutura do negócio, mormente porque está diretamente relacionada ao incremento 
da competitividade, às mudanças tecnológicas e ao ciclo de vida dos produtos. No entanto, para que uma cadeia de suprimentos tenha êxito deve integrar a organização (processos internos e externos), além de ser adaptável (sensível às variações do mercado), ágil (atenta às mudanças das demandas) e alinhada (integrantes devidamente alinhados a uma estratégia definida).

Em uma cadeia de suprimentos os materiais circulam por entre diferentes organizações. O gerenciamento da cadeia é responsável pela gestão dos fluxos físicos e de informações. A melhor forma de fazêlo é por meio da gestão integrada, reiterando que a gestão da cadeia de suprimentos é fundamental no planejamento estratégico da organização. A condição estratégica visa a melhor articulação ao longo das etapas, desde o fornecedor até o cliente final, que é propiciada pela logística empresarial. Entretanto, se a gestão da empresa não for coordenada, há riscos de desvantagens financeiras, mercadológicas, produtivas, devido a ruptura dos fluxos internos.

A gestão da cadeia de suprimentos possibilita que o produto esteja ao alcance do cliente, dentro da sua percepção de custo. A organização deve ter uma logística que distribua o produto no local que o cliente deseja, promovendo comunicação e informação ao longo da cadeia. O desempenho da cadeia de suprimentos leva em conta a capacidade de atender as demandas dos clientes, a qualidade dos produtos e/ou serviços, a inovação e a efetividade em custos e prazos. Nesse particular, o mercado com previsibilidade alta, isto é, demanda previsível, requer que a cadeia de suprimentos seja enxuta. Outros mercados com previsibilidade menor, ou seja, demanda variável, a agilidade é recomendável em termos de suprimentos. Seja qual for a característica que a cadeia (enxuto ou ágil), o valor analisado pelo cliente é a disponibilidade do produto.

Outro aspecto importante é o efeito chicote que ocorre na cadeia de suprimentos. O efeito chicote é a falta de coordenação e de informação na cadeia que conduzem a erros de previsão de demanda. Para obtenção de lucro na cadeia de suprimentos, coordenação e informação devem ser compartilhadas.
Se ocorrer, porém, a disseminação de erros ao longo da cadeia, deve-se agir na origem destes por meio da demanda atualizada, equilíbrio entre oferta e demanda, programação de ordens de produção e gestão de preço.

Pertinente ressaltar que a cadeia de suprimentos deve satisfazer o cliente final, fazendo-se necessário, portanto, o desenvolvimento de estratégias de retenção e de obtenção de novos clientes. Aspectos como tecnologia, estrutura organizacional, criação de alianças estratégicas são de suma importância na contribuição do sucesso na gestão da cadeia de suprimentos. A organização deve estar atenta ao que os fatores externos, como mudanças mercadológicas, tecnologia de informação e meio ambiente, trazem para o ambiente interno da organização.

\subsection{CORRELAÇÃO DOS ASPECTOS INTERFUNCIONAIS DO LEAN MANUFACTURING E DO LEAN LOGISTICS}

O lean manufacturing, ou produção enxuta, foi desenvolvido em um período de conjuntura econômica pouco favorável. Para enfrentar as condições hostis, as organizações passaram a analisar o desperdício ao longo de todas as etapas do processo. O desperdício pode ser classificado como: espera por pessoas, materiais, recursos; defeito com produtos que não atendem as especificações; transporte de materiais e pessoas que não agregam valor; e excesso de estoque, de produção e de processamento. A produção enxuta busca, também, aumentar e associar valor à produção. Agrega-se valor à produção quando se produz conforme a demanda, na quantidade certa, no tempo e no local certo. Para o cliente o conceito de valor está relacionado com o atendimento de suas solicitações, porém cadeia de valor é o somatório de ações para se chegar ao final do processo com o produto e/ou serviço que o cliente requisitou.

A partir do lean manufacturing surgiu o lean thinking, ou mentalidade enxuta, que contempla os princípios de valor ao produto, de cadeia de valor do produto, de fluxo da cadeia de valor, de produção puxada pelo cliente e de busca pela perfeição. Com a finalidade de produzir mais, com mais valor e menos desperdício, 
a filosofia lean busca otimizar e integrar o sistema produtivo. Qualidade nos produtos produzidos, flexibilidade nos processos, produção em função da demanda, compromisso com o cliente e fornecedores, fluidez ao longo de toda a cadeia produtiva e redução dos custos são alguns dos objetivos do pensamento lean.

O lean manufacturing e o lean logistics objetivam produzir mais com menos - menos recursos, esforço, tempo, espaço, equipamentos - convertendo os desperdícios em valor e atendendo o cliente final. O lean logistics é a eliminação dos desperdícios nos processos logísticos que compreende, dentre outras, as atividades de movimentação, armazenagem, distribuição, bem como todo fluxo de informações. Vale ressaltar que as atividades logísticas dão suporte e viabilizam à cadeia de suprimentos, agregando valor ao cliente seja pelo produto, seja pelo serviço. A filosofia lean possibilita que a empresa intensifique sua competitividade e longevidade.

\subsection{AVERIGUAÇÃO DOS ELEMENTOS DE CONVERGÊNCIA DA CADEIA DE SUPRIMENTOS E DO LEAN LOGISTICS}

As ações relacionadas à cadeia de suprimentos devem ser orquestradas, planejadas, pois somente assim poderãocontribuirpositivamente, sejaconferindofluidez aos processos, seja reduzindo custos, seja atribuindo qualidade ao produto/serviço, seja disponibilizando atendimento ao cliente. Em contrapartida, a falta de coordenação acarreta excessos de despesas em diversos estágios da cadeia, como na produção, no estoque, no transporte, na mão de obra e/ou no tempo de espera por recursos, promovendo desgastes nas relações interorganizacionais.

Paraque existaa coordenaçãonacadeia de suprimentos é fundamental o trabalho em conjunto, a formação de redes de organizações e o compartilhamento de informações e de recursos, de modo que objetivos, interação e gestão sejam de domínio comum entre os partícipes. Uma cadeia de suprimentos coordenada exige das empresas o alinhamento das estratégias e metas, de acordo com as necessidades dos clientes. Vale salientar que as estratégias devem considerar que as cadeias de suprimentos são dinâmicas em função do volume de movimentações de produtos, serviços, transações financeiras e de informações.

O principal objetivo da cadeia de suprimentos é atender o cliente que tem por expectativa a oferta do produto e/ou serviço ao seu alcance, no tempo certo, com qualidade, na quantidade certa e preço reduzido. Para que todas as ações dentro da cadeia atendam ao cliente a logística precisa desempenhar suas atribuições de forma a construir uma ponte de ligação da empresa com o cliente final por meio da distribuição física, validando todas as atividades logísticas.

Na cadeia de suprimientos há agregação de várias redes logísticas relacionadas, dentre outros, ao recebimento de insumos e aos processos produtivo e de distribuição física. Por estarem as organizações inseridas em um ambiente competitivo, a aplicação da filosofia lean nas redes logísticas, nos âmbitos administrativos, de manufatura e de logística é uma estratégia importante, principalmente para a determinação do posicionamento das empresas no mercado.

Uma ferramenta utilizada para coordenar de forma mais harmônica o fluxo de materiais e de informações e que está em consonância com o pensamento lean é o sales and operations planning (S\&OP). Essa ferramenta tem como foco o processo de planejamento de vendas e de produção, buscando o equilíbrio entre demanda e a oferta de produtos, na quantidade certa. O S\&OP promove o alinhamento dos planejamentos estratégico e de negócio nos níveis corporativo, tático e funcional das organizações envolvidas. Trata-se de um facilitador que aviva o equilíbrio e o funcionamento, sem rupturas, da cadeia de suprimentos, além de cooperar para a integração dos processos. Com o compartilhamento das informações e das estratégias há cooperação, há horizontes de informações de maior abrangência e volume, com variações de menor intensidade. As análises e dados produzidos pelo S\&OP favorecem o alinhamento da cadeia de suprimentos no tocante à produção e à logística (interna e externa), pois este relaciona a demanda às operações de vendas. A ferramenta permite, ainda, análises de situações presentes e futuras, corroborando com o planejamento 
estratégico, tornando-o mais ágil, robusto e coerente.

A Tabela 1 apresenta a síntese dos principais resultados obtidos.

Tabela 1- Principais resultados obtidos

\begin{tabular}{|c|c|c|c|}
\hline Etapas & Assertivas & Elementos & Autores \\
\hline \multirow{5}{*}{$\begin{array}{l}\text { Análise dos } \\
\text { Elementos } \\
\text { Chaves da Cadeia } \\
\text { de Suprimentos }\end{array}$} & $\begin{array}{l}\text { A cadeia de suprimentos demanda planeja-mento, } \\
\text { otimização de tempo, comunicação e redução de } \\
\text { custos. }\end{array}$ & $\begin{array}{l}\text { Planejamento, tempo, } \\
\text { comunicação e custo. }\end{array}$ & $\begin{array}{l}\text { Moura (2004); } \\
\text { Bowersox et al. (2006); } \\
\text { Davis et al. (2001). }\end{array}$ \\
\hline & $\begin{array}{l}\text { Uma maior coordenação dos processos na cadeia de } \\
\text { suprimentos auxilia na integração, principalmente, das } \\
\text { áreas comercial, de marketing e de distribuição física da } \\
\text { empresa. }\end{array}$ & Coordenação e integração. & $\begin{array}{l}\text { Arnold (1999); } \\
\text { Pozo (2010); } \\
\text { Simchi-Levi et al. (2010). }\end{array}$ \\
\hline & $\begin{array}{l}\text { Para que uma cadeia de suprimentos tenha êxito deve } \\
\text { integrar a organização (processos internos e externos), } \\
\text { além de ser adaptável (sensível às variações do } \\
\text { mercado), ágil (atenta às mudanças das demandas) } \\
\text { e alinhada (integrantes devidamente alinhados a uma } \\
\text { estratégia definida) }\end{array}$ & $\begin{array}{l}\text { Integração, } \\
\text { adaptabilidade, agilidade } \\
\text { e alinhamento. }\end{array}$ & $\begin{array}{l}\text { Davis et al. (2001); } \\
\text { Corrêa e Corrêa (2012); } \\
\text { Pozo (2010). }\end{array}$ \\
\hline & $\begin{array}{l}\text { O desempenho da cadeia de suprimentos leva em conta } \\
\text { a capacidade de atender as demandas dos clientes, a } \\
\text { qualidade dos produtos e/ou serviços, a inovação e a } \\
\text { efetividade em custos e prazos. }\end{array}$ & $\begin{array}{l}\text { Qualidade, inovação, custo } \\
\text { e tempo. }\end{array}$ & $\begin{array}{l}\text { Bowersox et al. (2006); } \\
\text { Pozo (2010); } \\
\text { Simchi-Levi et al (2010) }\end{array}$ \\
\hline & $\begin{array}{l}\text { Com planejamento e informação, reduz-se ou elimina- } \\
\text { se o efeito chicote, como erros no planejamento de } \\
\text { demanda. }\end{array}$ & $\begin{array}{l}\text { Planejamento e } \\
\text { informação. }\end{array}$ & $\begin{array}{l}\text { Lee (2004); } \\
\text { Bowersox et al. (2014) }\end{array}$ \\
\hline \multirow{3}{*}{$\begin{array}{l}\text { Correlação } \\
\text { dos Aspectos } \\
\text { Interfuncionais do } \\
\text { Lean Manufacturing } \\
\text { e do Lean Logistics }\end{array}$} & $\begin{array}{l}\text { A redução/eliminação dos desperdícios, produzindo-se } \\
\text { de acordo com a demanda (no tempo, na quantidade e } \\
\text { no local certos), agrega valor à produção. }\end{array}$ & $\begin{array}{l}\text { Desperdícios, tempo, } \\
\text { quantidade e localidade. }\end{array}$ & $\begin{array}{l}\text { Arnold (1999); } \\
\text { Ballou (2006). }\end{array}$ \\
\hline & $\begin{array}{l}\text { Qualidade nos produtos produzidos, flexibilidade } \\
\text { nos processos, produção em função da demanda, } \\
\text { compromisso com o cliente e fornecedores, fluidez ao } \\
\text { longo de toda a cadeia produtiva e redução dos custos } \\
\text { são alguns dos objetivos do pensamento lean. }\end{array}$ & $\begin{array}{l}\text { Qualidade, flexibilidade, } \\
\text { fluidez e custos. }\end{array}$ & $\begin{array}{l}\text { Womack et al. (2004); } \\
\text { Rodrigues (2014). }\end{array}$ \\
\hline & $\begin{array}{l}\text { O lean logistics é a eliminação dos desperdícios nos } \\
\text { processos logísticos que compreende, dentre outras, } \\
\text { as atividades de movimentação, armazenagem, } \\
\text { distribuição, bem como todo fluxo de informações. }\end{array}$ & Desperdício e informação. & $\begin{array}{l}\text { Rodrigues (2014); } \\
\text { Christopher (2009); } \\
\text { Bowersox et al. (2006); } \\
\text { Harrison, Hoeck (2003). }\end{array}$ \\
\hline \multirow{4}{*}{$\begin{array}{l}\text { Averiguação dos } \\
\text { Elementos de } \\
\text { Convergência } \\
\text { da Cadeia de } \\
\text { Suprimentos e do } \\
\text { Lean Logistics }\end{array}$} & $\begin{array}{l}\text { Para que exista a coordenação na cadeia de } \\
\text { suprimentos é fundamental o trabalho em conjunto, } \\
\text { a formação de redes de organizações e o } \\
\text { compartilhamento de informações e de recursos, de } \\
\text { modo que objetivos, interação e gestão sejam de } \\
\text { domínio comum entre os partícipes. }\end{array}$ & $\begin{array}{l}\text { Coordenação, redes, } \\
\text { informações, recursos e } \\
\text { objetivos. }\end{array}$ & $\begin{array}{l}\text { Christopher (2014); } \\
\text { Novaes (2015). }\end{array}$ \\
\hline & $\begin{array}{l}\text { Na cadeia de suprimientos há agregação de várias } \\
\text { redes logísticas relacionadas, dentre outros, ao } \\
\text { recebimento de insumos e aos processos produtivo e de } \\
\text { distribuição física. }\end{array}$ & $\begin{array}{l}\text { Redes logísticas, insumos } \\
\text { e processos. }\end{array}$ & $\begin{array}{l}\text { Novaes (2015); } \\
\text { Moreira (2014); } \\
\text { Ballou (2006). }\end{array}$ \\
\hline & $\begin{array}{l}\text { Uma ferramenta utilizada para coordenar de forma mais } \\
\text { harmônica o fluxo de materiais e de informações e que } \\
\text { está em consonância com o pensamento lean é o sales } \\
\text { and operations planning (S\&OP) }\end{array}$ & Coordenação e harmonia. & $\begin{array}{l}\text { Ching (2010); } \\
\text { Wallace (2001); } \\
\text { Correa et al. (2014); } \\
\text { Chopra e Meindl (2011); } \\
\text { Balestrin e Verschoore } \\
\text { (2008). }\end{array}$ \\
\hline & $\begin{array}{l}\text { O S\&OP promove o alinhamento dos plajamentos } \\
\text { estratégico e de negócio nos níveis corporativo, tático e } \\
\text { funcional das organizações envolvidas. Trata-se de um } \\
\text { facilitador que aviva o equilíbrio e o funcionamento, sem } \\
\text { rupturas, da cadeia de suprimentos, além de cooperar } \\
\text { para a integração dos processos. }\end{array}$ & $\begin{array}{l}\text { Alinhamento, } \\
\text { planejamento, equilíbrio e } \\
\text { integração. }\end{array}$ & $\begin{array}{l}\text { Ching (2010); } \\
\text { Wallace (2001); } \\
\text { Correa et al. (2014); } \\
\text { Chopra e Meindl (2011); } \\
\text { Balestrin e Verschoore } \\
\text { (2008). }\end{array}$ \\
\hline
\end{tabular}

Fonte: Autores (2016) 


\section{CONSIDERAÇÕES FINAIS}

Os elementos de convergência da cadeia de suprimentos e do Lean Logistics identificados foram: coordenação, redes, informações, recursos, objetivos, insumos, processos, harmonia, alinhamento, planejamento, equilíbrio e integração.

A análise do referencial teórico revelou as relações intrínsecas e as áreas de superposição entre os temas centrais.

O lean manufacturing e o lean logistics agregam valor à produção, reduzindo custos e otimizando e integrando o sistema produtivo. Apregoam a adoção de processos flexíveis e a produção em função da demanda, o que proporciona fluidez ao longo de toda cadeia produtiva (desde o fornecedor até o cliente final).

A ferramenta sales and operations planning (S\&OP) permite um fluxo mais equilibrado de materiais e de atendimento ao cliente, a partir da melhora no processo de planejamento de vendas e de produção. O S\&OP auxilia no funcionamento da cadeia de suprimentos, evitando rupturas, com o compartilhamento das informações e das estratégias.

A integração dos processos da cadeia de suprimentos, envolvendo fornecedores e clientes, colaboram com o incremento da competitividade, da longevidade, do lucro, do atendimento as demandas do cliente, da redução dos desperdícios e dos custos. Se a integração da cadeia ocorrer lastreada pela filosofia lean aumentam-se as chances de êxito da organização. Sugere-se ainda a aplicação da ferramenta S\&OP para subsidiar toda a filosofia lean.

\section{REFERÊNCIAS}

[1] ARNOLD, J. R. Administração de materirias. 1.ed. São Paulo: Atlas, 1999.

[2] BALESTRIN, A.; VERSCHOORE, J. Redes de cooperação empresarial: estratégias de gestão na nova economia. Porto Alegre: Bookman, 2008.

[3] BALLOU, R. H. Gerenciamento da cadeia de suprimentos logística empresarial. 5.ed. Porto Alegre: Bookman, 2006.
[4] BOWERSOX, D. J.; CLOSS, D. J.; COOPER, M. B. Gestão logística de cadeias de suprimentos. 1.ed. Porto Alegre: Bookman, 2006.

[5] BOWERSOX, D. J.; CLOSS, D. J.; COOPER, M. B.; BOWERSOX, J. C. Gestão logística da cadeia de suprimentos. 4.ed. Porto Alegre: AMGH, 2014.

[6] CHING, H. Y. Gestão de estoques na cadeia de logística integrada - Supply Chain. 4.ed. São Paulo: Atlas, 2010.

[7] CHOPRA, S.; MEINDL, P. Estratégia, Planejamento e Operações. São Paulo: Pearson Prentice Hall, 2011.

[8] CHRISTOPHER, M. Logística e gerenciamento da cadeia de suprimentos. São Paulo: Cengage Learning, 2014.

[9] CHRISTOPHER, M.; TOWILL, D. R. Supply chain migration from lean and functional to agile and customized. Supply Chain Management: An International Journal, v.5, n4, p. 206-2013, 2000.

[10] CORRÊAA, H. L.; CORRÊA, C. A. Administração de produção e operações: manufatura e serviços: uma abordagem estratégica. São Paulo: Atlas, 2012.

[11] CORREA, H. L.;GIANESI, I. G. N.; CAON, M. Planejamento, Programação e Controle da Produção: MRPII/ ERP, conceitos, uso e implantação. Base para SAP, Oracle applications e outros softwares integrados de gestão. São Paulo: Atlas, 2014.

[12] DAVIS, M., M.; AQUILANO, N. J.; CHASE, R. B. Fundamentos da administração da produção. 3.ed. Porto Alegre: Bookman, 2001.

[13] GAITHER, N.; FRAZIER, G. Administração da produção e operações. 8.ed. São Paulo: Thomson, 2002.

[14] HARRINSON, A.; HOECK, R. V. Estratégia e gerenciamento de logística. São Paulo: Futura, 2003.

[15] LEE, H. L. The Triple -A Supply Chain. Harvard Business Review. v. 82, n. 10, p. 102-113, 2004.

[16] MOREIRA, D. A. Administração da Produção e de operações. São Paulo: Cengage Learning, 2014.

[17] MOURA, C. Gestão de Estoques: ação e monitoramento na cadeia de logística integrada. Rio de Janeiro: Editora Ciência Moderna, 2004.

[18] MYERSON, P. Lean Supply Chain and Logistics Management. EUA: McGraw-Hill Companies, 2012.

[19] NOVAES, A. G. Logística e gerenciamento da cadeia de distribuição. Rio de Janeiro: Elsevier, 2015.

[20] OLIVEIRA, M. M. Como fazer pesquisa qualitativa. 3.ed. Rio de Janeiro: Vozes, 2010.

[21] PASCAL, D. Produção Lean simplificada. Porto Alegre: Bookman, 2008. 
[22] POZO, H. Administração de Recursos Materiais e Patrimoniais. Uma abordagem Logística. 6.ed. São Paulo: Atlas, 2010.

[23] RODRIGUES, M. V. Entendendo, aprendendo e desenvolvendo sistemas de produção Lean Manufacturing. Rio de Janeiro: Elsevier, 2014.

[24] SIMCHI-LEVI, D.; KAMINSKY, P.; SIMCHI-LEVI, E. Cadeia de suprimentos: projeto e gestão. Porto Alegre: Bookman, 2010

[25] SHIMOKAWA, K.; FUJIMOTO, T. O nascimento do lean : conversas com Taiichi Ohno, Eiji Toyoda e outras pessoas que deram forma ao modelo Toyota de gestão. Porto Alegre: Bookman, 2011.

[26] TRIVIÑOS, A. N. S. Introdução à pesquisa em ciências sociais: a pesquisa qualitativa em educação. São Paulo: Atlas, 1987.
[27] TURATI, R. C.; MUSETTI, M. A. Aplicação dos conceitos de lean office no setor administrativo público. In: XXVI Encontro Nacional de Engenharia de Produção, Fortaleza, CE. Anais eletrônicos...Cearás: ABEPRO, 2006.

[28] VIVALDINI, M.; PIRES, S. R. I. Operadores logísticos: integrando operações em cadeias de suprimento. São Paulo: Atlas, 2010

[29] WALLACE, T. F. Planejamento de vendas e operações: guia prático. S\&OP Sales \& Operations Planning. São Paulo: IMAM, 2001.

[30] WOMACK, J. P.; JONES, D. T.; ROSS, D. A Máquina que mudou o mundo. Rio de Janeiro: Campus, 2004. 


\section{CAPÍTULO 21}

\section{ANÁLISE SISTEMÁTICA DO ESTOQUE OBSOLETO DE UMA CONCESSIONÁRIA DE CAMINHÕES: APLICAÇÃO DA CURVA ABC}

\section{Franco da Silveira}

\section{Ederson Djair Sanches do Nascimento}

Filipe Molinar Machado

Janis Elisa Ruppenthal

Luis Cláudio Villani Ortiz

Resumo: Uma das grandes preocupações empresariais está diretamente ligada aos itens de estoque administrados incorretamente. Problemas em sua gestão podem resultar em obsolescência de produtos, volume excessivo de produtos em estoque e no seu alto custo. Diante disso, as organizações buscam o emprego de novas ferramentas na gestão de estoques, com o objetivo de reduzir custos e maximizar sua lucratividade. Este trabalho tem por objetivo analisar o sistema e controle de estoque de uma concessionária de caminhões. É muito crítico o controle de estoque de peças de reposição e peças obsoletas na maioria das empresas, devido ao alto custo associado da complexidade de vários itens para manter os mesmos em estoque. Com vista neste fator, será abordado neste artigo o dimensionamento do controle do estoque de uma concessionária de caminhões de uma rede autorizada. Será analisado somente o dimensionamento do estoque obsoleto. Nota-se que a administração do estoque não está sendo eficaz. Com isso, o artigo tem por finalidade orientar e mostrar os reais problemas para o gerente enfrenta dando soluções de engenharia para melhorias.

Palavras chave: Gerenciamento de Estoque, Concessionária de Caminhões, Curva ABC.. 


\section{INTRODUÇÃO}

Uma das grandes preocupações empresariais está diretamente ligada aos itens de estoque administrados incorretamente. Problemas em sua gestão podem resultar em obsolescência de produtos, volume excessivo de produtos em estoque e no seu alto custo, diminuição do capital de giro da organização entre outros. Diante disso, as organizações buscam o emprego de novas ferramentas na gestão de estoques, com o objetivo de reduzir custos e maximizar sua lucratividade (LETTI e GOMES, 2014; LUDWIG, 2016).

Um dos recursos utilizados na tomada de decisões para realizar o gerenciamento de estoques é a Curva ABC (ALMEIDA et al., 2015). Essa técnica facilita a classificação de materiais no estoque, possibilitando obter uma coerência no sentido de adequação de acordo com a necessidade existente, evitando armazenagem de materiais de pouco utilidade (BASSOLI et al., 2015). Quando refere-se a gestão de estoques as áreas envolvidas tratam-se de suprimento e logística voltadas para os setores de almoxarifado, manutenção, vendas, que tentam culminar um estoque mais seguro com o intuito de ajudar a empresa em suas funções de produções corroborando para que alcance os custos mínimos de estoque de peças de reposição (SOUSA JUNIOR et al., 2016).

Excesso no setor de estoque também é prejudicial. O material estocado torna-se obsoleto, contribuindo negativamente nos fins lucrativos da empresa, além disso, ocupa espaço na mesma. Logo, sua administração eficaz resulta em uma vantagem competitiva em relação aos seus concorrentes que não possuem essa característica (SELMA, 2016). Para um melhor funcionamento, as organizações fiscalizam suas filiais. Concedendo para as autorizadas a chamada "bandeira branca", que é vista em certas concessionárias. A mesma estabelece parâmetros de normas de conduta, a fim de expandir bons atendimentos.

Este trabalho tem por interesse esclarecer a causa de problemas de estoque em uma concessionária de caminhões, enfatizando os prejuízos provocados por este sério impasse. É fundamental que o estoque de uma empresa seja planejado. Primeiramente porque ocorre diferença entre fornecimento e demanda de materiais, por exemplo, para que a produção não pare é essencial que a matéria-prima esteja estocada. Desse modo, é ineficaz que máquinas e operários não estejam produzindo, fazendo com que a empresa deixe de lucrar por determinado tempo.

A concessionária de caminhões da rede autoriza que será realizado o estudo enfrenta grande problema no controle do estoque, o qual encontra-se antiquado por vários problemas, sendo os dois principais, falta de conhecimento em administração em estoques pelo gerente de peças e por lotes de peças que vem junto quando um caminhão é lançado no mercado, esse lote é obrigatório e muitas dessas peças se tornam obsoletas.

O presente estudo apresentará a análise do estoque que se encontra obsoleto, a dimensão do prejuízo de tal fato, cálculos de engenharia econômica para verificação do prejuízo em curto prazo, curva $A B C$ do estoque com índices que a empresa exige, simulação de investimento na poupança do prejuízo e financiamento para investimento na empresa.

\section{REFERENCIAL TEÓRICO \\ 2.1 GESTÃO DE ESTOQUES}

Através do fluxo dos estoques relacionados a produção e logística, em virtude da demanda do mercado e o serviço prestado aos colaboradores, verifica-se que as empresas atualmente são alvos de constantes redefinições de conceitos e estratégias. A importância desse elemento é evidente, visto que o sucesso da empresa estrutura-se através desse fator (SANTOS et al., 2015). Com isso, a tendência de qualquer empresa que não adote a prática da quantidade ideal no atendimento aos clientes e da compreensão de sua demanda para que os produtos não se tornem obsoletos no estoque, e estejam renovando-se, resultam-se em prejuízos e não sucede o retorno do capital investido para a organização (MORAIS e SOUZA, 2015).

Pode-se definir estoque como a acumulação armazenada de recursos materiais em um sistema de transformação (SLACK et al, 1997). O termo estoque 
pode ser considerado como representativo de matériaprima, materiais administrativos, componentes para montagem, sobressalentes, produtos semi-acabados e suprimentos variados. Desse modo, a gestão de estoques é um ato de gerir recursos ociosos que possui um valor econômico.

Os investimentos são diretamente para fins lucrativos, tais como em máquinas e equipamentos, destinado ao aumento da produção, e não são dirigidos para uma organização. Aparentemente alguns tipos de investimento não produzem lucro. Entre estes estão às inversões de capital destinadas a cobrir fatores de risco em circunstâncias imprevisíveis e de solução imediata, sendo o caso de investimentos em estoque que evitam que se perca dinheiro em situações de riscos. No Quadro 1 verifica-se alguns objetivos que estão relacionados ao estoque.

Quadro 1 - Lista usual e simplificada dos objetivos do planejamento e controle de estoque

I) Assegurar o suprimento adequado de matériaprima, material auxiliar, peças e insumos ao processo de fabricação.

II) Manter o estoque o mais baixo possível para atendimento compatível às necessidades vendidas.

III) Identificar os itens obsoletos e defeituosos em estoque, para eliminá-los.

IV) Não permitir condições de falta ou excesso em relação à demanda de vendas.

V) Prevenir-se contra perdas, danos, extravios ou mau uso.

VI) Manter as quantidades em relação às necessidades e aos registros.

VII) Fornecer bases concretas para a elaboração de dados ao planejamento de curto, médio e longo prazos, das necessidades de estoque.

VIII) Manter os custos nos níveis mais baixos possíveis, levando em conta os volumes de vendas, prazos, recursos e seu efeito sobre o custo de venda do produto.
A gestão dos estoques visa, portanto, primeiramente, manter os recursos ociosos expressos pelo inventário, em constante equilíbrio em relação ao nível econômico ótimo dos investimentos. E isto é obtido conservando estoques mínimos, sem correr o risco de não tê-los em quantidades suficientes e necessárias para manter o fluxo da produção da encomenda em equilíbrio com o fluxo de consumo.

\subsection{FERRAMENTAS DE ESTOQUES}

Utilizam-se técnicas para controlar os níveis de estoques, com a finalidade de diminuir ou minimizar os custos gerados em virtude do estoque parado (MORAIS e SOUZA, 2015). Nesse contexto, uma das ferramentas mais importantes é a da curva de estoque $\mathrm{ABC}$, pois atende com cuidado aqueles itens que precisam de mais atenção. Essa ferramenta fundamenta-se no Diagrama de Pareto, e é obtida através da ordenação dos itens conforme a sua importância relativa (OLIVEIRA e MELO, 2015).

Segundo os autores Cardoso et al. (2011), a curva ABC destina-se ao controle do estoque de componentes, classificando-os em classes de maneira proporcional ao seu retorno financeiro para a empresa, considerando a capacidade na questão de investimentos por parte da organização. Nota-se que a curva $A B C$ vem sendo utilizada pela administração de estoques para definir política de vendas, para a programação da produção, para o estabelecimento de prioridades e uma série de outros problemas usuais nas empresas.

Conforme a sua seriedade relativa obtém-se a curva ABC através da ordenação dos itens. Portanto, é indagado, que, uma vez obtida a sequência dos itens, sua classificação $A B C$ resultará de imediato da aplicação preferencial das técnicas de gestão administrativa, conforme a importância dos itens. O Quadro 2 demonstra como pode ser ordenado os itens das classes da curva ABC.

Fonte: (POZO, 2015) 
Quadro 2 - Classificação das Classes ABC

\section{Classe A}

Destina-se ao grupo de itens relevantes da curva que devem ser tratados com atenção especial pela administração. Corresponde por aproximadamente $20 \%$ dos itens e $70 \%$ do valor das vendas.

\section{Classe B}

Trata-se do grupo de itens em situação intermediária entre as Classes A e C. Corresponde por aproximadamente 30\% dos itens e $20 \%$ do valor das vendas.

\section{Classe C}

Refere-se ao grupo de itens de menor importância, que detém pouca atenção por parte da administração. Corresponde por aproximadamente $50 \%$ dos itens e $10 \%$ do valor das vendas.

Fonte: Adaptado de Dias et al. (2011)

A curva ABC torna-se um parâmetro utilizado na determinação do grau de investimento em relação a outros produtos. Desse modo, os itens de classe A são controlados rigorosamente, conservando o mínimo de estoque de segurança possível. Os itens da classe C são de menor importância e proporcionam maior tempo para sua avaliação e tomada de decisão. Nos itens da classe $B$, as medidas devem ser tomadas após as medidas do item $A$. Por isso, a classe B encontrase em situação intermediária (LETTI e GOMES, 2014; SELMA, 2015). A Figura 1 ajuda na compreensão da importância das diferentes classes.

Figura 1 - Classificação da curva de estoque ABC

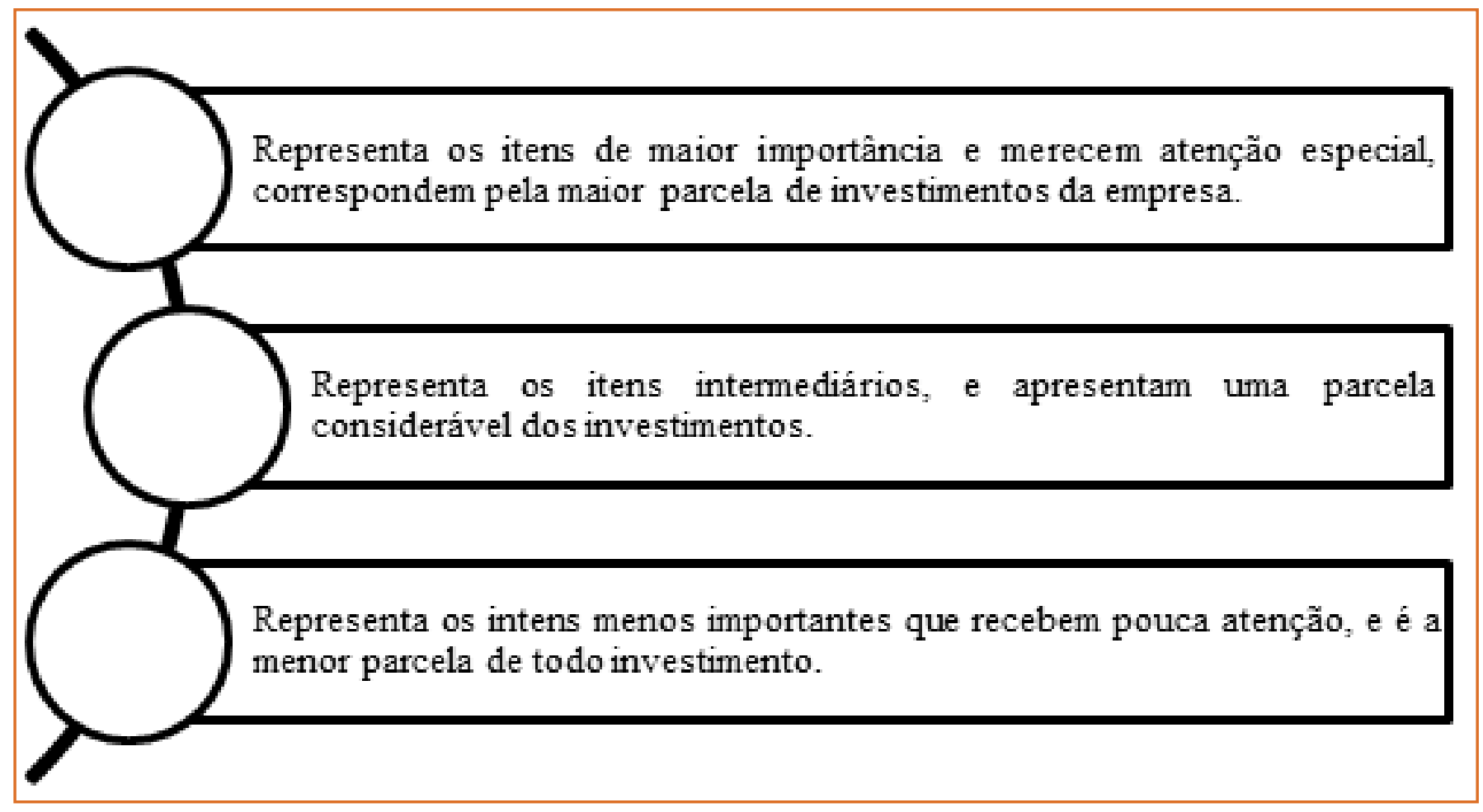

Fonte: Adaptado de Moreira (2008)

A curva $A B C$ considera a importância dos itens em relação aos valores totais, porém não demosntra o grau de importância no processo produtivo. Entendese que, se um item da classe $\mathrm{C}$ que caracteriza-se por apresentar baixo valor agregado, pode induzir futuras alterações no processo de produção, acarretando em uma interrupção momentânea da fábrica (SOUSA
JUNIOR et al., 2016).

\subsection{DIFERENCIAÇÕES DAS CURVAS ABC}

A curva pode apresentar comportamentos diversos, conforme ilustra a Figura 2. O autor Dias (2011) explana que para construir a curva $A B C$ deve-se seguir cinco 
passos:

- Realiza-se primeiramente uma discussão preliminar e a definição dos objetivos, através da necessidade identificada para concretizar a curva $\mathrm{ABC}$;

- Verifica-se, em segundo, as técnicas para análise, assim como o cálculo manual ou eletrônico e o tratamento dos dados;

- Em terceiro são classificados as classes A, B, C de acordo com a ordenação efetuada e suas tabelas explicativas, e elabora-se o gráfico;

- O quarto passo refere-se a análises e conclusões;

- E o quinto passo é onde acontece as providências necessárias que devem ser adotadas.

Figura 2: Concentrações da Curva ABC

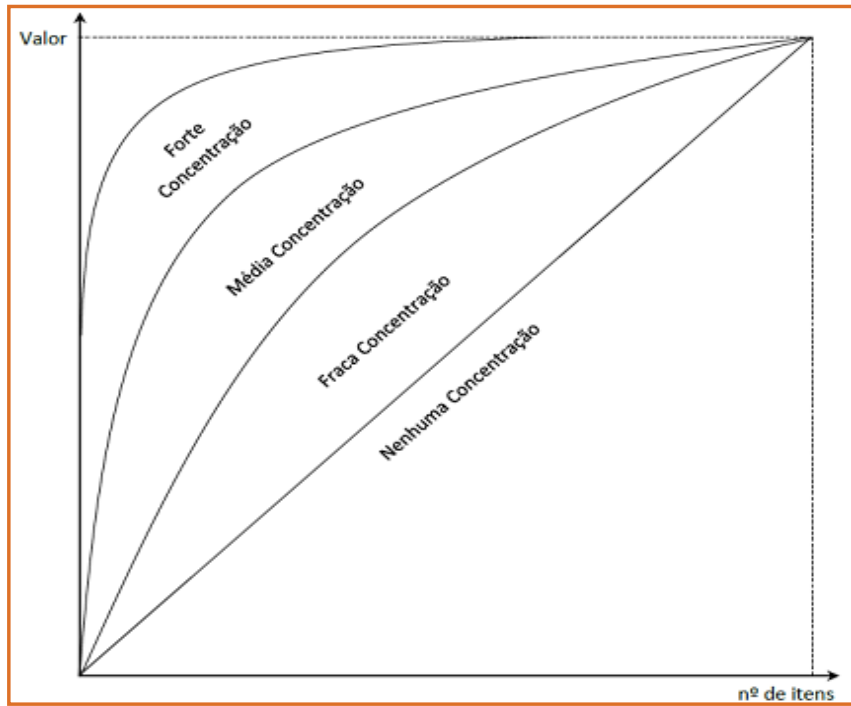

Fonte: (DIAS, 2010)

Nota-se que essa ferramenta de análise de estoque está contribuindo na tomada de decisão para saber quanto comprar de material e na identificação dos custos que podem ser afetados por essas escolhas. Assim, problemas podem ser evitados, como a falta de um item de baixo valor, por exemplo, porém de relevância vital para a organização, pois sem ele a organização não produz o seu principal produto (LETTI e GOMES, 2014).

\section{METODOLOGIA}

Para realizar a presente pesquisa, teve-se como metodologia o estudo de caso. Para Miguel (2010), esse método caracteriza-se por ser de caráter empírico com o intuito de analisar um dado fenômeno dentro de um contexto real por meio de uma investigação aprofundada do objeto em análise. Destaca o autor, que através do estudo de caso, são proporcionados novos conhecimentos sobre o fenômeno e pode-se resultar em novas gerações de teorias.

O estudo em referência trata-se da análise de uma concessionária de caminhões de uma rede autorizada para verificação do dimensionamento do controle do estoque obsoleto. O trabalho será realizado com aplicações de engenharia econômica para verificações reais dos prejuízos. Utilizou-se uma ferramenta de apoio, para o levantamento de informações. A coleta de dados foi realizada através de pesquisas junto aos gerentes da rede autorizada.

Essa pesquisa trata-se apenas em estudar o estoque obsoleto, a empresa trabalha com um software específico na área de estoque, fornecendo relatórios de toda a situação real do mesmo. O software utilizado pela empresa é CONSYSTEM, o mesmo necessita apenas de alguns dados de entrada que é comandada pelo gerente de peças, como, data de compra, preço e quantidade, para o software se encarrega de fornecer os dados, como produtos em excessos, produtos obsoletos, situação do estoque (inventário), resumo diário e mensal de peças, curva $\mathrm{ABC}$, índice de giro de estoque e itens não movimentados.

O relatório que será gerado é de todo o período de existência do estoque, para verificação de 100\% do estoque que se encontra obsoleto. O software de apoio para realização deste trabalho é Microsoft Office Excel 2007, onde construirá a curva ABC com seus respectivos gráficos, fará os cálculos de engenharia econômica, e também será utilizado para construção de tabelas e para os cálculos do custo médio. É fornecido ao programa os dados de entrada para realização e construção da curva e em seguida com esses dados resolve-se os demais cálculos. 


\section{RESULTADOS E DISCUSSÕES}

Com base no relatório gerado pelo software que a empresa utiliza, foi gerado o produto obsoleto do estoque e constatou-se os itens que se encontravam em obsolescência. O inventário do estoque registra 4398 peças, sendo que 2614 dessas peças são obsoletas. Desse modo, nota-se que 59,40 \% do estoque encontra-se obsoleto.

Logo, segundo o relatório, a empresa tem um prejuízo de $R \$ 348.956,00$. Os 4398 itens representam o estoque total, tendo um valor significativo de $\mathrm{R} \$ 958.133,11$. Assim, obtem-se uma porcentagem do estoque de $36,40 \%$, valor significativo de dinheiro parado, quee envolve todos os custos de armazenagens sobre esse valor.

Quadro 3: Limites das classes conforme dados da empresa

\begin{tabular}{|c|c|c|c|c|c|c|c|}
\hline Categoria & Percentual & Quantidade & Valor $\$$ & Total \$ & Percentual \$ & Valor & Valor Acumulado \\
\hline A & $20 \%$ & 523 & $257.331,45$ & $257.331,45$ & $75 \%$ & $261.717,00$ & $261.717,00$ \\
\hline $\mathrm{B}$ & $30 \%$ & 784 & $32.329,43$ & $289.660,88$ & $15 \%$ & $52.343,40$ & $314.060,40$ \\
\hline $\mathrm{C}$ & $50 \%$ & 1307 & $59.295,12$ & $348.956,00$ & $10 \%$ & $34.895,60$ & $348.956,00$ \\
\hline
\end{tabular}

Fonte: Autores

Com base no relatório obsoleto construiu-se a curva ABC. Considerando os índices ideias pela fábrica que autoriza a rede autorizada de caminhões, obtive-se os valores referente a cada classe. Os percentuais de cada item da curva foram concedidos diretamente com o gerente de peças, pois não havia nenhum documento oficial com os índices. A Figura 3 representa a curva $\mathrm{ABC}$ com os dados do estoque obsoleto.

Figura 3: Curva $\mathrm{ABC}$ do estoque obsoleto

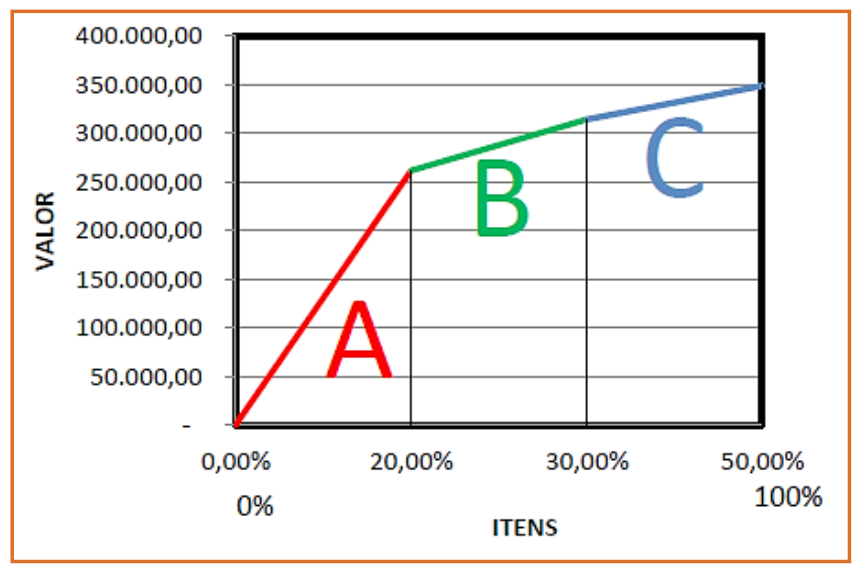

Fonte: Autores

Pode-se visualizar a concentração desta curva através da Figura 4, de modo que o comportamento da curva se enquadra em uma média concentração que pode ser comparada com a Figura 2.
Figura 4: Curva da concentração dos níveis

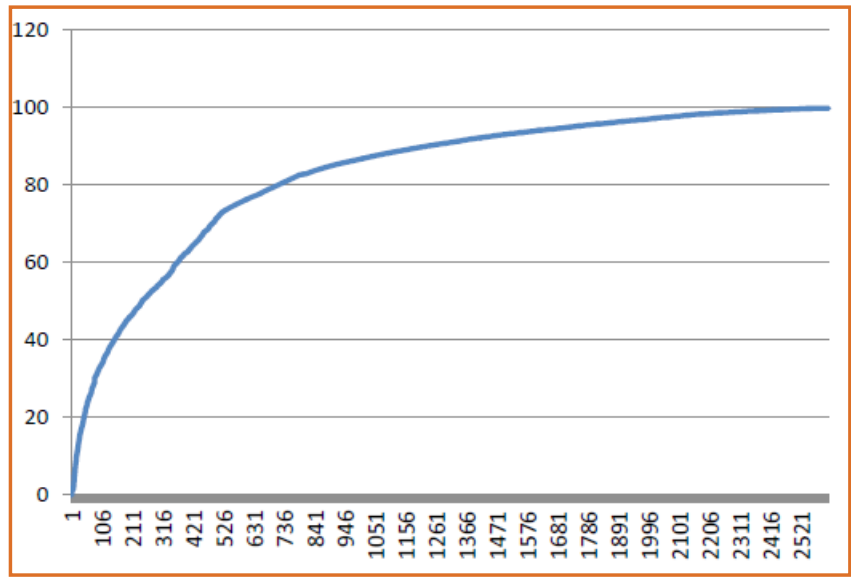

Fonte: Autores

Analisando-se o Quadro 3 verifica-se que mais de $59,40 \%$ dos itens em estoques se encontram obsoletos, sendo que o espaço ocupado sem utilidade é enorme, dando um prejuízo grande. Já em termos de dinheiros, que também pode ser visualizado no mesmo quadro, nota-se que mais de $36,40 \%$ do dinheiro não há movimento, dinheiro no qual poderia ser empregado em alguma outra finalidade.

Uma pequena observação sobre o relatório considerado para análise deve ser considerada, visto que percebe-se o valor total de prejuízo de estoque de $R \$ 351.977,18$; que subtraindo com o valor de 
$R$ \$ 348.956,00 resulta-se em uma diferença de $R \$$ $3.021,18$. A explicação para essa pequena diferença é que para elaboração do relatório obsoleto, levouse mais de 60 dias para realizar o registro dos itens obsoletos, e nesse período o gerente de peças vendeu essa pequena quantia do estoque obsoleto, dando então essa mudança no valor.
Posteriormente aos três meses da construção da primeira curva, realizou-se a construção de uma segunda curva para verificar novamente a situação do estoque. Os gerentes dimensionaram lotes de peças e se desfizeram de certa quantia, reduzindo assim seu número de peças paradas e uma quantia significativa do dinheiro parado. Para obtenção e construção da nova curva tem-se os valores do Quadro 4.

Quadro 4: Limites das classes conforme dados da empresa para construção da nova curva ABC

\begin{tabular}{|l|l|l|l|l|l|l|l|l|}
\hline Categoria & Percentual & Quantidade & Valor \$ & \multicolumn{2}{c}{ Total \$ } & Percentual \$ Valor & \multicolumn{3}{l}{ Valor Acumulado } \\
\hline A & $20 \%$ & 272 & $134.254,22$ & $134.254,22$ & $75 \%$ & $115.113,08$ & $115.113,08$ \\
\hline B & $30 \%$ & 409 & $5.043,55$ & $139.297,97$ & $15 \%$ & $23.022,61$ & $138.135,69$ \\
\hline C & $50 \%$ & 681 & $14.186,13$ & $153.484,10$ & $10 \%$ & $15.348,41$ & $153.484,10$ \\
\hline
\end{tabular}

Fonte: Autores

Desse modo, verifica-se na Figura 5 a nova curva ABC. Nota-se que os itens $\mathrm{B}$ e $\mathrm{C}$ foram priorizados nas vendas.

Figura 5: Curva $\mathrm{ABC}$ do estoque obsoleto depois de três meses

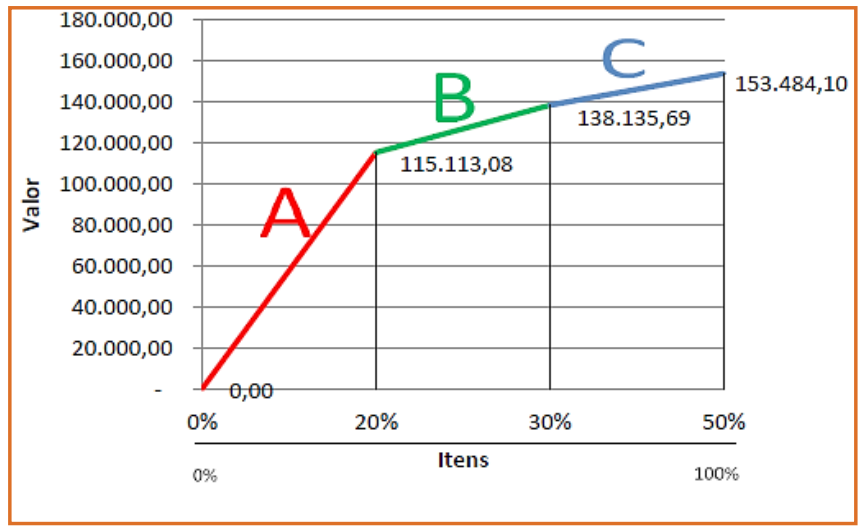

Fonte: Autores

A Figura 6 representa a concentração da curva depois dos três meses. Além disso, como já citado anteriormente, os gerentes da rede autorizada dimensionaram lotes e desfizeram de certa quantia de peças no estoque obsoleto, este processo ocorreu num período de 90 dias. Os valores antigos e atuais do estoque podem ser vistos no Quadro 3.
Quadro 3: Valor total de estoque

\begin{tabular}{|l|l|l|}
\hline Periodo & Anteriormente & Depois de 90 dias (Atual) \\
\hline Valor Total & $\mathrm{R} \$ 348.956,00$ & $\mathrm{R} \$ 153.484,10$ \\
\hline
\end{tabular}

Fonte: Autores

Observa-se que em termos de dinheiro, que em apenas três meses, obtive-se uma redução de $\mathrm{R} \$ 195.472,00$. Isso resulta-se da subtração do valor antigo de $R \$$ $348.956,00$ com o valor atual de $\mathrm{R} \$ 154.484,00$. Em porcentagem esse valor é de $44,20 \%$ de redução.

Figura 6: Curva de concentração de níveis (depois de três meses)

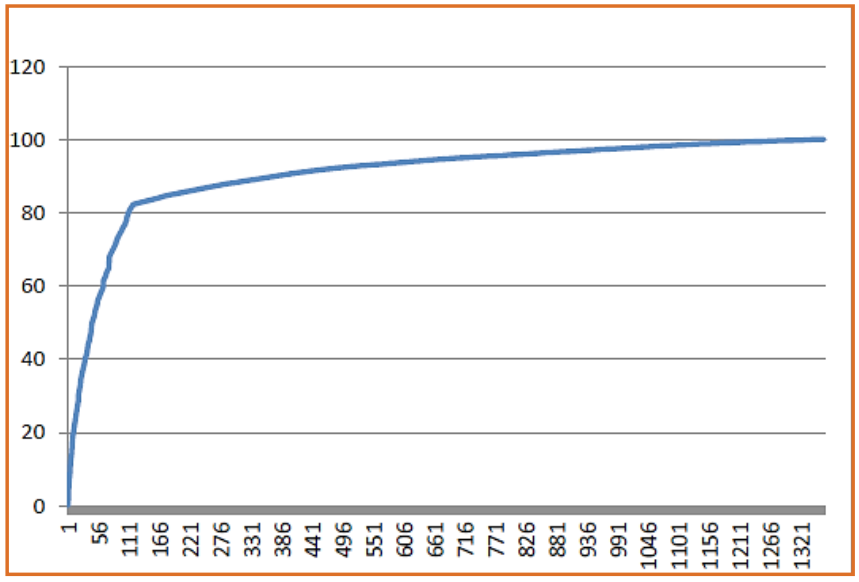

Fonte: Autores 
Analisando a Figura 4, verifica-se uma curva de média concentração, que pode ser comparada com a Figura 2 que trata dos diferentes tipos de concentrações. Diante disso, essa média de concentração é como a empresa estava há 90 dias antes do início do estudo. Após o período de 90 dias, foi feito um novo levantamento dos dados, pois os gerentes já venderam uma parte dessas peças e assim então foi construída uma nova curva ABC para a situação real, a Figura 6 , que demonstra uma nova concentração de curva, com uma tendência para forte concentração. Assim, torna-se relevante salientar que o motivo dessa mudança é que mesmo os gerentes se desfazendo de certa parcela de peças à concentração de vendas foi somente nas peças dos itens $B$ e $C$ deixando em reserva os itens $A$ que são de maiores valores.

\section{CONSIDERAÇÕES FINAIS}

Nota-se que o gerenciamento do setor de estoques vêm sendo um desafio constante para as organizações. Diante disso, por intermédio da revisão bibliográfica e ou outras metodologias conseguiu-se em primeiro momento demonstrar as peças obsoletas em estoque e construir a curva ABC para verificação do seu prejuízo, visto que quase $50 \%$ do seu estoque estava parado, completamente obsoletos.

Além disso, o presente estudo contribuiu com um levantamento de dados do real prejuízo da empresa, podendo a concessionária ter melhor controle da situação, sabendo assim, quais são as peças que estão obsoletas. Logo, o empresário pode manter um pouco do controle da situação. Neste trabalho não se pode concluir como evitar o acontecimento desse episódio novamente, pois para isso seria necessário um estudo mais avançado e de acompanhamento praticamente diário na empresa com seu fluxo de estoque.

Sabe-se que o estoque se torna obsoleto não somente pelo fato de mal dimensionamento feito pelo gerente de peças, mas sim, quando a empresa lança um caminhão novo, assim, para a concessionária poder comercializar este caminhão, a empresa os obriga a levar um lote de peças daquele caminhão, sendo que nem todas elas, são utilizadas. É mais fácil lançar um caminhão novo do que consumir com o lote de peças que a empresa obriga a levar junto com o caminhão. Diante do exposto, sugere-se alguns estudos:

- Com os dados reais do prejuízo, e sabendo quais as peças que são obsoletas e em qual categoria da curva se encontra, fazer lotes das peças da curva A e tentar negociar no mercado. Se não conseguir vender, tentar troca com as outras concessionárias ou oficinas que trabalham com caminhões.

- Quando um caminhão novo é lançado, o gerente já preparar pequenos lotes desta carga de peças que vai vir junto e vender no mercado paralelo, para não acumular mais peças e não se tornar obsoletas.

- Como sugestão para trabalhos futuros, recomendase em criar modelos matemáticos para não ocorrer mais situação de obsolescência do estoque.

\section{REFERÊNCIAS}

[1] ALMEIDA, D. S.; SILVA, J. D.; SOUZA, A. D. Análise da Gestão de Estoque de uma Micro Empresa de Autopeças de Campo Mourão - PR: uso da Classificação ABC dos Materiais. Revista FOCO, v. 8, n. 1, jan./ jul., 2015.

[2] BASSOLI, H. M., PIERRE, F. C., OliveIRA, P. A. Aplicação de Modelos de Previsão de demanda para a Gestão de Estoques de um Processo Produtivo de uma Indústria Madeireira. Revista Tekhne e Logos, v.6, n.1, jun., 2015.

[3] CARDOSO, F. S., LIMA JÚNIOR, D. R., FREITAS, F. F. T. Gestão de Estoque: Aplicação de Técnicas para Auxilio à Tomada de Decisões no Setor de Compras em uma Distribuidora de Medicamentos e Material Hospitalar. XVIII Simpósio de Engenharia de Produção. SIMPEP. Bauru, SP, 2011

[4] DIAS, M. A. P. Administração de materiais: uma abordagem logística. 5. ed. São Paulo: Atlas, 2010.

[5] DIAS, M. A. P. Administração de materiais: princípios, conceitos e gestão. 6. ed. São Paulo: Atlas, 2011.

[6] LETTI, G. C.; GOMES, L. C. Curva ABC: Melhorando o Gerenciamento de Estoques de Produtos Acabados para Pequenas Empresas Distribuidoras de Alimentos. Update Revista de Gestão de Negócios, v. 1, n. 2, p. 66-86, jul./dez., 2014.

[7] LUDWIG, J. P.; FAIZ, E. B.; SCHEIFLER, T.; DREGER, A. A. Aplicação da Metodologia Just in Time para a Redução de Estoques em uma Indústria do Ramo Moveleiro. Journal of Lean Systems, v. 1, n. 2, p. 25-39, 2016. 
[8] MIGUEL, P. A. C. Adoção do estudo de caso na engenharia de produção. In: MIGUEL, MIGUEL, P. A. C. (Org.). Metodologia de pesquisa em engenharia de produção e gestão de operações. Rio de Janeiro: Elsevier, cap. 6, p. 129-142, 2010.

[9] MORAIS, R. G.; SOUZA, N. M. O. Práticas de Gestão de Estoques e seus impactos nos Custos com Estoques: estudo de caso na Sapataria Muniz Schopping Difusora de Caruaru/ PE. Interfaces de Saberes, v. 14, n. 1, 2015.

[10] MOREIRA, D. A. Administração da produção e operações. São Paulo: Cengage Learning, 2008.

[11] OLIVEIRA, R. E.; MELO, J. A. M. A relevância das ferramentas de Gestão de Estoques - um estudo de caso em uma empresa do mercado Gráfico. Negócios em Projeção, v. 6, n. 1, jun., 2015.

[12] POZO, H. Administração de Recursos Materiais e Patrimoniais - Uma Abordagem Logística, 7ª edição. Atlas, 2015.
[13] SANTOS, J. O.; SANTOS, R. M. S.; MEDEIROS, A. C.; MARACAJÁ, P. B. A importância do Gerenciamento de Estoque no âmbito das Organizações. Revista Brasileira de Pesquisa em Administração, v. 2, n. 1, p. 01-09, jan./ dez., 2015.

[14] SLACK, N.; CHAMBERS, S.; HARLAND, C.; HARRISON, A.; JOHNSTON, R. Administração da Produção.1.ed. São Paulo: Ed. Atlas. 1997.

[15] SELMA, L. C. Administrando estoques: como obter melhores resultados em uma distribuidora de Resinas Plásticas. Revista REFAS, v. 2, n. 2, fev., 2016.

[16] SOUSA JUNIOR, F. A., ARROYO, C. S., CAMPOS, L. S. Gerenciamento de Estoque de Peças de Reposição em uma empresa de Fertilizantes. Nucleus - Revista Científica da Fundação Educacional de Ituverava, v. 13, n. 1, 2016. 


\title{
CAPÍTULO 22
}

\section{UTILIZAÇÃ O DE UM SOFTWARE DE GESTÃO DE CADEIA PRODUTIVA AGROINDUSTRIAL EM UMA USINA DE AÇÚCAR E ÁLCOOL}

\author{
Mario Henrique Bueno Moreira Callef \\ Eduardo MeneguettiHizo \\ Bruna Maria Gerônimo \\ Franciely Velozo Aragão \\ Willyan Prado Barbosa
}

Resumo: Com o aumento do preço da gasolina, cada vez aumenta-se o consumo de combustíveis alternativos, sendo um deles o álcool. Devido esse cenário a demanda nas usinas de açúcar e álcool aumentam significativamente, fazendo que haja um aumento dos integrantes da cadeia logística, portanto torna fundamental para as empresas otimizarem seus gastos e se firmarem no mercado, já que as mesmas são responsáveis por prover todos os recursos, equipamentos e informações. Esse trabalho tem como objetivo analisar o funcionamento do software de gestão de cadeia produtiva agroindustrial aplicado em uma usina de açúcar e álcool para controle de tráfego canavieiro na logística de transporte, com o intuito de identificar gargalos e falhas no transporte de cana-de-açúcar. Dessa forma foram aplicadas as ferramentas de qualidade CMMI e 5W2H com o intuito de obter melhorias dentro dessa logística. Com os resultados alcançados foi possível perceber que apesar do software agregar muito valor para a empresa, ele pode ser melhor utilizado, principalmente na otimização do tempo de entrega de matéria prima.

Palavras chave: Logística de transporte, Software de gestão, Tráfego canavieiro, CMMI, $5 \mathrm{~W} 2 \mathrm{H}$. 


\section{INTRODUÇÃO}

Desde a antiguidade, os líderes militares já elaboravam suas estratégias utilizando a logística,principalmente quando era necessário grandes e constantes deslocamentos dos seus recursos, como tropas, armamentos, carros de guerra, entre outros. Assim, era necessário planejar, organizar e executar as definições de rotas, armazenagens, e uma própria distribuição de suprimentos (DIAS, 2005).

Atualmente a logística tem por função planejar, implementar e controlar, de maneira eficiente, o fluxo e a armazenagem de produtos, bem como os serviços de informação associados, cobrindo desde o ponto de origem até o ponto de consumo, com o objetivo de atender aos requisitos do consumidor (NOVAES, 2001).

No que se refere à armazenagem e estoque, o papel da logística é fundamental no planejamento, controle e organização. No estoque, ela é responsável pela manutenção desde a entrada de material até a última etapa, a entrega ao cliente final. Já na armazenagem, é responsável pela administração do espaço necessário para a manutenção do estoque, a localização, o arranjo físico, toda a reposição de material e configuração do armazém (MOURA,2005).

$\mathrm{Na}$ logística de transporte, a prioridade deve ser máxima, seja para movimentar produtos e matériasprimas finais, componentes, pessoas. Ele deve ser rápido, barato, e principalmente eficiente (BERTAGLIA, 2009).

Dentro da logística de transporte, existem três fases principais, a fase de administração no processo de logística, que começa na compra de insumos e produtos, que devem ser entregues diretamente no local onde serão processados e organizados de modo a poder ser gradualmente liberados para processamento. Já na movimentação e manutenção, o foco é nas mobilizações dos produtos dentro do armazém ou entre unidades e áreas de uma mesma empresa. Ou seja, os itens não permanecem com os mesmos donos, mas precisam apenas ser movimentados e posicionados de modo a otimizar a continuidade do processo. Finalmente, a correta distribuição tem como objetivo principal fazer com que o produto ou insumo chega as mãos do consumidor, que acaba sendo a mais visível para a sociedade (MOURA,2005).

As usinas de álcool e açúcar procuram se adequar ao cenário da economia nacional por meio de inovações e uma melhor forma de integrar as áreas agrícolas e industriais. E essa integração também diz respeito ao sincronismo do transporte da cana e a chegada dessa matéria-prima até a usina.

Como toda a logística de transporte da Usina depende do software "S1" dos seus operadores, e da equipe de trabalho que informa os dados a serem atualizados no sistema em tempo real, será realizado um estudo de caso do funcionamento e operação desse processo, buscando otimizar a logística, aplicar melhorias na utilização do software e identificar os gargalos.

Nesse sentido, o objetivo desse trabalho é analisar o funcionamento do software de gestão de cadeia produtiva agroindústria "S1" aplicado na Usina "A" para controle de tráfego canavieiro na logística de transporte.

\section{REVISÃO DE LITERATURA 2.1. LOGÍSTICA}

A logística está atribuída a forma correta de se planejar, controlar, e implementar o fluxo e a armazenagem de produtos, bem como os serviços de informações associadas, cobrindo desde a origem até o consumo, com o principal objetivo de atender aos requisitos do consumidor (NOVAES, 2001).

Para entender a logística, basta analisá-la como o gerenciamento de fluxo de materiais, começando na fonte de fornecimento no ponto de consumo. É muito mais que uma preocupação com produtos acabados. Na verdade, a logística está preocupada com a fábrica e seus respectivos locais de estocagem, níveis de estoque e sistemas de informações (CHING, 1999).

A logística deve ser vista como um instrumento "marqueteiro", uma ferramenta capaz de gerenciar e agregar valor, por meio de serviços prestados, ou seja, a política de serviços deve ser o componente central 
da estratégia de marketing, que sob o ponto de vista operacional se torna uma missão a ser cumprida pela organização logística (MUSETTI, 2001).

\subsection{LOGÍSTICA DE TRANSPORTE}

As necessidades de transportes podem ser supridas de três modos, seja operando com uma frota própria, tendo especialistas em transportes, ou ainda contratando serviços de ampla variedade de transportadoras (BOWERSOX; CLOSS, 2001). Três fatores são fundamentais para o desempenho do transporte, são eles custos, consistência, velocidade.

$\mathrm{Na}$ organização de um sistema de transportes, é necessária uma visão sistemática, envolvendo planejamento, porém, é preciso que se conheça todos os fluxos nas diversas ligações das redes; o nível do serviço fornecido e desejado; as características e parâmetros sobre a carga transportada, todos os equipamentos disponíveis e suas características, como capacidade, fabricante, tempo de uso. Referente a carga, os principais fatores a serem considerados são: volume, peso, densidade média, fragilidade da carga transportada, dimensão do veículo, dimensão da carga, grau de perecibilidade, estado físico, assimetria, e o compartilhamento entre cargas diversas. (ALVARENGA; NOVAES, 2000).

\subsection{TECNOLOGIA E SISTEMA DE INFORMAÇÃO}

Todos os modos de produção, tomadas de decisões e de relacionamentos intra e inter organizacionais tiveram um grande impacto devido a crescente aplicação dos Sistemas de Informações dentro das empresas (TURBAN; MCLEAN; WETHERBE, 2004).

Dentro de uma companhia, é possível reduzir inúmeros custos trabalhistas, reforçar as políticas organizacionais, focando no atendimento mais rápido ao cliente, e aumentar a qualidade em geral, se a aplicação da Tecnologia de Informação for aplicada da forma correta (DEVANPORT; HARRIS, 2005).

De acordo com Alter (1999), Tecnologia de Informação é o hardware e o software capazes de produzirem informações para o Sistema de Informação. Os principais papeis da Tecnologia de Informação, afirmadas pelo mesmo autor, são fornecer elementos para estratégias empresariais; apoio aos gestores; promover maior velocidade na comunicação interna entra os membros participantes e clientes; facilitar atividades e ajudar a gestão da produção.

Inúmeras empresas poderiam explorar melhor o potencial de ganho com investimentos em Tecnologia de Informação, e que o maior desafio delas é não conhecer as possibilidades de benefícios oferecidos e analisar apenas como um investimento de risco (ALBERTIN, 2004).

\subsection{CMMI}

O Capability Maturity Model Integration (CMMI) é um modelo integrado que pode ser usado como um modelo de referência por organizações que desejam controlar melhor seus processos de desenvolvimento de produto de software, embora o termo "produto" é mais frequentemente usado, o âmbito de aplicação do modelo é o desenvolvimento de ambos os produtos e serviços(AMARAL, 2015).

Para Pressman (2011) o CMMl foca em melhorar os processos organizacionais e as habilidades em gerenciar o desenvolvimento, compra e manutenção de produtos e serviços. Organiza também as práticas em uma estrutura que ajuda a organização estabelecer prioridades para melhoria, fornecendo um guia na implementação destas.

\section{5. $5 \mathrm{~W} 2 \mathrm{H}$}

$\mathrm{O} 5 \mathrm{~W} 2 \mathrm{H}$ é uma ferramenta da qualidade que pode ser aplicada em diversas ocasiões, e sugere atitudes que venham a melhorar a sustentabilidade obtida, de acordo com uma ordem de prioridade, estabelecida através de critérios variáveis conforme o objetivo da técnica. Além de propor formas, indica quem será o responsável para colocar em prática todo o plano de ação, e informa 0 investimento necessário para tal procedimento. Ficando a critério do gestor a aplicação da proposta elaborada pelo método (PARIS, 2002). 
Para Daychouw (2008) este método consiste em fazer sete perguntas acerca de uma ação a ser tomada, com o objetivo de se obter as informações que servirão de apoio ao planejamento de forma geral. O nome do método, $5 \mathrm{~W} 2 \mathrm{H}$, deve-se aos termos da língua inglesa What, Who, Why, Where, When, How, How Much, conforme mostra a Figura 1:

Figura 1 - Método 5W2H.

\begin{tabular}{|c|c|}
\hline \multicolumn{2}{|c|}{ 5W2H } \\
\hline \hline WHAT? & O Que? / Que? / Qual? \\
\hline \hline WHO? & Quem? \\
\hline WHY? & Por que? \\
\hline WHERE? & Onde? \\
\hline WHEN? & Quando? \\
\hline \hline HOW? & Como? \\
\hline \hline HOW MANY? / HOW MUCH? & Quantos? / Quanto? \\
\hline
\end{tabular}

Fonte -Daychouw, 2007

\section{METODOLOGIA}

Existem várias formas de se classificar uma pesquisa, segundo Silva e Menezes (2005), este trabalho é considerado uma pesquisa aplicada, pois tem como objetivo gerar conhecimentos para uma aplicação prática dirigidos à solução de problemas específicos, além de envolver interesses locais.

Quanto aos fins, a pesquisa pode ter a investigação explicativa, que tem como objetivo esclarecer quais fatores contribuem para a ocorrência de determinado fenômeno. Já os meios de investigação, trata-se de uma pesquisa de campo, que segundo Moresi (2013), é o local onde dispõe de elementos para explicá-lo, com entrevistas, aplicações, questionários, testes e observações. Por fim, trata-se de uma pesquisa ação, com característica de profundidade e detalhamento.

Os passos identificados para a coleta de dados são:

- Caracterização da empresa: apresentação da empresa Usina "A", seus fundadores, ramo de atuação, colaboradores e processos produtivos;

- Revisão do conceito de logística de transporte: com o objetivo de mostrar sua importância dentro de uma Usina Sucroalcooleira, e como o controle do tráfego canavieiro de forma otimizada ajuda a minimizar estocagem de cana-de-açúcar, além de uma breve análise da qualidade da cana-deaçúcar e seu controle;

- Analisar o fluxo de informações disponíveis no software "S1": através de observação direta do ambiente de estudo: como funciona o software de controle logístico "S1"aplicado na Usina, quais suas principais funções, o modo de operação e comunicação,relatórios, gráficos gerenciais, controle de abastecimento, ajuste no ciclo do veículo,sistemas de alertas para manutenção, entre outros. A partir dessa análise, elaborar o fluxograma do transporte da cana-de-açúcar;

- Identificar os gargalos e falhas no transporte da cana-de-açúcar: através de análise individual de cada etapa do fluxograma desenvolvido na etapa anterior.

- Elaborar um plano de melhoria com as ferramentas da qualidade 5W2H e CMMI.

\section{DESENVOLVIMENTO}

\subsection{CARACTERIZAÇÃO DA EMPRESA}

Fundada em 1964, a Usina "A" é uma empresa brasileira de capital fechado que integra dez unidades produtivas no estado do Paraná e uma no Mato Grosso do Sul, A empresa produz e comercializa açúcar VHP, etanol (anidro e hidratado) e bioeletricidade. O ano safra 2014-2015 encerrou o quadro de colaboradores formado por 20983 pessoas.

Durante a safra de 2014-2015, a empresa plantou 64 mil hectares e foram moídas 18,2 milhões de toneladas de cana-de-açúcar. Além disso, foram produzidas 1,68 milhões de toneladas de açúcar VHP, $476.905 \mathrm{~m}^{3}$ de etanol- sendo $139.248 \mathrm{~m}^{3}$ de etanol anidro e 337.657 $\mathrm{m}^{3}$ de etanol hidratado, resultando em 694.784 megawatts/hora de bioeletricidade. A energia elétrica gerada durante a safra foi utilizada para suprir as 
necessidades energéticas da empresa, já o excedente de 368 megawatts foi comercializado.

\subsection{APLICABILIDADE DO SOFTWARE "S1" NO TRANSPORTE DE CANA-DE-AÇÚCAR}

O sistema logístico do transporte da cana-deaçúcar é de fundamental importância para eficiência operacional de uma indústria sucroalcooleira na estratégia gerencial, além de selecionar as frentes e suas respectivas fazendas para colheita, ela coordena os processos de corte manual e mecanizado, colhimento e carregamento da cana-de-açúcar do campo para a indústria, número de máquinas e funcionários necessários, carga máxima das máquinas, e manutenções preventivas

Na Usina, utiliza-se um software de Gestão de Cadeia Produtiva Agroindustrial, que fornece todo o controle de tráfego canavieiro de forma otimizada, minimizando a necessidade de estocagem da cana-de-açúcar. a utilização do sistema tem como seguintes resultados: garantia do abastecimento uniforme de cana-deaçúcar na usina, considerando um dimensionamento adequado dos equipamentos (caminhões, colhedoras, carregadoras e tratores); auxílio no dimensionamento da frota da usina, determinando as necessidades de equipamentos das frentes; maior eficiência na utilização da frota da usina (caminhões, colhedoras, carregadoras e tratores), com a redução das horas de fila dos caminhões e redução das horas paradas dos equipamentos das frentes por falta de transporte de cana; uma redução estimada dos custos do transporte entre 5 e 8\%; alta relação benefício/custo; e, grande facilidade de operacional.

No software é possível adicionar informações do início de uma colheita em uma nova área de plantio e também trabalha com um fluxo de informações para controle de tráfego, produtividade das máquinas e manutenções preventivas e preditivas. Além disso, o programa permite a sincronização da demanda de cana-deaçúcar com a capacidade de moagem da indústria, que por sua vez tem uma variação relativamente alta.

A partir de informações adicionadas no sistema em tempo real pelos funcionários das áreas de plantio, atualiza-se o tempo de carregamento dos equipamentos e por fim é realizado todo o controle logístico. Por meio de códigos pré-definidos o usuário pode inserir no sistema os motivos que ocasionaram as paradas dos caminhões, entre os motivos temos:abastecendo, borracharia, manutenção preventiva, oficina, carregado no pátio, entre outros.

O usuário pode consultar no "S1" quais são as cargas carregadas por cada caminhão da empresa e quais delas estão em atrasos, qual é a previsão de chegadaem toneladas de açúcar e quantas estão em atraso e também qual é a previsão de chegada de cana-de-açúcar e quais foram as últimas alocações dos caminhões. Entre os relatórios do sistema de maior importância principalmente em relação ao controle de gastos da usina, temos o relatório que fornece a localização de qualquer dos caminhões cadastrados em um determinado horário, o que lista os motivos de paradas das maquinas em determinado momento, o que informa abastecimento, consumo e autonomia dos maquinários e também o que apresenta a porcentagem de tempo gasto com cada parada.

A Figura 2 apresenta a alocação de todos os maquinários presentes na usina (representados por cores distintas, e por seu respectivo número de identificação) juntamente da localização da sua frente e fazenda (localizados na primeira e segunda linha de cada coluna), quantos caminhões estão no pátio, quais estão em funcionamento e quais estão desativados, e também porque estão desativados. A cor verde representa as colhedoras, o azul escuro os tratores reboque, azul claro os transbordos, branco os treminhões e o amarelo representa caminhões tetra. 
Figura2 - Quadro de alocação dos maquinários.

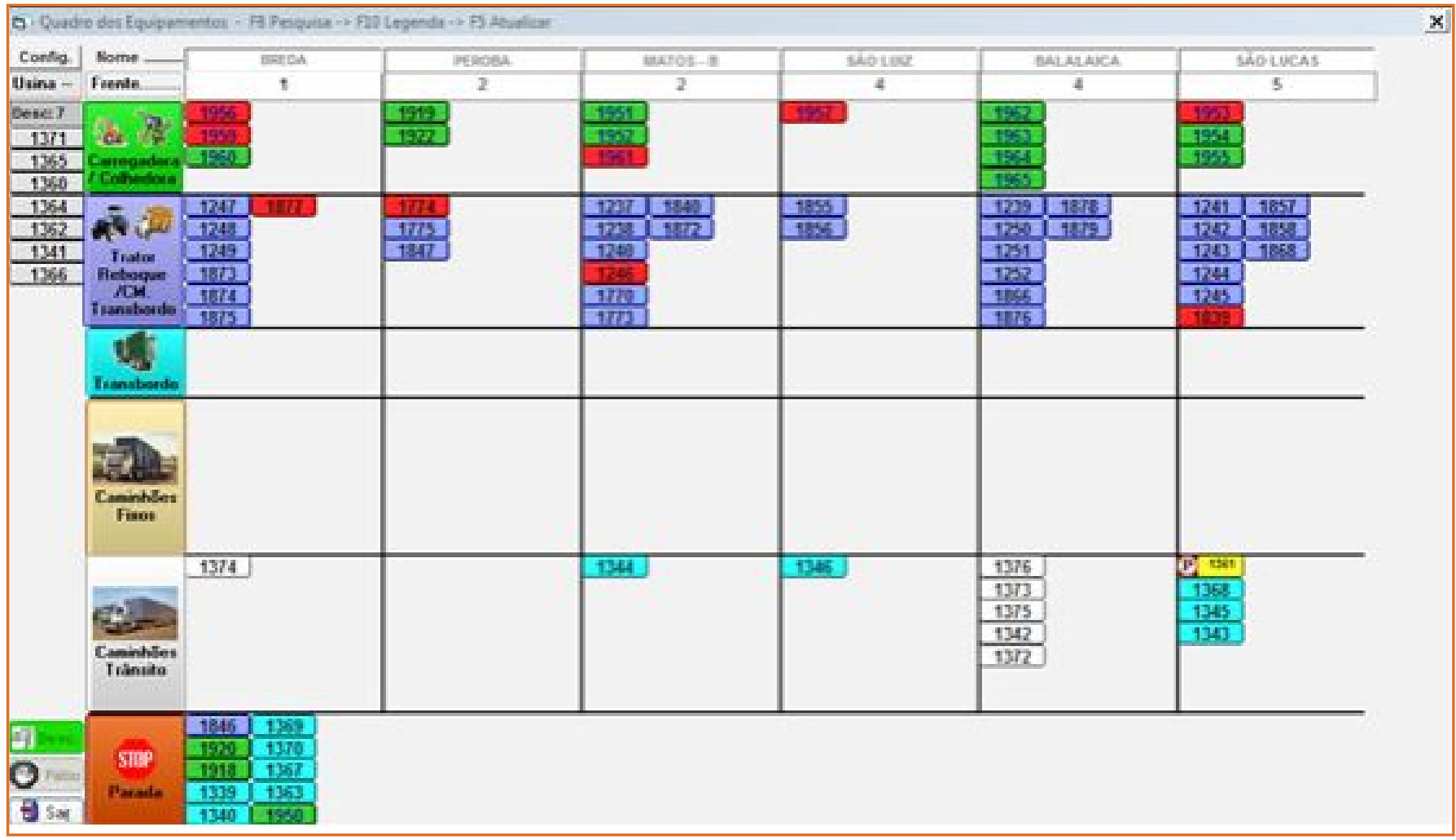

Fonte -Sistema "S1".

Tendo conhecimento de todas essas funções e como manusear de forma eficiente, é possível identificar gargalos dentro do processo que atrasam o transporte da cana-de-açúcar do campo para a indústria, e para essas possíveis correções será utilizado ferramentas da qualidade.

\subsection{ETAPAS DE LOGÍSTICA DE TRANSPORTE DE CANA-DE-AÇÚCAR}

O transporte da cana-de-açúcar é uma das áreas mais importantes e problemáticas dentro de uma usina, e qualquer empresário deve se atentar para todos os procedimentos, pois a logística de uma empresa do setor sucroalcooleiro deve basear-se em sistemas integrados devido à necessidade de coordenação de todas as atividades que envolvem essa cadeia produtiva.

A necessidade de implantar técnicas, investir em melhores equipamentos e recursos, buscando um melhor planejamento e o controle do processo produtivo decorre do aumento da competitividade nesse setor. O aprimoramento dos sistemas logísticos, por meio de novas estratégias gerenciais para o transporte da cana, é um exemplo dentre as inúmeras inovações que fazem parte do setor sucroalcooleiro.

Com esse conhecimento, é nítido que todas as etapas devem atuar como um fluxo, ou seja, a balança de pesagem, armazenagem intermediária e descarga de cana nas moendas, deve operar com um fluxo de cana transportada do campo à usina que permita uma alimentação uniforme das moendas. Caso isso não aconteça, pode haver falta de cana-de-açúcar no pátio e consequentemente paradas nas moendas, o que é altamente prejudicial por conta dos altos custos da ociosidade dos maquinários. Outro fato que também não é vantajoso é manter a moenda funcionando com uma quantidade de cana insuficiente, ou seja, moendo menos do que sua capacidade máxima, gera desperdícios de energia e desgaste desnecessário dos equipamentos. 


\subsection{ANÁLISE DOS RESULTADOS}

Uma das grandes dificuldades detectadas na utilização do software "S1" é a necessidade de muitas informações, de um grupo consideravelmente grande de funcionários, sempre em tempo real de utilização. As informações são feitas através de rádios em linhas conjuntas que muitas vezes são excessivas, não agregando valor ao processo, apenas causando congestionamento.

Dentro dessas informações que são feitas em tempo real, duas são as de maior importância e que podem causar grandes atrasos caso não forem comunicadas corretamente, são elas:

- Tempo de carregamento e transbordo: é o tempo necessário para uma colhedora carregar um trator transbordo com cana-de-açúcar mecanizada e o tempo necessário para o trator transbordo descarregar a carga dentro do caminhão com destino a indústria;

- Controle de maquinário ativo: é o quadro de todos os equipamentos, que informa em quais fazendas e frentes estão localizadas as máquinas, quais delas estão em funcionamento, e quais delas estão inativadas, e os respectivos motivos de parada.

Como já foi dito anteriormente, o software "S1" trabalha para gerar maior eficiência na utilização da frota da Usina, e ele decide para qual fazenda o próximo caminhão deve se deslocar de acordo com a quantidade de cana-de-açúcar que os maquinários em suas respectivas fazendas conseguem colher $e$ transbordar. Entretanto, alguns funcionários acabam não informando o setor da balança que um maquinário ficou inativo, e o software continua trabalhando como se estivesse com uma eficiência de $100 \%$ na fazenda, mandando um caminhão para uma fazenda que ainda não necessitava. Os casos mais comuns dentro desse processo é um funcionário esquecer de comunicar que um maquinário foi reparado e voltou a funcionar, e não desativar um maquinário para pequenas atividades, como engraxamento e abastecimento, achando que não haverá impacto dentro do processo.

\subsection{APLICAÇÃO DO CMMI}

Para a resolução dos problemas identificados, foi sugerido a utilização da ferramenta de qualidade de software CMMI e inicialmente, foi definido a área de Treinamento na Organização, pelo fato de que o software "S1" necessita de um grande grupo de funcionários trocando informações precisas para seu melhor funcionamento, com objetivo da melhoria na utilização do software através dos níveis do CMMI. Para isso, é preciso avaliar todas as práticas específicas, assim a empresa consegue analisar e atuar de forma individual nessa área, e implantar as melhorias mais urgentes destacadas. Com esse controle em um nível de escala maior, os benefícios seriam significativos. Também é interessante afirmar que em um prazo mais longo, a empresa deveria atuar em todas as áreas destacadas.

Com a finalidade de descobrir o estado atual do processo, foi feita uma avaliação dentro da Usina sobre qual nível de capacidade o software aplicado se encontra, assim é possível descobrir quanto foi sua melhoria após a implementação. Para avançar em um nível de capacidade, todas as metas sem exceção devem ser cumpridas, e quanto maior seu nível, maior a capacidade. As metas que devem ser realizadas no software "S1" para treinamento organizacional foram: estabelecer uma capacidade de treinamento na organização e proporcionar treinamento necessário.

Como os resultados obtidos pela avaliação de metas genéricas para área de treinamento na organização não atenderam todas as práticas, o nível 1 de capacidade do CMMI não foi atendido. Para se obter o nível de cada prática, ou seja, se ela está satisfeita, parcialmente satisfeita ou não satisfeita foi feita uma análise do sistema dentro da Usina na utilização do software "S1".

Para se estabelecer uma capacidade de treinamento na organização adequada é necessário realizar a análise de objetivos estratégicos da organização e o plano de melhoria de processo, definir parcialmente alguns treinamentos que são responsabilidades da organização e quais deles deveriam ser atribuídos a cada projeto ou grupo de suporte, elaborar um plano 
tático de treinamento e por último consultar à área de processos na análise e tomadas de decisões para saber como aplicar corretamente os critérios tomada de decisão para selecionar as abordagens de treinamento e de elaboração do material de treinamento.

Já para proporcionar treinamento necessário é preciso treinar os indivíduos para que desempenhem seus papéis de forma efetiva, estabelecer e manter registros dos treinamentos na organização na área de monitoramento e controle e realizar a avaliação da eficácia do programa de treinamento da organização.

Para que o primeiro nível seja atingido, algumas práticas precisam ser adotadas, o Quadro 1 apresenta as propostas de melhorias no processo de treinamento da organização.

Quadro 1 - Propostas de Melhorias dentro da Usina.

\begin{tabular}{|c|c|}
\hline Metas & Prática Aplicadas pela empresa \\
\hline \multirow{3}{*}{$\begin{array}{l}\text { Estabelecer uma capacidade de } \\
\text { treinamento na organização }\end{array}$} & $\begin{array}{l}\text { Analisar as prioridades de treinamentos dos projetos e grupos de } \\
\text { suporte, identificando exatamente as necessidades comuns de } \\
\text { treinamento que podem ser tratadas com mais eficiência na } \\
\text { organização, também podendo antecipar futuros treinamentos. }\end{array}$ \\
\hline & $\begin{array}{l}\text { Criação de um plano tático de treinamento, que conheçam os tópicos, } \\
\text { cronogramas baseados nas atividades, métodos utilizados, requisitos e } \\
\text { padrões de qualidade para o material, tarefas e responsabilidades pré- } \\
\text { estabelecidas, e os recursos necessários, que podem ser incluidos as } \\
\text { ferramentas, infraestrutura, ambiente, equipe, habilidade e } \\
\text { conhecimento. }\end{array}$ \\
\hline & $\begin{array}{l}\text { Ter determinado o material de apoio e treinamento, junto da } \\
\text { abordagem mais adequada para o público alvo (Utilização de salas de } \\
\text { aula, video aulas, seminários, etc.). Além disso, avaliar se é melhor } \\
\text { desenvolver o material de treinamento internamente ou adquiri-lo e } \\
\text { fontes externas, alguns fatores que podem influenciar a escolha são os } \\
\text { objetivos de desempenho, tempo disponivel para preparo do material, } \\
\text { treinamentos já oferecidos pelo cliente, treinamentos comercializados. } \\
\text { Caso tenha material próprio da organização, ter claro os tópicos do } \\
\text { treinamento, público-alvo, pré-requisitos para a preparação dos } \\
\text { participantes, objetivos, duração, planos de aula e constante } \\
\text { atualização. }\end{array}$ \\
\hline \multirow{3}{*}{$\begin{array}{l}\text { Proporcionar treinamento } \\
\text { necessário }\end{array}$} & $\begin{array}{c}\text { Selecionar os funcionários que que receberão o treinamento } \\
\text { necessário para desempenhar seus papéis de forma efetiva (focar } \\
\text { somente nas que realmente precisam de treinamento). Conduzir o } \\
\text { cronograma com instrutores experientes, em ambientes que lembrem } \\
\text { uma situação real de trabalho. }\end{array}$ \\
\hline & $\begin{array}{l}\text { Manter registros de todos os individuos treinados, independente da } \\
\text { aprovação ou não. }\end{array}$ \\
\hline & $\begin{array}{l}\text { Utilização de processos que determinem a eficácia dos treinamentos, } \\
\text { ou seja, que satisfazerem às necessidades da organização. Pode-se } \\
\text { utilizar testes práticos, pesquisas com os participantes e gerentes, ou } \\
\text { algum mecanismo presente no próprio curso. Utilizar esses dados para } \\
\text { atualização do material de treinamento. }\end{array}$ \\
\hline
\end{tabular}


Com a implementação de todas as melhorias propostas e cumprindo essas práticas, a empresa atingiria o nível 1 de capacidade do CMMI para utilização do software "S1", e seu processo seria considerado em fase inicial, e principalmente agregaria valor no processo de comunicação e gerenciamento de dados de toda a equipe.

\subsection{APLICAÇÃO DA FERRAMENTA 5W2H}

Apesar dos inúmeros problemas, principalmente meteorológicos, que causam atraso na entrega de cana-de-açúcar dentro da Usina, existem pequenos gargalos que só dependem de uma melhor organização e treinamento da equipe para serem resolvidos. Um deles é tempo de espera de um caminhão no pátio para descarregar a carga.
Para a estrutura da Usina estudada, um tempo médio aceitável seria aproximadamente 25 a 30 minutos para o caminhão descarregar e voltar para balança de pesagem. Entretanto, feito uma média dos tempos de espera dos caminhões no pátio gerada pelo software "S1", excluindo todos os valores muito altos (caminhões que foram fazer manutenção preventiva,24 concertos, borracharia, reapertar rodas, etc.) pois esses não refletem os caminhões que estão no pátio, foi obtido um valor médio para safra de 2015 de 54 minutos.

Como esse valor é muito alto (54 minutos), foi realizado um plano de ação com a ferramenta $5 \mathrm{~W} 2 \mathrm{H}$ com o objetivo de otimizar esse processo, além de indicar quem será o responsável para colocar em prática o plano de ação. A Figura 3, apresenta o plano de ação definido para o excesso de caminhões na fila do pátio.

Figura3 - Plano de ação 5W2H para excesso de caminhões na fila do pátio.

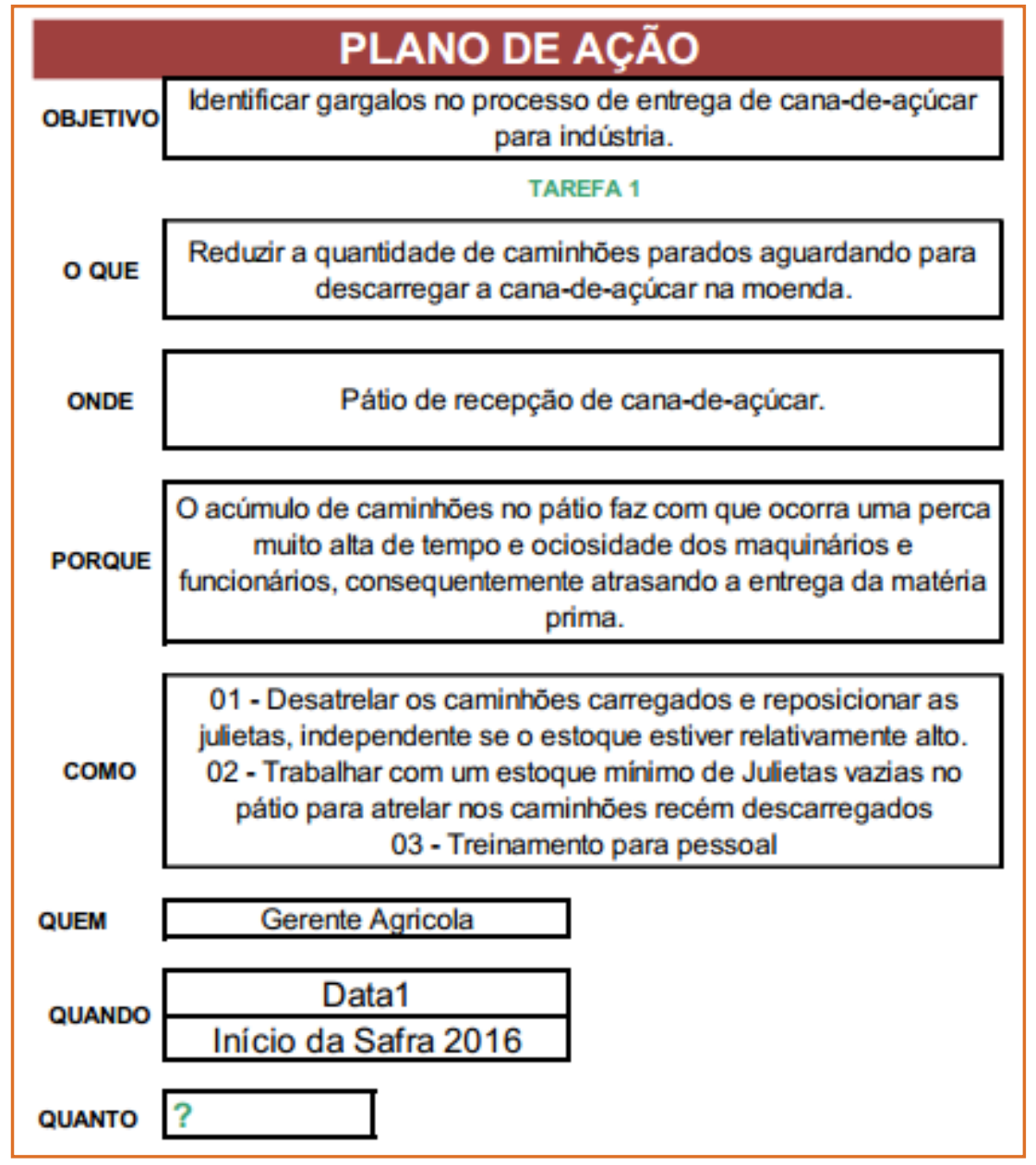

Fonte-Autor. 
objetivo de otimizar esse processo, além de indicar quem será o responsável para colocar em prática o plano de ação. A Figura 3, apresenta o plano de ação definido para o excesso de caminhões na fila do pátio.

Outro grande obstáculo encontrado na empresa é o tamanho da balança, que apesar de não se um problema atrelado diretamente ao software gera muito atraso na entrega da cana. A balança possuí 18m de comprimento, não atendendo corretamente as necessidades da etapa de pesagem dos caminhões. Atualmente, os caminhões são pesados por etapas, ou seja, primeiramente o caminhoneiro posiciona somente a carreta dentro da balança e é feito a pesagem número 1, depois disso, as julietas são pesadas duas unidades por vez, podendo ter até 3 etapas de pesagem e perdendo um tempo muito alto considerando o número de caminhões que são pesados diariamente.

Em outras unidades do grupo, já existem balanças de $34 \mathrm{~m}$ de comprimento, que conseguem realizar a pesagem completa de qualquer caminhão de uma única vez, tendo uma economia enorme considerando um ano de safra.

Com o objetivo de reduzir esse tempo em que os maquinários e funcionários ficam ociosos dentro do pátio, e dividir a etapa de pesagem em três partes, foi novamente utilizada a ferramenta da qualidade do 5W2H, sugerindo um plano de ação para melhorar o processo, de acordo com a ordem de prioridade, e o responsável para colocar em prática o plano de ação, juntamente com o investimento necessário. Na Figura 4 encontra-se o plano de ação desenvolvido:

Figura4 - Plano de ação 5W2H para reforma na balança.

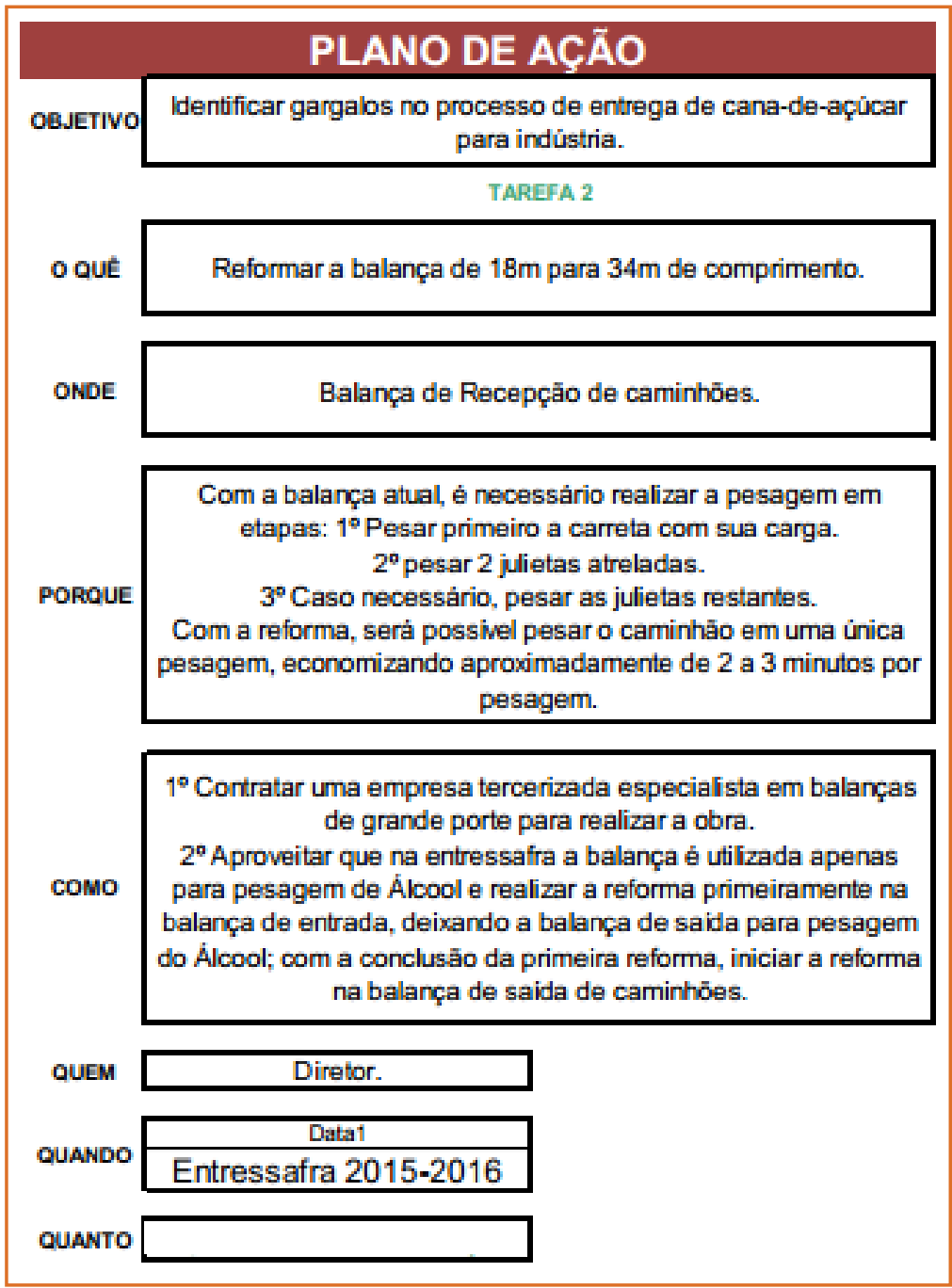

Fonte-Autor 


\section{CONCLUSÃO}

Este trabalho teve o objetivo de analisar o funcionamento do software "S1" aplicado dentro da Usina "A", que é utilizado para controlar o tráfego canavieiro. Com base na análise do fluxo de informações disponíveis no software, identificaram-se gargalos e falhas no transporte, e propôs-se um plano de ação baseado nas ferramentas de qualidade 5W2H e CMMI.

Um dos gargalos identificados, no processo de entrega de cana de açúcar, foi o número elevado de caminhões parados aguardando para descarregar na moenda. Para reduzir tal problema, foi proposto um plano de ação, que condiz em: desatrelar os caminhões carregados e reposicionar as julietas, independente se o estoque estiver relativamente alto; trabalhar com um estoque mínimo de julietas vazias no pátio para atrelar nos caminhões recém descarregados; e treinamento para pessoal.

Com a aplicação dos treinamentos propostos no plano de qualidade do CMMI, o número de informações imprecisas e atrasadas, dos funcionários que trabalham dentro das fazendas, seriam reduzidas, evitando que o software envie ou selecione fazendas que não estão realmente necessitando de caminhões. Pois com isso, fazendas deixam de ser abastecidas.

Apesar de tais falhas, com a análise aprofundada do software e suas funcionalidades, ficou nítido que ele agrega muito valor à empresa, pois facilita tomada de decisões no processo de transporte de cana-deaçúcar. Também ficou evidente que o Engenheiro de Produção tem papel fundamental na sua utilização, pois é ele quem pode indicar e sugerir melhorias a serem aplicadas nas inúmeras etapas do processo, fomentando ganhos substanciais à empresa.

De todas as melhorias apontadas, apenas uma requer um investimento consideravelmente alto, que depende muito da aprovação dos gestores da empresa. Por outro lado, as outras propostas de melhorias dependem principalmente da capacitação da equipe de trabalho, algo que não necessariamente precisa de um investimento alto, e sim de um trabalho de longo prazo sem resultados imediatos.

\section{REFERÊNCIAS}

[1] ALBERTIN, A. L.; BARTH, N. L.Produtividade virtual. RAE Executivo, São Paulo, 2004.

[2] ALTER, S.Information systems: a management perspective. 3. ed. Estados Unidos: Addison-Wesley EducationalPublishers, 1999.

[3] AlvarengA, A. C., NOVAES, A. G. N.Logística Aplicada - Suprimento e Distribuição Física. 3. ed. São Paulo: Edgar Blücher, 2000.

[4] AMARAL, M. A. L.Implantação de melhoria de processos de software com CMMI-DEV nível 2: planejamento baseado em exemplos.1. ed. João Pessoa: Editora IFPB, 2015.

[5] BERTAGLIA,P. R.Logística e gerenciamento da cadeia de abastecimento. 2. ed.São Paulo:Saraiva, 2009.

[6] BOWERSOX, D. J.; CLOSS, D. J.Logística empresarial: o processo de integração da cadeia de suprimento. São Paulo: Atlas, 2001.

[7] CHING, H. Y.Gestão de estoques na cadeia de logística integrada - supplychain. São Paulo: Atlas, 1999.

[8] DAYCHOUW, M.40 ferramentas e técnicas de gerenciamento. Rio de Janeiro: Brasport, 2007.

[9] DAVENPORT, T. H.; HARRIS, J. G.Automateddecisionmaking comes of age. MitSloanManagement Review, Cambridge, v. 46, n. 6, p. 8389, Summer 2005.

[10] DIAS, J. C. Q.Logística global e macrologística. Lisboa: Edições Sibalo, 2005.

[11] MORESI, E.Metodologia da Pesquisa. Brasília, 2003, Universidade Católica de Brasília - UCB, Pró-Reitoriade PósGraduação - PRPG Programa De Pós-Graduação Stricto Sensu em Gestão do Conhecimento e Tecnologia da Informação. Disponível em: <http://www.unisc.br/ portal/upload/com_arquivo/metodologia_da_pesquisa.pdf> Acesso em: 02/07/2015.

[12] MOURA, R. A.Sistema e Técnicas de Movimentação e Armazenagem de Materiais. Vol. 1. São Paulo: IMAM, 2005.

[13] MUSETTI, M. A.A Engenharia e as Capacitações para a Logística Integrada. In: XXIX CONGRESSO BRASILEIRO DE ENSINO DE ENGENHARIA, 2001, Porto Alegre, 2001.

[14] NOVAES, A. C.Logística e gerenciamento da cadeia de distribuição: estratégia, operação e avaliação. Rio de Janeiro: Editora Campus, 2001

[15] PARIS, W. S.Sistemas da Qualidade - Parte 2: Material de apoio dos seminários. Curitiba, out. 2002. 
[16] PRESSMAN, R. S.Engenharia de Software: Uma Abordagem Profissional. 7. ed. Porto Alegre: AMGH, 2011.

[17] SILVA, E. L.; MENEZES, E. M.Metodologia da Pesquisa e Elaboração de Dissertação. Florianópolis, 2005.
[18] TURBAN, E.; MCLEAN, E.; WETHERBE, J.Tecnologia da informação para gestão. PortoAlegre: Bookman, 2004 


\section{CAPÍTULO 23}

\section{O USO DE CERTIFICAÇÕES AMBIENTAIS COMO FORMA DE PROMOVER O DESENVOLVIMENTO SUSTENTÁVEL NA CONSTRUÇÃo GIVIL}

Diego Vieira Ramos

André Fogolin Machado

Marcelo Luiz Chicati

Generoso de Angelis Neto

Resumo: A adoção de conceitos de sustentáveis nas formas de consumo e produção, representa um dos grandes objetos de estudo da sociedade contemporânea, em virtude do atual cenário de escassez dos recursos naturais não renováveis e do esgotamento da capacidade de regeneração do planeta. Sendo assim, algumas áreas da sociedade, influenciam diretamente nesse contexto, como é o caso da construção civil. A atividade é considerada um dos pilares da economia nacional, fonte geradora de diversos postos de trabalho, mas que em contrapartida, figura entre as grandes consumidoras de recursos naturais, sendo alvo frequente de estudos que buscam a diminuição de seus impactos. Dessa forma, as certificações ambientais ligadas a construção civil, representam um importante instrumento incentivador da proliferação das construções sustentáveis. Sendo assim, o presente trabalho busca expor as vantagens do emprego de certificações ambientais na construção, identificando os ganhos socioambientais alcançados pelas edificações sustentáveis, obtidos através do emprego de materiais ecologicamente corretos e tecnologias adequadas a questão ambiental.

Palavras Chave: Sustentabilidade, Certificações, Construções Sustentáveis. 


\section{INTRODUÇÃO}

Miotto (2013) afirma que o atual modelo de produção e consumo tem comprometido a capacidade de regeneração do planeta, evidenciando a necessidade de se adotar formas mais sustentáveis de produção, capazes de minimizar os impactos causados aos recursos naturais não renováveis. Sendo assim, a degradação dos recursos é atribuída à evolução da ciência, da tecnologia, da produção industrial e do crescimento urbano (BROTHEHOOD; 2008). A transformação dessa realidade deve necessariamente estar fundamentada em uma abordagem ampla e concisa, onde a sustentabilidade é tratada como o ponto central da discussão, promovendo a reflexão a cerca das questões ambientais e produtivas.

O Relatório Brundtland (1987), citou como objetivo da sustentabilidade a preocupação pela preservação do planeta, condições de habilidade da sua população e gerações futuras, garantindo "um desenvolvimento que de resposta às necessidades do presente, sem comprometer a possibilidade de as gerações futuras satisfazerem a suas necessidades". Nesse contexto, a sustentabilidade possui o desafio de equacionar o uso dos recursos não renováveis.

No entanto, Ribeiro e Morelli (2009) relatam que o desafio não está apenas no uso dos recursos, mas no gerenciamento das atividades. Para os autores, o pensamento sustentável deve ser capaz de solucionar problemas advindos da ineficiência de políticas de gestão, da falta de leis mais rigorosas relacionadas ao assunto, da falta de fontes alternativas de matéria prima, da produção e da destinação de resíduos, da contaminação do solo, da água e do ar, entre outros fatores. Seguindo essa linha de raciocínio, o pensamento sustentável, deve ser fundamentado no uso inteligente dos recursos naturais e na prevenção do desperdício.

Marques e Salgado (2007) afirmam que para se alcançar o desenvolvimento sustentável, é necessário haver um equilíbrio entre o que é socialmente desejável, economicamente viável, e ecologicamente sustentável, formando um "tripé" que irá sustentar as esferas sociais, econômicas e ambientais. Dessa forma, o desenvolvimento sustentável deve ser abordado de uma ótica ampla e multidisciplinar, que promova conscientização global, sobre a necessidade de haver uma mudança efetiva na postura produtiva. Outro importante fator que tem contribuído para a degradação dos recursos, está atribuído a expansão do ambiente construído e o consequente crescimento das atividades relacionadas a construção civil. Para Silva et al. (2015), o aumento do consumo energético e de água está vinculado a necessidade de se sustentar padrões contemporâneos de conforto e de qualidade de vida, pautados no uso irracional dos recursos disponíveis.

Apesar de nociva ao contexto ambiental, a Construção Civil brasileira é incumbida de produzir parte considerável da riqueza nacional, exercendo papel fundamental no PIB e caracterizando a geração de inúmeros postos de trabalho. Em contrapartida, o setor é um dos maiores responsáveis pelo consumo de recursos naturais não renováveis e pela formação de área degradadas. Graim (2012) atribui a Construção Civil uma absorção de cerca de até $50 \%$ de todos os recursos naturais não renováveis extraídos.

Afim de contribuir como a exposição dessa realidade, Menezes e Oliveira (2008) quantificam o uso dos recursos naturais do setor no Brasil, ao afirmarem que a produção nacional de cimentos Portland no ano de 2008 se aproximou do número de 35 milhões de toneladas, e que se considerado o traço médio de 1:6, a quantidade de agregados necessários para o seu preparo, pode ter chego ao assustador número de 210 milhões de toneladas. Tais números sugeridos, confirmando a predatoriedade do setor em relação aos recursos naturais não renováveis, e demonstrando a incompatibilidade do setor em relação a realidade planetária, o que sugeri a urgência na adoção de medidas que proporcionem uma redução no consumo.

Santos (2012) afirma que as edificações construídas dentro dos parâmetros sustentáveis são capazes de apresentar benefícios no processo construtivo e nas fases de operação e manutenção, como maior vida útil do edifício e economia de materiais, melhor desempenho energético, entre outros benefícios. Sendo assim, como o intuito de contribuir para 
a propagação das construções sustentáveis e a consequente redução no consumo dos recursos naturais não renováveis, houve a necessidade de se desenvolver metodologias que servissem de parâmetro para avaliar a sustentabilidade na construção civil, as chamadas certificações ambientais.

Baseado no ideal de sustentabilidade, o presente trabalho pode ser justificado pela necessidade de se expor o papel das certificações na busca de novas formas de projetar e edificar, buscando racionalizar o uso de recursos naturais não renováveis, a fim de minimizar os desperdícios, amenizar os impactos causados ao meio ambiente, sem afetar a capacidade produtiva do setor e difundir o conhecimento, sobre o assunto, para que este possa atingir cada vez mais a indústria da Construção Civil, alertando para a atual realidade de escassez dos recursos naturais não renováveis, com o intuito de promover métodos de produção mais comprometidos com as questões ambientais. Com o objetivo de avaliar o papel das certificações ambientais, como forma de incentivo a propagação das construções sustentáveis, identificando os ganhos socioambientais e socioeconômicos obtidos a partir da adesão de conceitos sustentáveis na construção civil.

\section{MATERIAIS E MÉTODOS.}

Para a elaboração desta pesquisa, foi adotada a metodologia proposta por Anjos et al. (2015), que consiste em uma revisão da literatura a cerca dos conceitos de desenvolvimento sustentável e de sustentabilidade (aos demais conceitos a eles ligados). Foram pesquisadas obras produzidas nos últimos dez anos, artigos de autores que trabalham o tema, publicados nas principais revista e congresso ligados à área, a fim de detetar possíveis correntes emergentes de pensamento sobre o assunto.

Na sequência, o artigo apresenta a dimensão de aplicabilidade do conceito-tema, os passos dados em direção à escala de sustentabilidade, os problemas ligados ao assunto que necessitam serem resolvidos, os impactos causados pela construção civil ao meio ambiente, através do uso de recursos naturais não renováveis, como forma de construir uma base de conhecimento capaz de dar suporte à compreensão dos profissionais da área, sobre a adoção de medidas que promovam a sustentabilidade e o desenvolvimento sustentável no setor da construção civil. Através da exposição das principais certificações ambientais ligadas a área, como forma de avaliar a qualidade das construções sustentáveis produzidas e incentivar a multiplicação dessa modalidade construtiva.

\section{CONSTRUÇÕES SUSTENTÁVEIS.}

Segundo relato de Marques (2007), o termo construções sustentáveis surgiu em meados dos anos 1990, resultado da necessidade de responder e adaptar o setor da construção ao processo evolutivo das cidades, visto que a população urbana (mundial e nacional) tem crescido de forma exponencial nas últimas décadas, fato que acarretou a necessidade de novas construções, demandando quantidades cada vez maiores de recursos. Esse aumento, trouxe consigo, dentre outros fatores, problemas como a emissão de gases poluentes, degradação da biodiversidade, piora na saúde da população urbana. Sendo assim, no ano de 1994 Charles Kibert, criou um novo conceito adaptável à construção, denominado construções sustentáveis.

Na visão de Corrêa (2009) as construções sustentáveis são entendidas como o processo holístico responsável por restabelecer e manter a harmonia entre os ambientes natural e construído e criar estabelecimentos que confirmem a dignidade humana e estimulem a igualdade econômica. Em outras palavras, possuem a incumbência de promover o equilíbrio entre o desenvolvimento social, ambiental e econômico, tendo como objetivo principal a harmonização do ambiente construído com o ambiente natural. Sendo assim, Silva et al (2009) afirmam que as construções sustentáveis devem ser dotadas de princípios básicos como a redução no consumo de recursos, a maximização da reutilização de recursos, a reciclagem de materiais no final de vida do edifício, o uso de recursos renováveis, proteção do ambiente natural, eliminação de produtos ou sub-produtos tóxicos em todas a fases do ciclo 
de vida da construção e a obtenção de certificações, baseados em sistemas avaliatórios.

Baseado em tais primícias, Marques (2007) afirma que essa inserção de requisitos sustentáveis, esta vinculado à concepção projetual, sendo parte de uma metodologia denominada Processo de Projeto Integrado, que busca viabilizar a obtenção do funcionamento satisfatório do edifício. Nessa visão, o sucesso do processo construtivo está associado a perspectiva ampla e integrada da concepção do projeto, considerando todas as etapas do ciclo de vida útil do edifício. Para Silva et al. (2013) a sustentabilidade na construção está intimamente vinculada ao projeto de Arquitetura, com sua elaboração considerando questões ambientais, além de avaliar o impacto sobre o meio, em toda e qualquer decisão. Dessa forma, as construções sustentáveis estão condicionadas a uma metodologia projetual fundamentada no incentivo de medidas que promovam a eficiência em todas suas etapas e também adoção de materiais construtivos ambientalmente corretos.

Miotto (2013 p.73) salienta que no caso de uma edificação, existem muitas técnicas de projeto capazes de amenizar a sobrecarga dos recursos naturais, seja por meio de elementos construídos como telhados verdes (uma espécie de jardins instalados na cobertura das edificações, com o intuito de servir como um sistema de drenagem de água pluvial) ou por meio da seleção de materiais. A arquitetura deve estar focada na incorporação das ferramentas disponíveis a suas diretrizes projetuais, que vão desde a idealização de conceitos até ao conhecimento e o domínio técnico, capaz de proporcionar maior eficiência no uso dos recursos.

A eficiência no uso dos recursos está relacionada a muitas técnicas que envolvem o emprego de materiais adequados como métodos construtivos, o uso de produtos que minimizam os impactos da nova construção ou reforma, o desenvolvimento de projetos que utilizando componentes reutilizáveis, o ato de projetar que se preocupe com a posterior desconstrução do edifício, entre outros fatores. (MIOTTO;2013).
Igualmente importante na composição das edificações sustentáveis, se trata do desempenho energético. Para Gonçalves e Duarte (2006), as metas que tratam o conforto ambiental e a eficiência energética, devem contemplar a redução por demanda de climatização e iluminação artificial, suprindo-a sempre que possível por meios passivos, como o aquecimento passivo direto e indireto, a ventilação natural, a ventilação noturna, a iluminação natural e a demais estratégias complementadas por meio energéticos eficientes. A arquitetura deve buscar o uso de estratégias projetuais, capazes de potencializar a capacidade energética de uma edificação, de modo que promova sua auto sustentação. O alcance de tais objetivos, exigem da arquitetura, o emprego de medidas relacionadas a metodologia projetual. Gonçalves e Duarte (2006) relatam que o desenvolvimento de um projeto sustentável, deve considerar o estudo dos seguintes itens:

- Orientação solar e aos ventos

- forma arquitetônica, arranjos espaciais, zoneamento dos usos internos dos edifícios e geometria dos espaços internos.

- características condicionantes ambientais (vegetação, corpos D’Água, ruídos, etc) e tratamento do entorno imediato.

- materiais das estruturas internas e externas, considerando desempenho térmico e cores.

- tratamento das fachadas e coberturas, de acordo com a necessidade de proteção solar.

- áreas envidraçadas e de cobertura, considerando a proporção quanto a áreas de envoltória, o posicionamento na fachada e o tipo de fechamento, seja ele vazado, transparente ou translúcido. (GONÇALVES E DUARTE; 2006).

Sendo assim, Amorim (2003) descreve que a eficiência ambiental de um edifício deve estar ligada a demanda energética empregada em sua construção, seu uso, sua manutenção e sua demolição. Salientando que a lista de prioridades de uma construção sustentável deve englobar projetos energéticos eficientes, aderindo a fontes energéticas renováveis, a minimização 
de cargas com refrigeração e aquecimento, a otimização de luz natural, entre outros fatores. Sua eficiência deverá estar vinculada ao correto uso de elementos arquitetônicos, empregados a partir de uma metodologia básica para a obtenção do conforto térmico, como o posicionamento de abertura oposto, afim de proporcionar o efeito ventilação cruzada, o efeito chaminé, a iluminação natural direcionada, entre outros.

Com a crescente demanda por mudanças no setor da Construção Civil, a fim de adequa-lo aos preceitos de sustentabilidade, surgiu a necessidade da criação de métodos avaliativos dos impactos causados por essas edificações ao meio ambiente. Grunberg et al. (2014) afirmam que estes métodos são importantes porque sem eles, não há como verificar se as questões de sustentabilidade estão sendo atendidas de forma satisfatória. Sendo assim, diversos países têm se empenhado na elaboração dos Selos Ambientais.

Para Miotto (2013) os Selo Ambientais que merecem destaque são o BREEAM (Building Research Establishment Environmental Assessment Method), criado no Reino Unido no ano de 1990, o LEED (Leardership in Energy and Environmental Design), elaborado no ano de 1998, pela USGBC (U.S. Green Building Council) e o AQUA, desenvolvido na França no ano de 1997. No Brasil temos os Selos Procel, que avalia os níveis de eficiência energética de aparelhos (mais voltado ao desempenho de aparelhos) e Casa Azul. Este último, foi elaborado pela Caixa Econômica Federal, com o objetivo de classificar a qualidade de projetos de empreendimentos habitacionais. Com a propagação dos Selos Ambientais, é possível identificar a importância global que o tema sustentabilidade nas edificações, vem adquirindo.

\section{4 - RESULTADOS E DISCUSSÕES}

De acordo com Miotto (2013), o processo de criação dos selos ou rótulos ambientais, teve seu início na década de 1970, tomando como parâmetro, diretrizes como a peculiaridades dos produtos, a biodegradabilidade, a retornabilidade, o uso de materiais reciclados, eficiência energética, entre outros fatores. O rótulo verde, denominado Anjo Azul, criado no ano de 1977, pelo órgão federal do governo da Alemanha, foi considerado o mais antigo já criado.

Ainda segundo o autor, as normas ISSO 14.000 classificam os rótulos ambientais em três tipos diferentes, onde o tipo I é destinado a abrigar produtos criados por entidades independentes e concedidos aos produtos que apresentam determinados padrões ambientais desejáveis na sua categoria (como acontece com o Anjo Azul). No caso do Rótulo II (estabelecido pela norma ABNT NBR ISSO 14.021/2013), refere-se à reivindicação de autodeclararão, sem certificação independente, fato que não acontece no tipo III. Os rótulos do tipo III (objetos da norma ISO 14.025/2006), informam os dados ambientais dos produtos, os quais são quantificados por intermédio de um conjunto de parâmetros previamente selecionados e baseados na avaliação do ciclo de vida, são rótulos concedidos por organizações independentes (o selo brasileiro Procel é um exemplo).

Outra importante certificação citada por Anjos et al. (2015) é o Building Research Establishment Environmental Assessment Method (BREEAM). O BREEAM foi criado na década de 1990, no Reino Unido, com o intuito de avaliar as construções sustentáveis, dotado de grande rigor e profundidade em seus critérios avaliatórios, sendo constantemente atualizado e gerando rico material para o desenvolvimento de pesquisas acadêmicas. Esta certificação possui sua avaliação baseada em dez categorias distintas, com diferentes níveis de importância, dentre as quais estão a gestão, a saúde e bem-estar, a eficiência energética, o transporte, o uso de agua, os resíduos, os níveis de poluição, o uso do solo e ecologia, materiais usados e inovações empregadas.

Para Miotto (2013), o BREAAM permite avaliar o desempenho ambiental de vários tipos de construções, como habitações (EcoHomes), edifícios para escritórios (Offices), unidades industriais (Industrial BREEAM), edifícios comerciais (BREAAM Retail) e um sistema aberto para outras tipologias (Bespoke BREAAM). 
Assim como acontece com o BREAAM, a certificação LEED despontou no cenário das certificações, como um importante instrumento avaliatório das construções sustentáveis. Anjos et al. (2015) relata que a certificação LEED (Leardership in Energy and Environmental Design), foi criada no ano de 1998 e tornou-se uma das principais certificações ambientais para construções, cujo intuito é promover a implantação de edifícios sustentáveis e lucrativos, tornando-se lugares saudáveis para se viver e trabalhar. A edificação com certificação LEED deve obrigatoriamente ter sido implantada respeitando medidas socioambientais, contribuindo para a redução dos impactos ambientais causado por suas atividades. Ainda de acordo com o autor, o programa LEED possui um sistema avaliatório mais flexível se comparado com o BREEAM, sendo coordenado por leis de mercado, onde os empreendedores podem escolher quais indicadores deverão ser atendidos para obter maior valor para seus projetos.

Segundo Miotto (2013), vinculado ao U. S. Green Building Council - USGBC, órgão criador da certificação, no ano de 2007, foi criado no Brasil o Green Building Brasil (GBCB), cujo objetivo é promover a popularização da certificação e das construções sustentáveis no país. Entre as diretrizes proposta pelo GBCB para a avaliação para a obtenção da certificação estão os espaços sustentáveis, a eficiência do uso de água, materiais e recursos, a qualidade ambiental interna, a inovação e processos implantados e os critérios de prioridade regional. O Quadro 01, expõe de forma resumida as categorias da certificação LEED.

\subsection{CERTIFICAÇÃO NACIONAIS}

No Brasil, as certificações ambientais destinadas as construções sustentáveis são representadas principalmente pelo processo AQUA e o Selo Casa Azul. De acordo com Anjos et al. (2015) a certificação AQUA (Alta Qualidade Ambiental) consiste na versão nacional do processo HQE (Haute Qualité Environnementale), criado no ano de 1997, na França, destinado ao desenvolvimento da gestão da qualidade ambiental nos edifícios, cujas diretrizes consistem em reduzir os impactos dos edifícios sobre o meio ambiente exterior, ao nível global e local e também criar um ambiente interior confortável e sadio para os utilizadores.

Segundo Miotto (2013), o processo AQUA foi implantado no ano de 2007, pela Fundação Vanzolini (instituição privada sem fins lucrativos), cujo objetivo consiste em garantir a qualidade ambiental de um novo empreendimento, ou a reabilitação de construções antigas, utilizando-se de auditorias presenciais independentes. Os benefícios da certificação AQUA, incluem melhorias que atingem o empreendedor, o comprador e a questão socio ambiental. A figura 01 mostra o edifício Ecco Tower, um exemplo de construção certificada com o selo AQUA.
Quadro 01 - Categorias de certificação LEE

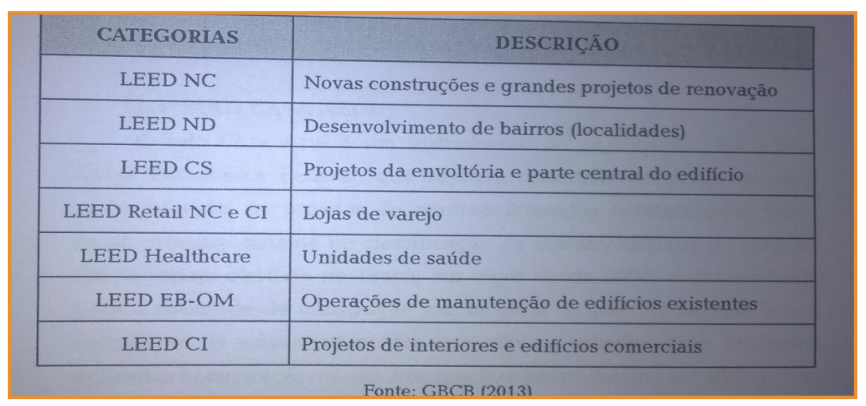


Figura 01 - Edifício Ecco Tower.

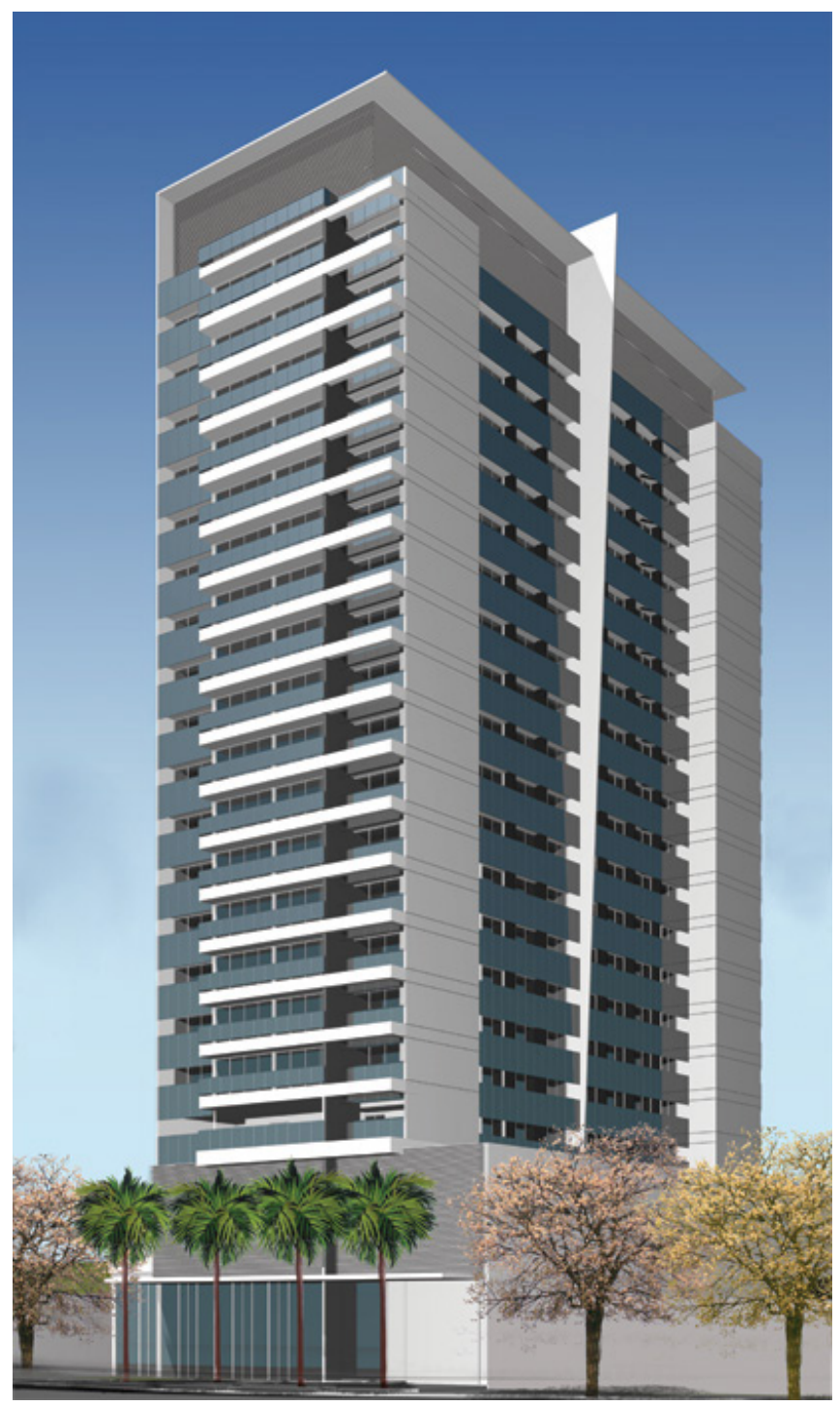

Fonte: Clavi Corporações. Disponível em < https://goo.gl/ ZB4k7H>

acesso em 19 de setembro de 2016.

Outra certificação de importância nacional, trata-se do selo Casa Azul, idealizado pela Caixa Econômica Federal, cujo objetivo é classificar a partir do ponto de vista sócio ambiental os projetos de empreendimentos. Segundo Miotto (2013), o sistema de avaliação está em vigor desde do ano de 2008, configurando-se como o primeiro sistema de classificação de projetos habitacionais ofertados no Brasil. O selo busca reconhecer os empreendimentos que adotam soluções mais eficientes aplicadas à construção, ao uso do solo, à ocupação e à manutenção das edificações, com o intuito de incentivar o uso racional dos recursos naturais e a melhoria da qualidade nas edificações.
O selo se aplica a todos os tipos de projetos de empreendimentos habitacionais, cujos critérios de avaliação resultam em um montante de 53 itens, distribuídos em seis categorias distintas, como a qualidade urbana, o projeto e conforto, a eficiência energética, a conservação dos recursos materiais, a gestão da água e as práticas sociais. Os selos estão distribuídos em três níveis principais, sendo eles bronze, prata e ouro. O nível bronze implica no atendimento mínimo de 19 critérios estabelecidos como obrigatórios, o nível prata exige o atendimento dos critérios mínimos e mais seis itens de livre escolha, já o nível ouro compreende o atendimento de todos os itens obrigatórios e mais doze itens de livre escolha.

Figura 02 - Edificação com selo nível prata - Edifício Ville Barcelona.

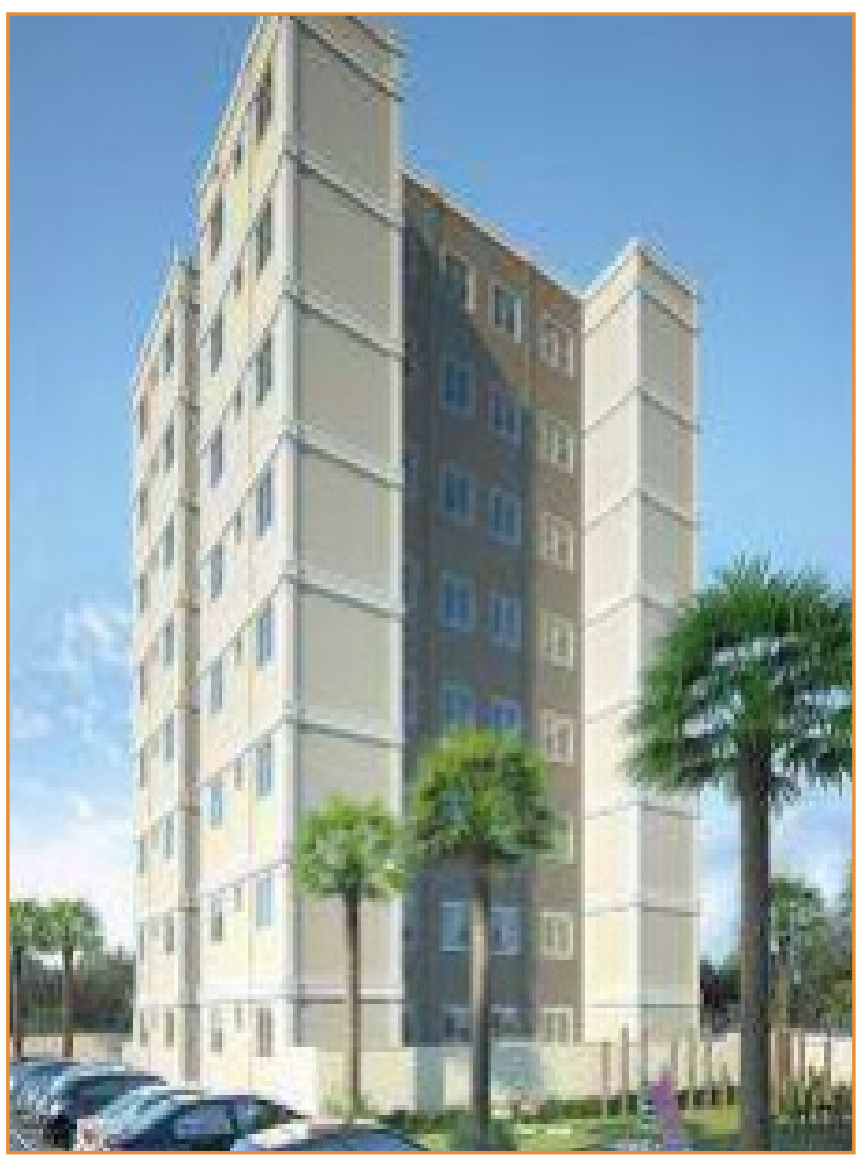

Fonte: Selo Casa Azul. Disponível em < https://goo.gl/ AgyQN6> acesso em 19 de set. de 2016.

O objetivo principal da criação do Selo Casa Azul, consiste no uso racional dos recursos naturais na 
construção habitacional, proporcionando a redução do custo de manutenção dos edifícios e as despesas mensais de seus usuários, além da conscientização de empreendedores e moradores sobre as vantagens das construções sustentáveis (MIOTTO; 2013).

\section{CONSIDERAÇÕES FINAIS}

A construção civil é considerada uma atividade de grande impacto ambiental, consumidora de quantias expressivas de recursos naturais não renováveis, o que contribui para a degradação de áreas cada vez maiores. Fato que tem atraído as atenções para a elaboração de métodos produtivos capazes de promover a mudança desse cenário, exigindo a reflexão e a discussão sobre os caminhos que o setor deverá seguir.

A partir do desenvolvimento desse trabalho, foi possível verificar que tal mudança está diretamente ligada ao planejamento do processo construtivo, que deve ser elaborado de uma forma abrangente e detalhada, fato que possibilitara a mudança dessa realidade de consumo. Tal resultado, poderá ser alcançado através da incorporação de diretrizes sustentáveis as edificações, influenciando no seu desempenho, econômico, ambiental e estrutural, entre as vantagens obtidas por meio de práticas sustentáveis, pode ser citado o desempenho energético, através do uso de energias alternativas (ex. solar), do aproveitamento da iluminação e da ventilação natural, a economia do consumo de água potável, a partir do aproveitamento de águas cinzas para fins secundários, a diminuição do volume de resíduos gerados (através da previsão de espaços flexíveis e de fácil adaptação, evitando assim a necessidade de reformas), a diminuição no consumo de água para a operação da edificação (com a capitação de águas pluviais e reutilização de águas cinzas), entre outros fatores.

A literatura pesquisada sugere que a criação dos selos ambientais (como o Casa Azul), podem promover a mudança de mentalidade no setor, servindo como uma forma de incentivo e contribuição para a propagação do pensamento sustentável, o que levaria a multiplicação das construções sustentáveis. No entanto, tal condição está ligada a uma maior popularização desse método avaliativo, a uma valorização por parte do mercado imobiliário e uma mudança cultural por parte da população e dos profissionais responsáveis. Ainda segundo a literatura consultada, alguns autores afirmam que há um longo caminho a ser percorrido no que diz respeito ao tema, mas que tal percursos, deve obrigatoriamente, passar por uma maior adesão profissional.

Dessa forma o trabalho evidencia que as construções sustentáveis são capazes de proporcionar benefícios sociais, econômicos e ambientais, onde o projeto é um dos principais responsáveis para obtenção destes resultados, buscando contribuir para a descoberta de novos horizontes no que diz respeito a formas mais sustentáveis de construir. Demonstra também a aplicabilidade do conceito tema através da apresentação de uma edificação planejada de forma sustentável.

\section{REFERÊNCIAS}

[1] ANJOS, F. X. DOS; RICCIARDI, R. G. F.; MIOTTO, J. L. Certificação Ambiental de Edificações: A importância da Sustentabilidade no Ambiente Urbano. Jornal Online, Maringá, set 2016. Disponível em < https://goo.gl/KtsjHn> acesso em 19 de set. de 2016.

[2] AMORIM, C. N. D. Iluminação natural e eficiência energética-Parte I estratégia de projeto para uma Arquitetura sustentável. Università degli studi di Roma, 2003.

[3] BROTHERHOOD, R. M. Educação e Desenvolvimento sustentável: das concepções teóricas às construções subjetivas. Iniciação. Cientifica. Unicesumar, Maringá, 2008.

[4] BRUNDTLAND, G. Our common future: The world commission on environment and development, pg. 400. Oxford University Press, Oxford, UK, 1987.

[5] CORRÊA, L. R. Sustentabilidade na Construção Civil. 2009, p. 70, Monografia - Curso de Especialização em Construção Civil - Escola de Engenharia, Universidade Federal de Minas Gerais - UFMG, Belo Horizonte, 2009.

[6] GONÇALVES, Joana C. S, DUARTE, Denise H. S. Arquitetura Sustentável: Uma integração entre ambiente, projeto e tecnologia em experiências de pesquisa, prática e ensino. Universidade de São Paulo - USP. São Paulo, 2006. 
[7] GRUNBERG, P. R. M, MEdEIROS, M. H. F., TAVARES, S.F. Certificação ambiental de Edificações: Comparação entre Leed For Homes, Processo Aqua e Selo Casa Azul. Disponível em: <https://goo.gl/5XfkOO> acesso em 07 de Abril de 2016.

[8] MARQUES, R. B. Resíduos da Construção Civil em Araguari - MG: Diagnóstico à Proposta de um Modelo de Gerenciamento Pró-ativo. 2007, p. 147, Tese (Mestrado em Engenharia Civil) - Programa de Pós-graduação em Engenharia Civil, Universidade Federal de Uberlândia. Uberlândia, 2007.

[9] MARQUES, F. M; SALGADO M. S. Padrões de Sustentabilidade Aplicados ao Processo de Projeto. Universidade Federal do Rio de Janeiro, Rio de Janeiro - RJ, 2007.08.
[10] MENDES, O; OLIVEIRA E. G. Gerenciamento de Resíduos da Construção e Demolição: Estudo de caso da Resolução 307 do CONAMA, Goiânia, 2008. Anais... Goiânia: PUCG, 2008. Disponível em:https://goo.gl/rcy7IA. Acesso em: 17 de novembro de 2014.

[11] MIOTTO, J. L. Princípios para o projeto e produção das construções sustentáveis. 1aㅡ Edição. Ponta Grossa: BICEN/ UEPG, 2013.

[12] RIBEIRO, D. V.; MORELLI, R. M. Resíduos Sólidos: problema ou oportunidade. Rio de Janeiro: Interciência, 2009.

[13] SILVA, V. G.; SILVA, M. G. Seleção de materiais e edifícios de alto desempenho ambiental. In: GONÇALVES, J. C. S.; BODE, K. N, Edifício ambiental. São Paulo: Oficina de textos, 2015 p. 129-151. 


\title{
CAPÍTULO 24
}

\section{ESCRITÓRIO VERDE: A CONTRIBUIÇÃO DA UNIVERSIDADE TECNOLÓGICA FEDERAL DO PARANÁ - UTFPR PARA O DESENVOLVIMENTO SUSTENTÁVEL}

\author{
Diego Vieira Ramos \\ André Fogolin Machado \\ Marcelo Luiz Chicati \\ Generoso de Angelis Neto
}

Resumo: A incorporação de conceitos de sustentabilidade as formas de consumo e produção, representa um dos desafios da sociedade contemporânea, em virtude da oposição de fatores culturais, sociais e econômicos. Algumas áreas da sociedade, influenciam diretamente nesse contexto, como é o caso da construção civil. A atividade é considerada um dos principais setores da economia do país, fonte geradora de diversos postos de trabalho, mas que em contrapartida, figura como uma das grandes consumidoras de recursos naturais em sua produção, sendo alvo frequente de estudos que buscam a diminuição de seus impactos. Dessa forma, a Universidade Tecnológica Federal do Paraná - UTFPR, por intermédio dos docentes que trabalham a questão ambiental e de parcerias com empresas privadas, buscaram demonstrar de forma prática, os benefícios da adoção de forma mais sustentáveis de construção, através da implantação do chamado "Escritório Verde". Sendo assim, o presente trabalho busca expor os ganhos socioambientais alcançados por esta edificação, obtidos através do emprego de materiais ecologicamente corretos e tecnologias adequadas a questão ambiental.

Palavras Chave: Sustentabilidade, Arquitetura, Construções Sustentáveis. 


\section{INTRODUÇÃO}

De acordo com Ribeiro e Morelli (2009), a concepção de desenvolvimento, esteve tradicionalmente associada a exploração e a transformação dos recursos naturais, caracterizando a ocorrência de frequentes problemas ligados a questão ambiental. As alterações sofridas pelo planeta, em virtude dessas ações, escancaram a necessidade de se desenvolver formas mais sustentáveis de produção, capazes de amenizar essa realidade. Essa interpretação é sustentada por Miotto (2013), ao discursar sobre a urgência em se repensar o atual modelo de produção e consumo, salientando que há sinais evidentes de que a atividade humana, está baseada em um modelo que compromete a capacidade de regeneração do planeta.

A degradação está associada à evolução da ciência, da tecnologia, da produção industrial e do crescimento urbano, expondo a necessidade de promover a conscientização planetária a respeito do pensamento sustentável, afim de favorecer o avanço da educação ambiental (BROTHEHOOD; 2008). Sendo assim, a transformação desse paradigma, deve estar fundamentada em uma abordagem ampla e concisa sobre a sustentabilidade. Para Kanashiro (2010), a sustentabilidade está habilitada a encontrar um mecanismo harmonioso de interação entres as sociedades humanas e o meio ambiente, de forma a reorientar o processo civilizatório. Nesse contexto, a sustentabilidade propõe parâmetros opostos a visão evolutiva tradicional, baseada em um desenvolvimento econômico, fundamentado na priorização dos lucros em contraposição a preservação dos recursos.

Para Ribeiro e Morelli (2009) o pensamento sustentável deve ser capaz de solucionar problemas advindos da ineficiência de políticas de gestão, da falta de leis mais rigorosas relacionadas ao assunto, da falta de fontes alternativas de matéria prima, da produção e da destinação de resíduos, da contaminação do solo, da água e do ar, entre outros fatores. Seguindo essa linha de raciocínio, o pensamento sustentável, deve ser fundamentado no uso inteligente dos recursos naturais e na prevenção do desperdício. Marques e Salgado (2007) afirmam que para se alcançar o desenvolvimento sustentável, é necessário haver um equilíbrio entre o que é socialmente desejável, economicamente viável, e ecologicamente sustentável, formando um "tripé" que irá sustentar as esferas sociais, econômicas e ambientais. Dessa forma, o desenvolvimento sustentável deve ser abordado de uma ótica ampla e multidisciplinar, que promova conscientização global, sobre a necessidade de haver uma mudança efetiva na postura produtiva.

Com o reconhecimento dos malefícios do processo de consumo, buscou-se estabelecer uma reflexão sobre o tema. De acordo com Ramos (2015), ações tem sido elaboradas em prol do desenvolvimento de medidas capazes de amenizar a questão. Pode ser citado a I Conferência Mundial sobre o Meio Ambiente, realizada em Estocolmo em 1972, a II Conferência Mundial do Meio Ambiente realizada no Rio de Janeiro (Eco-92), a Agenda 21, a Cúpula da Terra de Joanesburgo, em 2002 (RIO+10), o Relatório Brundtland e a Conferência da ONU sobre o Desenvolvimento Sustentável, realizado novamente no Rio de Janeiro, durante o ano de $2012(\mathrm{RIO}+20)$.

A degradação dos recursos naturais está vinculada a evolução da tecnociência, o aprimoramento das indústrias e a expansão urbana desordenada. Inclusa nesse grupo, a Construção Civil brasileira é incumbida de produzir parte considerável da riqueza nacional, exercendo papel fundamental no PIB e caracterizando a geração de inúmeros postos de trabalho. Em contrapartida, o setor é um dos maiores responsáveis pelo consumo de recursos naturais não renováveis e pela formação de área degradadas. Dessa forma, Graim (2012) atribui a Construção Civil uma absorção de cerca de até $50 \%$ de todos os recursos naturais não renováveis extraídos.

Afim de contribuir como a exposição dessa realidade, Menezes e Oliveira (2008) quantificam o uso dos recursos naturais do setor no Brasil, ao afirmarem que a produção nacional de cimentos Portland no ano de 2008 se aproximou do número de 35 milhões de toneladas, e que se considerado o traço médio de 1:6, a quantidade de agregados necessários para o seu preparo, pode ter chego ao assustador número de 210 milhões de toneladas. Tais números sugeridos, confirmando a predatoriedade do setor em relação 
aos recursos naturais não renováveis, e demonstrando a incompatibilidade do setor em relação a realidade planetária, o que sugeri a urgência na adoção de medidas que proporcionem uma redução no consumo.

Diante deste cenário, Santos (2012) afirma que as edificações construídas dentro dos parâmetros sustentáveis são capazes de apresentar benefícios no processo construtivo e nas fases de operação e manutenção, como maior vida útil do edifício e economia de materiais, melhor desempenho energético, entre outros benefícios. Com base no ideal de sustentabilidade, o presente trabalho pode ser justificado pela necessidade de se buscar novas formas de projetar e edificar, capazes de racionalizar o uso de recursos naturais não renováveis, a fim de minimizar os desperdícios, amenizar os impactos causados ao meio ambiente, sem afetar a capacidade produtiva do setor e difundir o conhecimento, sobre o assunto, para que este possa atingir cada vez mais a indústria da Construção Civil, alertando para a atual realidade de escassez dos recursos naturais não renováveis, com o intuito de promover métodos de produção mais comprometidos com as questões ambientais.

Os objetivo desta pesquisa, consiste em avaliar os ganhos socioambientais e socioeconômicos obtidos a partir da adesão de conceitos sustentáveis na concepção e implantação das construções, quantificar os benefícios da Arquitetura Sustentável para o meio ambiente, expor o exemplo de edificações que incorporam conceitos sustentáveis a sua concepção, classificando vantagens e desvantagens.

\section{MATERIAIS E MÉTODOS.}

Para alcançar os objetivos propostos, foi adotado o método de Casagrande e Deeke (2009), que consiste em na revisão da literatura sobre o conceito de desenvolvimento sustentável, de sustentabilidade (e dos demais conceitos a eles ligados) e na exposição de um modelo de construção sustentável. Foram pesquisadas obras de referência produzidas nos últimos dez anos, artigos de autores que trabalham o tema, publicados nas principais revista e congresso ligados à área, a fim de detetar possíveis correntes emergentes de pensamento sobre o assunto.

Na sequência, o artigo apresenta a dimensão de aplicabilidade do conceito-tema, os passos dados em direção à escala de sustentabilidade, os problemas ligados ao assunto que necessitam serem resolvidos, os impactos causados pela construção civil ao meio ambiente, através do uso de recursos naturais não renováveis e o papel do projeto arquitetônico no processo construtivo, como forma de construir uma base de conhecimento capaz de dar suporte à compreensão dos profissionais da área, sobre a adoção de medidas que promovam a sustentabilidade e o desenvolvimento sustentável no setor da construção civil.

Através da exposição de uma edificação que contou com a inclusão de conceitos sustentáveis em sua concepção o Escritório Verde, localizado na Universidade Tecnológica Federal do Paraná, situado na cidade de Curitiva, (projeto piloto desenvolvido dentro do campus da Instituição). Sendo assim, buscou-se confirmar a viabilidade da redução no consumo energético, de materiais não e também das emissões de gases poluentes.

\section{CONSTRUÇÕES SUSTENTÁVEIS.}

Na visão de Corrêa (2009) as construções sustentáveis são entendidas como o processo holístico responsável por restabelecer e manter a harmonia entre os ambientes natural e construído e criar estabelecimentos que confirmem a dignidade humana e estimulem a igualdade econômica. Em outras palavras, possuem a incumbência de promover o equilíbrio entre o desenvolvimento social, ambiental e econômico, tendo como objetivo principal a harmonização do ambiente construído com o ambiente natural.

De acordo com Marques (2007), essa inserção de requisitos sustentáveis as construções, esta diretamente ligado à concepção projetual, sendo parte de uma metodologia denominada Processo de Projeto Integrado, que busca viabilizar a obtenção do funcionamento satisfatório do edifício. Nessa visão, o sucesso do processo construtivo está associado 
a perspectiva ampla e integrada da concepção do projeto, considerando todas as etapas do ciclo de vida útil do edifício. Para Gonçalves e Duarte (2006) as construções sustentáveis devem provir de uma arquitetura que seja fruto do entendimento e da leitura contextual do ambiente no qual estará inserido. Tal opinião, expõe a necessidade de se promover uma maior reflexão sobre as formas de enxergar a arquitetura, onde a edificação deverá ser entendida como parte de um contexto e não apenas um elemento único na cidade.

Para Silva et al. (2013) a sustentabilidade na construção está intimamente vinculada ao projeto de Arquitetura, com sua elaboração considerando questões ambientais, além de avaliar o impacto sobre o meio, em toda e qualquer decisão. Dessa forma, as construções sustentáveis estão condicionadas a uma metodologia projetual fundamentada no incentivo de medidas que promovam a eficiência em todas suas etapas e também adoção de materiais construtivos ambientalmente corretos. Gonçalves e Duarte (2006) afirmam que as questões ligadas a sustentabilidade passaram a ser incorporadas a Arquitetura e ao Urbanismo, de forma incisiva, no término da década de 1980 e inicio dos anos 1990, com a implantação de novos paradigmas provindos do contexto europeu, que atuaram paralelamente a divulgação do Relatório Brundtland (1987). Essas discussões, sobre a sustentabilidade, passaram a interferir na forma de produzir Arquitetura e de entender o seu papel na sociedade.

No que diz respeito ao assunto Arquitetura Sustentável, ainda há dificuldade em atingir uma unanimidade sobre sua definição. Cândido (2012) diz que apesar da discussão ser abordada por diversos autores, não há um consenso global, o que abre espaço para o surgimento de outros termos, como o projeto sustentável, a construção sustentável, o edifício sustentável, entre outros, provocando a banalização do "termo sustentabilidade". Na visão de Gonçalves e Duarte (2006), a arquitetura sustentável pode ser compreendida como a continuação natural de um conceito passado, denominado Arquitetura Bioclimática. Para eles, a arquitetura bioclimática exerce importante influência dentro do contexto da arquitetura sustentável, devido a estreita relação estabelecida entre o conforto ambiental e o consumo de energia, que está presente nos sistemas de condicionamento ambiental artificial e de iluminação artificial. A Arquitetura passou a ter a tarefa de usufruir dos elementos naturais, como a água, o solo e o ar, na busca por uma maior eficiência dos edifícios.

De acordo com Joaquim (2012) a Arquitetura Bioclimática pode ser compreendida como o estudo que busca a harmonização das construções ao clima e as características locais, através da manipulação do desenho e dos elementos arquitetônicos, a fim de otimizar as relações entre o homem e a natureza, no que diz respeito à redução de impactos ambientais, quanto a melhoria das condições de vida humana, do conforto e da racionalização do consumo energético. A principio, os estudos bioclimáticos manifestavam a centralização das preocupações em torno do consumo energético, o que serviu de inicio para a reflexão sobre a relação ambiente natural e ambiente construído.

Sendo assim Gonçalves e Duarte (2006) atribuem substancial importância ao projeto, afirmando que este deve conter em sua concepção, estudos de formas arquitetônicas, de arranjos espaciais, de zoneamento, de usos internos, de geometria dos espaços externos, de condicionantes ambientais, de materiais da estrutura (vedações internas e externas), de detalhamento de proteções solares entre outras medidas.

Miotto (2013 p.73) salienta que no caso de uma edificação, existem muitas técnicas de projeto capazes de amenizar a sobrecarga dos recursos naturais, seja por meio de elementos construídos como telhados verdes (uma espécie de jardins instalados na cobertura das edificações, com o intuito de servir como um sistema de drenagem de água pluvial) ou por meio da seleção de materiais. A arquitetura deve estar focada na incorporação das ferramentas disponíveis a suas diretrizes projetuais, que vão desde a idealização de conceitos até ao conhecimento e o domínio técnico, capaz de proporcionar maior eficiência no uso dos recursos. A eficiência no uso dos recursos está relacionada a muitas técnicas 
que envolvem o emprego de materiais adequados como métodos construtivos, o uso de produtos que minimizam os impactos da nova construção ou reforma, o desenvolvimento de projetos que utilizando componentes reutilizáveis, $\mathrm{o}$ ato de projetar que se preocupe com a posterior desconstrução do edifício, entre outros fatores. (MIOTTO;2013).

Igualmente importante na composição das edificações sustentáveis, se trata do desempenho energético. Para Gonçalves e Duarte (2006), as metas que tratam o conforto ambiental e a eficiência energética, devem contemplar a redução por demanda de climatização e iluminação artificial, suprindo-a sempre que possível por meios passivos, como o aquecimento passivo direto e indireto, a ventilação natural, a ventilação noturna, a iluminação natural e a demais estratégias complementadas por meio energéticos eficientes. A arquitetura deve buscar o uso de estratégias projetuais, capazes de potencializar a capacidade energética de uma edificação, de modo que promova sua auto sustentação. O alcance de tais objetivos, exigem da arquitetura, o emprego de medidas relacionadas a metodologia projetual. Gonçalves e Duarte (2006) relatam que o desenvolvimento de um projeto sustentável, deve considerar o estudo dos seguintes itens:

- Orientação solar e aos ventos

- forma arquitetônica, arranjos espaciais, zoneamento dos usos internos dos edifícios e geometria dos espaços internos.

- características condicionantes ambientais (vegetação, corpos D’Água, ruídos, etc) e tratamento do entorno imediato.

- materiais das estruturas internas e externas, considerando desempenho térmico e cores.

- tratamento das fachadas e coberturas, de acordo com a necessidade de proteção solar.

- áreas envidraçadas e de cobertura, considerando a proporção quanto a áreas de envoltória, o posicionamento na fachada e o tipo de fechamento, seja ele vazado, transparente ou translúcido. (GONÇALVES E DUARTE; 2006).

Sendo assim, Amorim (2003) descreve que a eficiência ambiental de um edifício deve estar ligada a demanda energética empregada em sua construção, seu uso, sua manutenção e sua demolição. Salientando que a lista de prioridades de uma construção sustentável deve englobar projetos energéticos eficientes, aderindo a fontes energéticas renováveis, a minimização de cargas com refrigeração e aquecimento, a otimização de luz natural, entre outros fatores. Sua eficiência deverá estar vinculada ao correto uso de elementos arquitetônicos, empregados a partir de uma metodologia básica para a obtenção do conforto térmico, como o posicionamento de abertura oposto, afim de proporcionar o efeito ventilação cruzada, o efeito chaminé, a iluminação natural direcionada, entre outros.

De acordo com Gonçalves e Duarte (2006), são muitas as tecnologias disponíveis capazes de minimizar os impactos ambientais dos edifícios, tais como o uso de painéis fotovoltaicos na produção de energia, painéis solares para aquecimento de água e o reaproveitamento de águas cinzas. Com a crescente demanda por mudanças no setor da Construção Civil, a fim de adequa-lo aos preceitos de sustentabilidade, surgiu a necessidade da criação de métodos avaliativos dos impactos causados por essas edificações ao meio ambiente. Grunberg, Medeiros e Tavares (2014) afirmam que estes métodos são importantes porque sem eles, não há como verificar se as questões de sustentabilidade estão sendo atendidas de forma satisfatória. Sendo assim, diversos países têm se empenhado na elaboração dos Selos Ambientais.

Para Miotto (2013) os Selo Ambientais que merecem destaque são o BREEAM (Building Research Establishment Environmental Assessment Method), criado no Reino Unido no ano de 1990, o LEED (Leardership in Energy and Environmental Design), elaborado no ano de 1998, pela USGBC (U.S. Green Building Council) e o AQUA, desenvolvido na França no ano de 1997. No Brasil temos os Selos Procel, que avalia os níveis de eficiência energética de aparelhos (mais voltado ao desempenho de aparelhos) e Casa Azul. Este último, foi elaborado pela Caixa Econômica 
Federal, com o objetivo de classificar a qualidade de projetos de empreendimentos habitacionais. Com a propagação dos Selos Ambientais, é possível identificar a importância global que o tema sustentabilidade nas edificações, vem adquirindo.

\section{O ESPAÇO UNIVERSITÁRIO COMO AGENTEINDUTOR DO DESENVOLVIMENTO SUSTENTÁVEL.}

Para Casagrande e Deeke (2009) os princípios de sustentabilidade aplicados a Arquitetura, estão essencialmente fundamentados em teorias como o Capitalismo Natural, o Gerenciamento Ecológico, a Metodologia de Zero Emissões (Zero Emission Research Initiatives) e a Responsabilidade Social Corporativa, onde tais conceitos, devem ser capazes de formar uma nova mentalidade em que o desenvolvimento sustentável deixe de ser visto de forma negativa. Sendo assim, os centros universitários são vistos como importantes ferramentas para a experimentação de modelos de desenvolvimento sustentáveis. Dessa forma, os chamados greencampi (campi sustentável) entram em cena, se consolidando como uma realidade em países europeus, na Austrália, na Nova Zelândia e Estados Unidos. Ainda de acordo com Casagrande e Deeke (2009), os campis universitários propõem não apenas mudanças físicas através do formato de vilas, com moradias para estudantes, mas também da dinâmica que rege o cotidiano do espaço, por meio da implantação de escritórios voltados ao gerenciamento de práticas sustentáveis elaboradas no campus universitário (Green Office).

Segundo Borba et al. (2010), os campis possuem papel fundamental na divulgação de técnicas construtivas e operacionais mais adequadas ao novo contexto mundial, o que induz a propagação do conhecimento a cerca de tecnologias sustentáveis que reduzem os impactos negativos de carater socioambiental e socioeconomicos, provenientes de construções convencionais e seu processo construtivo.

Na visão de Casagrande e Deeke (2009), toda escola, colégio ou universidade, além do seu currículo explícito descrito em seu catálogo, possui outro curriculo implicito presente na infraestrutura dos edificios. Apoiando-se em conceitos da psicologia que afirma que o aprendizado se da, em sua grande maioria, através da vivencia, os autores propõem o uso dos edificios como instrumentos de interações e experiências, como indutores da conscientização acerca das questões ambientais. No entanto, tal inciativa ainda é pouco presente na realidade nacional, se comparado com o contexto dos países citados, porém, pode-se notar sua propagação. Silva e Casagrande (2009) citam como exemplo de universidades que adotaram tal iniciativa, a Universidade do Vale do Rio Sino (Unisinos), Universidade Federal de Santa Catarina (UFSC), Fundação Universal de Blumenal (FURB), a Universidade Federal do Rio Grande do Sul (UFRGS), a Universidade Federal de São Carlos (Campos Sorocaba), a Universidade Federal de São Paulo (Unifesp), a Universidade de Passo Fundo (UPF) e a Universidade de Campinas (Unicamp).

\section{4 - RESULTADOS E DISCUSSÕES.}

A Universidade Tecnológica Federal do Paraná UTFPR, que possui um histórico de iniciativas que lidam com a questão ambiental, buscou por intermédio dos professores que atuam em áreas ligadas a sustentabilidade e ao desenvolvimento sustentável, elaborar uma iniciativa que buscasse expor os beneficios do emprego de técnicas construtivas alternativas, capazes de promover o desenvolvimento sustentável na construção civil.

Casagrade e Deeke (2009) afirmam que a proposta do chamado escritório verde possui o intuito de integrar todas as ações relacionadas as questões socioambientais presentes no campi, com poderes administrativos para desenvolver e implantar políticas ambientais institucionais, sendo mantido pelo programa Tecnologia com Sustentabilidade - TECSUS e jurisdição institucional vinculada diretamente a reitoria. Ainda segundo os autores, a criação do escritório verde tem como intuito inicial, desenvolver programas de carater ambiental de curto, médio e longo prazo, como os programas CAZA, REZTO, TRECO, COMPRA VERDE e SELO VERDE UTFPR. 
O programa CAZA (Carbono Zero na Academia), visa estabelecer diretrizes para a promoção da sustentabilidade nas edificações já existentes e nas novas construções, através do uso de materiais que contribuam para a redução do impacto ambiental, eficiência energética, o uso racional de água e a correta gestão de resíduos. No caso do programa REZTO (Resíduo Zero: Tecnológico e ambiental), buscou implantar procedimentos para coleta, armazenamento, re-uso, reciclagem e tratamento adequado de residuos pelos departamentos da Instituição. Já o tratamento de resíduos eletrônicos, ficou a cargo do chamado TRACO, que consiste em ações responsáveis por estudar soluções que promovam o reaproveitamento e tratamento apropriado de computadores e periféricos defasados e sem uso que ocupam espaço fisíco, possibilitando o trabalho com a comunidade por meio de programas de extensão universitária. O escritório verde ainda previu a criação dos programas COMPRA VERDE, que visa implantar políticas de compras sustentáveis para a instituição, incluindo nos editais requisitos ambientais específicos, de acordo com cada material e do programa SELO VERDE UTFPR, que consiste na emissão de certidões para processos ecológicamente corretos para equipamentos, produtos, ações e etc. Mediante a teste realizados por profissionais da UTFPR.

\subsection{O PROCESSO DE CONSTRUÇÃO DO ESCRITÓRIO VERDE DA UNIVERSIDADE TECNOLÓGICA FEDERAL DO PARANÁ.}

Segundo Casagrande (2012), o escritório verde foi o primeiro Green Office implantado em uma universidade brasileira, baseado em modelos norte americanos, canadenses e europeus, a edificação está localizada no campus da Universidade Tecnológica Federal do Paraná - UTFPR, na cidade de Curitiba. A implantação das edificações foi viabilizada por meio da parceria público-privado firmada pela UTFPR e a iniciativa privada, onde diversas empresas contribuiram com a doação, a confecção e a instalação de materiais. De acordo com o autor, 95\% dos materiais empregados na obra, foram provenientes de doações recebidas pela instituição, que em troca ofereceu ampla divulgação das 50 empresas parceiras do projeto. Ainda conforme
Casagrande (2012), adotou-se a metodologia de construção a seco, através do emprego do sistema wood-frame, com paredes formadas por vigas de madeira (pinos) e por painés estruturais de OSB (um tipo de material proveniente da madeira).

Entre as vantagens obtidas com adoção de tal técnica construtiva, está a agilidade, onde a fabricação das paredes durou cerca de 12 dias e da edificação 5 dias. Foi utilizado também, materiais responsávei por promover o conforto termo-acustico. A escolha da madeira como sistema construtivo, possuiu o intuito de utilizar a edificação como uma espécie de fixador de carbono e também de comprovar a viabilidade do uso de materiais renováveis na construção civil. Na figura 01 pode ser observado as paredes constituidas por painéis de OSB.

Figura 01 - Vista interna doEscritório Verde.

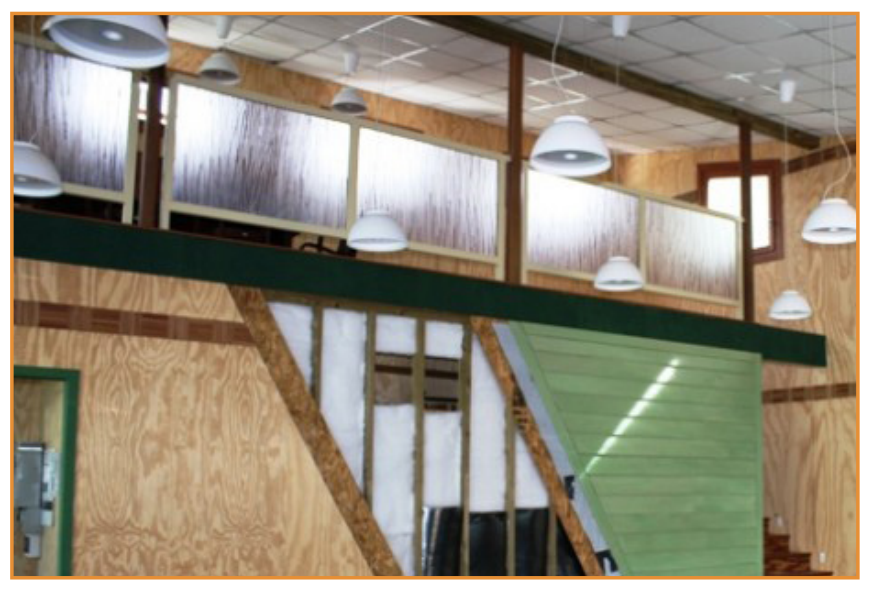

Fonte: ONU Premia projeto "Escritório Verde" da Tecverde Engenharia e UTFPR. Disponível em: <https://goo.gl/ Me7H5b> acesso em: 19 de setembro de 2016.

Em busca da eficiência energética, a edificação proposta faz uso de energias alternativas, como é o caso da solar, viavilizada através do uso de painéis fotovoltaícos, o que proporcionou autonomia energética, com a produção de aproximadamente 3.000 Watts instalados e conectados ao sistema energético paranaense. A figura 02 demonstra de forma esquemática o posicionamento dos painéis. 
Figura 02 - Posicionamento dos painéis fotovoltaícos.

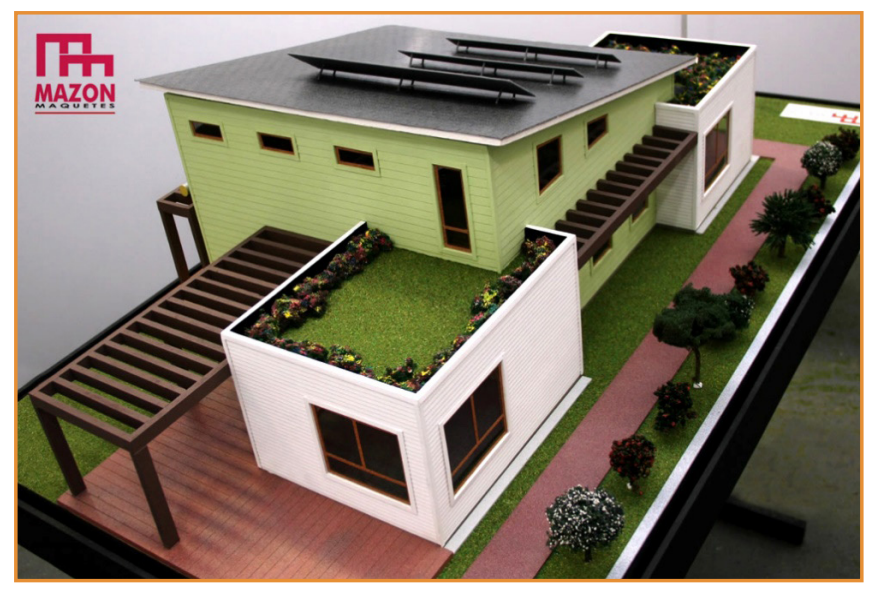

Fonte: Escritório Verde: Modelo de Edificação Sustentável Certificada. Disponível em <https://goo.gl/fmpqKx> Acesso em 19 de setembro de 2016.

Casagrande (2012) relata que complementaram o projeto, concreto para laje da base da edificação de alto desempenho, sistema de captação de água da chuva, sistema de telhado verde para maior isolamento térmico e absorção de água da chuva, uso de lajes e projetos paisagísticos que permitem a permeabilidade da água, instalação de painéis de energia termodinâmica para aquecimento da água e calefação, uso de equipamentos de controle de umidade e resfriamento de ar, sistema luminotécnico com uso de lâmpadas de LED, janelas de madeira provenientes de reflorestamento e com vidro duplo, isolamento térmo-acústico proveniente de materias derivados de garrafas PET e pneus, permeabilização com borracha líquida e tratamento de madeira, pisos, deck e elementos decorativos provindos de material reciclado e por fim mobiliário que faz uso de painéis de MDF e madeira de reflorestamento certificada.

\subsection{O ESCRITÓRIO E A CERTIFICAÇÃO}

De acordo com Casagrande (2010), o conjunto de procedimentos adotados e o uso de tecnologias de baixo impacto ambiental, permitiu que o Escritório Verde recebesse a qualificação da certificação AQUA - Alta Qualidade Ambiental para edifícios sustentáveis, em uma parceria com a Fundação Vanzolini, da Universidade de São Paulo.

\section{CONSIDERAÇÕES FINAIS}

Com papel importante na economia nacional, a construção civil possui um histírico de degradação dos recursos ambientais não renováveis, com a extração de materiais como calcário, minério de ferro, madeira, entre outros. Além disto, o setor chama a atenção dos defensores do desenvolvimento sustentável, devido ao quadro de desperdicio presente em seus processos construtovos, proveniente da má gestão do canteiro de obra e da inconsistencia do processo de planejamento e gestão. Fato que evidencia a necessidade da elaboração de métodos produtivos que promovam a alteração deste cenário, o que sugere um regime de reflexão e discussão.

Com o desenvolvimento deste trabalho, verificou-se que o procedimento construtivo deve ser elaborado de forma detalhada, de forma a abranger todos os aspectos que englobam as particularidades e direcione o resultado final a um quadro sustentavelmente eficiente. Tal premicia demanda a incorporação de diretrizes sustentáveis ao ato de pensar as edificações, o que influencia o seu desempenho, econômico, ambiental e estrutural. Dentre as vantagens obtidas por meio de práticas sustentáveis, pode ser citado o desempenho energético, através do uso de energias alternativas (ex. solar), do aproveitamento da iluminação e da ventilação natural, a economia do consumo de água potável, a partir do aproveitamento de águas cinzas para fins secundários, a diminuição do volume de resíduos gerados (através da previsão de espaços flexíveis e de fácil adaptação, evitando assim a necessidade de reformas), a diminuição no consumo de água para a operação da edificação (com a capitação de águas pluviais e reutilização de águas cinzas), entre outros fatores.

Dessa maneira, algumas iniciativas (como o Escritório Verde da UTFPR) representam formas de propagar os beneficios da adoção de conceitos sustentáves as construções. As construções sustentáveis são capazes de proporcionar ganhos sócioeconomicos e sócioambientais. Além do Escritório Verde da Universidade Tecnológica do Paraná (UTFPR), merecem destaque os programas CAZA (Carbono 
do conceito de Campi Verde, que possibilitou a equipe de trabalho do Escritório, legislar acerca das questões ambientais tratadas na Instituição.

\section{REFERÊNCIAS}

[1] AMORIM, C. N. D. Iluminação natural e eficiência energética-Parte I estratégia de projeto para uma Arquitetura sustentável. Università degli studi di Roma, 2003.

[2] BORBA, A. L. B.; FERRARI, A. M. W.; CASAGRANDE JUNIOR, E. F.; SILVA, M. C. Iniciativas para o alcance de uma cidade sustentável a partir dos exemplos do greencampi e seus escritórios verdes. In: Sustentabilidade e Habitação de Interesse Social, 1, 2010, Porto Alegre. Resumo expandido. Porto Alegre.

[3] BROTHERHOOD, R. M. Educação e Desenvolvimento sustentável: das concepções teóricas às construções subjetivas. Iniciação. Cientifica. Unicesumar, Maringá, 2008.

[4] CÂNDIDO, S. O. Arquitetura Sustentável: Uma questão de bom senso. Revista Vitruvius. Viçosa - MG, Agosto de 2012. Disponível em: https://goo.gl/oxvRDA. Acesso em 07 de abril de 2016.

[5] CASAGRANDE, E. F. Escritório Verde da Universidade Tecnológica Federal do Paraná: Inovação Tecnológica e Sustentabilidade na Prática. Universidade Tecnológica Federal do Paraná - UTFPR. APS Jornal Online, Curitiba, 2010. Disponível em < https://goo.gl/u70Q8Q>. Acesso em 19 de set. de 2016

[6] CASAGRANDE, E. F.; DEEKE, V. Implantando práticas sustentáveis nos Campi Universitários: A proposta do "Escritório Verde" da UTFPR. Revista Educação e Tecnologia. Universidade Tecnológica Federal do Paraná, Curitiba, n.9, 2009.

[7] CORRÊA, L. R. Sustentabilidade na Construção Civil. 2009, p. 70, Monografia - Curso de Especialização em Construção Civil - Escola de Engenharia, Universidade Federal de Minas Gerais - UFMG, Belo Horizonte, 2009,

[8] GONÇALVES, Joana C. S, DUARTE, Denise H. S. Arquitetura Sustentável: Uma integração entre ambiente, projeto e tecnologia em experiências de pesquisa, prática e ensino. Universidade de São Paulo - USP. São Paulo, 2006.

[9] JOAQUIM, F. S. Arquitetura Bioclimática - Bons ventos a trazem. Revista Habitare Ecologia. 2012. N. 12. Disponível em: https://goo.gl/lkWik3. Acesso em 07 de abril de 2016.

[10] KANASHIRO, V. Produção Acadêmica sobre Sustentabilidade: Análise da Base Scielo Brasil. Universidade de Campinas, Campinas - SP, 2010.

[11] MARQUES, R. B. Resíduos da Construção Civil em Araguari - MG: Diagnóstico à Proposta de um Modelo de Gerenciamento Pró-ativo. 2007, p. 147, Tese (Mestrado em Engenharia Civil) - Programa de Pós-graduação em Engenharia Civil, Universidade Federal de Uberlândia. Uberlândia, 2007

[12] MARQUES, F. M; SALGADO M. S. Padrões de Sustentabilidade Aplicados ao Processo de Projeto. Universidade Federal do Rio de Janeiro, Rio de Janeiro - RJ, 2007.08

[13] MENDES, O; OLIVEIRA E. G. Gerenciamento de Resíduos da Construção e Demolição: Estudo de caso da Resolução 307 do CONAMA, Goiânia, 2008. Anais... Goiânia: PUCG, 2008. Disponível em:https://goo.gl/rcy7lA. Acesso em: 17 de novembro de 2014

[14] MIOTTO, J. L. Princípios para o projeto e produção das construções sustentáveis. 1aㅡ Edição. Ponta Grossa: BICEN/ UEPG, 2013

[15] RAMOS, D. V. Programa de Gestão de Resíduos Sólidos de Construção e Demolição (RSCD). In: Encontro Internacional de Produção Científica Unicesumar, 9, 2015, Maringá. Artigo completo. Maringá: Centro Universitário de Maringá, p. 1-8.

[16] RIBEIRO, D. V.; MORELLI, R. M. Resíduos Sólidos: problema ou oportunidade. Rio de Janeiro: Interciência, 2009. 
Alutary 


\section{Hélcio Martins Tristão (Organizador)}

Possui graduação em Ciências Econômicas pelo Centro Universitário de Franca (1985), especialização em gestão, contabilidade e recursos humanos, mestrado em Administração pelo Centro Universitário de Franca (2000), doutorado em Engenharia de Produção pelo Programa de Pós-graduação do Departamento de Engenharia da Universidade Federal de São Carlos - UFSCAR (2013), membro do Grupo de Pesquisas em Qualidade - GEPEQUFSCAR. É professor titular do Centro Universitário de Franca. Tem experiência na área de Administração, com ênfase em Administração Geral atuando principalmente nos temas: teorias administrativas, cluster, cadeia produtiva, cooperação, estratégia empresarial, inovação e aprendizagem organizacional.

\section{Aiury Daniele Correa da Silva}

Graduanda em engenharia de produção (2014), pela universidade do estado do Pará. Atualmente bolsista do programa de iniciação científica UEPA/Fapespa.

\section{Alencar Silveira Roth}

Mestre em Projeto e Processos de Fabricação (2014) e Graduado em Engenharia Elétrica/ Eletrônica (2009) Pela Universidade de Passo Fundo / RS. Engenheiro Sênior, atuando há 10 anos no ramo de projetos elétricos para carrocerias de Ônibus, como Líder de Projetos do setor de engenharia mecatrônica. Como trabalho destaque tem-se o desenvolvimento e implementação do Projeto Elétrico Modular para Construção de Carrocerias de Ônibus, utilizando projetos elétricos em 3D.

\section{Alexandra Maria Sandy}

Engenheira de Produção formada na Faculdade Pitágoras (Campus Poços de Caldas-MG) em 2015.

\section{Amanda Daniele de Carvalho}

Graduanda em Engenharia de Produção pelo Instituto Federal de Educação, Ciência e Tecnologia de Minas Gerais - Campus Congonhas, onde desenvolveu um projeto de iniciação científica ligado à modelagem matemática para ensino de cálculo. Atua na linha de pesquisa "Análise de Indicadores de Sustentabilidade: um estudo comparativo luso-brasileiro", como bolsista PIBIC. Atualmente, é membro do grupo de pesquisas "Núcleo de Estudos em Gestão, Produção, Empreendedorismo e Inovação", do IFMG. Possui experiência na área administrativa de microempresas. 


\section{Ana Celia Vidolin}

Graduada em Geologia pela Universidade Federal do Paraná, licenciado em negócios pela Unisinos e em Administração de Negócios pela Unisinos, é professora de comércio exterior, estratégia e jogos de negócios e administração de organizações do CNEC Business College em Campo Largo. Especialista em negócios de logística, logística e operações, MBA em gestão de negócios é pesquisadora nas áreas de gerenciamento de cadeia de suprimentos, operações enxutas, logística. Possui experiência profissional nos setores privados com planejamento de materiais e produção, comércio exterior e atividades enxutas.

\section{Ana Elaje Azevedo Simões da Mota}

Graduanda em Engenharia de Produção da Universidade do Estado do Pará (UEPA)

\section{Ana Paula Souza de Freitas}

Graduanda em engenharia de produção (2014), pela universidade do estado do Pará. Atualmente bolsista do programa de iniciação científica UEPA/Fapespa.

\section{André Clementino de Oliveira Santos}

O autor possui Graduação de Tecnologia em Processamento de Dados pelo Centro de Ensino Superior do Pará (1993), Graduação em Engenharia Civil pela Universidade Federal do Pará (1995), Mestrado em Engenharia de Produção pela Pontifícia Universidade Católica do Rio de Janeiro (1998). É Professor Assistente IV da Universidade do Estado do Pará atuando na área de Gestão da Produção com ênfase em Engenharia de Métodos, Planejamento, Projeto e Controle de Sistemas de Produção. Publicou diversos artigos científicos na sua área de atuação e é co-autor de capítulo do livro "Engenharia de Produção: tópicos e aplicações" da Editora da Universidade do Estado do Pará.

\section{André Fogolin Machado}

Formado em Engenharia Ambiental pela Centro Dinamica das Cataratas - UDC, localizado na cidade de Foz do Iguaçu/PR. Mestrando em Engenharia Urbana pela Universidade Estadual de Maringá - UEM, tendo como orientador o Prof. Dr. Generoso De Angelis Neto. Pósgraduando no curso de especialização de Engenharia de Segurança do Trabalho, pela Universidade Estadual de Maringá - UEM.

\section{Antonio Andrei Braga}

Graduando em engenharia de produção pela Universidade do Estado do Pará. Possui experiência em aplicação de estudo de tempos e movimentos em fábricas de tapioca e açaí. Estagiário na indústria de polpas de frutas Bela laçá. Gerente em projeto de extensão sobre integração acadêmica.

\section{Antônio Caio Cézar Costa dos Santos}

Graduando em engenharia de produção (2014), pela universidade do estado do Pará. Atualmente bolsista do programa de iniciação científica UEPA/Fapespa. 


\section{Ayllan Cesar de Sousa Galvão}

Graduando em engenharia de produção (2014), pela universidade do estado do Pará.

\section{Bárbara Heliodora Negreiros Salomão}

Graduanda em Engenharia de Produção da Universidade do Estado do Pará (UEPA)

\section{Bruna Maria Gerônimo}

Possui graduação em Engenharia de Produção, com ênfase em Agroindústria, pela Universidade Estadual de Maringá (2016). Tem experiência na área de Modelagem e Simulação Dinâmica, atuando principalmente em simulação computacional. Desenvolvimento de Especialização em Engenharia de Segurança do Trabalho, pela Universidade Estadual de Maringá, em andamento.

\section{Camila Gonçalves Castro}

Graduada em Desenho Industrial - Projeto de Produto pela Universidade do Estado de Minas Gerais (2007). Mestre em Engenharia de Materiais pela REDEMAT - Rede temática em engenharia de materiais, uma parceria entre UFOP-CETEC-UEMG. Tem experiência na área de Desenho Industrial, atuando principalmente nos seguintes temas: design, sustentabilidade, avaliação de ciclo de vida e inovação, seleção de materiais, desenho técnico mecânico.

\section{Cássia Taisy Alencar de Andrade}

Graduada em Engenharia de Produção Mecânica pela Universidade Regional do Cariri URCA (2012 - 2016). Mestranda em Engenharia de Produção pela Universidade Federal de Pernambuco - UFPE PPGEP CAA, orientada pela professora Dra. Ana Paula Henriques de Gusmão.

\section{Cezar Augusto Romano}

Doutor e Mestre em Engenharia de Produção pela Universidade Federal de Santa Catarina, graduado em Engenharia Civil pela Universidade Federal do Paraná. É Professor Titular da Universidade Tecnológica Federal do Paraná (UTFPR) onde atua desde 1979. Foi DiretorGeral do Campus Medianeira da UTFPR (1992-1996) e Vice-Reitor da UTFPR (1996-2002). Atualmente é Diretor-Geral do Campus Curitiba, Conselheiro Eleito do Conselho Universitário (COUNI) e do Conselho de Planejamento e Administração (COPLAD). É Professor Permanente do Programa de Pós-Graduação em Engenharia Civil (PPGEC) e do Mestrado Profissional em Administração Pública (PROFIAP) atuando nas áreas de estratégia, planejamento, gestão com foco na produtividade organizacional. 


\section{Christiane Wagner Mainardes Krainer}

Doutoranda em Engenharia Civil pela Universidade Tecnológica Federal do Paraná (2017), Mestre em Engenharia Civil pela Universidade Tecnológica Federal do Paraná (2012), MBA em Marketing pela Fundação Getúlio Vargas (2000), graduada em Engenharia Civil pela Universidade Federal do Paraná (1994). Professora colaboradora do curso de Engenharia Civil da Universidade Federal do Paraná e pesquisadora da Universidade Tecnológica Federal do Paraná. Atua nos seguintes temas de pesquisa: construção civil, supply chain, logística, gestão integrada da produção, relacionamento interorganizacional, gestão da construção com foco na produtividade organizacional e gestão do conhecimento.

\section{Claiton Emilio do Amaral}

Graduado em Engenharia Mecânica e Engenharia Civil pela Universidade do Estado de Santa Catarina - Udesc, com Mestrado e Doutorado em Engenharia de Produção pela Universidade Federal de Santa Catarina - Ufsc. Desenvolve pesquisas e orientações nas áreas de gestão do conhecimento, desenvolvimento de novos produtos, projetos de melhoria de qualidade e redução de custos em produtos e processos. Professor universitário nos cursos de Engenharia de Produção e Engenharia Mecânica. Possui larga experiência profissional no desenvolvimento e implementação de projetos de produtos na empresa Whirlpool Corporation, líder mundial na fabricação de eletrodomésticos.

\section{Claudilaine Caldas de Oliveira}

Doutoranda em Engenharia de Produção pela Universidade Federal de Santa Catarina (UFSC). Mestrado em Engenharia de Produção pela Universidade Tecnológica Federal do Paraná (UTFPR). Especialização em Vigilância Sanitária em Alimentos pela Universidade Tecnológica Federal do Paraná (UTFPR). Graduação em Engenharia de Produção Agroindustrial pela Faculdade Estadual de Ciências e Letras de Campo Mourão/PR. Atualmente Professora colaboradora do Curso de Graduação em Engenharia de Produção Agroindustrial da Universidade Estadual do Paraná - UNESPAR, campus de Campo Mourão/PR

\section{Custódio da Cunha Alves}

Graduado em Matemática pela mesma Universidade da Região de Joinville(UNIVILLE). Doutor e mestre em Engenharia de Produção pela Universidade Federal de Santa Catarina (UFSC). Professor titular da Universidade da Região de Joinville (UNIVILLE). Trabalhou na Empresa Brasileira de Compressores S.A. - EMBRACO no período de 1989 a 1998 onde desempenhou funções na área de Controle da Qualidade. Atualmente é professor dos cursos de Engenharia de Produção e Mecânica da UNIVILLE.

\section{Daniela Oliveira de Lima}

Daniela Oliveira de Lima, nascida em 04/01/1994 em Manacapuru-AM. Engenheira Civil (2016) formada pelo Centro Universitário do Norte -UNINORTE. Atualmente, mestranda pela Universidade Federal do Amazonas -UFAM no curso de pós-graduação em Engenharia Civil, com ênfase em Materiais não convencionais (2017/2019). 


\section{Décio Estevão do Nascimento}

Possui graduação em Engenharia de Operação, Modalidade Eletrotécnica (1982), pela Universidade Tecnológica Federal do Paraná (UTFPR), especialização em Engenharia da Produção (1985), pela Universidade Federal de Santa Catarina (UFSC), mestrado (1997) e doutorado (2001), em Ciências do Homem e Tecnologia, pela Université de Technologie de Compiègne (França) e pós-doutorado em Política Científica e Tecnológica pela Unicamp (DPCT). É professor titular e pesquisador da Universidade Tecnológica Federal do Paraná, vinculado ao Departamento Acadêmico de Eletrônica, com atuação nos Programas de PósGraduação em Tecnologia e Sociedade (PPGTE) e em Planejamento e Governança Pública (PGP).Integra o BASIS - Banco de Avaliadores do INEP/MEC, com participação em diversas comissões de avaliação na qualidade de avaliador institucional. Dentro de sua área de interesse de pesquisa, que são "Processos e Dinâmicas de Territorialidade e Sustentabilidade", estuda temas como: Desenvolvimento Territorial, Redes Sociotécnicas, Cidades, Estudos de futuro, Indicadores Socioeconômicos e Ambientais, Universidades, Tecnologia e Inovação, Políticas Públicas, Economia da Funcionalidade, Internacionalização da formação do engenheiro. Lidera o Grupo de Pesquisa Território: Redes, Políticas, Tecnologia e Desenvolvimento (TRPTD).

\section{Denilson Ricardo de Lucena Nunes}

Possui graduação em Engenharia Civil pela Universidade da Amazônia (1999) e mestrado em Engenharia Civil pela Pontifícia Universidade Católica do Rio de Janeiro (2002) e doutorado em Engenharia de Produção (2014) pela Pontifícia Universidade Católica do Rio de Janeiro. É professor assistente II da Universidade do Estado do Pará no curso de Engenharia de Produção. Tem experiência na área de Engenharia Civil, com ênfase em Estruturas de Concreto e metálica. Na Engenharia de Produção atua principalmente nas seguintes áreas: planejamento e modelagem de estoques, logística e modelagem matemática.

\section{Diego Henrique de Almeida}

Engenheiro Industrial Madeireiro formado em 2011 pela Universidade Estadual Paulista Júlio de Mesquita Filho (UNESP). Mestre em Engenharia Civil (Engenharia de Estruturas) formado em 2014 pela Universidade de São Paulo (USP). Mestre em Ciência e Engenharia de Materiais formado em 2017 pela Universidade Federal de Alfenas (UNIFAL). Doutor em Engenharia Civil (Estruturas e Construção Civil) formado em 2017 pela Universidade Federal de São Carlos (UFSCar). Foi coordenador de cursos de graduação (Engenharia de Produção e Engenharia Ambiental) da Faculdade Pitágoras, campus Poços de Caldas (MG) entre 09/2015 e 06/2017. Atuou como professor universitário na Faculdade Pitágoras (08/2014 a 06/2017) e Pontifícia Universidade Católica (PUC) (02/2014 a 12/2014), ambas em Poços de Caldas (MG). Possui mais de 70 artigos publicados em periódicos nacionais e internacionais. Possui mais de 100 trabalhos publicados em anais de eventos nacionais e internacionais. É revisor de periódicos nacionais e internacionais. É revisor de artigos submetidos a congressos nacionais, entre eles: CBCTEM (Congresso Brasileiro de Ciência e Tecnologia da Madeira - 2017) e CONBREPRO (Congresso Brasileiro de Engenharia de Produção - 2015, 2016 e 2017).

\section{Diego Vieira Ramos}

Arquiteto e Urbanista formado pelo Centro de Ensino Superior de Maringá (2013) e Especialista em Educação Ambiental pela Faculdade Eficaz (2016), Engenheiro de Segurança no Trabalho pela Universidade Cândido Mendes (RJ) e Mestrando em Engenharia Urbana pela Universidade Estadual de Maringá. 


\section{Diego Willian Nascimento Machado}

Diego William Nascimento Machado, Arquiteto e Urbanista graduado pelo Centro Universitário Franciscano - UNIFRA. Tem experiência na área de Arquitetura Paisagista e Engenharia Civil pela Universidade de Trás-os-Montes e Alto Douro em Vila Real, Portugal. Possui licenciatura plena atribuída pelo PEG - UFSM. Mestre em engenharia Civil no curso de construção civil e Preservação Ambiental - UFSM. Atualmente é professor adjunto na Universidade Luterana do Brasil - ULBRA/SM no curso de Arquitetura e Urbanismo.

\section{Douglas Felipe Galvão}

Possui graduação em Tecnologia em Gestão Ambiental (2011), especialização em Gestão Ambiental em Municípios (2013) e Mestrado em Tecnologias Ambientais (2016), todas realizadas na UTFPR - Campus Medianeira.

\section{Ederson Djair Sanches do Nascimento}

Graduado em Engenharia Mecânica pela Universidade Regional e Integrada do Alto Uruguai e das Missões (URI).

\section{Edimar Nunes Dias}

Graduado em Engenharia de Produção Agroindustrial pela Universidade Estadual do Paraná UNESPAR. Atuou como consultor Júnior na Otimiza EJ no período de 2014 - 2016. Projetos de pesquisas realizados durante a graduação: análise das regras de prioridade para a programação da produção em uma indústria de confecção: um estudo de caso; e modelos matemáticos formulados a partir de problemas de planejamento e programação da produção em processo de batelada utilizando programação linear e redes de estados e tarefas (STN). Formação Green Belt - 6 Sigma e Lean manufacturing pela RL associados. Atualmente, atua como analista técnico no setor de produção de um abatedouro de aves.

\section{Eduardo Meneguetti Hizo}

Graduado em Engenharia de Produção pela Universidade Estadual de Maringá.

\section{Edullis Garcia Rodrigues}

Graduando em Engenharia de Produção pela Universidade do Estado do Pará.

\section{Eliane Rodrigues dos Santos Gomes}

Possui graduação em Engenharia Química pela Universidade Estadual de Maringá (1987), graduação em Disciplinas Técnicas Especializadas -Esquema I (química aplicada), pelo Centro Federal de Educação Tecnológica (1996), mestrado em Engenharia Agrícola pela Universidade Estadual do Oeste do Paraná (2002) e doutorado em Engenharia Química pela Universidade Estadual de Maringá (2006). Atualmente é professora no curso de graduação em Engenharia Ambiental da Universidade Tecnológica Federal do Paraná, UTFPR Campus Medianeira, professora no programa de mestrado PPGTAMB e coordenadora do curso de especialização em Gestão Ambiental em Municípios, modalidade EaD. 


\section{Emerson Jose Corazza}

Possui graduação em Engenharia de Produção Mecânica (2008) pela Universidade da Região de Joinville - UNIVILLE e Mestrado em Engenharia de Processos (2012) pela Universidade da Região de Joinville e Pós Graduação em Engenharia de Segurança do Trabalho (2014) pela Sociedade Educacional de Santa Catarina - SOCIESC. Atua como professor de carreira adjunto nos cursos de Engenharia de Produção e Engenharia Mecânica da UNIVILLE, no qual atua também como coordenador do curso, ministrando as disciplinas de Processo de Fabricação Mecânica e Manutenção Industrial. Experiência na área de Engenharia de Produção, com ênfase em Desenvolvimento de Produto e vasta experiência profissional na maior empresa de Fundição da América Latina, área de Manutenção Industrial.

\section{Felipe Augusto da Silva}

Graduando em Engenharia Civil pelo Centro Universitário de Patos de Minas - UNIPAM (2015 - atual).

\section{Ferdinand van Run}

Graduado em Engenharia de Produção pela Universidade de Araraquara (UNIARA) em 2017; Atuou por um ano e seis meses em uma empresa de grande porte do setor alimentício, como analísta de performance produtiva no setor de qualidade. Atuou por três anos em uma empresa multinacional de grande porte do setor aeronáutico, sendo estagiário e membro das areas de planejamento, programação, controle de produção e logística na aviação comercial e de defesa e segurança. Efetuou cursos extra-curriculares em Lean Manufacturing, SAP system e programação de softwares, auxiliando na implantação de sua tese, que veio a ser publicada no congresso nacional brasileiro (CONBREPRO - 2016). É estudante de mestrado em gerenciamento de Supply Chain na Holanda. Morou na Inglaterra por 5 meses, onde estudou sobre a lingua e cultura inglesa. Atuou na escola internacional de idiomas Shane Global Hastings, como líder de atividades extracurriculares e guia turístico durante excursões e viagens socioeducativas. Pondo em pratica seu conhecimento sobre coach e gerenciamento de pessoas em um ambiente completamente cosmopolitano.

\section{Filipe Molinar Machado}

Graduado em Engenharia Mecânica pela Universidade Regional e Integrada do Alto Uruguai e das Missões (URI). Mestre em Engenharia de Produção pela Universidade Federal de Santa Maria (PPGEP/UFSM). Doutorando em Engenharia Agrícola no Programa de Pós-Graduação em Engenharia Agrícola da Universidade Federal de Santa Maria (PPGEA/UFSM). Professor no Departamento de Engenharias e Ciências da Computação (URI), campus Santo Ângelo. É Perito Criminal, área Engenharia Mecânica, no Instituto-Geral de Perícias (IGP-RS).

\section{Franciele Lourenço}

Mestre em Organizações e Desenvolvimento pelo Centro Universitário Franciscano - UniFae (2011), Área de Concentração: Sustentabilidade Socioeconômica, Linha de pesquisa: Sustentabilidade e Desenvolvimento Local. Possui especialização no curso de MBA em Gestão Financeira com Ênfase em Controladoria pelas Faculdades Integradas do Brasil UNIBRASIL (2013), formada como Bacharela em Ciências Econômicas pela Pontifícia Universidade Católica do Paraná - PUCPR (2005). Atualmente é professora contratada do Centro Universitário Autônomo do Brasil - UNIBRASIL desde o ano de 2007, atuante nas disciplinas de Economia I; Mercado de Capitais e Governança Corporativa e; Gestão de 
Pessoas. E, assistente técnica de grupo financeiro setorial da Secretaria de Estado da Fazenda do Paraná.

\section{Franciely Velozo Aragão}

Graduada em Engenharia de Produção pela Universidade Estadual do Paraná UNESPAR/FECILCAM (2011), também é Mestre em Engenharia Urbana na área de concentração Infraestrutura e Sistemas Urbanos, pela Universidade Estadual de Maringá UEM (2014). Atualmente é docente do Departamento de Engenharia de Produção (DEP/UEM) da Universidade Estadual de Maringá.

\section{Franco da Silveira}

Graduado em Engenharia Mecânica pela Universidade Regional e Integrada do Alto Uruguai e das Missões (URI). Mestrando em Engenharia de Produção do Programa de Pós-Graduação em Engenharia de Produção da Universidade Federal de Santa Maria (PPGEP/UFSM). Membro e Pesquisador do Núcleo de Inovação e Competitividade (NIC). Participou como administrador do Projeto URI BAJA MISSIONEIRO no ano de 2014, para a $12^{\text {a }}$ Competição BAJA SAE BRASIL - Etapa SUL.

\section{Frédéric Huet}

Economista, professor da Université de Technologie de Compiègne (UTC-França), desde 2006, Frédéric Huet desenvolve seu trabalho dentro da economia industrial e das organizações, voltado à pesquisa das dinâmicas das relações inter-organizacionais. Membro do laboratório Costech, suas pesquisas e colaborações científicas apresentam uma abertura interdisciplinar (filosofia, sociologia, engenharia industrial ...).

\section{Generoso De Angelis Neto}

Possui graduação em Engenharia Civil pela Universidade Estadual de Maringá (1988), mestrado em Geotecnia pela Escola de Engenharia de São Carlos da Universidade de São Paulo (1994), doutorado em Engenharia de Construção Civil e Urbana pela Escola Politécnica da Universidade de São Paulo (1999) e pós-doutorado em Engenharia de Recursos Hídricos e Ambiental pela Universidade Federal do Paraná (2015). Atualmente é Professor Titular em Construção Civil - Gestão de Resíduos da Construção Civil do Departamento de Engenharia Civil da Universidade Estadual de Maringá, Membro do Conselho Editorial dos periódicos Journal of Urban and Environmental Engineering e Acta Scientiarum. Atua na área de Engenharia Urbana, principalmente com os seguintes temas: planejamento ambiental de áreas urbanas, gestão de resíduos sólidos e recuperação de áreas urbanas degradadas.

\section{Gustavo Henrique Judice}

Engenheiro Mecânico com mestrado na área de materiais. Experiência acadêmica atuando como docente em cursos de graduação na área da engenharia e como coordenador dos cursos de Engenharia Mecânica, Engenharia Elétrica e Engenharia de Controle e Automação. Experiência também na área industrial com projetos, P\&D e manutenção em empresas multinacionais de grande porte. 


\section{Igor Caetano Silva}

Graduando em Engenharia de Produção pelo Centro Universitário de Patos de Minas UNIPAM (2014 - atual).

\section{Igor Santos Costa}

Graduando em Engenharia de Produção pela Universidade do Estado do Pará. Possui experiência nas áreas de gestão da qualidade em serviços de saúde e gestão de projetos.

\section{Jackson de Sousa Silva}

Graduando em Engenharia de Produção com habilitação Mecânica pela Universidade Regional do Cariri (URCA). Atualmente, sob vinculo institucional com a Coordenação de Aperfeiçoamento de Pessoal de Nível Superior (CAPES), exerce atividades como bolsista de graduação sanduíche no Programa CAPES/BRAFITEC com admissão à spécialité Management de l'innovation et Design industriel (MIDI) do master Design Global da Université de Lorraine (UL), por parte da Ecole Nationale supérieure en Génie des Systèmes et Innovation (ENSGSI) de Nancy (França).

\section{Jair Paulino de Sales}

Graduado em Engenharia de Produção pela Universidade Regional do Cariri (URCA). Realizou período de graduação sanduíche pelo Programa Ciência sem Fronteiras no curso de Ingegneria Gestionale da Università Degli Studi di Modena e Reggio Emilia (UNIMORE). Atualmente cursa mestrado acadêmico junto ao Programa de Pós-Graduação em Desenvolvimento Regional Sustentável (PRODER) da Universidade Federal do Cariri (UFCA), sendo membro do Grupo de Pesquisa em Modelagem Estatística, Simulação e Otimização de Risco (MESOR).

\section{Jamile Pereira da Silva}

Jamile Pereira da Silva, graduação em Arquitetura e Urbanismo em andamento pela Universidade Luterana do Brasil, Campus Santa Maria/RS. Participa como voluntária do Grupo de Pesquisa em Eficiência Energética em Edificações e é estagiária em escritório de arquitetura. Possui artigos acadêmicos aprovados e apresentados em Congressos e Eventos locais, nacionais e internacionais.

\section{Janaína Aparecida Pereira}

Possui graduação em Engenharia Mecânica pela Universidade Federal de Uberlândia (2006). Possui mestrado em Engenharia Mecânica pela Universidade Federal de Uberlândia (2009). Atualmente é aluna regular do Programa de Pós Graduação em Engenharia Mecânica da Universidade Federal de Uberlândia, doutorado.

\section{Janiely Lima de Almeida}

Engenheira Civil, formada pelo Centro Universitário do Norte - UNINORTE em 2016. Atuou como Assistente de Engenharia na empresa Eficaz Consultoria e Projetos; Atuou como 
Projetista na empresa Sigma Engenharia e Consultoria. Atualmete exerce o cargo de Engenheira Civil Pleno na Prefeitura Municipal de Borba.

\section{Janis Elisa Ruppenthal}

Graduada em Engenharia Química pela Universidade Federal de Santa Maria (UFSM). Especialização em Engenharia de Segurança do Trabalho. Mestrado e Doutorado em Engenharia de Produção pela Universidade Federal de Santa Catarina (PPGEP/UFSC). Professora dos Cursos de Engenharia da Universidade Federal de Santa Maria desde 1996. Atua também no Programa de Pós-graduação em Engenharia de Produção da UFSM (PPGEP/UFSM).

\section{Janser Queiroz Oliveira}

Possui graduação em Engenharia de Produção pelo Centro Universitário do Triângulo - Unitri (2009). Especialização em Gerenciamento de Projetos pela Faculdade Católica de Anápolis (2013). Atualmente é professor do Centro Universitário de Patos de Minas - UNIPAM. Possuindo experiência nas áreas de Gerenciamento da Cadeia de Suprimentos, Gestão da Qualidade e Gestão por Processos.

\section{Jaqueline Luisa Silva}

Graduanda em Engenharia de Produção pelo Centro Universitário de Patos de Minas, UNIPAM; Grupo de Pesquisa: Grupo de Estudos e Pesquisas em Inovações Tecnológicas (GITEC)

\section{Jefferson Augusto Krainer}

Doutorando em Engenharia Civil pela Universidade Tecnológica Federal do Paraná (2017), Mestre em Ciência, Gestão e Tecnologia da Informação pela Universidade Federal do Paraná (2013), possui Bacharelado em Direito pela Faculdade de Direito de Curitiba (1995). Professor colaborador da Universidade Estadual do Paraná nos cursos de Ciências Sociais e pesquisador da Universidade Tecnológica Federal do Paraná. Atua nos seguintes temas de pesquisa: construção civil, supply chain, logística, gestão integrada da produção, relacionamento interorganizacional, gestão da construção com foco na produtividade organizacional e gestão do conhecimento.

\section{Jéssica Citron Muneroli}

Graduada em Engenharia de Produção pela Universidade Luterana do Brasil-ULBRA, cursando MBE em Engenharia de Produção e Serviços na Universidade Luterana do Brasil ULBRA.

\section{Jocarly Patrocínio de Souza}

Professor Titular da Universidade de Passo Fundo, Passo Fundo (RS), Faculdade de Engenharia e Arquitetura, curso de Engenharia Elétrica. Possui graduação em Engenharia Elétrica pela Universidade Federal do Espírito Santo (1989), mestrado em Engenharia Mecânica pela Universidade Estadual de Campinas (1992) e doutorado em Engenharia 
Mecânica pela Universidade Estadual de Campinas (2001). Pós-doutorado na École CentraleSupeléc - Gif-sur-Yvette, França (2015-2016). Professor do programa de PósGraduação em Projetos e Processos de Fabricação. Tem interesse nas seguintes áreas: controle de sistemas mecânicos: robótica manipuladora e móvel, automação industrial, teoria de controle, instrumentação e ensino de engenharia.

\section{Jonathas Sampaio dos Santos}

Graduando em Engenharia de Produção pela Universidade do Estado do Pará. Experiência em Projeto de Otimização do Delivery de uma Hamburgueria.

\section{José Roberto de Queiroz Abreu}

Engenheiro Civil formado pela Universidade Federal do Amazonas (UFAM) em 1993, Especialista em Gerenciamento na Construção Civil, também pela Universidade Federal do Amazonas (UFAM). Atuando como docente desde 1999 (no Instituto de Tecnologia da Amazonia - UTAM e posteriormente Universidade do estado do Amazonas -UEA), atualmente é Professor do Centro Universitário do Norte - Uninorte da Rede Laureate International Universities.

\section{Juan Pablo Silva Moreira}

Graduando em Engenharia de Produção pelo Centro Universitário de Patos de Minas UNIPAM (2014 - atual). Possui experiência em pesquisas científicas nas áreas de Engenharia da Qualidade, Gestão por Processos, Gestão do Desempenho e Gestão Ambiental com ênfase em Certificações Ambientais e Gerenciamento de Resíduos Sólidos.

\section{Kátia Madruga}

Graduada em Letras (UFRGS), mestrado (UFRGS) e doutorado (Universidade Bremen, Alemanha) em Administração de Empresas com foco em Gestão socioambiental. Projetos de pós-doutorado incluem o projeto de 'Internacionalização do Portal Oekoradar' da Cátedra de Gestão Ambiental da Universidade de Hohenheim, Stuttgart e o projeto sobre 'Políticas estratégicas para gestão de energia industrial' realizado junto ao Instituto de Economia da Energia e Uso Racional de Energia da Universidade de Stuttgart. Professora adjunta da Universidade Federal de Santa Catarina e atua no Depto de Energia e Sustentabilidade. Coordena o Programa de Pós-Graduação em Energia e Sustentabilidade e é Agente de Internacionalização do Centro de Ciências, Tecnologias e Saúde da UFSC/Araranguá.

\section{Leony Luis Lopes Negrão}

Graduado em Engenharia de Produção pela Universidade do Estado do Pará (2003), mestre em Engenharia Civil pela Universidade Federal do Pará (2009) e doutor em Engenharia de Produção pela Universidade Federal de São Carlos (2016). Atualmente é Professor Assistente IV do Departamento de Engenharia de Produção e Diretor de Planejamento Estratégico da Universidade do Estado do Pará. 


\section{Liliane Cristine Schlemer Alcântara}

Pós-doutoranda do Programa de Pós-graduação em Gestão Urbana - PPGTU/PUCPR. Doutora em Desenvolvimento Regional pela Universidade Regional de Blumenau PPGDR/FURB. Doutorado Sandwich no Instituto de Estudios Cooperativos de Mondragón Unibertsitatea (MU) - (LANKI) - Facultad de Humanidades y Ciencias de la Educación (HUHEZI) com bolsa da CAPES - Programa de Doutorado Sanduíche no Exterior (Processo N. 99999.000381/2014-04). Mestre em Administração. Especialista em Programa de Apoio ao Ensino e à Pesquisa Científica e Tecnológica em Educação Profissional Integrada à Educação de Jovens e Adultos - PROEJA, Administração Rural e Metodologia e Didática do Ensino Superior. Graduada em Administração pela Sociedade Educacional Três de Maio (1987). Linhas de pesquisa em Desenvolvimento Regional: Desenvolvimento Territorial Sustentável, Educação para o Ecodesenvolvimento, Educação para o Cooperativismo e Bem Viver (Buen Vivir). Pesquisadora dos Grupos de Pesquisa: Agroecologia: Ciência, Prática e Movimento. Núcleo de Pesquisas Públicas (NPP/FRUB). Análise Ambiental e Ecodesenvolvimento (FURB/SC). Resiliência e Agricultura Familiar na Amazônia e Núcleo de Ecossocioeconomia (NEcos) da UFPR/PR. Professora do Centro de Ciências Agrárias (CCA) da Universidade Federal de São Carlos (UFSCar) de 2012 a 2017. Professora do Mestrado do Programa de pós-graduação em Agroecologia e Desenvolvimento Rural (PPGADR/UFSCar) e Professora da Faculdade de Administração e Ciências Contábeis (FACC) da Universidade Federal de Mato Grosso (UFMT).

\section{Luciana Cristina de Carvalho Ramos}

Engenheira de Produção formada na Faculdade Pitágoras (Campus Poços de Caldas-MG) em 2014.

\section{Luciane Cristina Ribeiro dos Santos}

Com graduação em Tecnologia em Gestão de Recursos Humanos pela Pontifícia Universidade Católica do Paraná (PUCPR), recebeu o prêmio Marcelino Champagnat, por mérito acadêmico, ao formar-se em primeiro lugar. Mestre em Gestão Urbana, pela PUCPR. Doutoranda no Programa de Pós-Graduação em Engenharia de Produção e Sistemas (PPGEPS), pela PUCPR. Sua experiência inclui Docência na modalidade EaD no curso de graduação em Turismo pelo Grupo UNINTER e na modalidade presencial pela PUCPR. Foi Pesquisadora e Bolsista, na Trilhas Incubadora Social Marista. Integra o Núcleo de Estudos em Ecossocioeconomia (NEcos), vinculado ao PPGTU da PUCPR, ao Programa de Meio Ambiente da Universidade Positivo e ao Programa de Pós-Graduação em Meio ambiente e Desenvolvimento (MADE) pela Universidade Federal do Paraná. Atualmente é bolsista pela Capes/Fundação Araucária. No momento, orienta Trabalho de Conclusão de Curso em MBA em Gestão de Eventos, Assessoria Executiva e Administração pelo Grupo UNINTER e Bacharelado em Turismo pela PUCPR. Possui experiência na área de Administração, atuando principalmente com gestão de pessoas, consultoria interna e análise de crédito. Temas de pesquisa: ecossocioeconomia, políticas públicas, governança, arranjos institucionais e socioprodutivo local, desenvolvimento, participação, sustentabilidade, economia solidária, turismo de base comunitária, consumo consciente, gestão interorganizacional e integração de produtos orientados à sustentabilidade. 


\section{Luciano Wallace Gonçalves Barbosa}

Mestrando em Engenharia Mecânica na Universidade Estadual de Campinas (UNICAMP), na área de processos de fabricação. Engenheiro de Produção pelo Instituto Federal de Minas Gerais (IFMG), onde atuou como tutor de disciplinas, projetos de iniciação científica e também no grupo de pesquisa de Gestão de Operações, Logística e Pesquisa Operacional. Tem experiência na área de logística, com ênfase em custos logísticos e gerenciamento de estoque.

\section{Luciene Vanessa Maia da Rocha Judice}

Possui graduação em Engenharia Química pelo Centro Universitário das Faculdades Associadas de Ensino (2010), mestrado em Engenharia Mecânica pela Universidade Estadual de Campinas (2013) e cursando doutorado em Engenharia Mecânica pela Universidade Estadual de Campinas (2016). Tem experiência na área de Engenharia Química, com ênfase em Ciências Ambientais e como docente na área de Engenharia Mecânica, Produção e Ambiental.

\section{Luis Cláudio Villani Ortiz}

Graduação em Ciências Econômicas pela Universidade Regional do Noroeste do Estado do RS (UNIJUÍ), Pós-Graduação em Economia Monetária. Mestre em Economia pela UFRGS (Porto Alegre) e atualmente cursa o Programa de Pós Graduação a nível de Doutoramento em Desenvolvimento Regional (UNISC/RS). Na carreira acadêmica têm experiência profissional nas Faculdades Integradas Machado de Assis/RS, Instituto Cenecista de Ensino Superior de Santo Ângelo e Universidade Regional Integrada do Alto Uruguai e Missões (instituição atual, do qual além de docente universitário, desempenho a coordenação de Projeto de Extensão Universitária - NEPI Missões.

\section{Maiara Baldissarelli}

Maiara Baldissarelli, graduação em andamento no curso de Arquitetura e Urbanismo na Universidade Luterana do Brasil- Campus Santa Maria, RS. Participa como voluntária dos grupos de pesquisa: Teoria, história e crítica da arquitetura e Eficiência energética em edificações, com artigos acadêmicos apresentados em congressos e eventos nacionais e internacionais. Experiência profissional na elaboração de projetos arquitetônicos e de interiores, definição de materiais, e estudos de viabilidade financeira, econômica e ambiental.

\section{Manuela Gortz}

Doutoranda na Universidade Tecnológica Federal do Paraná (UTFPR), no Programa de PósGraduação em Tecnologia e Sociedade (PPGTE), na linha de pesquisa Tecnologia e Desenvolvimento. Mestre em Tecnologia e Sociedade pelo PPGTE/UTFPR, na linha de pesquisa Tecnologia e Desenvolvimento (2017). Graduada em 2013 no Curso de Bacharelado em Design pela Universidade Tecnológica Federal do Paraná (UTFPR). Estagiou na Secretaria de Educação à Distância da UFPR e na FIEP/SESI-PR. Possui experiência como designer e gerente de projetos, supervisora de criação e gestora de atendimento. Atualmente é aluna bolsista de Doutorado, com dedicação exclusiva. Seu foco principal de pesquisa é em temas relacionados à Economia da Funcionalidade, Sistemas Produto-Serviço (SPS), Design Emocional e Teoria de Ator-Rede (ANT). Participa também do Grupo de Pesquisa Território: Redes, Políticas, Tecnologia e Desenvolvimento (TRPTD). 


\section{Marcelo Luiz Chicati}

Possui graduação em Agronomia pela Universidade Estadual de Maringá (2004), mestrado em Agronomia pela Universidade Estadual de Maringá (2007) e doutorado em Agronomia pela Universidade Estadual de Maringá (2011). Exerce atualmente o cargo de Coordenador Adjunto do Programa de Pós-Graduação em Engenharia Urbana da UEM (PEU/UEM).Tem experiência na área de Agronomia, com ênfase em Geoprocessamento, Topografia, Agricultura de Precisão e Sensoriamento Remoto atuando principalmente nos seguintes temas: sistema de informações geográficas, sensoriamento remoto, manejo e classificação de solos e cadastramento rural.

\section{Márcia de Fátima Morais}

Possui graduação em Engenharia de Produção Agroindustrial pela Faculdade Estadual de Ciências e Letras de Campo Mourão (2002) e mestrado em Engenharia (Engenharia de Produção) pela Universidade de São Paulo (2008). Doutoranda em Engenharia de Produção e Sistemas pela Universidade Pontifícia Católica do Paraná. Desenvolve pesquisas na linha Modelos de Apoio à Tomada de Decisão da área de concentração Gerência de Produção e Logística. Atualmente é professora assistente da Universidade Estadual do Paraná, Campus de Campo Mourão. Tem experiência na área de Engenharia de Produção, com ênfase em Pesquisa Operacional.

\section{Marcos Roberto Lopomo}

Mestrando em Energia e Sustentabilidade pela Universidade Federal de Santa Catarina, Depto de Energia e Sustentabilidade em Araranguá-SC. Graduado em Engenharia Elétrica pela Universidade Mackenzie e MBA em Gerência de Energia pela FGV. Atua no setor de energia há 18 anos, nas áreas de Regulação Técnica, Comercial e Econômico-Financeira em empresas de grande porte de Energia Elétrica e Gás Natural. Atualmente é consultor e proprietário na Matriz Energética Consultoria e Treinamento.

\section{Mario Fernando Mello}

Professor universitário de graduação e pós-graduação, graduado em engenheira mecânica e ciências contábeis, especialista em formação de gerentes e diretores pela FGV Rio de Janeiro, pós-graduado em gestão de negócios internacionais pela Universidade da CalifórniaEUA, mestre em engenharia de produção e doutorando em engenharia agrícola pela UFSM. É professor na Universidade Federal de Santa Maria-UFSM, na Universidade Luterana do BrasilULBRA, Na Faculdade Antonio Meneghetti-AMF e na Fundação Getúlio Vargas.

\section{Mario Henrique Bueno Moreira Callefi}

Atualmente mestrando em Engenharia Urbana pela Universidade Estadual de Maringá. Graduado em Engenharia de Produção -Software pela Universidade Estadual de Maringá (2016). Também cursando MBA em Administração e Logística pelo Centro Universitário Internacional - UNINTER.

\section{Matheus Amaral Damasceno}

Graduando em Engenharia de Produção da Universidade do Estado do Pará (UEPA) 


\section{Osíris Canciglieri Junior}

Possui graduação em Engenharia Industrial Mecânica pela Escola de Engenharia Industrial de São José dos Campos - EEI (1991), mestrado em Engenharia Mecânica pela Universidade Estadual de Campinas - DEF/FEM/UNICAMP (1994), doutorado em Automação da Manufatura na Universidade de Loughborough - LU (Inglaterra - 1999) e Pós- Doutorado também na Universidade de Loughborough - LU (2008). Atualmente é professor titular da Pontifícia Universidade Católica do Paraná e Coordenador do Programa de Pós-Graduação em Engenharia de Produção de Sistemas (PPGEPS/PUCPR), é professor nos cursos de Engenharia de Controle e Automação (Mecatrônica), de Engenharia de Produção e do Programa de Pós Graduação em Engenharia de Produção e Sistemas (PPGEPS/PUCPR). Tem experiência na área de Desenvolvimento de Produtos tendo como ênfase a integração de sistemas atuando principalmente nos seguintes temas: Projeto e Manufatura Assistidos por Computador (CAD/CAM) com foco no suporte ao projeto e concepção de proteses incluindo a área odontológica, Projeto Orientado para a Manufatura e Montagem (DFM/DFA), Projeto Orientado para a Sustentabilidade, Engenharia Simultânea, Desenvolvimento de Produtos Sustentáveis, Desenvolvimento de produtos voltados para a produção/geração e utilização de energias renováveis, é pesquisador do projeto \&quot;Pesquisa e Desenvolvimento de Células Fotovoltaicas Utilizando Filmes de Diamante CVD - ANEEL\&quot;. O Prof. Osiris Canciglieri Junior é membro editorial da revista Sodebras e avaliador (?referee?) dos periódicos científicos: International Journal of Computer Integrated Manufacturing (IJCIM), International Journal of production Research (IJPR), Computer Aided Design (CAD), Revista Produção, Revista Produto e Produção, Brazilian Journal of Operations \& Production Management (BJO\&PM) e Revista Produção Online.

\section{Rayane Ester Felício Santiago}

Graduanda em Engenharia de Produção pelo Instituto Federal de Educação, Ciência e Tecnologia de Minas Gerais. Atuou como tutora na disciplina de Cálculo I, e participou do projeto de pesquisa sobre a ISO 55000 de Gestão de Ativos. Participa do programa de estágios de uma importante empresa do setor Ferroviário e possui experiência em Gestão de Projetos.

\section{Renato Augusto Pereira Archer}

Graduando em Engenharia de Produção da Universidade do Estado do Pará (UEPA)

\section{Renato Cristofolini}

Bacharel em Engenharia Mecânica pela Universidade do Estado de Santa Catarina (1982), Mestre em Ciência e Engenharia de Materiais pela Universidade do Estado de Santa Catarina (1997) e Doutor em Engenharia Mecânica pela UNICAMP (2009). Foi Instrutor com Mestrado no SENAI e atualmente é professor Adjunto I (Doutor) da Univille de Joinville. Tem experiência na área de Engenharia Mecânica, Engenharia de Produção, atuando principalmente nos seguintes temas: compósitos, reofundição, conformação mecânica de metais, mecânica dos sólidos, resistência dos materiais, vibrações, tixoconformação, usinagem convencional e CNC. Experiência em: simulação computacional dinâmica e em estruturas metálicas; consultorias; A RTs ; perícias; cálculo estrutural. Ampla Experiência Industrial. 


\section{Rennan Silva Italiano}

Engenheiro Civil, formado pelo Centro Universitário do Norte - Uninorte em 2016. Cursando Pós-Graduação em Estruturas de Concreto, Alvenarias Fundações e Contenções e Auditoria, Avaliações e Perícias da Engenharia, ambas pelo Instituto de Ensino Superior Brasileiro ESB. Atualmente trabalha na elaboração de Laudos Técnicos de Inspeção Predial e de Avaliação de Bens, além de Cálculo de Estruturas.

\section{Rodrigo Vielmo Moura}

Rodrigo Vielmo Moura, graduação em Arquitetura e Urbanismo em andamento pela Universidade Luterana do Brasil, Campus Santa Maria/RS. Participa como voluntário do Grupo de Pesquisa em Eficiência Energética em Edificações e é estagiário em escritório de arquitetura. Possui artigos acadêmicos aprovados e apresentados em Congressos e Eventos locais, nacionais.

\section{Rony Peterson da Rocha}

Doutor e Mestre em Engenharia Química - Modelagem e Otimização de Processos, pelo Programa de Pós-Graduação em Engenharia Química, Universidade Estadual de Maringá (UEM) (2015-2011). Especialista em MBA em Gestão Empresarial e em Gestão Ambiental pela FECILCAM - Faculdade Estadual de Ciências e Letras de Campo Mourão (2012-2007). Graduado em Engenheiro de Produção Agroindustrial, pela Universidade Estadual do Paraná - Campus de Campo Mourão (2004). Professor Adjunto do Colegiado de Engenharia de Produção, Universidade Estadual do Paraná - Campus de Campo Mourão, Campo Mourão/PR. Pesquisador do Grupo de Estudos e Pesquisas em Processos e Gestão de Operações (GEPPGO). Coordenador do Curso de Engenharia de Produção Agroindustrial (2016-2017).

\section{Tânia Maria Coelho}

Graduada em Física pela Universidade Estadual de Maringá. Mestre e Doutora em Física pela Universidade Estadual de Maringá. Professora Associada da Universidade Estadual do Paraná - UNESPAR. Líder e Pesquisadora do GMPAgro - Grupo de Pesquisa em Materiais Agroindustriais da UNESPAR

\section{Thalasso Bezerra Bispo}

Bacharelado em Engenharia de Produção Mecânica pela Universidade Regional do Cariri (URCA). Mestrado pelo Programa de Pós-graduação em Desenvolvimento Regional Sustentável na Universidade Federal do Cariri - UFCA.

\section{Wesley Gomes Feitosa}

Possui Graduação em Licenciatura Plena em Matemática pelo Ministério da Defesa - CIESA e Graduação em Engenharia Civil pelo Centro Universitário do Norte - UNINORTE. Possui Mestrado Profissionalizante em Engenharia da Produção pela UFAM. Atualmente é Doutorando em Educação pela Universidad Columbia del Paraguay (UCP) e Especialização em Engenharia de Segurança do Trabalho pela UNINORTE. Atua como professor horista do Laureate International Universities (UNINORTE), professor da SEDUC e SEMED. 


\section{Willian de Morais}

Possui Técnico Mecânico (2009) pelo Centro Educacional Profissional - CEDUP e Graduado em Engenharia de Produção Mecânica pela Universidade da Região de Joinville - UNIVILLE. Trabalha na General Motors (2014) na área da qualidade, atualmente participa do time de projeto de expansão da fábrica com atividades de engenharia da qualidade. Trabalhou na SCHULZ (2010 - 2013) com atividades na área de ensaios não destrutivos na qualidade da fundição. Trabalhou na SCHULZ (2009 - 2010) como estagiário na área da qualidade de compressores.

\section{Willyan Prado Barbosa}

Graduado em Engenharia Civil pela Universidade Estadual de Maringá (2010). 


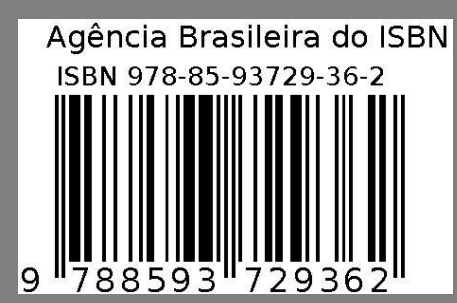

